\section{AFEHAN JHAD}

A Quarterly Publication of The Cultural Council of Afghanistan Resistance MANAGING EDTTOR:

Sabahuddin Kushkaki April-June, 1988

\section{SUBSCRIPTION}

$$
\begin{aligned}
& \text { Per Six Annual } \\
& \text { copy months }
\end{aligned}
$$

Pakistan

(Rs.) $30 \quad 60 \quad 210$

Foreign

(\$) $6 \quad 12 \quad 30$

\section{Resistance}

House No. 886, St. No. 27, G/9-1 Islamabad, Pakistan

Telephone 85379.7

\title{
Contents
}

EDITORIAL, POLITICAL ANALYSIS,

MILITARY REPORT,

Grand table of Afghan war casualties

(April-June, 1988)

Afghans and the Geneva accord on Afghanistan 14

MAJOR DOCUMENTS:

1. Text of charter for mujaheddin transitional government; (2) Text of Geneva accord on Afghan1stan; (3) IUAM and the Geneva accord; (4) Mujaheddin offer general amnesty; (5) IUAM President urges trial for PDPA high brass; (6) Biographies of IUAM transitional cabinet; (7) Biographies of three IUAM leaders; ( 8 ) Charters of the IUAM organizations; (9) Annual report of Amnesty International on Afghanistan.

AFGHANISTAN IN IN'TERNATIONAL FORUMS:

1. Islamabad Conference on Afghan future

2. Karachi Islamic meeting

3. Paris Conference: Afghan Agriculture

IRC Survey on health in Afghan refugee camps.97

CATALOGUE OF MUJAHEDDIN PRESS

DIGEST OF MUJAHEDDIN PRESS

(APRIL-JUNE 1988)

BOOKS BY THE MUJAHEDDIN, FOR THE

MUJAHEDDIN

CHRONOLOGY OF AFGHAN EVENTS

(APRII-JUNE 1988)

AFGHAN ISSUES COVERAGE:

By Radio Kabul, Radio Moscow

(April-June, 1988)

MAPS 


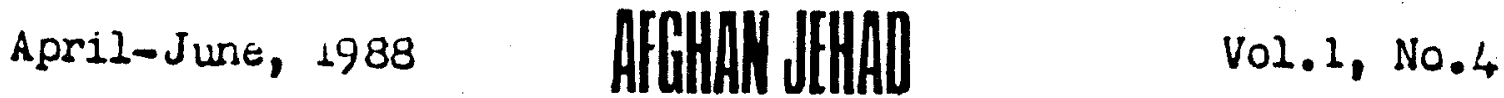

\section{$\underline{\text { Editorial }}$}

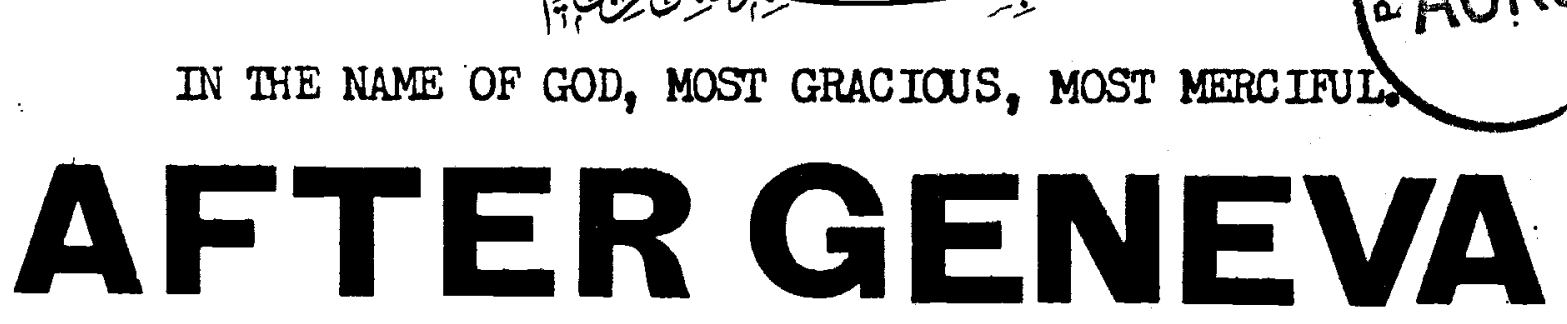

Now that the Russian troops are on thejry way out from Afghanistan, the focus on the Afghanistan issue is on two subjects: the nature of government in Kabul and finding a channel for the huge humanitarian assistance which the international commurity has indicated will provide to the war ravaged Afghanistan after the Soviet troops withdrawal. There are no indications so far how these two issues are going to be tackled. The puppet government in Kabul considers itself as the legal govermment of Afghanistan and says it is ready to embrace what it calls the opposition within a coalition, a posture flatly rejected by the mujaheddin. The mujaheddin position has been that their jehad had actually begun against the Kabul atheist regime which had captured power at Soviet instigation in 1978 and it was a result of a naicional jehad for the toppling of this very government that the Russians invaded Afghanistan in 1979. Not only did they invade Afghanistan but the government which is now in power in Kabul was installed by the occupation forces. The Najib government is a successor of that very govermment. Therefore this government should also be dismantled along with the withdrawal of Soviet forces.

As regards the distribution of the economic assistance to the people of Afghanistan, one should say that, before tackling that problem, the situation should be made conducive for the five million refugees from neighbouring countries and another two million from the Afghan cities to return. The $r \in f u-$ gees are not going to return to the country until there is a peaceful atmosphere and a government of thej.r choice is installed. The Afghan mujaheddin have vowed not to stop war until they dismantle the Kabul puppet regime. Therefore, there is not going to be peace in Afghanistan in the immediate future and no refugees will retum. This vicious circle would only end if realisin and tactfulness is heeded. This realism and tactfulness will also lead to a just and honorable solution of the Afghanistan problem. The Russians 
have to come to the point to realize that the government instailed by them in Kabul is not supported by the overwhelming majority of the people of Afghanistan and this will not lead to a situation which the Kremlin is claining to be trying to achieve, i.e. a peaceful, independent and non-aligned Afghanistan, friendly to Moscow.

The mujaheddin have al.so to make some hard choices. They have either to seek a peaceful solution accepting some kind of compromise government or work a decisive strategy - - entailing the speedy fall of the Kabul regime with a minimun of casualties.

The kind of scenario projected by the UN mediator on fifghanistan Diego Cordovez in which various Afghin f'actions - - including the PUPA - - are to share power is not only not practical and will not lead to peace but is rejected by all other Afghan groups including the forces that are considered in the Afghan scene as "liberals." The very idea of a coalition with the communists - - those who are to the overwhelming majority of our people traitors - is not only repugnant to us, but such a government will not be practical as well.

The most urgent question in the mind of the Russians ought to be the emergence of a system in Afghanistan which will live with it in peace and harmony. If it tries to sustain a Marxist regime - no matter under what guise it contradicts the very claim it makes. For a communist regime will not be able to maintain peace in the country but it will further the Afghan antiRussian sentiments.

The Afghanistan mujaheddin, represented in the framework of the IUAM, had proposed a government comprised of the mujaheddin themselves, the Afghan refugees and the Afghan Muslims who now live inside the country. Although only recently the IUAM came out with a list of twelve cabinet members for its interim government, the Afghan nation expects it to really move fast and come out with a complete govermment list showing that it has broadened its bases. Although, according to a mujaheddin new plan, elections are to be held until mid-October to convene a council to also ratify the interim govermment, the fact is that this interim government has to be formed in its entirety and ought to be assigned with specific tasks. In case there is a peaceful solution of the remaining of the Afghanistan issue - - i.e. there is an agreement on the establishment of a mujaheddin supported government in Kabul - - this govern- 
ment ought to tackle four main issues: (1) maintain law and order; (2) pave the way for the return and repatriation of the refugees;(3) rebuild some of the essential infrastructure of the economy and(4) hold general elections to be held in a peaceful Afghanistan throughout the country and draft a constitution to be approved by the first elected parliament convened on the basis of a nation-wide elections in a peaceful Afghanistan. The mujaheddin proposed interim government, in addition to being closely associated with the commanders inside the country, ought to be very much in a position to tackle the immediate problems of economic revival of the country at least to the point of pre-1978.

The second scenario calls for a master military plan which will require coordination of all military forces of the mujaheddin. The biggest stumbling block in the implementation of an allout military plan, after the Soviet withdrawal and in case the mujaheddin are determined to embark upon a war of the cities, is the fear about civilian casualties. In order to minimize civilian casualties, the Kabul regime has to be dismantled both from the outside and from the within. Dismantling it from the outside would require coordinated, united and joint military action. And dimantling it from the within requires utmost resort to psychological warfare prompting the civilian population to also bring about the fall of the regime by any method, fall short of wasting innocent lives.

These are trying times for the Afghan nation. The socalled Geneva peace accord has proved to be no nore than a mockery, for through it the Russians are now been left free to achieve what they failed to get on the battle front: the establishment of a puppet regine in Kabul suceptible to Kremlin dictates. The Afghans are resolved not to allow the Russians to get away with this. But the Afghans, in order to undo and frustrate this Kremlin strategy, should do a lot of homework. We should move fast but prudently. We should not hestitate in implementing our plans just because it might deprive this or that interest from a share in the power. For as long as we are stead-fastly moving towards our ultimate goal - - the establishment of the government of God in Afghanistan - - we are safe.

In summary we should demonstrate clearly and in black and white terms that we have gone as far as Islam - - the religion of peace, justice and fairness - has allowed us to seek a peaceful and honorable settlement of the remaining of the Afghanistan issue. But if the other side does not heed, we have to inflict decisive blows to it to bring a fall of the regime at the earliest. 


\section{April-June, 1988

\section{Political Dimensions TOPPLING KABUL REGIME, RESETTLEMENT, TOP AFGHAN EVENTS Drive for Capturing Courtryside Accelerates}

After the signing of the Geneva accord 14 April, the pace of intemational developments in regard to solving another crucial aspect of the Afghanistan - - the formation of an interim government - - issue slowed down. The Russians began their troops pullout from Afghanistan 15 May as envisaged in the accord and the UN monitoring teams went to Afghanistan and Pakistan to observe primarily the troops withdrawal from Afghanistan and non-interference in the internal affairs of Afghonistan and Pakistan. The Russians officially made it known that they lost more than 13,500 of their men in the Afghan war since their invasion December 27, 1979. They had more than 35,000 injured and more than 300 un-accounted for. The Kremlin and its Kabul puppets launched an international drive to obtain the release of Russian prisoners with the mujaheddin. In doing so, the communists once again exhibited their 'true nature of chameleon by calling their soldiers with the mujaheddin "prisoners of war", a term which they in the past had purposefully avoided in referring to the mujaheddin since they do not consider the Afghan mujaheddin a party to a war but rather they call them "rebels".

As to where these prisoners are - - in Pakistan or inside Afghanistan - - was not known. The Russians have primarily appealed to Pakistan to obtain their release. The mujaheddin want to obtain several concessions before agreeing for their release: clearing of mines laid down by the coumunists; war reparation; the release of their men in Kabul jails; Soviet pledge to have the 15,000 or so Afghan children now studying in Russia return home, etc. One such deal was already made when for one Russian prisoner seven mujaheddin were exchanged in Kandahar in June. The Russians said they have obtained the release of 11 of them by the end of Jume.

The fussian pullout began from Afghanistan on time. There was an artificial atmosphere of fanfare on the day the withdrawal took place. The renegade comminists showered flowers on the departing invading forces who, according to them, had come to perform an internationalist duty. The Afghen mujaheddin, on the other hand also considered the event a great success because they had kneed down the enerny.

The mujaheddin still vowed to hit the Russians even at the time of their withdrawal. They demonstrated in action that they have nothing to do with the so called Geneva peace accords which, anong other things, anticipated a ceasefire in the country. The mujaheddin were not a party to the treaty and, therefore, they did not consider themselves bound to its provisions. The remarks made by the head of the UN monitoring team that the mujaheddin should refrain from attacking the departing Soviet troops was unheeded and treated by the resistance as yet another proof of the partiality of US mediators. 
Not only the mujaheddin did not refrain from attacking the departing Russian soldiers but their battles against both Kabul forces and Russian units sti]l stationed in different parts of Afghanistan, increased. The monitoring service of the CCAR has reported an unprecendent increase in comparison to January-March, this year in the number of war news since the signing of the Geneva agreement. The volune of military news in April-June jumped by $20 \%$. The mujaheddin constantly captured posts, sub-districts and towns and recovering large cache of arms and ammunition. The monitoring service of the CCAR reported that the mujaheddin captured between 21 March - 21 June, 32 subdivisions and, three sub-districts.

Another aspect of the Afghanistan issue still prominent in international scene was the issue of arms supply to the mujaheddin. The Kabul regime and Moscow both accused Pakistan of still allowing the mujaheddin to bring in arms to Afghanistan, which, according to the commuigts, was a clear violation of the Geneva agreements. It may be recalled that the question of arms supplies to the mujaheddin - - primarily by the US - - had at one point threatened the very signing of the Geneva agreement. While Kremlin insisted that, under its obligation to the Kabul govermment, it has to continue supplying military equipment to the regine, the mujaheddin, who to the communists are simply "rebels", should not be furnished with arms and equipment. The US, on the other hand, argued that the Kabul government was not the legal government of the Afghan people and it was the mujaheddin who had under their control more than $80 \%$ of the Afghan territory and, until the Russians continued arms supply to the Kabul regime, Washington will also ship arms to the mujaheddin. It was with a tacit understanding that both Washington and Moscow will continue their military supplies that the US finally agreed to sign the treaty as a guarantor.

The charges levelled by the Kabul regime against Pakistan for not adhering to the provisions of the Geneva accords and that Islamabad continued its interferences in the international affairs of Afghanistan also figured prominently in the news. As a matter of fact Kabul filed until $19 \mathrm{June}$ 30 protests or complaints - - almost one every day since the Geneva accords went into force 15 May - with the United Nations monitoring team in Kabul.

Pakistan, on the other hand, turned down the Kabul charges saying that the Afghan war against the Kabul regime was indigenous and stemmed from the determination of the people to topple the communist Kabul regime. Until the question of an interim govermment - entailing the replacement of the Najibullah regime - - was not settled, the war will continue, said Pakistan and, therefore, the Kabul regime should not use Pakistan as a scapegoat for.its misfortunes. The Pakistanis added, the UN monitoring teams have alrady visited several Afghan-Pakistan border check points and they found no indication to support the Kabul allegations.

But the most prominent aspect of the Afghan issue in the midst of Soviet troops withdrawal was the question of rehavilitation of the Afghan refugees and the revival of its economy. The UN Secretary General Perez de Cueller appointed Sadruddin Aga Khan, an old hand in refugee affairs, to head the world organization's efforts for creating a fund and then administering it for a rem covery program in Afghanistan. He visjted Pakistan and Afghanistan in May-June and then announced that his office - - United Nations Aids Coordination for Afghan Refugees (UNACAR) - - would need $\$ 1.16$ billion for this purpose and the UN then launched a fund raising drive.

But the question of helping Afghanistan to recover economically from the ravages of a devastating war obviously is very much related to political conditions in the country, and the 
fact whether the war will stop or continue after the Soviet withdrawal. As a matter of fact, the fate of the entire international program for the recovery of Afghanistan hinged on the future of a government in Afghanistan. The Russian insistence that the puppet regime in Kabul ought to stay will undoubtedly compel the mujaheddin to find a military solution to the remaining of the Afghan problem. How long will it take to bring about this fall pretty much depends on the existence of a coordinated mujaheddin strategy which could include bringing the entire mujaheddin f1ghting machinery under a single command or, at least, coordinating it to achieve an early downfall of the puppet regime. It would also entail the working out of a program to incite and mobilize the civilian Afghan popriation inside the cities to help in the destablization process of the Kabul regime. Once the mujaheddin conquer the remaining parts of the countryside - - a process that is gaining momentum as time passes - - the inevitable issue of launching war against the cities have to be tackled. How much lives are going to be sacrificed during such" war 'of the cities has been a source of concern for the mujaheddin for some time. Remember the times when the Russians in operations against the mujaheddin intentionally drove the Kabul army recruits in front lines so that (1) the mujaheddin will refrain from attacking their own compatriots or (2) if an attack came about, the Afghans would absorb the strongest blows leaving the Russians with lesser casualties? This strategy could very well be repeated by the Kabul communists once the war of the cities start. They might create conditions in which the mujaheddin would be forced to either kill the civilians or abandon their whole operation for the sake of not killing the civilians.

The mujaheddin are said to be already faced with such a test of choice in Jalalabad the center of the eastern province of Nangarhar from where the Russians are said to have pulled out.

What about a peaceful scenario? Are the Russians ready to provide in deeds - not in words - - that they want a peaceful, independent and non-aligned Afghanistan, an Afghanistan which will still hold amicable and workable relations with the Russians not because of any heart-felt love for them but because of a number of necessities and constraints? This will, anong other things, show to the world whether the Russians are sincere in their new policy towards so called Fegional issues or they are actually working out a new version for their traditional policy of expansion and domination.

In the scenario of finding a peaceful solution for the remaining of the Afghanistan issue, it seems as though the world is waiting for the UN mediator on Afghanistan Diego Cordovez to orice again lay out his magic carpet and find a solution to the question of an interim government. But Cordovez, who has lost the confidence of the Afghan mujaheddin, this time seemed to be not in a position - - as he was in inducing the parties to sign the Geneva accords - - to work out a coalition government which will include the communists as well, a solution already rejected by a wide spectrum of Afghans, except some isolated groups apparently thirsty for a share in the power. He started a visit to the region at the end of June and seemed to be trying new approaches to end the deadlock.

Cordovez lost the Afghan trust after he, at one point, has promised that any solution of the Afghan problem should entail (1) the withdrawal of Soviet troops from Afghanistan and (2) the formation of an interim government. As far back as a year, he had said: at present his principal function is "to promote a convergence of the process to setule the Afghanistan question, now being pursued on two tracts - - the Ceneva talks and the proposal for national reconciliation." He said, "there has to be some convergence, without which there will be no settlement" (see Afghan Jehad,june- 
August, 1987, p.10).

Therefore, his scenario - - or for that matter any other scenario of having the Afghan factions, including the communists, join a coalition - - is not acceptable to the majority of the Afghans. If there has to be a peaceful solution, it should be around the idea of an interim government based on the concept of excluding die-hard communists but one which will undertake good relations with Afghan neighbours including Russia. After what the Russians had done in Afghanistan they should be happy with a solution of this sort and halt activities which will further anroy and alienate the Afghans. Gorbachev - - claiming non-association with the Russ: an blunder in Afghanistan - - is in a. relatively better position to take such a course.

This whole explanation was necessary to impress how impossible will it be for the UN - - or any other agency. - - to implement a resettlement and reconstruction program in Afghanistan without first of all achieving peace. Peace in Afghanistan is not going to be just around the corner unless it is worked for. The mujaheddin have now the leverage to bring about the fall of the Kabul conmunist regime through military action, and therefore, the Kabul government will fall sooner or later.

The Mujaheddin's program is not only military, but, as they are determined to form the next govermment of the country, for some time they have been busy working out and issuing programs. The following are some of the pros and cons of these activities:

- - At present for only a period of three months a spokesman is selected from the leaders of the seven party alliance to head the alliance - - the IUAM. But they have not been able to create a permanently staffed secretariat and with each spokesman a group of aides come to the ecretariat from the organization of the spokesman and, then, after three months, another tean of staff takes over, something similar to a "spoil system." Permanent staff could evolve long term policies which is very crucial for the effectiveness of the very office of leadership.

- - The IUAM Supreme Council announced the establishment of an interim mujaheddin government headed by Ingineer Ahmad Shah 22 February this year. That govermment was actually formed and held its first session 18 April (see Al-Noor, 21 April, 1988). Ahmad Shah was to serve both as head of the State and head of government. With seven leaders, according to IUAM charter (see section on jehad documents) collectively symbolizing the head of the states on 19 June Ahmad Shah again annou nced names of 12 men who will serve in the portfolios of the ministries of Defense, Interior, Fore Ign Affairs, Finance, Resettlement and Reconstruction, Education, Agriculture and Cattle Raising, Scientific Research, Justice, Planning, Public Health, Guidance and Cilture.

- - The Charter issued by the IUAM 12 May has listed 21 portfolios (not including the head of the government and his deputies).

- - According to the original IUAM communique of 22 February, the formula worked out for an interim government had said that 14 portfolios will be allocated for the mujaheddin organizations, seven for the "refugees" and seven for the Muslims inside Afghanistan. That government had to have a 75 member council comprised of two individuals from each province adding up to 56 . One third of the members of this council, comprising of 19 persons, was to be from wise and pious scholars. The mujahoddin have said they will hold elections for such a council until mid-October.

- The IUAM Supreme Council had called on thi Council to work out an interim basic law for carrying forward the affairs of the country until the enforcement of a new basic law by an elected 
council.

- Provincial agencies were to be established to administer the provinces.

- - The communique had said that the "IUAM is determined to immediately establish a commission of reconstruction and invite all educated Afghans to apply (for positions) and to begin woik afterwards in the office..."

The mujaheddin are achieving miracles on the battle front. But they have to get on the ball in other fields as well.

What about the Kabul government? It is a maxim of politics that the majority is complacent and the minority organized and vocal. The majority thinks that because it is in the majority, it has all the time and the opportunity at its disposal and the minority is under the impression that the time is running short and hostile forces are intent to destroy it. But only the minorities that stand for just cause grow and prosper. However the Kabul government's mood was one of despair and helpless, helplessness to the extent that in order to win supporters, it once again did not hesitate to relapse to the past - - a past which, to communist progressivism, reactioniry and ro pugnant: resort to the loya jirgah - - a feudal institution - - reviving the Afghan name for the Wolesi Jirga (The House of the People in vogue during the "corrupt Zahir Shah's Constitutional Decade", 1963-73) for the lower house of the Parliament, bringing into the government names like Mohammad Hasan Sharq (the number two man in the government during the first twa years of the Deoud Presidency but known among all knowledgeable Afghans as the No.1 KCB Afghan), Dr. Abdul Fatah Najem (personal physician of King Zahir) Engineer Mohamad Ghofran (an American educated old hand in the Zahir Shah Ministry of Agriculture), Dost Mohammad Fazel (the Mayor of Kabul and, before that, President of the Food Procurement Department at the time of Zahir Shah), etc. The communists, for their own tactical purposes, also adopted a number of constitutional procedures of the time of Zahir Shah: Sharq presenting his members of the government and "pollcy statement" to the "House of the People"; the House debating the proposed govemment's policy statement and then passing to it a vote of confidence and Sharq and his cabinet being received by the Head of the State (Najib) in an audience and Najib signing decrees for the appotntment of the members of the new Goverment, and so it goes on..All these were aimed at creating an atmosphere of the past, a past to which the new generation of Afghans will not return, but the communists are resorting to it tactically and out of sheer despair.

But the Afghan people were not moved. There has been virtual freeze or standstill on the anticipated refugee return. The war has not only continued but intensified and the majority of the people of Afghanistan are at a count down, waiting the fall of the Najib regime. It may sound samcastic but that is how one finds best to give a roundup of events taking place on the other side. But, wait, Najib went to New York to address an empty General Assembly at the UN and face angry egg throwing Afghan demonstrators and an American demand that his plane could not be towed in US territory. He went to India all right to usher the support of the only non-communist country for his govermment. But the Indian stand on the whole Afghan issue has been so supportive of Russian agression and of help to sustain an illegitimate regime in Kabul that any New Delhi initiative to save the Najib regime only adds to the monentum for the downfall of the puppet regime. 


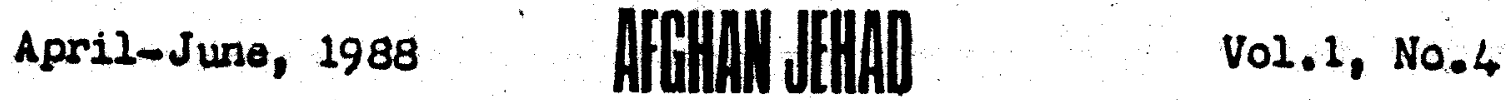

\section{Military Dimensions}

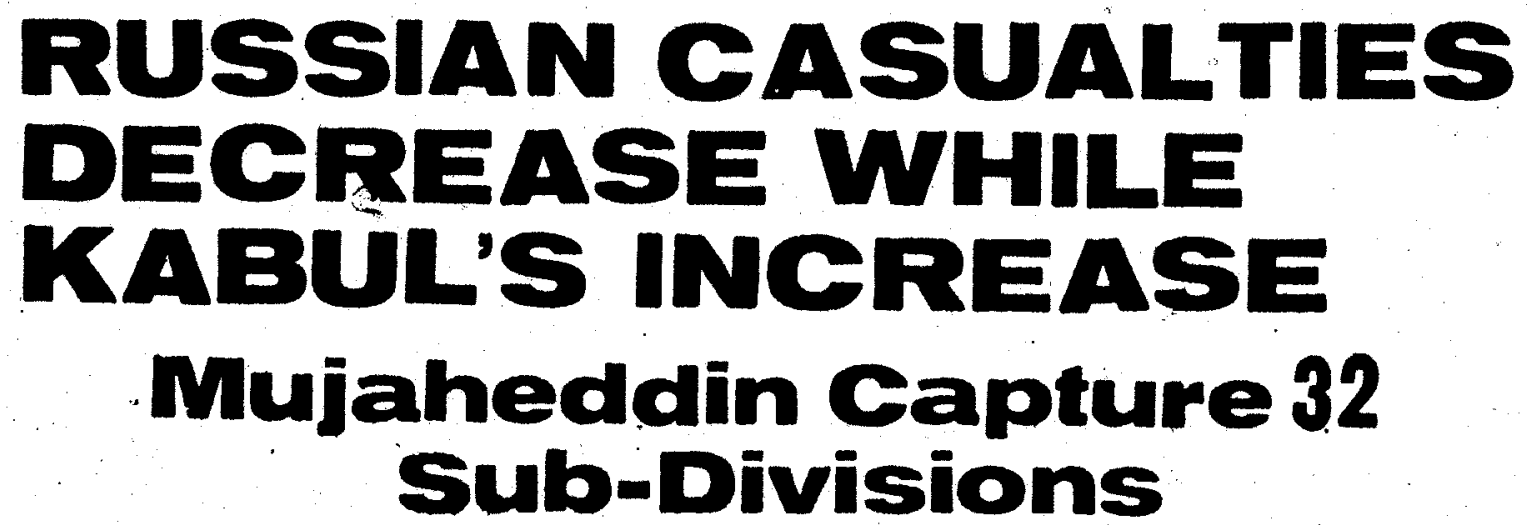

The war in Afghanistan intensified in the pest three months. The number of news published in this issue of the Afghan Jehad about military activities in Afghanistan was $20 \%$ more than the news published in January-March. According to the news monitored by the CCAR, the mujaheddin have made important headways and the Kabul regime army is retreating throughout the country.

War on the ground has, further intensified and there has been a marked drop in the air operations against the mujaheddin and civilian population targets.

During the past three months (April-June) the mujaheddin eliminated 1,573 enemy vehicles, , including tanks and armored cars. During the three months before this they had destroyed 773 such vehicles. However the number of planes downed during this period has dropped from 101 to 63.

While there has been a marked drop in the number of casualties among the Soriet soldiers, the number of casualties among the Kabul government soldiers and militia has increased. The Rus,slans, according the CCAR monitoring service, lost 294 of their men in the past three months while during January-Karch they had lost 1,090 men. The number of those killed from the Kabul side during April-June want up to 7,413 from 4,659 .

The reduction in Russian casualties is naturally related to their withdrawal from Afghanistan and the increase in the number of Kabul regime casualties is fodicative of the fact that they are becoming further involved in the war and the majaheddin have been escalating their offensive against the regime.

The mujaheddin casualties also have gone up during the past three months comparing them to the casualty figures of January-March. This time the figure for their killed is 813 while in January-March it was 438.

Also the number of civilians killed during this period increased. The figure has gone up Irom 615 in January-March to 848 in the previous three months.

The mujaheddin have captured during the past three months 3,593 items of arms while the Iigure for this in January-March was 2,257 and, on the other hand, the number of arms which the. Kabul regime claims to be recovering fram the mujaheddin has markedly decrease from 469 to onjy three.

In the number of villages destroyed by the enemy there has been on decrease. In January 
Harch 527 villages were reported bombed while in April-June it dropped to 226.

During January-March the communists had claimed to have demolished 108 mujaheddin bases or posts while during April-June they reported none.

\section{AREAS CAPTURED BY MUJAHEDUTN}

EDITOR'S NOTE: The following is a list of sub-districts (alaqadari), subdivisions (uluswali) which have fallen to the mujaheddin during the past three months.

(1) BADAKHSAHAN: Jurm sub-division; (2) BACHIAN: Andrab sub-division; (3) FARAH: Shorabak, Golestan and Khak-o-Safaid sub-divisions; (4) GHAZNI: Qarabagh, Ander, sub-divisịons; Giro subdistricts; (5) HETMAND, Sengin, Khan ShIn sub-divisions; (6) HERAT: Ghorion sub-division;(7) KUNAR: Berikote border cantonment; (8) NANGARHAR: Mogiani, Hesarak, Ma Ma thel sub-divisions; Sher Zad Madirpoor and Lalpur sub-districts; (9) NIMROZ: Khashroad, Charburjak sub-divisions; (10) PAKTIA: Tcamkan;, Jaj1, and Ahmadkhel sub-division; (11) PAKIIKA: Wazikhwa sub-divisions; (12) PARWAN: Gerd, Chorband, Panjsher and Bagram sub-divisions; (13) TAKHAR: Dasht-e-Qala and Khawaja Ghar subdivisions; (14) WARDAK: Tangi Wardak, Sayyedabad, sub-divisions;' (15) ZABUL: Kalat., including Atghar, a post in Shinkai and Darwazgai base. 


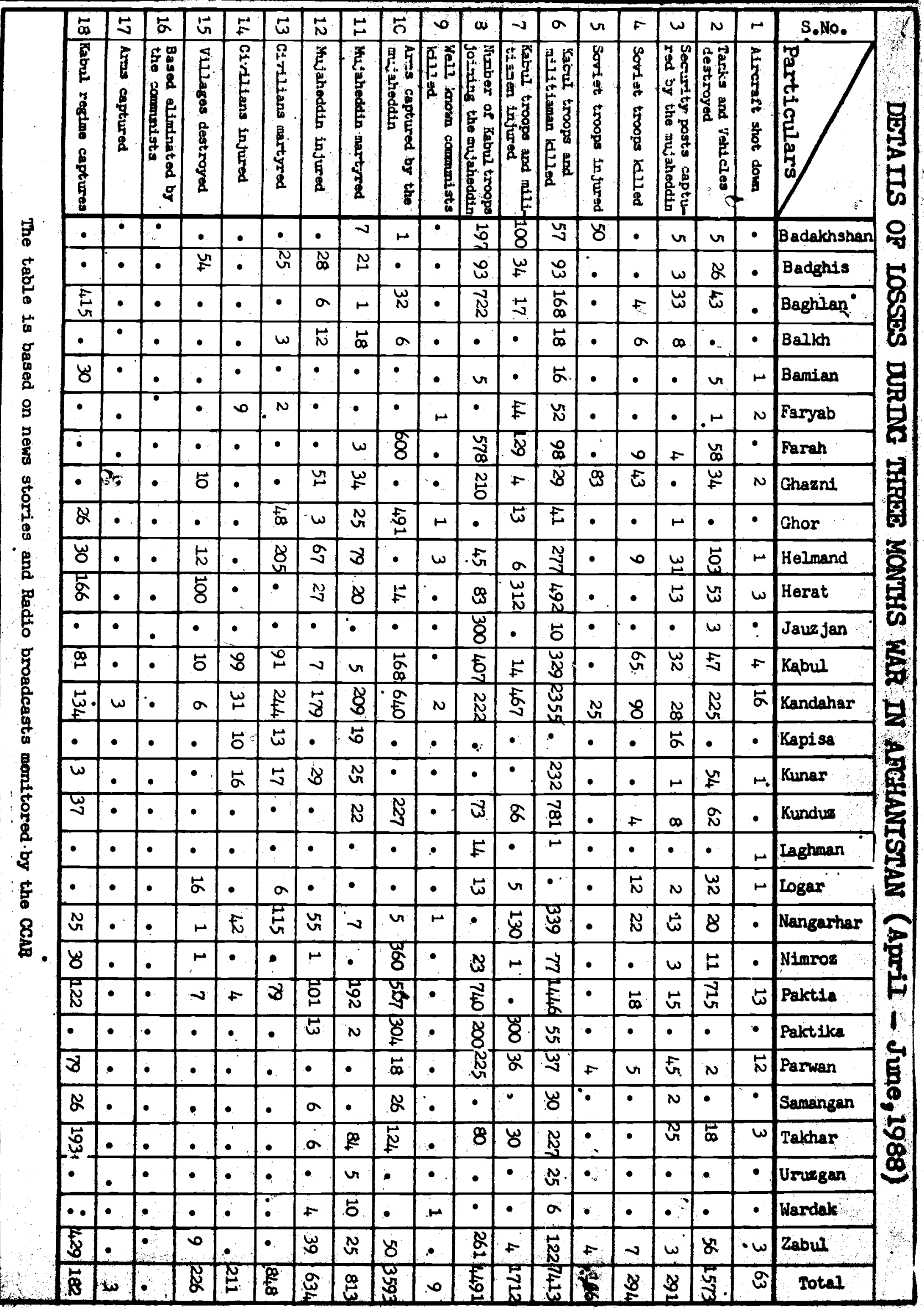




\section{April-June, 1988}

AFEHAN JHADD

$\mathrm{Vol}, 1, \mathrm{No} .4$

\section{AFGHANS AND GENEVA ACCORDS}

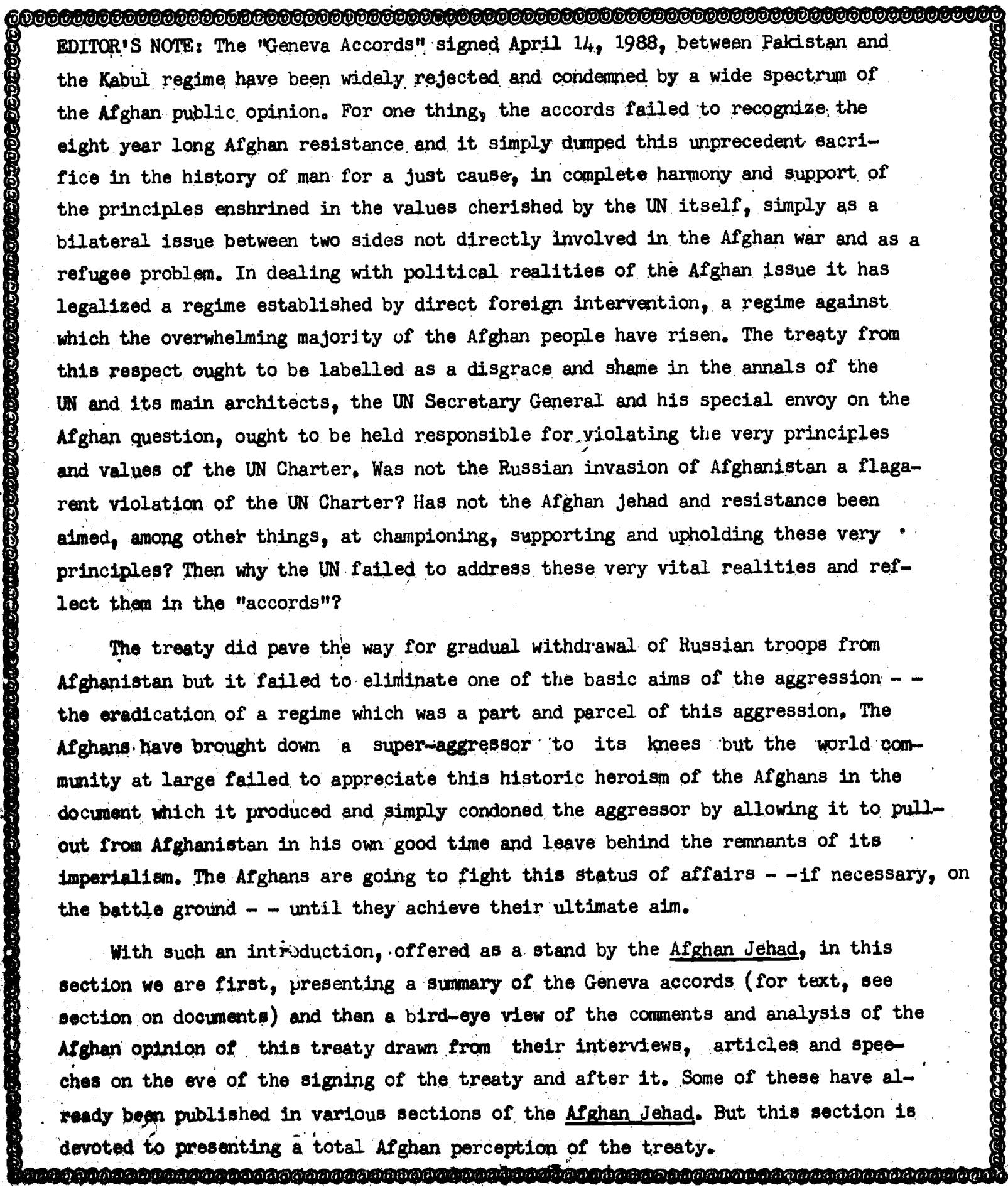




\section{THE FIRST ACCORD}

The first and foremost of the accord series is a bilateral agreement between the Kabul regime and Pakistan on the principles of mutual relations, in particular non-interference and non-intervention. According to this agreement, the two parties undertake:

- - To respect the sovereignty, political independence, territorial integrity, national unity, security and non-alignment of the other.

- - To refrain from threat or use of force in any form, whatsoever, so as not to violate the boundaries of each other, to disrupt the political, social or economic order of the other,

- - To ensure that its territory it not used in any manner which would violate the sovereignty, political independence, territorial integrity and national unity of the other.

- - To refrain from almed intervention, subversion and military occupation.

- - To prevent within its territory the training, equipping, financing and recruitmeht of mercenaries of whatever origin, for the purpose of hostile activities against the other.

- To abstain from any defamatory campalgn or hostile propaganda.

\section{THE STCOND ACCORD}

This is a bilateral Kabul regime-Pakistan accord and deals with the voluntary return of the Afghan refugees. Both countries have undertaken that:

- - All refugees shall be allowed to return in freedom to their homeland.

- - All returnees shall enjoy the free choice of domicile and freedom of movement.

- - All returmees shali enjoy the right to work and to adequate living conditions.

- All retumees shall enjoy the right to participate on an equal basis in the civic affairs of the Kabul regime.

- All returnees shall enjoy the same rights and priviliges including freedom of religion and have the same obligations as any other citizen of the Afghanistan.

- The Kabul regime undertakes to provide, within its possibilities, all necessary assistance to the process of repatriation.

- Pakistan shall facllitate the orderly and peaceful return of all Afghan refugees, staylng whin its territory.

- Joint commissions will be set up to organize and supervise the repatriation process.

- The Commissions shall determine frontier crossing points and establish necessary transit centres.

- - The U.N. HIgh Commissioner for Refugees shall provide assistance in the process of repatriation.

\section{THE THIRD ACCORD}

This is a guarantee signed by the Soviet Union and the USA which provides that the two countrios undertake: 
- - To refrain from any form of interference and intervention in the internal affairs of Afghanistan and Pakistan and to respect the commitments contained in the bilaterel agreement between the Kabul regime and Pakistan on the principles of mutual relations, in particular non-interference and non-intervention.

- - To urge all states to act like-wise.

\section{THE FOURTH ACCORD}

The four parties i.e. the USA, the USSR, the Kabul regime and state that:

- - In accordance with the time frame agreed upon between the USSR and the Kabul regime there will be a phased withdrawal of the foreign troops which will start on the date of entry into force mentioned above - - May 15, 1988.

- - Fifty percent of Soviet troops will be withdrawn by August 15, 1988, and the withdrawal of all troops will be completed within nine months.

\section{THE AFGHAN PERCEPTION}

* "Although Pakistan has ratified the Geneva accord on Afghanistan, its implementation will not be In the interest of jehad. As a result of the implementation of this accord, the jehad forces will shatter apart and the blood shed by hundreds of thousands of the martyrs will go idle. Leaders of the organizations should set aside their specific politicel considerations and should be more united than in the past and by virtue of their unity they should foil the heinous effects of Geneva accord (Mawlawi Jamil-ur-Rehman, leader of the Jama'at-e-Dawa-Al-Afghan, interview, 26 May 1988, VOAPS).

* "25 Saur, 1367 (15 May, 1988) which corresponds with. the implementation of the Geneva agreement on the withdrawal of Soviet forces from Afghanistan, is an important day in the history and unprecedented jehad of the Muslim and mujahed people of Afghanistan. This historic day, of course, symbolizes one of the phases of the righteous jehad of the people of Afghanistan in the path of defending their fafth, dignity and national rights (Interview of ex-King Mohammad Zahir Shah, 5 May 1988, VOADS).

* If the Russians puilout from Afghanistan, it is by the virtue of the bravery of the mujaheddin and it is a matter of pride for the whole nation that the Russians are withdrawing from our territory and they have admitted their defeat. Even in the past, forces which invaded Afghanistan, were defeated there (Noor Ahmad Muslim, Deputy 11th term of the Afghan Parliament, interview, BBCPS 17 May 1988).

* "Though the real parties to the Afghan problem - - the real representatives of the Afghan nation and the Soviet Union - - did not take part in the Geneva agreement, it is hoped that the accord has paved a way for the Soviet troops withdrawal from Afghanistan and, as a result, the complete independence, territorial integrity and the right of self determination of the people of Afghanistan will be restored".(Statement of former King Zahir Shah, 14 April, 1988, VOAPS).

* The Geneva accord is an unjust agreement and, in fact, it has done nothing for peace and about the painful catastrophe emerging out of the Soviet military invasion in Afghanistan. The most unJust and oppressive factor from my point of view is that, as the Afghan nation had the right of 
self determination, representative of the Afghan nation was not present at the accord

(Burhanuddin Rabbani, leader of the Janiat-u-Iolimi Mlyliuistur, interviuw, 16 April, 1988, VOAPS).

* "The agreement recently signed in Geneva cannot represent the people of Afghanistan because the people of Afghanistan have not been allowed to take part in the accord ( Dr. Moosa, Professor in the US, interview, 18 April, 1988, VOADS)。

* "Our Jehad had begun neither on the basis of Geneva talks nor it will end as a result of Geneva talks. Our Jehad had begun against the communists and, as long as the communists are in Afghanistan, our jehad will continue (Captain Muzaffaruddin, Commander of mujaheddin Brigade in Zabul interview, 18 April, 1988, VOAPS).

* "nsome speakers have also expressed optimism on the signing of the accorc. But what the Russians failed to achieve through war have now accomplished through the Geneva talks. By signing an agreement with the Kabul puppet regime, the government of Pakistan has in fact recognized the Kabul regime. Thus, the Kabul regine was assisted and boosted, while Pakistan pledged itself that it will not extend assistance to the freedom fighters from its territory (Mohammad Hasan Ulusmal, Editor of The Mulahed Ulus magazine, interview, 19 April, 1988, VOAPS).

* "The Geneva accor $\phi$ is not acceptable to us because it has not solved our problem. The real factor for the immigration and jehad had been the establishment of communist government in Afghanistan. As long as the communist govermment is in power in Afghanistan, neither the mujaheddin will evacuate their trenches nor the refugees would return to their country". (Teacher Khalil, Zakhel Camps,Peshawar, interview 19 April, 1988 VOAPS).

* The Geneva agreement is totally unjust and impracticable and it is not at all acceptable to the mujaheddin. The result of the accord will be that there will be more bloodshed in Afghanistan and more devastation would occur and war would continue" (Abdul Rahman Pazhwak, former Afghan diplomat, interview, 20 April, 1988, VOAPS).

* The main objective of the Geneva accord was the Soviet troops withdrawal from Afghanistan and this has been achieved and thus it is a useful agreement. Of course it is only a first step towards the settlement of Afghanistan problem. The main objective of the Geneva accords way to secure a Soviet troops pullout from Afghanistan and every body should support it. The Geneva accord includes the honorable and dignified return of the Afghan refugees to Afghanistan which is also not against us and it should be endorsed. It has been provided in the Geneva accords that both the super powers should guarantee the security of Afghanistan, which is also of importance. Geneva talks should have included ceasefire and the end of Kabul government and its replacement by a transitional govermment, but this was not included in it. The thing which is mostly criticized is that the mujaheddin were not represented in the Geneva talks" (Dr. Abdul Hakeen Tabibi, former Afghan diplomat, interview 24. April, 1988, VOAPS).

* "The Geneva accord is contrary to the provisions of the UN Charter which says the people should determine their own fate. What a shame and mockery is that talks are held and instruments signed about us and nobody asks us anything. Our jehad will continue until total withdrawal of the Soviet troops and the establishment of an Islamic goverment. (Statement by Dr. Farooq Azam, the Deputy leader of NIF, 27 April, 1988, VOAPS).

* Me have been refecting the Geneva talks stnce the very beginning Now the Geneva accord has been 
signed. With all the loopholes in the agreement, the accord should be welcomed because it is the only political means which provides for the Suviet troops to withdraw from Afghanistan. Restoration of our political independence and territorial integrity have been part of the many objectives of our Jehad (Dr. Mohammad Yousuf, Former Prime Minister, interview, 1 May, 1988, voAPS). * We had understood from the very beginning of the Geneva talks that the Soviets needed a face saving device to show to the people of the world that they had gone to Afgharistan legally and now. they want to create the impression that those reasons have been eliminated. Thus they are now ready to withdraw their troops Irun Af'ghanistan. There are no provisions in the Geneva accord to bring peace to Afghanistan and, as a matter of fact, with the implementation of these accords war would be further increased". (Mawlawi Jalaluddin Haqqani, Commander of Hezb-o-Islan - - Khales - in Paktia, interview, 6 May, 1988 VOAPS).

* The Geneva accord cen neither end war nor it can pave there way for the return of Afghan refugees to Afghanistan. The rejection of Geneva accord does not mean that we aim at continuing war in Afghanistan. We are interested in peace more than any one else but peace in dignity and a durable peace" (Gulbuddin Hekmatyar, leader of Hezb-e-Islami Afghanistan, interview 9 May, 1988 , VOAPS).

* The agreement between Pakistan and the Kabul regime, as a (mere) bilateral document, are meant to solve their present and future difficulties. It is based on the concept of providing security for Pakistan and for the continuation of the rule of present soviet client cormunist regime in Kabul. The agreement recognizes the Kabul government as a lawful government which has the right to sovereignty and represent the people and is entitled to respect.

"In. the agreement attempts have been made to secure this position for the Kabul regime by eliminating (the realities) of the jehad and calls for the return of refugees under the POPA rule. In the eyes of the agreement, the resistance of the Afghin feople against the Russian invasion and their migration to reighbouring countries is a crime worthy of condemnation and punishment. And the agreement promises graciousness on the part of Kabul regime by saying that, after their return, the refugees will be granted amesty and they will be pardoned.

( Dr. Afghan - - psuedo name - - in Pamphlet, The Geneva Accords, October, 1987).

"In Islam there is no place for peace with apostates" .. Our Jehad has a three pronged special objective: (1) unconditional withdrawal of Russian troops from Afghanistan, (2) the toppling of the present Communist government and (3) establishment of an independent Islamic, government .. - After the withdrawal of Russian forces it is within the jurisdiction of the mujaheddin as to what form of government they are going to establish . . (Judge Mohammad Amin Waqad, the leader of the Afghanistan Mujaheddin Islamic Unity Movement, in interview with Neda-o-Sangar; 17 Aprịl 1988.

* "Both the imperial1st super powers alongwith their lackeys, embarrassed from the triumph of freedom loving Islamic revolutions, have joined hands to impose their plans on our mujahed nation" (The Qest journal, March-April; 1988).

* "The Geneva accord has been worked out by aljens and it is rejected by us from outset. Wo do. not accord any respect and adherence to that agreement and its consequences" (Prof. Abd Rasool Sayyaf, leader of the Islamic Unity of Afghanistan in the Qest journal March-April, 1988) 
* The tidings blessed today to the Muslims of Afghanistan is that the Soviet Union, considered to be a super power, is shivering and is admitting its defeat and is soon to withdraw from Afghanistan (Prof. Sebginatullah Mojaddedi, leader of NLF in The Qest journal, March-April, 1988).

* We have resolutely rejected the Geneva accord and we do so because forces which symbolize Afghanistan (mujaheddin) have not been allowed to participate in Geneva talks. On the contrary, the atheist government which came on Soviet tanks was recognized as the representative of Afghanistan. These are international conspiracies aimed at doing away with Islam in Afghanistan and, therefore, we do not accept the accord. (Mawlawi Mohammad Yunus Khales, leader of Hezb-o-Islami Afghanistan in The Qest journal, March-April 1988).

* "Sovlet behaviour shows that it does not want to solve the Afghanistan issue. Ore of the main draw-backs of the Geneva talks from the very beginning has been that these did not take place between the real parties of the dispute - - the Afghan mujahoddin and the Russians. Instead the talks were held between secondary parties - - the Soviet installed govemment in Kabul and Pakistan. Iranian refusal to take part in the talks was based on principle and was logical. The agreenent is not a durable solution and is not capable of ending the war in Afghanistan. It cannot pave the way for the voluntary return of the Afghan refugees to their country and it will not result in changing the Soviet-backed govemment in Kabul. Signing of Geneva accord is a previlige given to the Soviets by the Pakistan government and the US (Editorial Ittehad-e-Islami journal, 14 May, 1988 ). * "The accord signed in Geneva will not be able to restore peace in Afghanistan. There is no guarantee that it will be implemented inside Afghanistan. The Geneva talks were rejected and condemned as far back as six years ago by the mujaheddin." (The Rah-e-Islam magazine, 16 April 1988). * "The Afghan mujahed nation has from the very beginning condemned the Geneva talks. We condemn it again and continue our holy Jehad because the accord is between the US and the Soviet Union and the Afghan mujahed nation has nothing to do with it. We condemn imperialist tactics (The Ekhlas journal, 17 April, 1988).

* We expect and ask you not to link your future with the Geneva talks and its decisions. Instead you should put your trust and future on continuing jehad. (Higineer Ahmad Shah, President of the. mujaheddins interim government in Ittehad-o-Islami joumal).

* We do not trust the Geneva talks and we do not consider ourselves bound to the decisions of these talks. The war has been between the mujaheddin and the Russians but the talks were held between Pakistan government and the conscienceless Afghan fommunists. These talks were unnatural and illegal and did not represent the real will of the Afghan people. The people of Afghanistan are themselves capable of discharging their affairs and they do not need any advocate (Ayatulah Mohseni in message to Paris conference published in The Payam-e-fehad, April 1988). * nonly those who have signed the Geneva accord are bound to it and the difficulty facing the Russians and their puppets, too, lie in it. (Wahid Mozhds in Shahadat, 10 April, 1988).

"Any treaty which does not result in the fall of comminist goverment in Kabul and does not establish the mujaheddin sovereignty wlll not be implementable in the country and, other than going through the trouble of signing on a piece of paper and wasting the Ink, the Geneva accord will not bear any other result and naturally the signing of this treaty will further complicate the Pakisten difficulties. With the intensification of war, the number of refugees in Pakis- 
$\tan$ will increase further and, with a communist govermment in Kabul still in power, no refugees will return to Afghanistan (Neda-e-Sanyar Journal, 17 April, 1988)

"A treaty which contradicts itself and illustrates the foolishness of the super powers. Although some people of the world congratulate each other, the mujaheddin consider this treaty as another catastrophe ... However, it is an evil in which, God willing, lies our good. Although they have described the Russians withdrawal from Afghanistan as the miracle of the 20th Century because it is the first time the Russians in the history of their invasions have been defeated and are withdrawing and that too at the hands of an oppressed and poor nation, the day is not far that the second miracle of the 20th century may also take.place when the international collus ion in Geneva vis-a-vis this holy Jehad witl be reduced to a mere blackening of the paper and in the midst of this Russian defeat, Americans will also be defeated.

We have nothing to worry about this agreement because we know that this jehad of ours is the divine light which cannot be extinguishẻd. However what makes us unhappy is that how is it that the Muslim nations do not have their own free will and power and are tools in the hands of others? (Moharmad Yaser, in Ittehad- - -Islami, 19 April, 1988).

Because both super powers have been left free to send military assistance to the bellegerents and such a course of events will result in further fanning the civil war in Afghanistan and, the signing of Geneva accord and withdrawal of alien troops are good steps but we should exert efforts to find a way for an overall solution to the Afghanistan issue. The issue of the Soviet troops withdrawal from Afghanistan is one aspect of the solution of Afghanistan and its second aspect is the formation of a broadbased interim governnent in place of the present government in Kabul ... (In case a broad based goverrment is not formed in Kabul) the Geneva agreement will lose its nature and importance and, floods of refugees will once more come to neighbouring countries and will double, multi-dimensional wars will ensue. There will be one war among the (Mujaheddin) organizations and another war between the (mujaheddin) organizations and Kabul government but the worst of them all will be a war due to linguistic, ethnical, religious and regional differences (Zalmai Zwan, Afghan Mellat, 17 April, 1988).

" I do not say that a deal has been made on the blood and souls of the Muslims but what I say is that Islam was sold, the Quran was sold, the religion of Mohammad, the Prophet of God, was sold, the Islamic revolution was sold, the tears of the widows and the orphans were sold and the hopes and aspirations of the Muslim world were shattered into pieces ... I say that why General Mohammad Ziaul Haq the President of Pakistan closed his syes on everything? Why did he not honor his words and promises when he was saying the Afghanistan mujaheddin are defending Islam and Pakistan and helping them is our obligatio.'" (Mawlawi Nasmullah Mansoor, leader of the Harkat-o-Enqelab-eIslami Afghanistan, Neda-e-Haq, 22 May, 1988) 


\section{MAJOR DOCUMENTS;}

TEXT OF CHARTER FOR MUJAHEDDIN TRANSITIONAL GOVERNMENT

TEXT OF GENEVA ACCORD

IUAY AND THE GENEVA ACCORDS

MUJAHEDDIN OFFER GENERAL AMNESTY

IUAY PRESIDENT URGES TRIAL FOR PDPA HICH BRASS

BIOGRAFHIES OF IUAM TRANISTIONAL CABINET

BIGORAPHIES OF IUAM IEADERS

CHARTERS OF IUAM ORGANIZATIONS

ANNUAL REPORT OF AMNESTY INTERRATIONAL ON AFGHANISTAN 


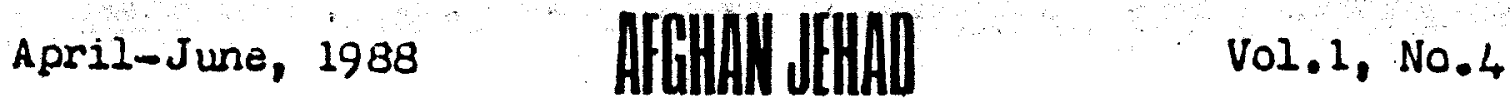

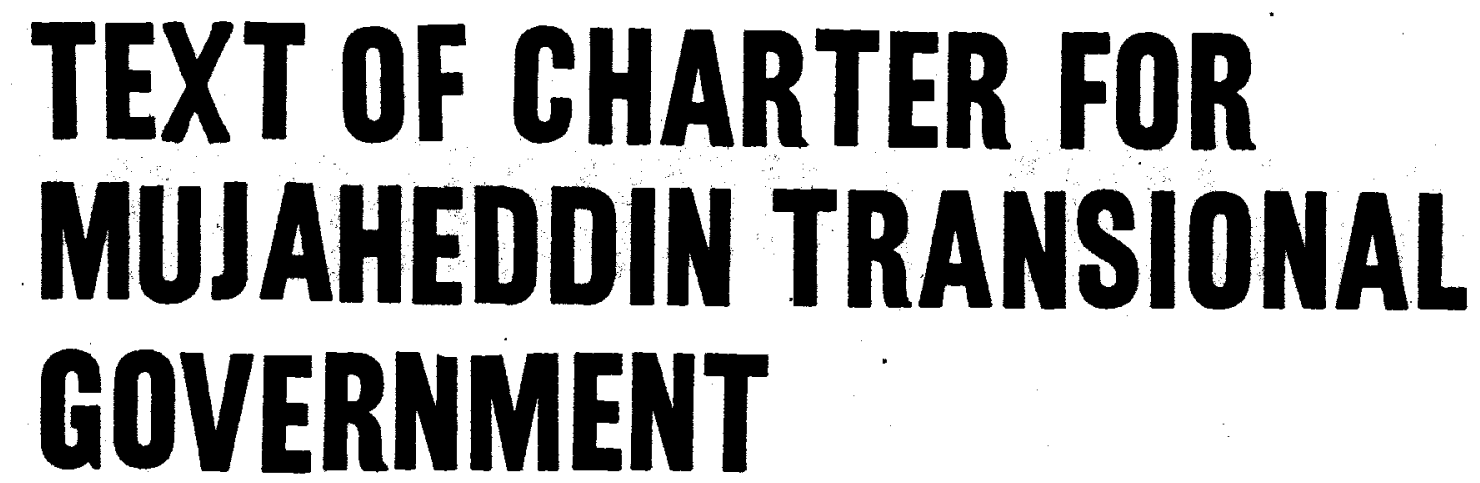

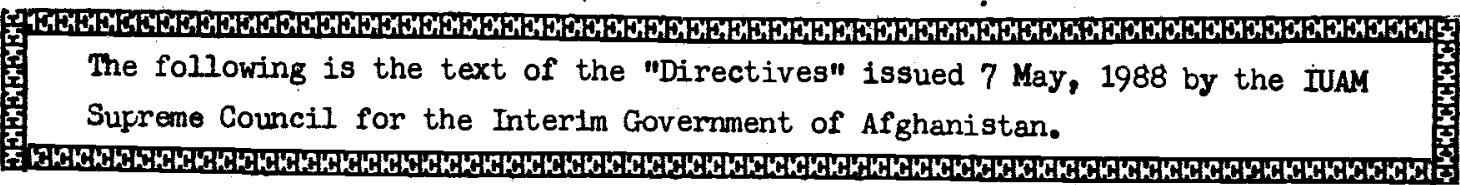

IN THE NAME OF GOD, MOST GRACIOUS, MOST MERCIFUL. CHAPTER ONE OBJECTIVES

Article I. Establishment of an Islamic Order in accordance with the Qur'anic verse: And those who strive in our (cause), - - We will certainly guide them to our paths: For verily God is with those who do right.

Article II. The administration and running of the country's affairs based on the Islamic Sharia' injunctions within the scope of Hanafi Jurisprudence.

Article III. Continuation of armed struggle until the complete, prompt and unconditional withdrawal of Soviet forces from Afghanistan, the overthrow of the puppet regime and establishment of an independent, free and Islamic Afghanistan,

Article IV. Defense of the territorial integrity and safeguarding the political independence of the country.

Article V. Establishing and maintaining public security and the transfer of power to the elected governnient.

Article VI. Dissemination of Islamic Da'wa (invitation to islam).

Article VII. Resettlement of refugees and looking after the families of martyrs and the handicaps of the Jehad.

Article VIII. Reconstruction of Afghanistan.

Article IX. Holding elections for the establishment. of an elected Council and government.

Article $X_{0} \quad$ Establisnment of administrative units in the country based on the principle of centralization.

Article XI. Defense of the nation's interest and representation of Afghanistan in the international assemblies.

\section{CHAPTER TWO LEADERSHIP COUNCIL}

Article XII. The Leadership Council is comprised of (the) heads of the Seven-Party Islamic Unity of Afghan Mujaheddin (IUAM) and those who are admitted to this Council with the 
unanimous consent of the party leaders.

\section{POWERS OF THE LEADERSHIP COUNCIL.}

Article XIII. Safeguarding the gains of the Islamic Jehad and fine scrutiny in the implementation of injunctions of the sacred religion of Islam in accordance with the Hanafi Jurieprudence.

Article XIV. Supervision of the entire State organs.

Article XV. Supreme command of the Armed Forces.

Article XVI. Declaration of the State War, peace and ceasefire

Article XVII. Appointment of thie head of the government and approval of his government.

Article XVIII Withdrawal of confidence in the head of goverment and his cabinet.

Article XIX. Approval of the policy statement of the government.

Article $\mathrm{XX}$. Questioning and interrogating of the cabinet.

Article XXI. Appointing and dismissing of the judges.

Article XXII. Approving important contracts and international treaties.

Article XXIII. Granting amnesty or commuting punishment according to the provisions of the Islamic Sharia'.

Article XXIV. Approval of the appointment of country's ambassadors abroad.

Article XXV. Acceptance and rejection of credentials of foreign ambassadors and representatives.

Article XXVI. The Leadership Council of the IUAM as whole is equivalent to the Transitionel Islamic State of Afghanistap.

Article XXVII. Decisions of the Leadership Council with regards to ordinary issues are adopted with majority vote whereas vital issues are decided unanimously. To identify importantissues a two third majority is required.

\section{CHAPTER THREE GOVERNMENT}

Article XXVIII The government is comprised of the head of government, deputy head of government, ministries and related departments.

\section{POWERS AND DUTIES OF THE GOVERNMENT}

Article XXIx. Proposing the internal organizational forms of the ministries.

Article $\mathrm{XXX}$. Proposing the regulations and powers of the ministries and (other) respective departments.

Article $x 0 \times 1$. Approving the internal regulations of the government of fices,

Article XXXII. Proposing the ordinary and developmental budget of the state.

Article XXXIII.Implementing the decisions of the Leadership Council.

article XXXIV. Enforcing and implementation the infunction of Islamic Sharia'.

Article $600 \mathrm{~V}$. Implementing the ordinary as well as development schemes. 
Article XXXVI. Enfoining what is right (according to Islamis Sharia') and forbidding what is wrong . (according to the Islamic Sharia').

Article XXXVII. Drafting the Constitution and the election laws and other laws in accordance with the Islamic Sharia'.

Article XXXIX.Adopting Islamic measures with regards to the entire illegal conduct of the nonIslamic government (s) of the past in relation to public and private properties.

Article XXXIX. Drafting plans for reconstruction of the country.

Article XIn Looking after affairs of the refugees and their resettlement.

Article XII. Looking after the afflicted of the Jehad.

Article XIII. Preparing educational curriculum for the Afghan education and implementating it.

Article yIII. Taking necessary measures in the execution of the final decisions of the courts.

Article XIIV. Members of the government, during their tenure of office in the cabinet, cannot be employed in other state enterprises, institutions and private companies. Educational and scientific research matters are excluded.

Article XIV. Members of the government are collectively responsible for the general policies of the government and individually responsible to the head of government and to the Leadership Council.

Article XLII. The rights and duties of the government employees and other workers are to be regulated by law.

\section{POWERS AND DLTIES OF THE HEAD OF GOVERMMENT}

The head of the government, in addition to the duties and powers referred to in Chapter three under the title of "Fowers and Duties of the Government", has the following specific duties:

Article XIVII. Signing of the cabinet decisions.

Article XIIIX. Signing of the intemational contracts and treaties on government level.

Article XLIX. Proposing the appointment and dismissal of cabinet members for approval to the Leadership Council.

Article L. Employing and appointing of government employees and functionaries within the framework of law.

Article II. The head of the interim government is responsible before the Leadership Council.

Article LII.' The Deputy Head(s) of governrent assists the head of govermment in all of his duties and powers and is answerable before the Leadership Council.

THE DOMESTIC AND FOREIGN POLTCY OF THE GOVERNMENT

Article IIII. a) DOMESTIC POIICY: The continuation of armed struggle until the total and unconditional withdrawal of Bussian troops from Afghanistan and the establishment of Islamic order based on the Hanafi Jurisprudence.

Article IIV. Dissemination of Islamic Dawa in the country. 
Article LV. Appointment of persons on the basis of piety and in accordance with their experience and erudition.

Article LVI. Prevention of difference stemming from immermissible religious, ethnic, linguistic national and organizational prejudices.

Article LVII. Serious efforts for broadening the sphere of Islamic teaching's and education.

Article IIIX. Developing moral virtues and combating corruption and evil, observing the principles of vei. (parda), ensuring the inalineable rights of all individuals, men and women alike, in the light of Islamic injunctions and the provision of a dignified status of life for all the people.

\section{FOREIGN POLTCY}

Article LIX. Protecting the territorial integrity, independence and non-alignment of Afghanistan in military pacts.

Article IX. Full observance of the tenets of the sacred religion of Islam in all national and international relations, commitments and dealings.

Article IXI. Allout effort towards achieving international peace and security.

Article LXII. The Muslim nation of Afghanistan is a part of the Islamic Ummah and cannot remain indifferent to the issues of the Islamic World.

Article LXIIV. Strengthening of brotherly relations with nations, organizations, Islamic parties, institutions and with the governments of the Islamic countries supporting the Jehad in Afghanistan.

Article LXIV. The government has the duty to bring home to those Islamic countries their responsibilities, who have been antagonizing the Jehad in Afghanistan.

Article IXV. The government relations with the non-Islamic countries supporting our Jehad will be normal and fair, taking into account their position vis-a-vis the international issues and the Muslim Ummah.

Article LXVI. The State will always have free Islamic judgment in the face of all national and international problems.

Article IXVII. Boycotting participation in all forums which would be damaging to the prestige of Islamic causes at an international level.

Article IXIIX. Encouraging friendly countries to participate in the reconstruction of Afghanistan and foregoing conditional assistance.

Article LXIX. The government shall render support to the Islamic cause of the subjugated and oppressed Muslims in all parts of the world.

Article ixx. Afghanistan, on the basis of its regard for the principle of concept of universality of Islamic principles and broadmindedness and achieving universal peace, shall establish reciprocal relations, wthin the framework of Islamic norms, whth all countries which desire friendly relations with Afghanlstan. :

Article LroI. The government, on the basis of its Islamic policy, shall support the rights of all 
oppressed and subjugated peoples and will exert efforts for the eradication of colonialism and exploitation.

Article LXXII. The government considers the liberation of Al-Quds one of its Islamic objectives and shall exert in this regard (all) possible efforts.

\section{THE CABINET}

Article LXXIII. The Cabinet is composed of the head (of the government), three deputies and - ministers of the following ministries:

1. Ministry of Justice, 2. Ministry of Interior, 3. Ministry of Agriculture and Cattlo-Raising, 4. Ministry of Education, 5. Ministry of Public Works, .6. Ministry of Water and Power, 7. Ministry of Auqaf and Accountability, 8. Ministry of Defense, 9. Ministiry of Da'wat and Guidance, 10. Ministry of Communications, 11. Ministry of Higher Education, 12. Ministry of Resettlement and Reconstruction, 13. Ministry of Planning, 14. Ministry of Scientific Research, 15. Ministry of Foreign Affairs, 16. Ministry of Public Health, 17. Ministry of Commerce, 18. Ministry of Mines and Industries, 19. Ministry of Finance, 20. Ministry of Transportation, 21. Ministry of Gas and Petroliym.

\section{CHAPTER FOUR GENERAL ORDERS}

Article LXXIV. The only source and resort of all laws and regulations are the sacred Sharia' of Islam.

Article LXXV. The right of determining the destiny of the Afghan nation rests with the Muslim people of Afghanistan.

Article LXXVI. The entire population of Afghanistan is totally free to enjoy their legal legitimate rights.

Article LXXVII. Making use of illegal means, even for achieving a noble cause, is impermitted.

Article LXXIIX. Those who return to the fold of Islam and are repentant of their past deeds and signs of repentance and amendment are observed in their conduct, shall be pardoned in accordance with the injunctions of Sharia'.

Article LXXIX. The city of Kabul is the capital of Afghanistan.

Article Ixox. To the government an administrative unit is the province. The number, area, components and organization of a province will be regulated by law.

Article IXXXI. The flag of the interim State of Afghanistan, is a white piece of cloth the length of which is the double of its width. The insignia of the State is composed of two ears of wheat and two swords in a semi-circular form. In the middle of the semi-circle is an alter and the Holy Quran is placed at the top of the alter. "Bismillah-her Rahman-ner Rahim (In the name of God, Most Gracious, Most Merciful) and Allah-u-Akbar (God is Great), between which are rays of the sun, form the upper part of the insignia.

Article LroxilI. The Judiciary is one of the independent organs of the state. The mode of its organ- 
ization and jurisdiction shall be regulated by law.

Article IroxuV. The Leadership Council and the interim government shall be dissolved after the approval of the Constitution, completion of elections and creation of the elected Coumcil and govermment.

Article LOOXV. Amendments in these interim directives will take place on the unanimous decision of the members of the Leadership Council.

Article wroxi. The text of an oath (for assuming office) is included as an appendix to these directives.

Article LOOXVII. These directives are in four chapters and eimhty-seven articles and are enforced after their official declaration.

\section{TEXT OF GENEVA AGREEMENT ON AFGHANISTAN}

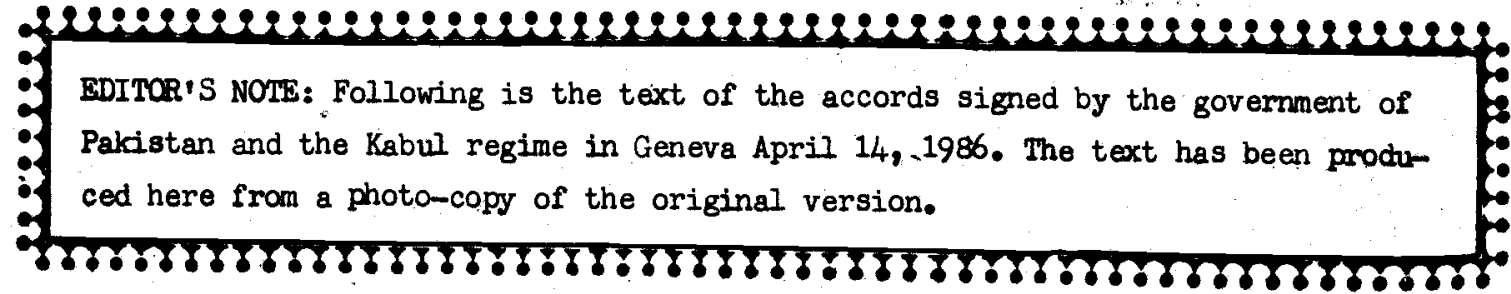

BIIATERAL AGREEMENT BETWEEN THE REPUBIIC OF AFGHANISTAN AND THE ISLAMIC REPUBLIC OF PAKISTAN ON THE PRTNCIPIES OF MUTUAL RELATIONS,

IN PARTICULAR ON NON-INTERFERENCE AND NONTNTERVENTION

The Republic of Afghanistan and the Islamic Republic of Pakistan, hereinafter referred to as the High Contracting Parties,

Desiring to normalize relations and promote good-neighbourliness and cooperation as well as to strengthen international peace and security in the region,

Considering that full observance of the principle of noninterference and nonintervention in the internal and external affairs of States is of the greatest importance for the maintenance of internationsl peace and security and for the fulfilment of the purposes and principles of the Chartar of the United Nations,

Reaffirming the inalienable right of States freely to determine their own political, economic, cultural and social systiem in accordance with the will of their peoples, without outside intervention, interference, subversion, coercion or threat in any form whatsoever,

Mindful of the provisions of the Charter of the United Nations as well as the resolutions 
adopted by the United Nations on the principle of noninterference and nonintervention, in particular the Declaration on Frinciples of International Law concerning Friendly Relations and Cooperation among States in accordence with the Charter of the United Nations, of 24 October 1970, as well as the Declaration on the Inadmissibility of Intervention and Interference in the Internal Affairs of States, of 9 December 1981,

Have agreed as follows:

\section{Article I}

Relations between the High Contracting Parties shall be conducted in strict compliance with the principle of noninterference and nonintervention by States in the affairs of other States.

\section{Article II}

For the purpose of implementing the principle of noninterference and nonintervention each High Cuntracting Party undertakes to comply with the following obligations:

(1) to respect the sovereignty, political independence, territorial integrity, national unity, security and nonalignment of the other High Contracting Party, as well as the national identity and cultural heritage of its people;

(2) to respect the sovereign and inalienable right of the other High Contracting Party freely to determine its ow pulitical, economic, cultural and social systems, to develop its international relations and to exercise permanent sovereignty over its natural resources, in accordance with the will of its people, and without outside intervention, interference, subversion, coercion or threat in dry form whatsoever;

(3) to rafrain from the threat or use of force in any form whatsoever so as not to violate the boundaries of each other, to disrupt the political, social or economic order of the other High Contracting Party, to overthrow or change the political system of the oth High Contracting Party or its Government, or to cause tension between the High Contracting Parties;

(4) to ensure that its territory is not used in any manner which would violate the sovereignty, political independence, territorial integrity and national unity or, disrupt the political, economic and social stability of the other High Contracting Party;

(5) to refrain from armed intervention, subversion, military occupation or any other form of intervention and interference, overt or covert, directed at the other High Contracting Partý, or any act of military, political or economic interference in the internal affairs of the other High Contracting Party, including acts of reprisal involving the use of force;

(6) to refrain from ary action or attempt in whatever form or under whatever pretext to destabilize or to undermine the stability of the other High Contracting Party or any of its institutions;

(7) to refrain from the promotion, encouragement or support, direct or indirect, of rebellious or secessionist activities against the other High Contracting Party, under any pretext whatsoever, or from any other action which seeks to disrupt the unity or to under - 
mine or subvert the political order of the other High Contracting Party;

(8) to prevent within its territory the training, equipping, financing and recruitment of mercenaries from whatever origin for the purpose of hostile activities against the other High Contracting Party, or the sending of such mercenaries into the territory of the other High Contracting Party and accordingly to deny facilities, including financing for the training, equipping and transit of such mercenartes;

(9) to refrain from making any agreements or arrangements with other States designed to intervene or interfere in the internal and external affairs of the other High Contracting Party;

(10) to abstain from any defamatory campaign, vilification or hostile propaganda for the purpose of intervening or interfering in the internal affairs of the other High Contracting Party;

(11) to prevent any assiatance to or use of or tolerance of terrorlst groups, saboteurs or subversive agents against the other High Contracting Party;

(12) to prevent within its territory the presence, harbouring, in camps and bases or otherwise, organizing, training, financing, equipping and arming of individuals and political, ethnte and any other groups for the purpose of creating subversion, disorder or unrest in the territory of the other High Contracting Party and accordingly also to prevent the use of mass media and the transportation of arms, ammunition and equipment by such individuals and groups.

(13) not to resort to or to allow any other action that could be considered as interference or intervention.

\section{Article III}

The present Agreement shall enter into force on 15 May 1988.

\section{Article IV}

Any steps that may be required in order to enable the High Contracting Parties to comply with the provisions of Article II of this Agreement shall be completed by the date on which this Agreement enters into force.

\section{Article V}

This Agreement is drawn up in the English, Pashtu and Urdu languages, all texts being equally authentic. In case of any divergence of interpretation, the English text shall prevail.

Done in five original copies at Geneva this fourteenth day of April 1988.

(Signed by Afghanistan and Pakistan).

\section{DECLARATION ON INTERNATIONAL GUARANTEES}

The Govermments of the Union of Soviet Socialist Republics and of the United States of America. Expressing support that the Republic of Afghanistan and the Islamic Republic of Pakistan have concluded a negotiated political settlement designed to normalize relations and promote good-neigh- 
bourlines between the two countries as well as to strengthen international peace and securlty in the region:

Wishing in turn to contribute to the achievement of the objectives that the Republic of Afghan istan and the Islamic Republic of Pakistan haye set themselves, and with a view to ensuring respect for their sovereignty, independence, teritorial integrity and non-alignment:

Undertake to invariably refrain from any form of interference and intervention in the internal affairs of the Republic of Afghanistan and the Islamic Repulic of Pakistan and to respect the cammitments contained in the the bilateral Agreement between the Republic of Afghanistan and the Islamic Republic of Pakistan on the Principles of Mutual Relations, in Particular on Nan-Interference and Non-Intervention:

Urge all States to act likewise.

The present declaration shall enter into force from May 15, 1988.

For the Government $\quad$ For the Government

of the Union of Soviet. of the United States of

Socialist Republics Anteriad

\section{BILATERAL AGPEEMENT BETWEEW: ME RETLBLIC OF AFGHANISTAN}

AND THE ISLAMIC REPUBIIC OF PAKISTAN ON THE VOLUNTARY RETURN OF FEFUGEES

(EDITOR'S NOTE: In the Pashtu official text provided by the UN the word refugees has been translated "nomads" an evasive term used by Kabul communists aimed at denying the existance of refugees).

The Republic of Afghanistan and the Islamic Republic of Pakistan, hereinafter referred to as the High Contracting Parties,

Desiring to nomalize relations and promote good-neighbourliness and co-operation as well as to strengthen international peace and security in the region,

Convinced that voluntary and unimpeded repatriation constitutes the most appropriate solution for the problem of Afghan refugees present in the Islamic Republic of Pakistan and having ascertained that the arrangements for the return of the Afghen refugees are satisfactory to them,

Have agreed as follows:

\section{Article I}

All Afghan refugees temporarily present in the territory of the Is latiic Republic of Pakistan shall be given the opportunity to return voluntarily to their homeland in accordance with the arrangements and conditions set out in the present Agreement.

\section{Article II}

The Govermment of the Republic of Afghanistan shall take all necessary measures to ensure the following conditions for the voluntary return of Afghan refugees to their homeland:

(a) All refugees shall be allowed to return in freedom to their homeland;

(b) All returnees shall enjoy the free choice of domicile and freedom of movement within the 
Republic of Afghanistan;

(c) All returnees shall enjoy the right to work, to adequate living conditions and to share in the welfare of the State;

(d) All. returnees shall enjoy the right to participate on an equal basis in the civic affairs of the Republic of Afghanistan. They shall be ensured equal benefits from the solution of the land question on the basis of the Land and Water Reform;

(e) All returnees shall enjoy the same rights and privileges, includ ng freedom of religion, and have the same obligations and responsibilities as any other citizens of the Republic of Afghanistan without discrimination.

The Goverment of the Republic of Afghanistan undertakes to implement these measures and to provide, within its possibilities, all necessary assistance in the process of repatriation.

Article III

The Government of the Islamic Republic of Pakistan shall facilitate the voluntary, orderly and peaceful repatriation of all Afghan refugees staying within its territory and undertakes to provide, within its possibilities, all necessary assistance in the process of repatriation.

\section{Article IV}

For the purpose of organising, coordinating and supervising the operations which should effect the voluntary, orderly and peaceful repatriation of Afghan refugees, there shall be set up mixed commissions in accordance with the established international practice. For the performance of their functions the members of the comissions and their staff shall be accorded the necessary facilities and have access to the relevant areas within the territories of the High Contracting Parties.

\section{Article V}

With a viow to the orderly movement of the returnees, the commissions shail determine frontier crossing points and establish necessary transit centres. They shall also establish all other modelities for the phased return of refugees, including registration and communication to the country of return of the names of refugees who express the wish to return.

At the request of the Governments concerned, the United Nations High Comnissioner for refugees will cooperate and provide assistance in the process of voluntary repatriation of refugees in accon dance with the present Agreement. Special agreements may be concluded for this purpose between UHHCR and the High Contracting Parties.

\section{Articie VII}

The Present Agreement shall enter into force on 15 May 1988. At that time the mixed commissions provided in Article IV shall be established and the operations for the voluntary return of refugees under this Agreement shall comence.

The arrangements set out in Articles IV and $V$ above shall remain in effect for a period of eighteen months. After that period the High Contracting Parties shall review the results of the repatriation and, if necessary, consider any further arrangenents that may be called for. 


\section{Article VIII}

This Agreement is drawn up in the English, Pashtu, and Urdu languages, all texts being equally authentic. In case of any divergence of interpretation, the English text shall prevail.

Done in five original copies at Geneva this fourteenth day of April, 1988.

\section{AGREEMENT ON THE INTERRELATIONSH IPS FOR THE SETTLEMENT OF THE SITUATION RELATING TO AFGHANISTAN}

1. The diplomatic process initiated by the Secretary-General of the United Nations with the support of all Governments concerned and aimed at achieving, through negotiations, a political settlement of the situation relating to Afghanistan has been successfully brought to an end.

2. Having agreed to work towards a comprehensive settlement designed to resolve the various issues involved and to establish a framework for good-neighbourliness and comopation, the Govelament of the Republic of Afghanistan and the Government of the Islamic Republic of Pakistan entered Into negotiations through the intermediary of the Personal Representative of the Secretary-General at Geneva from 16 to 24 June 1982. Following consultations held by the Personal Representative in Islamabad, Kabul and Teheran from 21 January to 7 February 1983, the negotiations continued at Geneve from 11 to 22 April and from 12 to 24 June 1983. The Personal Representative again visited the area for high level discussions from 3 to 15 April 1984. It was then agreed to change the for mat of the regotiations and, in pursuance thereof, proximity talks through the intermediary of the Personal Representative were held at Geneva from 24 to 30 August 1984 . Another visit to the area by the Personal Representative from 25 to 31 May 1985 preceded further rounds of proximity talks held at Geneve from 20 to 25 June, from 27 to 30 August and from 16 to 19 December 1985 . The Personel Representative paid an additional visit to the area from 8 to 18 March 1986 for consultations. The final round of negotiations began as proximity talks at Geneva on 5 May 1986, was suspended on $23 \mathrm{Kay}$ 1986, and was resumed from $31 \mathrm{July}$ to 8 August 1986. The Personal Representative visited the area from 20 November to 3 Decenber 1986 for further consultations and the talks at Geneva were reoumed again from 25 February to $9 \mathrm{March} \mathrm{1987}$, and from 7 to 11 September 1987. The Personal Representative again visited the area from 18 January to 9 Febmary 1988 and the talks resumed at Geneva from 2 March to 8 April 1988. The format of the negotiations was changed on 14 April 1988, when the instruments comprising the settlement were finalized, and, accordingly, direct talks were held at that stage. The Govermment of the Islamic Republic of Iran was kept informed of the prom gress of the negotiations throughout the diplomatic process.

3. The Government of the Republic of Afghanistan and the Govermment of the Islamic Republic of Pakistan took part in the negotiations with the expressed conviction that they were acting tn accordance with their rights and obligations under the Charter of the United Nations and agreed that the political settlement should be based on the following principles of international law:

* The principle that States shall refrain in their international relations from the threat or use of force against the territorial integrity or political independence of any State, or in any other manner inconsistent with the purposes of the United Nations;

* The principle that States shall settle their international disputes by peaceful means in such a manner that international pace and security and justice are not endangered; 
* The duty not to intervene in matters within the domestic jurisdiction of any State, in accordance with the Charter of the United Nations;

* The duty of States to cooperate with one another in accordance with the Charter of the United Nations;

* The principle of equal rights and self-determination of peoples;

* The principle of sovereign equality of States;

* The principle that States shall fulfil ingood faith the obligations assumed by them in accordance with the Charter of the United Nations.

The two Governments further affirmed the right of the Afghan refugees to return to their homeland in a voluntary and unimpeded manner.

4. The following instruments were concluded on this date as component parts of the political settlement:

A Bilateral Agreement between the Republic of Afghanistan and the Islamic Republic of Pakistan on the Principles of Mutual Relations, in particular on Non-interference and Non-intervention;

A Declaration on International Guarantees by the Union of Soviet Socialist Republics and the United States of America;

A Bilateral Agreement between the Republic of Afghanistan and the Islamic Republic of Pakistan on the Voluntary Return of Refugees;

The present Agreement on the Interrelationships for the Settlement of the Situation Relating to Afghanistan.

5. The Bilateral Agreement on the Frinciples of Mutual Relations, in particular on Non-interference and Non-intervention; the Declaration on International Guarantees; the Bilateral Agrecment on the Voluntary Return of Kerugees; and the present Agleement on the Interrelationships for the Settlement of the Situation Relating to Afghanistan will enter into force on 15 May 1988. In accordance with the timeframe agreed upon between the Union of Soviet Socialist Republics and the Republic of Afghanistan there will be a phased withdrawal of the foreign troops which will start on the date of entry into force mentioned above. One half of the troops will be withdrawn by 15 August 1988 and the withdrawal all troops will be completed within nine months.

6. The interelationships in paragraph 5 above have been agreed upon in order to achieve effectively the purpose of the political settlement, namely, that as from 15 May 1988, there will be no interferene and intervention in any form in the affairs of the Parties; the intemational guarantees will be in operation; the voluntary return of the refugees to their homeland will start and be completed within the timeframe specifjed in the agreement on the voluntary return of the refugees; and the phased withdrawal of the foreign troops will start and be completed within the timefrane envisaged in paragraph 5. It is therefore essential that all the obligations deriving from the instruments concluded as component parts of the settlement be strictly fulfilled and that all the steps required to ensure full compliance with all the provisions of the instruments be completed in good faith.

7. To consider alleged violations and to work out prompt and mutually satisfactory solutions to questicins that may arise in the implementation of the instruments comprising the settlement re- 
fresentatives of the Republic of Afghanistan and the Islamic Republic of Pakistan shail meet whenever required.

A representative of the Secretary-General of the United Nations shall lend his good offices to the Parties and in that context he will assist in the organization of the meetings and participate in them. He may submit to the parties for their consideration and approvalisuggestions and reconmendations for prompt, faithful and complete observance of the provisions of the instruments.

In order to enable him to fulfil his tasks, the representative shall be assisted by such personnel under his authority as required. On his (stet) own finitiative, or at the request of any of the Parties, the personnel (stet) shall investigate any possible violations of any of the provisions of the instruments and prepare a report thereon. For that purpose, the representative and his personnel shall receive all the necessary comoperation frcm the Parties, including all freedom of movement within their respective territories required for effective investigation. Any report submitted by the representative to the two Governments shall be considered in a meeting of the Parties no later than forty-eight hours after it has been submitted.

The modalities and fogistical arrangements for the work of the representetive and the persorm nal under his authority as agreed upon with the parties are set out in the Memorandum of Understanding which is annexed to and is part of this Agreement.

8. The present instrument will be registered with the Secretary-Genergl of the United Nations. It has been examined by the representatives of the parties to the bilateral apreements and of the States-Guarantors, who have signified their consent with its provisions. The representatives of the Parties, being duly authorized thereto by their respective Governnents, have affixed their signatures hereunder. The Secretary-General of the United Nations present.

Dane, at Geneva, this fourteenth day of April 1988, in five original copies each in the Bas11sh, Pashtu, Russian and Urdu languages, all being equally authentic. In case of any dispute rogarding the interpretation the Inglish text shall prevail.:

$$
\text { (Sigried by Afghanistan and Pakistan) }
$$

In witness thereof, the representatives of the States-Guarantors affixed their oignatures hereunder:

(Stgned by the USSR and USA).

\section{ANNEX}

\section{MEMORANDUM OF UNDERSTANDING}

\section{Basic $r \in q u i r e n e n t s$}

(a) The Parties will provide full support and co-operation to the Representative of the Secretary-General and to all the personnel assigned to assist him;

(b) The Representative of the Secretary-General and his personnel will be accorded every facility as well as prompt and effective assistance, including freedom of movement and communication, accomodation, transportation and other facilities that may be necessary for the performance of their tasks. Afghanistan and Pakistan undertake to grant to the Representative and his staff 
all the relevant privileges and immunities provided for by the Convention on the Privileges and Immunities of the United Nations.

(c) Afghanistan and Fakistan will be responsible for the safety of the Representative of the Secretary-General and his personnel while operating in their respective countries.

(d) In performing their functions, the Representative of the Secretary-General and his staff will act with complete impartiality. The Representative of the Secretary-General and his personnel must not interfere in the internal affairs of Afghanistan and Pakistan and, in this context, cannot be used to secure advantages for any of the Parties concerned.

II. Mandate

The mandate for the implementation-zssistance arrangements envisaged in paragraph 7 derives from the instruments comprising the settlement. All the staff assigned to the Representative of the Secretary-General will accordingly be carefully briefed on the relevant provisions of the instruments and on the procedures that will be used to ascertain violations thereof.

III. Modus operandi and personnel organization.

The Secretary-General will appoint a senior military officer as Deputy to the Representative, who will be stationed in the area, as head of two small headquarters units, one in Kabul and the other in Islamabad, each comprising five military officers, drawn from existing United Nations operations, and a small civiliar auxiliary staff.

The Deputy to the Representative of the Secretary-General will act on behalf of the Representative and be in contact with the Parties through the Liaison officer each Party will designate for this purpose.

The two headquarters units will be organized into two Inspection Teams to ascertain on the ground any violation of the instruments comprising the settlement. Wheriever considered necessary by the Representative of the Secretary-General or his Deputy, up to 40 additional military officers (some 10 additional Inspection Teams) will be redeployed from existing operations within the shortest possible time (normally around 48 hours).

The nationalities of all the Officers will be determined in consultation with the Parties.

Whenever necessary the Representative of the Secretary-General, who will periodically visit the area for consultations with the parties and to review the work of his personnel, will also assign to the area members of his own Office and other civilian personnel from the United Nations Secretariat as may be needed. His Deputy will altemate between the two headquarters units and will remain at all times in close communication with him.

IV. Procedure

(a) Inspections conducted at the request of the parties

(i) A complaint regarding a violation of the instruments of the settlement lodged by any of the parties should be submitted in writing, in the English language, to the respected headquarters unit and should indicate all relevant information and details.

(ii) Upon receipt of a complaint the Deputy to the Representative of the Secretary-General will immediately inform the other party of the complaint and undertake an investigation 
by making onmite inspections, gathering testimony and using any other procedure which he may deem necessary for the investigation of the alleged vlolation. Such inspection will be conducted using headquarters staff as referred to above, unless the Deputy Representative of the Secretary-General considers that additional teams are needed. In that case, the parties will, under the principle of freedom of movement, allow immediate access of the additional personnel to their respective territories.

(iii) Reports on investigations will be prepared in English and subritted by the Deputy Representative of the Secretary-Generai to the two Governments, on a confidential basis. (A third copy of the Report will be simultaneously transmitted, on a confidential basis, to United Nations Headquarters in New York, exclusively for the information of the SecretaryGeneral and his Representative.) In accordance with paragraph 7 a report an an investigation should be considered in a meeting of the parties not later than 48 hours after it has been submitted. The Deputy Representative of the Secretary-General will, in the absence of the kepresentative, lend his good offices to the parties and in that cantext he will assist in the organization of the meetings and participate in them. In the context of those meetings the Deputy Representative of the Secretary-General may submit to the parties for their consideration and approval suggestions and recommendations for the prompt, faithful and complete observance of the provisions of the instriments. (Such suggestions and recommendations will be, as a matter of course, consulted with, and cleared by, the Representative of the Secretary-General.).

(b) Inspections conducted on the initiative of the Deputy Representative of the Secretary-General.

In addition to inspections requested by the Parties, the Deputy Representative of the Secrotary-General may carry out on his own initiative and in consultation with the Representative inspections he deems appropriate for the purpose of the implementation of paragraph 7. If it is considered that the conclusions reached in an inspection justify a report to the parties, the same procedure used in submitting reports in connection with inspections carried out at the request of the Perties will be followed.

\section{LEVEL OF PARTICIPATION IN MEET RIGS}

As indicated above, the Deputy Representative of the Secretary-General will participate at meetings of the parties convened for the purpose of considering reports on violations. Should the parties decide to meet for the purpose outlined in paragraph 7 at a high political level, the Representative of the Secretary-General will personally attend such meetings.

v. Duration

The Deputy to the Representative of the Secretary-Ceneral and the other personnel will be established in the area not later than twienty days before the entry into force of the instruments. The arrangements will cease to exist two months after the conpletion of ail timeframes envisaged for the implementation of the instruments,

\section{Financing}

The cost of ail facilities and services to be provided by the parties will be borne by the respective Governments. The salaries and travel expenses of the personnel to and from the area, as well as the costs of the local personnel assigned to the headquarters units, will be defrayed by the United Nations. 


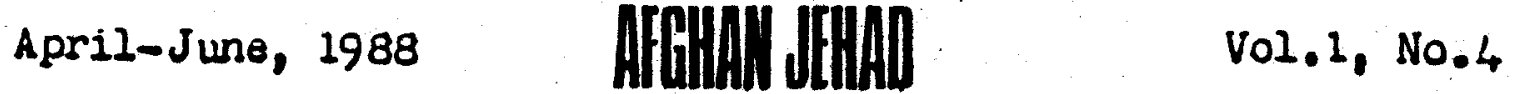

\section{IUAM Condemns Geneva Accords}

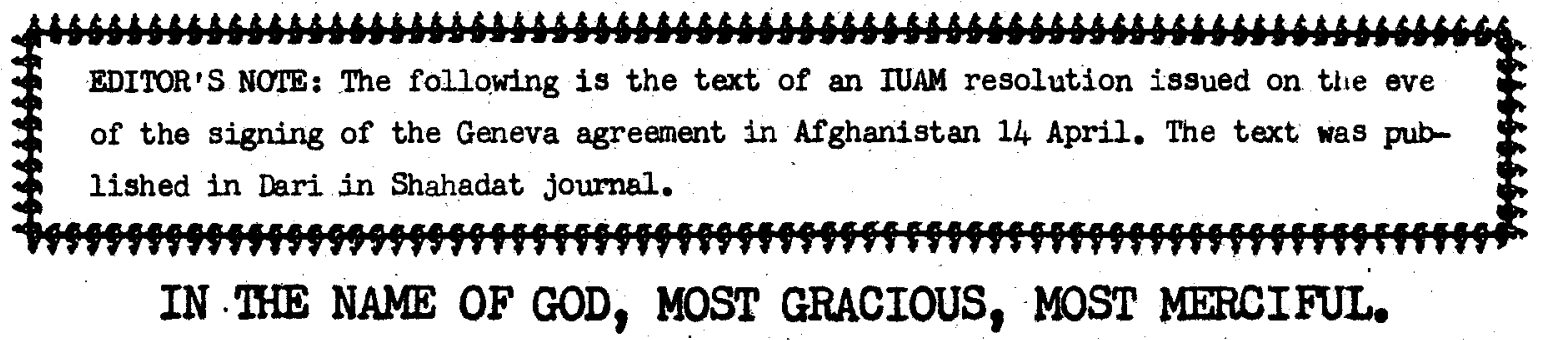

Verily God will defend (from ill) those who believe; Varily God loves not any that is a traitor to faith, or shows ingratitude (The Holy Quran).

In the Geneva talks which has now concluded, the parties at the talks, in the absence of Afghan nation and without the consent of this oppressed nation, are to sign such an agreement which cannot bring about conditions to end the war, restore peace and pave the way for the voluntary return of the five million Afghan Muslim refugees to their country: Representing their Muslim nation, the Afghan mujaheddin have already opposed the present iorm of the talks and have described them as unjust.

The mujaheddin are not bound to such agreement because: (a) our true Muslim nation did not participate in these talks; (b) UN resolitions stressing the right of self determination of nations has ot been heeded in the agreement. It coes not guarantee the right of the Afghan people to dem termine their fate without foreign pressure or threat, (c) In the Geneva talks the repeated resolum tions of the UN General Assembly which assigned the UN Secretary General to work for an immediate and equitable solution of the righan problem based on an understanding wth all the parties in the dispute have not been heeded. Because, since the very beginning no contact has been established with the Afghen mujaheddin who are one of the two real parties in the problem a decision has been made in their absence: (d) in these talks, contrary to the important un resolutions calling for inmediate and unconditional Sovi troops withdrawal, a nine months timotable has been accepted for the withdrawal, (e) instead of securing a Russian pledge not to interfere in the intermal affairs of Afghanistan in the future, and simultaneously with their troops pullout, the Russians should bring to an end the mercenary government, which was coercively imposed on the Afghan Muslim nation through Rusgian tanks and troops, they want that the puppet Najib regime remain intact in power and an agreement is signed on non-intervention sigmed between the Pakistan government and the puppet Najib regime; (f) the real objective of the Soviet invasion of Afghanistan was to once again impose under threat the atheist communist regime of Khalqis on the Muslim nation of Afghanistan. This regime was about to fall as a result of the resistance and jehad by the Nuslim people. Now the Geneva accord is giving to the Russians what they could not accomplish during the eight years of war. So why there should be a need for the presence of Soviet troope in Afghanistan? As such, so long as the Soviet puppet regime in Kabul, an outcome of the Soviet invasion of Afghanistan, is not toppled, it means that soviet direct armed intervention has not ended. This oppressive and 
unjust accord is in no way acceptable to the Afghan Muslim nation. We will continue our armed resistance and jehad until all Soviet troops are unconditionally withdrawan from Afghanistan and an Islamic government is established in Afghanistan in place of the Soviet installed atheist govermment in Kabul. We have waged jehad for discharging a religious duty trusting in the might of Almighty God and we consider his help sufficient for us. Even if the entire world leaves us alone, by the help of Almighty God, we will continue our course and jehad until we establish an independent and free Islamic govermment in Afghanistan. God Almighty says, "Ary one who puts his trust in God, sufficient is (God) for him" and orders the Muslims "And fight them on until there is no more tummult or oppression and there prevail justice and faith in Cod":

Although the Russians are satisfied as a result of the decision in the Geneva accord with the survival of their puppet regime and extended large scale military assistance for the survival of this regime, all these will fall to. the mujaheddin by the grace of God and the mujaheddin will topple this atheist regime.

In Afghanistan, staired with the blood of the martyres, only the inherants of the aspirations of martyres - - the mujaheddin - - can rule. Therefore the IUAM has established the transitional govermment and has decided to announce this govermment in one of the liberated areas in Afghanistan. This government will by the grace of God.soon take up the affairs of the country and elections will be held under its supervision and an elected Islamic govermment will be installed.

\section{MUJAHEDDIN OFFER GENENRAL AMNESTY}

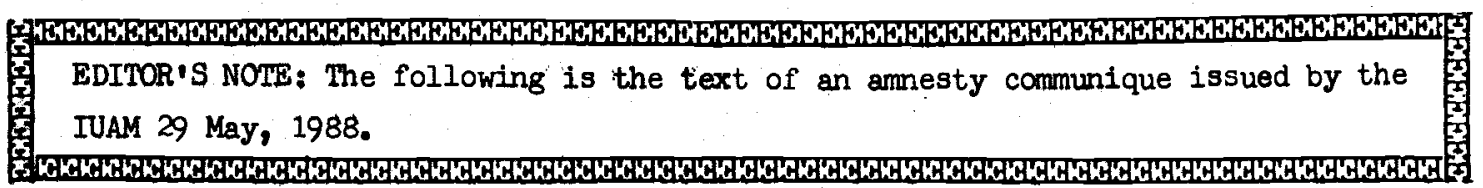

A large number of soldiers and officers of the army of the Najib govermment and the security forces and the socalled guardians of the revolution have joined the mujaheddin ranks and they have warmly been welcomed by the mujaheddin. But it is once again announced that, according to the directives listed in the general amnesty communique, those who regret their past (deeds) and repent and take refugee in the mujaheddin fronts within one month after the evacuation of their regions. by the Soviet troops, their lives and property will be safe and they will not be subjected to trial for their pest deeds and they will not be harmed and even their transferable or contransferrable property acquired from the Russians or their puppet govermment will not be confiscated provided other peoples' right have not been usurped. Those who have obtained arms and ammunition from the Russians and the mercenary regime for their self defense and were dragged to war against their well, will not be disarmed after their joining the mujaheddin. All the mujaheddin are duty bound to accept the returnee groups and persons keeping in view the aforesaid guarantees, and make all arrangements for their safety and security.

The communtque is repeated so that repentants are not harmed and the mujaneddin exert all efforts for their safety. 


\section{April-June, 1988}

\section{AFHAA UWHAD}

Vol.1. No.4

\section{IUAM PRESIDENT URGES TRIAL FOR PDPA HIGH} BRASS

The following is the directives issued by the IUAM President to the Judicial Board for the trial of the members of the Communists Central Committee including Najib. The text has been translated into English from Pashtu text published in the Shahadat journal.

\section{IN THE NAME OF GOD, MOST GRACIOUS, MOST MERCIFUL.}

The esteemed Judicial Board of the IUAM: Whereas the Russians have now understood that it was a blunder to despatch troops to Afghanistan, they have signed the Geneva accord for the pullout of their troops from our country. Undoubtedly the Najib puppet regime will also not be able to survive after the Soviet troops pullout. This hated regime cannos resist the brave mujaheddin without the Russian forces. A decision under the Shariat should right now be taken about those who have been fighting side by side the alien forces against the nation throughout the last 10 years and have stained their hands with the blood of 1.3 million martyrs and are responsible for the sorroful tragedy of the country. Although we have announced amnesty and have given assurance to all those who repent and once again join the nation, there are undoubtedly some who have committed so many crimes and their hands are so much stained with the blood of so many people that they have clo sed all the doors for a return to the lap of the nation. However as the IUAM President, I want a verdict based on Shariat about such criminals.

From my point of view, all members of the PDPA's Central Committee, including Najib, should be tried in absentia right now and shariat verdict about them should be announced to the entire nation, so that after a complete Soviet troops withdrawal from Afghanistan. These criminals may be dealt with in accordance with the shariat requirements. The ordinary people who were deceived and induced by these criminals, to act as enemies of the nation, should be granted general amnesty and should not be harmed. I also consider it appropriate that you should announce to the nation that from now on the exchange of Sovlet POW's should be avoided and these POW's should be kept until Soviet troops are withdrawn from Afghanistan, the Najib government is toppled and an Islamic government is established so that, by exchanging these Soviet POW's. we may get hold of those criminals who must be tried but have fled the country and sought refugee in Russia. It is hoped that you will soon announce your verdict on the issue in accordance with the Islamic Shariat. With regards,

Engineer Hekmatyar, President of the IUAM 


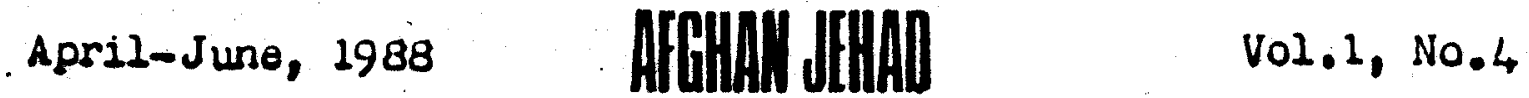

\section{Biographies of IUAM Ministers For Interim Government}

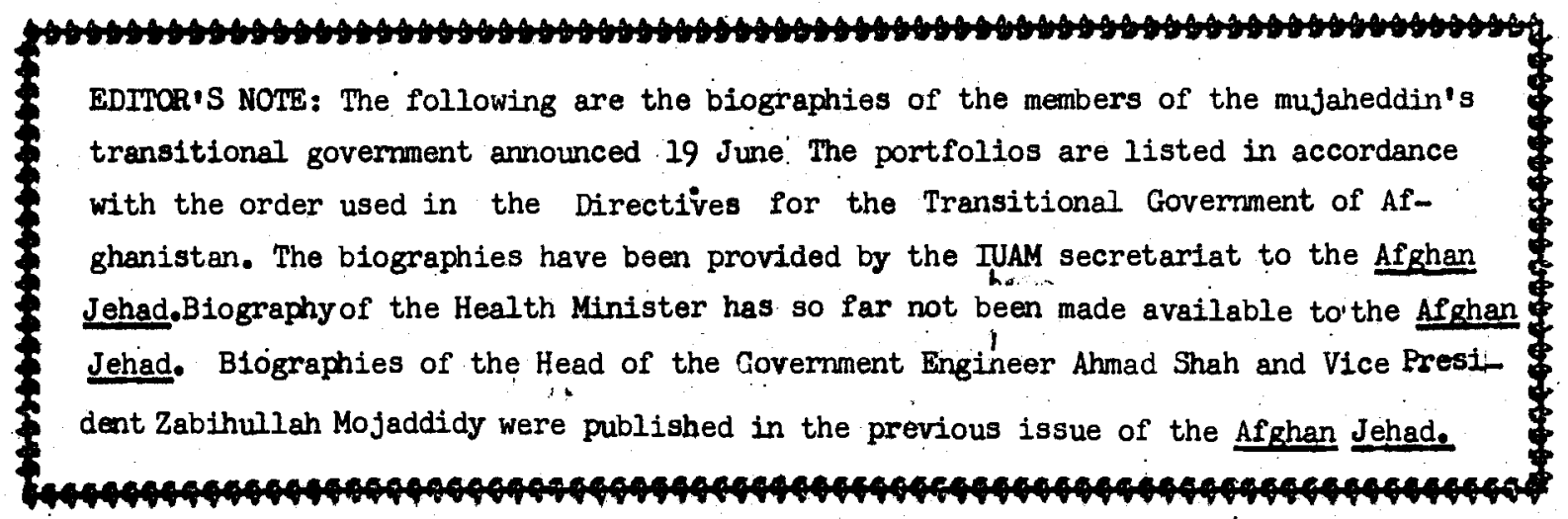

\section{MAWLAWI MOHAMMAD SHAH FAZLI: VICE PRESIDENT}

Son of Fazel Shah. Born in 1934 in Rokok, Paktika. During the early years of his life, he studied the Shariat and continued his education in religicus schools. Later he taught religion. His struggle against communism began in 1966 and he declared jehad against the communists 28 April 1966 and has been carrying the fight until now. He is also serving as the Vice President of Harakat-e-Enqelabi Afghanistan.

\section{PROF. AII ANSARI: MINISTER OF JUSTICE}

Son of Gul Ahmad Khan. Born in 1947 in Baraki Barak, Logar. He has a BA in law. His anticomunist activities began in 1970 specially in Kabul University. He has been serving as Director of Cultural, Educational and Training program in the Hezb-e-Islami (Hekmatyar).

\section{HAJI DIN MOHAMMAD: MINISTER OF DEFENSE}

Son of Mohammad Aman. Born in 1951 in Surkhroad, Nangarhar. He has a university Education holding a BA. He has started jehad against communists since 1974 and was always participating in armed jehads. He is also serving as Vice President in the Hezb-e-Islami (Khales).

\section{JUDGE NAJIULIAH: MINISTER OF FOREIGN AFFAIRS}

(EDITOR'S NOTE: The following biography of Najiullah has been adopted from The Shahadat newspaper,1 October, 1987).

Son of Mawlaw Atta Gul. Born in 1946 in Andar, Ghazni. He has recelved his BA from the College of Theology of Kabul University. He has served as representative of Hezb-e-Islami AfghanIstan (Hekmatyar) in Kuwait and in the Political Comittee of the Hezb. In the elections held by 
the Hezb-o-Islami in 1987, he was elected as a member of the Central Council of the party and later elected Chairman of the Educational Comittee by the party's Central Council.

\section{SAYYED NOORULIAH EMAD; THE MTNISTER OF INTERIOR}

Son of Sayyed Ahmad. Bom in 1948 in Enjeel, Herat. He holds a BA from Kabul University. He joined the jehad in 1977. He started a fierce struggles against the communists and he has been active particularly in recruiting the youth for a struggle against communism. He had served as a teacher. At present, he also serves as the General Secretary of Jamiat-o-Islami.Afghanistan.

\section{MOHAMMAD YASSER: MINISTERR FOR DA 'WAT AND GUIDANCE}

(EDITOR'S NOTE: The biography of Mohammad Yasser. has been adopted from The Shahadat newspaper. 24 June, 1988).

Son of Malek Esmatullah Khan. Born in 1953 in Bamby village of Chak-e-Wardak. Received his primary education in Chardehi, Kabul province and later went to Habibia High School, Kabul. He went to the US for one year in 1972 from 11 th graue of the high school. He entered the College of Law and Political Science at Kabul University in 1974 and the same year migrated to Pakistan: Later he was enrolled in the Islamic University of Madina, Saudia Arabia, previously he had been working as director of party organization and recruitment, and meaver of the executive committee of Jamiat-o-Islami Afghanistan. He is also presently a member of Brecutive Council and Chairman of the Political Committee of the Ittehad-e-Islami Afghanistan. •

\section{NOTIULLAH MOTEY: MINISTER FOR AGRICULTURE AND CATTLE-RAISTNG}

Son of Lal Shahbaz. Born in 1947 in Zerok, Paktika, After completing his primery education, he studied in Teachers College in Kabul. Then he sorved as teacher. He started jehad in 1974. He had been engaged in jehad as provincial diroctor for the Hezb-iolani Afghanistan (Khales) in Paktika.

\section{MAWLAWI MIR HAMZA: MINISTER OF EDUCATION}

Son of Gul Marjan. Borh in 1942 in Chorband, Parnan, He has a Ka. degree from Damam Uhiversity of Saudi Arabia in religion. After the establishment of commust regime in Kabul, he began jehad against atheists in 1978 and, within the framework of the Jamiat-e-Islami Afghanistan, has supervized the jehad activities in several provinces of Afganistan.

He has participated in several international forums on behalf of the Afghan mujaheddin. Among these have been an Islamic conference in London; the conference on the enforcement of Shariat in Sudan; serving as a member of the mujaheddin delegation during the UN General Assembly session in 1987. He also attended the conference of the OIC in Jordan in 1988 as the head of mujaheddin delogation. He is currently also serving as the Chairman of the Department of Party Organization and Recruitment in the Jamiat-e-Islami Afghanistan.

\section{GHUIAM FAROUK AZAM: MDNISTER OF SETTIEMENT AND PECONSTRUCTION}

Son of Akhtar Mohammad Khan. Born 13 December, 1942 in Kandahar. He holds a Ph.D. and before the April coup of 1978 he served as an adviser in an Afghan Ministry. He left Afghanistan 30 April, 1978, Just after the coup and becane engaged in Jehad and, within the framework of NIF, he was entrusted with the duty of party organization and recruitment and presently also serves as the leputy leader of the NIF. 


\section{MOLAMMAD ISMAIL SIDDIQI: MINISTER FOR FINANCE}

Son of Haji Ghulam Siddiq Khan Tokhi. Born in 1925 in Zabul. Completed high school education at Habibia in Kabul and later took a course ir Law and political science. He migrated in 1979 and started work within the framework of the Harakat-e-Enqelab-e-Islami Afghanistan. He has served as member of the Revolutionary Council of the Harakat, Chaiman of Refugee Committee, Chairman of Cultural and Press Affairs in the three party alliance and Secretary and Chairman of the Secretariat of Harakat.

\section{ABDUL AZIZ FEROCH: MINISTE'R OF PLANNING}

Son of Khawaja Mohamad. Born in 1937 in Kandahar. After completing his education in Kandahar and Kabul, he went abroad for higher education and received his MA in planning. His last position in Kabul was Deputy Minister of Planning before 1978. He migrated in 1981 and has served in various international agencies.

\section{DIN MOHAMMAD GRAN: MINISTER OF SCIENTIFIC RESEARCH}

Son of Taqwadar Khan. Born in 1937 in Gardez, Paktia. He has conpleted his education upto Mh and before the communist takeover in Kabul, he served as teacher in the college of Theology at Kabul University. In 1979, he began his jehad against communism in the framework of NIF and also participated in battles. He has also served as an adviser in the Department of Fducation of the three party alliance, President of the Cultural Affairs in that alliance, President of Party Organization and Recruitment of the NIF and member of the Executive Council of this organization and now also serves as a member of the IUAM council. 


\section{April-June, 1988 \\ Vol.1, No. 4}

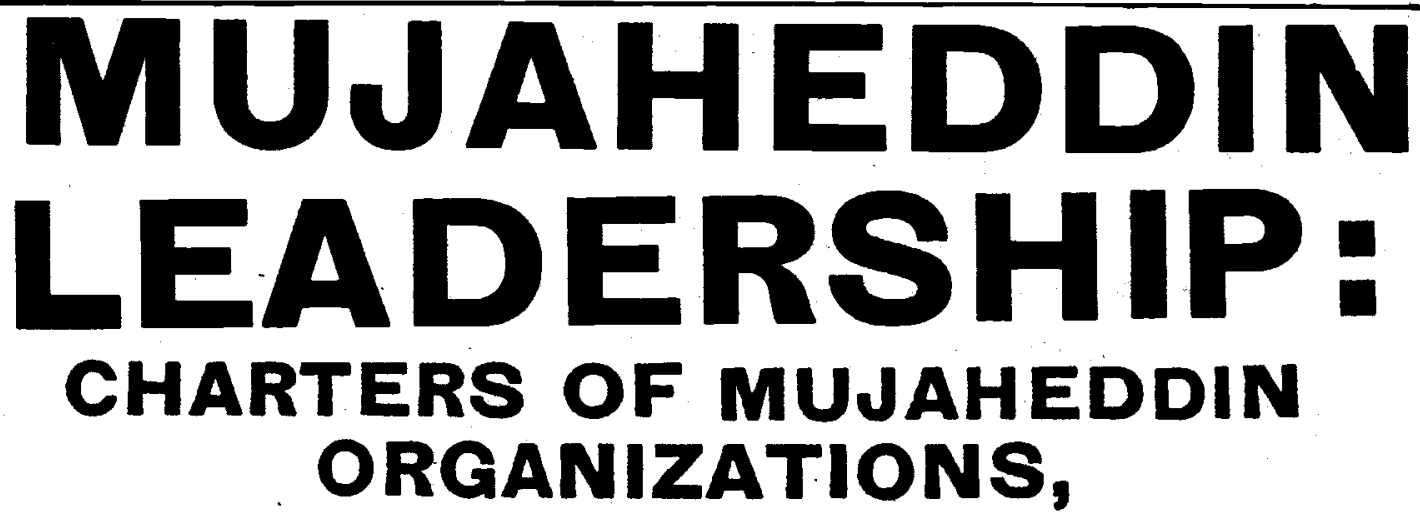

The following are the biographies of the three remaining leaders of the IUAM and their views, writings and charters of their organizations. They are Mawlawi Khales, leader of the Hezb-e-Islami Khales, Mawlawi Mohammad Nabi Mohammadi, leader of the Harakat-e-Enqelab-e Islami Afghanistan and Abd Rasool Sayyaf, leader of the Ittehad-eIslami Afghanistan. The biographies of the leaders and charters of four other organizations were published in the previous issue.

\section{Mawlawi Khales} EDITOR'S NOTE: The first part of the biography of Thales dealing about his life until 1978 has been taken from a pamphlet by Khales himself under the title of who an I? Why I have Launched a Resistance?"

\section{Biography}

Mawlawi Mohammad Yunus Khales, leader of Hezb-o-Islami Afghahistan was torn in Qazian village of Gandomak in Khogianey sub-division of Nangarhar province. He is now 68 years old. He first studied under the tutorship of his father Abdul Akbar and later, when his father died, his maternal uncle taught him. He finished part of his studies in the frontier area.

Until 1949, he was engaged in learning and conducting Prayers in mosques and, for a while served as a teacher in a school training judges. In, 1951 he entered as a staff in the department of "inlightenment" in the Department of Press. For a'time he was the editor of The Message of Truth magazine and The Warangai journal, both owned by the government. When the Afghan people had an opportunity for organized political activities he and a number of friends gathered to start political activities and later joined their mujahed brethren. With the arrival of Daoud, once again on the scene in 1973, he had to seck refugee in the Pashtoon land and engaged himself in organized resistance. After three years, however, he again entered Afghanistan and his companions induced him to become the leader of his organization.

After the communists came to power in 1978 for some time he staged his jehad in Paktia and Nangarhar and Kunar. He later served as deputy leader of the Hezb-o-Islami Afghanistan (Hekmatyar) and in 1979 formed his own mujaheddin organization under the same title. In October, 1987 he was elected as President of the IUAM, Before that twice he had served as spokesman of the IUAM in 1987 and 1985.

\section{His writings}

The following are names of his writings. brought out either as book or pamphlets.

1. Who an $I$, why I have launched my resistance"; 2. The Pearls of Religion; 3. The spirit of Society"; 4. Religion and Human 
Givilization; 5. "Sweets to the Sweet

Ones"; 6. Ramadan (Month of Muslim fasting)

7. Islamic spirit.

\section{His Views}

SDITOR'S NOTE: The following remarks by Mawlawi Thales on important topics are being quoted from the official newspaper of the Hezb-e-Islami Afghanistan (Khales).

* We never expect either the East or the West to follow a policy which will fulfill our wishes (Al-iloor 27 April, 1986).

* Until a government comes into power whose lans are based on the Quran and the Sunnah, and the power is assumed by people who have Islamic knowledge and their deeds are also Islamic, and have undergone a test and trial during the jehad, we will not hand over the government to any one elsen. (Al-Noor 22 December, 1986).

* Today we observe that Russia is colluding with its big eneny the United States and the two are fointly exploring ways for enslaving this Muslim and proud (Afghan) nation. (AlNoor, 6 January, 1986).

* Whe UN has decided to let the Afghan nation decide its own destiny but (UN mediator Diego) Cordevea is making Irantic efforts to hand over Afghanistan to the Russian servants". (Al-Noor, 6. January 1986).

* Who can possibly accept the fact that the Mujahed, Mohajer and pious people are to be placed at par with corrupt people. For we have brwzen our swords against corruption and corrupt elements are our enemies and the mujaheddin and mohajerrin are the dear ones at our hearts. So under the pretext of elections, putting them on an equal footing is an act of cruelty to the mujaheddin and mohajerrin (Al-Noor, 22 June, 19:7).

* "All the ahl-e-hal wa Aad (men of wisdom) ought to get together and they should be allowed to put their hand on any Muslim and pious mujahed to be the Shariat (legal in Islamic term) leader (Al-Noor, 8 October, 1966).

* We want to assure all Muslims who have migrated to the West, America and Iran, that they will be given a role, according to their ability, in the reconstruction of Afghanistan and with these brethren our ties have not been broken". (Al-Noor 7 December, 1987).

* We give priority to unity in the mujaheddin ranks (Al-Noor, 22 December, 1987).

* Mour jehad did not begin to (topple) any particular individual but it has been for changing the regime." (Al-Noor, 6 January, 1988).

* Mne who does not serve the religion of a country and serves (causes like) language (etc.) is actually deceiving the people (from his own autobiography: "Who Am I?").

* "A Muslim is obliged to search for goodness and grandeur only in Islem (from his own autobiography: Who Am IP".

\section{Mawlawi Mohammadi}

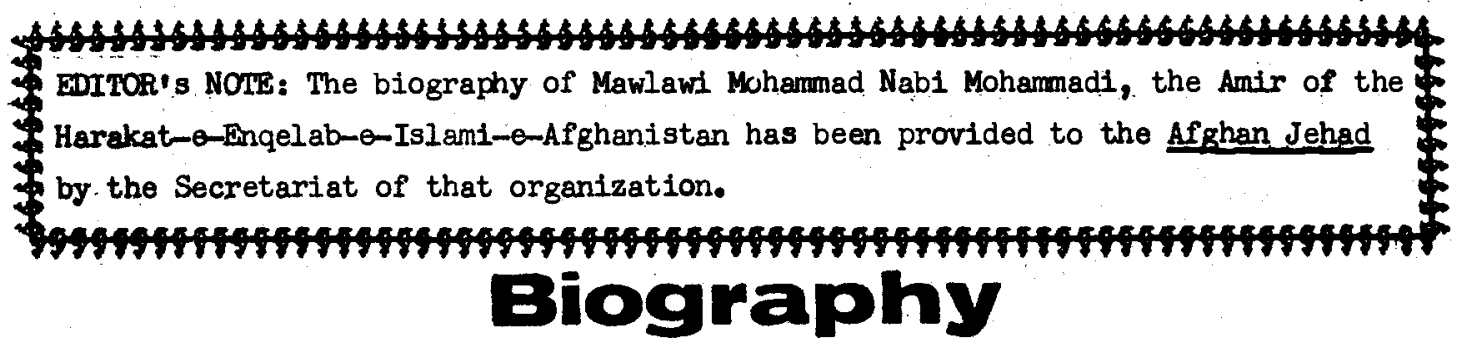

Mawlawl Mohammad Nabi Mohmmadi, son of Al-Haj Mullah Abdul Wahhab was born in 1921 in the Abbas Shraa village of Baraki Barak, Iogar. He began his primary education when he was five years. 
old and learned Islamic subjects in Logar, Maidan and Laghman scholars and finished his studies in 1953 and later became engaged in teaching religion.

He was elected as a deputy to the House of the People from the Baraki Barak, Logar, in the 13th term of Parliament (1969-73) and migrated afterwards to Marja, Helmand, where he established a religious madrasa. He himself also became a teacher.

He was arrested 2 November, 1973, by the Daoud regime accused of conducting anti-communtat propaganda but was released after some time.

At the time of the government of Taraki he migrated 11 May, 1978, to Quetta, Baluchistan, to launch a national uprising against communism. In Quetta he founded the Harakat-o-Inquelab-aIslami Afghanistan and then later went to Peshawar at the request of Gulbuddin Helmatyar, leader. of the Hezbe Islami and Burhanuddin Rabbani, leader of the Jamiat-e-Islami Afghanistan and took over as leader of the mujaheddin alliance. The alliance was dissolved six months later.

Mohammadi later entered Afghanistan via Miranshah with a number of his followers and demolished seven communist government border posts and announced a national uprising against atheism and infedility.

In 1981 his organization became a member of an alliance with the NIF and NLF for the sake of improving the affairs of the jehad, lasting until 1985.

\section{His Views}

* In regard to the formation of a coalition government, we must make it clear that auch a coalition will not be among political forces and parties of a nation but it will be a coalition between Islam and infedility, between worshipping God and atheism and: between the suppressor and the suppressed. These are all diamatrically opposed to each other and they cannot coalesce (Hedayat-ul-Islam 5 November, 1987).

* If today we are to think about questions such as leadership, occupying important positions and enjoying ourselves, then we are not sincere and truthful to our God Almighty and we will be accountable before Him and this will be a big disgrace for us (Hedayat-ul-Islam, 5 November, 1987).

* A country, where the law of Shariat is not enforced, will never be immune from alien aggression (Haqiqat-ul-Islam 28 August 198\%).

* We are not fighting for gaining power but we are conducting the jehad for the establishment of an Islamic government (Haqiqat-ul-Islam 22 June 1987).

* If conditions become unfavorable and circumstances are such which will make it impossible to form a mujaheddin interim government, in that case we agree for the appointment of a neutral person (at the head) of govermment provided he is an Afghan and a Muslim (Haqiqat-ul-Islam, 22 June, 1987). * Our jehad is not dictated by the east or the west but it is for the sake of God and with His help (Haqiqat-ul-Islam 21 March, 1986).

* Muslims should avoid slandering and labelling each other (Haqiqat-ul-Islam, 3 Pebruary, 1985 ).

* Russian aggressors and oppressors should have a second thought about their imperialist ideas, should stop massacre of the defenseless people of Afghanistan and recognize the independence and 
the right of self-determination of the Muslim people of Afghanistan (Haqiqat-ul-Islam 21 March 1984)

* Proposing a cessefire with the Soviet aggressive forces who are the real factor of conflict in our country can be considered only when they pull-out of our country without any condition (Yujahed, 27 January, 1986).

* The Islanic Iranian Republic authorities should not give a helping hand to opportunistic elements seeking splits and should not give permission for the activities of those who are working for their own grandeur and cliques (Azadi, $14 \mathrm{July}, 1986$ ).

* We are optimistic about a peaceful political solution of the Afghanistan issue. We consider it as a good sign and welcome it. We do not reject or condemn it and at the same time consider it Islamic (Azadi 14 July 1986)The Russians are trying hyprocratically to pave the way for the practicipation of those in the future government of afghanistan who have not refrained from any kind of oppression and atrocities so that these PDPA criminals and traitors are protected, However, leaders of the Afghan mujaheddin will never be deceived by such intrigues (Hedayat-ul-Islam,18 February, 1987).

* We consider the issue of Afghanistan as an issue of the entire free world, The mujahed nation of Afghanistan in their defensive war with the Russians are not only defending Afghanistan but they are defending the entire humanity (Azadi, 21 November, 1987).

* We are not refecting the efforts being exerted by the well-wishers under the name of political solution or under any other name for the solution of Afghan issue and we ask Almighty God for the success of real and healthy solution of the problem (Haqiqut-ul-Islam 22 June, 1987).

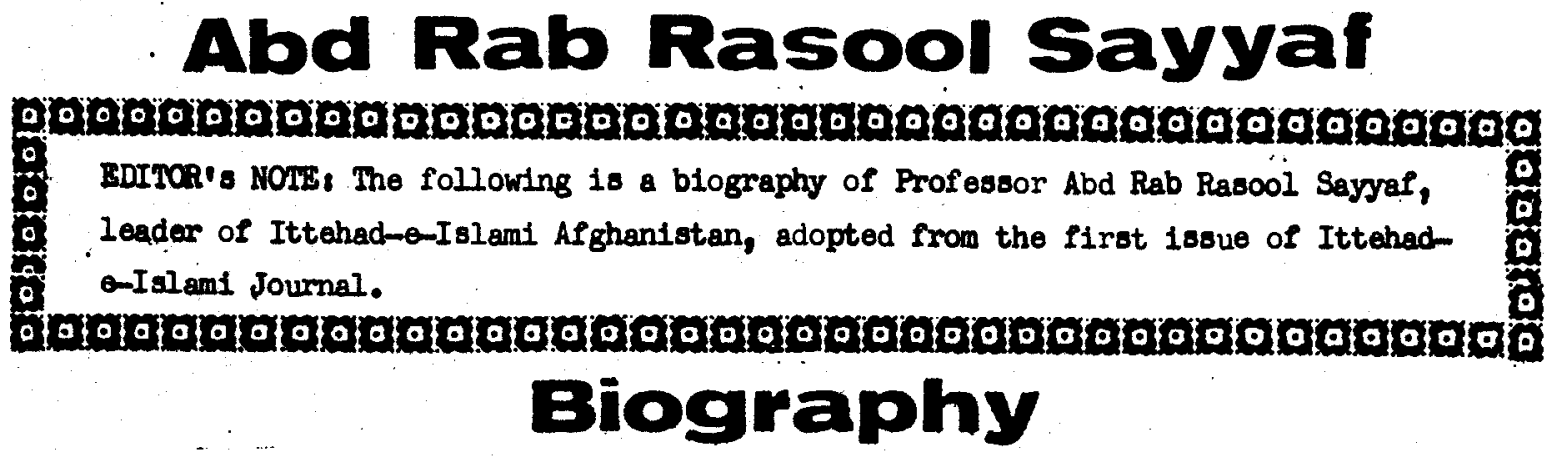

Prof. Abd Rab Sayyaf, leader of Ittehad-e-Islami Afghanistan, son of Faqir Mohammad, was born in 1944 in Paghman of Kabul province, He is a Saadat (descendent of Prophet Mohamad). He was six year old wen his lather died and was enrolled in the Paghman primary. school when ho was seven and graduated from there in 1956.

In 1957 po entered the bn-O-Sine high school and, after two years, was enrolled in Abu Hanifa Madrasa fram here he graduated in 1963 and was enralled in the College of Theology of the rabul University in 1964. He graduated from the university in 1967 and went through the milltary. resarve course to serve hils army term.

In 1969 ho was appointed in the teaching otaff of the College of Theology of Kabul Univaroity

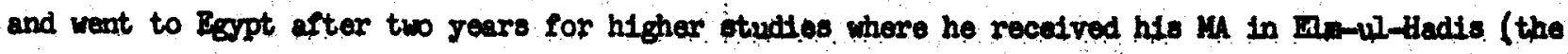
science of learning about the saying and remarks of Holy Prophet Mohanude pasce be upon him). In 1973 he returned to the country and reamed teaching at the Kabul Universtty and, in 1974, when he: 
was at the airport to go to the US for legal training, he was arrested by the Daoud police and spent six years. in jail and in 1979 was released from jail in a "miraculous way".

It is to be mentioned that Prof. Sayyaf was the top honor student from the 12th grade of the high school right through the years during which he received his MA.

\section{His writings}

1. "A lesson in warning" (pamphlet) 1986

2. Warning" (pamphlet) 1986

\section{His Views}

* Whoever hands over the power of the state to anyone else but the mujaheddin will be committing a big cruelty to Islam" (Shahadat, 24 may, 1987).

* "In order to gain the pleasure and help of AImighty God, we are whole-heartedly ready to face the enimity of the entire world (Ittehad-e-Islami, 18 November, 1985).

* Russia and the US do not have the right to negotiate about the Afghan issue. (Shahadat, 17 December, 1987).

* The continuation of armed jehad is the only honorable alternative for us (Ittehad-e-Islami, 10 March, 1985).

* Until the Russians completely withdraw from Afghanistan, until atheism and infedility are completely wiped out from Afghanistan and until a completely Islamic government is established in Afghanistan by the mujaheddin, we will not lay down our arms and will continue our armed resistance (Ittehad, 10 March, 1985).

* Political solution and political talks do not cure the problem of the Muslim nation of Afghanistan and they cannot achieve the objectives (of the Afghan people) (Ittehad, 10 March, 1985).

* Those who are waiting for a political solution (of the Afghan issue) lack ideological and party support and backbone. They have not been brought up within the framework of principles and current of thoughts and it is for this reason that they do not appreciate the value of the bloodshed by the martyres and the price of Jehad (Ittehad-o-Islami, 8 April, 1986).

* The filthy face of communism can be well known through the blood, smoke and ashes which have engulfed the entire atmosphere of Afghanistan (Ittehad-e-Islami 11 May 1987).

* The mujaheddin should determine the future of the Afghan nation and the system and order which are to be established in Afghanistan can be no other than Islam (Ittehad-e-Ialami 11 May 1987).

* We are endowed with freedom and the right of self-determination. It is our own right to decide about our fate. We will never accept the dishonor to allow others decide our fate. The issue of Afghanistan can be solved in the warw and blood-stained trenches of the jehad (Ittehad-e-Islami, 14 Decembar, 1987).

* The Afghen mujahoddin never accept a coalition goverment. If such a thing happened, the mujabeddin will continue their jehad. The entire Geneva negotiations, unless the mujaheddin are direct party to 1t, wlll not bo binding (Ittehad-e-Islami, 11 January, 1987).

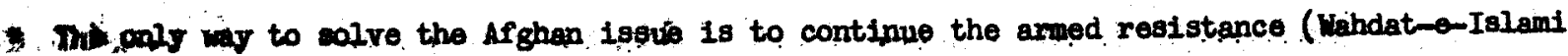


30 March 1983).

* We will not be content with an incomplete and defective solution (of the Afghanistan issue).

We should always demand our complete right (Azadi, 12 March, 1985).

* The basic aim of the Russians in their intervention in Afghanistan is to establish a satanic order and expand the red line of communism. If the jehad forces are not united under one banner, hope for a victory will be futile (Ittehad-e-Islami, 8 March, 1987).

* The basic policy of Ittehad-e-Islami is the unity of the entire Islamic Ummah. It works for the unity of the entire Islamic Ummah without thinking about the issue of leadership (Ittehad-eIslami, 4 November, 1987).

\section{Charter of Hezb-e-Islami Afghanistan (Khales)}

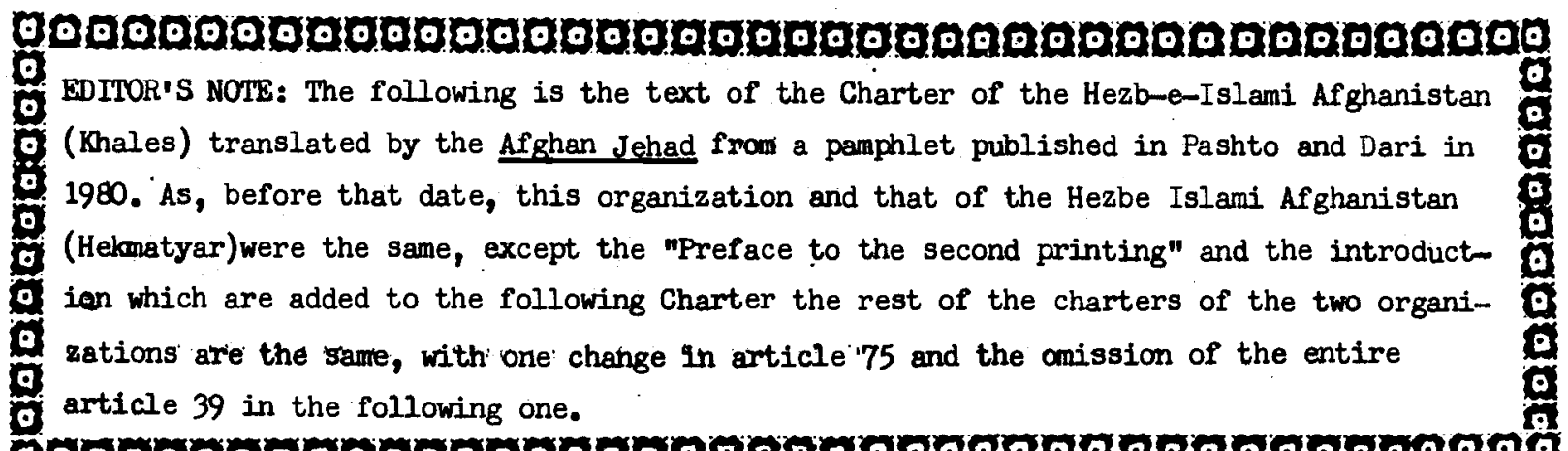

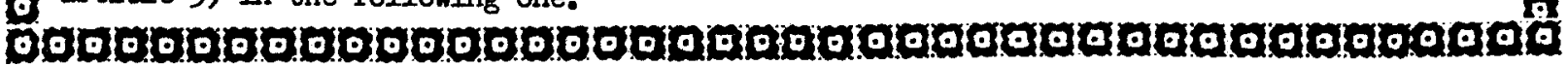

\section{IN THE NAME OF GOD, MOST GRACIOUS, MOST MERCIFUL.}

"Truly, my prayer and my service of sacrifice, my life and my death, are (all) for God, the Cherisher of the Worlds" (The Holy Quran). "But no, by your God, they can have no (real) faith until they make you judge in all disputes between them and find in their souls no resistance against your decision, but accept them with the fullest conviction". (The Holy Quran)." But whołoever turns away from my Message, verily for him is a life narrowed down, and we shall raise him up blind on the day of Judgement." (The Holy Quran).

\section{PREFACE TO SBCOND PRINTING}

We are publishing the Charter of the Hezb-e-Islami so that our Islamic brethren at these delicate times, when people under the guise of Islam, once again try to advance their evil and anti-Islamic objectives, people who have neither gone through the test of religiousness in the past and nor at present shy away from friendship with anti-Islamic elements and until the time when a real Islamic government is established and has supported our sacred objectives we are not going to lay dorm our arms. From God we seek helpi(Mawlawi Mohamad Yunus Khales.)

\section{INTRODUCTION}

The Heab-o-Islomi Afghanistan, as a rightful and revolutionary movement of our country, is 
endeavouring to see that a wide ranging plat form which has been offered by Islam for proper guidance of mankind is enforced in its entirety. This party believes that the only solution for the difflculties and miseries engulfing mankind is the establishment of an Islamic order. Until the Islamic Shariat is enforced in different spheres of the social life of the people, humanity will always be faced with difficulties and constraints and will never achieve (real) social progress.

History is a living testimony of the fact that if evil intrudes into any aspect of human life it will undoubtedly penetrate further into the society. In such a society people will refrain from accepting the commandments of Almighty God. In such societies the valuable guidances issued by the distinguished messengers of Almighty God as the basis of life are not accepted.And (in these socioties) the feeling of accountability in the Hereafter will be defeated in the conscience of mankind.

In any society where the axis of social life of the people revolves around the wishes and passions of those incharge of affairs, instead of being based above mentioned principles, justice and faimess will inevitably give way to begemonism and oppression.

Yes, until an obedience to God, belief in the Hereafter and following of the guidance provided by the messengers of God do not form the basis of human life, there will be no possibility for the establishment of justice and faimess.

Without completely observing the above mentioned principles, any other belief in or opinion used for establishment of justice and faimess will have no result other than bringing about new versions of oppression.

Although in our country there are too many people who believe in these (Islamic) principles, the belief and order in which the overwhelming majority of the people believe have not been enforced and the living order for the people is not based on the pillars of their beliefs.

Therefore, despite the fact that our country is an Islamic country, the nation is deprived of the Islamic blessings and thus neither themselves can have benefit from Islamic guidance nor they can offer any assistance to the people of the world in this respect.

This party has resolved to see that Islamic principles are implemented actively in various spheres of the social life and relations among the people are conducted on the basis of Islamic principles and instructions. A wide ranging dissemination of Islamic thoughts, long range and consistent struggle against corruption and evil, untiring battle against deviations originating from old and new types of ignorance of the people constitute the rightful objectives of our party and this party is of the opinion that, until governments and leaders are reformed, no reform program (per se) can be implemented. Corrupt governments always bar as a great obstacle the implementation of reform programs and they support and defend the reasons leading towards corruption and deviation. Without a complete reform of the ruling order, neither individual reforms nor the establishment of complete justice and fairmess is possible. This party has mobilized all possible means and will try with all necessary measures to take positive steps for amending and changing the ruling order and pave the way for Islamic reforms.

In case we want to summarize the objectives of this party in a few limited sentences we are resorting to following explanations: (1) Following Islamic principles, adopting the deeds of the four Caliphs after Holy Prophet Mohammad, peace be upon him, and complete implementation of Islamic comandments; (2) complete eradication of oppression and exploitation, doing away with evill 
and corruption, organizing the social life on Islamic principles and establishing justice in varlous spheres of the life of the people; (3) nourishing virtues and goodness and fighting against corruption and evil, (4) putting an end to oppressive and autocratic regimes, establishing the sovereignty of Islamic principles and rules and using the ruling order for the service of the people; (5) popularizing and extending Islamic way of thinking, reviving the Islamic and nourishing the religious feelings of the people; (6) exerting efforts towards strengthening Islamic dur ties and hoisting the Word of God throughout the world (from God we seek help).

\section{GENERAL}

1. It is an obvious and clear fact that Afghanistan is an Islamic country the existence of which has been achieved at the cost of the blood of faithful elements and thousands of God worshipping mujaheddin have fought for the defense of its integrity undertaken at the cost of their lives. Therefore, in this land the kind of political and cultural activities aimed at propagating unIslamic beliefs and ideologies and replacing 11 legally the Islamic society of Afghaniatan into an un-Islamic one, all such activities, ws a matter of fact, are tantamount to attempts aimed at eliminating our country's historic existence. As a staunch guardian of the existence and integrity of the country, Hezb-e-Islami is struggling against such activities.

2. Diligent defense of the territorial integrity, independence and complete unity of the country forms the prominent duty of the Islamic movement of the country and political activities aimed at thedisintegration of our country and (inciting) linguistic, local, regional, racial and sectarian prejudices will be met with stiff resistance of this party.

From our point of view, the independence and survival of the country and security and pros. perity of the nation can only be achieved if a sense of unity, fraternity, and brotherhood is revived among the ranks of the members of the nation and a social system based on justice is established in a manner which will enable all the people of the nation to live in (an atmosphere of) complete confidence without any type of racial, linguistic, regional and secratrian discrimination and enjoy human and legitimate rights and God worshipping and piety is the criteria for super-lority and privilege.

3. We are of the opinion that, unless the following points are truthfully and sincerely accepted the possibility of evolving a firm and durable order will not exist in our country.

a) Since the absolute majority of the people of the country demand the establishment of a complete Islamic order, the sovereignty of this order should be accepted in a practical manner and those who do not heed this obvious fact and are exerting efforts for the introduction and dominance of an un-Islami. order should be identified as the real anemies of the nation and struggle against them should be recognized as a legal obligation of all members of the nation.

b) Thas territory is a common land of all the faithfull subjects of this country and is not the private property of any specific family. As such, no one has the right to exert impermissiole efforts towards the consolidation of the foundation of the rule of any specific individuals and to consolidate the foumdation of an oppreselve and dictatorial order and prevent the people of the nation from intervention and participation in national issues and to consider the government his personal and inherited property.

c) Political leadership of the nation should be organized within Islamic principles and whth the 
advice and guidance of the real representatives of the nation, and should takeover the role of supervising the affairs of the country. Those political statemen who have not received the confidence of the legal representatives of the nation and the responsibility of the supervision of the regime has not been entrusted upon them in accordance with the provisions of Islamic shariat, will never be able to prevent internal tensions and take constructive steps for the progress of the country.

d) Every Kuslim Indivicual of this ooctety, as matter of principle, has the right to put forth his personal opinion about national affairs and to communicate it to others by using legal meens. Illegal restriction over this will make members of the nation to use other means for obtaining power, which would obviously be more costly to our nation.

e) Complete prevention of the subversive activities of those political groups which do not support the Islamic status of Afghanistan or have set forth as the objective of their efforts the consolidation of an un-Islamic order in this country and are opposing the unity and safety of this country.

4. Hezb-o-Islami Afghanistan has launched (its) struggle for the realization and establishment of such a social order that will embrace the following values, principles and programs in various aspects of life:

\section{CHAPIERR-I.}

\section{IN THE FIELD OF CONSTITUTION}

1. The Holy Quran and the valuable Ahadis (sayings) of the Holy Prophet of Islam, peace be upon him, will be established in clear and irrisistible trime as the primary sources of laws. In matters of ijtehad action will be taken in accordance with the Hanafi jurisprudence.

2. An authorized and competent administration will be established to bring at the earliest all laws and official rules of the government in conformity with the spirit of Islam.

3. The shariat courts will be delegated sufficient authority and complete independence of the Judiciary will be guaranteed. The office of the judiciary will be assigned only to those ulama whose piety and fidelity are completely proven.

4. Necessary rules and regulations will be worked out at the earliest for a total implementation of all the Islamic injunctions.

5. All legal suppressive and oppressive matters, through which the ruling circles abrogate the legal and human rights of the people and which put an end to their freedom, prevent the obvious right of expression of opinion and create obstacles for legitimate and legal propagation (of ideas) will be totally abolished.

6. Laws and regulations that will curb at the earliest adultery, drunkenness, gambling; obscenity, and moral corruption will be enacted. Publication and distribution of obscene books, periodicals and(other) published material will be prohibited and the display of unethical and obscene films will be banned.

7. The issue of veil by women, as dictated by the shariat, will be totally observed throughout the country and their shariat and legal rights will be restored. 
8. Necessary and essential rules and regulations will be laid down for the improvement of social life and establishment of healthy relationship among the people.

9. (The establishment of) suppressive military governments will be definitely banned.

10. In relation to the declaration of emergencies and continuation of military governments, conditions will be laid down to limit in a reasonable framework the unconditional powers of governments. 11. Secret and military courts will be totally abolished and the trial of the military officers and others attached to the army would be conducted only in the courts (set up by the) judiciary; 12. The parliament of the country will be formed on the basis of free and direct elections and its members would consist of pious members of the country.

13. Amendments will be made in the rules pertaining to courts so that problems of the people are solved speedily and necessary facilities are provided for an early execution of an equitable and fair Justice.

14. About the persons entrusted with the government of fices, it will be kept in view that they should perform their duties with honesty and piety and adhere to the Islamic tenets in their private life. Comission of mortal sin will have bearing on the promotion and, if the situation demands, on the termination of the services of the government officials.

\section{CHAPTER-II.}

\section{IN THE FIELD OP RELIGIOUS AND ETHICAL REFORMS.}

The programs of the Heab-o-Islamt in the fteld of religious and ethical reforms is as follow: 15. All necessary measyres will be adopted to ensure that no slugglahness takes place in offering the prayers. In this connection, sufficient facilities will be provided to government officials and workers. In assessing the performance of official duties (by government of ficials) attention will be given to the performance of religious obligations (by these officials).

16. In the light of the provisions and directives of the shariat, conditions to ensure profound respect to (and observance of) the holy month of Ramadan will be provided.

17. Sufficient facilities will be provided in connection with the performance of Haj and all unnecessery and unreasonable hindrances, presently faced by the people, will be completely eliminated in this respect.

18. The prominent role which mosques should have in the social life of the Muslims will be revived and appropriate arrangements will be made to achieve honorable means of livelihood for the imems, khatibs (preachers) and custodians of the mosques.

19. All possible efforts will be exerted to make the situation conducive to higher Islamic stum dies and to inform the people about religious beliefs and injunctions so that every member of our Huslim society beccmes aware of that part of religious instructions, the learning and understanding of which constitutes an obvious daily need of every Muslim.

20. The regular expansion of madrassas religious schools) and darul hufaz (schools for menorizing the entire of the Holy Quran) will be achieved in a manner so that difficulties in training religious scholars and the hufaz (those who meworize the entire of the Holy Quran) are solved with 
a better manner within the country and that free pursuance of higher Islamic studies are available in every province of the country.

21. By making use of all legal ways and means and by utilizing all government resources and possibilities, and with all power efforts will be exerted to abolish corruption and evil and the ways and means through which crimes are propagated.

22. In regard to the ethical training of the people and for the healthy improvement of public and traditional relations, measures will be adopted to revive in the heart of the believing people the fear of God and a sense of obedience and service to God Almighty, so that they may realize their obligations and responsibilities in the light of their faith and a spirit of respect for the limits and dictates of the shariat is hourished in then and, as a result, our Islamic society may reach from the point of view of ethical maturity, a stage where abstention and refrain from evil and attending to social obligations may not be based only on the force of law.

23. Repairing of mosques, training of religious scholars and the hufaz, the delegation of the heavy responsibility of imamat (the duty of leading people to prayers) and remedying the economic difficulties of the imams of the mosques, constitute the important duties of the Department of the Endowments. Imposing on the people to render materiel support to imams and moazzens (one who calles people to prayers) are tantamount to a contempt and insult of religion and piety.

24. The non-Muslim minorities will enjoy all permissible and legal rights in accordance with the dictates of Islamic shariat, and Islamic hudood (Iimits) will be fully applied to them.

25. And finally the government will have the duty to conduct the trial of the apostate elements and punish them in accordance with the provisions of the shariat.

\section{CHAPTER-III}

\section{EDUCATION}

Attention to the issues of education and training, from our point of view, are of vital importance. Programs of the Hezb-e-Islami in this field are summarized as follows

26. The existing form of programs for educational and training institutions of the country, which have become totally obsolete and : useless, will be reformed. Because (at present) only technical persons - - and that too, in a very defective manner - - are being trained in these institutions and religious and spiritual education of students have been completely forgotton. This has entailed a profound mental vacuum in the present educational institutions of the country. This intellectual vacuum paves the way for the nourishment of all types of degraded and dejected thoughts among the ranks of the various components of education.

The various stages of educational system will be shaped in such a manner so that, from the very beginning of education until its final phases, this eninent need constitutes the pivot of our attention that the educational institutions of our country should train such persons and offer them to the society, who, in addition to (acquiring) specialization in their particular fields, would also attain a completely assured level of Islamic knowledge and would be aware of the Islamic infunctions about his profession. Similarity, during the various stages of this program, subjects that will nourish in the hearts of the students a sense of obedience to the Divine commands and injunctions wlil be taught. Education and training will not be only confined to enable (the 
students) to read and to acquire knowledge, but spiritual and ethical training will also be inclum ded in each one of the departments so that the scholarly qualifications of those offered to the society by educational institutions, are based on the elements of piety and a fear of being accountable before God.

27. During the course of studies, every Muslim student will gradually leam Islamic beliefs, injunctions and guidances related to the daily life of believing people and will gradually move fomiard from the level of (reading and) reciting the Quran upto the level of grasping and understanding its utmost vital concepts。

28. In the field of scientific research, institutions for advanced research will be established and attention will be specially devoted to (conducting) wide-ranging research of Islamic sciences. 29. Necessary measures will be adopted to simplify the difficulty pertaining to the continuation of education and necessary conditions are provided so that no one is deprived of continuing edum cation due to lack of sufficient resources.

30. Educational and training institutions will be opened in every nook and corner of the count.y. 31. The present system of comeducation, where girls and boys acquire education side-by-side, will be abolished altogether.

32. A free academic atmosphere will be created in educational and training institutions of the country and the universities will enjoy complete freedom in the framework of an approved policy. 33. Positive steps will be taken to provide better conditions of living for the teachers and in. order to encourage the best of the talents to (enter) this (profession), salaries for the teachers, will be arranged in a way to enable them achieve, the highest standard of living in the country. 34. Specific attentions will be devoted to the basic training of teachers and efforts will be exerted to offer desireable teachers to the society - - teachers who, on the one hand, would have a complete hold in their fleld of specialization and, on the other, serve successfully in the taak of Islamic and ethical trairing of their students.

35. As far as the appointment of teachers is concerned, their academic credentials will not be the sole criteria; importance will also be attached to the fact that they may not be opposed to the fundamental principles of Islamic status of Afghanistan and from the point of view of their techniques and ethics they may bo capable to train the youth.

36.In the educational program of the acadenic institutions of the country, necessary military training will be kept in view so that the young generation would have sufficient orientation in the task of the defense of the country.

37. Teaching programs, at their various phases, will be pursued in official languages of the country and efforts will be made that every one is taught in his mother tongue. Necessary measures will be adopted for the promotion of unofficial languages and special attention will be devoted to the teaching of Arabic language.

38. Supervision of the educational institutions will be entrusted to those professionel officials who are endowed with religious knowledge and are symbols of piety and rightiousness so that their day-to-day lives, per se, may serve as a practical guide to the students.

39. Regular lessons will be initiated for the military officers in Islamic Jehad and a spirit of 
perseverance, faithfulness and sacrifice and a sense of understanding, awareness and interest to the nation will be nourished in them. Side by side with equipping them militarily, utmost efforts will be exerted to equip them with the precious Islamic guidances so as to make the army af our country an active force for defending religious and national principles and virtues and they mey not become a tool in the hand of suppression and of non-patriotic and irreligious leaders.

CHAPTTRR-IV.

\section{SYSTEM OF ADMINISTRATION}

From our point of view, until healthy institutions comprised of religious, responsible and com petent officials, are formed no reform program can prove to be useful and fruitful. The Hezb-eIslami Afghanistan has the following programs for reforms in the administrative system of the country.

40. In order to check embezzlement, fraud and lawlessness in government departments, effective measures will be adopted. All necessary means will be provided to strictly check bribery particularly anong government officials and workers.

41. At the time of the appointment of high ranking officials to most important and sensitive posts, their financial conditions and that of their close relatives will be ascertained. Iater, during the course of their service, they will be kept under strict surveillance so that their wealth may not increase to such an extent that it will show a clear and obvious discripancy with their permissible and legal income.

42. Those government servants whose standard of lifving appears to be beyond their remunerations or obtain such property or wealth that its permissible and legal source camot be tract down will be interrogated at the earliest and dealt with under the shariat laws.

43. An independent department will be set up to check the government employees from resorting to injustise, encroachment and unjustified exercise of power. The department will listen to the complaints and objections of the public against goverrment servants. Separate rules will be adopted about the procedure of work by this department.

44. Unnecessary expenditure in government offices will be strictly checked and bringing pub? ic property into illegal possession will be stopped.

45. A specific national uniform will be prescribed for government officials for use during office hours and uniforms, medals and insignias which have been introduced as a result of the influence of western corrupt civilization will be abolished.

46. Resorting to savage and cruel methods now used by the filtly hands of the police during the investigation of crimes and interrogation will be completely banned.

47. The use of unnecessary espoinage networks and secret police, particularly for creating an atmosphere of fear and terror, will be strictly prohibited. The (intelligence)networks,will(only)be usedfor keeping a watch on government officials and for a complete eradication of corruptian and - bribery and preventing the commitment of crimes.

48. Unjustified savage and impermissible dealings, resorted to presently against the poor and defenseleseprisoners:inside theprisons of the country, will be totally abolished and basic changes will be introduced in this regard in accordance with the requirements of an Islamic approach. Pri- 
sons will be converted into centers of reform, amendment and education of the criminal elements to enable them acquire the capability of earning honorable and respectable ways for their living.

49. Salaries of the governient servants will be increased to an appropriate and necessary level. The standard of this increase will be to an extent to meet the economic difficulties of government officials and workers in a best manner and to stop a brain drain from the country.

50. The govermment will be bound to fix equitable remunerations for the military personnel and to recruit, at the first instance, such persons who voluntarily prefer Islamic holy Jehad over other engagements. However measures will also be adopted for the military training of others as well.

51. The armed forces of the country will be organized and expanded in a manner so that it may. emerge as a strong and assured defense power of the country and all efforts will be exerted so that the armed forces of the country may not come under the influence of imperialist powers.

\section{CHAPTER-V.}

\section{IN THE FIELD OF ECONOMIC ORDER}

The existing economic relations of the people, which has formed the basis of the economic order in the country, are based entirely on oppression and injustice. The system is a (in fact) manifestation of all the corruption, cruelties and injustices of non-Islanic orders and particularly the wrong economic policies of the un-Islamic govermments have further increased this corruption and adversity. Until profound and fundamental changes are brought about in the economic order, establishment and realization of justice will not be possible. The fundamental changes (in this sphere) should be carried out in the light of Islamic principles and, under these, the legal rights of the people should be maintained.

Islamic guidances in the field of economic order contain clear, directives and Islamic jurisprudence has in this connection rendered complete explanations. The economic order, which we want to achieve, is based on the clear explanations rendered by the Islamic jurisprudence and principles.

The economic policy of the Islamic order consists of the following fundamental points:

a) observance of justice and faimess in different spheres of economic order,

b) complete exadication of different types of oppression, injustice and exploitation,

c) creation of appropriate, uniform and favourable working conditions and benefits for all the people,

d) consistent struggle against poverty and hunger and untiring efforts for providing such conditions that no one may be deprived of his permissible and natural rights, and

e) skillful and equitable use of national and social (wealth and)capitals,

For the accomplishment of the aforesaid objectives, the program of the Hezb-o-Islami Afghanistan in the economic field is sumned up in the following four sections:

\section{AGRICULTURE:}

For a long time, as a result of the prevalence of oppressive and un-Islamic system in the country, inequities and (undue) privileges have prevailed in the sector of agricultural land owner ship and benefits from it.

For a complete elimination of these oppressive conditions, the following legal steps will be 
taken:

52. Ownership of properties which have been put illegally at the disposal of sources of power will be nullified in accordance with the provision of the slariat and will be returned to their legally deserving persons.

53. Cultivable land owned by the state will be distributed free of cost or on easy terms among landless cultivators and to the owners who do not hold an economic unit of land,

In regard to the distribution of land,priority will be given to the deserving people of the area where the land is located and not in an unjust and arbitrary manner among non-deserving people. 54. Serious attention will be devoted to the (implementation) of laws and regulations issued by the Islamic shariat about land ownership,agricultural and farming relations and un-Islamic dealinge will be completely stopped.

55. At the time of the distribution of state-oined agricultural land, all possible efforts will be exerted to see that the land (to be owned) by a farmer and cultivator is to the extent that vill achieve an honorable standard of living for him.

56. Measures will be taken to directly put at the disposal of cultivators and onners of the land the fair and reasonable income which they are to receive from their agricultural products and a part of their profit does not fall in the hand of Intermediaries, specially in the case of cotton crop.

57. For achieving a healthy (system of) agriculture, the desired agricultural implenents, chemical fertilizer and improved seed will be put at the disposal of farmers with a fair price.

58. In order to preserve, develop and properly make use of the forests, necessary measures wrill be adopted; however, in no way, pastures and properties that are meeting the daily needs of the people will be misappropriated.

60. Except on the occasions that Islamic rules or Islamic econonio princtoles require, fertile agricultural land will not be used for industrial purposes, etc.

61. Basic attention will be devoted to the utpost development of cattle rafing in the country. In order to encourage cattle raisers, sufficient sacilities will be provided to them and necessary measures will be adopted for the predervation of pastures.

62. The problem of shortage of foodstufe will be eliminated with adopting the following fundamental measúres:

a) the land that has been fit for agriculture but have remained arad due to unfair reasons, will be put into use at the earliest,

b) in order to develop agricultural land, arid land will be made suitable for cultivation aid agriculture,

c) best efforts will be exerted to construct water dams, canals and irrigate deserts and fertile land,

d) in connection with the buying, selling and the traneaction of foodstuff, measure will be adopted that, on the one hand, do not stop the flow (of agricultural comodities) and, on the other hand, cultivators and famers obtain fair and desired price for their agricul- 
tural product, and also consumers will be able to make use of them with a fair price.

e) in fixing the volume of foodstuff supplies (to the public) and for comnercial purposes, it will be ascertained that no shortages of foodstuff occur (in domestic markets), and

f) in orcer to increase the income of farmers and to put an end to unemployment and lack of opportunies, cottage industries will be developed in rural areas.

\section{II. - TRADE AND INDUSTRY}

In order to utifize the wealth and capital which, as a result of wrong, illegitimate and oppressive policies of un-Islamic government in our country, are being concentrated in the hands of specific people, and to realize the public interests, the following legal measures are to be adopted:

64. Usury, gambling; impermissible speculation, hoarding and other impermissible and illegal means that have been banned in the Islamic sharlat, for obtaining wealth will be legally banned and only lawful means of obtaining wealth will be recognized. Similarly, action will be taken, on the basis of hariat, about the capital illegally incorporated as private properties.

65. Supervision of the affatrs of companies and banks will be handed over to the elected representative of (thoir) pertiners and shareholders.

66. Necessary messures, thatuding extending aid in losn will be adopted, to encourage and incresse the nuber of companieg, Including ana.7l and limited companies.

67. In regand to fixing the price of industrial products, measures will be taken not to make these prices alsadvantageous etther to the omers of the companies or consumers.

68. Fectorles and compantes will be obliged to produce only essential goods such as machinery, Industrial goode, otc. and refrain from producing non-essentiel and luxuty items.

69. (Both) in business trarsaction and in the production of industrial goods in the country, basic attention will be devoted to meeting the domestic needs of the country.

70. The goverment will control those industries which may play a vital role (for the country) and"privately owning them is hamful to social (public) interests. Otherwise we are not in favor af nationalizing industries.

71. The preseint banking system, will be reformed, in accordence with Ialamic principles, on the basis of moearobat (Iimited partnership) and mutual cooperation.

72. In our effort to have complete prejeredness for the defense of the country, we are attaching great importence to the weapon production industry.

74. Modern and heavy industries will be created and, for the sake of the development and extension of amall industries, necessary measures will be adopted and, in this respect, maximum use will be nade of the experiences of other countries.

74. We are supporting the process of the extension and development of industries in appropriate regions and do not agree that industries ought to be built only in specific and special areas.

75 In order to completely protect home industries, the government will be obliged to otrictly obsemve ben on the import of the goods that are being sufficiently produced inaide the country. 
III-RICHTS OF WORKLRS AND LOW RANKING OFFICIALS:

76. The present system of wages (paid to government workers and official) which, due to various ressons, is unjust, will be reformed gradually. In fixing the salaries, always the obvlous factor, is observed that parallel to changes in conditions and keeping in view the prices of goods (and services), the minimum wage should meet the basic needs of a family. With a rise in prices of essential goods, the total of wages (paid) will be proportionally increased.

77. For government servants and low ranking officials sufficient facilities will be provided in the best manner to meet their needs in housing, medicare as well as proper (and healthy) education of their chtldren.

78 In regard to eapital and labor, laws willi bo enacted as a result of which cooperative relationship is established between capital and labor' and legal wages of the workers are in no way abused and an attempt will be made that, in case of disputes arising between the worker and the owner of the factory, Islamic ways for solving the issue are found and a fair settlement is reached.

79 The government is to refrain from employing and putting into work children and will adopt necessary measures for the healthy upbringing of children.

80. The system, under which men and women are working together, will be completely abolished and Islamic principles will be strictly observed in this respect.

81. In ceses of illness and at times when workers' health is affected, while working, proper arrangements will be adopted for their treatment.

82. The obvious right of every individual to demand his permissible and legal wage will be legally guaranteed.

The government will seriously feel itself' responsible to attend to people's complaints and defend their rights.

The government's work program in regard to attending to the complaints lodged by the people will be adopted in such a way so as the objections made and complaints lodged by the poople are heard in the shortest and easiest manner.

IV. GENERAL ECONOMIC REFORMS.

83. Necessary measures will be adopted so that the (various kinds of) zakats (compulsory and defined tax paid by the Muslims from their income) alms given under the provisions of the "one tenth" (of the income to be given to the needy);, etc. are collected by the state and are spent according to the shariat laws. Taxes which have no basis in the shariat will be completely abolished.

84. The economic policy of the country will be prepared with the participation of the elected representative of the people and will later be implemented after its ratification by the par 11ement.

85. The state treasury will be refined in such a manner so that, in no way, it is based on lawful shares. 
6. Impermissible investments in illegal fields and unnecessary expenditures are to be completely benned. Specially unnecessary expenditure on constructions serving as show pieces will be stopped.

87. Factors which contribute towards a rise in prices are to be eliminated.

88. Efforts are to be exerted to end unemployment and lack of opportunities.

8. Sultable conditions will be created for medical treatment with little expenses.

90. Iffective neasures will be adopted for the development and extension of hospitals.

91. Basic needs of the handicap and distitute will be met from the public treasury by (extending to them) salaries to meet their basic needs. Similarly they will be brought under regular Islamic training (and education).

\section{IV - IN THE FIELD OF FOHEICN POLTCY.}

In the field of foreign policy, too, changes will be introduced so that, like the policies (pursued) in the toméstic affeirs it is based on Islamic principles and on the principles (corresponding with) basic needs of the country.

92. We will consistently keep alive the matter of continued resistance for the complete realization of the truth and justice and will vehemently struggle against oppression, aggression and Injustice. In our relations and dealings, we will be honest and truthfull and persuade others to also do likewse and we will seriously honor our commitments.

93. We are strong supporters of world peace and security and will not refrain from all kinds of sacrifices for achieving this objective. However, from our point of view, only the non-existence of war is not tantamount to peace and security. Our definition of peace and security is (the prevalence) of a condition (as a result of) which right and justice are achieved throughout the world and such a favorable atmosphere prevail in relations anong nations as a result of which disputes and tension are completely eliminated and nobody will be able to step over the legitimate rights of others or create obstacles and difficulties on their path towards peace and progress. (Indeed this noble objective can be achieved only when Islamic order is adopted in practice in organizing and leading human affairs in a healthy manier). *.

94. We resolutely condemn various manifestations of calonialism, exploitation and oppression and consider the continuation of colonial order as violation of the requirements of justice and equity and recognize the remainings of the colontal oppression as the main element of tension, disputes and Insecurity.

95. Bqual struggle against East or West imperialism is considered by us as the fundamental obligation of nations and, in order to put an and to this, we will use all the means at our disposal. 96. Those backwand nations which in one or another way, are under colonialisn will enjoy our iupport for their freedom, in the light and principles of Islamic guidance, specially the Kuslim nations wose independent Islamic existence is under the threat of the force(s) of oppression, aggreasion and imperialisin.

97. We want the establishment of good and reciprocal as well as the consolidation of cooperative relations with all countries of the world. However, in no way we are ready or never we will to lerate to devlate from our principles and beliefs and damage our national interests under the name * Brackets thise of the original . 
of establishment of good relations with others, or agree to the kind of relations that wlll affect the freedom and independence of the country. Furthermore our Islamic sense of reform does not allow us that our relations with a country of the world are established in such a manner to pave the way for the penetration of their deviated beliefs and ideas opening the doors of the country for them to undertake the task of propagating and dissemiriating their thoughts.

98. We will resolutely refrain from entering military blocks and we do not want our country"to become a part of race among big imperialist powers.

99. In international issues, the accords and contracts contrary to Islamic texts will in no way be honored.

100. Our untiring effotts will continue for the consolidation of brotherly and friendly ties with the world of Islam and we confirm our good and sincere efforts for the establiahment of relations among Islamic countries around the axis of common objectives.

Under the present circumstances, we are trying to see the revival of the spirit of unity and fraterity among Muslims for achieving the survival and solidarity of the world of Islam.

And finally we are considering as necessary the adoption of a comon strategy for the Islamic countries:

(a) Revival of Islamic culture and civilization and prevention of the influence of unIslamic civilizations (In Islamic societies), (b) Joint investments for the development of arms industries of Islamic countries to the extent that these countries, once more, become self-sufficient in arms and military equipment, (c) recognition of Arabic as (an) international language and joint efforts for its wider dissemination, (c) establishment of a competent intermational court for solving mutual disputes among the Islamic countries, (e) providing easier facilities for travelling within Islamic countries, ( $f$ ) taking necessary measures for expansion and develorment of trade and financial transactions (among Islamic countries), and ( 8 )effective assistance to be rendered to Muslim minorities living in various countries of the world under the burden of oppression and transgression.

FROM GOD WE STEK SUCCESS

\section{Charter of Harakat-e-Enqelab- e-Islami Afghanistan}

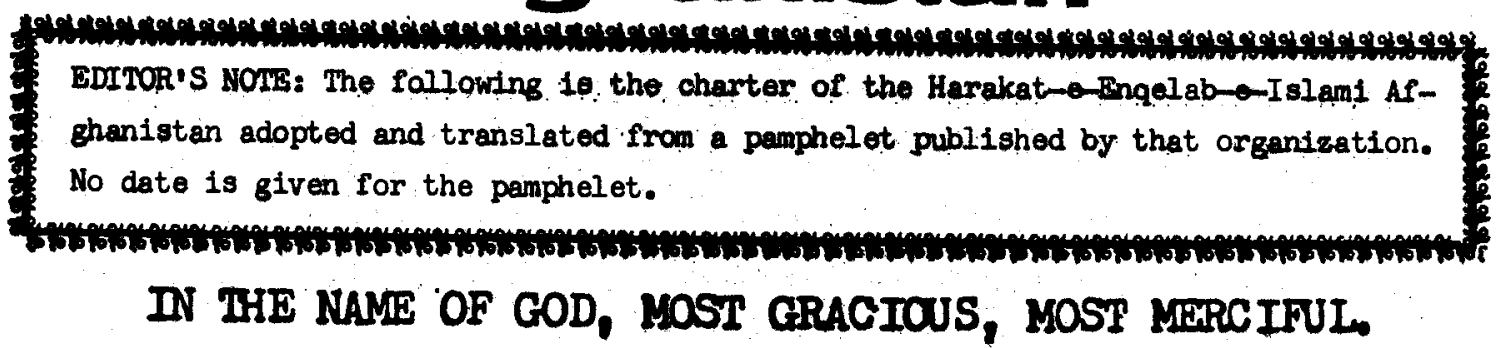

WHAT DO WE WANT

1. Organizing all disperesed Muslim forces through the help of true ulama and all sympathetic and respansible Nuslims, 
2. Launching of Jehad against the enemies of Islam.

3. Delivering the sacred soil of Afghanistan from all kinds of colonilaism and exploitation.

t. Prompting and encouraging jehad in the hearts of all the Muslim people of Afghanistan for the , cause of God, freedom, progress and sacrifice.

5. Creating an atmosphere of good will with the states and countries of the world and particularly stretching a hand of fraternity to the world of Islam in accordance with the teachings of Islam. 6. Reaching to a stage of executing properly the religious, social, cultural, economic, political. and administrative affairs of the country in accordance with the complete implementation of the (teachings of the) Quran and the tradition of the Holy Prophet Mohammad, peace be upon him.

7. Creating a true and proper Islamic republic in Afghanistan.

8. Organizing all economic relations among the people of Afghanistan in accordance with the Islamic economic system and eliminating all un-Islamic habits and traditions so that on the one hand, the Muslim' and oppressed people of Afghanistan are delivered from the hell and homocitidal system of capitalism and, on the other hand, from the fire of atheism and communism. 9. Struggling against all kinds of discrimination and racialism and honoring the people on the basis of the standards of piety and delegating power to the people who are capable of executing a
task. 10. Struggling against unlawful groups and eradicating unethical behavior and opposition to the
shariat.

11. Nourishing the talents of young generation on the basis of correct and proper programs so they may be able to enjoin and guarantee faimess and prohibit injustice.

12. Reviving the legal rights of the women and orphans, and, in accordance with the principles of shariat, nourishing their standard of knowledge and education.

13. Implementing land reform and providing agriculturul land and pasture for the koochis (nomads) and homeless in accordance with the legal principles of the sacred religion of Islam.

14. Exerting fruitful efforts towards the restoration of the freedom and independence of all Islamic nations who are going through a bitter and unpleasant life in the fire of red or black Imperialism.

15. Defending the legal and firm rights of Islamic minorities in non-Muslim countries.

16. Preserving the geographical boundries of Afghanistan.

17. Fursuing a positive, active and neutral policy.

18. Paying attention to the construction and development of public institutions such as mosques, madrasas, schools, hospitals, dar-ul-hefaz (schools for memorizing the Holy Quran), etc.

19. Activating the cormercial and banking affairs of the country on the basis of Islamic shariat.

20. Mobilizing all the labor and human resources of (our) beloved country in a practical manner towards an allout promotion of industry and paving the way for the active and honorable participation of these forces in the development and construction of the (our) beloved country.

21. Paving the way in accordance with the true requirements of the armed forces for the physical and moral progress of the religious and patriotic elements for holsting the banner of "there is no cod but Allah and Mohammad is His Prophet". 


\section{April-June, 1988}

\section{AFEHAN JHAD}

Vol.1, No.4

\section{Charter of Ittehad Islami- e-Afghanistan}

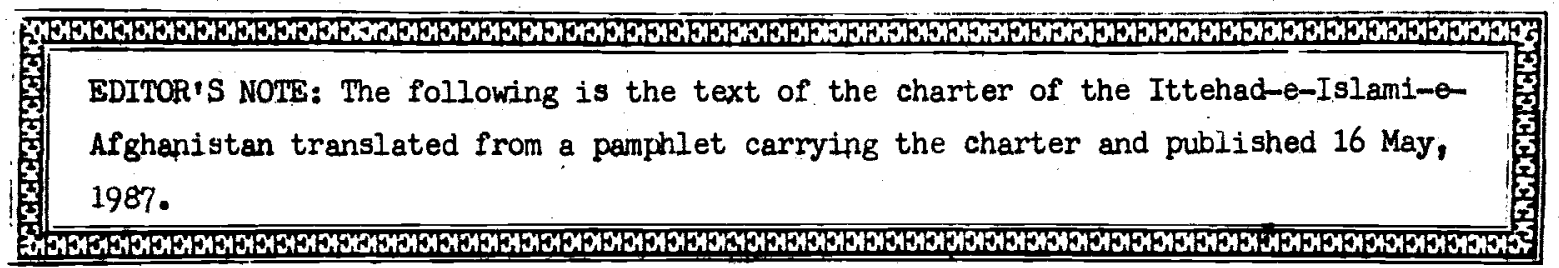

\section{IN THE NAME OF GOD, MOST GRACIOUS, MOST MERCIFUL.}

"Prajse be to God, the cherisher and sustainers of the world. The end of the affairs is (for the benefit) of those who fear cod. There is no trespass against any but the one who commits injustice. Geetings and peace to Prophet Mohammad and all his household and his companions until the hereafter and to those who have been guided to their path. But, then, Almighty God has said in his Holy Books

"God has promised, to those among you who believe and work righteous deeds, that He will, of a surety, grant them in the land inheritance (of power), as He granted it to those before them; that He will establish in authority their religion - - the one which He has chosen for them; and that He will change their (state) after the fears in which they (lived) to one of security and peace: They will worship Me (alone) and not associate anything else with Me. And if any reject faith after this, they are rebellious and wickedn. (The Holy Quran Sura Noor (Light) Verse 55).

The faithful Muslims and conscious ulame of Afghanistan, endowed with perception, during the obligatory times have discharged their duty towards da'wat (invitation to Islam) and jehad individually and collectively and, when the un-Islamic western democracy of the corrupt Zahir Shah regime in 1965 paved the way only and only for the emergence of infidel and atheist groups and parties, from that very time the conscious and knowledgeable Muslims of the country, on the one hand, decided to stand against, the oppression and corruption of the ruling order und, on: the other hand, prevent the growth and dissemination of irreligiousness and eradicate it..

We are a group of Muslims who, since that time, have begun our efforts towards invitation of the people to the religion of Almighty God for the sake of establishing the caliphate in the style of Khulfa-e-Rashedeen (the four Caliphs who succeeded the Holy Prophet of Islam, peace be upon him, one after the other). Our group, from the very beginning upto now, either in the framework of the organization of the Muslim Youth or in the framework of the activities of faithful, Muslims and conscious ulama, have followed the genuine Islamic line and, in the course of this period, we have been facing infidel and atheist activities and the institutions which have been guarding them and we have passed through trying and hard tests facing many difficulties which is in the nature of such a struggle and we have moved forward towards our objective. Our organization, which is now shouldering the brunt, of many difficulties, has been following a healthy and straight: forward path for the sake of the preservation of the objectives and genuineness of the jehad and, In relation to the vital issues and matters which decide the fate of the nation, is enjoying a proper and noble position. The believing sons of this assembly, who have now gathered in this organi- 
zation under the title of "The Ittehad-e-Islami-e-Afghanistan", by a deep grasp of their responsibilities towards their religion, jehad and Islamic land and with the understanding, awareness and grasp which they have from the teachings of Islam, are all desiring the unity of the nation and the ummah and consider divisions and disunity to be the biggest factor for a delay in our victory and success. The Ittehad-e-Islami-e-Afghanistan, while continuing its ceaseless efforts towards the unity of the faithful sons of the Jehad and unity of the Ummah, will (also) continue its armed resistance and rightful struggle against wrong in the light of the objectives, principles and fundamentals incorporated in this charter for the hope of victory of Islam and the rule of the Quran and establishment of the mature Islamic order.

\section{GENERAL PHOVISIONS}

Article 1- The name of our organization is "Ittehad-e-Islami-e-Afghanistan".

Article 2- Our objective is to achieve the pleasure of Cod Almighty by believing in Him and to properly follow the Book of God Almighty and the Sunnah of the Holy Prophet, peace be upon him.

Article 3- Our bellef is the belief of the Ahl-e-Sunnat wal Jamaat in the same manner that it was understood by our competent predecessors.

Article 4- (Verdict) and command belong to God.

Article 5- Our direction is (determined by) the Quran and we make all our rules and laws in the light of the Book of God and the Sumnah of the Holy Prophet Mohammad, peace be upon him, and in whatever case where there is no clear text and injunction (in the holy Quran and in the Sunnah) and ouch cases belong to issues related to iftehad (practice of religious jurisprudence), we follow the Hanafi. jurisprudence.

Article 6- Our understanding of Islan is not from particular angle but it is based on an under standing of this religion from all directions, the kind of understending enjoyed by the knowledgeable and authentic ulama of the ummah, the ulame who have followed the Sunnah of the Holy Prophet Mohammad, peace be upon him, and the Khulfa-er-Rashedeen.

Article 7- Our path is to enjoin what is fair and correct and to proflibit what is unlawful and jehad for the sake of Almighty God. Of course we are pursuing this path through an organized group which believes in the rules of Islamic shariat and is free of collusion and compromise and make use of the experiences of those who have already pursued this path.

Article 8- Our objectives are summarized in the following two phrases:-

a- to enrole the people to the worship of Almighty God, the Lord of all,

b to establish Islamic Caliphate (In the style of the four Khalifas after the holy prophet, peace be upon him) on the earth. Also we can explain our objectives (in more detail) in the following two sections:

i) SPICIAL OBJWCTIVES AND(ii) GENERAL OBJECTIVIS

i) SPBCIAL CBJECTIVES: These are: (a) recruiting Muslins individuals; (b) bringing up Kuslim fantlies; (c) creating of an Islanic society; (d) bringtng about an 
Islamic order based on the caliphate order; (e), unification of the Islamic ummah;

(f) restoring of all the occupied and usurped Muslim territories.

11) GENERAL OBJECTIVES: These are (a) propagation of Islamic da'wat (Invitation) throughout the world; (b) leading the process of enjoining correctness and fairness and prohibiting the unlawful; (c) leading the people from the servitude of the servants towards the servitude of the one and only God; (d) eradicating ovil from the surface of the earth (e) capturing of specific places of the world in accordance with the traditions of Prophet Mohammad, peace be upon him; $(f)$ jehad with infidels until they succumb to the objectives of the da'wat;

Article 9- Our line of action in these endeavours is sustained through knowledge and piety, belief and reliance (upon God), gratefulness (to God) and perservance and piety in this world and preference of the Hereafter.

Article 10- Our friendship and reliance are with God Almighty, the Holy Prophet, peace be upon him, and wth Muslims.

Article 11- Our enimosity is with the atheist, pagans, infidel, hypocrites, oppressors and other enemies of Islam. Our line of approach in our da'wat is based on wisdom, preaching of goodness, struggle in a proper manner and in the spirit of jehad.

Article 12- Our outlook is universal because our invitation to Islam is for the entire humanity and cannot be confined to a particular time, place, geographical borders, language and nation.

Article 13- Fraternity, helping each other and cooperation among all Muslims are obligatory and constitute one of our principles.

Article 14- We belleve in the Quranic saying that the Muslim umah is a single urmah and a multiplication of the Qiblas (objectives) and stretching away the land and boundaries of the Muslims should not pull away the Muslims from a single umah and we are andeavouring that the country and government of the Islamic umah should also be a single one.

Article 15- The basis of belongingness of the Muslims to each other and specially of the members of this organization are spiritual and moral and is not affected by material considerations.

Article 16- Our roward is with the God Almighty and we are not expecting any reward from anybody In this world.

Article 17- Ability, plety and efficiency are considered by us the basis for assigning duties to the people and we do not consider titles endowed upon the people for executing a responsibility as a privilege but, rather, as an obligation.

Article 18- In cases of assessing the bad or good qualities of a person and in cases of serving as a witness for friend and foe, we always consider God Almighty to be present and follow justice and faimess.

Article 19- Populepization of Islamic knowledge is anong the basic duties of our organization, restoration of Islamic way of Iife, nourishment of ethical standards and creation of 
the spirit of honoring one's obligations and undertakings are among the necessities of our organization.

Article 20- Each member of this organization, in addition to preparing himself to serve as a party activist for recruiting members and inviting people to Islam, is also a member of a committed army and ready to place himself in the trench of jehad and considers jehad to be his continuous obligation until the hereafter and is sure that; by doing so the process of invitation to Islam will get momentum and the doors for the da'wat will further open.

Article 21- Counsel, being among the important principles of the Islamic order, constitutes the spinal column of our organization.

Article 22- For the sake of better admihistration and execution of jobs, the following administrative organs will perform the related duties:

a) the Assembly of the Muslims; b) the Council of the staff; c) Supreme Council;

d) Leadership Council; e) The Amarat; f) the Deputy of the Amir;

B) (i) Department of the Secretariat (ii) Department of Justice and Verdicts (iii) Department of Finance and Services (iv) Department of Da'wat and Guidance ( $v$ ) Department of the Army (vi) Department of Political Affairs (vii) Department of Education (viii) Department of Cultural Affairs (ix) Department of Agencies ( $x$ ) Department of Refugees ( $x i$ ) Department of Health (xii) Department of Security.

Article 23- The principle of reward and punishment is being observed by this organization.

\section{THE ASSEMBLY OF THE MUSLIMS}

About the assembly of Muslims it is necessary to say that the preferred view is that this assembly is comprised of the ahl-e-hal wa agd (men of wisdom) who have agreed upon an Amir and the ummah (nation) follow them, although the purpose of the assembly. of Muslims is (to represent) the majority of the public of Muslims, Some others think that the assembly of Muslims is comprised of the mujtaheddin(religious jurisprudents). However, taking in view all these definitions, one can say that the majority of the Muslim public, for the sake of executing of their affairs, elect the elite of their representatives who have specific Islamic qualities, enjoy specific understanding and vision, piety and proper maturity and they, in turn on behalf of the ummah and the majority of the Muslim public resort to the election of the Amir. Of course, according to another interpretation, the assembly of Muslims comprise those who represent the entire umah and on behalf of that umah select (a single) Amir.

Since in present days such a condition does not prevail in the Islamic world, in the place of assembly of the Muslims we consider ourselves one of the essemblies of the Muslims. Yes, we are a group of the Muslims who have organized the people related to us and by following such an objective, among our other Islamic aims, we are also exerting efforts towards organizing and creating a (single) assembly of Muslims. Right now, as far as our organization is concerned - - the assembly which represents all the members of the organization and possesses special Islamic qualifications we call it the Council of the Staff. Therefore, the authority which in our organization ought to undertake the duties of the group of the ahl-e-hal wa agd is called the Council of tho Staff. For the rules, on the basis of which members of the Council of Staff are to be elected, separate regu- 
lations have been enacted in accordance with which the Council members are elected from among the members of the organization in accordance with the qualifications set forth.

\section{QUALTFICATIONS OF THE MEBERS OF THE COUNCIL OF THE STAFF}

1) Conformity with the five principles of Islam, wisdom, maturity, liberty and a varility; (ii) understanding of the Boak and the Sunnat to a degree to know Islamic obligations and religious necessities and distinguish between the lawful and unlawful and having a grasp of the general spirit of Islam and a general concept of Islamic order and knowing the objectives of the da'wat and jehad and analyzing the prevailing situation on the basis of the objectives of Jehad and a general insight about international issues; (iii) piety to an extent of being able to refrain from mortal sins and do not insist on committing minor sins; (iv) being bound to religious obligations and following the sunnah and an assiduity to. mustahebbat(religious precepts); (v) truthfulness; (vI) being bound to party rules and regulations; ( $V i i$ ) having worked for a minimun of nine years in the affairs of da'wat and jehad; (vili) having faith and concern about Hereafter and not being tempted by hypocricy and a lust for wealth and position; (ix) honoring his pledge; $(x)$ faimess in Judgement about his ownself and others; ( $x i$ ) economy and moderation in the affairs and refrain from extremism; ( $x i 1$ ) endowed with mental and physical joy, liveliness and dynamism; ( $x$ ili) having a spirit of sacriftce and selflessness; (xiv) should not be adventurous and should not try to impose his own views under all circumstances; (xv) should be able to keep secrets and exhibit maturity in discharging affairs; (xvi) should not have an undesirable background; (xvii) his party Iinks with un-Islamic groups should not have been proven; (xvili) should have had a raliance on Almighty God, the Holy Prophet Mohammad, peace be upon him, and for the cause of God on his oun Amir and organization and other Muslims; (xix) after reliance on Almighty Cod should have rellance and trust on his own self; (xx) should enfoy Islamic universelism and open-mindechess and believe in supremacy of Islam; (xxi) should practice chastity of speech and writing; (xxi1) should be a man of resolution and trust; (xoxii1) should be perseverant and patient; (xoxiv) should possess courage and valor and, in seeking the truth and rightfulness, should refrain from fear and rashness (xxv) in the framework of shariat, should be an obedient individual; (xxvi) should be perseverant and stable and ahould be able to refrain from instability and shakiness; (xxvii) elements of allegiance should be generally observed in him; (xoviii) should have be participated in the armed Jehad.

\section{THE DITIES AND POWERS OF THE COUNCIL OF STAFF:}

(1) Electing of the Amir of the-organization proposed by the Supreme Council from amongst its members by a two third majority, (2) taking decisions about peace and war, (3) electing members of the Supreme Council, (4) taking decisions about the vital issues such as dissolution of the organization, the merger of the organization with other Islamic groups and the form of the formation of the govermment, etc, (5) dismissal of the Amir after the approval of the issue by the Supreme Council with a two third majority of its entire membership.

\section{THE SUPREYE COUNCII}

Comed is a basic principle of govermment in Islam and its formation in all places and at 
all times is part of the obligations of the Muslim rulers. The decree of Almighty God and the practice of the Holy Prophet of Islam, peace be upon him, and of his esteemed associates all confirm this principle. Furthermore, to hold counsel is part of the nature of mankind and reduces the chances of committing errors in judgement and compensates for man's defect in analyzing and pondering.

For the sake of upholding the institution of Council and its special importance, value and role in the construction of an established Islamic society, special Islamic qualifications are called for the assumption of membership in the Council and since the number of members of the Council, for the sake of easiness in obtaining Consel and reaching at a decision, are to be limited, therefore, only a limited number of the nembers of the Council of the staff are being elected to serve in the Supreme Council and it is on this basis that the qualifications, required by the members of the Council of the Staff are also the same for the members of the Supreme Council. In addition to those qualifications, members of the Supreme Council should have the following qualifications as well:

(1) In the qualifications mentioned for the members of the Council of the Staff, members of the Supreme Council should have priority (2) should have a clean record of life in their relations with Almighty God and with the creation of Almighty God, (3) should have more knowledge of the Book (Quran) and Sunnah and of, what makes easy the understanding of the Book and the Sunnah such as language, Tafseer (Interpretation of the Holy Quran) and Hadis (the science of understanding the sayings of the Holy Prophet); (4) should have enough tntellect, perception, wisdom and experience and the horizen of his knowledge should be wide and extensive; (5) should be humble and forbearing and should not have a superiority complex over other people; (6) should be able to pay attention to the decrees and commandments of Almighty God and should have the status of their guardian; (7) in addition to observing (Islamic) obligations and essentials and following the Sunnah, should also heed Mustahebbat (religious precepts): (8) in addition to refraining from mortal sins and not insisting on committing minor sins, should also keep distance from the abominable(things disapproved but not absolutely unlawful) and incompassionate things; (9) should refrain from pessimism and not be swayed by unnecessary and exaggerated optimism; (10) should have special and fruitful knowledge in the field which he is asked to give advipce (11) in the election of the members of the Supreme Council the issue of delegating power to the people who have the capacity to discharge that power is being considered; (12) should have correct and proper perseverance and should not become tired and frustrated in the middle of the road.

DUTIES AND PONERS OF THE SUPREME COUNCIL

(1) enacting the Charter, the policy, laws and regulations (of the organization). in accordance with the principles of Islamic Shariat; $(\mathcal{)})$ determining the domestic and foreign policy of the organization; (3) extending vote of confiderice to the members of the Leadership Council whose members are being proposed by the Amir (COMAONT: In case the proposal of the Amir about the election of the Chairman of a department is not approved twice, the Supreme Council has the right to elect the concerned chairman at its own initiative); (4) approving of the budget and financial expenditures of the organization; (5) supervising the affairs of the executive organs of the organization through commissions; (6) interpellating and seeking answers from the Leadership Council or any of its executive councils; (7) amending or abrogating laws and regulations at times necessary; (8) in cases that are necessary, extending vote of no confidence to the Leadership 
Council or any of its members by a $2 / 3$ majority of all members of the Council; (9). if required, proposing the dismissal of the Amir to the Council of the Staff with a two third majority of all the members of the Supreme Council; (10) proposing the appointment of the Amir to the Council of the Staff; (11) defining the powers of the Amir and Leadership Council in the light of the excellent Shariat of the Prophet Mohammad, peace be upon him; (12) adopting proper decision for the improvement of the affairs of the organization; (13) issuing the financial and military regulations of the organization; (14) approving the general framework of the organization after the proposal of the Leadership council; (15) approving the proposal of the Amir of Ittehad in relation to the chairman of the Southwest region; (16) approving the proposals of the Amir in relation to the appointment of the provincial heads and committee deputies; (17) establishing independent institutions and teams outside the framework of the departments; (18) determining the financial and military powers of the Amir; (19) the Emirate and the Leadership Council are completely responsible to this Council about the enforcement and implementation of the regulations and the policy of the organization; (20) in cases other than excepted by the Shariat, all decisions of the Supreme Council are valid and enforceable.

\section{THE IEALERSHIP COUNCIL}

The Leadership Council consists of: (1) The Amir, (b) Deputy Amir, (c) Chairmen of the organs (d) Other important individuals of the da'wat and jehad, whose number should not exceed five.

\section{DUTIES AND PONERS OF THE LEADERSHIP COUNCIL}

The Council is established on the basis of the proposal of the Amir and the decision of the Supreme Council. Its members should be endowed with qualifications mentioned for the members of the Supreme Council. In addition to these, members of the party must be confident about their perception, enthusiasm, piety, carability and efficiency on the basis of their past experience and background. They are to discharge the following duties: (1) the actual functioning and guidance of the organization; (2) enforcing of the decisions of the Supreme Council,issuing better system and useful methods for discharging the affairs of the organization; (4[3]) organizing departments and organs for the sake of discharging the affairs of the organization; (5[4]) determining the needs of the jehad in relations to arms and supplies and cash expenditures and logistical material in the provinces and jehad centers; (6[5]) approving of the proposals by the chairmen of the organs about the members of their councils; (7[6]) approving of (the establishment of) relations and (concluding) agreements with governments and groups in the light of the policy of the organization: (8[7]) determining the departmental bucgets and extra expenditure of the organization; (9[8]) controlling and overseeing the daily affairs of the departments; (10[9]) determining the military bases, units and institutions of the jehad proposed by concerned departments (11[10]) approving the proposal of departments about the appointment of political agencies of the organization; (12[11]) approving the proposal of the Amir in relation to the appointment of the members of the Executive Council of the Southwest region; (13[12]) determining the work procedures and authorities of departnents; (14[13]) members of the Leadership Courucil shall not engage in duties which may bring to a standstill the affairs of the department or may be contrary to them.

\section{EAIRATE}

The Emirate is considered one of the important necessities of the Islamic life. Many indivi- 
duals and social obligations cannot be realized without its existance. Both Abu Saeed Khidri and Abu. Horaira have quoted the Holy Prophlet, peace be upon him, as saying "If three persons are embarking on a journey, they should appoint one from amongst themselves as their Amir." And since the obligation of the Amir is very important and grave, his appointment should be meticulousiy arranged and a person who may not violate the trust should be elected (as the Amir): The responsibility by its very nature is a trust, the same trust which, according to the Quranic verse "we did indeed offer the trust to the Heavens and the Earth and the Mountains; but they refused to undertake it, being afraid thereof; but man undertook it ..." The heavens, the earth and the mountains have expressed their helplessness to uphold and discharge the trust. It is on this basis that the Holy Prophet peace be upon him, has described the violation of this trust, which occurs as a result of Improper election of the Amir, one of the signs of the end of the world. At any rate, since Islamic life and even life in the society (in general), depends on the Bmirate and since care and precision in selection (per'se) are the basis for the welfare, improvement and goodness and heading it save the society from the danger of collapse and disaster, therefore, in addition to the qualifications requited for membership in the Leadership Council, the following qualifications are considered. necessary for the Amir. of course, the numerousness of these qualifications in our times and environment are to be relative.

1- He should be fair and just and his faimess and justice should be based on the five principles of Islam, intellect, maturity, freedom and virility. By intellect, according to scholars, it is meant the power of perception which will enable a person to grasp his responsibilities. Furthermore the kind of intellect which is meant for an Amir is not the intellect which distinguishes him from insane and provides him with the grasp of his responsibilities but it is the kind of intellect which requires the capacity to ask questions and delegate and define responsibilities and the one who falls to fulletl responsibilities entrusted upon a God loving and God worshipping individual cannot be considered as an iritellectual. The Quran says: had we (sinners) but listened or used our Intelligence, we should not (now) be among the comparifins of the blazing fire:" On another occasIon Almighty God has said. "It is those who are endued with admonition - - those who fullfil Coyenent of God and those who fail not in their plighted Word. "The required intelligencefor the Amir includes experience, prudence, wide range frursuance of knowledge, speed of understanding, sagacity, etc.

2. The Amir should be a scholar and his scholarship in the Boak and Sunnah and the Quranic and Sunnah sciences and in the Arabic language - - including its finities - - and in the principles of Shariah and deduction should be to such a degree to help him in being familliar with related commandments and verdicts on various questions in the revelations and in the remarks and sayings of the Holy Prophet, peace be upon him.

3- The Amir should be brave and valorous and the Holy Prophet, peace be upon him was the bravest man of the history and was endowed with a strong heart. Defining of the limits of affairs, implementation of lsws, control of the people who use their passions (against the detriment of others), and ruling the country recuire extraordinary courage and valor.

4- The Amir should be chaste. He should have chastity of speech and hand as well as of his self. He should not have greec: and inclination towards wordly things and towards what is of the people.

5- The Amir should be izenerous. Imam-e-Ghazall in his definition of generosity has said that when there is a noed for generosity thriftiness is tantamount to misery and spending is considered 
wastefulness when there is a need for restrain. And between these two conditions there is a condition of moderation which is called generosity and this is recommended.

6- The Amir should be fore-bearing because he might hear unpleasant things and tongues may speak to him about what is in their sorrowful hearts or people might deal cruely with him because of their ignorance. Under all these conditions, it is befitting for an Amir is that he should exercise forebearance.

7- The Amir should honor his promises and commitments. Of course this is a necessary ethical standard for all Muslims specially for those who are engaged in inviting others to Islam but above all for the Amirs and those responsible for discharging public affatrs. Because this qualificstion enhance trust and, on the contrary, its ausence creates an atmosphere of doubt and hesitation and weakens confidence and trust.

8- The Amir should be patient and perseverant. Since the path to invitation to Islam has many ups and downs and is full of thorns and its responsibilities are many and its obstacles, sufferings and trials are consistent and successive, therefore all the workers of Islamic Tehrik, and specially those who are in charge of the affairs should enjoy the qualities of patience, preserverance and consistency in action and should have noble aspirations and practical wisdom: "ch you who believe, seek help with patient, perseverance and prayer: for God is with those who patiently perseveren, (The Holy Quran) mOh you who believe, persevere in patience and constancy; vie in such perseverance; strengthen each other; 'and fear cod; that you may prosper' (The Holy Quran).

9- The Amir should enfoy the quality of utmost forgiveness and, as a number of wise men of Islan . have said, "the best quality of the Kings is the quality of forgiveness." And the Holy Prophet, peace be upon him, has said "exercise mercy so you may receive mercy and forgive so you may be forgiven." Forgiveness makes the Amir popilar and beloved in the eyes of God and among the creation. In forgiveness man gives up, despjte the fact he has the power to revenge (and recover his right). Almighty God has given the Amirs and those in charge of affairs the power to revenge. Hxpecting forgiveness in cases related to the Emirates is greater then ordinary circunstances. 10. The Amir should be frlendly and kind. The Holy Prophet, peace be upon him, has said, "the worst shepherd is the cruel shepherd." On another occasion the Holy Prophet, peace be upon him, has said, mindoubtedly God is gracious and loves graciousness." And on another occasion he says, "Oh, God, pleasebe gracious to the one who executes any affairs of my Ummah and expresses kindness to my Ummah, and please show softness and lentency to any one of my Ummah who executes any affair of my Ummah.

11- The Amir should be gentle and should avold harshness and peevishness so that the people may gather around him with love and voluntarily and without hesitation. And, if it is not 80, the people will become disgusted with him and he will lose his central role. Almighty God has said about his Holy Prophet Yohanmad, peace be upon him, "It is a part of mercy of God that you deal with them gently. Were you severe or harsh-hearted, they would have broken away from about you."

12. The Amir should ponder (In the execution of affairs) and should refratn from hastiness. Almighty God has said "Oh you who believe, if a wicked person comes to you with any news, ascertain the truth, lest you harm people unwittingly and afterwards become fuil of repentence for what you have done." The wise men of the Unmah say prosperity is with those who ponder and refrain from hastiness 
and it has been also said that pondering (and having a second thought) about things is fortification for safety and hastiness is the key for repentence. Truly a return from fait accompli is of no use. All people, specially the Amirs and those who are engaged in important and vital affairs of the people, should not issue verdicts or embark on things with hastiness because it will worsen the affairs and entail regret.

13- The Amir should be horest and truthful. The Holy Prophet, peace be upon him, as quoted by Salman-e-Farsi, has said there are three persons who will not enter the Paradise: the old man who commits adultery, the leader who says lies and the arrogant beggar." Yes, honesty and truthfulness provide man with dignity and increase his value and reverarce among the people and, on the contrary, deceit and lie destroy man's confidence and value and people will not respect him.

14- The Amir, in addition to reliance and resolution should have complete decisiveness and should be free from hesitation and inertia. Those Amirs who lacked decisiveness will actually incite the opportunist to resort to further evil and corruption and deviate. Lack of decisiveness will always keep the nation and the subjects in an atmosphere of wander and uncertainty and will pave the way for speculations.

15- The Amir should be honest and trustworthy. This honesty is all embracing. The Amir is the guerdian of the property, life, religion, honor, dignity and safety of the subjects and territorial integrity of the nation. "On you who believe, betray not the trust of God and the apostle, nor misappropriate knowingly things entrusted to you." (The Holy Qựan).

16- The Amir should have prudence in the context of jehad. In other words, in addition to having a high spirit of jehad he should be aware of the conditions and relations of the environment affecting the Jehad and should enjoy complete awaremess of the pursuance of the jehad and of preserving and guarding its results and quantity. In analyzing, interpreting and adopting a stand and reaching a conclusich, he should not be influenced by deceitful rolitifis of the tine and his jehad tactfulness should prevail.

17- The Amir should enjoy the gualities of speed in action and enthusiasm in discharging his affairs. For he is an example to others and people tume their speed and enthusiasm in executing their affairs in according to his pace of action and enthusiasm. Frrtlielmore, in comparison to the multitude of obligations, the time at our disposal is very limited or, in other words, the volume of responsibilities is greater than the time and opportunity available and, thus, we have to discharge many tasks in a short period of time and during a limited amount of opportunities.

18- The Amir should have domination over his work and should not be overwhelmed by helplessness in discharging his responsibilities because such a sense of helplessness is the first sign of defeat and failure and, furthermore, unless man has dominance over his work, the possibility of instability in the affairs and failure to execute properly one's job will always exist.

19- The Amir should have the avility to manage. In other words he should have the power to manage the affairs making use of better methods, and coordinate the training and employment of his subJects in a proper manner taking in view the priorities and, within the franework of laws and regulations, evolve them as a single body and, assign them proper positions within an appropriate franework.

20- The Amir should have the capability of leadership. In other words he should be able to execute 
in the best manner the tasks of the delegation of power (to others), controlling, employing and achieving results. During the execution of affairs, he should enjoy the support of and popularity among the people and should mobilize his followers easily and properly towards the realization of the Islamic objectives of the organization and should make maximum use of the talents and capability of his people and preserve the unity of his followers.

21- The Amir should not have inclinations towards special individuals and cliques within the organization because this will serve as a great detriment to the unity of the organization and reduce the general support and trust and thus the Amir will lose his (public) support among his followers. of course this does not mean that he should refrain from rewarding and caressing the good members of the organization and from the support of what is right and holding justice among members of the organization.

22- More important is that the Amir should be among the adherence and students of the Hereafter His heart should be enpty of love for material things and wealth and of attaining higher positions and his action should be purely for the sake of Almighty God.

23- The Amir should have a clean heart and his mind and heart should be clean towards his subjects and followers and this requires that he should not succumb to backbiting. of course, it does not mean that the Amir should not make use of seeking information and closely controlling and following things for the sake of the preservation of public security and interest because the latter is among the requirements of the Emirate and government.

24- The Amir should enjoy Islamic moderation in all affairs and should strongly avoid extremism which will result in difficulties and unpleasantness. The Amir should not be skepticle and should be hopeful about his future and should create hopes among his followers as well. Of course unwarranted optimism, too, is not worthy of an Amir.

THE DUTIES AND POWERS OF THE AMIR:

The following are the duties and powers of the Amir:

(1) (POWERS:) serving as the Chief Cormander of jehad in Afghanistan; (2) serving as President of the Councils of the Staff, Supreme Council and Leadership Council; (3) implementing the policy and plateform of the organization(Ittehad-e-Islami Afghanistan) in accordance with the promulgated rogulations; (4) signing of the decision for the sake of its enforcement and promulgation; (5) signing of International agreements and treaties after their approval by the Supreme Council; (6) proclamation of war and peace after the decision of the Council of Staff; (7) proposing members of the Leadership Council from among the members of the Supreme Council to the Suprene Council; (8) proposing members of the Supreme Council from among the members of the Council of Staff to the Coincil of Staff; (9) approving the appointment of the deputies of departments and director generals and directors; (10) appointing and transferring of the officials lower than the rank of the members of the comittee councils; (11) the Amir of the Ittehad has the power to grant 10 of the total cash, kind and military property of the organization through extraordinary orders as it is deemed necessary and required. Of course he can grant upto $15 \%$ of the military supplies; (12) the delegation of a part of the powers of the Amir to his deputy is also within the power of the Amir; (13) for the sake of the execution of related affatrs, he can delegate from his powers to one or several people; (14) proposing the deputy of a depertment to the Supreme Council on the basis 
of consultation with the chairman of the department, (15) proposing the heads of provinces to the Supreme Council; (16) proposing the chairman and members of the executive council of the Southwest Region to the Supreme Council and Council of Leadership; (17) appointment of the one tenth of the membership of the Supreme Council from among the members of the Council of Staff (COMMEN: (A) the deputy of the Amir in case of the presence of the Amir serves as his aide and in ausence of Amir holds his powers; $(B)$ in cases of emergency, the Supreme Council can make use of the powers of the Council of Staff, the Leadership Council from the powers of the Supreme Council and the Amir from the powers of the Leadership Council, provided that in the first meeting (of the concerned council) information and satisfaction are provided to the responsible authority in relation to the emergency, its extent and the intrusion which has taken place.

\section{DUTIES OF THE AMIR}

(1) guarding of the sanctities of Islam, defining the limits of the Shariat of Almighty God, not allowing usurpation of the principles, fundementals, fites, regulations, values and ethics of Islam; (2) supervising the implementation of promulgated rules and regulations; (3) responsibility before the Council of Staff, Supreme Council and Leadership Council in regard to a failure to execut the affairs on the basis of the promulgated principles and. laws; (4) carrying through the ideas and policies of the organization on the basts of the provision of this Charter; (5) submitting the monthly report of the activities of the Leadership Council to the Supreme Council and of the six months report of the activities of the Supreme Council to the Council of Staff (6) subaitting political accounts about the Afghanistan issue and the Islamic World from time to time to the Leadership Council and Supreme Counctl.

\section{MISCELLANDOUS}

(1) The tenure of office of the Amir is not limited; (2) the term of office in the Supreme Council and the Bxecutive Counctl is three years; (3) every regulation, in former laws and regulations of the organization, if contrary to the provisions of this Charter, is null and void; (4) any amendment and change in this Charter can take place after a proposal by the one third of the entire membership of the Supreme Council and the approval of the two third of the entire membership of this Council. 


\section{April-June, 1988 \\ AFHAW WHAD \\ V01.1, No.4}

\section{International Amnesty Still Concerned About Human Right Abuses by PDPA, Russians in Afghanistan}

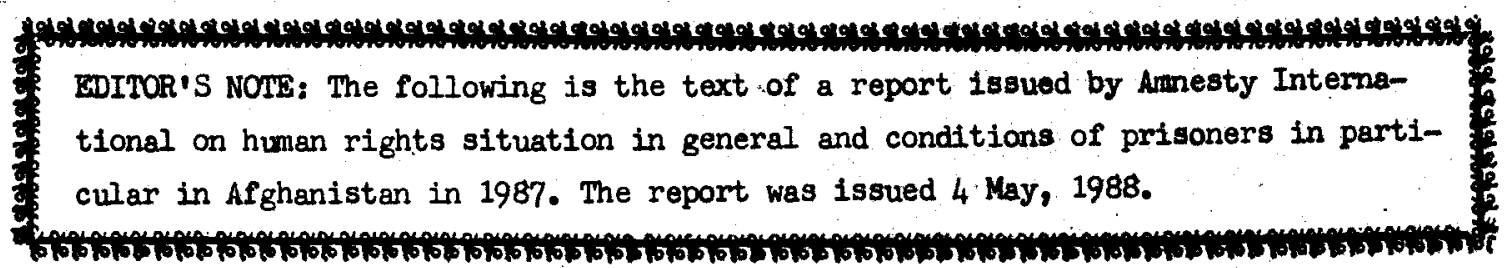

\section{BACKCROUND}

On 1 January 1987, Dr Najibullah, the General Secretary of the ruiling People's Democratic Party of Afghanistan (PLFA) and now also the country's President, announced a policy of National Reconciliation. He listed six principles of reconciliation - a cesse-fire for six months, an end to armed struggle in order to resolve political differences, just representation in the political structure and economic life of Afghanistan of political groups other than the PDPA, a general annesty, protection and consolidation of historical, national and cultural traditions, and respect and observance of the sacred religion of Islam. This policy was announced with the full offictal. backing of the Soviet Union.

The Reconciliation policy was rejected by the armed opposition which said it was aimed at allowing the Soviet Union to remain in Afghenistan while getting the opposition to disarm. The amed conflict in Afghanistan intensified during 1987, particularly in the northern part of the country and in the south-eastern province of Kandahar. Unarmed civilians continued to be victims of the war. The UN Special Rapporteur on Afghanistan estimated that there were just over 14,000 civilian casualties between the end of 1986 and August 1987. As a result of the escalating conflict, the refugee influx into Pakistan continued. In August 1987, according to the official Pakistani registration lists, there were 3,156,569 Afghan refugees in the country. The UNHCR estimated that there were 2.2 million Afghan refugees in Iran. Afghans formed the largest refugee group in the world.

In this situation of political polarisation and amed conflict, it was defficult to confirm and corroborate testimony on human rights violations within Afghanistan; most information came from rafugees who had fled from the conflict. Amnesty International interviewed refugees in Pakistan and India during October to December 1987. The testimony was taken from the victims and witnesses of human rights violations. This paper limits itself to cases on which first-hand information could be gathered from victims and witnesses. Due to a continuing sense of personel insecurity and political uncertainty, most informants did not wish to be named.

Amnesty International is concerned about evidence of a policy of deliberate killings by 
Soviet and Afghan government forces during 1987 of Afghan refugees moving towards Pakistan. This targeting of refugees has been descrilie in the testimonies of survivors and witnesses of such attacks. Amnesty International is equally concerned about the deliberate killing of unarmed civilians in reprisal for attacks by armed opposition groups. It is further concerned about continuing torture in KHAD security police interrogation centres, military posts and in the Pul-e-Charkhi central prison in Kabul; and about political prisoners who were taken directly from prison into military service.

The attacks on refugees occurred in the context of the governnent's National Reconciliation policy of 1 January 1987. The goverriment had proclaimed under that policy that it wanted Afghans already abroad to come home. As for those taken directly into military service from prison, it was officially announced that they were "released" under an amnesty declared as an integral part of the National Reconciliation policy.

The negotiated withdrawal of Soviet troops from Afghanistan, if implemented, would reinforce the responsibility of the authorities in Kabul to make every effort to Investigate past incidents of unlawful kjlilings and torture and to bring to Justice those involved in these incidents in order to curb the future occurrence of such illegal acts. Amnesty International has written to the Afghan and Soviet authorities spelling out these issues.

\section{EXTRANUDICIAL EXECUTIONS OF REFUGEES}

Sovilet and Afghan government military forces seem to have been carrying out a policy of deliberate kfling of refugees fleeing to Pakistan by attacking buses and groups of women, children and men moving on foot and on horseback. Most of these refugees were fleeing from the intense bombing and shelling of their villages by Soviet and Afghan Government forces retaljating against hit-and-run guerri]lia attacks by the armed opposition.

Amesty International uses the term extrajudicial execution to describe unjawful and deliberate killings carried out by governments or with their acquiescence. In armed conflicts, extraJudicial executions are distinglishec from killings that occur as a direct consequence of clashes between contending parties - such as the killing of civillans during attacks on positions defendod by warring parties - and from killings by accident or error.

Amnesty International has received first-hand information from eye-witriesses and survivors of attacks on refugees. A farmer, aged 30 , who is a refugee in Pishin district in the Baluchistan province of Pakistan, and does not wish to be identified, has provided details of two attacks on the group he was trekking with on their way towards Pakistan. Two other members of the group have corroborated his testimony. This account is based on their statements.

The group of about 100 families left their village of Sherkhudo in Darzab district of the extreme north-western province of Faryab, bordering the Soviet Union, in mid-September, 1987, after the intense bombardment of their village by government forces due to the presence there of members of the armed opposition. Most of the group trekked on foot and a few on borseback or on donkeys for two months before reachire the borcier near Pishin in Pakistan, which is 500 kilometres (as the crow flies) from Faryab.

In early October, about a quarter of the way through their trek, a guide who the refugees suspect was a government agent, found out that they were attempting to leave Afghanistan. He led 
them to an 1solated field near Darg-e-Takht ir Herat province where they were surrounded and fired on by government forces without any provocation. They sald they were defenceless as there were no armed men within their gloup bud that rifle-fire and shelling killed 19 of the refugee group and wounded three. Among those who died, seven were children: Mohammad Afzal, eight months 0ld, son of Maulvi Abdul Haqi Khajrullah, a year old, son of Salfuddin; Bibi Zara, 14 months, daughter of Khan Mohammad Rashid, three years, son of Sultan; Sayyed Rahman, also three years, son of Fakir Mohanmaci; Sher Alam, five years, son of Ahmed Shah; and child whose name is not known. Pive women died in the attack, As is the Afghan custom, their names were not divulged. Seven men died - Sija Khan, aged about 1E; Abdul Nabi, 22; Dost Mohammad, 25; Mninullah, 27; Gulgulab, 30; Khawaneen, 38 and Baseer, 45.

Fifteen days later, the refuge group was attacked agaln, They were encamped in a field whose exact location they do not know, but wich is sonewhore in the Iashkargah area of Helmand province. They said there had been no fighting in the area. Three, apparently Sovlet, helicopters arrived and opened fire without warning on the refugees. Rockets fran the holicopters kIIled five men; Mullah Mohamad Gul, aged 17, who was given the title of Mullah at an early age as he was already well-versed in the religious texts; Spin Gul, aged 18; khan Gul, aged 20 ; Lohammad Afzal, aged 28; and Maulvi Saheb Khan; aged 35.

A 12-year-old Uzbek boy from Dahana-o-Ghouri village in the northerm provlnce of tunduz, who is a refugee in Pishin district of Pakistan, and whose nume cannot be divulged, told Imesty International of another attack on trevelling civilians by government forces which he sald took place in mid-October 1987. He, his widowed mother, whose husband had died in an eir bonberoment of the village, and some other persons from his village, were walking on their why to Pakiatan when they were fired on without warning by government forces lying in wat on both sides of a road. Helicopters also fired rockets at the refugee group. Two persons were killed in the attack and four were wounded, Including the boy. An ugly, half-healed flesh-wound an the calf of his laft leg was clearly visible during his interview. He was close to tears while recounting the incident. He did not know exactly where it hadihappened.

Another incident was recourited by an Afghan peasant, aged 20 , in a refugee camp in Peshawar district of the North-West Frontier Province of Pakistan. He sajd that In Soptaiber 1987 government soldiers supported by tanks surrounded the group of refugees with whon he was trekking near Sarak Mazar village in the Pul-a-Khumri area of Baghlan province.Hoat of the refugees vere arrested, two were shot dead on the spot and some, including the pessant, ran away. The peasant who witnessed this attack had been living in Archa in Kundus province before he decided to leave Afghanistan.

Another peasant from the Dasht-emarchi area of Kunduz province said he decided to leave his village and take refugee a road some weeks after he lost three of his sons and his house during a July 1987 combined assault by Soviet and Afghans plenes and tanks on the village. He said this attack was in retaliation for an ambush of Soviet forces by an armed opposition group led by Maulvi Padal, and came after the group had retreated, so that most of the victims were unarmed villagers. About 300 families left the village a few weeks after the assault. Only a few persons stayed behind.

According to his teotimiony, the peasant's extended family of 15 persons trekked on foot from 
Dashtmo-Archi and in September 1987 reached the Pul-e-Khumri area of Baghlan province, where they were attacked. The children of the family were playing in an open field watched by the adults sitting near a hillock. When planes attacked, the adults took shelter by the hillock while the childaren were caught in the open in the bombardment. The peasant from Dasht-e-Archi lost another of his sons, aged five, and two of his daughters, aged eight and ten.

At the end of May 1987, a student teacher, aged 21, from Kabul, travelling with 80 other refugees towards the Pakistan border, sald he found the bullet-ridden bodies of about 130 persons whom he belleved were refugees using a known refugee trail leading towards Pakistan. The condition

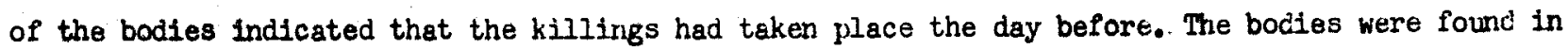
the Yakpaya valley of Charkh aistrict of Logar province, near the Pakistan frontier.

Nost of the reported cases of killing of refuges attempting to leave the country occurred In 1987, after the annourcement of the National Reconciliation policy in January that year. Amnesty International has, however, received some reports of unlawful killings of refugees in 1986. According to an eye-kitness, one group of refugees was attacked on 16 November 1986. He said that 14 people, includine two women and a child, were killed and five people were wounded when a Toyota mini-bus carrying 32 passengers towards the border, 60 kilometres away, was attacked without provocation on a road in Fakiran sub-district, about five kilometres from Zargonshahr. town in Paktika province. Survivors said they heerd the atteckers shouting in Russian cluring the ambush. There had been no recent fighting in the area but Soviet troops had been discouraging movement close to the border.

The killing of refustes trying to go abroed has been accompanied by attempts to encourage refugees who are already abroad to return home, in line vith one of the stated goals of the National Reconeillation policy. At times, the attempts at persuasion have been accompanied by arrests. According to his nephew, a 67-year-old man in Kabul was arrested in March after he rejected police officers' requests to write to his step-brother in the United States to return to Afghanistan. The man told the police officers that be was not on good terms with his step-brother and therefore he could not persuade him to return. He was then arrested and at the end of 1987 he was believed to be still detained.

Public criticism of the National Reconciliation policy bas also reportedly led to detention. A cloth merchant, aged 40 , from Kabul is reported to have objected to a call for national reconciliation made in a speech by an official of the ruling Feople's Democratic Party of Afghanistan (PCPA) after prayers at a central mosque in Kabul on the occasion of the holy Muslim festival of Id-a-Khorban (also known as Id-al-Adha) on 5 August. The cloth werchant asked the party official how there could be nationsl reconciliation while Soviet soldiers remained in Afghanisten. On the fourth day after the Ic-o-Khorban festival, KHAD agents in a jeep came to his house and took him to their Sedaratrinterrogation centre. A few days later he was shifted to Pul-a-Charkhi and was reported to be still in detention at the end of 1987.

\section{OTHER REPORTED EXTRAJUDICIAL EXXCUTIONS}

There were also reports of alleged summary extrajudiclal executions of Afghan civilians who remained in their homes despite the war. An eye-witness recently reported an incident which had taken place a year earlier, on 13 October 1986. He says six tanks and some military vehicles ent. 
ering Chardee village, two kilometres from Sharan tow, the capital of Paktika province. The witness was in Amberkhel, a neighbouring hamlet, from which the houses and streets of Chardee are clearly visible. The Afghan soldiers from the convoy, directed by Soviet advisers, ordered everyone to stay in their houses. They searched each and every house. They found no guerrillas and no arms. They seized two men Prom their homes, one of whom was a known sympathiser of the resistance while the other was the son of a sympathiser. They marched the two men to the wall of the little local fort behind the village and shot them. One of the executed men was Abdul Majid, 60.' The other man to die was aged 30. His name cannot be divulged as his father still 1.ves in Chardee.

Similar killings continued in 1987. A 32-year-old former official of the Information Department of the Ministry of Frontier and Tribes, now the Ministry of Nationalities and Tribal Affairs, reported that 17 civilians, all males aged from 14 to 60 , were killed by government troops in August 1987 at Mushwani village in the Mir Bacha Kot district of Kabul province. They were said to have been killed with grenades after which their bodies were dumped in a well, apparently in reprisal for the killing of some govermment troops by guerrillas in an earlier incident near the village.

Two Norwegian nurses and an Afghan paramedic who had been working in Ghazni province for some months in 1987, separately confirmed that they had met and examined a man who had survived despite having suffered over a dozen bullet wound during a reportedly unprovoked attack by Soviet soldiers on a civilian bus in March 1987. According to their account, there were 45 men, women and children in the bus, of whom on'y three survived. Two of those who survived had managed to $\operatorname{run}$ away whlle the man with multiple wounds hod successfully feigned death, although he claimed the Sovlet soldiers had checked other victims after their initial attack and shot dead those who were.discovered to be still alive.

A peasant, aged 50, related another incident of apparent reprisal killings of civilians in his village of Sabzak in the Nareen sub-district of Baghlan province on 6 September 1987. Artillery shelled the village without any immediate provocation and eight persons were killed, including the peasant's daughter, Bibi, aged eight, and his brother, Mohammad Hasan, aged 60. The other villagers killed were two women - Gulbegum, 20, and Zeba, 30 - and four children. Two of the children were Daulat, four, and Amir Khan, four. The names of the other two children are not known. Sabzak village had earlier sheltered guerrillas of the armed opposition but there was reportedly no fighting in or near the village and no guerrilla presence when the village was shelled. The assault appeared to be purely punitive in nature, in accord with the principle of collective responsibility for guerrilla actions in and around the comnumity.

On 10 October 1987, Soviet forces reportedly set fire to a vehicle carrying 29 marmed civilians, most of them women, children and old men, apparently after stopping it in a narrow gorge between Dadu and Khoshi in Logar province. All those in the vehicle died. The Soviet attack may have been a reprisal for a guerrilla ambush the day before in the same gorge in which 17 Soviet soldiers had been killed. A second source corroborated this version of the incident.

The director of a hospital for Afghan women and children in Quetta, Pakistan, confizined that the hospital often receives and carries out surgical operations on women and children to remove: bullets lodged in their bodies. For instance, according to the hospital's surgical records, a bulle vas rewoved fram the sacral region of the spine of a woman, Whand1 Gul, on 29 November 1987. 
which she said had been fired at her about a year before when the bus she was travelling in wa attacked without provucation by government forces in Ghazni province.

On 16 January 1988, 12 men belonging to the armed opposition were taken prisoner in Kolalgu village of Paktia province by a mixed group of Soviet and Afghan Government troops. According to testimony provided to a representative of Amnesty International by two of the prisoners who survived, the 12 men were marched into the village mosque and their hards were tied behind their backs by the Soviet and Afghan soldiers. Rockets, mortar shells and ammunition were brought into the mosque by the soldiers and piled up next to the prisoners. A detonator operated by a cable leading into the mosque was then used to blow up the mosque and the prisoners within it. Three prisoners survived the b-ast while nine were killed. One of the survivors was seriously injured with irectures in both his legs. The other two got away with relatively minor injuries and recounted this incident after escaping into Fakistan. The explosion in the mosque also caused the death of seven children when an adjacent house collapsed on them. The testimony of the two prisoners was corroborsted by several other persons from Kolalgu who had witnessed. the incident.

\section{TORTURE}

Amnesty Intermational has interviewed a number of Afghans who described having been tortured during 1987. These testimonies indicate that torture continues in Afghanistan, although the available information suggests torture may not be as systematic and as routine a form of interrogation as it was till early 1986. However, the extent and frequency of recent torture cannot yet be assessed because many of those detained by govermment agencies in 1987 have not yet had the opportunity to disclose their experiences under detention. Those who have been able to relate their detention experiences were held for short periods or managed to escape from security police or military detention centres. Others described having been tortured shortly before their release from Pul-e-charkhi prison in Kabul.

One of those detained for a short period was a woman of 36 who was formerly a stock-keeper at a govermment pharmacy in Kabul. She was arrested near Jalalabad town while trying to get to Pakistan. The owner of the house where she was staying was also detained. They were taken to a Jalalabad detention centre which seemed to be under the control of the KHAD security police (KHAD has been renamed as WAD - Wazarat-e-Aamniyat-e-Daulati, Ministry of State Security, but is still generally known as KHAD).

The women says she was verbally abused, beaten and given electric shocks with wires attached to her ears and feet. Then the interrogators, whom she was able to identify by name, sat on her feet and sharply banged her knees together. The torture took place during the first two days of her detention while she was kept in a small cell. She could not lie down in the cell because the floor was strewn with sharp pebbles and stones. She was not taken to the toilet. A bucket in the tiny cell served as a toilet and attracted hordes of mosquitoes. Her daughter was reportedly severely beaten and was not allowed to see her mother during the two days at the detention centre.

After two days of interrogation, she said she and her daughter were transferred to the Jalalabad prison where she was kept for 20 days before being released. In the prison, she was kept in a room with 40 women and their small children. All but 10 of the women were in prison in connection wth allegations either of trying to go to Pakistan or helping the resistance. The prison 
authorities did not provide any food. A friendly guard smugglod in one piuce of bruad a day for her. Other prisoners had to bribe the guards to get something to eat. Water was provided in dirty buckets. There were no toilet facilities. The prisoners had to use a half-demolished room as a toilet. Her ordeal at the detention centre and at Jalalabad prison has caused severe psychological problems and she has been undergoing treatment at a psychiatric clinic in Pakistan after having managed to cross the border on her second attempt.

A young guerrilla fighter, aged 18, was captured in action by Soviet troops near Nani village in Ghazni province in May 1987. He was in possession of a rocket-launcher when captured. He said he was taken to the local Soviet military headquarters at Eenote village wher he was beaten with sticks. He was then confined to a basement for 15 days and beaten on four occasions.

From the basement at the Soviet headquarters he said he was removed to the KHAD interrogation centre in Ghazni town and questioned about the identity of his accomplices in the armed opposition and weapons' sources. During his first week at the KHAD centre, he was beaten every day. During his second week, he was given electric shocks three times with wires tied to his tongue, ears, fingers and toes by KHAD agents. He said that during the interrogation-and-torture sessions, two Soviet officers took notes of his replies to questions and, on one occasion, they attached the wires for shock treatment.

After two-and-a-half months at the KHAD centre, he was being taken to the main prison in Ghazni when he escaped, with the help of the opposition. He was brought to Pakistan for medical treatment. He was still suffering from severe pain on the left side of his stomach due to the beatings and shocks when interviewed by Annesty International at a medical centre in Peshawar. He was also unable to sleep and was in a chronic state of fear.

An 18-year-old student of Persian (Dari) literature at Kabul University died on 20 April 1987 apparently as a result of torture at the KHAD detention centre at Shashdarak in Kabul. He was arrested at his family's home by KHAD agents on 1 April in the presence of his parents, sister and three brothers. According to one of the brothers, who later came to India as a refugee, the KHAD agents said that they were arresting the student for "anti-revolutionary activity". The brother claims that the young man was never involved in violence, though he did distribute opposition pamphlets, locally called shabnameh (night letter). He was in perfect health when arrested. After several weeks of fruitless inquiries about his fate, friends of the family suggested that they should make further Inquiries at the Four-Hundred-Bed Irmy Hospital in Kabul where detainees injured during interrogation are often taken. The family discovered his name on the list of dead posted at the hospital. The list stated that he had died an 20 April. It did not state the cause of of death. His body wes not retumed to the family. As the rest of his family are still living in Kabul, the brother in India does not wish to make public the name of his dead brother.

Another student, aged 21, who was also taken to the Four-Hundred-Bed Army Hospital in Kabul after being injured during interrogation, later give the following account. He had gone to the village of Pashaee, in the outskirts of Kabul, on 5 May 1987 for the nourning ceremony of his brother, a guerrilla of the Jamiat-e-Islami opposition group who had been killed ir action during a battle with government troops on 18 April in the same village. Sporadic fighting nad continued around Pashaee and on 8 May government forces fired at the village with a multiple rocket launcher. In the attack, the visiting student was infixed on his head, back and nose, and lapsed into a semi. 
conscious state. Soon after, the troops entered the village and rounded up all males between the ages of 16 and 50. They were then transported to the Shashdarak centre of the KHAD in Kabul. He was still bleeding from his injuries when he was tied to a chair and questioned about his connections with the armed opposition. During the questioning, the niddle three fingers of his right hand were branded with a hot iron. After 48 hours at Shashdarak, he was moved to the Four-HundredBed Army Hospital. Eight cays later he escaped from the hospital with the help of a cousin who was a guard there. Scars on the upper surface of the three fingers of his right hand were still visible when he was interviewed in India.

Beatings and physical abuse during 1987 have also been reported to Amnesty International by ex-prisoners who were held in the Pul-e-Charkhi central prison in Kabul. Often the beatings and ill-treatment were administered by prison warders for minor transgressions like reading a religious book or demanding the right to collective prayer as is prescribed in the Islamic code. At other times, ill-treatment followed what were regarded as more serious offences such as distributing mujaheddin (armed opposition) literature anong prisoners. Some of those who were about to be released and taken straight into military service were reportedly beaten for refusing to appear. on television to praise the govermment's policy of National Reconciliation. Other prisoners were kept in isolation for a week for refusing to sign a statement in favor of the National Reconciliation policy. One prisoner alleged that in April, 1987, he was so severely beaten for refusing to spy on fellow prisoners that one of his ribs was fractured. A group of 23 prisoners was kept in 1solation in March 1987 for attempting to inform a foreign visitor about prison conditions. Some prisoners were beaten just before they were relessed and taken straight into military service in an apparent effort to intimidate them and thereby prevent them from engaging in any ant1-government activity.

Among those physically ill-treated at Pul-e-Charkhi was an engineer who later told Amnesty International that he was repeatedly requested to appear on television and testify in favor of the government but had refused. One morning in Jume 1987, prison officials took him to a room and said that they wanted to discuss his forthcoming interview on television. He refused to discuss the matter. The prison officials reportedly started beating him, pulled his hair and then dragged him Into a bathroom where they pushed his head into a toilet bowl. They kept him in the bathroom all morning. In the afternoon they transferred him from prison straight to a military barracks to serve in the army.

A former car mechanic, who was imprisoned at Pul-e-Charkhi for seven years and was transferred to do military service on $27 \mathrm{May}, 1987$, said that earlier in the same month he was severely punished for distributifig the (Holy) Quran and religious and resistance literature among the prisoners. He had also been exhorting prisoners to support the resistance. Informers inside the prison reported his activities. He was taken to an isolated roon and beaten till he became unconscious. His beard was pulled and his face was pushed into a tollet bowl. He was then removed to a punishment cell for 11 days and given no food or drink for three days.

Another prisoner reported that in March, 1987, he was severely beaten and made to stand under a cold shower by a prison warder for reading a religious book. About a month later, he was beaten and kicked so severely in the chest that he was st1ll coughing up blood in November when Amesty International interviewed him in Pakistan. He had been given this second beating by three prison 
guards, one of whom he named, for asking why he was not being given his full helping of food in the prison canteen. He was transferred to do military service on $13 \mathrm{July}$ and subsequently fled the country. He said he knew of two children who were gravely injured in Pul-e-charkhi due to 11l-treatment, one of whon was kicked in the stomach.

\section{CONSCRIPTION OF POLITICAL PRISONERS}

As part of its policy of National Reconciliation, the government announced a general amnesty on 25 January 1987. According to government figures, over 7,000 political prisoners were released between January and July 1987 and at least another 3,000 were said to have been released. by the end of the year. These flgures have not been confirmed by any independent source and the governwent has not replied to repeated request by Aminesty. International seeking names and other detalls of those said to have been released. However, Amnesty International's information indicates that thousands of prisoners were released during the year. Most of them were, however, between the ages of 18 and 40 and therefore liable for military service. They were released uncier Decree No.37. dated $26 \mathrm{April}, 1987$, of the Presidiun of the Revolutionary Council which declares that the prison terms of "prisoners who are eligible for service in the armed forces should be remitted". Amnesty Internationel has intervilewed at least 15 men of military age who were released under the 25 January omeaty and 26 April Decree and taken straight from the gates of Rul-o-Charkhi prison to a military berracks, depot or unit. Thiey have informed us that hundreds of pripners released with thea were also taken straight from Pul-e-charkhi to a milltary facility. We understand that in many ceses those raleased in this way were told that the remaining part of their prison sentence was to be spent in military service. Meny heve subsequently fled to Pakistan. Amnesty Internstional believes that the direct involuntary transfer of political detainees from prisons into military service conotatutes a punitive prectice stmilar to continued imprisonment.

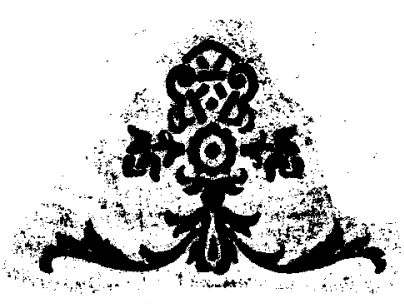




\section{Islamabad Conference} Discusses Afghan future Afghan, Pakistan Sholars Debate

\section{Reconstruction}

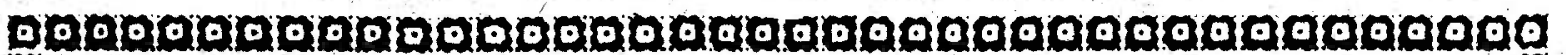

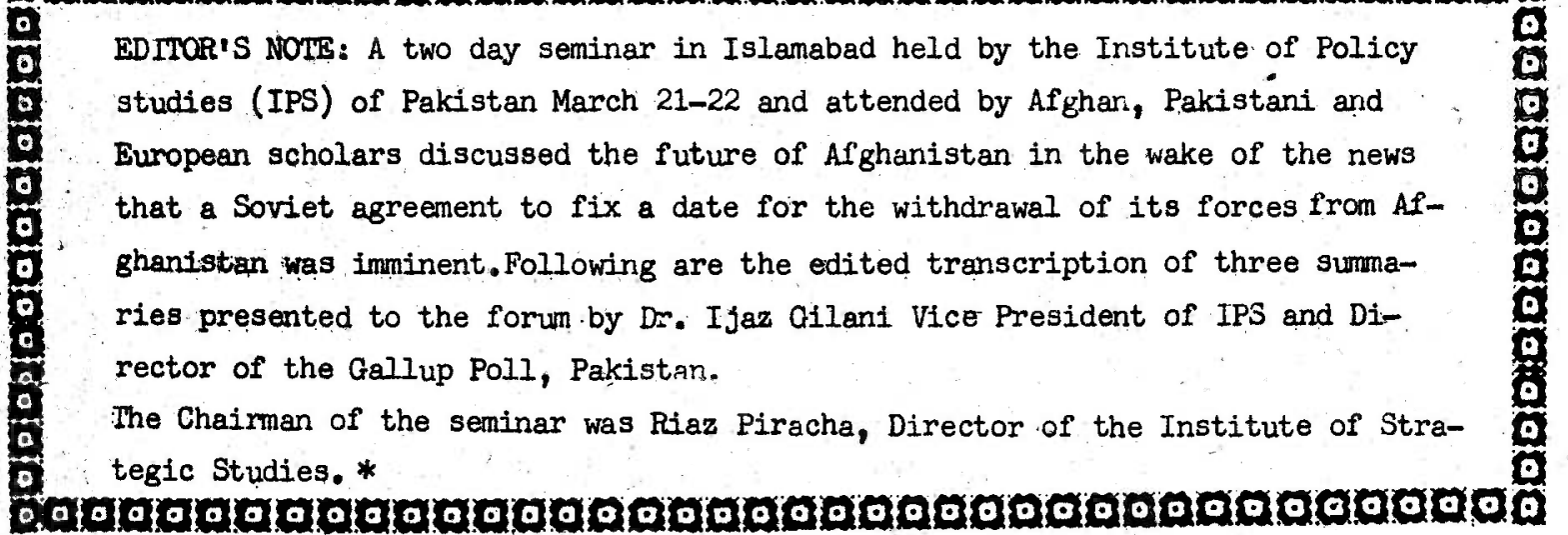

\section{SUMMARY I}

It Is quite clear that there are two scenarios of expectations regarding the Soviet Union: Adt the Sovlet Union is unlikely to leave in the near future but, it has interests in the area and to safeguard-those interests, it will stay there in its present form. The second scenario is that the Soviet Union has interests and it will continue to serve those interests but without its

W. Those who took part in the seminar were:-

1. Dr. IJaz Gulani, Vice President of the IPS and Director of the Gallup Poll in Pakistan, Islamabad, 2. Dr. Tahir Amin, Department of International Relations, Quiad-i-Azam University, Islamabad, 3. Mr. A.B. Awan, House No.14, St. No. 1, Sector P-6/3, Islamabad, 4. Prof, Raja Ensan Aziz, Department of International Relations, Quiad-i-Azam UniFrorsity, Islerabad, 5. Dr. Ahsan Chaudry, B-254, Block 11, Federal B Area, Karachi-38, 6. Prof. Yusuf Elmi, Director Af than Jehad Works, Iranslation Center, Peshawar, 7. Prof. Mohanasd Fazel, Former Deputy Minister of Education of Arghanistan Kabul, 8. Sabahuddin Kushkakd, Cultural Council of Afghanistan Resistance, Islamabad, 9. Ross Masood, House No.5, Street No.19, Sector F-8/2, Islamabad, 10. Col. (Retd) Altaf-Ur-Rehman, Deputy High Commissioner for Afthan Refugees House No.1, St.No.30, F-8/1, Islamabad, 11. Z.A. Suleri, No.43/302, thurshid Alam Road, Lahore, 12. Col, Sayyed Iqbal Ahmad, Research Department, National Defense College, Rawalpindi, 13. Engineer Abdul Rahim, IsiamaGad Ropresentative of the Jemiatwe-Islani Afghanistan, House No.31, St.No.38, Sector F-8/1, Islamabad, 14. Dr. Farooq Moma, Institute of Strategic Studies, Islamabad, 15. Fazal-Ur-Rehman, Research Associate, Institute of Strategic Shudios, Islamabad, 16. Mohamad Ali Durrant, 115-A, New Muslim Town, Lahore, 17. Sheikh Zahid, Lajnat ul Dawa AI Indmigeh, PO Box No.906, University Town, Peshawar, 18, Wael Juleidan, Saudi Red Crescent, Po - No.347, 2-Gul Hokar Bosd, Peshawar, 19. Dr. Abdul Rahman, House No.1011, Street No.67, Sector G-9/4, IsIama T Rahanas Seed, C/0 Inlamia Rell of Agency, 17-Chtnar Road, University Town, Peshawar, 21. Dr. Iftikhar Un, w.

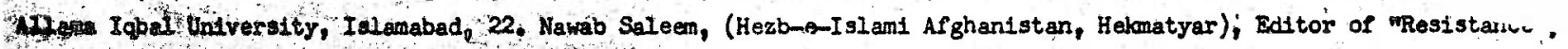
PGhamar, 23. Dr. Gert Poetbaring, Member of Europoen Parliament, 24. Dr. Dieter Braun, Research Associate, Institute

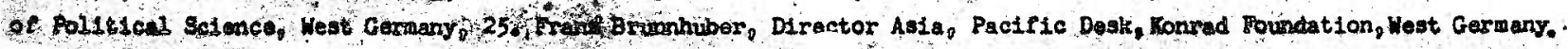


presence In the current form. Dr. Bruun and Mr. A.B. Awn would clearly represent these two point of views. Dr. Braun gave a series of reasons to support his pessimistic argument. His pessimistic scenario is based on the assumption that the military losses of the Soviet Union in Afghanistan are not compelling for it to be enough to leave Afghanistan. The political price which the Soviet Union is paying within its own country is also something that it can still afford. Not only that it can afford but for Mr.Gorbachev's owm existence it would not be unlikely for him to take a step which would present him as a loser. Dr. Braun's assumption regarding global politics are that the Soviet Union would be successful in co-opting the West - - in particular the US - - for such a strategy which would prolong indecision, and while this prologation of indecision continue, it will. renain in Afghanistan.

His assumption about the Afghan struggle itself is that the internal rifts within the resistance will be used by the Soviet Union for promoting its own existence in the country including the dissentions in Pakistani public opinion. So divisions within the Afghanistan resistance and possible divisions in the Pakistani public opinion would be used to sustain Soviets presence.

Dr. Braun, nevertheless, ended his pessimistic projections on the note that this cannot contznue for too long. Even though in the short the Soviet Union is likely to promote indecision, coopt the West, promote dissentions among Afghans struggle, promote divisions within the Pakistani. public opinion to withhold the possibilities of being presented as a loser.

Mr. A.B. Awan, on the other hand, said the interests are too valuable for the Soviet Union to ever completely arrogate those interests but the present form is far too costly. So, in his judg ment, to cut off costs, the Soviet Union will withdraw but, as he very graphically put up it, it will be like an Octupus that has many tentacles and it will leave behind many of those tentacles.

This has some similarity with Dr. Braun's assessment also, according to which the most important tentacles that Soviet Union might leave will be in the north of Hindukush. In his judgement the north of Hindukush has most tangible interests of the Soviet Union both by way of borders, by way of Central Asian proximity and of the minerel resources.

But Mr. Awan, however, has interesting suggestion for how to confront with a situation in which the Soviet Union would withdraw but leave behind its interests. He thinks proper attention should be paid to the essence of the Afghan society. That essence, in his judgement, is the landlocked geographically constraint of Afghanistan. In his judgement this landlocked situation has been the heart of the Afghanistan foreign policy in the last 50 years. The suggestion, therefore, is that in that scenario, while the Soviet Union would be withdrawing, Afghanistan would still romain in a difficult situation, because of the existence of Soviet tentacles. Pakistan and other friends of Afghanistan should help Afghanistan to get out of it geographical constraint - - the landlocked situation - - - and provide to Afghanistan a more institutional form of access to the oceans even to the extent of providing formal port favilities to that country.

\section{SUMMARY II}

Our discussion was broadly divided into two subjects: (1) the kind of govermments which aro possible and (2) how each one of those governments would behave vis-a-vis Pakistan and othar related issues? I should first take up the summary of the various loinds of gavernments which were considered to be feasible for possible options in the future. 
I could list five major types mentioned here. First, the three options mentioned by Dr. Tahir Amin 1.e. a socialist government, a liberal secular goverment and an Islamic government. The. fourth was no government and the fifth option is a split government between the Soviet-backed regime and the mujaheddin. It was pointed out that this very classification in itself has certain pollcy implications for Pakistan. Were you to consider all of them feasible that would have one Bet of policy implications because then in some ways you would make yourself willing to deal with anyone of those. Were you to rule out some of these options that would have another set of policy implications, the polnt which is well taken.

The second area of discussion was how each one of these would behave on certain set of issues. The first one was a boundary issue, Durand line. How that issue. would be taken by anyone of these options? How would the Pakhtunistan issue be treated by anyone of these government? What kind of bilateral relations would be established under anyone of these five sets? How would multilateral relations be framed inder any one of these? How would the relations in the region particularly Kabul-Islamabad-Tehran would be framed under one of these fivt options? What would be attitudo towards Islam and the Islamic governments under anyone of these options?

Firstly, what degree of chance would one give to anyone of these five for the subject discussions. A majority - - and not all - - ruled out a future socialist government. It was not quite so mentioned - - but some did point out - - that if the Soviets presence in Afghanistan continues, that would be the only way of the continuation of a socialist government. So a socialist government can continue in Afghanistan but that would not be a post-Soviet scenario. So. if we are talking about post-Soviet era, the first option is ruled out. The second option is a liberal govermment. Most of the speakers, but again not all, ruled out the possibility of a liberal government in Afghanistan. The arguments given on why a liberal government is not feasible was mainly based on the existence of socialist goverment which has taken roots in Afghanistan in the last ten years. Also it should be remembered that the liberal forces have not made any significant contribution in the Afghan resistance whereas the Islamic forces have. And, as a consequence, the liberal forces have lost their political and social role in a future post-Soviet Afghanistan.

* The third option, which to Mr.Suiehri is the inevitable future scenario of goverment in Afghanistan, is the logical conclusion of the mujaheddin's struggle. A future government to him, It would be a mujaheddin government and, since the mujaheddin struggle is an Islamic struggle, it would have to be an Islamic government. He made an interesting contrast with the Paldstan Movement which he said would not have logically ended because the struggle was not framed in terms of Islam and Kufr (infedality). The struggle was framed in a preferable government and a non-preferable Boverment.

The fourth option, as mentioned by the Sudanese friends, and our Afghan friend Rngr. Rahin elaborated on it, is that the Soviets have realized that the first two options i.e. the socialist and liberal government, is not feasible in Afghanistan. The only government, that the Soviets have discovered will be feasible in Afghanistan is an Islanic one. Therefore the Soviets might loave Afghanistan in a situation where there is neither a socialibt nor seculan and nor an Iotamic government but a situation of no government.

The fifth option suggested by one of the speakers hare was a split government in which the 
Soviets move themselves to the northern part of the country and sustain a soviet-backed socialist govermment in the northerm half of the country and leave the southern half to the mujaheddin.

How would the different forms respond to the Durand Iine, the Pakhtunistan issue, bilateral, multilateral relations, Islam and Iran? A very definitive set of opinion did not emerge but there was a fair amount of disagreement on how these governments would behave. A socialist government would not recognize the Durand Line so it may use the Pakhtunistan issue as a weapon against Pakistan whenever it finds it desirable. Under a socfalist regime bilateral relations with Pakistan would be poor. In multi]atertl relations there will be no progress, and Iran will sontinue its present policy. Obviously a socialist Soviet-backed goverruent in Kabul, would not have any positive attitude towards Islamic political ideals.

The liberal government, it was suggested by Dr. Tahir Amin, may not emphasize disputes with Pakistan on the Pakhtunistan issue. I do not think there was enough discussion on this particular subject but many of us dispute this assertion that a liberal government would forgive the PakhtoonIstan issue as a possible weapon against Pakistan. There was not enough discussion, I would say, on bilateral and multi-lateral relations and relations with the Afghans under a liberal secular. regime in Kabul possibly because it was ruled out as very viable future.

We probably had more discussion on the Islamic govermment in Kabul. How would an Islamic goverment in Kabul frame its relations with Pakistan? First of all, regarding Durand Line and Pakhtunistan, several speakers - - in particular the Afghan speakers - - pointed out that the Durand Line dispute and Pakhtunistan in particular was used as a publicity instrument against Pakistan and an Islamic government is unlikely to revive the same instrument. It. was also pointed out that the Pakhtunistan issue has certain vested interests on both sides of the bourdaries not only in the central government in Afghanistan but also in the tribal areas of NwF. But there was some suggestions that, under the changed circumstances, these vested interests have transformed. their nature and, as a result, the entire nature of the Pakhtunistan issue and the Durand Line dism cussion might be transformed in the future. It was particularly pointed out by one speaker that we might have $a^{-}$different set of issues as far as Pakhtunjistan is concerned and that it might also be colored by the role of the Pashtu speaking population within Afghanistan.

On the multilateral issue, one point raised was where should Afghanistan be placed, in West Asia or in South Asia? Even, under an Islamic and friendly environment, would Pakistan want to . deal whth Afghanistan as part of West Asia in combination with Iran and Turkey or world it would deal Afghanistan as part of South Asia possibly in the SAARC relationship?

Pakistan would not like to place Afghanistan in a forum in which India has a big brotherly position. The most controversial assessment was regarding the multilateral combination including Iran. Would it be feasible for a future Islamic brotherly scenario to have a Pakistan-Iran-Afghanistan Islamists combination or would there be an Iran-Kabul Islamists combination state against an Islamic government in Pakistan? In other words, are we looking forward in that Islamic scenario to the three govermments working in unison or are we foreseeing a future in which anyone of these two - - whether it is Teheran - Kabul against Islamabad or Islamabad-Kabul against Tehran. We had a lot of disegreenents. in this but $I$ do not think that a substantial discussion on the subject actually. took place. 
Finally, on the subject of Islan, how would one interpret Is lam and would there be three different interpretations of Islam, one in Kabul, another in Tehran and the third in Islamabad? As Engr. Rahim pointed out, the basic principle is rather simple which is law and the formation of a leadership. He said that the minimuin on which Islam could be interpreted would be Islamic law and establishing a govermment through the people. An interesting issue which was raised by Prof。Fazel was on the Afghan character. Going beyond these specific jssues - - some legal and others political - - there is the question of national character. According to him, the Afghans have a national character with two principal values; one, they would not be subdued to pressure even from their own king and, the second, they would remember to return a favor which is done to them.

\section{SUMMARY III}

It has been a long journey from 9.30 this morning to almost 5.00 'clock this afternoon, with a wide range subjects - - some happy and some unhappy - - being discussed here. Some with great unanimity, the others with disagreement. It is, therefore, rather difficult task for me to enlist all of those and to reflect the sentiments. I will, nevertheless, try. In the micro-picture, will the Soviets leave or will they not leave, is still an uncertain subject, and, as Mr. Sulehri pointed out, we are still in mid-stream. If the Soviets leave, will we have a socialist government or liberal government, an Islamic government, no government, split government, is also still a subject of great uncertainty. What is, however, a subject with evidence is destruction which the Soviet Union has actually caused in the last 10 years or so: destruction of the physical qualities of Afghanistan, destruction of its education, destruction of its culture, destruction of its social fabrics. Education was perhaps most concrete item. We found out that in Kabul University 14,000 student body was reduced to 6,000 and even those, all of them not very serious students, and in the Polytechnic and Engineering College a similar kind of situation has prevailed. Destruction, therefore, is a concrete thing which the Soviet Union has brought to Afghanistan. In the view of the mujaheddin while the Soviets destroy, the mujaheddin, despite fighting a war, build Afghanistan. And as Engineer Abdul Rahim told us this morning, on the one side, the mujaheddin are fighting the war and, on the other they are managing the liberated territories. In these liberated territories supplies, which are brought from Soviet Union, are distributed by the mujaheddin. Although supplies to the bazar are managed by Soviets but the supply from the bazar to the rural economy of Afghanistan are managed by the mujaheddin themselves. The mujaheddin manje agriculture, they mun rudimentary schools, some hospitals and cultural activities in the liberated areas. These are the constructive activities which they project they can carry over to the post Soviet period in Afghanistan. They say the jehad has taught them to manage the liberated areas and that lesson is precisely what will be a valuable legacy for them in the post-Soviet period. They say the outside world should start supporting them in their move for reconstruction from this very day. And, as Mr. Paracha pointed out, war has its glamour, and peace does not. While it is still glamorous, the mujaheddin say, there should be a support for them for the post Soviet period. In the beginning of that support, could be the liberated territories where educational, medical, agricultural and other programs have already started and these programs should be implemented while the glamour is still on. That experience and that tradition could be carried over to that uncertain, yet to many of us a likely future, in wich the Soviets would have gone but the needs caused by destruction will still be lingering along. This is where the proposal made Dr.Poettering yesterday about a fund created now - - rather 
than after' withdrawal - - appeared to be a very relevant one. A fund, whose disposal begins now for the liberated areas rather than after the withdrawal, could be a beginring, whose experiences could then be carried over in the years to come, hopefully after the withdrawal.

* While destruction is a subject with great uranimity, reconstruction cbviously and naturalily is not. Reconstruction requires priorities, the priorities by definition, and in all civilized societies, are a subject of differences and conflict. Yet there are certain principles through which those differences can be resolved. Do the Afghans have enough experience and have they come to some terms on how to resolve their differences? The Afghans pointed out here yesterday, they have had the experience in the last century and in this century to resolve their differences and come to reasonable terms. That experience is also helpful for them to resolve future conflicts, conflicts not on matters of principles but conflicts on priorities, priorities of reconstruction.

Reconstruction also requires funds, as the Chairman pointed out in his summary earlier this morning. Where these funds come from - - from domestic sources, from friendly countries, from the Islamic world, from non-Islamic friendly countries? If friendiy Islamic countries provide funds to finance, what would they be willing to provide funds for and on what terms would they be willing. The same apply to the non-Muslim countries. The Afghans were very clear and strong on this issue. If funds must be provided without strings, would funds come in areas where priorities do not conflict? Would funds come from other sources in some cases which are different to your priorities but where interests are not subservient to the interest of the other party.

With a more detailed observation on the same subject, the funds could be with strings, yet with interests which are neither conflicting nor subserviant to the interest of the other. It was pointed out that Pakistani experience of the last 10 years - - as of the experience of many western countries in.providing outside support to Afghan resistance - - has been a rather successful experience. It has been an experience in which aid has been provided but the recipient has not been dishonored. If anything, the recipient has been honored, and the least of conflict has arisen between the doner and recipient. Could that experience of the jehad be carried over? This was particularly pointed out by a Pakistan refugee commissioner who said the experience of providing assistance to the Afghans during the jehad could be carried over to the peace time. The kind of harmony that existed between the doner and the recipient during the war could be carried over to peace time, is a subject worth a lot of concern.

Reconstruction, in addition to funds, would require modern technology and trained persomel. To what extent other countries - - Pakistan,Muslim countries and the rest of the world - could provide the technology and personnel for the Afghans is again a subject worth considering. There is obviously a potential to playing a big brother's role or mercenary's role. It was pointed out, that both big brotherly and mercenary's role should be avoided in providing technology and personnel and, above all, it would be best personnel come from within Afghanistan, from its own resources and its own people. The Afghans themselves have a reservoir of technology and personnel, some living in Afghanistan today under Soviet subservience, some living in Pakistan and Iran and some living in western world and the small number in the Soviet Union itself. It was pointed out that, since all are compatriots, neither one of these four sources should be discrp 
dited right from the start. Ifghans living within the country and at present, either forced or otherwise, collaborating with the Soviets, those living in the west and culturally alienated, those. living in the Soviet Union and Sovietized or temporerily Sovietized, those living in Pakistan and Iran should be provided with the opportumity to rebuild their country. And in that the Islamic principle of tolerance and love must be given precendence to any other motive of revenge or rengeance or conflictual interests. In rebuilding specific social and political values, the Afghans should make the ultimate choice. To some of the speakers the new generation of Afghan brought up in the age of Jehad places a very high value, first on their religion Islam, the Islamic principle of equality of every citizen - - man and woman - - the Islamic principle of placing verv very high value on education and theIslamic principle of openness in society and not dividing society into different groups; elites and others. * Within this new society, the formal role of consultation expressed through the loya jirgah, and other noteables in the society, have lost their relevance. While the principle of consultation has a longer continuity, its expression has given way to the new generation which has come forth in time of jehad and are today to be organized through jehad parties rather than in a traditional patriarchical structure. That the reconstruction will have a set of values to itself, a set of velues not only to educate but also to re-educate the entire country, educate by way of literacy, but re-educate to change the society from Sovietized influences, which, the speakers pointed out, were rather superficial and were not deep in the society. A set of values - - 10 specifically - for such re-education were pointed out: a faith in God which has made the struggle successful, a beliof in Islam which is so characteristic of the Afghan character in the recent struggle, a belief in responsibility, responsibility on their own behalf not to engage in bloodshed, seeking responsibllity from other perties which might even include seeking reparations from the Soviets, creating a logical and rational mind to rebuild the society, rebuilding the society in terms of creating a value for economic development, to develop the ability of language to communicate and, inclusive of this, to have an esthetic sense to be able to see the beauty of life and to have a belanced personality and a balance between quality and quantity. These sets of values which are atmed at a Muslim personality, can even be applied to those who have either been Sovietized or, in the West, have been allenated from their own society.

What will be the requirement for such reconciliation, after the Soviet withdrawal, within the Afghen socioty? It was pointed out,it would require a great deal of trust, among these various segments of society who have been both geographically and spiritually separated fram each other. And in that trust the inttiative must come not from the rural masses but from the more oducated and the more sophisticated segments of the society including the intellectusls who, at the beginning, may be received by the masses of the society as alien to their own values. So the burden of responsibility, as far as reconciliation in the split society is concerned, would lie with the "Afghan intellectuals an not with the large masses of the Afghan population.

The idea that Pakistan, the West, and oven India, should be careful about what role they can play in reconstructing the Afghan society. was not only mentioned here but perhaps even demonstrated. The Afghans would be ready to invite conflict and displeasure if their options are obstructed. That the west and Pakistan at the same time would also like to exercise their own right to support or not to support was also demonstrated and expressed here. The fact that during the jehad these two interests or interests among the different groups did not conflict, it is not essential that con- 
flict would not occur after the withdrawal. The Afghan jehad brought together in unison and in some ways melted, a rumber of conflicting parties. 'To what extent the same would be possible in the post-Soviet period? This is a subject which would require a lot of pondering. If what was a reality in jehad is to be a reality in the post Soviet period, it was demonstrated here very strongly, would require a lot of efforts and a lot of wisdom. To some countries, however, the message was very clear. Air Marshal Ayyaz Khan pointed out that, if India wanted to intervene, they might have to go through a one way journey. That brought us back to what Mr. A.B. Awan described to us in the beginning, yesterday morring, that only a century ago a few thousand soldiers went into Afghanistan and played and enjoyed feasts and flutes with the Afghans but only one of them returned, even that of half dead. Lessons from the Afghan society, from the Afghan terrain and from the Afghan tenasity have been expressed here very strongly and clearly in the last two days. The reser voir of support and the compassion from the outside world, just like the strength of the emotions and the sincerity in the genuineness of the Afghans, has been presented here not only through arguments but it has also come through the emotions and the flavor of the discussions. The future that could be predicted is extremely hard. The futureology is very hazardous and two days of thinking perhaps would not make a dent in the uncertainty which could be expected from the future. But that uncertainty could perhaps be made more manageable, in some cases more humane and in other's more desirable, if there were intellectual thinking and exchange of ideas such as the one that we experienced in the two days, yesterday and today.

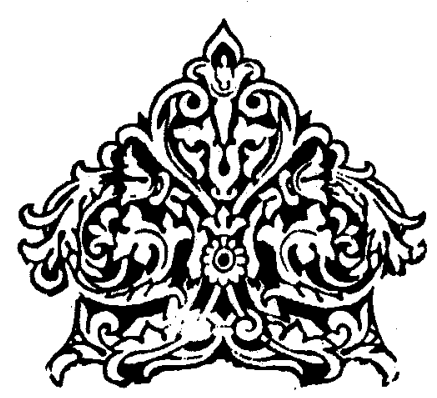




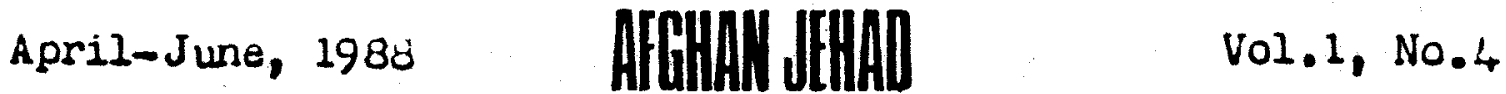

\section{Scholars offers view on Afghanistan in Karachi Islamic Conference}

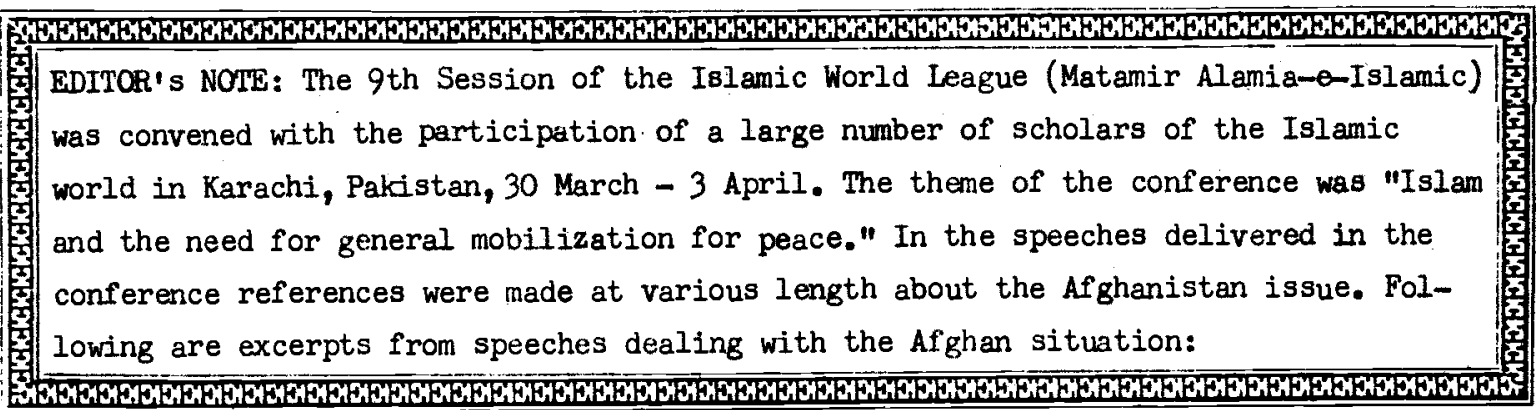

\section{IN THE NAME OF GOD, MOST GRACIOUS, MOST MERCIFUL.}

\section{ANWAR HARJONO (Indonesia)}

He spoke about continuoue fighting at regional and international level and about what he called the ineffectiveness of seminars, conferences, resolutions and demands made by humanity for a cessation of war and bloodshed and said "in these last decades, all of us are witnessing how barbarian fightings are taking place in Palestine, while, nobody in our modern and civilized world could stop it. Let alone with Afghanistan, whose people are still fighting against their (the) occupying military forces from outside. We have to admit, that many diplomatic actions have been taken by the super powers, but it seems to be very slow . ."

\section{AURANG JABBAR, Deputy Minister of Parliamentary Affairs (Malaysia).}

He spoke about oppression and atrocities in the occupied West Bank and the Ghaza Strip and described the killing and massacres of the civilians and specially of the innocent children by the Israelis, disrespect, to human dignity and honor and added "Similar events in Afghanistan demonstrate the extent of the irresponsibility of super powers". He said that "they are the ones that are hindering love and friendship, feace and harmony among human beings".

ABDUL HAKTM TABIBI, Representative of the Islamic League in Europe (Afghan)

Despite all the destruction and despite the fact that the Afghan mountains and valleys, being stained with the blood of more than one million martyrs, despite the fact that over the valleys, and graveyards; the flags of known and unknown soldiers are waving like a thick jungle all-over the length and breadth of Afghanistan, we welcome with some caution the latest declaration of the Secretary General Mr. Mikhail Gorbatchev in his speech on February 8th, 1988, announcing the with- 
drawal of Soviet forces from Afghanistan.

We should also point out that the degree of cooperation and understanding is clearly defined in the declaration of 23 February 1988 issued by Afghan mujaheddin is an important one.

In that declaration while submitting a draft.of a mechanism for an interim government, they proposed a "transitional government" which will ensure a ceasfire and a peaceful transition to law and order and the establishment of a provisional council to adninister the provinces in order to permit the safe and complete withdrawal of the Soviet forces.

The mujaheddin also stated in their declaration that:

"The transitional government will sign the Geneva accords and undertake responsibility for their implementation including the safe return of the Soviet forces when the accords become acceptable to the Afghan people and the resistance. The transitional government will persue also an independent and non-aligned foreign policy and will have friendly relations with all countries, particularly with its neighbours, provided that there is no interference in its internal affairs. For the purpose of reconstruction, the IUAM requests all the countries of the world, and in particular the Soviet Union, to participate generously in the reconstruction of the infrastructure and economy of Afghanistan.

This declaration is indeed a sign of good faith and magnanimity. Now the Afghans inside and outside of Afghanistan expect the alliance of the Afghan mujaheddin to fulfill the real aspiration of the Afghan people, in consultation with all Muslim Afghans who participated in jehad in any manner as was necessary and useful, whether in the battle field or in the political and diplomatic arena. Furthermore the world is expecting from the Soviet Union, which needs peace along its southem border for its own benefit and for the safety of its soldiers and youngsters, to fulfill the objective of peace in the world. Finally, the world is expecting the UN and its permanent members to carry out its obligation under the nine year mandate of the General. Assembly, to bring peace in Afghanistan, in Asia and the world at large. Indeed if the tragedy of Afghanis$\tan$ is solved, it will be a great experience in the settlement of disputes in this part of the world.

\section{MOHAMMAD HASHIM MOJADDADI (Afghan)}

"The Afghan Muslim mujahed nation declares clearly that it will never accept communism and until they topple the communist regime and clean their land from the filth of communism, they will continue their jehad. It is strange that leaders of Islamic countries consider Gorbachev's proposal as a kind of softness and compassion to Muslims. But the fact is that our Muslim brethren are to know that never one should expect kindness and good from the enemy. Today Gorbachev has been faced with a disgraceful defeat in Afghanistan and his softness and flexibility are the result of this defeat and that of the Soviet puppet regisue. The Russians and their hirelings in Afghanistan have been faced with the strong resistance of Muslim mujaheds who consider martyrdom for the cause of God as their sacred aspiration and jehad for the cause of God and hoisting the word of God are parts of their Islamic obiligations.

"The Muslims should know that it is far from truth and reality to believe that the Soviet. Union has been soft and flexible towards the Muslims of Afghanistan. It will be far from reality 
because it was the resistance of the mujahed Afghan Muslims who did not accept the offer of national reconciliation and coalition government with the puppet Russian government. The mujaheddin urged the unconditional withdrawal of Russian troops from Afghanistan and if their demands in these two respects are fulfilled it is possible they would return to their country.

"The Afghan mujaheddin want to make it known to Islamic govermments not to be deceived by the propaganda snares of the Russians and their hirelings and should know that their purpose is not peace and tranquility in Afghanistan but they want to bring Afghanistan under their complete occum pation and convert their defeat into a victory.

" We clearly proclaim that the mujaheddin will never accept any kind of treaty until they achieve their objective for which they had begun their jehad. They are not afraid of Russian resistance but believe that the punishment of God on infidels is great and His help for the believers is close and they are going to continue their sacred jehad with the hope of success and until the time of success".

\section{MESSAGE BY FAHD BEN ABDUL AZIZ, SERVANT OF HARMAIN SHARIFAIN (THE HOLY KABA} AND THE HOLY SHRINE OF PROPHET MOHAMQMAD PEACE BE UPON HIM.)

". - I find it appropriate to draw your attention in this conference to the Afghanistan issue the people of which for the sake of the defense of their rights and human dignity and the protection and preservation of their Islamic belief and faith are engaged in jehad and fighting. We whole heartedly want that peace and tranquility prevail in all Islamic lands. The mujahed nation of Palestine and the Mujahed nation of Afghanistan and other deprived nations whose rights are being usurped in Africa should achieve their legitimate objectives and live in peace and security.

\section{SHEIKA ABDUL QUDUS MUJAHED, CHAIRMAN OF THE WORLI ISLAMTC JEHAD (BURMA)}

(Read by Mohammad Noorul Islam in the Conference).

The Muslims of Burma have had originally been Arabs, Afghan and Indians. They ruled this country for a long time but unfortunately they were faced with the same situation that today prevails upon the Muslins of Palestine, Philippines, Vietnam, Cyprus, Afghanistan, India and and a number of Islamic minorities in various parts of the world.

We praise God that we the Muslims of Burma were afforded with the opportunity to have a role in the jehad of the people of Afghanistan alongside with the mujahed Muslim people of Afghanistan who haye been defending Islam and Muslims for the last nine years. In one of the important battles two of our Burmese compatriots Mohammad Salim a student in Karachi and Sheikh Ershad Ahmad, the first Amir of World Islamic Jehad were martyred. Earlier another Burmese brother, Noor Mohamad, had also been martyred in the Afghan jehad. May God bless their souls. The martyrdom of these brethren had auch a deep rooted affect on the morale of the Muslims of Burma that day by day their interest to take part in the jehad increased. We pray Almighty God to accept our sacrifices in His cause and enable us to continue our Islamic jehad with complete sincerity. 


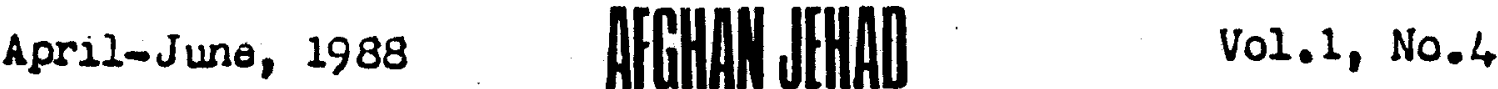

\section{AFGHAN AGRICULTUREHUSBENDARY INBAD CONDITION \\ Afghan Specilist Conducts Nationwide Survey}

EDTOR'S NOTE: In the international conference held in Paris 18-19 March this
year, Afghan Professor Azam Gul presented the summary of a survey conducted by
him and the ACRISYSTEMS - - a group of consultancy companies specializing in
agricultural and rural development, mainly in developing countries on the status
of agriculture in Afghanistan. The following is a sumary of the paper which he
presented in the Paris conférence and also of the report itself. The report has
been sponsored by the Swedish Committee for Afghanistan and had begun th 1986 . A number of voluntary organizations had made financial contributions for the
survey.

* This report is based on a survey which airectly interviewed the heads of about 20,000 farm family households in Afghanistan and in the refugee camps in Pakistan, of which, after screening for reliability, 11,000 were entered into a computerised database. This represents more than $1 \%$ of all farm households in Afghanjstan, counting together those still in the country and those in Pakistan. The database occupies over 30 megabytes of disc space and took six men 12 months to input. It was obviously not possible to cover areas controlled by the Kabul regime and which are estimated by independent observers to be up to $20 \%$ of the country (and estimated to be no more than $25 \%$ by its President). Nevertheless, it is the largest, most wide ranging and most comprehensive survey of agriculture ever conducted in Afghanistan in peace or war.

* The survey is not a census and gives no estimates of the total agricultural scene. Rather the survey focuses on the farm family and its situation, the factors that have affected it, and trends in production; means of production, farm resources, and physical farm inputs which have occurred over the last ten years. The results will take several more months to analyse and this report provides only a rapid overview of some of the main findings.

* The results show that the refugees and those who stayed to fam in Afghanistan are two different groups in terms of area farmed, ownership of livestock, use and avallability of labour, use of fertiliser, and a number of other factors. Those who became refugees were better off in terms of farm resources, but on the other hand their farming operations suffered more from the direct effocts of war.

* The results also show that yields have declined substantially; $33 \%$ for irrigated wheat and 50 \% for dryand wheat between 1978 and 1986, and that the area cultivated by individual farmers has 
declined by 30\%. On these two counts alone the survey indicates that total agricultural production in 1986 fell to about 45\% of its 1978 level. There was an increase in yield levels in 1987 which increased production to about 53\% of the 1978 level. This increase can be attrituted to good rainfall as well as reduced levels of attacks on agriculture. It is important to note, however, that the figures apply only to those farms which were still worked at the time of the survey and does not take into account abandoned farms.

* These figures confirm the worst fears and the most pessimistic reports on Afghan agriculture which have reached Peshawar through refugees, journalists and other observers over the last few years, but which have been unsubstantiated till now.

* The reasons for this decline, apart from the direct effects of war, are first, a reduction in family and hired labor availability, so that the use of family labor by farmers still in Afghanistan fell by $19.5 \%$ and hired labour by $19 \%$, while for farmers who left in 1987 the figures were $44 \%$ and $29 \%$. Second, the number of draught oxen owned by farm families has fallen by $40 \%$. Third, although the survey has evidence which is not yet analysed, it appears that the genetic potential of wheat seed has declined substantially. Fourth, the proportion of farmers using urea (or white) fertiliser has declined to $53 \%$ from $76 \%$. Added to these figures of the decline in the means of production, there has also been a decline in livestock numbers. It is against livestock that the Afghan farmer has traditionally fallen back after poor harvests. For farmers who stayed in Afghanistan the decline in the numbers of Karakul sheep, and of ordinary sheep and goats, was 70\% and $67 \%$, and for those who fled in 1987, the decline was $60 \%$ and $56 \%$ up to 1986, after which they lost, or disposed of, almost all their flocks. The decline in the numbers of horses, and donkeys and or mules has beenless. For those who still farmed in Afghanistan in 1987 the figures were $45 \%$ and 6\%, while for those who left in 1987 the figures were $8 \%$ and $24 \%$.

* The direct effects of war on agriculture reached a peak in 1985, and although they have since declined they are still substantial. In 1985,53\% of farmers who stayed in Afghanistan, and $65 \%$ of those who left in 1987 had their villages bombed. The equivalent figures for the destruction of irrigation systems are $24 \%$ and $36 \%$; for livestock shot, $23 \%$ and $31 \%$. Those who eventually left also had more livestock shot each year compared to those who stayed - -4 compared to 5. In addition to animals shot, $6 \%$ of farmers who left in 1987 were losing 5 head a year to mines. In $198722 \%$ of farmers still experienced bombing of villages, $12 \%$ had their irrigation system destroyed, $6 \%$ had their livestock shot, on average losing two head a year this way and the same number to mines. Three percent had their grain stores destroyed, down from 13\% in 1985.

* Now that repatriation of refugees may become a political possibility, it is relevant to ask what picture does the survey provide of Afghan agriculture and what may be some of the problems facing returning refugees. Would the returning farmers be able to plough? Would they have sufficient irrigation water? Would it be more cost effective to improve the health of existing cattle, or to import draught oxen, or to encourage tractor mechanization? If they are able to grow a crop of wheat, what will be the yield, and therefore for how long must they receive supplementary food, and how much? What farm inputs do they require, in what order of importance, in what quantities, and how does this vary from province to province? The information collected can assist in answering these questions.

* The main conclusion to be drawn from data so far analyzed is that the present agricultural pro- 
duction is insufficient to support the existing population let alow a large number of returning refugees. The steady inpoverishment of farmers who renained in Afghanistar, and of their farm rosources, is shown in the report. Returning refugees, as well as the existing farmers, will therefore require food support during the first season while crops are growing. Thereafter food assistance will still be required, but at a decreasing level dependirig on how quickly the returning refugees are able to rehabilitate their own agriculture. Returning refugees might ease the labor shortage, but it is clear that, if draught oxen are to be bred locally, it will take several years to reach pre-war herd sizes, and that the froblem of shortage of farm lower will persist for some time. Similarly, even if the nationel sheep and goat lluck increasus by $25 \%$ year (an optimistic assumption) it will take five years for it to reach its 1978 level. Improved wheat varieties will need time for testing and multiplication. Irrigation systems will need to be rehabilitated and farm inputs will need to be procured and distributed.

* The indications are, therefore, trat large amounts of aid will be required. This aid will be in two forms: immediate inputs of food and, in addition, a comprehensive agricultural input program. This program should be designed to meet the individual requirements of provinces and districts, and quite possibly valleys. The survey can provide information at least on a provincial basis, as well as case studies on a more detailed level.

\section{SURVEY

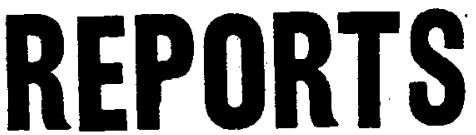 IMPROVED HEALTH

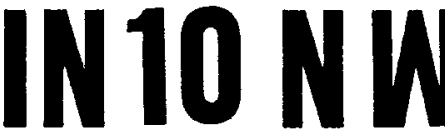 REFUGEE

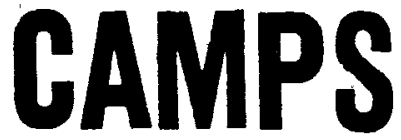

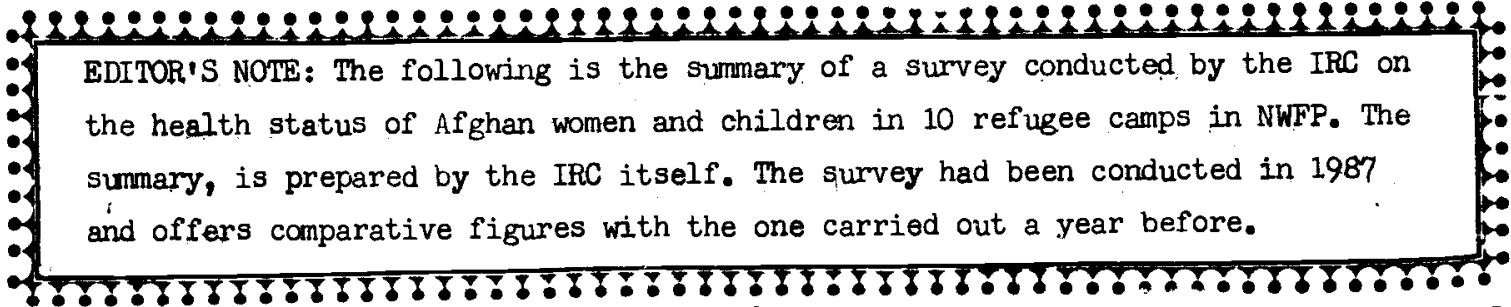

All 10 camps in the Kohat area that are served by the IRC, were included in the survey: Lakhti Banda, Mohammad Khoja, Kata Kanra, Dallan, Thal I, Kahi, Thal II, Darsamand and Kotki 1 \&. Within 50 sample sites, interviews were conducted with 674 women. In total, tr:ese women had 997 children below 5 years of age. Of those children, 19 had died during the preceding 12 months, and 979 were alive at the time of survey.

The data collected have provided a base of information from which trends can be assessed for the 10 camps served by the IRC since the last survey was carried out in 1986 . These are some of the findings.

- a continued decreasing trend of infant mortality from $87 / 1000$ to $52 / 1000$.

- a decrease of child mortality from $11.8 \%$ to $10.4 \%$. 
- a decline of Iriarrhoea prevalence from $39 \%$ to $27.7 \%$.

- a decline of moderately malnourished children fror $8 \%$ to 1.:x, and of severely malnourished children from $4.2 \%$ to $0.3 \%$.

- a rise of BCG scar evidence from $68.7 \%$ to $79.3 \%$.

- a decline in prevalence of measles, from $15.2 \%$ to $8.6 \%$.

- an increase in the use of drinking water from an improved source, from $32 \%$ to $64.9 \%$.

- a rise in the use of ventilated improved pit latrines, from $43 \%$ to $46.4 \%$.

- an increase in the presence of poultry and livestock in the conpounds, from $52 \%$ to $100 \%$.

With these results, the Kohat region may be considered one of a very small number of project areas in the world that have evidenced such enormous changes in such a short period of time.

On the other hand, solid reason has been found to believe that the improvement of overall health and decline in infant mortality, combined with a unique socio-cultural envirorment, have produced a fertility rate that may well be the highest in recorded history. More specifically, if the trends exhibited over the last two years were to continue, by the end of her childbearing years the average Afghan woman would have given birth to $13 . \dot{6}$ children. Implications of such exceptional fertility bear weight in all sectors. Health, nutrition, education, agriculture and other development efforts must all take into account that the refugee population can possibly double within 15 years. Furthermore, when it does, more than $50 \%$ of the population will be less than 15 years of age. 


\section{April-June, 1988

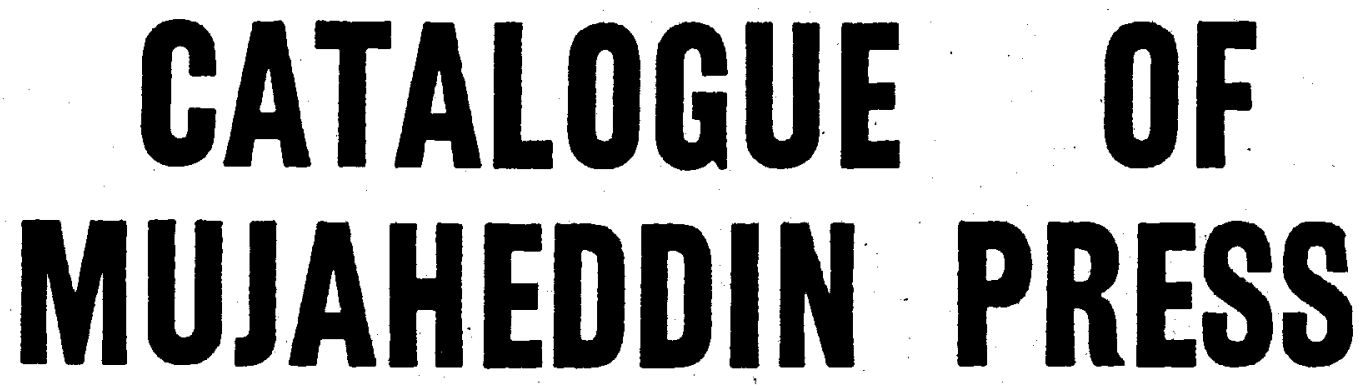

Part IV

(in alphabetical order)

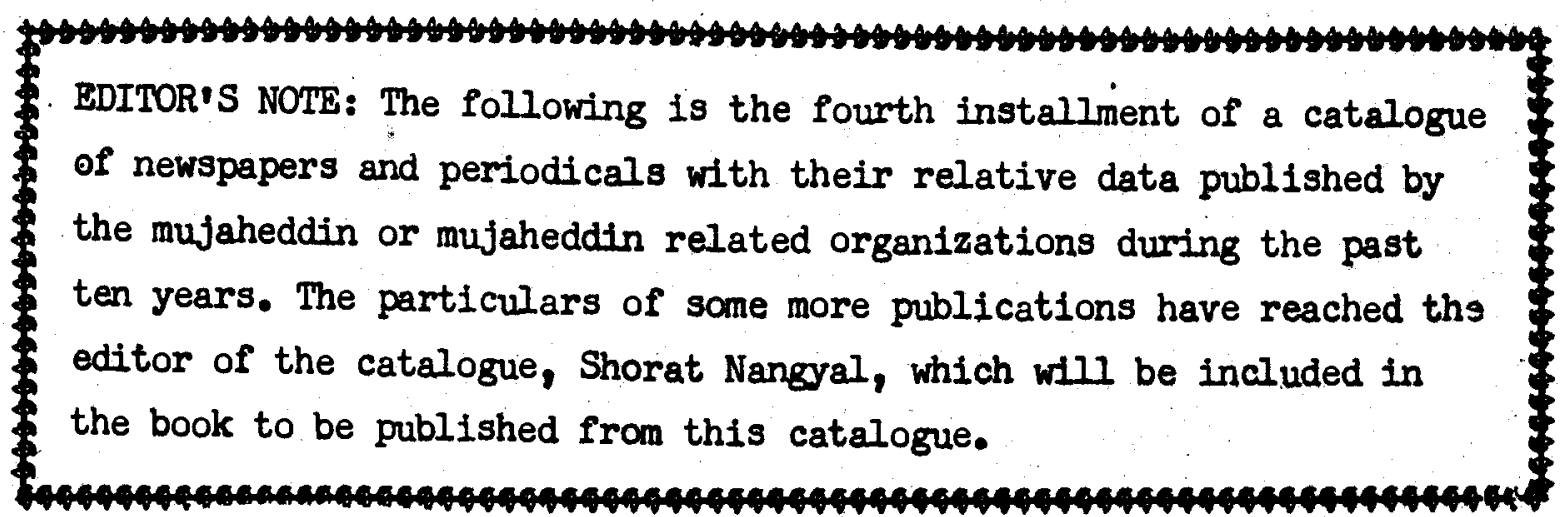




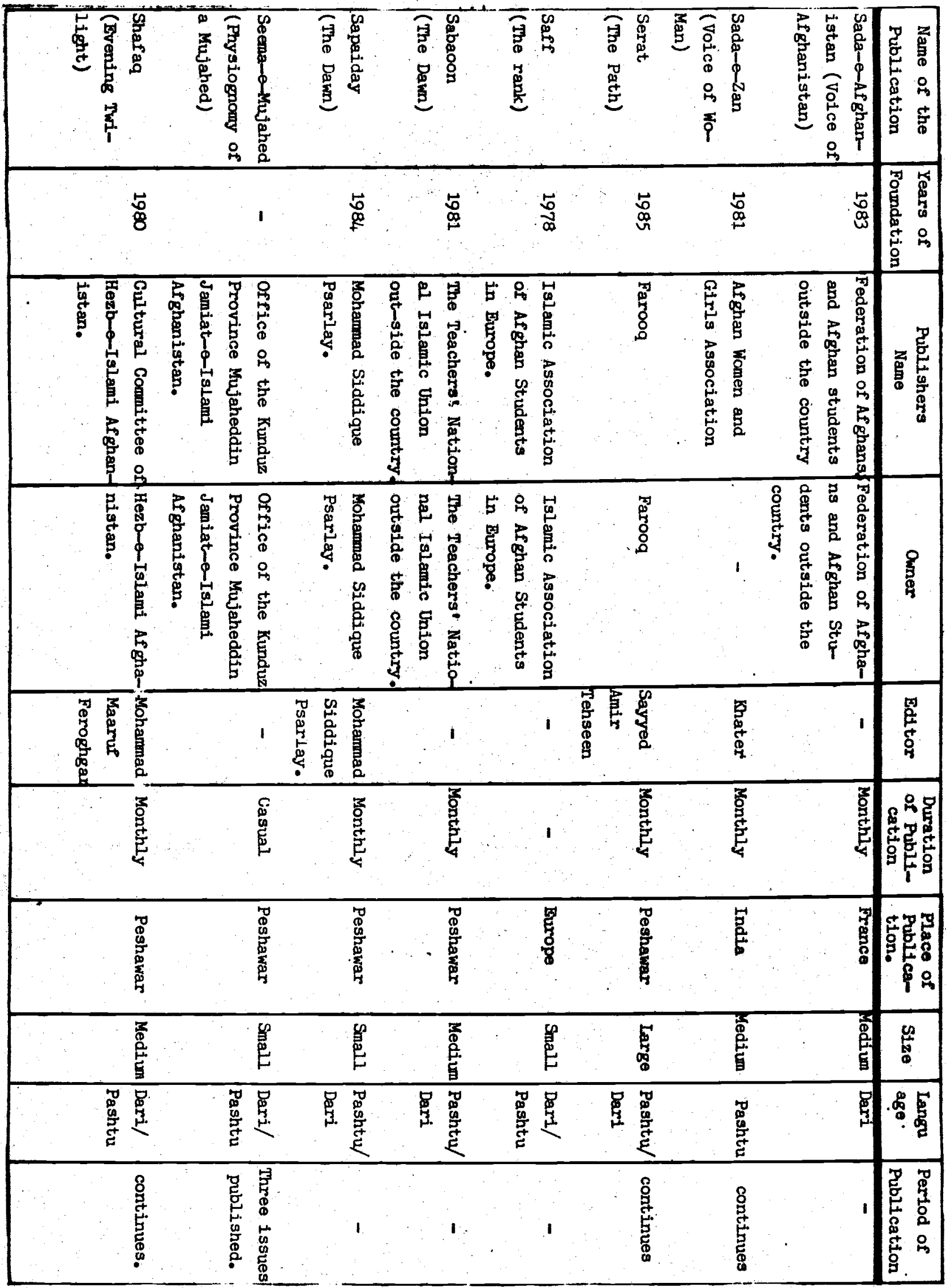




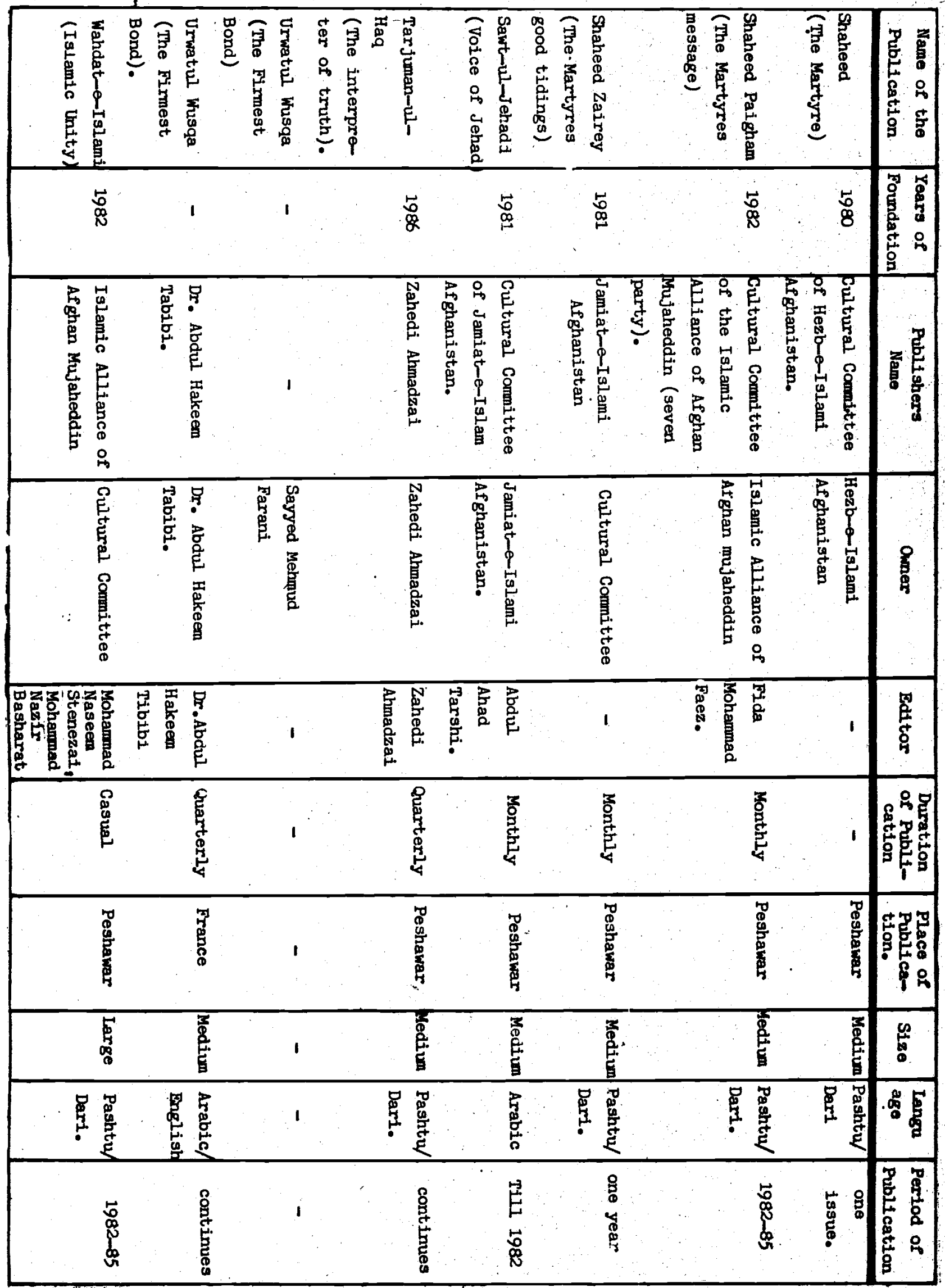




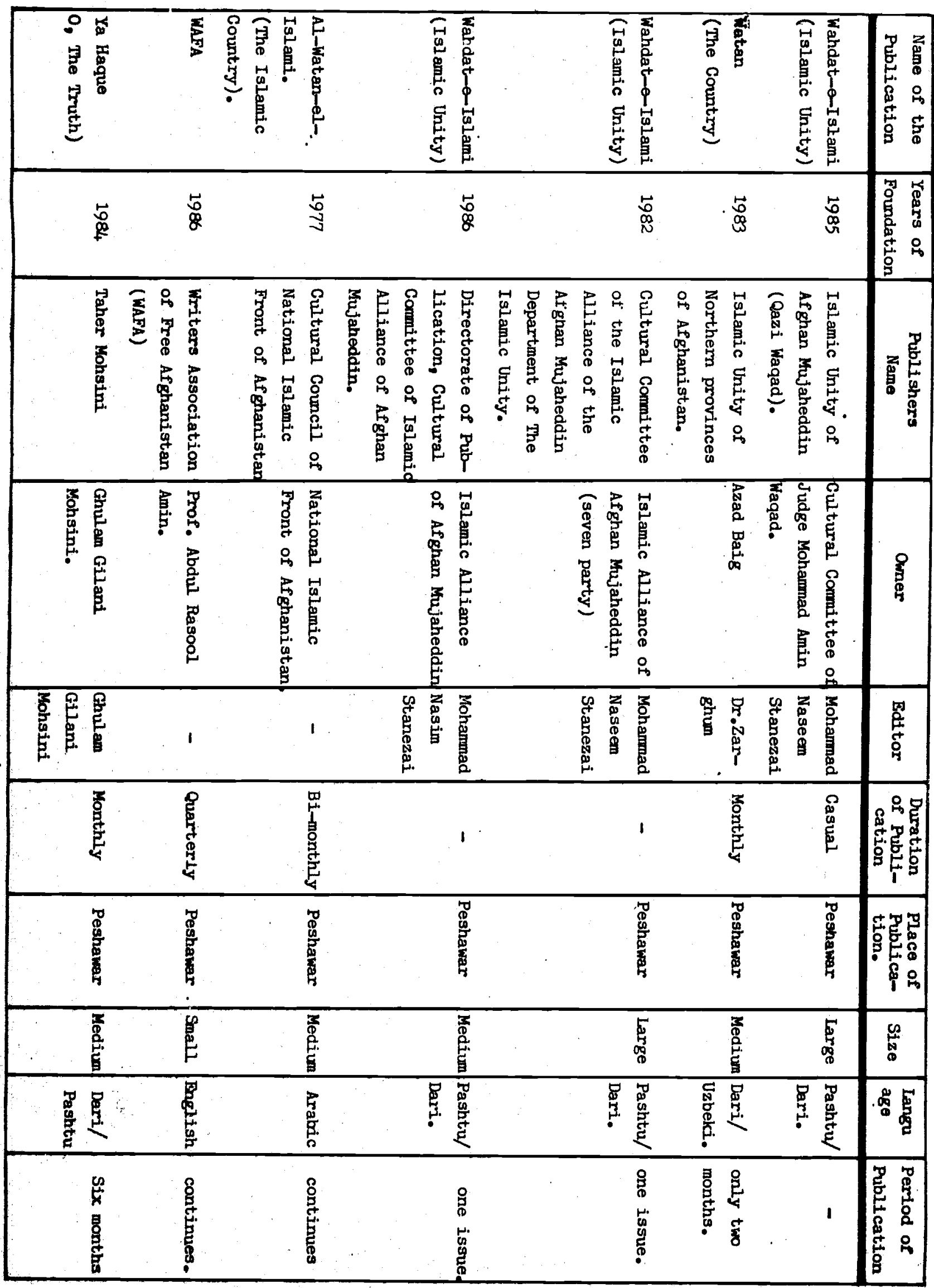




\section{A GLANCE AT MUJAHEDDIN NEWSPAPERS,PERIODICALS}

Complete identification of each publication is at the end of this section

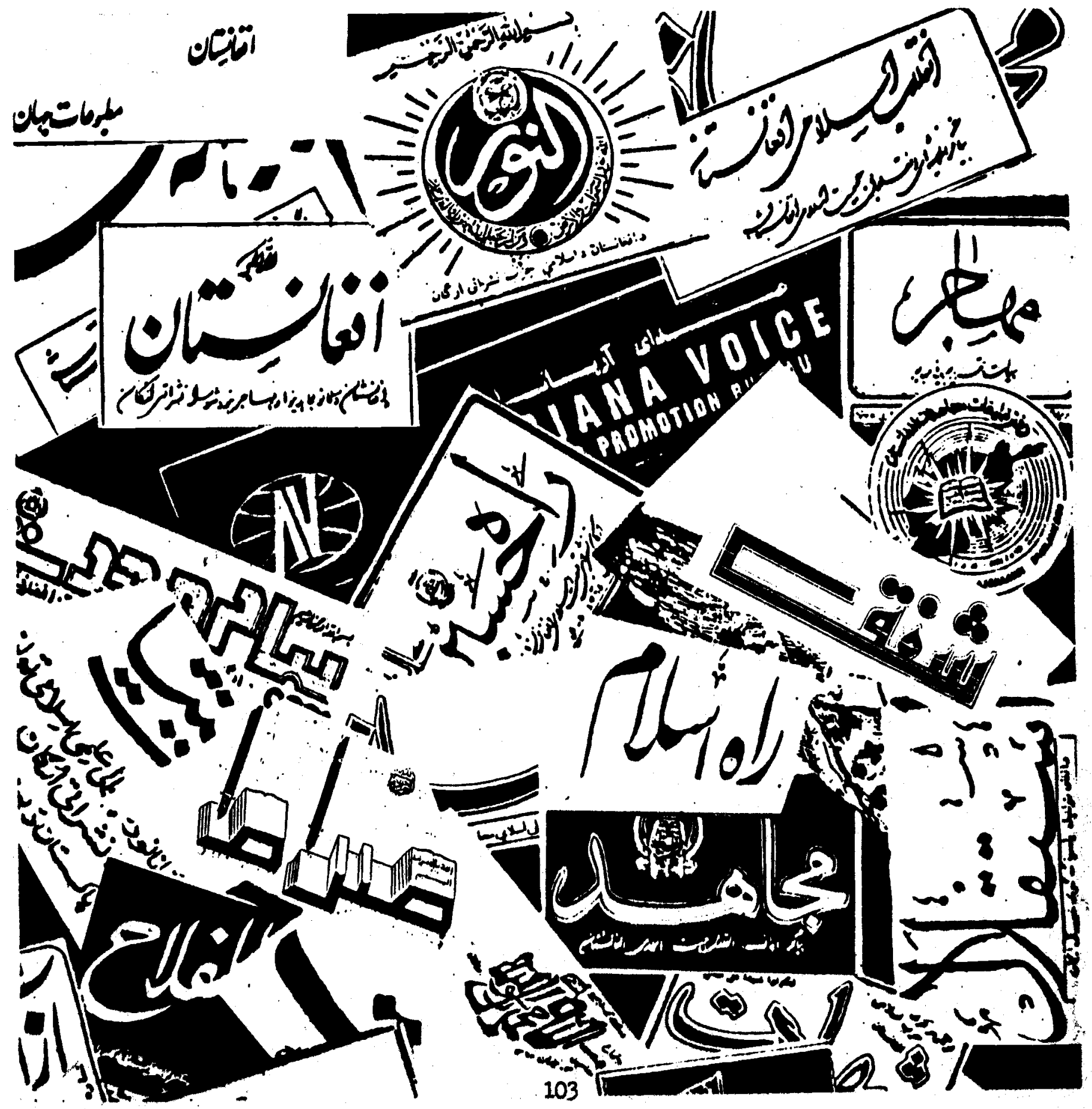




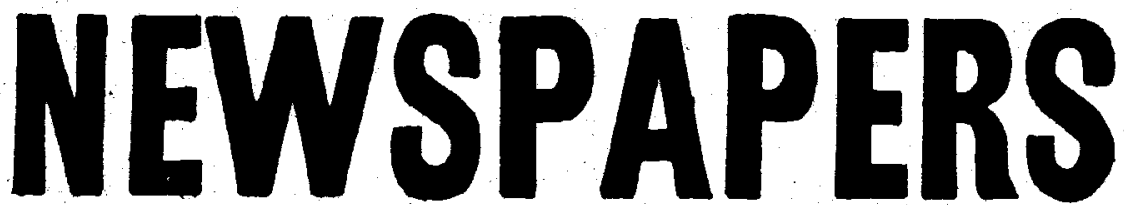

\section{Ukhuwwat 19 perinury 1988} DDITORIA: "Whe new communique about the formation of interim govermnent". It praises the inteFin government decision about (1) paving the way for the withdrawal of Soviet forces, (2) maintatning law and order in the country (3) creating an atmosphere conducive for the return of the refugees and (4) reconstruction of the dovastated Afghanistan. However, it adds "the IUAM in its statement 17 January, 1986, in the presence of hundreds of thousand of refugees and mujaheddin in the Nishat Mills Grounds near Peshawar had promised the formation of a provisional government, adding that such a government will be formed and announced in one month's time. It is a pity that now one year and 24 days have pessed but the promised government has not yet been established. The Afghan Kuslim and mujahed nation are offended when they find out that ouch statements are not heeded and the question comes to their mind that why the fate of the heroic nation is in the hands of : sueh people who are not able to honor their words and the difference between their words and deeds is like the difference between the earth and sky?"

* The editorial on behalf of the organization which the newspaper represents - - "The Society of Afghan Peace Movement" - - strongly demands that "the esteemed leaders of the IUAM should revlse their policies and should no longer suppress the aspirations of the Afghan mujahed, heroic and Muslim nation as well as those of the 1.5 million martyrs and hundreds of thousands of handicapped and orphans".

ARTICIE: "For the attention of the Human Rights Commission and the Jehad Organizations. Whe Society of Peace Movement strongly demands that. something should be done about 128 thousand political prisoners who are serving hard labor terms in Soviet prisons and 5,000 prisoners in Bala Hesar whose fate has not been determined and are in jail. The jehad organizations should find out about the fate of these people through the Human Rights Commission so that Afghans may know about their fate.

\section{Enqelab-e-Islami Afghanistan 22 rebraary 1988} EDITORIAL: "The bloodstained uprising of Kabul in 1980 was a waming to Kremlin hegemonists". This uprising was staged by all Kabul people against the enemy aggression after 58 days had passed from Soviet invasion of Afghanistan. This was the first reaction of the Afghan people and a grave warming to Krealin leaders telling them that they had committed a blunder by deciding to invade Afghanistan.

INTERVIEN: Hohammad Hashem Saren, the Deputy Leader of Martyr Ghulam Mohammad Niazi Military Base has said in an interview the base has under its jurisdiction the Bnjil, Adreskan. Gozara, Karrakh, Pashtun Zarghoon, Obay subdivisions, the center of Herat province and bor der areas. Whe mujaheddin of this base are heroically fighting the infidels. About what he has called the cultural resistance, he says "any movement which begins without a revolum tionary vision and ideological basis will only last for a short time. Therufore, close attention should be paid to the cultural dimension of our Islamic jehad. It has been for this reason that our brethren, who have a deep vistoin 
of the jehad, have not only created centers of thinking in the liberated areas but also in areas under the domination of the regime. Those young people who have not been able to complete their education have been provided to undertake Islamic ideological courses either during the night or day time and many of these people are now engaged in jehad activities. There are ten primary schools consisting of grade $1-6$, five centers of knowledge where boys of upto 15 years ald acquire knowledge in Islamic jurisprudence and political science, centers of learning for those who have completed their education or had served in govermment in past times.

\section{Payam- $\theta-J e n a d$ 12 March, 1988} EDITORIAL: nAn analysis of the Geneva talks on Afghanistan". During the course of eight years of war in Afghanistan, the Russians have made use of all their war machinery to defeat our nation. However, finally it had to admit its helplessness in the face of this valorous people. It found out that it is not capable of a face to face fighting with the people of Afghanistan and, instead, resorted to propaganda, deceit and political smares. But the Afghans are aware of these plots as well and, until they decide their own fate, they will not accept any kind of mandate from whatever source it may be.

MESSAGE: Issued by leader of Harakat-e-Islami of Ayatullah Al-Azami Nohseni: "Now that blood is being shed to topple the Russian and their puppet rulers in Afghanistan, the defeated enemy is trying to continue its domination of Afghanistan through its satanic efforts even in a covert form. Some opportunist friends, lacking a clear objective and ideology, too, knowingly and unknowingly; serve Russian causes. It is time to (1) have the pioneering Islamic parties further coordinate their activities, (2) avoid opportunism, selfishness, unnecessary religious, tribal and ethnical prejudices which cause bloodshed among the people thenselves,
(3) not to be deceived with promises given by the Russians and preserve our independence through self-reliance $(4)$ insist on the Islanic character of the resistance in order to pave the way for the sovereignty of the Quran in our land, (5) Reserve the power (of the state) to the mujaheddin and their representatives and do not provide an opportunity to in-Islamic movements (to make headways in this respect), (6) give priority to public interests over individual interests, (7) have faith in social justice for all the Muslim peoples of Afghanistan, (8) be not afraid of the Russians and to block their imperialists overtures, (9) strengthen the resistance quantitatively and qualitatively, (10) refer to Almighty God and seek more help from Him (11) raise the intellectual level of the people, (12) prepare long term and short term plans for the complete defeat of the Russians."

NEWS: Recently in a seven day fighting with the enemy in Herat, the mujaheddin demolished 23 enemy tank and killed 300 soldiers and militiamen.

* The mujaheddin in Mazam-e-Sharif captured 25 January three enemy posts.

* One Russian base and four posts were destroyed by the mujaheddin 28 January.

RFPORT: The general commander of the Harakat-e Islami for the Kabul province Anwari said in a press interview 7 February "we clearly announce our stand that we would fight the Russian until our final victory and will not strike a political deal and we conderm any political solution of the Afghanistan problem."

In regard to the formation of an interim government by the seven members of the IUAM, he said the Shia and Sunni brethren ought to work together. Taking decisions about Afghanistan in the absence of the Shias is not possible and will be void". 
Jabha-e-Jehad 12 arach 1988 ARTICIE: "Soviet.stand in regard to the political solution of the Afghanistan issue" (By Khurram). It reviews Russian "plots and intrigues" in regard to the political solution of Afghanistan issue. "The rejection of an interim government proposed by the government of Pakistan on the basis of the wishes of the mujaheddin and the rejection of American proposal about the cutmoff of assistance to the puppet government were the two issues which clearly demonstrate Russian plans towards Afghantstan: Russian objective towards Afghanis tan is quite clear: (1) The belt on the border between Afghanistan and Pakistan should be closed and mujaheddin supply Itnes cut-off so the hireling government will be free to annihilate the mujaheddin, (2) recognition of the puppet goverment by the government of Pakistan and the signing of the Geneva accords, (3) expelling the Afghan refugees from Pakistan and handing them over to the Russians and the establishment of a stable communist order In Afghanistan. If the Geneva agreement is signed before the establishment of an interim government in Afghanistan, the people of the world will be Judged by history in an atmosphere of shame and humiliation and they will look to each other for the gradual death and annihilation of the free countries of the world one after thu other. Because the occupation of Afghanistan will be tantamount to the occupation of Asia and the fall of Afghanistan into the mouth of the red dragon will absolutely result in the fall of the world.

REPORT: Prof. Sebghatullah Mojaddedi leader of the NLF in a meeting withdrew his resignation and said "Dear brothern, I find myself overwhelmed and want to thank you for the extreme sentiments wich you have selflessly exhibited towards one of your servants. I had not pendered any other secrifice but to offer my resignation from the position of your leadership and membership of the IUAM. My resignation had taker place on the basis of a number of principles. There were issues to which I was opposed and I saw them to be detrimental to the cause of the Afghan nation. I had resigned because $I$ was demanding that the fate of the Afghan people should be at their own hands. We Afghans have a long ancient history. Our traditions are based on Islamic traditions and they have Islamic roots. If we are to adopt an important and major decision about the leadership of the Afghan government and other imm portant Afghan matters, there are two alternatives for us. One is the Islamic way which says that the ahl-e-hal wa agd (men of wisdom) have the right to decide on important issues or a loya jirgah which represents the ahl-e-hal wa agd should take decisions. History shows that all the people of Afghanistan have follow ed the decision of such loya Jirgah"

ARTICLES: "Determining the fate of the Afghan people is the obvious right of the mujahed Afghan nation". "The momentum and historical dom cision of the esteemed leader of the NLF Prof. Sebghatullah Mojaddedi wich was relayed through world media 6 March, 1988, has opened a new chapter in the proud history of the heroic and mujahed Afghan nation showing once more to the free world that the Afghans in dom termining their future will not allow any other factor to interfere than the free will of the peoples themselves. In the past in our country religious and national uprising of the Afghans have taken their inspiration from this obvious and undeniable principle. (EDITOR's NOTE: The major portion of the newspaper is devoter to letters, signatures and pictures of the peuple who have urged Prot. Mojaddadi to withdraw his resignation).

\section{Neda-e-Mujaheddin 14 March 1988 \\ EDITORIAL: "The Geneva Talks": Raferd to the}


Russian cleverness in chess and says that. they have made chess a part of their foreign policy as well. They are playing tricks some tinies for offensive purposes and at other times for defensive atms but, at the same time, confronting the other side with unexpected defeat and predicaments. Today the Russians want the Geneva accords to be signed so that its puppet government in Afghanistan is recognized by Pakistan, Iran and US. This puppet govermment would later Join other Soviet republics by becoming part of the Socialist Republics of the USSR. Commenting on a coalition govermment with the communists, the article says our jehad is not a war and is not for gaining power or occupying ministerial portfolios. The Afghans will in no way stop their Jehad. They become either martyrs or free.

* The mujaheddin shot down 8 February two hellcopters in Moosa Qala, Helmand and destroyed 40 tanks. Five mujaheddin were killed in the operation.

* In a mujaheddin attack 27 January in Dand, Kandahar, seven soldiers of the atheist government were $\mathrm{kllled}$. One mujahed was martyred in the operation.

* The mujaheddin in an attack 2.8 January on the Kandahar milltary Garrison killed 25 atheists.

REPORT: Habioullah Achekzai a Kandahar mujahed who has rendered four of his sons martyrs and he himself is now continuing jehad with his only son has said in an interview, "the love of child is deep rooted in man's heart. However a Muslim should love his religion more than anything else and should not place at par anything else with the love of God and with the love of His Prophet Mohammad. Such a love is a real love and for this reason God has bestowed upan me the blessing of everlasting patience and I thank cod for granting to my children

\section{the rank of marty rdom". \\ Neda-e-Sangar}

15 March 1988

EDITORIAL: "The ruines need to be reconstructed": After evaluating of "Russian aggression and savagery" the article considers the $15 \mathrm{March}, 1979$, lprising of Herat as a strong reaction to Soviet policies in Afghanistan. It says "the Afghan nation of today is not the nation of yesterday. Today after 10 years of sacrifices, bloodshed and martyrdom, the level of political consciousness of each member of the revolutionary society of Afghanistan has gone up to an extent that 1 cannot be understood and grasped by the enemies of Islam and the heroic trench holders, - - who during the past 10 years of their unparalleled resistance have guarded their belief and faith, by sacrificing their beloved selves - - can easily distinguish between their friends and enemies. They know well what to do and how to encounter the plots or Iriteruational imperialism. The enemies of Islam should know that the Afghan nation will not foresake the aspirations of 1.5 million of its martyrs who have sacrificed their beloved selves for the sake of the proclamation of the Word of fod and Islam and, by observing an overall unity in the light of Islam, this nation will remain stable and steadfast.

MESSAGE: In connection with the anniversary of the 15 March, 1978, uprising of the people of Herat against communist rule in Afghanistan, leader of the Jamiat-e-Islami Afghanistan, Prof. Burhanuddin Rabbani has said "This day is the banner headline of the grandeur of our believing nation and the.pride of all the generations of the God worshipping people of Afghanistan in the annals of history. The inspiring resurrection of this day has helped us to continue our. revolution"。 
MEWS: (no dates have been' given)

* The mujaheddin in their planned operations in the city of Herat occupied eight enemy security posts, set ablaze one tank, killed 28 Soviet hirelings and captured 15 militiamen.

* The Ghorian, Herat, mujaheddin in an operation on Herat-Islam Qala highway set ablaze five communist military vehicles, killed 15 militiamen and captured 10 others.

* The mujaheddin of the center of the Farah province in an operation destroyed two enemy tanks and two armored vehicles.

ARTICIES: "Herat, the land of uprisings and epic making" (by Mohammad Ekram Andaishmand): the writer has spoken about the Islamic period of Herat history and says the historic and beautiful city of Herat, during the reign of of Ghoris, had 12,000 shops and 350 madrasas and Khanqas (Islamic monastries). This in itself was a testimony of progress and brilliant civilization of Herat. Herat is the land of blood and martyrdom, the land of agonies and misfortumes, the agonies and misfortumes which the cruel and aggressive infidels have inflicted upan this beautiful and ancient land and have ruined all the manifestations of its knowledge, art and culture.

Whe brave and mujahed people of Herat, despite these cruelties of the past, have been in the forefront of the battles of resiatance agatnst agressors and the rule of communist atheism rith steadfastness and an iron will. 15 March, 1978, is among the important and proud days of the Herat mujaheddin and the people of Herat are volorously and sincerely defending the blood of 25,000 martvrs of the 15 of March.

* "Jehad and its repurcussion in the world media $\mathbf{n} /$ (by Dr. Mohamad Zahir Siddiq). It has spoken about the the truthiulness and maturity of the Afghan jehad as an introduction to the article and the main theme of the article is said to be published in the next issue of the paper.

\section{Enqelab-e-Islami Afghanistan 14 March 1988} EDTIORIAL: WThe glorous uprising of the Muslim people of Herat, 15 March 1978" is a historic and important day in our country and is considered a big event in the world of Islam and Islamic revolution. The day is marked with the blood of 25,000 martyrs making it an everlasting glory of the mankind. On this day the Muslim people of Herat - - women, men, old and young, government officials and those working on their own, farmers and workers - - poured into the streets with the weapon of faith and power of Allah-W-Akbar (God is great) and the slogan of "victory for the Islamic revolution" and "down with communism". The people moved forward in the midst of blood and fire towards the nests of spying and centers of atheism and communism and tore down the flags of infedility from the skies of Herat. On the other end of the town a brave battle was continuing between the Muslin officers and soldiers of the 17th Division of Herat, on the one hand, and forces of atheism on the other. Russian bombers flew from Tashkent and dropped thousands of bombs on our people around the sun set on that day killing 25,000 defenseless Muslims. But on that day, that uprising and that urge for martyrdom was neither a first day of such an event for our Muslim people and nor it was the last day. Deam pite the savagery of the communists on that day, our Islamic movement continued with the same intensity and unity and with the same enthusiasm and is now marchirig towards another day, the day of the victory of Islamic revolution of Afghanistan".

INTERVIEW: Engineer Ziauddin, deputy leader of the Shaheed Hafizuliah Afzali Fronts has said in an interview about the 15 March Herat uprising, excepting the handful Russian puppets and the new recruits of the hated $F D P A$, all others 
who were living in Herat, including those who were visiting the city on that day, joined the uprising. In the beginning the uprising was scattered and in random and in the outskirts of the city and areas such as Ghorian and Pashtoon Zarghoon and some other locality and the Russians and their hirelings were anticipating such an uprising but it was too late for them to suppress the glows of faith and the inreconcilability of the Muslims with the infidels and aggressive Soviet atheists and, despite all their precautions, the general uprising took place annihilating all the symptoms of wretched and evil conmunism from Herat and the headquarters of the province, security forces, prison guards, sub division of Enjil and Herat airport as well as other govermment centers were captured by the mujaheddin of .Islam",

\section{Al-Bayan}

18 March 1988

EDITCRIAL: "Negotiations and domestic tensions" By Fazlur Rahman. The editorial considers "the changes in the colors of the flag,cries about Islam, reshuffling of Russian puppets, unilam teral ceasefire, the NRP, the fake loya jirgah as a compensation in the international negotiations for the defeat of 150,000 Russian troops in Afghanistan."

Similarly it considers contrary to the objectives of jehad reaching a settlement with the enemy on the basis of the latter's choice and bringing back Zahir Shah through a Russian and US decision. It says "today's Afghanistan is not the Afghanistan of yesterday. More than 1.2 million peoples' blood has streamed in this land, the public of this land is no longer the same public of yesterday. But this nation has confronted a super power for the last 10 years and has spent its time in the trenches of war. Today's Afghanistan is a revolutionary Afghanistan which is not satisfied with anything else but Ialsmic government.
"The IUAM has chartered a sound and reasonable program $\mathrm{I}^{\circ}$ the future of Afghanistan which is to be implemented after the withdrawal of the Russian forces. The question of domestic tension will not arise. Now that, despite the presence of 150,000 Russian troops and their puppets and despite the hard and toiling conditions of war, the control of Afghanistan is in the hands of the mujaheddin, how is it that the Afghan people would not be able to form an independent Islamic government under a single leadership?"

NEWS: The Deputy Commander of the Kandahar garrison, alongwith 15 other officers, of the enemy were killed recently by the mujaheddin in Kandahar.

* The KHAD member Naimatullan ana nis five armed guards were captured by the mujaheddin 31 January in Herat.

* Fifteen nembers of the atheist government were killed recently by the mujaheddin in $\mathrm{Hel}-$ mand.

\section{Mujahed 20 March 1998}

EDITORIAL: "On the occasion of the valorous uprising of 15 March" (By Nangyal). In commemorating the 15 March, 1978, valorous Herat uprising in which 25,000 peoples martyred themselves, the editorial says "now that 10 years have passed since that historical and examplary events, we now see many other uprisings and resurrections in other parts of the country and the enemy has been faced with a humiliating defeat and our proud and Islamic revolution is nearing its. success". According to the editorial "world arrogance has been hatching plots against this distinguished revolution but thei. efforts are being frustrated and our Muslim nation will not allow to lose the success and viatory wich it has achieved in the battlefield around the negotiating table through the snares of the enemy". 
BEFORT: Prof. Burhanuddin Rabbani leader of the Jamiat-o-Islami of Afghanistan in a large meeting in a speech about latest political changes in regard to Afghanistan said "there is no doubt that the Soviet announcement that it is going to withdraw from Afghanistan is a historical defeat for Moscow. However, we should not lose sight of the intrigues and objectives which the Russians have next to their withdrawal. Under present circumstances what we need is unity, unity between the mujaheddin offices and the jehad trenches so that, God forbid, the enemy may not hatch other plots and our differences and lack of harmony may not pave the way for the success of enemy intrigues".

ARTICIE: "Cold war, an important weapon against the people of Afghanistan" (By Sekander). The fussians and their hirelings have been trumpeting the issue of the withdrawal of Russian forces and NRP in order to compensate for the defeat in the military sphere and thus weaken our jehad. Therefore it is the duty of every Afghan to strengthen the Jehad and continue the war of liberation until victory".

\section{Serat-ul-Mustaqeem}

EDTTORIAL: "The real key to success of our jehad is the sovereignty of mujaheddin in Afghanistan" (By Dr. Abdul Hai)。 Two factors have played as basic motives in the Islamic jehad of Afghanistan. One has been the establishment of the sovereignty of communits in Afghanistan and, second, the occupation of Afghan soil by Soviet aggressive forces. Therefore, only the withdrawgl of Soviet forces from Afghanistan is not our objective but we first of all seek the downfall of the atheist regime, secondly, the withdrawal of Soviet forces and, thirdly, the establishment of an Islamic government are the basic objectives of our people in their jehad. Any solution in which the dismantling of the Kabul regime is not discussed will fail to bring peace in Afghanistan. Until the Kabul regime is in power, bringirig the war to an end in Afghanistan will be imlossib:e. Another point which forms the main spirit of the mujaheddin objective is the formation of an Islamic government in Afghanistan".

NEWS: NewS reaching from Kabul say that the Najib regime, afraid of the mujaheddin, has ordered the removal of Lenin, Marx and Angele's statues from Kabul ministries and other institutions.

* In a mujaheddin operation 17 January in Roadat, Nangarhar, five conmunist tanks were destroyed and 15 militiamen killed.

ARTICIE: "What next?" (by Bawar Mazinwal). The article discusses the importance of the Afghan jehad at an international level and then lists the political weaknesses of this jehad. The writer proposes that the leaders of the Afghan mujaheddin should completely merge their offices and agree to a single leadership. They thenselves should cure their weaknesses, recognize the true jehad forces and mujaheddin, commission experienced individuals of the society to jobs without discrimination or jealousy, discard nepotism, avoid being entangled with unnecessary and unimportant affairs and deal with main issues of the society, assure the people that past unpleasant events will not occur again, consolidate the forces of intelle ctuals, not paint palaces with the blood of martyrs, rights of the orphans are not usurped, unnecessary expenditures should be legally banned; writers and literary figures should be given the opportunity to offer constructive suggestions for the sake of restoring law and order and reforms in the society, experienced people should be taken into confidence and assigned to participate in the reconstruction of the society. other than implementing such measures this nation will surely further slip away from its true objectives.

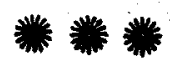


Neda-e-Jundullah

21 March $\$ 988$

ARTICIES: "The blood stained Nauroz (New Year)" The Nauroz is an auspicous day which has been celebrated for centuries with special occasions among the masses of our people. Yes, there were Nauroz holidays which were marked with utmost joy and felicitation. However, it is a pity that now for several years the people of Afghanistan are not able to celebrate the occasion and misfortune and agony rule on this day as well. Yes, it has been ten years now that instead of fresh snow water, on the mountain slopes and pastures of our country, streams of the blood of our thousands of martyrs are flowing and from them tulips are growing. Today, when we are entering the 11th bloodstained spring, we are sure that this new year is going to be our year of victory and triumph and the next Nauroz will be celebrated in freedom and independencelo"

* Two other important itens of the newspaper are a serial under the heading of "Oppression and Massacre of Muslims in Russian and the other one is, also a serial, under the heading of "Bring the enemy under the seige" wich is a manual of guerrilla warfare.

\section{Al-Noor}

21 March 1988 EDITORIAL: What do the Russian Want" (By Mawlawi Shales). "During the reign of Zahir Shah no sympathy was offered to the Muslim people of Afghanistan in material or moral spheres. Due to the lack of a proper policy by the Afghan leadership, the Russians were able to send their advisers, workers and teachers to deviate the people fron straight path and it has been (due to those faulty policies)that bloodshed has been continuing upto now. The mujahed and Wuslim people of Afghanistan started their re sistance, Russian troops were inflicted with nany economic and human casualties. The enenies if Irlam wish that no Islamic government should be established in Afghanistan and under the name of a neutral goverment a govermnent come into being in Afghanistan to block the way for the establishment of an Islamic one. Because neutral government or coalition government are only two different names having the same purpose."

NEWS: The Kandahar mujaheddin captured 19 March the Panjwaee sub-division of Kandahar province.

* The mujaheddin set ablaze 22 February the gasoline pipeline and demolished one tank in Samangan.

* The mujaheddin attacked 9 March the Kandahar airport destroying four airplanes and killing tens of soldiers.

REPORT: In a graduation ceremony of the students of the Madrasatul Hijrat wal Jehad, Mawlana Abdul Qayyum, lecturer at the Haqqania Madrasa, while placing turbans on the heads of graduate students, said these same turbans of virtue and excellence were placed on the heads of Mawlawi Mohammad Yunus Khales, Mawlawi Jalaluddin Haqqani, Maulana Mufti Mahmood Sheikhul Hifz, Mahmood Hassan, Maulana Hussain Ahmad Madani, Nohammad Shah Kabir and Maulana Abdul Haq. But these people did not take them only for decoration but the turbans served for them as symbols of knowledge, jehad and martyrdom. To them, these turbans have been the turbans of responsibility and discharging of their obligations. STATEMENT: The leader of the Hezb-e-Islami Afghanistan (Mawlawi Khales) who resigned some times ago from the Presidency of the IUAM, said in a statement $17 \mathrm{March}$, "In the future government of Afghanistan I am not going to be a candidate for any portfolio and God may bear witness that I desire complete unity (in the mujaheddin ranks)".

\section{Mujahed Ulus 21 march, 1989}

INTERVIEWS: Mawlawi Mohammad Yunus Khales, Prosident of the IUAM, in an interview with the 
newspaper has said: Now we are faced with an emergency. If God Almighty helped and Afghanistan became free, then no one particular individual would claim to be the sole inheritor of power. Neither the mullah can make such a claim nor anybody else. In taking decisions about the future of Afghanistan, the Afghans who had participated in the struggle for freedom of the country through speech, writing or fighting will participate in accordance with their talent and ability.

* Nohanmad Zahir Shah, the former King of Afghanistan, in an interview with the newspaper. has said: Legally any govermment enjoying the support of the majority of the people is entitled to assume power and it is up to the people of Afghanistan to determine the shape and composition of their future govermment.

ARTICIES: "tA comedy in political tragedy." (By Abdul Rahman Pazhwak). While reading press speculations about the Geneva parleys, I came across a remark by the UN mediator on Afghanistan Diego Cordevea who has said he had no permission so far to contact the Afghan mujaheddin. This has brought home to me several points: (1) Did he not have such a mandate for the last few years? If he did not have such a mandate, who had barred him from doing so? (2) Who has now given him the mandate 3 to establish such a contact? Cordevez is an international servant in the biggest international organization (the UN) and is free from receiving order from any member government of the organization including his ow native country and not only he is free from doing so but prohibited to do so... All those who are working in the UN are obliged to. act only in accordance with the resolutions of the UN specialy of the Security Council and the General Assembly and they have no other alternative, otherwise they would be violating the UN Charter. None of the UN resolutions, assigning the Secretary General to exert efforts for seeking a political solution to the.
Afghanistan issue which has in letter and spirit called for a comprehensive settlement, has barred Cordovez to contact the national strugglers and mujaheddin of Afghanistan or to do so from the beginning of his mandate. Therefore, it is relevant to ask who denied him permission to contact the strugglers and the mujaheddin and, after five years of parleys of Geneva - - which has been lengthy and futile eram the beginning - - which authorized source has given him the permission to hold such contacts or which source could have given him such a permission. On the surface all this sounds comical. But there are many comedies which have had tragic ends. At any rate, according to observers, this round of Geneva talks on Afghanm istan might be the last one. But, in the absence of the Afghan strugglers and mujaheddin, no resolution will be considered just, practical and acceptable and if it is done so, its historical responsibility is with Pakistan and the US".

* "Two almonds in one shell "(By Abdul Rahman Pazhwak). In the first part of the article; he writes" now it is being said that the Geneva talks will be revived in January or February, as a result of concentrated Russian attempts. If such is going to be the case, with all prom babilities from the point of view of national interests of Afghanistan and inflicting possible damages to the national resistance and jehad for the cause of God and restoring the usurped rights of the $99.99 \%$ people of Afghanistan, this round is considered to be the most crucial round of political and diplomatic arrangements that might to be adopted by the UN, Pakistan, Russia and the US."

In the second part of the article he says, "putting up at par the cases of Afghanistan and Nicaragua by the US President Reagan is a mistake. The Nicaraguan issue is a local and regional issue while the Afghanistan issue is a world issue. The very first resolution of the UN Security Council spells out and confirms 
this fact. In the UN General Assembly, which has been debating the Afghan issue for several years, the Afghanistan item in the agenda is listed in the following words "The situation in Afghanistan and its harmful consequencess on world peace and security". The Afgharistan issue is an issue of an attack by a UN member country on another member nation. If Mr. Reagan or another gentleman places the Afghanistan issue in the list of regional issues, truely he is making a mistake."

The article concludes by saying "The basis of new Russian tactics and specially Gorbachev's tactics have been that whatever the Russians lost during the last few years ought to be gained for them by others. In plainer words, Moscow intends that Washington, Islamabad and the UN Secretariat should help fulfil its designs. If the Russians succeed in this, this writer in no way will interpret this as a mistake by Washington and Islamabad. Because they both are competent and mature political centers and, therefore, their consensus with any politital arrangement which would not correspond with the national interests of Afghanistan and aspirations of its people, in my view, will not be unintentional. It will be a delibrate act. Until now there has been no doubt with me about the courage of our national strugglers. They are Afghans, Muslims and valorous and faithful people. If such a thing is imposed upon them, this might be accepted by the leaders of the Afghan struggle and Jehad. However it will not be implementable and possible through the Afghan nation.

* "Revolution or Coup" (By M.M. Seddiq Farhang) The Soviet leader Gorbacher in an interview with the NBC (National Broadcasting Company), In addition to expleining the reasons for the military intervention of his country in Afghanistain, has described the Saur coup as a revolution. The use of the word "revolution" about this epipode by an indivldual in the status of
Gorbachev is indeed surprising and casts doubts about his insistence that he is ready to bring to an end the Soviet intervention in Afghanistan. Because we all know that what took place in Kabul on the 7 Saur ( 27 April) and, in addition to the people of Afghanistan, the foreigners living in Afghanistan, also observed, was a political coup and not a people's revolution. In order to explain this point one can offer many arguments and the following are some of them: (1) Revolution entails a total upheaval wich takes place with a wide spread participation of various strata of the people while the 1978 coup was executed as a result of an initiative by a small group of military officers and the masses not only did not participate in it but were unaware of its nature, (2) A real revolution has always a virtuous reality and emerges out of the miseries and discontent of the masses while the 7 Saur coup, according to confession by one of its big comnanders, Hafizullah Amin, was brought about under an already planned secret conspiracy which was implemented under his own command, (3) Revolution has a real motive, the objective of wich is the realization of the aspirations of the people and after its success, it endeavors to realize those aspirations, whereas the 1978 coup was based on incidental slogans unfamiliar to the people and it was rejected by the people at the very outset and the regime was dragged $t_{1}$ the threshold of fall. Thus, whatever happened in Kabul 7 Saur was a coup and not a revolution and the use of the term revolution in that context, in addition to misrepresenting the reality, tantamounts to a contempt of the very concept of a revolution."

\section{Shahadat}

22 March 1988.

EDITORIAL: While welcoming the Afghan New Year it has hoped for the mujaheddin success and asked Almighty God to make 1988 the year of complete victory of Islam over infidelity and communism.

REPORT: Gulbuddin Hekmatyar leader of the Heab- 
e-Islami Afghanistan ir relation to latest events told prayer offerers after the jumah prayer 19 March "We will prove to the world that no agreement will be implementable in Afghanistan without the consent of the mujaheddin". He added "you should believe, if there were only one percent chance for the Russians to continue the stationing of their troops in Afghanistan and if they had some hope for occupying Afghanistan, they would have never come to the point to leave Afghanistan. The Russians are leaving Afghanistan to save themselves from further disgrace".

NEWS: The Takhar mujaheddin shot down 6 March two enemy helicopters and killed 70 atheists.

* The Baghlar mujaheddin in an operation 27 January captured six govermment soldiers with their weapons.

* Guerrillas in Kabul city recently killed a well-known spy woman, Aisha.

* Two Tadjek soldiers killed eight Russian soldiers inside their base (place not given) during late February. One of these soldiers was killed in a mine explosion and the other one came to the mujaheddin and saved himself. ARTICIE: "The Red Shirts are again being deserted" (By Sayyed Gulab Sabaoon). It reflects on the "historical friends" of the Red Shirts and writes, "during the partition of Pakistan and India,Gandhi and Nehru incited Khan Abdul Ghaffar Shan to oppose the establishment of Pakistan. However, much time had not passed when Nehru started whispering in the ears of Pakistani leaders and deserted the Red Shirts. But Abdul Chaffar Khan did not learn a lesson from history and once again expressed preparedness fulfilling Indian designs in the region. The Red Shirts, who have a lust for power by legal or 1llegal means, also colluded with Russian world devourers. And now history once again repeats itself. The Russians and their contemptible hirelings, in order to save them- selves from the Afghan whirlpool, by recognizing the Durand Line, are playing a game at the cost of Red Shirts. However, Ajmal (Khattak) and other red shirts should have learnt from history. There is a saying "the blind loses his cane only once". The Red Shirts should not have been dependent on others so much. However, the eyes of (Than Abdul Wali Whan) and Ajmal (Khattak) have been blinded because of their own (personal) objectives and it is very much possible that they will continue their dependence on the Russians and Indians".

\section{Ittehad-e-Islami}

23 March 1988.

EDITORIAL: "The message of freedom on the threshold of the new year of revolution". The editorial welcomes the new year as a good sign for Afghanistan; a year of mujaheddin unity, and says "the unity of mujaheddin organizations and their joining together is tantamount to the formation of a new and deadly front against the enemy and, in case this new unity is realized on all fronts, the enemy will find himself in a complete state of defeat. The new year is not going to be like other years when the enemy was resorting to the creation of disunity. The jom had forces are going to frustrate the snares of the East and the West arrogance and are moving forward towards the realization of Islamic values in the shadow of Islamic revolution and they will leave only two options open for the Russians; (1) the unconditional withdrawal and (2) accepting Afghanistan as the graveyard of conmunism..."

REPORT: Prof. Sayyaf, leader of the Ittehad-eIslami has told the Supreme Council of the organization "we want the formation of an Islamic goverrment by the mujaheddin and from among the mujaheddin. We are rejecting resolutely a coalition or a neutral govemment. There is no alternative before us other than the continuation of armed resistance."

* The Sipreme Council of the IUAM decided 
about the armouncement of the mujaheddin provisional govermment 16 March and spokesman of the IUAM Gulbuddin Helmatyar said "we are united;" we are golng to strongly preserve this unity, nobody can hinder our unity, the government which has been announced under the leadership of Engr. Ahmad Shah is a govermment which leads to a reasonable.solution of the Afghanistan issue and we ask the entire world to recognize this govermment of the mujaheddin".

INTERV IEN: Hazrat Sebghatullah Mojaddadi was asked to comment about an interview which the $B B C$ had said he had given. The BBC had quoted Mojaddadi as saying that the govermment which the fundamentalists wanted to form in Afghanistan had no difference with the government of Najib. Mojaddadi, in answer to this, has told the newspaper, the $\mathrm{BBC}$ report is completely false and we never place at par a Muslim brethren with an atheist."

RESOLUTION: The refugees and the mujaheddin of six camps in Badabira in a meeting 19 March attended by 15,000 people resolved: (1) we re sorted to hejrat due to the formation of an atheist government and Soviet aggression in Afghanistan and we are going to continue our holy jehad until the establishment of an Islamic government, (2) we are not willing to accept a government formed as a result of collusion among outside powers, (3) we are rejecting any kind of decision in the absence of the refugees and mujaheddin about the future government of Afghan istan, (4) we are not accepting the formation of a coalition government with communists, (5) about the solution of the Afghanistan issue, we will only accept the decision which has been made with the participation of the leaders of the mujaheddin, (6) we are expecting the leaders not to be swayed by others, (7) we are supporting the interim govermment of the mujaheddin and (8) we are not going to return to the country until the formation of an Islamic government.
ARTICIE: The article, by Mohammad Yasser, is about the issue of sending a mujaheddin delegation to Geneva. It says there were two views about the issue: (1) the sending of the delegation to Geneva is useful because we will be able to announce the following matters; the govermment of mujaheddin has been formed, we are not ready for direct or indirect talks with the govermment of Najib, we are not ready to form a coalition government, we have reservations about the continuation of the Geneva tafks. Such announcements will strengthen our political stand and no harm will be done (2) As we have already rejected the Geneva talks and consider them illegal and do not want to participate in them during the signing stages of the Geneva accords. If the sending of a delegation is for the purpose of conducting indirect talks with the Kabul puppet regime, in which Cordovez may mediate about the issue of an interim government, this could be accomplished next to Torkham (an Afghan-Pakistan border check point) because Najib had asked the leaders of jehad to enter talks with the Kabul regime and all the leaders of the jehad had unanimously rejected his offer. But if the sending of a delegation is for the amouncement of the mujaheddin position, this could be accomplished in Peshawar in a meeting attended by one million mujaheddin and refugees. Therefore, the sending of a delegation will not be an affective and successful venture and will, in addition entail, the following political liabilities and Pitfalls: (1) the sending of a delegation for the announcement of (an Afghan) stand behind the doors of collusions will show that we are expecting to enter from the back door while we have been against negotiations from the outset (2) as most of the means of mass communications are in the hands of our enemies, they might announce to the world that the mujaheddin delegation has gone to Geneva to participate in the Geneva talks and in that case nobody might hear our dissenting voice, (3) as in the Geneva talks the two 
sides of the negotiations are the Kabul government and Pakistan and the American and the Russian delegations are also present for the sake of interpreting the positions of the two sides, the presence of a mujaheddin delegation in Geneva will mean that actually we have appointed the Pakistanis as our advocates to speak on our behalf (4) if talks are held with Cordovez and that, too, in secret, two damages are envisaged: one; nobody will know what was discussed and this will be tantamount to indirect talks as Cordovez will be forced to discuss the issue with the Kabul puppet regime because he himself is not a party to the issue and furthermore Cordovez had spent days to meet the Afghan mujaheddin delegation in Islamabad and finally. the IUAM President agreed to meet him at the request of $\mathrm{Ziaul} \mathrm{Haq}$ and now waiting by the mujaheddin delegation behind the office door of Cordovez will trample our previous political posture, dignity and position, (5) the Geneva talks is like a political gambling house where deals are made about the fate of millions of Afghan mujaheddin ... Thanks God the Russians did not offer to hold talks with the mujaheddin and for this reason the sending of a delegation was ignored. Since the sending of a delegation was yet another degradation we say "the best is what happen" (Arabic proverb).

\section{Shahadat}

27 March 1988

EDITCRIAL: "Kremlin in the defile of its fate". The editorial discusses the mistake of the Russian aggression against Afghanistan and draws the conclusion: "outside the Russian sphere of influence all others are aware of the disgraceful Russian defeat at the hands of the Afghan Muslim mujaheddin and inside Russia, Moscow is trying to brand the withdrawal of its forces from Afghanistan as an act of peace-lovingness. However, events of Azarbaijan and Arministan show the Russian mask has been revealed to the enslave nation of Russia and they, too, have found out that the powers of the usurper are to be defeated with exerting efforts; The path that the Musiim Afghan nation chose for unshackling of the chain of slavery is a path which will undoubtedly form the path of the enslaved Russian nationalities and the Russian problem will not be solved with the withdrawal of its forces from Afghanistan. The Russians will find in the future that the Afghan blunder has been indeed costly for them. Many political analysts know this even now but the Russians are going to be the last ones who will realize it.

REPORT: Hekmatyar, the Amir of Hezb-e-Islami. Afghanistan and President of the IUAM, said in a press conference 19 March "there is no doubt that the withdrawal of Russian forces will be coupled simultaneously with the downfall of the Najib regime." In relations to the Geneva talks he said "we are not like the little birds in a cage to be sold by someone in the market and that others may play with our fate."

NEWS: The mujaheddin captured alive 11 February 56 enemy personnel in Barikot, Kunar.

* Fifty-two Russian soldiers were killed and seven tanks demolished 4 February in Parwan.

* Eight Russian hirelings were killed and a number of others.injured-27 February in Roadat, Nangarhar.

ARTICIE: "Gorbachev is after the title of the hero of peace" By Feda Mohammad Faiz. The article has rejected "the boast of Russian peace-lovingness" and says "How somebody, whose hands are stained with the blood of 1.2 million people, can be considered as a hero of peace?" The writer says indeed the Afghanistan issue has become a bleeding wound for the Russians because the more it tries to find a face saving device for its withdrawal from Afghanistan, the more it faces difficulties and world-wide condemnation. 
victories". "Last year the Russian communists and their coward puppets, in the process of their aggression and oppression, staged more savagery than the year before. During the past year, they committed such crimes against the noble Afghan nation that cannot be compared with anything in the history of the past or of the present. On the other hand, the mujaheddin, due to their valor and heroism, were able to strengthen their jehad and resistance trenches throughout the country more than before.

"Last year the jehad organizations were able to strengthen their. unity and take forward steps in political fields. They sent a joint celegation to the W General Assembly, announced the main features of an interim government to take over after the withdrawal of Soviet forces from Afghanistan, announced their solid stand viz-a-viz the Geneva talks by saying 'we will never accept the kind of cecision that will not fulfill the aspirations of hundred of thousands of our martyrs and refugees.' We are of the opirion that, like last year during which the mujaheddin achieved political and military success and victories, this year, too, our Muslim and mujahed people will be crowned with new victories. NEWS: The mujaheddin killed 40 Russian soldiers in an attack 9 January in Bak, Paktia.

* In a mujaheddin operation in Alauddin, Kabul province, 5 January four Russian soldiers and one high ranking military officer of the puppet regime were killed.

* The mujaheddin killed 18 January four Russian soldiers in Sarobi, Kabul province.

ARTICIES: " Why the Russians are leaving Afghanistan?" (By Abdullah Gujrian). The Russians, by utilizing the tactics of two steps backward and one step forward, have announced they are going to withdraw from Afghanistan. The writer, by comparing similar tactics used by. Moscow during the war with the Germans and in Crechoslovakia as well as in Central Asia, concludes that the Russian purpose has been to isolate the mujaheddin in political arena.

* "Paying attention to the mujaheddin, the handicap and their children in the light of the teachings of Islan" (By Mawlawi Abdul wasay $\mathrm{Na}$ amani). It is an Islamic obligation. for us all to attend to the needs of the mujaheddin and those who have been handicapped in the jehad and their families.

\section{Shahadat 4 aprat, 1998}

ELITORIAL: "A 19 ytar old movement under trial"

"The Islamic movement in Afghanistan has left behind 19 years and has entered its 20 th one. In the scale of time, 19 years are not many in the life of a movement but the ufs and downs that this Islanic movement has gone through during the course of its short life ane unprecedented in the history of contemporary Islamic movements. In Afghanistan the Islamic movement has gone through the zigzag of the struggle by shedding blood and right now is moving in this direction by sacrlficing lives and for this reason it has become a thorn in the eyes of the enemies of Islam.

"Those who are still dreaming about a relapse to the past and to regimes which have been declared null and void have not understood ws properly. Tomorrow there will be no Russian gunships or planes to protect them, there will be no barriers of tanks and not ranks and files of armed soldiers to shield them.At that time, who will have the guts to enter. the arena and resort to the formation of any other regime than an Islamic one. And, granted if such a courage is shown, which force will save this regime from our bullets and the fire of our wrath.

REPORT: President of the IUAM and leader of the Hezb-e-Islami Gulbuddin Hekmatyar in a press conference 2 April about latest developments in the Geneva accord said met the world once more know that we are free and independent in 
taking our decisions". He added "we are not afraid of the signing of the Geneva agreement because we are perfectly capable of continuing the war." He added, "no body can collude on our behalf with others."

* Twenty five thousand refugees, who took part 9 April in a grand meeting in Mianwali refugee camp called the continuation of Jehad as the only altermative for their freedom and said "until conditions are fit for an honorable return of the refugees, we will continue our aforts and activities".

NEWS: In the Sisi region of Wardak, the mujaheddin recently killed the commander of the government post and 20 of his soldiers.

* The mujaheddin shot down in January three enemy planes in Parwan.

* Eighty enemy personnel were killed and three tanks demolished in Taira, Paktia 5 January.

ARTICIE: "The role of the Islanic revolution of Afghanistan in the region and the world"

"The Afghanistan Islanic revolution clearly has demonstrated to all the Islamic Ummah that only through a return to the letter and spirit of Islam will they be able to rise for the re alization of their honor, independence and as pirations and tie the hands of the satanic oppressor and aggressor.

\section{Neda-e-Jundullah}

4 April, 1988.

EDTTORIAL: "The final plot of the imperialism". It refers to the fertility of northerm provinces of Afghanistan and then points out to speculations according to which the Russians intend to divide Afghanistan. It says; "Russian communist criminals want that as a result of dividing Afghanistan and transferring the puppet regime to northern provinces, on the one hand, bring under their control the natural and agricultural resources of that area, and on the other hand, come closer to their long cherished dream of reaching the warm waters ... Furthermore, the Muslims of Central Asia, inspired by the Jehad of the Muslim people of Afghanistan, have felt the spirit of freedom and independence and the Russians are afraid that their withdrawal from Afghanistan will usher the beginning of an uprising in Central Asia and with this plot they want to create a curtain between Central Asia and the Islamic government south of Hindu Kush. However, jmperialists ought to know that in every inch of this land of brave people, the valorous heroes have taken positions who would clean away the stains the imperialists with their blood. The people of Afghanistan know that the northern provinces are like jugular vein of the country without which life is impossible in the southern areas and above all, how the Muslims can remain silent against such a conspiracy ... It is definite that the program of the imperialist criminals would prove to be the beginning of another headache for them and the jehad of the people of Afghanistan would further infuse awakening among the people of Central Asia ..." REPORT: Witnesses say the Embassies of Poland, Czechoslovakia, Cuba, India, North Korea, VIetnam and Iraq have been told by Kabul authorities to raise the walls of their compounds by another meter. Thus, the nests of spying by the Eastern Block and India have been brought under emergency conditions.

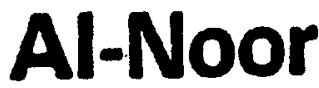

5 April 1988

EDITORIAL: "Why the interim government is not being established?". It is strange and regretm table that, while it has been several weeks that the IUAM has announced the framework of an interim govermment, neither the cabinet of this new government has been appointed nor leaders of the seven parties have delegated the (necessary) powers to the President and Vice President of the interim govermment. If the IUAM or a member of this organization has a second thought about this goverrment, it 
should say so; however, if the IUAM and its components are completely supporting it, then what is the reason for not establishing the govermment.

REPORT: Mawlawi Khales in a speech 25 March told the refugees and mujaheddin, "now the East and the West are trying that, in case a communist reglare cannot be established in Afghanistan, an Islamic government should also not be established. They want a third type of government to be set up. It is for this reason that we are rejecting the Geneva talks as well as the idea of a neutral government."

* Mawlana Zahed Al Rashidi, Assistant Secretary General of the Jamiat-e-Ulema-e-Islam of Pakis$\tan$ visited, curing the first week of the month of Hamal (last 10 days of March) mujaheddin trenches in Paktia province. He described his trip as useful and said the mujaheddin are guarding their trenches with very strong morale.

NEWS: The mujaheddin of Hezb-emIslami captured 23 March 50 officials of the Kabul government and military posts belonging to Zarkeli pass. Four mujaheddin were killed and four others wounded in the operation.

* Recently in a mujaheddin operation in Paktia 40 enemy tanks were demolished and hundreds of atheists kiled.

* The deputy head of KHAD in Takhar province along with 16 other atheists were killed 3 March. ARTICIRS: "New Russian Plan" (By Sharafat). "The new plan envisaged by the Russians wich they want to implement is to divide (geographically) the Islamic Afghanistan. The following are the reasons which make one believe that the Russians are planning to split Afghanistan:

1. The Russians have created a portfolio for the Prime kinister of Northern vrovinces in the organization of the Kabul resime.

2. They have established a university in Balkh.

3. The have carved out a new province from sou- thern secturs of the Balkh and Jauzjan provinces under the name of Sar-empul.

4. They have been signing direct agreements with northern province.

5. Rumors in Kabul have gained momentum that the cupital of Afghanistan will be shifted. from Kabul to Mazarie-Sharif.

* According to the Russians this move will have two benefits:

1. A new country will be carved out for the Khalqis and Parchamis under the name of North Afghanistan,

2. Southern Russian borders will be shielded from the wrath of a nation which has rendered 1.5 million martyrs.

* At present it is difficult to definitely say whether the Russians are planning to divide Afghan:stan but, judging from evidences, one can say the Russians are hatching such a plan and it is now up to the leaders of the jehad and all compassionate elements of the Afghan nation to pay attention to such a program and deal with it with alert:

\section{Ittehad-e-Islami \\ 5 April, 1988}

EDTTORIAL: Najib, the trattor, wants to create hues and cries under the name of parliamentary elections and, on the basis of the dictates of his masters, tell the world that a peaceful atmosphere is prevalling in Afghanistan."

"However, parlianentary elections are taking place at a time when peace and security in the country is prevailing due to the fact that the people themselves are in power and, as far as the puppet government is concerned, its domain has become confined to a few buildings inside the city of Kabul and their staff are living like risoners under the supervision of Russians and Rusitan forces are present in some cities by transgressing the independence of the country. Bloody conflicts are 
continuing and major portions of the country are invmujaheddin hands. Then who and in which part of the country is going to set up election booths?

REPORT: A grand tribal jirgah in Mohmand Agency 31 April expressed solidarity with the mujaheddin and declared: (1) we urge the formation of an independent Islamic government by the mujaheddin themselves (2) the Russian should quit Afghanistan soon without any conditions (3) a political solution of the Afghanistan issue should be in accordance with the wishes of the mujaheddin (4) until an Islamic government is formed in Afghanistan, we are going to fight side by side with the mujaheddin against the atheist govermment (5) we are going to sever ties with those who in our region have established ties with atheist govermment in Kabul and declare that their killing is permissible under the shariat.

* The tribal chiefs of Whyber Agency under the leadership of Haji Malek Nader Khan Afridi, in a meeting with Eng. Ahmad Shah, President of the provisional govermment of the mujaheddin, offered all out support for the mujaheddin on behalf of the Afridi Tribe.

NEWS: The mujaheddin, in an operation 19 March, demolished four eneny MIG planes and one helicopter in Kandatiar airport.

* In a two-day mujaheddin operation recently in Helmand, 23 militia posts were captured and 220 militiamen killed.

* The mujaheddir set ablaze 24 March two enemy jet fighters in Kabul airport.

ARTICIE: (By Mohammad Yasser) "The butchers of politics, have tied the hands and feet of the Afghanistan issue and slaughtered it in the Geneva slaughterhouse. These butchers are not only putting an end to the life of one being but are doing away with the lives of millions of innocent. people. They slay a whole nation. They are neither afraid of the cries of the opp- ressed and orphans nor of the condemation of the history ...

"Cordovez is cherishing the hope of receiving the Nobel Prize for Peace and is keen to see his name recorded in the annals of the w. Others want to compensate Pakistan for signing the Geneva agreement by putting an end to the Durand Line border problem as a result of which the Russians with the cost of Afghanistan, are going to forresake their internal servants who worked under the name of Pakhtunistan and also the Russians will start for Pakistan iron and steel factories, power plants in Multan and the development of rural and production programs. The US, ir return, wants to have its share in armament agreements and Soviet installed governments in Latin America, the Middle East and other international issues. Other butchers of the arena of politics are also emerging to have their share in deals concerning the selling of the blood of the oppressed Afghan nation.

\section{Mujahed 9 apri1}

EDITORIAL: "The 17th session of the Islamic Foreign Vinisters". The editorial comments about the Islamic conference held in Amman the capital of jordan and the Afghanistan issue. It says "in this session, the IUAM delegation took part and, under the leadership of Mujahed Brother Mawlawi Mir Hamza expiained the essentials of the Afghan Jehad and Fussian political maneuvers. The dolegation attended the conference as observer. On the basis of prudence and skill of the leadershif, the delegation was able to secure a clear cut resolution about Afghanistan issue which contained new points in comparison to previous years.

"The meeting, with a clear cut majority, urged the unconditional withdrawal of Russian forces, praised the struggle of the Afghan mujaheddin and asked for the right of the people of Afghanistan to determine their own fate. 
"The conference declared that the Kabul puppet regime has lost its right of membership in the conference and tho OIC will not establish any kind of political and diplomatic relations with that regime. It has also been mentioned in the resolution that the unity of the mujaheddin and establishment of interim government Will help restoring the Islanic prestige and nonaligrment status of Afghanistan and it is necessary that, on the basis of mujaheddin unity and formation of an interim government, the Afghan issue will be solved in accordance with the wishes of the mujaheddin.

NEWS: Strong explosion of bombs took place in Kabul last week.

* The Russians have trained 30,000 school boys to safeguard communist interests within the framework of the Interior Ministry.

* According to a report, the Governor of BaghIan was executed 5 April by the mujaheddin.

* Tro spies of the hireling regime of Afghanis $\tan$ have been arrested in Teheran.

ARTICIES: "Elections by the Kabul regime" (By Mohamad Nasim Faqiri). The article, describing the drama of the parliamentary elections by the Kabul mercenary regime as another disgraceful attempt, says Russia and its local hirelings know very well that such tactics cannot deceive the people and would definitely fail. So, why do they resort to such attempts? The answer is clear. A significant Russian objective is to legalize the self styled Kabul regime and all these attempts, tactics, policies and plans are mostly not oriented for domestic purposes but are directed to abroad in order to convince the people and governments of the world that the Kabul regime was workable one and fulfills all conditions of being recognized. But informed people of the world would not be deceived by these snares and elections held by the Russian hirelings would fail in deceiving the public opinion at the world level as they were frus-

trated inside the country.

"An article without caption has been translated from American sources by Mohammad Roohani which writes "in Panjshir I met a 36 year old man whose name was Siddiq, brother of Najib President of the puppet government of Afghanistan. Siddiq says "the Russians picked up Najib because he was an appropriate servant and Karmal had become old and sick. Najib is an actor. and a shameful talkative better for the Russians than Karmal because the former had a way into the secret police and can endanger Iran and Pakistan."

\section{Ittehad- $\theta-I$ slami \\ 12 April}

EDITORIAL: "The multitude of problems in fact is a sign of the divine help". The editorial, while referring to problems which had faced the Muslim at the time of Mohammad (peace be upon him) in the Ahzab War, concludes," It is being heard from world radio stations recently that the treaty on the Afghanistan issue is going to be signed in Geneva shortly. As a result of the conclusion of this accord, it is feared that life for the mujaheddin and refugees will become harder and in that case what is to become of the future of the jehad and this leads to other questions and worries. An answer to all these is that a multitude of difficulties and a cut in worldly means in fact signal, the approach of the time for the fulfillment of divine promise of help. We are confident that Almighty God will not leave this jehad alone and he is our real and true supporter. It was the help of God which enabled the empty-handed mujaheddin to bring a big world military power to its knees and force it tolannounce the withdrawel of its troops. Our brothers should be in guard against those, who by talking about possible defficulties, are causing unwarranted panic and worries among the people. They are in fact helping the enemy and are agents of the enemy". 
REPOAT: Prof. Sayyaf, the Amir of Ittehad-e Islami Afghanistan told a gathering of the Jumma prayer offerers 9 April "let all the infidals join hands against us. They will not be able to harm us. Now the rays of the torch of our jehad have reached the entire world. Nobody can extinguish this light. The time is near when you will be going towards the country proudly under the banner of unity."

* Prof. Sayyaf, the Amir of Ittehad-e-Islami Afghanistan in a speech to the staff of the University of $\mathrm{Da}$ 'wat and Jehad said 6 April, "I am sure that no one be able to close the door of God's help on us and God will not foresake this Jehad (or ours)."

* A meeting of the refugees, velonging to Peshawar camps, in a joint statement 8 April declared; (1) we strongly support the provisional government of the mujaheddin (2) we do not accept the Geneva negociations (3) we do not accept a coalition government with Najib. ARTICIS: "Hospitality Offered by others is always conditional." In connection with signing of the Geneva accords the article says," (1) What does the honorable return of refugees to their country entail? They thought that the refugees will sit down in buses after the signing of the agreement and go to Kabul via Torkham where Najib's team will garland and welcome them. However this is not so. As long as the root cause of hejrat (seeking refugee from atheism and oppression(2) - the establishnent of a communist regime in Kabul - - is not eradicated, the refugees will remain (in Pakistan) and the hejrat will continue, (2) it is indeed strange that despite that fact that we have so far not of fered any ceasefire with any body and we are not going to reconcile with the government of Kabul, we are still being urged to go to Afghanistan and to live under the rule of a regime hose hands are stained with our blood and is the root cause of our hejrat. If they are thinkin that the refugees will voluntarily return to live under a communist regime, this is a kind of evasion. But if they think that they will be sent forcibly, then one must rast assured, they will be returning to Afghanistan to continue the jehad and not to give up themselves to the Najib government, (3) sending the refugees under the Finnish General (deputy of the Representative of the UN Secretary General for observing the implementation of the Geneva agreement on Afghanistan), this will be tantamount to handing over the refugees to the enemy. In response, the refugees will resort to a second hejrat just like the Muslims of the time of Mohammad (peace be upon him) who first sought refugee in Abyssinia and then to Madina,* (4) our refugees ought to know that stranger's hospitality is limited and up to a time and they should prepare themselves for a Long jehad and for living with their families in jehad zónes. If five millions of our people have become refugees, ten millions of our Muslim and mujahed people have so far lived in the very arena of war and struggle. Yet the condition of life for them inside the land of the brave is many times better than living in refugee camps, (5) the refugees should be sure that the withdrawal of the Russians from Afghanistan is a sign of Moscow's defeat and success of the mujaheddin. Under such a reality, the internal communists have not other alternative than to give themselves up to us to flee. Therefore, you, the muhajer brethren; be prepared for an allout jehad. Don't allow anybody to act as an advocate for you. Wait for the command of the jehad leadership and of the government of mujaheddin."

* (EDITOR'S NOTE: The Muslins who went fron Abyssinia to

Madina ought nut to be comparud with a projectud situation in the life of afghan refugees. However, a similarity exists in the case of a number of Muslims who sought refuge in Abyssinia but they ware sent back to Kakkah by the Abyssinia government, but, as conditions were still bad in Makkah, members of the group once against sought rafugee An Abrainia). 
Wahdat-e-Islami

14t April 1988

EDITORIAL: "A glance at the Geneva talks"。 "The Soviet actions prove that Moscow is not in favor of a permanent solution of the Afghanistar! issue. A major drawback of the Geneva talks have been that the talks did not take place between the main parties of the issue - . - the mujaheddin and the Soviet Union - - - but were held between the side parties - . - the Soviet puppet government and Pakistan - .. and that too indirectly . - We are to mention that neither the individual leadership of the Jehad urged the government of Pakistan to enter the talks on their behalf nor the government of Pakistan became aware of the repurcussions of its position (for holding talks at the Geneva framework). Because such talks with the Kabul regime - - - direct or indirect - - - in fact deny the right of the mujaheddin to be treated as a real party ... Refusal on the part of the Islamic Republic of Iran to particjpate in such talks was indeed legal and logical... The fact that the mujaheddin have so far not participated in these talks, have made the parleys insignificant ... We should also add that in Afghanistan no agreement or peace can be implemented without the cooperation of the mujaheddin ... The signi$\mathrm{ng}$ of the agreement indeed makes clear a number. of 1ssues. For instance (1) as a result of the signing of the Geneva accord, war will not end, (2) all signatories of the accord are trying to bar each other from taking any advantage, (3) serious issues related to the Afghan problem would still remain unsolved and numerous contradictions will be observed in the text of the agreement. So, in other words, what will be signed on the paper will be one thing and what will actually happen in Afghanistan will be another. In short, the agreement is not going to pave the way for a stable and durable solus tion. It will not be instrumental in ending the war in Afghanistan, it will not pave the way for the voluntary return of the Afghan refugees and will not result in a change in the hireling Russian government in Kabul. The signing of this agreement is in fact a previlige which the govermment of Pakistan and the US have extended to the Russians... In our opinion, the hollow treaty of Creneva, also full of contradictions, will solve none of the problems of our nation and our mujahed nation will achieve its objectives of the holy Islamic Jehad by continuing it under a united and healthy leadership within a commu crganization and, therefore, we favor the continuation of armed resistance and the elimination of multiplicity and division in the mujaheddin ranks and the formation of a united Islamic order and leadership and will have no obligation in regard to accepting and following the provisions of the Geneva agreement and the collusion between the super powers.

INTERVIEW: Judge Mohammad Amin Waqad, the leader of the Afghanistan Mujaheddin Islamic Unity Movement, in an intervi $\in w$ about the current affairs and Geneva talks, has said "In Islam there is no place for peace with apostates". He added "our Jehad has a three pronged special objective: (1) unconditional withdrawal of Russian trocps from Afghanistan, (2) the toppling of the present Comrunist government and (3) Establishment of an independent Islamic government". In regard to a coalition govemment he said," After the withorawal of Russian forcee it is within the jurisdiction of the mujaheddin as to what form of government they are going to establish. Of course all know that nobody is going to make the murderers of the nation as a partners for determining his fate... The idea of forming a coalition govemment with the puppet and murderer regime of kabul is completely objectionable and un-Islamic. Such a thing whll mar our Islamic identity and Jehad status. It will be the mujaheddin who will form the Islamic government in Kabul. Our Jehad had begun for this purpose and not for forming a coalition 
government with the communist.s".

NEWS: The Islamic Republic of Iran rejected 10 April the Geneva accords on Afghanistan in a Radio Teheran broadcast.

* Shah Aqa, a general of the commurist regime in Kabul was injured in a mujaheddin attack. He later died.

\section{Rah-e-Islam} 16 April 1988

REPORT: The newspaper has published many features about the Geneva accord. They deal with the following aspects of the issue;

- - The accord, signed in Geneva, will not be able to maintain peace in Afghanistan,

- Russia, the US and Pakistan demand the formation of a coalition government with communist while the mujaheddin are not going to accept this design even if it is going to cost them their lives,

- The Geneva talks were condemned by the mujahedain six years ago and were declared void.

* A US Senator Cordon Hamphrey has said the US should not sign the Geneva accord.

* We have no altemative than toppling the Najib government and establishing an Islamic govermment - - Hekmatyar.

* With the signing of the Geneva agreement and even with the withdrawal of Russian forces from Afghanistan, regional security problems will still persist for Pakistan.

* With the signing of the Geneva agreement, imperialist treaties and agreements between Russia and Kabul regime are going to remain crem dible and the present crime could once again be repeated.

* Although the signing of the Geneva agreement is a major and historical event, it will not result in peace in Afghanistan - - The New York Times.

* Iran has condemned the signing of the Geneva agreement.
* The pivotal role of the Afghan mujaheddin should be taken into account in the Afghan issue - - the Islamic Republic of Iran. NEWS: The Kabul-Jalalabad highway remained closed for three days after 4 April.

* The Karghah Division was subjected recently to mujaheddin attacks as a result of which one arms depot was set ablaze and 88 enemy personnel injured.

* Willy Brandt has said Gorbachev has told him that Kremlin decided in 1985 to withdraw its troops from Afghanistan.

\section{EKhas . 17 April, 1988}

EDITORIAL: "Geneva or the slaughter house of the' aspirations of the Islamic Ummah". Five atheist world powers do not wish prosperity for any one else but themselves and, during the World War II, these very five countries had divided the entire world among themselves. These very powers also decided that if by dominating one of the nations of the world the interest of one of them is being threatened all of them will refrain from colonizing that country and that region will be considered as a free international zone. One such country is Sweden (stet) the carital of which is Geneva (stet).

"After the Russian aggression against Afghanistan, the Russians and the Americans in their secret talks at the UN - an institution acting as an enemy to Islam - - decided that if the Russians were defeated in Afghanistan, a face saving device will be provided for Moscow under the name of declaring Afghanistan a free zone so that the Russians may be enabled to pullout their troops from that country ... Now that the Russians have been brought down to their knees in Afghanistan, the so-called Geneva peace formula has been invoked to enable the Russians to withdraw their troops from Afghanistan while the Afghan mujahed nation had condemned the Geneva talks from the very beginIning and now we are condemning the very accords 
and their signatures and we will continue our Jehad for the cause of God. Because the treaty is actually between Russia and the US and the mujahed Afghan nation has nothing to do with it and we are condemning this imperialist snare".

NEWS: The Takbeer magazine in its 31 March issue writes that 90,000 KGB and KHAD spies are busy in political and terrorist activities in Pakistan.

* The Logar mujaheddin shot down a Russian plane in the month of Hamal (March-April).

* The mujaheddin in Urgun, Paktia, killed 19 March 10 enemy soldiers and captured another 15 of them alive.

* The Baghlan mujaheddin recently captured 12 enemy posts in that province.

ARTICIE: "The transitional government announced by the mujaheddin is a prelude to the formation of an Islamic govermment in Afghanistan" (by Janan Onarkhel). The article epumerates the duties of the interim government and says "this government has six months time from the period it begins work to pave the way for the establishment of an Islamic govemnent in Afghanistan. It is also assigned to maintain law and order in the country and to draft laws and rules for elections and the future government in Afghanistan.

Neda-e-Sangar ${ }_{17 \mathrm{pr}+1,1988}$ EDITORIAL: "The plot behind the withdrawal of the Red Army from Afghanistan". The editorial gives an account of the Soviet aggression against Afghanistan and its "economic, political and military defeat" as well as the UN resolutions urging the withdrawal of the Russian forces from Afghanistan and says that the Russians, "in order to relieve themselves from such deadlocks, have in the past resorted to intrigues and today also they are hatching another intrigue . . Russian tactical activities in northern provinces of Afghanistan are another dangerous plot which Moscow is contemplating". The editorial says the Geneva accords are not acceptable and adds that the warm trenches of the Jehad are going to become warmer than before.

NEWS: The office of the Iranian President has urged greater activities by the Islamic coalition council of Afghanistan in political arena.

* As a result of nationalistic conflicts, 34 people have been killed in the Soviet Union.

* During the last 10 days of March, one enemy

MIG fighter was shot down and 15 tanks demolished in Helmand.

ARTICIE: "Would the conclusion of the Geneva agreement result in solving the Afghanistan issue?". The article reviews the history of the Geneva talks on Afghanistan and reasons for the Afghan war and says "Any kind of treaty which does not result in the fall of communist government in Kabul and does not end in establishing the mujaheddin sovereignty will not be implementable in the country and, other than going through the trouble of signing on a piece of paper and wasting the ink, the Geneva accord will not bear any other result and naturally the signing: of this treaty will further complicate the Pakis. tani difficulties. With the intensification of war, the number of refugees in Pakistan will increase further and, with a communist government in Kabul still in power, no refugees will return to Afghanistan.

\section{Ittehad-e-Islami} 19 April, 1988

EDITORIAL: The editorial of the newspaper is about the virtues of the holy month of Ramadan. REPORT: The IUAM, in a big meeting 17 April condemned the Geneva agreement and vowed until the Russians complete withdrawal from Afghanistan and the establishment of an Islamic government in that country "we will continue our armed resistance". The meeting was addressed by the President of the IUAM, leaders of mujaheddin organizations and head of the interim government, in which they reaffirmed the joint mujaheddin 
position in regard to the Geneva talks.

* Prof. Sayyaf leader of the Ittehad-e-Islami

in a speech to the seminar on making prepara-

tions for the Jehad said "The Geneva agreement and its signing are not going to hinder our will and intentions whatsoever."

* In a Jehad conference,held at the Islamabad hotel by the JUP, Mawlana Samiul Haq said the empty handed and powerless nation of Afghanistan on behalf of the weak nations of the world, has Inflicted such a devastating defeat upon the Russian super power that Moscow will no more dare to colonize others.

NEW: The heroic Ghazni mujaheddin in their operations 7 April killed the Director of the Ghazni KHAD as well as head of the Intellegence office of the 14th Division of the arthy alongwith eight soldiers.

* The Ghazni mujaheddin intercepted 3 April a Russian convoy. In a 10 hour fighting, 40 Russian - Kabul officers were killed or infured.

* The mujaheddin demolished 8 April an enemy post in Shakardara capturing its officers and soldiers alive.

ARIICLE: "The disgraceful treaty of the history" (by Mohammad Yasser). "Finally the ominous and disgraceful Geneva agreement was

signed 14 April and the signatories turned into black another page in the political history, and, and this became a veil of shame for the UN, a treaty which contradicts itself and illustrates the foolishness of the super powers. Although some people of the world congratulate each other, the mujaheddin corisider this treaty as another catastrophe. - However, it is an ovil in which, God willing, lies our good. Although some have described that Russians withdrawal from Afghanistan as the miracle of the 20th Century because it is the first time that the fussians in the history of their invaolons have been defeated and are withdrawing and tbat too in the hands of an oppressed and poor nation, the day is not far that the second miracle of the 20th century may also take place when the international collusion in Geneva vis a-vis this holy Jehad will be reduced to a mere biackening of the paper and in the midst of this Russian defeat, Americans will also be defeated.

"We have nothing to worry about this agreement because we know that this jehad of ours is the divine light which cannot be extinguished. However what makes us unhappy is that how is it that the Muslim nations do not have their own free will and power and are tools in the hands of others?. . If the blood thirsty Russians remained in our country for eight years as aggressors, thieves and looters, it was not difficult to understand this. However nine months of their stay in Afghanistan under the UN permit is indeed painful because the world body too, became a part of this Russian aggression... This treaty will not bear any practical effect other than reducing the possibility of political and economic assistance to the refugees. We are of the opinion that Almighty God is the best sustainer and the expanse of the earth of God is quite wide. If life were to depend on ration for the refugees, who then is sustaining the mujaheddin inside the country? The weapons that we have in our hands cannot be snatched. And if we are to face a shortage of supplies of bullets, the Russians have already filled up the Khalqi depots for us. We are the same Ummah whose share of life is in their spearhead. If the volture is eating the carrion, God is providing for a falcon the pigeon meat. A collusion by frustrated parties against this Jehad gives us the good tidings of the collapse and fall of the East and West imperialism,

\section{S19016ी April, 1988.}

EDITORIAL: "The Geneva accord has been signed". The article throws light on commint "savagerym and then, referring to the Geneva talks writes, 
"This is the first time in history that our mujahed nation has shaken the rorld by its heroism. However, despite this, it has no right to determine its fate. Even the representatives of the puppet regime have been admitted to becone a party to the talks but the people who have brought the enemy to his knees have been denied this right. Why? Who has done this? ... All Afghans have been nourishing the hole for the last 10 years that we should have had a united leadership, trench and center against the enemy. However; we have notbeen able to achieve this status and so what ishappening now is due to our own doings. If we do not give up our personal ambitions, why should we claim that we love our religion and the country? And if we have neglected both our religion and country by giving up to devisive schemes aimed at fulfilling alien interests, then what is the difference between us and the present Kabul regime wich is also subservient to alien interests.

"One thing is clear: The arrogant and aggressive enemy has been defeated. Whatever shepe the technical solution of the issue may take is of no importance. But the Afghan nation, due to its struggle, is confident that, God willing, the future Afghanistan will be a Muslim, Iree, self reliant, free of East and West dictates and snares, a country with positive, active and neutral policy and independent judgement in intermational affairs, a country in which there will be no place for the filthy communist ideology, nor it will be a market of the illegal commercial transactions or of moral decadence of the capitalist countries. In that country the people who have made deals at the expense of the oppressive and aggrieved people of Afghanistan will also be called to give an account of their deeds.

\section{LEIIEA TO THE EOITOR:}

It is about Mohammad Amin Wakman written to the Editor and Publisher of the Mujahed Ulus as an explanation. It says, "now 22 years have pasm sed since the establishment of the Afghan Mellat Party. Wakman has spent 20 years of this abroad. When in 1973, Daoud Khan staged a coup and conditions for political struggle and movement became difficult, he left the country and, at any rate, he has been completely away from the party for the last 14 years and for the last three years, he has been an offjcial of the US government. The damages which he has inflicted to the party will take a long time to rectify. When the Khalqis were busy at ruthlessly massacring the Afghans, 8 March, 1978, he told the BBC in an interview "We are happy about the progressive programs of the Tarakai regime and we do not want a reactionary Islamic government in Afghanistan," We do not know which Tarakai program had attracted his attention. Despite such things, we do not know what actually Mr. Wakman expects from the Afghan Mellat Party. Furthermore, he is a member of the same government in exile which was formed on the basis of an understanding with Najib. When Party elections were being held, Wakman gave Rs. 500,000 to a representative similar to his own character and sent him to Peshawar. It was said on Wakman's behalf that the Afghanistan issue will be solved soon and Wakmar will be the Prime Minister of the next goverment. Despite such hectic activities, he has not achieved anything and now he is sending emmissaries from the US and other areas to appease Najib ... Mr. Wakman should come (to Peshawar) to find out for himself whether party members will embrace him or stone him.

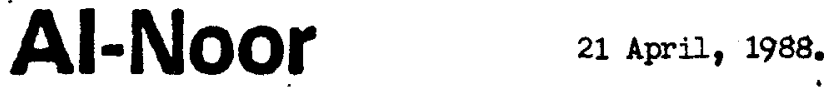
EDITORIAL: "Is it a peace treaty or a pact of war?" "Despite the fact that attempts are being made to create the impression that the Geneva accord on Afghanistan will bring peace and tranquility in Afghanistan, in practice the treaty antisipates a continuation of fighting. Because the real problem has not been mentioned in the treaty. As long as the communist regime remains in power in Afghanistan neither the Afghan refugees 
will return to Afgranistan nor tree mujaheddin will lay down their arms and stop their jehad. Therefore the Geneva agreement is not aimed at achieving peace in Afghanistan but rather is an accord about war."

REPORT: The Amir of Hezb-e-Islami Mohmmad Yunus Thales in a grand meeting of the mujaheddin and refugees 16 April held to condemn the Geneva agreement on Afghanistan said: "The Geneva talks were rejected by us from the very beginning and the accord between Pakistan and the Kabul regime, is being condemred by the mujaheddin, refugees and the entire people of Afghanistan."

* The first historic meeting of the interim govermment of the mujaheddin was held 18 April attended by the ministers already appointed to their portfolios. The cabinet decided that a delegation should be sent to different parts of the country to find a location for the headquarters of the interin mujaheddin government.

NEWS: The mujaheddin killed 11 April Sobadar Amin Than in the Chanikhel region of Nangarhar. He was a member of the National Front and the Advisory Cormcil of the Kabul govermment.

* In the operation during the month of Hamal (March-April) the Kandahar mujaheddin ki]led 17 atheists and demolished three vehicles.

* The Dahana-o-Chori district of the Baghlan province was captured by the mujaheddin recently: During the operation for capturing the district 15 militiamen, were killed and three more injured.

ARTICLE:The so called elections held by the Najib regime is already over but the fact is that neither the people took part in these elections nor the mujaheddin left the government in peace to hold the elections. Najib himself admitted that during the course of elections, many people but actually many communists - - were killed. It also becane apparant in the elections that most of the candidates were Khalqis and Parchamis or

\section{other atheists." \\ Mujahed Ulus ${ }_{21 \text { April, } 1988}$}

INZEiliIEW: "National struggler Niohmmad Hasan Kakar in an interview with the Mujahed UIus about his five years imprisonment in Kabul said: 'as far as it is known to me, I was jailed by the officials of the Kabul regime on the basis of instrnctions issued by their masters because of my opposition to Soviet invasion (of Afghanistan). The K.G.B. is supervising the activities of the KHAD in Kabul. The K.G.B. officials are specially after the intellectuals and people of thinking, specially professors of Kabul University. A new teacher recruit at the Department of history - - Wasay Qarar - - perhaps was dolivering his duties as a spy better than the others as I was arrested specially on the basis of his reports. I was sentenced to eight years of imprisonment. However, I was released due to the pressure put on the officials of the Kabul regime by international orgarization specially Amnesty International and the UN Human Rights Commission as well as many scholars."

ARTICIES: "The US-USSR foreign ministers talks". (By Abclul Rahman Pazhwak) 24 March: "Talks between the foreign ministers of the US and the USST ended in Washington after three days.

25 March: The Geneva talks continue to be deadlocked. The Russians once again said there are other ways than (procuring) an American guarantee. By this it is meant that Russia will then resort to a unilateral programme to pull out its troops from Afghanistan. Adopting such a stand is tantamount to a great pressure and threat. It is very dangerous. It is aimed at asking bigger things in order to convince the other side to become content with giving what you actually want. The present (unfavorable) condition is all due to mistakes committed by Pakistan and the US. However, at this juncture, a small mistake will inflict irreparable damage to our national interest which will also Laffect Pakistan, the US and the free world. We 
Afghans also have played a role in these mistakes. Specially the leaders of the mujaheddin and national strugglers should be aware of this. History will not forget in this respect the discord and lack of real unity among the mujaheddin parties.

And then the writer reviews events between 29 March - 10 April and refers to important aspects of the Geneva accord. He considers the acceptance of the text of the Geneva agreement by the US and Pakistan not a "mistake" but a "consquence of a conscious state of satisfaction." He says thus, the Russians have hit two birds with one stone: (1) by singing the agreement, Pakistan recognized the Kabul regime and (2) recognition of the socalled NRP:" * "The Geneve accord of April 14" (By Abdul Rahman Pazhwak). "The day of the signing of the Geneva accords was the hay day of politics in which the national interest of Afghanistan were sold; on this day the souls of martyrs were sad and the blood (of wrath) was sugning in the veins of heros of the war. on this day Pakistan forgot the religious teachings of Islam and in the presence of the mohaJerrin (those who migrate for the cause of Islam) cut the throat of the responsibilities of the ansar (those who have given shelter to Muslim refugees); the US trampled over the principles of its people; the UN did not pay any attention to its Charter and the history of mankind will record the event of this in these very terms. It is obvious that the purpose on this day was not to restore peace in Afghanistan because the Geneva accord will f'urther intensify war and bloodshed. If the aim has been to pave the way for the return of refugees to Afghanistan, then has any of the conditions which forced them to migrate been changed?... If the purpose was to induce the Russians to leave Afghanistan, what is the use of a physical pullout? ... When the Russians came to Afghanistan at the invitation of an illegal regime, then it can of course come much easier at the invitation of a recognized government as it will have stronger argument to offer from a legal point and according to international rules and regulations. Pakistan, which had refused to hold direct talks with Kabul regime, sat with it on one table. What was the aim of American promises taking us to the skies and then pulling the ladder from under our feet? Is it possible that, after this, small countries of the world would trust the UN?... In short, the Geneva accords are unjust, impracticle and futile. In addition to not solving any problem, it creates other problems. Its non-recognition and rejection by the mujaheddin and national strugglers is a stand which in no way should be altered. We support (this stand) fully and hope for the success of (the mujaheddin and national strugglers)."

\section{Shahadat 23 aprin, 1989}

EDITORIAL: "A sensitive phase for the fate of Islamic revolution." After condeming the pressive and shameful Geneva agreement" and recommending to "world circles to review their stand in relation to the Afghan issues relatied to its Islamic jehad and revolution", it writes: "at any rate ... Russia has been defeated, the fall of Najib is inevitable and in this way, God willing, the Islamic revolution is on the threshold of success and victory and this is a very important and sensitive phase for the mujaheddin, the nation and ummah. All mujaheddin and the entire Muslim Afghan nation, specially conscious Islamic and faithful strugglers, are responsible for keeping an eye on the conditions. Oniy a faith, based on Islamic vision, wisdom and sense of sacrifice as well as coordination, unity and seriousnes in making decisions can frustrate the final possible plots of the imperialism so that we may be able to bring to a success this Islamic revolution of ours." REPORTS: Engr.Hekmatyar leader of Hezb-e-Islami who attended 16 April a grand meeting of the Refugee Union, held to conderm the Geneva agree 
ment, said "it would become known to the entire world very soon that no agreement could be implemented in Afghanistan without the mujaheddir consensus." He added, "Justice demands that, simultaneous with the pullout of Soviet troops, the puppet regime, which was sent to Afghanistan together with Russian tanks, should also dismantled."

NEWS: The mujaheddin killed 2.3 February 25 armed men of the Dehdadi division in Samangan province.

* As a result of recent mujaheddin operations, the Chaparhar, Nangarhar, security post was captured and 12 Russian slaves were killed.

* As a result of successful mujaheddin operation in Alizai, Herat, 22 January nine members of the KHAD were killed.

ARTICLE: (translated from The Jassarat). The article portrays the scene of signirig the Geneva accord. It says: "The curtains were raised. In the hall, eight tables were placed in a circle: Only the tips of the tables were joined to each others. All Muslims of the world are watching the people sitting behind these tabls. The Secretary General of the UN Perez de Cuellar is sitting behind the first table with Zain Noorani, the Pakistani Foreign Minister behind the second table on his right side and the Poreign Minister of the Kabul puppet regime on his left, in the third table. Nobody was sitting behind the fourth table but behind the fifth table is the Russian Foreign Minister, Eduard Shevardnadze. The sixth table is again empty and the American Secretary of States George Shultz is sitting behind the pth one with the eighth table again empty. These full and empty places not only were being observed in the area where these personalities were sitting, but there were empty and full looks in their eyes as well... The dociment's were signed with tight lips ... Six long years of talks were brought to a con- clusion in only 26 minutes. The delegations left the hall through the same door which they had entered it ... Signatures of those who had shed their blood for the last nine years were not included and all these other signatures were a testimony of the fact that (for Muslims) Islamic logic and reason are the most precious investment and independence and freedom are more precious to them than their souls and it has been for this reason that (the Afghans) by sacrificing their selves are putting their signatures on the future destiny of their country."

\section{Rah-e-Islam 25 arri, 1989.}

EDITORIAL: "The Russians want to withdraw from

Sfghanistan but they do not intend to give it up." The editorial says "according to latest world press reports, the Russians have been planning since 1985 to quit Afghanistan and, therefore, on the surface, by prolonging the Geneva talks they were actually hiding their true intentions in order to implement their real plan by iritroducing the Kabul, regime as the axis of events and activities. The NRP ought to have been implemented in one or another way according to which all would have accepted the Kabul regime and would have recogniered all the Russian crimes in Afghanistion as a mere joke ..."

REPORT: Prof. Burhanuddin Rabbani in a meeting 16 April said, "if our Islamic brethern in neighbouring countries were serving as ansars on the basis of Geneva accords, now their responsibilities have come to an end. However, if they have been acting on the basis of divine command, that command is still in force and the ansars still have responsibilities to discharge."

NEWS: Fazel Ahmad Salehi, a General of the Arry and a high ranking official of the Afghan Defense Ministry, sought refuge recently with the mujem heddin in Herat.

* The Darwazagai, Kandahar, military base fell to the mujaheddin 17 April after a 25 day battie. 
* The Khak-e-Safaid sub-division, Farah, was conquered 4 April by the mujaheddin. In the operation for capturing the base 129 government soldiers were killed and 12 mujaheddin martyred. ARTICIE: "History repeats itself - - Pakistion comitted the same mistakes which were conmitted by former Afghan regimes," The article discussuses the historical talks between Afghanistan and Russia over the issue of Bukhara and Khaiwa and writes that on 31 August, 1926, in a treaty signed between Afghanistan and Russia it was pledged that the two sides will not Interfere in each other's affairs and would not allow the transfer of war supplies destined against the contracting parties to be shipped through their territories and later another treaty, signed in 1931 during the reign of Nader Khan in 1931, a similar pledge was made entailing a ban on the Bukhara mujaheddin and now Pakistan by signing the Geneva treaty has repeated the same mistake. Neda-e-Haq 25 Aarit 1988. EDITORIAL: "The Geneva accords." The Editorial discusses the last phases of the talks held for signing the Geneva accords and adds "this defective accord is not acceptable to our Muslim nation because it does not anticipate the elimination of the communist regime, does not condemn the aggressor, does not require repariation for the loss of lives and materials, does not put to a stop the Russian and American intervention (in the Afghan affairs) and, more important, the two sides of the issue - - the mujaheddin and the Russilans - - were not included in the treaty.

BEPORT: Teader of the Harkat-e-Enqelab-e-Islami Afghanistan Mawlawi Nasmullah Mansoor in his series of conferences to the refugees said in Haripur "it is a plot that today in Geneva docisions are being made at our cost. We are saying that there should be no Russians (communist) Ideology in Afghanistan but, as a result of the success of jehad for the cause of Allah, an Islemic government will be established in our country." .

NEWS: In successful mujaheddin operations 7

March in Paktla 88 Russian-Kabul soldiers were killed or injured.

* In a mujaheddir attack 5 March in Zormat, Paktia, 25 Moscow mercenerios were killed.

* The Kankar military post near Torkhua has been conquered by the mujaheddin.

ARTICIRS: Would the Geneva talks iron out the difficulties or increased them?" It says, "we are confident that a great power wdll emerge in the near future from the midst of the jehad forces and on the basis of consultation with all the heroes of the jehad, they w1ll take steps about the fate of the nation, and would present a realistic and fundamental plan void of all 'defects to their glorious nation.

\section{Mujahed}

EDITORIAL: It is the last editorial mittem by

Shohrat Nangyal in wich he has offered his farewell as the editor of The Mujahed. Nangyal has discussed the importance of crusades in fournalism and then has mentioned the services reodered by the newspaper during the past 10 years of its life, and the difficulties facing the newspaper at present time. He says, despite these difficulties, he was able to bring positive and progressive changes in tine paper and recently due to 1 llness he has been unable to shoulder the heavy responsibilities of an editor and has proposed that this heavy responsibility should be transferred to another brother who would be able to successfully unclertake the duties of realizing the aspirations of the mujahed nation and of the revolution.

REPORT: In a grand meeting 16 April to reject the Gerieva agreement, Prof. Rabbani, leader of the Jamiat-e-Islami Af ghanistan said in a speech, "The Geneva agreement in itself is a mantfestation of the defeat and disgrace of the Russlans in international scene and will in no way hinder our hejrat, jehad and epic makding upri- 
sing."

INTERVIFW: Engr. Ahmed Shah, President of the mujaheddin interim government in an interview, with the head of the Department of Compilation and translation of the Jamiat-o-Islami Afghanistan, has said, "If the Russians pledge not to Interfere in the internal affairs of Afghanism tan in the future and refrain from supporting filthy and commint causes, in that case there is no reason that we will not establish good relations even with the Russians".

AFITCE: The most dangerous Russian Plan: dividing Afghanistan" (Mohammad Nasim Faqiri). He has discussed speculations that the Russians are plaming to divide Afghanistan. He says, "if the world devouring Russian imperialism, for the sake of the natural resources of northern Afghanistan such as oil, gas, fruits, carpets, etc. separate the nothern part from the main body of our land and convert the area into a nest of securlty for its defeated hireIngs, they should definitely know that the people of Afghanistan will defend every stone and thorn: of their Islamic land and every inch of this land of the mujaheds, by sacrifieing the last drop of their blood and will recond in the history of mankind another Ruesian defeat in its attempt to divide AfghanIstan following its present defeat and disgrace." Ittehad-e-Islami 26 April 1988.

BDITORIII; "Seventh of Saur, the morro of Hood," "The Editorlal reviews the "crimes" of those who staged the coup of 7 Saur (27 Apri1) coup and refers to their gradual defeat and praises the victorious uprising and the resistance of the mujaheddin and explains the ultimate objective of the Muglin Afghan nation by witting "owr nation does not think about anything else but Islam and in the conscience of each one of them the hopes that in his beloved country the Islamic order should be established and the Mag of Islam holsted are hidden."
MESSAGE: Prof. Sayyaf in a message, condemning the Saur coup, has said "I hope that during this Saur their (Red Army) structure will be on the verge of fall and destruction and until the next Saur the foundation of the Irlamic structure would have been established in a free Afghanistan and Afghanistan will become the abode of confidence and hope for all the Muslims of the world."

NEWS: Twelve enemy tanks were demolished in the Wardak region when the mujaheddin attacked a Russian convoy on Kabul-Kandahar highway in Yousuf Khail area.

* The Laghman mujaheddin shot down an enemy hell copter in the Badpakht. area putting the helicopter ablaze and killing Its occupants.

* The mujaheddin, in an attack 12 April on a Russian convoy, killed nine Russian soldiers. REPORTS: Prof. Rabbant in his speech 17 April told a grand meeting, held to conderm the Geneva accord, "with the signing of Geneva accords the decisive phase of our jehad also began. While we are condeming the Geneva treaty we are at the same time congratulating our heroic nation for their success which entails Russian ultimate defeat."

* The President of the interim government told a meeting held to condemn the Geneva accords 17 April "the super faith and will of the Muslim Afghan nation has today defeated the Russian ouper power and has forced the Russians to write in their newspapers that the Russians will never repeat their Afghan experience anywhere else."

\section{Nâl2 27 April, 1988.}

EDITORIAL: We are going to keep alive the torch of jehad" The editorial, in connection with the signing of the Geneva agreements, says "The Muslims and patriotic people of Afghanistan have resolved not to return under any circumstances under the political domination of the atheist puppet Kabul regime. They are in 
no way ready to form a coalition govermment with the murderers of their people. Despite the fact that the withdrawal of Russian forces from Afghanistan is considered as a big and effective step for the solution of the Afghanistan problem, the real solution of the issue will take place when, after the withdrawal of Russian forces, an interim govermment is established in accordance with the conditions set forth by the mujaheddin.

REPORT: Pir Sayyed Ahmad Gailani in a grand meeting held to condem the Geneva accords said in a speech, "we are not going to accept any compromise until an interim government is formed on the basis of our conditions." In the same meeting Dr. Farouq Azam said tat this sensitive moment, the Russians want to gain the things through negotiations which they have lost in the battlefield ..."

NEWS: Credentials for those who attended the first-aid courses of the IUAM were distributed

\section{Narch.}

* Credentials were issued to 135 graduates of the Jailania Dar-ul-Uloom 3 April.

* The Channi mujaheddin, in a series of operations 9 Narch in Ghazni, killed the head of the criminal investigation department of the province.

ARTICLE: "The undefeatable one who has now been defeated" (By Fat-ul-Bari Ghairat) "Russian agents, on the basis of instructions by their overlords, speak about the undefeatability of the wretched Saur revolution. In the beginning they cmployed force and oppression and later they resorted to snares and deceit. How ever, the will and faith of our people still becane atronger and now the Russian troops confess their defeat and thus the imeverseable revolution has now become reversable. The Russlans must lnow that no power has been able to defeat the Afghan nation in the past and no one wil defeat it in the future. Therefore, to quit Afghanistan will be in their own interest." Qheी EDITOKIAL: "Ten years after the coup". It says, "ten years have passed since the black Saur coup, a coup which, as a result of direct Russian intervention, brought the PDPA into power. Futile attempts are still being made to keep this puppet regime in power. This futile attempt brcught as a gift for the Russians one of the most expensive wars after the Second World War. Although the Russians have so far preferred silence and secrecy about their casualties, even a conservative estimate would. indicate that they have at least lost one soldier against each member of the communist party of Afghanistan. Those who staged the Saur coup, never thought that they will face such an uprising and resentment by the entire people of Afghanistan. They ruthlessly resorted to the slaughter of the people because in their culture slaughtering and revolutionary methods are entirely synonimous ...

"After all. these years the Russians are now admitting their defeat in Afghanistan and they have found out that their intervention in Afghanistan and an attempt to impose a communist regine have brought for then the very opposite of what they were expecting .... The Russians alongwith their withdrawal will also take away with them the final remnants of the shameful Saur coup in Afghanistan. It is riecessary that right from now we should think of measures for arresting these criminals and for trying them j.n the presence of our mujahed nat1on."

REPORT: Leader of the Hezb-e-Islami, Hekmatyar told the officers of the Hezb-e-Islemi recently. in Nasrat Meena "only the present form and style of party organization would not solve our difficulties because in an Islamic organization and party the real issues are the nature and quality of relations among each other,mutual love, affec- 
tion, benevolence and selflessness." He added, "until we pay special attention to the issue of the invitation of people to Islam and our organization, we would not achieve the desired results in our jehad ..."

NEWS: The joint military council of the IUAM is to work on a plan for liberating an important region (inside Afghanistan).

* The mujaheddin in an operation 10 March in Naiknam district of Zurmat, Paktia, killed 35 enemy personnel.

* Sixteen so-called security posts of the enemy were conquered recently in Parwan by the mujaheddin.

\section{Ittehad-e-Islami}

EDITORIAL: "Inverted values". The editorial says, "independent and free nations in their history have days which they honor and revere, days of the regaining of independence, days of achieving important tasks and days during which positive and useful changes have taken place. People have a right to celebrate and welcome auch occasions. Howeyer, according to the beastly and savage communist philosophy, values are usually inverted. They claim slavery to be freedom and oppression and barbarism to be justice, genocide to be heroism, destruction to be a just atruggle and finally black to be white and white to be black".

The editorial discusses the "savagery of the Saur coup". which was followed by the uprising of the Muslim people of Afghanistan and. has condenned the "Inverted values" upheld by the communist and which are being celebrated. It says, "people in the world are celebrating Ireedom and Independence days but the communists are marking slavery days. The 7 th of Saur is a day of mourning. However, the infidel and conscienceless communists are celebrating this day by organteing parties of joy." arorar: The mujaheddin in various meetings consemed the anniversary of the shameful Saur coup. Prof. Sayyaf, leader of Ittehad-a-Islami said in the Akori Camp "The Saur coup was like an arrow which hit the hearts of the Muslims." Prof. Rabbani, leader of the Jamiat-e-Islami told a gathering in the Khurasan Camp "the 7th of Saur was the beginning of disgrace of communism and of a shameful aggression." Gulbuddin Hekmatyar, leader of the Hezb-e-Islami, said in the Jalozo Camp, "nobody can defeat the power of faith with iron and gunpowder." Dr. Farouq Azam, the deputy leader of NIF, told a meeting in Munda Camp, "the Afghan mujaheddin demonstrated to the entire world that the secret to their success lies only in Islam." Prof. Sebghatullah Mo jaddedi, leader of the NLF said, "we should put aside, in accordance with the divine comands, all party, linguistic and regional discrimination and deal with each other as Muslims." PHOCIAMisTON: Refugees in the Tall, Dera Ismail Khan and Mardan camps, in separate proclamations, have declared that they. were relentlessly suppor ting the government announced by the mujaheddin and,until an Islamic government is formed by the mujaheddin in Afghanistan, they would not raturn. to Afghanistan.

\section{Neda-e-Sangar 4 May, 1988}

EDITORIAL: "The Saur Coup; the beginning of disgrace for the disgraced school of comminian". INTERVIEW: Judge Ghulam Farouq Sherzadi, the Amir of the Adraskan, Herat, in answer to a question about the administration of the coumtry, specially of the localities after the withdrawal of Soviet forces, has said, before the withdrawal of Soviet forces from Afghanistan, in order to prevent domestic tension, the formation of an interim goverment inside peghanistan is very essential. However, until complete sovereignty is established over all localities in Afghanistin, a council of comanders and a council of rellfour soholars should be formed to control the enfeter of thaty regions." 
NaW: A plan to possibly partition Afghanistan Into two northern and southern areas and mining fields around the city of Kabul is underway.

* Najib, leader of the pro-Soviet goverrment denies that he is a communist.

* The border Brigade of Darwazagai, Zabul, has been conquered by Muslim revolutionaries at a time when the Red Army is preparing for their escape from Afghanistan.

\section{Shahadat}

EDIronIAL: "In these fingl moments". The editorial has discussed what it calls the delicate situstion about the Afghanistan issua and writes "undar these circuptances when the Rusians are Heaing and ratreating, the deapair and ahakeness of their puppets and, in contrast, the victoriouasotind and high spirit of our mujehed nation are such realities which call for serlous work and fast moves by the responsible forces of IBlanic revolution.

RRPORT: Leader of the Hezb-e-Islami Gulbuddin Haknatyar has said in a speech "general electLons is a principle. In other words, no one will asayme power after this as a result of a coup and no one will be able to impose upon our nation aftor this a specific femily or a governwent hich way belong to familities." He has Bafd mobody thought that the Russians will be defeated in Afghantatan and this is the first time that the Red Aruy is being defeated.".

INTSEDFN Leader of the Hezb-e-Islami Gulbuddin Holonatyar, in a press conference 26 April said wy own underatanding is that the Russians are going to gather thatr troops and concentrate them in cition tuoh al Kabul. Aloo the Rusidans Whe to diflde Afghanistan if possible and provide a foothald for tho lfghen communtst party. Aowover, this ts not precticel beceuse our restatence th the porth If Iar more stronger then in other part of the spuntry and when the Busians have started to retrant 1 rom tha south and the West and that, too, at a time when the mujaheddin have no central govermment and lack necessary facilities for a govermment, such as airport and other means and also lack relations with the countries of the world, after the establishment of a mujaheddin central govermment the Russians will in no way be able to remain in the north and it is not possible for the communist party to establish a government there."

\section{Arman-e-Mujahed 5 May, 1988}

ARTICIE: "Those who are urging a single leadership through elections should not forget the oath which was taken in the presence of the Holy Quran and Bulchari Sharif (the most authentic book of quotations from Holy Prophet, Nohamad, peace be upon him) and the pledge made in the house of Kaabe in Makkah.

Wnder the present circumstances and, within the kind of a framework in which our destiny and fate are being decided, and at a time when the doors are closed on us (to participate in deciding our fate) and we ourselves are entangled in bickerings and divisions; the right of the self determination of the people of Afghanistan has been handed over to others. Others say that by a mere withdrawal of Soviet forces we have achieved victory while Najib is still in power. However, it ought to be remembered that the Afghan fehad did not start after the Fussians launched their military aggression but our jehad was undertaken before that against the establishment of an atheist govermment. Despite varying conditions in Afghanisten, there are forces who are urging elections under the pretext of achieving unity but actually for the sake of remaining in power. But this has no precedent in the history of Is1am. By exploiting the present conditions they are aiming at achieve their own objectives ... Those who have a lust for power and a desirg to echlove high status, are forgetting the 
undesirable conditions which might be imposed upon the Muslim nation of Afghanistan as a rom sult of incorrect yolicies. They are always aiming at increasing their power and grandeur... These elements, contrary to the practices of the time of Mohamad,peace be upon him, are suggesting elections in order to establish a single (one man ?)leadership over the Muslim people of Afghanistan. This is a political maneuver aimed at remaining in power. It is necessary that the religious leaders of new Afghanistan should relate these events to our Muslim people before it is too late and they should make use of their authority bestowed upon them by the .Shariat."

\section{Wahdat-e-Islami}

EDITORIAL: "Forsaking the principles of Islam and its undesirable consequences". It says, "The Islamic Jehad of Afghanistan began on the basis of a verdict issued by the ulama for toppling the atheist and Soviet puppet regime. In a short time, this jehad had reached the stage to topple that regime. But Soviet aggressors came to Afghanistan to save their puppets from being toppled ... From the very beginning of the jehai upto now, the objectives of our Islamic jehad have been fixed in accordance with the commandments and principles of the Shariat. The lawful. principles of revolution urge our Muslim and mujahed nation that both the people and those responsible for executing the affairs of socioty should nourish the struggle and jehad so that our noble objectives are achieved. Adopting an opportunistic stand will in the final run bring our jehad to failure. And such a stand will in no. way be acceptable to the Musiim and mujahed nation of Afghan1stan. Taking such a stand will also result In the expulsion of those people from the ranks of fehad who are favoring such approaches.... Unfortumately, as a result of a lack of atten- tion by the jehad leadership, the jehad and hejrat environments are facing political and cultural discorders and, as a result of intrusions by the east and the west in our jehad; it is very near that the jehad might deviate from its correct course."

NEWS: Hundreds of Afghans demonstrated 27 April in New Delhi, burning the Russian flag and condemning the Geneva agreement on Afghanistan.

* The Russians have shown readiness for the exchange of political prisoners (stet) with the mujaheddin.

* The mujaheddin will continue their jehad until victory.

\section{Al-Noor}

6 May 1988

EDIIORIAL: "We and the enemy" (By Watandar). It discusses the current situation such as the failure of the Saur coup and the aspirations of the mujaheddin and concludes, "in Afghanistan the toppling of the communist regime is not our only objective but, in addition to this, we have the historic responsibillty to establish such a regime there which will be able to provide peace and welfare to the nation and that could only be realized when an Islamic order is established in the country."

REPORT: Haji Din Mohammad, Deputy leader of Hezbo-Islami. Afghanistan, who was personally present in the Barikot battle in Kunar said "we laid down in the area the foundation of an advisory council. All seven members of the IUAM are equally represented in the council." :

* Reports from Kunar, Kandahar and Zabul say that the enemy fled from Barikot, Kunar 22 March from Marouf, Kandahar, and Ata Char, Zabul, 23 April and these regions were captured by the mujaheddin alongwith large depots of military. supplies.

ARTICIES: "The fall of Barikot" (By Sharafat). The article reviews the pros and cons of the situation in Barikot during the last few years 
and says "the Kabul government might have evacuated the Barikot garrisons and other places due to one of the following reasons: (1) judging the mujaheddin offensive, the regime reached the conclusion that these areas will fall to the mujaheddin sooner or later; (2) the Kabul regime wants that in such regions, where all the mujaheddin parties have fighters, it should incite clashes among these groups; (3) the ro gime wants to evacuate a large area along the border regions so that the refugees would return voluntarily to these liberated areas, (4) the regime wants to withdraw its experienced persomel from such places and concentrete then in Kabul or other sensitive regions for the defense of those areas. Now leaders and commanders of the mujeheddin should contemplate counter policies which will be beneficial to the mujaheddin and detrimental to the Kabul regime.

\section{Ittehad-e-Islami iongy, 1988}

EDITORIAL: WThe weapon of faith is the guarantor of our victory". The editorial discusses the long range policies and collusions of the Russians and reliance on their material power but says, desplite this, our nation, with an empty hand but armed with the weapon of faith and belief came out victorious against Russia: Therefore, the editorial calls on the mujaheddin: mon, You, the heroic mujaheddin, and, Oh, you dear refusees, let us join hands and resort to Islom whout seeking any previlige and superiority over each other and hold fast the rope stretched for us by Almighty God. God wllling, the Benevolent Almighty God will make our wujahed and martyr loving nation victorious and w11 defeat and frustrate the impure enemy. INTERV IEN: Engr. Ahmad Shah, President of the transitional govermment of Afghanistan has said In an Interview "the Supreme Couneti of the IUAY has approved the establishment of 21 ministries and three deputy leaders of the government and of course after determining a site for the headquarter of this government, measures will be adopted to announce it."

* Abclul Qadir the commander of the center of the cabul province in an interview with the newspaper has said "when we were coming towards Pakistan we had already captured the Darwazgal fort. The mujaheddin launched a two pronged attack on the Fort. We captured between 50-60 people alive of whom eight were officers. Thirty five people were killed and we captured large quantities of arms. During these operations 14 mujaheddin were martyred and 18 others injured.

REPORT: Gulbuddin Hekmatyar leader of the Hezbe-Islami in a meeting held in Jalozai camp to condenn the Saur coup said Mussian troops are not withdrawing from Afghanistan because the Geneva talks were conducted successfully. Rather, they are withdrawing because no other alternative is left for Moscow. Russia made full use of all. its powers for 10 years but it could not occupy even $10 \%$ of the Afghan territory."

\section{Serat-ul-Mustaqeem}

EDITORIAL: "This Muslim and brave nation has always defeated aggressive colonialists in our country. However, unfortumately in each century leaders and elders of the time have treated this Muslim and valorous nation in an unjust manner and have rendered useless the sacrifices of this nation. For the sake of their own personal wishes, they have not taken tnto account the future integrity of the country. Whatever they have done has served the interest of colonial powers so that only the king and leaders may survive and remain safe ...n

"Durirg the 10 years of the jehad this under-privileged nation of Afghanistan-a people who have faith and valor, has rendered many sacrifices and brought down a world power to its knees through the power of its faith in such a way which surprised the entire world. But, unfortunately since previous kings had exploited the sacrifices of the nation only 
because the nation, on the basis of the command of Almighty God, is faithful to its legal anirs. However, in proportion to this, the amirs are neither faithful to their society nor they care about the society so much ... and they Bacrifice the interest of the people for their ow personal inclinations and views and, as a result of this, they draw the nation to. ideological and party divisions so that they may implement their own designs upon the nation. This benefits the imperialist powers. As these leaders have reached their high social status as a result of the victorious Jehad of a valor ous nation, this very nation has the right to address the leaders by telling them to come out of the ear of the elephant and, instead of selfishness, take the course of unity. Because If they were united; the Geneva agreement would not have been signed ....

Wave meetings with the nation and consult them and ask them about their views and do not rely on just a few people who are around you. The power of the nation is vast and if you are concerned only about the preservation of your own power, then what is the difference between you and leaders of previous regimes because they, too, for the sake of their personal interests sacrificed national interest and you are also doing the same thing.

INWER IIEN: Engr. Ahmad Shah, President of the transitional govermment in an interview with the newspapers has been asked "you have been Indicating in your interviews and speeches that if an Islamic government is established in Afghanisten there would be no borders (between Afghanistan and Pakistan). Is this view of yours, which is an Islamic one, accepted by Pakistan?" Answer: "this is upto Pakistan. How ever, this is our Islanic stand which we should make it known to the Islamic countries, as IsLam dọes not accept borders among its followers. So far, we have not discussed this with Pakistan but we want the world to know our views ..."n
ARTICLES: "Pakistan has made a dangerous and harmful deal" (By Andeshmand). It writes about the Geneva accords. "Pakistan by signing the Geneva accords has concluded a dangerous and harmful deal which not only is considered a treason to the mujahed nation and the jehad of Afghanistan, but the implementation of such an agreement has also trampled the national and Islamic interests of Pakistan. These are the shortcomings and defects of the treaty; (1) The unstable, puppet, illegal, un-Islamic and antinational government of Kabul has been recognized by Pakistan; (2) The claim by the Russian puppet regime that the Afghanistan jehad is actually tantamount to a Pakistani intervention in the internal affairs of Pakistan has been established in the treaty because Pakistan froved that one of the parties in the Afghanistan issue is Pakistan and not the mujaheddin; (3) the Afghanistan nation has begun an armed jehad against communism for the last ten years and, for achieving their objectives, the people of Afghanistan have not appointed any advocate or attorney. However, Pakistan, without resorting to resson, according to its own logic, thinks that it has solved the Afghanistan issue with the enemies of the nation in the absence of the Afghan nation. More than one million mujaheddin, are fighting inside Afghanistan under the Pakistani command. Does Pakistan believe that, if it did not wish, the Afghans would not fight? Despite the fact that this is not so and our mujahed nation did not consult Pakistan for beginning its jehad now, too, they do not find themselves obliged to accept the Geneva treaty; (4) the text of all four instruments of the treaty are detrimental to Pakistan and benefits the Russians and their government in Kabul; (5) the Russians and their puppet regime in Kabul consider the Afghan jehad as a foreign intervention and by saying that this foreign intervention, should be ended, it means that the mujaheddin's war against the communist regime should also be terminated, the mujaheddin's hands should be tied and 
they should be handed over to the Kabul regime; (6) the Geneva agreement is contrary to the provisions of the UN Charter; (7) this treaty cannot establish peace; (B) the Pakistani stand vis a vis the 1ssue was an incorrect one during the past six years; (9) the Geneva agreement in no way guarantees the security and national in terest of Pakdstan. National interest of Pakis tan is related to a support for the continuation, exdstance, esteem of the Islamic jehad of Afghan1otan. And, as we see 1t, Pakistan has so far gatned many matertal and moral aids from its support of the Afghan jehad.

\section{Shahadat}

11 May, 1988

EDITORTAL: "Comments and Plots". The editorial considers western propaganda about conditions in Afghanistan either similar or very close to the Pussian propaganda. The West says that, with the wthdrawal of Soviets troops from Afghanistan, this country w1ll be changed into a blood bath). This and other similar propaganda are aimed at confusing the public opinion and is an attempt to justify the Russian aggression and the mujaheddin should frustrate these plots through unity."

RRPORT: Leader of the Hezb-e-Islami Afghanistan Helmatyar in a speech $8 \mathrm{May}$ in a meeting also attended by the leaders and representatives of the Islamic parties of Paldstan in the IUAM center said, "Pakistan and Afghanistan have a common destiny. In Afghanistan an Islamic govermment w111 be established by the mujaheddin. In Afghanistan only an Islamic government can guarantee balance of power in this region." Mawlana Anir Shah said in the mecting, "I assure you on behalf of the Paklstant nation that we w11 support your. Islamic struggle unt1l its very end".

* Leader of the Hegb-o-Islam1 Afghanistan Gulbuddin Helmatyar in a meeting held at the Arabic Darul-ulum of Hadiqa-tul-Ulum, which was attended by the members of Jamat-e-Islami and other ansars, 3 May, said we are complaining about those Pakistani parties who falled to respect the opinion of their own people, and failed to notice that the Afghan nation has been oppressed and that their war has been a just war and these parties did not pay attention to their national and religious ties with the nation and opposed us from the very beginning. It was actually necessary that they should have considered the Afghan war as a war for the integrity and defense of Pakistan as well and should have realized that if the Afghan mujaheddin had not halted the Russians, God knows what would have happened today to Baluchistan, Sind, NWFP and Punjab? ... I an surprized about such a nationalism, a nationalism which means slavery to the Russians, a nationalism which means enmity with one's own peoples and nation, a nationalism which means supporting oppression and opposing the oppressed, a nationalism which means friendship with the Russians and opposing the oppressed Pakhtuns and, despite all these making a claim about Pashtoonwala1! What kind of nationalism is this?"

NEWS: As a result of a mujaheddin attack 1 Marm ch on Gardez-Urgun highway, 92 enemy tanks and vehicles were demolished.

* As a result of successful mujaheddin operation 17 April, the 79 th unt of govermment in Khawaja Ghar, Takhar, fell to the mujaheddin.

* The brave Sayyedabad, Wardak, mujaheddtn captured recentlv six enemy vehtcles loaded with supplies.

ARTICIES: India ought to know that Afghanistan is not Sri Lanka" (By Hekmatyar) "India is Inviting Najib to visit that country at a time when in a little móre than a week, Russian troops are to pull out from Afghanistan and, thus, Rajiv Gandhi wants to tell our people that, after the withdrawal of Russian troops, they should not think that $\mathrm{Najib}$ is alone and without a protector." 
IFITHR: About the merger of the Ittehad-eIslami with the Jamiat-a-Islami" (Summary of several letters) "... There are rumours in rofugee circles that brother Prof. Sayzaf has decided to merge and dissolve his Ittehad-eIslami organization into the Jamiat-e-Islami and, in this comection, he has reached a inal agreement with Prof. Rabbant, leader of the Jemiat-e-Islani and their final dectsion w111 be announced soon."

SHAHADAT: While we consider a principled unity of two Jehad organizations and their natural nerger and dissolution as a an evolutionary atep, in regard to the question raisou by these brothers, so far we have no precise and authont1c information.

\section{Mujahed} 16 May, 19,88

BDITORIAL: What have been the gains of the Saur Comminist coup for the Russians?"(By M. Y.Shahbaz) "The editorial discusses the Saur coup, Russien atrocities and tactical compromises. It also rofers to the Russian defeat in military, and political fields and to its economic losses and says "today the Russians have been reaping the gatns of this black coup which they launched in Afghanistan 10 years ago. It has brought nothing for then but diagrace. The Russians are still making futile attempts to show that they had. undertaken a peaceful policy but in no way they can hide the realities. It is quite late to change the situation and any attempt for hiding realities will bring further shame and disgrace for the enemy."

INIERRVIFN: Prof. Rabbani, leader of the Jamiat-e Islami Afghanistan, in an interview with an American Joumalist, about a possible Russian plan for the partition of Afghenistan has said "if the Russtans are entertaining such an 1dea, the same way that they falled and were disgraced in Afgham atstan as a whole, they will also be defeated in their plan for the partitition of Afghanistan."
hRTICLE: "Russian satantc policy" (Mohamad Zaher Siddiq). "Russian policy in Afghanistan has gone through three phases during the pest 10 years: (1) (1) the decistreness phase: durine this phase - the 20 months rule of the Khalqis and two years of Russian Invasion - - It was said that the Saur revolution was irreversible and the resistance would soon be extinguished; (2) the hesitation phese; during thio phase which corresponds with final years of Brezhnev, who mastermineded the invasion of Afghanistan, the Russians started talking about peace but still used force (3) the phase of defeat end admission: This phase began after the toppling of Karmal. The new Rusatan puppet spoke tubout an end to fraticide, peace and the withdrawal of Red Army forces from Afghan1stan and the Russians also took the blame for the bloodshed, savagery and war in Afghanistan and now, by withdrawing their forces from Afghanistan, they want to restore their credibility. However we are sure that, alongwith their pullout from Af ghanistan, the Russians should also be ready for a number of other developments. Because freedom of Afghanistan is a signal for an end to Russia and communism.

\section{Shahadat 16 lasy, 1988}

EDITORIAL: "The E1d of victory". It says "this year the Afghan mujahed nation is celebrating the Eid of the holy month of Ramadhan at a time when it is on the treshold of its finel joumey, though very sensative one, towards the realization of their Islanic aspirations ..." The editortal then refers to the "sacrifices and pains of the oppressed nation" and concludes "However, it is a matter of satisfaction to all the nation that, lod willing; these days are tho beginning of the time when, with the completion of the withdrawal of Russian forces from Afghanistan, infidelity and cormunism and all its effects will be brought to an end in Afghanistan and upon their ruins the banner of Islamic government will be hoisted."

REPORT: Hekmatyar, leader of the Hezb-e-Islami 
Afghanistan, in a press conference 10 May has Given details about the mujaheddin state and Govermment. He has said, "this government is the mujaheddin transitional govormment. It will. be manifested through the leadershlp counc1l of the IUAM. From the leadership counc1l ono leader will be elected every three months on a rotation basis, and this person represents the state. The transitional govormunt of the mujaheddin is under the Jurisdiction of the leadership coinc1l. The transitional government has a cabinet and an executive body. The power of dismissal or appointment of this government is wth the leadership council. The council makes policy statements for the govermment and supervises the activities of the trensitional government. Th1s state w11l have an elected counc1l which will be convened on the basis of voting for parties. Until an elected council is convened for the state, the present 21 member counctl will act on 1ts behalf ... The counc1l wlll be formed on the basis of representation from all sub-divisions, sub-districts as well of the mujaheddin."

NWNS: Abdul Hai Shaida, the provincial Amir of the Heab-e-Islani in Baghlan has been martyred. In addition to being a leader and ploneer in the battlefield, he was a great contributor of the literary trench of jehad and a collection of his johad and revolutionary poems has been left to us as a memolr.

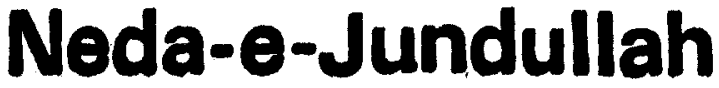

17 May, 1988

RDIDAIAL; "Oh Muslims of the World" (By Whurasand). The ntre month old government of Habibul. 1ah, the Servant of Holy Prophet Mohemmad, peace be upon him, was brought to an end by Mohammad Nader Khan. The government of Habibullah did not give the alightest chance for the penetration of communtem in Afghenistan and, therefore, one can say that, in the modern history of Afghan1otan, the most independent pollcy had been pur- sued during the govermment of Habibullah. If inperialism and arrogance had left us alone, indeed, we would not have been entangled with present difficulties and we would have achieved a far more better position than our present condition. Nader Khan, who found his way to the Royal Pulace as a result of an Anglo-Soviet consensus, during his reign made the atmosphere favorable l'or the influence of imported atheist culture ... The first cooperation and collusion of the Nader than regime with red aggressors wae to drive out Iorahim Beg, the brave and valorous mujahed leader of Bukhara from Afghanistan. This, in Ats own way, was one of the best services one could offer to the glant of red arrom gance..."

ARTICLE: "Victory of Afghan Muslims or the beginnting of an end of Russian imperialiam". The article seys in the same mannel that the Russians eliminated their other neighbours from the pages of the world political geography and merged them with red empire, for a long time they have been working for the occupation of Afghanistan in order to reach the warm waters of the Indian Ocean and. O1I rlch regions of the Fersian Gulf. The Rusilans, after their fatlure to occupy Indian Ocean and o1l rlch regions of the Gulf' under the pretext of fulfilling a friendship pact with Af'ghanistan, came to this couritry to flght. Leaders who had a stand detrimental to the public, athiest intellectuals with no commitment, hireling joumalists and politiclaris attached to selfish interests were deceived in the very bcolinning by the doulve standard policies of the Russiens and they sang songs for the Russians in the menory of the evil souls of ancient Russian Tzars... Afterwards, movements of a people, ineplred by eplc making. Islam, began throughout the country. But then, the Russians and thoir local hirem lings roso against Islanic movements as they were greatly shocked to see an Islamin movement taking 1ts roots from the grass roots of the ippressed Af ghan nation and considered this 
movement a factor for their own annihilation and as an important factor in awakening and 11berating the Islamic Turkistan, and the beginning of an and of the blood thirsty imperialism of the neo-Twars.

\section{Wahdat-e-Islami}

17 May, 1988

FDITORIAL: "Any move by Seudi Arabia will further complicate the situation in the Gulf". The severance of diplomatic relations by Saudi Arabie with Iren has been discussed and the editorial considers this to be in the interest of the US. It says, now it is upto the non-Arab Muslim world, such as Turkey and Pakistan, that bofore the situation becomes grave, they should not sllow the Islamic countries face such a misery and internal wars and strifes entangle the Iolanic world."

MBSSACE: Qazi Mohammad Amin Waqad, leaden of Da'eela-e-Ittehad-e-Islami Mujaheddin-e-Afghan1stan (Notive of the Islamic Unity of Afghan1stan Uujaheddin) in his message on the occasion of the Remadan BId, after throwing Ii!tht on the Badr Battle fought during the tine of Holy Prophet Mohammad, peace be upon him, has sald "imperialist intervention in the region should be brought to an end; peace and security should be restored in the Gulf; Al-Quds should be liberated and the Palestinians should be given the Ight to live freely; relations between Saudi Arabla and Iran as two Islamic countries should be reestablished Irantan pilgrims should not be demrived of going to Haj; we do not accept the Genova plot; the Russians should quit Afghanis$\tan$ without any premconditions; the refugees should not be forced to return home in case the Najib regime remeins in power; and the refugees will only go home when there is a peace and security in the countiry and until the communist regime remains there; there is no possibility to restore peace in Afghanistan; divisions and splita whould be avolded so the way may be paved for a united Islamic leadership as a result of which in an Islamic independent Afghanistan an Islamic govermment may be established. Ittehad-e-Islami 17 May, 1988 EDITORIAL; The editorial addresses the Eld: O Eid, Go to the people who have the privilege of being able in deciding theirow fate, don't come here.Do not come until the atmosphere is favorable for your coming.God wlling, the time is not far for us to recelve you. You are the tiding of the greater Bid of independence. The hearts of the black and long night of grievances will very soon stop beating and the twilight will glow. When the Md of our Independence is at hand, we will then mush towards you with aniIIng face and hearts full of love and affection." REPORT: Prof. Sayyaf, leader of the Ittehad-eIslami Afghanistan in a speech $15 \mathrm{May}$ in the Conference Hell of the Ittehad-e-Islani in connection with the fast pace of Afghan ovents and also the transfer of a number of the centm ral offlces of the Ittehad to the intersor of Afghanistan said "Once again, I issue the command of alertness to all of you. All of you get ready as mujaheds and prepare yourselves for top mobilization and for the sake of Almighty God and for the sake of victory of Islam and for the sake of the Independence of your Islamic land, give to yourselves the name of death". * Engineer Ahmad Shah, leader of the traneitionel govermment of the Afghan mijaheddin in a message on the occasion of Eld of Ramadan has said "Dear mujahed and muhaj1s brothren, it was your chantings raised for the cause of trum th which brought the Kremlin arrogance down to 1ts knees. It was the patient one of the coum try who burnt the blood thirsty communtem in the fire of hinflidition and defeat. It was the high ambition of our vigllantios in the sacred trenches of jehad which defeated and Irustrated the savagery and fear of the communtet satanic athelem." 


\section{Ekhlas}

18 May, 1988

EDITORIAL: "Why the power is not being transLerred to the transitional government of the mujaheddin?". It says, "It is now almost three months that the IUAM announced the Afghan mujaheddin transitionel government headed by Mujahed Brother Ingineer Ahmad Shah. This announcement was received with Joy by the Islamic world in general and the mujahed Afghan nation in particular. We thought that, with the help of Almighty God, due to foresightedness of the leaders of seven IUAM members, divisions were brought to an end anong us .... However, it is unfortunate to see that this hope has not been realized during these three months and st111 we observe that the seven organizations are working separately .... We expect respoctfully that our esteemed leaders on the basis of their own valuable decisions dissolve their organizations and hand over their personnel to the transi tlonel government. This is the will and wish of our mujahed nation, and, by doing so, we can prevent divisions in johad trenches and succeod in the establishment of a truely Islamic government in Afghanistan.

Pareorar Mawlawt vit Hamza, in his speech in the OIC Forelon kintaters conference said "The Rus sians want to impose their aggression on smaller countiries and, were it not so, why then they are not pulling out from Afghanistan uncondtionally, imediately and completely?"

* Prof. Rabbani, leader of the Jantat-o-Islami Afghanistan, in a message to the Jehad commanders and other competriots has said, "You should rest assured that the govemment which is formed by your mujahed brethren is going to belong to you all and it will be government of all the aggrieved tuslims. It is going to be an enlightened, peace loving and freedom loving government of all the belleving and compassionate men and memen of. the country. It will be a government of truth, justice, faimess and Iraternity, a gov- erment of knowledge and wisdom and ethics and goodness.

\section{Mahaz}

21 May, 1988

EDITORIAL: "The 7th of Saur". It discusses the tragedy of the 7th of Saur and the policies pursued by the PDPA after the event and the uprising of the Muslim Afghan nation.

REPORT: On the occastion of condemning the PDPA coup of 27th April, a grand meeting was held In the Munde Oamp in which Dr. Farouq Azam, the Deputy leader of the NIF said "an outcome of our 10 year old jehad has been that the Russian theory and philosophy saying when the Russian army puts its feet somewhere, it will not move back until it accomplishes its objectives are rendered futile. You, the people of Afghenistan, thanks God, forced the Red Army to pull out disgracefully and shanefully whthout achieving any of its objectives. You killed them and disgraced them to such an extent that the whole world founci out that a super power was not able to bring even a small town under 1ts control." NEWS: The alujahedditn of Athghar, Zabul, captured 24 April the center of the Athghar sub division.

* The mujaheddin conducted an operation on the Asmar, Kunar, 5 May.

* Eight liussian soldiers were killed and three tanks burnt 21 March in Baghlan by the mujaheddin.

\section{AD-NOOP 22 May, 1988} EDITORIAL:" inthe Russians and the past nine years" (By Watandar). It says one can divide the Russian activities in Afghanistan into two parts; (1) militaxy and (2) political. "As far as the military activities are concerned, the Russians thought they will eastly be able to swallow Afghanistan. However, as time passed, they found out that their estimate and projection was wrong. Because, on the one hand, the nationwide resistance got further momentum and, 
on the other hand, Moscow had tu deal with an Inefficient communist group .... Despite this, the Russians thought they will ba able to extinguish the glow of Islam and fretiom in the hearts of the Afghars. But they were selther able to conquer Afghanistan nor make a communist regine workable.

"As far as the Russian political engagoments are concerned, the Russians found out that a reason for the resistance of the Afghan peopile was the lack of proper attention by the Communist party to the Islamic belief of the people. For this reason they established the Ministry of Islanic Affairs ... They spoke about peace but, despite this, the Russians could not acheive their aim. Afterward, through Naj1b, they 1ssued the somcalled NRP coalition government and tens of other progrems .... but with no result ..."

INTHRVIEW: Qaz1 Hussain Ahmad, the Amir of JI, was asked: some Paldstant 'political thinkers and commentators urge the recognition of the Najib government and severance of relations with the mujaheddin. Do you think that, by doing this, the issue will be solved? Answer: "Those who speak these words in Pakistan ere on the pay roll of the Russian Imbassy and are Russian agents and they have no status and prestige in the politics of this country."

\section{Neda-e-Haq}

DDITORTAL: mine Geneva agreement and the 1nterests of the two satanic powers". The oditorial first speaks about the Russian interest. It says, "(1) The Russlans will no longer be able to rematn in Afghenistan and therefore, the Geneva accord serves as a good excuse for them; (2) Russio wants to gain legetimacy for 1ts hirelings in Afghanistan; (3) in the outside worid and especially in the Islanic countries, the Russians want to restore credibility and repair their political, military and economic damages; (4) but more
Important, by embarking on such a plot, Russis wants to provent the cstablishment of an Islamic government in Afghanistan.

"The American 1nterest: (1) To show to the wurld that, as a world power, it can inm terfere in the Afghen 1ssue; (2) to prevent the success of Islantc revolution in Afghan1stan and to detract the Afghan Jehad; (3) to obtain certain prevtliges from the kusslans in Nicaragua, the Persian Gulf and the Middle East; (4) To find a foothold for its hirelings (in the Afghan affairs) once more ...

" However thit is just a wishful thinking on the part of the enemies of the cod and religton and they will be frustrated very shortly with the help of Almighty God."

REPORT: Mawlaw1 Nasrullah Mansoor,ileader of the Harkat-o- Engalab-o-Islan1 in a large meeting held to condenn the Geneva accord said "I do not say that a deal has been made on the blood and souls of the Muslims but what I say is that Islam was sold, the Quran was sold, the religion of Mohannisd, the Prophet of God, was sold, the Islamic revolution was sold, the tears of the ryldows and the orghans were sold and the hopes and aspirations of the Muslim world were shattered Into Ifeces ... I say that why Generel Mohammad Ziaul Haq the President of Pakdstan closed his eyes on everytling? Why did he not honor his words and promises when he was sayting The Afghanistan mujaheddin are defending Islam and Pakistan and helping them is our obligation."

\section{Ittehad-e-Islami ${ }_{z 3 \text { mav, } 1988}$}

EDITOKIAL, What gift the Russians are going to take with then?". The editorial while discussing the Russians disgraces as a result of thetr invaston of Afghanistan says "Yeo, Naj1b, the head of the hireling regime in a speech on the occasion of the start of the pullout of the Soviet troops remarked shamefully 'You have ful- 
P1iled your intemationalist duty. You built our country. You taught our children the lesson of peace and reconciliation.' But later he sald 'I sincerely request all those who are outside the country to return to their country and participate in the construction of the devastated Afghanistan.' What a stupldityl Has a country, which has boen butlt and its children taught the lesson of peace and reconciliation by the Russtans, need to be reconstructed. The fact is that they have lost their memory as well ..." MESSACE: Prof. Sayyaf, leader of the Ittehad-eIslami Afghanistan, in a message to the mujahoddin has said, "The day has reached that you should establish the government of mujaheddin in the land of the mujaheddin. The Russians are fleeing and you should not feel tired. Take firm steps behind them by making use of the inal moments to inflict your heavy blows on their dirty backs while they are fleeing. For the healthy administration of the affairs of your country under the leadership of the mujaheddin you should be completely prepared. You should not entertain any concerm or anxiety about the administration of the conquered areas." ARTICIS: "The histortc defeat of the Russians" (By Abdul Razzaq Nabelyar). By giving, a choronology of the Russian aggression he says "While the Russians have been defeated and want to Withdraw Irom Alghanistan on the basis of the Genova agreement, they remember very well the historical defeat and escape of the British from Afghanistan in 1842 as a result of which from 7,500 only one reached Jalalabed - - even he hall alive on his horseback ... It will not be too far that the Russians, too, will have similar fate during their escape from Afghanistan."

Shahadat 25 May 1988

EDITORTAL: Worrles and concem in pro-Russian circles". It says, "the announcement about the withdrawal of Russian forces from Afghanistan has created an intense anxiety and concern in pro-Russian circles in Kabul, India and Pakistan ... In Kabul the Central Committee of the PDPf. during many sessions has so far falled to reach a conserisus ... The role of Indie also is worthwhile to mention in this connection. This country during the long rule of the Congress Party over its political fate has elways fanned differences between Afghanistan and Paldstan ... The establishment of an Islamic order in Afghanistan,leading to closer ties between Afghanistan and Pakistan, in as much as it is contrary to a Russian desire, also creates concern to India .... In Pakistan, too, the announcement about the withdrawal of Russian troops has bothered promussian circles as it has created concern among the militia forces in the trenches .... And now we have ample proof to show that for years our jehad has been criticized and sabotaged by these circles in Pakdstan on the basis of Soviet-Kabul regime-Indian instigations. They demonstrated that nationalism and a worship of blood and soil cannot produce unity and brotherhood and it was as a result of Islamic brotherhood that the Musidm Pakdstani nation opened Its arms to the Afghan ro fugees."

REPORT: Gulbuddin Hekmatyar, leader of the Hezb-e-Islami in a speech after the Juma prayer 20 May in Nasrat Meene said "Until woman is not aware of religton, an Islamic society cannot be formed." He added "Islam has come both for women and men and both of them are responsible to understand their religtion." * "Views and stands about current events". The newspap $r$ has asked the men of opinion to talk atour such events. Nuhzatyar has said nour elders ought to walk in to the other side of the bom dér as well". Abdul Wakil Akbarl: "To wo the will of the poople is inportant. The Afghanistan nation has the right to trust any person they wish." Dr. Jan Mohammad hamkar: "By making use Lof the opportunity, an elected council should be 
formed." Kashaf:" The real factor and reason behind all these tragedies in Afghanistan is Zahir Shah. There is no longer any foothold for this servant of Mussia in Afghanistan, Qazi Mohammad Amin Waqad's name has been mentioned among the people who have been asked to answer to the question put forward by the newspaper but he has apparently not given any reply.

\section{Ittehad-e-Islami}

$30 \mathrm{May}, 1988$

EDITORIAL: "Pre-destination". The editorial has discussed the battles fought during the time of the Holy Prophet Mohammad, peace be upon him, and says in conclusion "the number and weapons of the Muslims were always less in compartion to infidels'. However the Muslims alway came out victorious and defeat and humilation were the lot of the followers of satan and this was so because this is the law of pre-distination. The writer has considered the Afghanistan jehad to be a follow up of those same jehads and writes "now the time has reached that in free and Muslim Afghanistan an end should be put to non-ausplcious atheism and Islamic order should be established and enforced there by the mujaheddin and it should be proved to the whole world that the triumph of truth over the false is inevitable and predistined."

REPORT: Prof. Sayyaf, leader of Ittehad-e-Islami in a speech 22 May to the teachers and students of the Mujaheddin Military Academy said "We have not appointed any body as our advocate to decide about our future."

* Engineer Ahmad Shah Ahmadzai, leader of the mujaheddin transitional goverrunesit in a press conference $8 \mathrm{May}$ said "The major portion of the country is under our control and we have the power and authority to establish a government in areas under our control. All the mujaheddin are unanimous about the establishment of such a government and famous commanders of various parties have expressed their loyalty to this govermment."

ARTICLE: "A shaneful defeat". The article discusses the Russian intervention in Afghanistan and also its defeat and says "Finally the disgraceful Geneva agreement has been signed. On the basis of this agreenent the Russians agreed to recall their troops from Afghanistan. The Russians are withdrawing their troops after many human and financial casualties without achieving their objective. And they have admitted their defeat at the hands of the mujaheddin of the truth. This to me is not only the Russian defeat but a defeat of the socialist world and of the hallow and meantngless philosophy of communism.

\section{Shahadat 2 June, 1988}

EDITORIAL: "The nation should not give up." The editorial says an obvious charateristic of our Islamic revolution and movement is that for the fulfilment of our aspirations, which correspond with the aspirations and belief of the Afghan nation and the entire Islamic ummah, all our nation should be alert in the determining their own fate. Imperialism and agents of arrogance are trying hard to exclude and isolate the nations from the arena of the realities of life. Because it is in the absence of the decision and will of nations that they can decide against their will about their fate and future." REPORT: Gulbuddin Helomatyar, leader of the Hezb-e-Islami APghanistan in a meeting 29 May with tribal elders and notables in the Peshawar Club said, "I do not say that I have weapons, an organization and jehad power and therefore the government should be mine. But I say that the decision of who should become a leader should be made by the nation.") He added "Zahtr Shah can only come to Kabul through Moscow. He will not be able to come through Padistan or through the tribes or Iran."

ARTICLE: "Counting the dead is yet too early for the Russians" (By Wahid Mazhdak). The article has rejected the statistics gixen by 
the Russians which says 13,310 of their men were killed in Afghanistan. It says that Russian casualties are many times more than that. It adds, "at any rate, the mujaheddin have yet to settle account with the Russians, and months are left until the last soviet soldier pullout from Afghanistan. It will be appropriate for Russia to count the number of its dead at that time."

\section{Scientific Awakening}

EDIMORIAL: "Need for unity." Sayyed Noorullah 2 June, 1988 Murad) The editorial discusses the need for unity and reminds the promises made by the jehad leaders in this connection and says "if in the near future our leaders do not move fast in. fostering unity, it is going to be too late because the enemies are making hectic activities under this or that pretext and let us not allow them to bring some one else into power who might be a Russian agent in disguise...." ARTICIES: "Guidances of Abu Bakr, Siddiq (the first Caliph of Islam) about war." (By Sayyed Abdul Jamil Murad) "Do not fight any body and do not kill him as long as he pronounces the Kalema, (There is no God but Allah and Mohamad is the Messenger of Allah). Those who. read the Kalema, let them go free and those who do not read it fight them until the end and wherever you find them slaughter them". * What do the Youth want?" (By Abu Jehad) The article discusses the sacrifices rendered by the Afghan youth during the course of jehad and says their one and only desire and aspiration is the unity of leaders and ranks of the jehad.

\section{Serat-ul-Mustaqeem \\ 2 Jume, 1988}

EDITORIAL: "The miracle of revolution". It says, "the oppressed, Muslim and empty handed nation of Afghanistan began an unequal war with a few old swords for the sake of complete victory of the Islamic revolution and toppling of
Russian imperialism. By its attacks aimed at dofeating infidelity, it covered this long journey only in a few years and in the face of this struggling nation the Russian imperialism, which was fed with the blood of the oppressed for many centuries, was defeated in the battle-field and Russia admitted to the entire world its defeat ... Yes, defeating the Russians was a task which could not be imagined but the Afghans not only disgraced and belittled the Russians but also purged their own ranks (from impurity) ... This is an astonishing revolution. We cannot ignore its realities, but can say that its. every minute and hour is a ground for trial and test where every one shows his true colors and mantle."

NEWS: The 1.7th army division of Zelmey Kot, Herat, joined the mujaheddin. The Muslim officers in the division, who were on the side of mujaheddin, set ablaze the army establishments by explisives and a completely demolished them 20 May.

* Wakil Azan, who under the deceitful program of general amnesty joined the communists and was appointed' as the Governor of Nangarhar, after finding out that he has no power and authority, has now become repentant for what he has done.

* An enbezzlement of 375 million mupees has taken place and the newspaper has promised that it will throw light on the matter in the future through an interview with the Jamiat-e-Islami Afghanistan.

\section{Arman-e-Mujahed 5 June, 1988}

ARIICLE: "The loya jirga". It says under special and grave historical conditions the Muslims of Afghanistan have resorted to loya firgas to reach final decisions through this grand national assembly. History has recorded in golden words the role played by the loya Jirgas in the Afghan history. One of these loya jirgahs was held in 1941 in which Hazrat o-Nur-AI-Mashaikh Mojaddedi told the loya 
jtrga, held to make clear Afghanistan's position in regard to World War Two 'We are supporting the policy of complete neutrality. We are not ready to entertain any proposal which might trample our honor, traditions and independence directly or indirectly. We will not allow any foreign country to occupy our country or a part of it or to force us to concede to any privilege to foreigners, ....) Such has been the nature of loya jirga which has. been held in the light of Islamic laws. The Russians also resorted to convene a loya jirgas' after their occupation of our country. Neither the jirgas called earlier nor the one held by Najib was able to achieve its purposes. Wthout the participation of the true ulama it is not possible to reach an effective decision about the fate of our nation."

merger or Cooperation with Communism."

Mhose Marxists who are holding the book of Narx in one hand and the Holy Quran in other hand, in order to deceive the youth of our Islamic society, talk about common objectives and joint fronts. They are either deceiving themselres or may be the people who are being addressed do not know about the nature of Marxism .... Otharwise, It is quite obvious that nobody is going to listen to such lectures."

\section{Freedom}

IFis: The pullout of Soviet troops from Afghaniatan is Inevitable but shadows of the Russian pressures are still lingering over Afghantetan.

* The $10 \mathrm{~s}$ is thought to be involved in explosLons that take place in Pakistan.

* The Interin government of Afghanistan has been formed. In this connection the newspeper Lets the fallowing names which it says are probuble to be Indiuded in the govermment:

- Frou Heab-Islant (Hekmatyar): Dr.Abdul

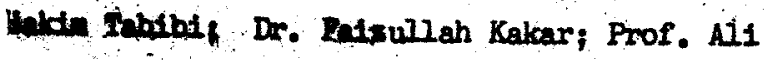

Ansari; and Judge Najiullah.

- From Jamiat-o-Islami Afghanistan: Abdul

Aziz Ferogh; Sayyed Noorullah Emad; Mawlawi. Hanza and Sedeq Sarwari.

- From Ittehad-e-Islami Afghanistan: Dr. Abdul Sattar Seerat; and Zmarak Yasser.

- From liLF: Ghulam Nabi Nawshad.

- From Hezb-e-Islami (Khales); Dr. Abdul

Sammad Hamed and $\mathrm{Haji}$ Din Mohammad.

- From NIF: Ghulam Farouq Azam.

* The Russians have begun violating the Geneva agreement before its ink dries.

* An American delegation, headed by the former US ambassador in El-Salvador, participated in a three day conference in Kabul with Russian and Kabul puppet regime officials to discuss issues related to the settlement and reconsm truction in Afghanistan. But the delegation is said to have rejected the adoption of any decision on these matters until the formation of a legal goverrment in Kabul.

EDITORIAL: (1) The Geneva accord brings no peace in Afghanistan but war will continue in that country; ( 2 ) how could the US serve as a guarantor of an agreement in which a principal partner is not a party; (3) return of 80,000 Afghan children between the ages of 7-14 has not been made part of any negotiation; (4) the US should launch a diplomatic offensive and $r e$. cognize the interim government of Afghanistan. ARTICIES: The newspaper has accused the American media of giving proninence to Russian views about the war in Afghanistan especially after Russian leader Gorbachev's official announcement that he is going to pull out the Russian troops from Afgtianistan. The newspeper has published figures wich seys show the biasediness of the US media.

* A Japanese uniter and Joumalist Hideo Asano, in an article witten for the nerspaper has given an eye wtness account of the Afghan Jehad. 
The writer has travelled together with the muJaheddin inside Afghanistan.

* Dr. Sayyed Makhdoom Rahin, under the title of the "Cemented Structure.", has written, "In our truthful uprising against the Russian aggression and etheist ideology, its ideological dimension gives further prominence to our sacred jehad." Comparing this jehad with the ones fought against the British in the 19th century, the writer say, this aggressor has not only violated our territorial integrity and national. sovereignty but, in addition to this, it is trying to impose infidelity and atheism on our nation by using force, oppression and massacre."

* Six Afghans (Dr. Mohammad Siddiq Noorzai, Dr. Ravan Farhadi, Painda Mohammad Koshani, Yar Mohammad Mojaddedi, Dr. Abdul Qayum Koochi and Dr. Abcul Hayee Hamid) in a letter to Mawlawi Mohammad Yunus Khales, then President of the IUAM, have sent the draft of a proposal in which Afghan demands from Russia are listed. The list contains: (1) Complete and immediate withdrawal of all Soviet forces from Afghanistan; (2) complete and immediate withdrawal of Soviet or other communist countries specialists, teachers, advisers from Afghanistan; (3) dissolution of all kinds of Soviet military bases; (4) return of all Kabul government forces to their barracks; (5) dissolution of all armed groups belonging to Kabul regime such as militia, and tribel brigades for the defense of the revolution, etc, and collection of their arms; (6) dissolution of the PDPA and all other communist and Narxist parties; (7) dissolution of KHAD and the Ministry of National Security at home and abroad: (8) dissolution of all organizations and units established under the nane of youth, women, farmers; artisans and workers from April 26,1978 untiz now by the regime; (9) dissolution of all organizations belonging to the socalled National Front and NRP; (10) return of all Afghan children under 18 from the Soviet Union; (11) return of Afghan prisoners who are in Soviet prisons and camps at present; (12) abrogation of all treaties and agreements concluded in political, border, military and arms fields since 26 April, 1978: r,etween the puppet Kabul regime and the Soviet Union; (13) review of all other agreements including economic, trade, etc. and the question of the education of Afghan students in the Soviet Union; (14) confining official Soviet cuties to Kabul in accordance with the requirements of international laws and rights and limiting the personnel of the Soviet Embassy and closure of all other Soviet agencies in Afghanistan; (15) reviewing the volume and price of the Afghan natural gas exported to the Soviet Union since April 16, 1978, and clearance of their accounts taking into view the price of natural gas in accordance with normal interna-. tional prices; (16) transfer of the guaging apparatus of gas export into the Afghan territory from the Soviet Union; (17) return of all historical or cultural items or those belonging to the National Archives of Afghanistan sent to the Soviet Union since 26 April, 1978; (18) public trial of all war criminals including Soviet citizens or those related to the Kabul puppet govermment who have resorted to the slaughter of the people and activities contrary to authentic international convention related to human rights in accordance with the provisions of these conventions; (19) general amnesty to others who do not cane under article 18, provided they promise sincerity to the Islamic state of independent and free Afghanis tan and adhere to their expression of sincerity and exert efforts for the consolidation of this state; (20) the Soviet Union should compensate for all damages caused during the war and occupation of Afghanistan. The funds that the Soviet Union had offered as loan or. grant in cash or in kind to the Kabul regime since 26 April, 1978, will not bo eccepted as part of this raparations. The Soviet Union $1 \mathrm{~s}$ also responsible to pay the total damages inflicted to private Afghan properties as a result of 
the war and occupation. (21) non-aligment of Afghanistan and non-participation in hostels military world groupings and participation of independent Afghanistan in the UN, OIC and NAM.

\section{Al-Noor \\ 6 June, 1988}

EDITORIAL: "The coming and going out of the Russians from Afghanistan" (By Qanet) "It is not surprising that the Russians are going back home after being humiliated and crushed, but it is surprising that why the Russians had been kept unaware of the valour of the Afghan people. Were they aware of the fact that from Afghanistan they would leave with their ears and noses cut, never they would have attacked Afghanistan ... The withdrawal of the Soviets from Afghanistan is testomony to the fact that they became convinced that, other than receiving human and property casualties, they carnot have any other gain ... The casualties given by the Russians during their involvement in hifganistan is far less than the actual figures ..."

NEWS: Forty five enemy soldiers were killed and 16 captured, $27 \mathrm{Msy}$ in Kunar. During the operation, the mujaheddin occupied four military posts and set ablaze arms depots.

* The mujaheddin killed 25 April 30 atheists and captured two military officers on Mazarmem Sharif-Jauzjan highway.

* The mujaheddin killed 12 May, eight communists, including a cormander in Paktia.

ITTEFAD-E-ISIAMI: - 7 June, 1988.

EDITORIAL; "The demends of the time and conditions". The editorial says "... Now that the Russians are busy evacusting a number of important strategic areas and, at the same time, they are trying to change the face of the Kabul puppet regime by convening a farce parliament and cabinet to deceive some naive people, it is time for the Muslim people of Afghanistan to urge once more the jehad leaders to face the reelities and amounce the establishment of a. mujaheddin interim government inside Afghan is$\tan . . . "$

REPORT: President of the transitional government of the Afghan mu.jaheddin Engineer Ahmiad Shah Ahmadzai in answer to a question in a meeting 5 June with a foreign delegation said, "Wie have chosen four centers in mujaheddin control regions for the establishment of the transitional government. We hope so succeed establish our government within the country in a near future."

PROCLAMATION: The Supreme Council of the IUAM has decicied to turn down a lequest for a meeting between the mujaheddin leaders and the UN special envoy on Afghanistan, Diego Cordovez. Because Cordovez is trying to arrange talks betveen the mujaheddin and Najib and this is contrary to the position taken by the mujaheddin.

NEWS: The Baghlan mujaheddin have captured 22 enemy posts and 800 Kilashinkovs.

* In recent fightings in Kandahar 200 Russians have been killed and 300 unaccounted for.

* A Russian ailitary convoy heading from Thairkhara towards the Shamali came under mujaheddin attack resulting in 300 casualties to the Russian soldiers.

ARTICLE: "Changing the beads" (By Enqineer Abdul Wadood Khaled). The article discusses the activities and failure of Russian puppets in Afghanistar and says "One should not forget, that, during the past nine years, the changes in the top heirarchies of the puppet regime and the killings that have taken place of the leaders of that regime, have all been due to the rightful jehad, patience, perseverance and trust upon Almighty God by the Muslim Afghan nation and the fact that this Muslim nation did not allow the fall of their hot trenches to the atheists and the enemy's last plot offered in the guise of the Geneva accord will also prove futile ..." 


\section{Shahadat 9 June, 1988.}

EDITORIAL: "Changing of beads will not save

the Kabul regime from the danger of being toppled". It discusses the recent cosmetic changes by the puppet regime and the introduction of the so called non-party individuals into the cabinet. It concludes, "the Russians should know that the mujaheddin are not going to be content with anything but the dawn of an Islamic govermment and the end to all the manifestations of evil and corruption. The same way that the Russians were not able to reform this regime in the last ten years, it is quite certain that introducing of changes in the wake of Soviet withdrawal has no other purpose than appeasing the forces wich oppose the communists" REFORT: Gulbuddin Helenatyar, President of IUAM and leader of the Hezb-e-Islami Afghanistan in an interview with the American television network of Columbia Broadcasting Company (CBS) said June 9 "The victory of the people of Afghanistan is the victory of freedom loving people of the world. This victory is the victory of God worshipping people over atheism. The defeat of the Russians in Afghanistan is a living example of the fact that nobody can enslave freedon loving nations through the force of arms".

\section{Also 9 Jume Hekmatyar told a French} joumalist that the mujaheddin government was not a government in exile and, God willing, very soon this government will be established inside Afghanistan ... The real capital of the mujaheddin government is Kabul. However, for temporary purposes, right now it will be established somewhere else inside Afghanistan. ARTICIRS: "The dissolution of the Junejo govermment and the Afghanistan issue". The arti.cle is a translation of an article by a Pakistani journalist who has described the Junejo policy vis a vis Afghanistan as negative, lacking courage. It says "the Afghanistan je- had is a decisive phase for the revival of
Islamic Ummah. If an Islamic government is established in Kabul, it will have the role of a strong and reliable fortress for Pakistan in the region. Otherwise Pakistan, caught between India and Kabul, will never feel secure. If the govemment of Mr. Junejo had continued, the existence of a pro IndianRussian government also was certain and it would have meant that what Pakistan did during the past eight years would have been thrown to the sea ... The most important draw back of the Junejo government was that it lost the opportunity for the formation of ar Islamic interim govermment in Kabul."

\section{Ittehad-e-Islami}

14 Juṇe, 1988

EDITORIAL: "New tactics". The editorial speaks of the oppression committed by the communists and then of the policy of bringing in new faces by them and describes this as futile. It says, Until the Russians withdraw completely and unconditionally from our country and the hireling Najib is done away with and, in his place, an Islamic system is established and the banner of Islam is hoisted all over Afghanistan, the mujaheddin will not lay down their arms." REPORT: The President of the mujaheddin interim government, Ahmad Shah Ahmadzai, while talking 10 June to the Japanese and Saudi journelists, said, "when the mujaheddin government is formed and all the Jehad organizations are fully organized, the Russians will no longer be able to remain in Afghanistan.

* A conference of solidarity with the mujaheddin was convened 10 June in Islamabad Hotel under the auspices of the religious scholars of the Ansar-ul-Mujaheddin, Pakistan. The conference described the Geneva accord as a collusion between the US and Russia and condermed it. ARTICLES: "The drawbacks of the Geneva accord" (By Abdul Aziz). "The Muslim nation of Afghan- 
istan rejects the Geneva accord because: (1) it was concluded in our absence and does not include our demands; (2) the OIC, the NAM, European Community and the UN had demanded the unconditional Russian withdrawal while now the withdrawal is taking place in nine months time; (3) the Afghanistan issue is not a border dispute between Pakistan and Afghanistan; (4) in the accord the Soviet invasion has not been mentioned; (5) there is no provision about stopping the Russians to repeat their aggression in Afghanistan; (6) there is nothing about the fate of thousands of Afghan political prisoners who have been sent to Russia; (7) nothing is mentioned about Wakhan; (8) there is no mention about the formation of an interim govermment for the restoration of peace; (9) there is no guarantee for the establishment of a free, Islamic and non-aligned Afghanistan, (10) the accord is apt to create rift among Pakistan, Afghanistan and the tribes (11) the position of Islamic parties has not been kept in view ... Shahadat 15 Jume, 1988 EDTTORLAL: "The leadership of the Islamic revolution and the imperialist propaganda". The editorial rejects the propaganda against the Hezb-eIslami in connection with the current political developments in Afghanistan and writes "at one time Hezb-e-Islami and its leadership was accused of being extremist as that they did not want unity with the other organizations and fanning differences and depriving the Afghan people from a single leadership under these sensitive conditions. When the Hezb-e-Islami comes forward for unity and brings about unity and thereafter, the Hezb-e-Islami leadership improves the atmosphere for a coalition among the parties for taking a united stand on a number of specific issues and fulfils an active and serious role in fostering the coalition process among the jehad parties, they very shamelessly keep quiet."

REPORT: In a speech 1 June in the grand mosque of Nasrat Meena, Hekmatyar said "it has been always my stand that it is the right of the nation to take any decision about the future government (in Afghanistan). Pledge to a leader with whom the people are not happy is not legal from an Islamic point of view. Some people think that the present number of parties and conflict among them will continue as it is in the future too. No, rest assured that the revolution will solve this problem. You will see that, following the liberation of Afghanistan, a single approved leadership and party will emerge in the society."

ARTICLES: "The enemies and the confederation issue" (By Waheed Muzhdah). "In his meeting with Najib, Rajiv Gandhi described the establishment of an Islamic government in Afghanistan as a danger to India. Commenting on Gandhi's state ment, the western press considers the proposal of a confederation of the jehad fundamentalists proposed by Hekmatyar with Pakdistan a point of axiety for Gandhi because a large number of Musm lims are living also in India who are anxious to launch a struggle and jehad for Islam and a change in the political dimensions of the region may incite their feelings as well.

LETTER TO THE EDITOR: The name of the writer not readable. It says The Afghan Jehad magazine in its excerpts from the mujaheddin press also has been giving quotations from a number of newspapers and magazines which are either unknown, non-Islamic or fail to help the cause of jehad. The letter has particularly mentioned the name of the journal Afghan Mellat and magazine Payam-e-Zan (message of the woman). It urges the Afghan Jehad to refrain from quoting these publications as they are not supporting the cause of an Islamic jehad.

\section{Payam-e-Jehad JUNE, 1988.}

MESSACE: Ayatullah Mohsini on the occasion of the Eid-ul-Fetr, has said in a message, "Our Muslim nation should not be content only with 
the pullout of Russians and our Jehad and struggle should continue until we achieve our final objective which is the establishment of an Islamic govermment based on social justice, a government under which all strata belonging to any religious, sect, color or race should live a life of human beings and achieve their legitimate rights ... Although, as a result of our jehad, we have inflicted heavy b-ows to the aggressor, you should not accept any deal and which all the strata of the people are not included in it."

INTERVIEW: Mujahed brother Captain Mukhtar in answer to a question about the capture of the Seyal Gird sub division, Parwan, said, "in the battle for the capture of Seyal Gird which lasted more than a month in March-April this year, many enemy troops were annihilated, injured or captured alive. Some of them fled. All their light and heavy weapons and other supplies fell in the hands of the mujaheddin and the mujaheddin shot down two helicopters." coalition and even an interim government in

REMINDEH: It is regrettable that Mr. Kushkaki (Managing Editor of the Afghan Jehad) despite the fact that he himself attended the Paris international conference together with Brother Anwari and he was very well aware that Anwari is a well known member of the Harakat-o-Islami Afghanistan, in the January-March, 1988, issue of the Afghan Jehad, this famous ccrnmander has been described as a member of the Jamiat-e-Islami. The magazine also has been labelling the activities of the Harakat-e-Islami Afghanistan under the name of seven party alliance of Peshawar. (EDIIOR's NO'TE: The mistake was committed only in the Pashtu and Dari editions of the Afghan Jehad. Originally the interpreter at the Paris conference had committed the mistake. The English edition of the magazine has carried Anwari's title correctly. The Afghan Jehad does not carry any news item of its own and, therefore, it will. not be correct to say that the magazine has been been labeling the activitits of any jehad organization under another's rame.
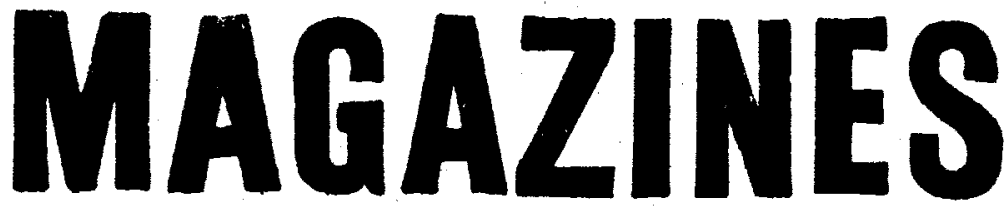

\section{Payam-e-Banowan - De 0 February - March 1988} ARTICIrs: Under the Mask of Islan": The article reveals what it calls the anti-Islamic face of the kabul communist regime. It refers to the "hypocratic claims" of the regime about its respect of Islam and the mention of Islam in the so-called Constitution. It says it is the same government that, on the other hand, invites in advertisements boys and girls to attend daricing courses and the kind of "arts" which are contray to an ethial Iife and Islan.

- The famous wonen of Islan "t the article speaks about that phase of life of the second Caliph of Islam Umar during which he had still not accepted Islam but his sister had already become a Muslim. He was not able to prevent his sister from becoming a convert, instead, but his sister's steadfastness and courage induced Unar to accept Islam.

* "Jehad": The article is about the virtues of Jehad. It says jehad should be only for earning the pleasure of God. The present Afghan jehad is of this type. In this jehad we find out that the enemy eventually retreats in every encounter with the mujaheddin and is humiliated and the mujaheddin emerge from the smokes and dust of the battle with shining victorous faces. 


\section{Payam-e-Sangar}

FEBRUARY, 1988

ARTICIES: "Iet us know Najib, the hireling." After a lengthy introduction about $\mathrm{Najib}$ and his family the article says: "after the victory of Nader Shah, all the military personnel (belonging to Nader Shah) looted the golds of the Royal Palace and among those who took part in the loot was the grandfather of the Secretary General of the Central Committee of the ruling atheist in Kabul, Najib. His sather, after receiving his share of the loot from the Royal $\mathrm{Pa}$ lace, engaged himself in comrerce and smuggling and eventually inherited this to his son Akhtar Mohammad the father of Najib. Poor Akhtar Mohmmad, who had just embarked on the business, also came across smugglers and step by step opened his way to the Ministry of Commerce in Kabul until from 1958-1962, he served as head of the transport section of the Afghan Agency in Peshawar. Naik Mohammad Kalakani later kidnapped his daughter and he agreed to marry her to the kindnaper. He was no longer by himself as he had at his side a man like liajk Mohmmad Kalakani as his son in-law and close associate -.. At this juncture, when the foundation of the atheist regime was being iaid down by the Russians in Afghanistan under the patronage of Daoud and his close associate Karmal in 1964 as a workers party, in it a number of the nobility and capitalists were also recruited as members and, among them was Najib the son of Akhtar Mohmmad, a merchant or shrewd smuggler. Parallel to this, the position of Akhtar Mohmmad in the government was also boosted and in 1973 he was appointed as the representative of Afghan merchants in Peshawar and his son-in-law also was given a post in the same office... Meanwile, sufficiently being helped by the position of his father as the representatives of Afghan merchants - - and thus his contacts with frontier area - - and also his own training in the intelligence service of the KCB,
Najib was appcinted as the head of the intellegence service in the communist government after the fall of the govermment of Pakhtunists (Taraki and Amin) and the establishment of the governnent of fiarsis (Karmal).

"Najib who has inherited the profession of smuggling from his father and grandfather, during his service in the intelligence office of the communist regime, embezzled as much as he could the public wealth for himself and for the Russians and sent a number of KHAD workers under the pretext of serving in various commercial offices to the areas where the refugees and the mujaheddin had concentrated to create tension and rift among them."

* "15 February the Day of the uprising of the people of Darame-Soof." "The brave people of Dara-e-Soor, Samangan, under the guidance of their spirituals had for the first time the honor to start their uprising 15 February, 1978, after the establishment of a communist regime in their Islamic land. The bloodshed by the people of this region during their uprising against the Kabul regime which had come to power as a result of a coup served as an incentive for a general uprising in other parts of the country, an uprising which surprised the world and shook the foundation of atheism and inficelity in Moscow. It is for this reason that we honor this historic day."

INTERVIEW: 'Brother Alawi, responsible for the Base No.16 of Sayyed-ush-Shuhada, and deputy military commander of the Maidan province gave details about the Sanglakh, Maiden, jehad:". The freedom loving and Muslim people of Sanglakh rose 15 June, 1979, against the administrators of the puppet govermment of Kabul with solid unity of all the strata of the nation and with high religious sentiments but with empty hands and a minimum of primitive weapans. Up to now these areas have remained free ... He said, since the beginning of the Islamic revolution until now the God worshipping people of Sanglakh; 
both its army and the civiliars, have rendered without an exaggeration more than one thousand martyrs for the Islamic revolution and, despite this high rate of casualty, the morale of the people is still high and they are ready to render further sacrifice until victory."

\section{KhPulwaki 17 Jamarary_tarch, 1988} ARTICIES: "The Loya Jirgah and its historical significance in the Afghan Society." (By Sayyed Qasem Rishtia). The writer says the loya jirgah is a thousand years old institution in Afghanistan and then mentions the loya jirgah held in 1707 by Mir Wais Whan in the Safa city of Zabul and, in relation to the 1964 loya Jirgah, he writes: "... its result was the disappearence of Daoud Khan from the scene and the formation of govermment for the first time whose leader was not a member of the royal family. The first action of this government, headed by Dr. Mohmmad Yousuf, and comprised of a number of intellectuals and technocrats, was to prepare a new constitution on the basis of a constitutional monarchy and a parliamentary system. The structure of the loya jirgah at this time was more or less based on the election of its delegates and thus brought out of its traditional pattern. In it, in addition to the outgoing members of the National Assembly and Senate, an equal number of delegates from all the provinces and 40 well known and experienced religious, cultural and administrative figures were brought in by the King and in this manner the loya jirgah totally becane a constitutent assembly. As a result of free debates lasting nirle days, the first democratic and liberal constitution of Afghanistan was adopted in October, 1964, which was welcomed by the people with optimism and hope .... Only the Soviets were indifferent to it because it would create a big obstacle for the implementation of their hopes and designs in regard to Afghanistan, hopes and desires which existed even then ..." The writer says that "by making illegal use of the law" a communist party was established anci demonstrations were being held. He says, "when the first elected Parliament convened, a series of illegal and threatening demonstrations were held. These were being incited by a number of students. The demonstrators started to attack the constitution and the very state and government which had brought about these unprecendented changes. They marred the procedures of a parliamentry vote of confidence for the government and attacked the security forces and, as result of their incitement and ensuing clashes, three persons. were killed and a number injured and tension built up specially at the university. This created concern and panic among govermment officials who did have experience in dealing with such events and the net result was a change of the government. The new govermment appeased the demonstrators in order to calm down the tension and thus responsible for what happened."

* "The Institute of Islamic Affairs in Afghanistan" (By Yousufzái). "When in 1931, Nader Khan wes brought into put to put down the Bachae-Saqao rebellion. Nader entrusted the duties of the Ministry of Justice to late Fazel Ahmad Mojaddedi. A Jamiat-ul-Ulama was established within the framework and this ministry and the irstitution had existed ever since.... When in 1978, the Saur coup took place under the leader ship of Taraki, the role of the Jamiat-ul-Ulana also changed and its Presidency was given to Abdul Azizi Sadeq Uruzgani a close friend of Hafizullah Amin. He brought in many supporters of the Khalq party and launched a propaganda in support of that group ... Karmal changed the name of the Jamiat-ul-Ulama to the Department of Islamic Affairs anc made it a part of the Prime Ministry and appoint Saeed Afghani as its President. Afghani was dismissed as a result of a rivalry with Keshtmand, the Prime Minister and Abdul Wali HujJat was appointed in his place and when the department was promoted 
to a ministry he became its Minister. The father of Hujjat was Tadjek and his mother was Uzbek. He was born in Samarkand of Uzbekistan and later came to Afghanistan with his family and finished his studies in Kabul. He was a prominent member of the Setam-a-Melli ... During the Najib leadership, a center of Islamic Research was also founded within the framework of the Ministry of Islamic Affairs. The center has three departments: (1) Tafsir and Ahadjs (2) Jurisprudence and law, (3) history and philosophy. Non-party people were invited to join these offices but no one volunteered. In the Afghan Army, too, members of the Ministry of Islamic Affairs are active but this has served no purpose. Also some memters of the party recite verses of the Holy Quran and quote from the Ahadis but with no avail because it is impossible to induce the people to accept communism no matter how they sugar coat it. The same policy was adopted by Ienin after the October Revolution to deceive the Muslims of Central Asia."

\section{Jehad Palwasha}

FEBRUARY-MARCH, 1988

EDITORIAL: "Let us frustrate the last hope of the enemy." "If the Russians have lost their last hope of success in the military field in Afghanistan, they have, instead, launched a wideranging political and propaganda offensive against the Muslim Afghan nation and through this they try to fulfil its objectives in. Afghanistan. Russia in its political and propaganda war wants to achieve two objectives:(1) to deceive the Afghen and world public opinion and (2) to create mistrust anong the people of Afghanistan themselves and between the people of Afghanistan and those who sympathize with them ... By creating distrust among our own people, it aims at prolonging the rule of its puppet regime. If, by uniting ourselves, we frustrate this last hope of the enemy, at that time the enemy will say "let us pack up, let us pack up," Just as the pagans of Makkah cried when the Muslims at the time of Holy Prophet Mohmnad, peace be upon him, overwhelmed that city. It will be then that the enemy will be leaving Afghanistan for sure ..."

AFTICLE: HUW much one should trust the Russian communists?" The article has reviewed the contracts concluded by communists since they came to power in Russia at times when they were forced to sign such pacts and says, "now victory is near, Russia has accepted its defeat but, as during the period of 1920 and 1930 (stet) the Russians communists deceived the world by singing agreements of peace and friendship to compensate for them weaknesses, now too, they will try to trick the Muslims. Signs of such a policy could be observed to a certain extent in the so called NRP, etc.... However there is no chance that our people will trust the Russians or their Inalq and Parcham hirelings. * "Rcots of an Islamic revolution are sprouting in Palestine." (By Mir Wali Ahmad Sabri Herawi). It reviews the historical struggle of the people of Palestine and says for the last six months it has been assuming an Islamic character and quotes Munir Shafaq, the "Islamic theorician of the Palestine" as saying "ro other revolution than the Islamic rovolution has way in our countries. No real independence, no revolution of cultural, economic or construction movements can take place other than under the shadow of Islam and under the banner of Islam". "THE COUNCIL OF SUPERVISORS": The article analyzes the reason for the establishment of a "Council of Supervisors" for the northerm provinces of Afghanistan by the mujaheddin and speaks about the Russian motives in creating a special status for northern provinces of Afghanistar and explains the program prescribed by the Council of Supervisors to frustrate these moves.

\section{Qelome FraRUARY-MARCH, 1988}


15th Febriary 1979, Herat urrising and the February 22, 1980 Kabul uprising severely shook the Russians and their hirelings and accelerated the pace of other uprisings throughout the country.

ARTICLES: "Important events of the fourth year after the Hejrat, (By Alhaj Kemal Shinwari) These are some of the important events which occured in the course of this year: (1) The battle of Banu Nadeer, (2) Birth of Imam Hussain (3) the marriage of Zainab with the Holy Prophet Mohammad, peace be upon him, and her death in the same year,

* "Legal show pieces of an illegal regime; (By Habibullah Rafie). The article has reviewed events related to what the writer calls the illegal formation of the Communist party in Afghanistan in 1965 and its illegal capturing of power in 1978 and the illegal assumption of power by the authors of the socalled new phase of the Saur revolution in 1979. He considers the illegal government of Najib the continuation of the former illegal regime. He says the legal acts staged by the PDPA's, and attempts to give a legal face to a puppet regime are foundless and Iutile attempts which will further disgrace the actors.

* "The new and old imperialism and their writings about Afghanistan" (Haji Ghulam Hazrat Koshan).

* "During the eighteenth and the nineteenth centuries, Afghanistan was subjected to British inperialismt greed. The Afghans embarked on a jehad and attacked the enemy troops. The aliens, in order to legitimize their moves against us, have written in their books that the Afghans are "man devouring and savage" ... and when a 20 th century imperialist invaded Afghanistan, the Afghans again resorted to jehad and the Russians and their servants called us rebels.
Now we are writing our own history. Our history is no longer being written by aliens. The writers who write about Afghanistan are Muslims and free. So write, oh, you Afghan writers that the Afghan people are not savages but they are civilized and they are not rebels but are virtuous and consider Islamic civilizations and Islamic ethics to be in their interest and they have chosen this path consciously. To write in such nords as we are is also jehad, a jehad with pen, side by side the jehad with sword. * "How long the Afginan children should burn in the oven of war? "(By Toryalai Jaji). "The world is marking the Childrens Day every year with special attention and by holding functions and are embarking on necessary programs for the proper growth and sound education of the children... But the situation with the Afghan children is different. The invading soviet forces during the eight years of their savage aggression have brought as a 'gift' to the Afghan children many miseries. Today the Afghans, as a result of this imposed war upon them, are faced with insufficient food, imporer dwellings and are deprived of medicine and in the grips of deadly diseases. Children are special victims of these conditions. No other parallel can be found to the condition facing now the Afghan children in the history of other wars in which children are specially affected. Russian military contingents in their raids in rural areas for searching and arresting people to be recruited in the army and for terrorizing the population, are dealing with the children in the same manner that they deal with the elderlies. The Russians murderers attack all creatures and among them the number of children are greater." The article mentions a number of stories about the Russian atrocities against the children in the Afghan war.

\section{Meesaq-e-Khoon}

February-March, 1988

"The Islamic Movement and the Enemies in 
the West and East." (By F. Fazel). "The jehad of Muslim Afghan nation which is beint led by the Islamic movement is under pressure from several direction. One is the imperialists of the East which, by the very virtue of the spirit of its imperialism, is afraid of the name of Islam and had indirect or direct involvement in all anti-Islamic activities in Afghanistan... History bas proven that western imperialists, led by the Americans, are colluding with the communists. However never it is possible for them to do something in the interest of Islam and its movement launched against arrogance." MESSAGE: Prof. Rabbani, leader of Jamiat-eIslami Afghanistan, in a message on the occasion of the anniversary of the uprising of Herat in 1979 has said, "the day is a living witness of the victory of the will of the believing nations over the atheist usurpers and oppressors." He has added, "The proud uprising of 15 February, 1979, in historical Herat is the most valuable memory that will remain for ever in the concsience of history."

INTERVIEN: Amena, a mother whose eight children were martyred in one day by the Russians, has said in an interview "from my family so far 21 persons have been martyred ... Eight of my children were martyred in one day by infidel militiamen and five of my daughter-in-laws, alongwith their children, became widows or orphans." She has added "I only wish that God would have biven me ten more children so that people would have brought their blood stained shirts to me. and reported to me: 'take this, your son has beur nartyred. "She lived in the Folor valley or the slopes of Hidu Kush Mountain. Her sons were martyred in a battle with the Russians 23 July, 1900. She is to years old and has recently come to Peshawar.

ARTICIE: "Kabul, the cradle of uprisings." The article has given an account of the battles fought by the people of Kabul With the British and then it discusses the 22 February, 1980, up- rising in the city.

* In a translated article, the activities of the Soviet intellegence agency G.R.U. has been discussed. It explains the history of this "dargerous institution" which was formed in 1920 by the Russian communist party and have played many roles under different masks.

* "The Resistance of the Afghan Muslim Nations against aggressors."(By Hussain Ahmad Mojaddedi). It has a given a detail account of the old history and geographical position of Afghanistan after the fall of King Amanullah and then says, "Sardar Eriyatullah (brother of King Amanullah) was banished by Habibullah, the Bacha-a-Saqao who was supported by the majority of the people of Afghanistan. The Bacha-e-Saqao in 1929 assumed power and took for himself the title of the servant of the religion of the Messanger of God. As soon as he assumed power he told the world that he would liberate Bukhara and bring back the Sandal Gate. Such a policy was obviously undesirable in the eyes of the Russian communist govermment and the British capitalist power. Russia immediately dispatched 4,000 troops led by Ghulam Nabi Charkhi, then the Afghan Ambassador in Moscow, to Mazar-e-Sharif to incite rebellion. He captured Mazar-e-Sharif with Russian help and headed towards Samangan ... The British, observing this tense relations of the Afghan government with the Russians, took advantage of the situation and entered talks with Nader Khan who was serving as ambassador in Paris. Nader Khan came to Kabul with the help of tribes from southern Afghanistan and, by, pursuing the British policy of divide and rule he allowed

Jaji and Mangal tribes to raid areas belonging to the Shamali tribes..."

\section{Meesaq-e-Khoon \\ March-April, 1988}

ARTICIES: "Political Solution: fears and hopes" (By Mohammad Nasim Faqiri). The writer says the political solution of the Afghanistan issue has been described as a last resort of the imperia- 
lism. He reviews the benefits that, according to the author, the Russians are going to make from raising such slogans. These are all part of Soviet snares he says. He adds, the only factor in a mujaheddin victory is unity and consolidation of the ranks of jehad.

* Whe Role of Islamic Revolution in establishing unity among the Muslims." (By Andeshmand) "Islam not only suggests ideological and religious unity for bringing about a single Ummah and united society, but also strongly recommends inner unity and signleness of heart of the Muslims."

* "Afghanistan: the center of hopes for the Muslims of the Central Asia." (Translated by Jamal). It is an article based on the one published by the Institute of Political Teachings (stet) of Pakistan which refers to signs of an uprising among the Muslims of Central Asia in relation to Afghan jehad.

\section{Haq Pasoon March-Apris, 1988} EDITORIAL: "Only Jehad can achieve our objectives." It says, "a so called political solution can neither achieve our objectives nor can we have hope from political talks now going on about the Afghanistan issue because these talks have been centered around Russian interests during the past six years and not that of the mujaheddin. If the Russians are saying that they are going to withdraw their troops from our country it is due to sacrifices rendered by our valorous mujaheddin and not because there has been any change in the nature of savage Russians and only jehad will lead us to the achievement of our objective. Others are not going to secure our freedom and independence for us. We are a free and Muslim nation and have the capability and power to decide ourselves about isoues affecting our fate and to secure our independence by rendering sacrifice and then preserve 1t. A neutral or coalition govermment in Afghanistan in fact is tantamount to the selling of the blood of 1.5 million martyrs and neither ourselves are ready to make a deal with this blood of our martyrs nor we are going to let others do so. No pressure and threat can prevent us to reach our noble objective. We have begun this jehad by putting trust. in God Almighty and are completely confident that God Almighty will not leave us alone."

PAYAM (MESSAGE): "The uprising of the Truth" (By Professor Sayyaf). Whereever truth has an abode in the hearts of the people, there is also an uprising and commitment for the cause of truth because it is one of the characteristics of the truth to stand against falsehood ... The Muslim nation of Afghanistan, guided by the Islamic movement, has undertaken an uprising under the name of truth and for the truth .... As long as the up rising of the people of Afghanistan is to advance the cause of truth, God will help it. May Cod grant us to recognize the truth and then follow it ..."

INTERV IEW: The leader of Ekhwan-ul-Muslemin (name not given) in an interview about the Afghanistan Jehad has said, "the peaceful ro conciliation, proposed by the Russians, is no more than a deceit. The puppet Soviet government in Kabul wants to trick the people by the socalled NRP. Pages of history are full of these tactics and show that those who have succumed to these snares and to alien interest want to deprive the mujahed people of Afghanistan from their belief and commitment ... To remain stable on the path of Jehad is the only altemative and people's bellef and dignity can only be preserved when the spirit of jehad is kept alive among the Muslims."

ARTICLES: "The new brokery of Cordovez" (By Fazal Ahmad Hasif). Wne should not relate so much this political brokery undertaken by Con dovez to the political solution of the Afghan issue. Rather, it is a futile and treacherous 
effort aimed at frustrating and undoing the gains of Islamic jehad and the 10 years of the resistance of the valorous and brave people of Afghanistan. Corciovez wants to redeem the Russians from their military, political and ideological defeat, a defeat of atheism, communism and Leninism and to save the Krem? in leaders from sinking.

* "Khost caught between victory and defeat". The writer discusses the ups and downs of the battle of Khost and what he terms the cammor American-Russian objective in the battle of Khost. He also iiscusses the plans undertaken for the battle of Khost and the hues and cries of the enemy, etc., and says: (1) It is possible that the Russians and their hireling troops might build new posts on the top of mountains sorrounding Khost and create a security belt around Khost, (2) it is also not improbable that another troops might lauch a surprise attack against the mujaheddin forces in Urgun to cut the mujaheddin main supply routes, (3) it is possible that the communists might conduct operations against important muJaheddin centers around Khost to destablize strong mujaheddin trenches in the area. * "A look at the Al-Bunyan News Agericy (ANS)" (By Sulaiman Shah). "In order to familiarize the public about the facts of the current jehad. and unvell the deeds of savage Russian army and the Afghan comnunists against human dignity, the ANS were founded 19 October, 1986. Now the ANS has become a reliable source for the media in the Arab countries and Pakistan and Saudi Arabia Radio, $V O G, B B C$ and VOA use the ANS as a source and reply on it."

\section{Afghanistan World Press March, 1968}

EDITORIAL: "Third year of the Magazine". "With the advent of new year, the anniversary of the founding of the magazine Afghanistan in the World Press is also being marked ... We are grateful to Almighty God that despite difficulties and many kinds of distress has enabled us to stand side by side with our roaring military jehad through our writings and to be of a service to our aggrieved nation and country. Although what we have done is rot ideal and we do not overlook our shortcomings, our efforts have been to obtain the coverage of vorld media about the jehad of the oppressed nation of Afghanistan and to trarislate them in our own languages. As far as it has been possible, we have fulfilled our mission properly by offering more than 100 comments, analyses, projections and. reports to our mjahed and refugee compatriots. ARTICLES: "Russian propaganda about Afghanistan" (A report by the US Department of State). The Russian propaganda is aimed at: (1) Russia came to Afghanistan because it was invited (2) because foreign intervention in Afghanistan would have made things difficult, (3) the US does not want peace in Afghanistan, (4) the mujaheddin are"bandits", (5) according to Najib the Kabul goverrment is not communist.

* "It is an article adopted from The Pakistan Times of $8 \mathrm{March}, 1988$ abcut Soviet intervention in Afghanistan and its prospects. The title of the article is "Wanting to disengage but still trying to be smart."

\section{Afghanistan World Press April, 1988} ARTICIES: "Soviet forces in Afghanistan" (By J. Collins). The writer says that the Russians invaded Afghanistan urder the pretext that the Amin regime was on the verge of fall and the Afghan army did not have any political base and could not stand against the rebels, the economy of the courtry was shattered and from anong the 26 (stet) provinces of the country, the government controlied only 18. If the Soviets had not resorted to an action at that time, Amin would have been eliminated undoubtedly and a heavy blow would have been inflicted to Soviet prestige. 
According to Soviet strategists, by launching a military intervention in Afghanistan, there would not be any reaction or the people would support the Karmal regime. However, these strategists seemed to have no knowledge about the history of this country. The article says "in the beginning of 1984, the military situation was apparently as follows; 105,000 120,000 Soviet soldiers and 30,000 Afghan troops against 85,000 - 100,000 Afghan resistance fighters, 40th Soviet Corps including seven motorized divisions, five airborne Brigades each with 2,000 additional which included expert units, 240 armored helicopters, 400 helicopters, a number of units of $M I G-21$ and $M I G-23$ and $a$ unit of SU-25. It is worthwhile to mention that the Russians have chosen Afghanistan to test these weapons for the first time. There are 90,000 infantry, 30,000 logistics, and 10,000 air force Soviet men. Furthermore about 30,000 men are kept on the other side of the border to be deployed inside Afghanistan at any time necessary.

"The Russians confessions" (By Andrew Ilve) Alaxander Prokhanov, the Russian writer who was busy writing articles to legitimize the Soviet military intervention in Afghanistan has now admitted that the Soviet Union committed mistakes in supporting a government which was unable in obtaining the support of the Afghans. A communist regine was not able to succeed in Afghanistan. Soviet experts should have anticipated this. Furthermore stationing of Russian forces in Afghanistan would serve no purpose and they should be recalled.

* "The Future of the People of Afghanistan (By J. Collins).

"The anticipated withdrawal of the Soviet troops from Afghanistan is taking place due to a new leadership in Moscow, or Soviet regrets about the past mistakes or due to a wave of liberalism and reform. But the fact is that the
Russians were not able to defeat the resistance of the Afghan mujaheddin. After the withdrawal of Soviet forces from Afghanistan, that country is not going to necessarily become a land of tranquillity and democracy. The transition from dictatorship to a Jeffersonian democracy will not take place over night. Although the Soviet Union and the US are both anxious to drag Afghanistan towards themselves, it is possible that the Geneva accord might only cause another storm in. Afghanistan.

\section{khurasan Apri1-Nay, 1988.}

ARTICLES: "The Geneva agreement and its consequences" (Eiy Dr. Rahin). The article has discussed the positive and negative aspects of the agreement and writes "George Shultz, the US Secretary of State has called the withdrawal of Soviet forces from Afghanistan a big success emanating from the war ability of the mujaheddin." The writer has hoped that the jehad commanders and political leaders through sacrifice and realism would not allow the war devastated Afghanistan enter an ela of civil war. This can only happen if a national and Islamic government is established in accordance with the will of the people of Afghanistan.

* "The Geneva agreement and the Afghen Nation". (Dr. Rauf Roashan) "The accord has provided an opporturity for the UN to at least take some steps as an obedient servant for fulfilling. the wishes of super powers and undertake futile efforts for reducing the political meaninglessness of the treaty.

"The treaty, despite all its legal, political and even social drawbacks has achieved one important objective - - the withdrawal of Soviet forces from Afghanistan.

"This is the first time that the Russian super" power has come down to its knees as a result of the rightfui resistance of the Afghan nation to an extent that it is resorting to an international agreement to find a way out." 
* What will be the future of Afghanistan" (By Mir Mohannad Siddiq Farhang). The witer, after a long introduction, says, "Solving the question of the administration of the country after the withdrawal of the occupation forces and collapse of the hireling regime has become for us the most difficult question. During the last
10 years, when at the military level due to unprecedented sacrifices of the nation, the jehad was continuing successfully, if parralel to that, work were done at the political level as well and the leadership of free Afghanistan established, we would not have faced difficulties today."

\section{IDENTIFICATION OF NEWSPAPERS, PERIODICALSQUOTED}

\begin{tabular}{|c|c|c|c|c|}
\hline $\begin{array}{l}\text { Name of } \\
\text { Publication }\end{array}$ & Publisher & Editor & $\begin{array}{l}\text { Type of } \\
\text { Publication }\end{array}$ & Address \\
\hline $\begin{array}{l}\text { Afghanistan in } \\
\text { the World Press }\end{array}$ & $\begin{array}{l}\text { Afghan Jehad } \\
\text { Works Center }\end{array}$ & $\begin{array}{l}\text { Prof. Sayyed Moham- } \\
\text { mad Yusuf Elmi }\end{array}$ & Periodical & $\begin{array}{l}\text { P.O. Box } 417 \text { GPO, Peshawar, } \\
\text { Peshawar }\end{array}$ \\
\hline $\begin{array}{l}\text { Arman-e-Muja- } \\
\text { hed }\end{array}$ & $\begin{array}{l}\text { Islamic Alliance } \\
\text { of Afghanistan } \\
\text { Mujaheddin under } \\
\text { the leadership of } \\
\text { Rafiullah Moazzen }\end{array}$ & not mentioned & Journal & $\begin{array}{l}\text { P.0. Box } 903 \text { University, } \\
\text { Peshawar, Pakistan }\end{array}$ \\
\hline Azadi & $\begin{array}{l}\text { not mentioned, } \\
\text { Independent }\end{array}$ & Zaman Stanizai & Journal & $\begin{array}{l}\text { P.0. Box } 35385 \text { Los Angeles, } \\
\text { Ca. } 90035 \text { USA }\end{array}$ \\
\hline Al-Bayan & $\begin{array}{l}\text { Hezb-e-Islami } \\
\text { (Khales) }\end{array}$ & $\begin{array}{l}\text { Mohmmad Ma'a- } \\
\text { soom Poya }\end{array}$ & Journal & P.O. Box, Quetta, Pakistan \\
\hline Ekhlas & $\begin{array}{l}\text { not mentioned, } \\
\text { Independent }\end{array}$ & $\begin{array}{l}\text { Mawlawi Zahedi } \\
\text { Ahmadzai }\end{array}$ & Journal & $\begin{array}{l}\text { Bartakal, Shaheen Town, St.No. } \\
10 \text { (1197) Feshawar, Pakistan }\end{array}$ \\
\hline $\begin{array}{l}\text { Enqelab-e-Is- } \\
\text { lami Afghan- } \\
\text { Istan }\end{array}$ & $\begin{array}{l}\text { Jamiat-e-Islami } \\
\text { Afghanistan }\end{array}$ & Abdul Hamid Salek & Journal & P.O. Box 159 Tehran, Iran \\
\hline Esteqlal & $\begin{array}{l}\text { Afghan National Soc: } \\
\text { list Party }\end{array}$ & cia- not mentioned & Journal & $\begin{array}{l}\text { Afghan Mellat Office, } \\
\text { Warsak Road, Kababian, Peshawar, } \\
\text { Pakistan }\end{array}$ \\
\hline De Haq Pasoon & $\begin{array}{l}\text { Ittehad-e-Islami } \\
\text { Afghanistan }\end{array}$ & not mentioned & Periodical & P.0.Box 467 , Peshawar, Pakistan \\
\hline $\begin{array}{l}\text { Ittehad- } \theta \\
\text { Islani }\end{array}$ & $\begin{array}{l}\text { Ittehad-e-Islami } \\
\text { Afghanistan }\end{array}$ & $\begin{array}{l}\text { Mohammad Ibrahim } \\
\text { Praishan }\end{array}$ & Journal & $\begin{array}{l}\text { P.0. Bax } 467 \text {, Peshawar, } \\
\text { Pakistan }\end{array}$ \\
\hline Jabha-O-Jehad & NLF & not mentioned & Journal & $\begin{array}{l}\text { P.0. Box } 377 \text { Sader, Peshawar, } \\
\text { Pakistan }\end{array}$ \\
\hline Jehad Palwashay & $\begin{array}{l}\text { Jamiat-e-Islami } \\
\text { Afghanistan }\end{array}$ & Esmat Qaney & Periodical & $\begin{array}{l}\text { P.0. Box } 345 \text { Peshawar, } \\
\text { Pakistan. }\end{array}$ \\
\hline
\end{tabular}




\begin{tabular}{|c|c|c|c|c|}
\hline $\begin{array}{l}\text { Name of } \\
\text { Publication }\end{array}$ & Publisher & Editor & $\begin{array}{l}\text { Type of } \\
\text { Publicatior }\end{array}$ & Address \\
\hline Khpulwakd & WAFA & Niazi Umaidwar. & Periodical & $\begin{array}{l}\text { P.0. Bax } 867 \text { University } \\
\text { Peshawar, Pakistan }\end{array}$ \\
\hline Whurasan & not mentioned & $\begin{array}{l}\text { Mohmmad Qawi } \\
\text { Koshan }\end{array}$ & Periodical & $\begin{array}{l}\text { Afghan Center, SIx Union Square, } \\
\text { Suiteg Union City, CA. } 94587 \\
\text { U.S.A. }\end{array}$ \\
\hline Mahaz & NLF & not mentioned & Journal & $\begin{array}{l}\text { P.O. Box } 542 \text { Warsak Road, } \\
\text { Kababian, Peshawar, Pakdstan }\end{array}$ \\
\hline Meesaq-a-Khoon & $\begin{array}{l}\text { Jamiat-e-Islami } \\
\text { Afghanistan }\end{array}$ & F.Fazel & Periodical & $\begin{array}{l}\text { P.0. Box } 1106 \text { Peshawar, } \\
\text { Pakistan }\end{array}$ \\
\hline Mujahed & $\begin{array}{l}\text { Jamiat-e-Islami } \\
\text { Afghanistan }\end{array}$ & A. Nangyal & Journal & $\begin{array}{l}\text { P.0. Box } 1107 \text { Peshawar, } \\
\text { Pakistan }\end{array}$ \\
\hline Mujahed Ulus & $\begin{array}{l}\text { Information Center } \\
\text { of Afghan Mujahed }\end{array}$ & $\begin{array}{l}\text { Mohammad Has- } \\
\text { san Uluamal }\end{array}$ & Journal & $\begin{array}{l}\text { Leili } 44 \text { Schous Plass } 3 \mathrm{~A} \\
0552 \text { OSIO Norway }\end{array}$ \\
\hline $\begin{array}{l}\text { Neda-a-Mujahed- } \\
\text { din }\end{array}$ & $\begin{array}{l}\text { not mentioned, } \\
\text { Independent }\end{array}$ & $\begin{array}{l}\text { Khalil-ul-lah } \\
\text { Mateen }\end{array}$ & Journal & P.O.Box 296 Quetta,Pakdstan \\
\hline $\begin{array}{l}\text { Neda-e-Jundul- } \\
\text { lah }\end{array}$ & $\begin{array}{l}\text { Jundullah Cultural } \\
\text { Center }\end{array}$ & not mentioned & Journal & $\begin{array}{l}\text { P.0. Box } 560 \text { Sadder Peshawar, } \\
\text { Pakistan }\end{array}$ \\
\hline Neda-e-Haq & $\begin{array}{l}\text { Harkat-emgelab- } \\
\text { e-Islami Afghanis- } \\
\text { tan. }\end{array}$ & $\begin{array}{l}\text { Shujauddin } \\
\text { Khaddam }\end{array}$ & Journal. & $\begin{array}{l}\text { P.0. Bax } 164 \text { Sadder Peshawar, } \\
\text { Pakistan }\end{array}$ \\
\hline Neda-o-Sangar & $\begin{array}{l}\text { Agency for South- } \\
\text { west Region }\end{array}$ & $\begin{array}{l}\text { Naimatullah } \\
\text { Taeebi }\end{array}$ & & P.0. Box, Peshawar, Pakistan \\
\hline Al-Noor & $\begin{array}{l}\text { Hezb-e-Islami } \\
\text { Afghanistan (Whales }\end{array}$ & not mentioned & Journal & $\begin{array}{l}\text { P.0. Box } 454-466 \text {, Peshawar, } \\
\text { Pakdistan. }\end{array}$ \\
\hline $\begin{array}{l}\text { Payam-a-Zanmen } \\
\text { Musalman }\end{array}$ & $\begin{array}{l}\text { Islamic Society of } \\
\text { Afghan women }\end{array}$ & not mentioned & Periodical & $\begin{array}{l}\text { P.0. Box } 126, \text { Peshawar, } \\
\text { Pakistan }\end{array}$ \\
\hline Payam-onehad & $\begin{array}{l}\text { Harakat-e-Islami } \\
\text { Afghanistan }\end{array}$ & A. Karar - & Journal & $\begin{array}{l}\text { GPO Bax 337, Peshawar, } \\
\text { Pakistan. }\end{array}$ \\
\hline Payam-e-Sangar & $\begin{array}{l}\text { Harakat-e-Islami } \\
\text { Afghanistan }\end{array}$ & not mentioned & Periodical & $\begin{array}{l}\text { Office of the Kabul Provin- } \\
\text { cial Council, Peshawar, } \\
\text { Pakistan }\end{array}$ \\
\hline Qalam & $\begin{array}{l}\text { The Jehad Research } \\
\text { Center of Afghan- } \\
\text { istan }\end{array}$ & $\begin{array}{l}\text { Dr. Faroog } \\
\text { Azam, Chief of } \\
\text { the Editorial } \\
\text { Board }\end{array}$ & Periodical & $\begin{array}{l}\text { P.0. Box } 1155 \text { Sadder, } \\
\text { Peshawar, Pakistan }\end{array}$ \\
\hline
\end{tabular}




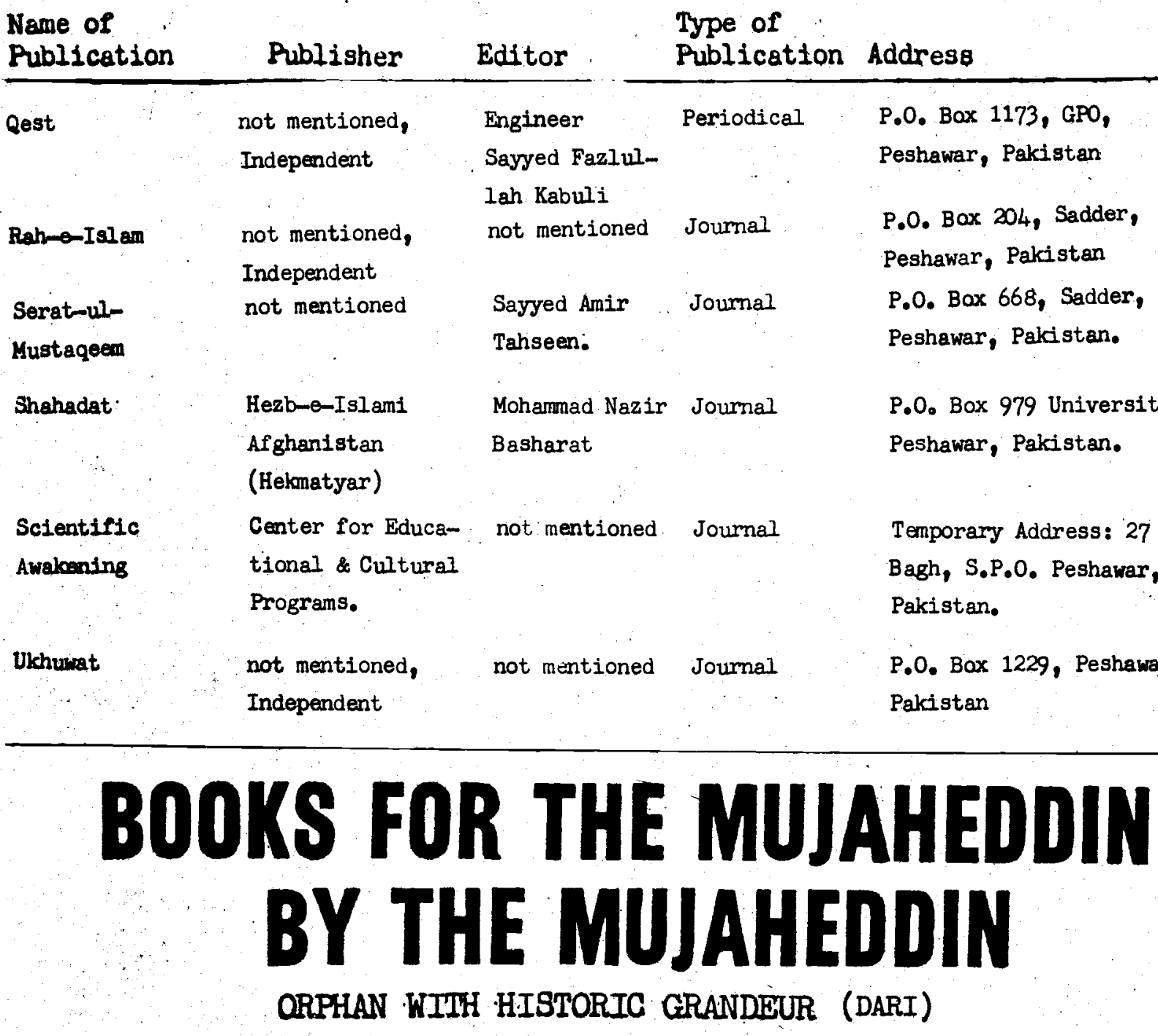

By Abdul Hamed Salek; published by Jamiat-e-Islami Afghanistan, Teheran; 1987. 119 pages.

Studies in the life of Prophet Mohammad, peace be upon him, from childhood until the age of 35 and in this edition, the author has compiled stories about his honesty, wisdom and behaviour in the society.

\section{HOW AN ISLAMIC GOVERNMENT IS SET UP (PASHTU)}

By Sayyed Abul Aala Mawdoudi; translated by Mawlawi Zahedi Ahmadzai; published by the Ekhles Journal; 1987; 95 pages.

Contents: natural growth of governmental system; legal government; God's Caliphate; Islamic revolution; present Islamic society; fundamentals of the Islamic movement; monotheism is not a religious Ideology; virtues of the leader of Islamic movement and the first Islamic govermment.

\section{THE WISDOM OF MUSITM (DARI)}

By Abu Khaled Mohammad Gul; published by Taj Mahal Company; 1988, 282 pages.

The book contains several topics about the proof of the existence of one God by observing the 
nature and the very knowledge which man acquires. It has also discussed Islamic ethics, laws and regulations issued by the prophets. It has also a chapter on the nature of prayer.

\section{FANATACISM AND ITS MOTIVES (PASHTU)}

By Abdul Ahad Tarshi; translated by Fazal-o-Hadi; published by Jehad Cultur; 1988; 109 pages.

It has studied linguistic, national,tribal, racial, religious and party discrimination from an Islamic point of view and unveils the ugly face of discrimination.

\section{A PICTURE OF RUSSIA IN THE MIRROR OF HISTORY (DARI)}

By Dr. S.N. Haq Shenas; Published by Jamiatme-Islami Afghanistan, 1987; 213 pages.

Contents: Birds eye view on the history of Russia; hegemonism of the Tzars; and the beginning of the Russian imperialism; 19th Century and the Monster of Communism; New imperialism and the oppression of the sickle and hammer; historic crimes by Lenin and Stalin in Iran; Soviet imperialism and aggression in northerm, eastern and central Europe.

\section{SHORT BIOGRAPHY OF ENGINEER AHMAD SHAH (PASHTU)}

By the office of Ekhlas; 1988; 27 pages.

Contents: short biography of the President of the interim government of the mujaheddin, Engineer Ahmad Shah; a rebutal of the heinous propaganda of the enemies against him; message of The Ekhlas magazine to the mujahed nation of Afghanistan.

\section{MM MEDIUM MORTAR: TECHNIQUE AND MANNER OF ITS USE (DARI)}

Compiled by Senior Captain Abdul Fateh Zahed and Captain Qurban Shah; Riblished by NIF, 1988; 22 pages:

Studies the components of a mortar, targetting it and methods of shelling.

\section{THE VOICE OF THE NATION (PASHTU)}

By Motiullah Ahmadzai; published by Taj Mahal Co. 1987; 202 pages.

A collection of religious, jehad, nationalist and devotional poens of the Ahmadzai.

\section{MATTER AND SPIRIT (DARI)}

Compiled by Abul Wafa Afghani; published by WAFA; 1987; 163 pages.

Contents: Matter and materialists; understanding of matter; instict; idealism and logical dofinition of man; definition of matter; Lenin's political motive in defining the matter; theory of reaction; Kant's link with materialism; What is idea?, from idea to ideal; ideal and material as a method.

\section{MESSAGE}

Poet: Mohammad Moosa Shafiq; preface by Shorat Nangyal: published by Jehad Culture; 1988; 84 pages.

A collection of selected verses from the book "Paigham" of late Mohammad Moosa Shafig.' 


\section{IN THE MFMORY OF ESTEEMED MARTYRE SAYYED QASEM (PASHTU).}

A collection of Sayyed Qasem's writings by his brothers; published by the Jamiat-e-Islami Afghanistan, Teheran; 1987 ; 55 pages.

It is a compilation of the biography, elegies and memories about mujahed Sayyed Qasem.

\section{ISLAM AND THE APOSTATES AND THE LTERS (PASHTU)}

Translated by Mawlawi Barkatullah Musta!an; Published by Hezb-e-Islami Afghanistan in 1987; 103 pages;

Contents: Religion as an instinct; sending of prophets; the mission of Islam; Quran, a miracle and guidance; Islam, a belief and a system; Islamic system; relationship between the rich and the poor; slavery in the eyes of Islam; relations between the ruler and subjects in Islam; policy of Islam in war and defeat; relations between man and woman; Islam and knowledge; sources of Islam; difference between religious laws and religious jurisprudence.

\section{IESSONS AND MESSAGES FROM THE PROPHET MOHAMMAD,} PEACE BE UPON HIM, (DARI)

Complled by Dr. Mustafa Sabaee; translated by F.Fazel; publisher not mentioned: 1988 ; 218 pages.

Contents: A life sketch of the Holy Prophet before his Prophethood; the conduct of the Holy Prophet from Prophethood until the migration of the Muslims to Ethiopia; conduct of the Holy Prophet after the migration of his companions to Ethiopia until their migration to Madina; the Prophet's migration from Makkah and his arrival In Madina; jehads conducted by the Holy Prophet against the Infidels; death of the Holy Prophet of Islam.

\section{MESSAGE FROM THE TRENCH (DARI)}

By Nisar Ahmad Noori; published by Taj Mahal Co. 1987; 95 pages.

A collection of folkloric poens on jehad.

\section{RUSSIAN EXXPANSIONIST POIICY IN ASIA (PASHTU)}

Compiled by Joseph Propovsky; translated from Urdu by Moosa Khan Jalalzai; published by WAFA; 1987: 143 pages.

Contents: Britian and Russia; Russian advances in Asia; Soviet ambitions for capturing India; Will Britian hinder Russian advance in Asia?

\section{DENIAL OF HADITH OF THE PROPHET , PEACE BE UPON HIM. IS INFIDELITY (PASHTU)}

Author: Abdul Aziz Ibn-e-Baz; translation by Mawlawi Zahedi Ahmadzai; published by The Ekhlas journal; 1988 ; 74 pages.

Contents: First source of reference in Islam is the Book of God; the second source is sunnah of the Prophet; Prophet's own remarks about the necessity to abide to his cormands; proving the authenticity of the Hadith through the statements of the Prophet's companions, followers and scholars. 


\section{MESSAGE TO JEHAD COMMANDERS AND COMPATRIOTS (DARI)}

By Prof. Bựhanuddin Rabbani; published by Jamiat-e-Islami Afghanistan; 1988; 9 pages.

Felicitates the Muslim Afghan nation on the Soviet defeat and disgrace and $j$ ts withdrawal from Afghanistan. It also warns the Afghans to remain alert.

\section{THE WEEPING HEART (DARI)}

Poet: Ishqari; published by Taj Mahal Co; 1st edition June 1987; 2nd edition March 1988; 141 pages;

A collection of mystic poem by late Ishqari, an Afghan poet.

\section{WARNING: THE GENEVA ACCORD ON AFGHANISTAN (DARI)}

By Dr. Afghan (pseudonym), publisher not mentioned; 1st edition 1987; The year of 2nd edition not mentioned; 25 pages.

Contents: opportunities missed by the Afghans; opportunities missed by Pakistan; opportunities missed by the US; the Geneva talks on Afghanistan; text of the instruments so far adopted and their meaning to the Afghan people. 

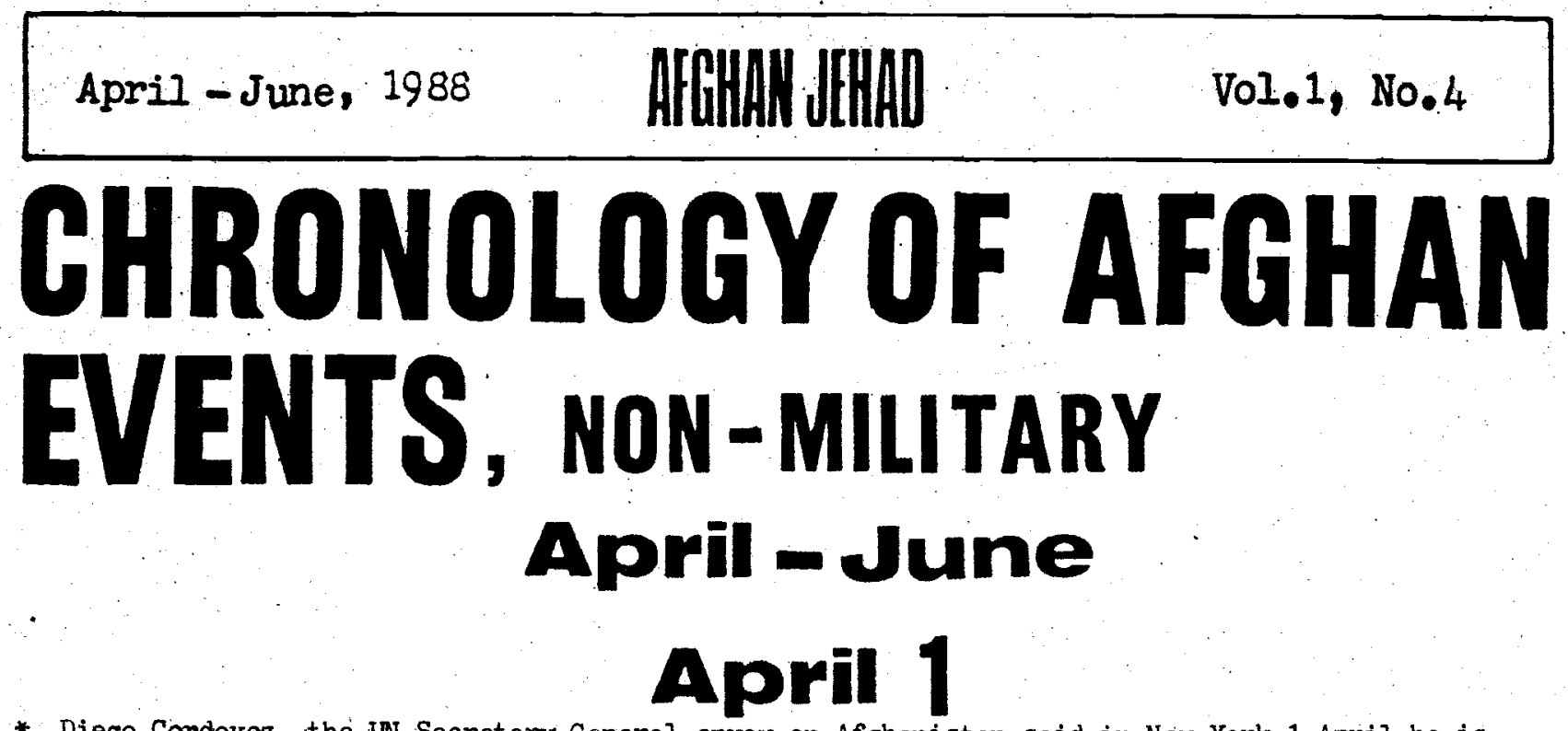

* Diego Cordovez, the UN Secretary General envoy on Afghanistan said in New York 1 April he is of the opinion that the time is approaching whether the talks on solving Afghanistan issue would either succeed or fail completely (RPDS).

* Richard Von Weizsacker the President of tre FRG, in a meeting with the Pakistani Ambassador in that country has praised the principled stand taken by Pakistan on the Afghanistan issue and has hoped that Soviet intervention in Afghanistan will soon come to an end (RPUS).

* Nicolai Kozyrev, a Soviet representative for talks on the Afghanistan issue has said in Geneva that US continued assistance to Afghan rebels during the period when the Soviet troops are being withdrawn from Afghanistan does not fit with its role as a guarantor (BBCFS).

* George Shultz, the US Secretary of State, has confjrmed reports suggesting that Moscow and Washingtion have been talking about a solution to the Afghanistan problem. Their talks concentrate on making arrangements for continued US-Soviet assistance to the Afghan mujaheddin and the Kabul regime respectively during the period when Soviet troops are being withdrawn from Afghanistan (BBCFS).

* The Pakistani newspaper Nawa-i-Waqt in its 2 April issue has published an interview with Gulbuddin (Hekmatyar) in which he has said that he will soon announce his interim government in an area controlled by the mujaheddin and the mujaheddin will abolish visa formalities for Pakistanis visiting Afghanistan ( $R A$ ).

* Gulbuddin Hekmatyar, leader of the IUAM has tumed dows the latest of fer by Kabul leader Najibullah for the participation of Afghan mujaheddin in a coalition government (VOCDS).

* A West German newspaper Deuche Zeiture has said in its 31 March editorial that no body wants to be blamed for the failure of the Geneva talks on Afghanistan and, therefore, trese talks are being continued (VOGDS).

* Aperican Secretary of State George Shultz has told newsmen now that the Soviet Union has given a satisfactory timetable for the withdrawal of its troops from Afghanistan, the next important issue is to find ways to keep the balance of power within the country in the aftermath of withdrawal (VOAPS).

* Quoting The Washington Fost and The New York Times, the VOA has reported that the US President Ronald Reagan and Pakistan President Ziaul Haq had telephonic conversation for removing the current 
deadlock in the Geneva proximity talks on the Afghanistan issue. The VOA added that President Mohammad Ziaul Haq and Prime Minister Junejo also exchanged views with George Shultz on the latest situation on the matter (JG).

* The New York Times reported 31 March that the Soviet Union has indicated it will consider allowing American military aid to continue to reach the Afghan mujaheddin after the cut-off date set in a peace accord now being negotiated (PT).

* The VOA reported that the ruling communist party in Afghamistan is facing a sevire rift while it is preparing to hold the so-called general elections in the country (PT). * A big protest demonstration was staged 31 March by the Islamic Association of Afghan Students (IAAS) in Karachi before the Indian Consulate General. The demonstrators chanted slogans "Down with Russia", "Down with Rajiv" and "Rajiv if you want death enter Afghanistan" (PT).

* Soviet Foreign Minister Eduard Shevardnadze said 31 March in an interview with the Bulgarian newspaper Rabotrichesko Delo (Workers cause) that Moscow would conclude a "separate agreement with Kabul on a pull-out of its troops if the worse came to the worse and the Geneva talks on Afghanistan falled" (DN).

* American representative in the talks on Afghanistan Robert Peck has again expressed the confidence that, despite the recent statement of the Soviet Union that it would not reduce military aid to Kabul government, there is a possibility of signing the agreement (MIM).

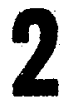

* Talking 1 April to newsmer in Bhakkar the JI Chief Qazi Hussain Ahmad said the Afghan mujaheddin will continue fighting until an Islamic governuent is set up in Afghanistan (NWT).

* In its editorial captioned "Geneva talks - - Soviet new stand", The Jang 2 April described the Soviet new stand Baying that Geneva accord can be signed even without a US guarantee as unjustified (JG).

* The IS Secretary of State George Shultz said 1 April the US could help guarantee a peace settlement in Afghaniatan if Washington and Moscow continued balanced aid to their Afghan allies (DN).

* Pir Sayyed Ahmad Gailani, the NIF chief told The Muslim 1 April in Islamabad he sees as encouraging recent indications that arms assistance to the resistance will continue if Moscow continues to provide aid to Kabul. He viewed this as a step towards an Afghan solution (MIM).

* The Soviet Union has rejected proposal that after the signing of Geneva accords, American military assistance may still continue to the Afghanistan resistance. Micolai Kozyrev, Soviet envoy in Geneve said 1 April that the idea of symmetrical assistance by the Soviet Union and the uS is not acceptable (VOADS).

* The American Broadcasting Company ( $A B C$ ), said 1 April that US military satillites have relayed reports that Soviet radar equipment are being withdrawn from bases in Afghanistan and Kabul troops are being deployed to replace Soviet soldiers, indicating the Soviet preparations for withdrawing its army from Afghanistan (VOADS).

\section{3}

* Soviet Foreign Minister Shevardnadze, after meeting with Indian Minister for External Affairs. 
Natwar Sing in Moscow, expressed the hope that, the proximity talks on Afghanistan held in Geneva bear results (VOGDS).

* American Secretary of State, George Shultz, has said the US will not sign the Geneva agreement until there is symetrical reduction of ams provided to different Afghan groups (RPDS).

* According to TASS, the Soviet Foreign Minister Eduard Shevardnadze, has gone to Kabul on an official trip. The BBC Moscow correspondent says that Westem observers think the trip is about reaching a separate agreement with the Afghan government in case the Geneva taiks on Sovlet troopo pull out from Afghanistan were not signed (BBCFS).

* The Soviet Foreign Minister Eduard Shevardnadze has told a Bulgarian journalist that Soviet. decision to withdraw forces from Afghanistan is irreversible (RMDS).

* A protocol of direct cooperation between the Ghazni province of Afghanistan and the Moldavian Republic of the Soviet Union for 1988-89 was signed 3 April in Kabul (RA).

* The Sunday Times (London) has quoted a French joumalist that the mujaheddin two weeks ago with the perticipation of 30 Muslim youth from Saudi Arabia, Egypt and Pakistan occupied the Dobandi base in Paktia. The Sunday Times correspondent says that the of fensive is indicative of the fact that the morale of the Kabul troops has been deteriorating (BBCFS).

* President of the IUAM said in a statement 2 April if the Geneva peace accord on Afghanistan were signed in its present form, the Afghan mujaheddin will continue their jehad against the Soviet puppet government and the mujaheddin are not faced with any dearth of arms (VOAPS).

* Afghan refugees met 1 April in the Afghan refugee camp of Mianwall, Punjab, to constdar current events in relation with their country. Thousands of mujaheddin and refugees who participated in the gathering said that they wanted a mujaheddin government in Afghanistan and until an Islamic government is established, they will not return home (VOAPS).

* Engineer Ahmad Shah, President of the interim government set up by the mujaheddin told a group of tribesmen in a meeting in the Hejrat village in Peshawar 2 April, in Afghanistan we do not wish to have a government that will render martyrs another 3 million Afghans (VOAPS)..

* The Islamic News Agericy says according to reliable sources, the Moscow is Intent to keep northern Afghen provinces under its sway despite an agreement on the withdrawal of its troops from Afghanistan and the city of Mazar-e-Sharif, wherefor some time now, important buildings have been. constructed, will serve as the capital of the northern provinces of Afghanistan (VOAPS). * Senator Cordon Humphrey Chairman of the U.S. Congressional Cormittee on Afghanistan, now visiting Pakistan, has said in an interview that very soon the Afghans will have the opportunity to decide about their own fate. He said the Afghans will have the chance to form their own government. However he edded that if the Afghans fought each other, they will miss the opportunity to decide thetr own fate (VOAPS).

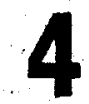

* The Soviet Foreign Minister Eduard Shevardnadze is engaged in negotiations with the Afghan authorities to remove the deadlock in the Geneva Afghan peace talks. He described the present deadlock an outcome of Pakdstani and American stand (BBCFS). 
* The American Under-Secretary of State Robert Peck told newsmen 4 April, after a meeting with the UN mediator on the Afghan issue Diego Cordovez, we have evidence that the Soviets are supplying arms to the Kabul government at present. He pointed out that they may reach an agreement soon on the quastion of symmetrical supply of arms to the Afghan mujaheddin and Kabul government (RPDS). * A member of the British Parliament Teddy Taylor held talks with the Pakistani Prime Minister Mohammad Khan Junejo on the possibility of an early solution of the Afghan issue (RPDS).

* A four-member American delegation as well as a 31-member Bangladeshi delegation visited 4 April the Afghan refugees camps near Peshawar (RPDS).

* Correspondents say the Afghan issue was reviewed 4 April in a meeting between the American Secretary of Defense and his Indian counterpart in New Delhi. During the meeting, India was reported to have been asked to play a more active role vis a vis the Afghan issue (BBCFS).

* Diplomats in Islamabad say a convoy of 4000 trucks, loaded with goods from the Soviet Union, has arrived in Afghanistan. The Russians have been unloading the vehicles. The diplomats have re ported an unprecedented increase in the traffic at Kabul airport (VOCDS).

* According to reports from Islamabad, a former mujaheddin commanders Esmatullah Muslim, who had defect to the Kabul authorities three years ago, surrendered 2 April to the Pakistani officials in a post near Chaman, but was later captured and taken inside Afghanistan after Afghan armed forces attacked the post (VOGDS).

* A Presidential decree, endorsing the government employee's law, adopted by the Revolutionary Council in a recent session has been promulgated (RA).

* The Washington Post has reported the mujaheddin have been receivirig large quantities of military aid lately. The paper, quoting diplomats in Islamabad, said the aid includes anti-tanks, rockets and artillary (VOAPS).

* In a message to the Chairman of the UN Commission for Human Rights, President Najibullah of Afghanistan has invited a delegation of the commission to visit Afghanistan to familiarize itself with the process of elections for the National Assembly and that Afghantstan has been moving forward in observing international norms and obligations (RA).

* Soviet First Leputy Chairman of the Council of Ministers arrived in Kabul 4 April and held talks wth Afghan authorities in the eighth session of Soviet-Afghan Permanent Commission for Economic Cooperation. During the meeting, matters relating to:

- - mutual economic and technical obligations in the fremework of direct cooperation,

- - result achieved towards the realization of the 1987 protocol of (aid?) and exchange of goads,

- - an evaluation of the Afghan-Soviet trade prospects in 1988 were reviewed (RA).

* Eight Afghen militiamen were killed while more than a dozen sustained injuries following a severe clash between the Pakistan border securtty force and the Afghan militia 2 April (MIX).

* Speaking at a press conference 3 April, the US Secretary of State George Shultz said the US will not sign the Geneva accord until both the US and the USSR agree on the symetry of aid to the rival groups in Afghanistan (JG).

- Spoeking 3 April at Abasin Art Council in Peshwwar, President of the mujaheddin interim govern- 
ment, Bngineer Ahmad Shah, said the Geneva talks are not the solution of Afghanistan issue and it ahould be solved according to the wishes of the Afghan people (NWT).

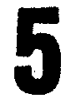

* US Senator Gordon Humphrey called 5 April on President Ziaul Haq, in Rawalpindi to discuss wth him the Afghan issue (PRDS).

- The Soviet Communist Party newspaper, Pravda reported 5 April there is an identity of views between Soviet Foreign Ministel. Fduard Shevardnadze and the Kabul leader Dr. Najibullah that regardless of an agreement in Geneva, Soviet troops will be withdrawn from Afghanistan (BBCFS).

- A BBC comentator says election called by the Kabul regime for the National Assembly have mostly been viewed as a show and not more than $10 \%$ f the voters are expected to go to the polls. (BeCFS).

- Nestern diplomats in Pakistan say Soviet troops Af'ghanistan are pulling back from war fronts and gathering at their centers. At the same time, there are increased evidences that the Soviet Unton has increased its military supply to the Kabul regine by road and air (VOADS).

- The New York Times, quoting an American official, says Soviet arms supply to Afghanistan in lave quantities is a sign that Moscow intends to withdraw from Afghanistan with a simultaneous propging-up of the Kajul regime (VOADS).

- Mechan intellectuals, in Quetta say that a reason for an attempted defection by the Afghan Hitu comander Esmat Muslim was that, perceiving the definite fall of the Kabul government aftar the Soviet withdrawal, he wanted to ensure his own survival (VOADS).

- than 10,000 Soviet experts are on duty in Afghanistan at present with most of them working for Afgmo-Soviet joint institutions (FMDS).

* President Viajibullah and the first Deputy Chairman of the Soviet Council of Ministers exchanged vien 5 April on matters related to oconomic growth of Afghanistan (RA).

- The National Herald (India) has said an objective of Indian policy is to see a settlement of the aituation around Afghanistan. India hopes Afghanistan will be a peace-loving country having good relations with its neighbors (RA).

* Spoalding to nowamen 4 April, the Pakistan Minister of State for Foreign Affairs said in Geneva that with the Sovlet troops withdrawal from Afghanistan, Soviet advisers will also have to leave Afghanistan (JG).

* Addressing a public gathering in Tando Adam, the JI Chief, Cazi Hussain Ahmed said the US, UsSi andia do not want an Islamic govermment come into being in Afghanistan (JG).

- In - tatement 4 April in Peshawar, the IUAM President Ingineer Gulbuddin Hekmatyar said his objactlye to to 1tberate the country and to establish an Islanic government in Afghanistan (JG). - In an Interview with The Jang the JUI Secretary General Mawlana Fazlurrehman said, instead of alring the Afganiatan issue, the big powers are further complicating it (JG).

- Wile tallding 4 April to reporters in Geneva, Pakistan Minister of State for Foreign Affairs Zatn Hoorand sald Pakistan would sign the Geneva accords when all the other four signatories 
were ready and present to sign them (MIM).

* Soviet Foreign Minister Eduard Shevardnadze, currently holding talks with Kabul leeders, has proposed to Pakistan to sign bilateral agreements with Afghanistan to end the Afghan crisis (DN).

\section{(1)}

* The US Secretary of Defense Frank Carlucci, who concluded his talk in India and left for Pakistan, told newsmen in case of a Soviet troops withdrawal from Afghanistan, the US is determined to see. neither the US nor the Soviet Union supply arms to its allies in Afghanistan (VOGDS).

* In an interview in West Germany leader of the Harakat-e-Islami of Afghanistan Ayatullah Mohammad Asef Mohseni described the Geneva talks illegal and unnatural and said, as the talks are being held in the absence of the Afghan nation, they will have no bearing and credibility and will be fuțile (VOGDS).

* Informed sources in Geneva have said that the United States and the Soviet Union are closely in touch on the question of symmetry about the issue of stopping aid to the warring parties in Afghanistan within the framework of Geneva accords (BBCFS).

* The Soviet leader Mikhail Gorbachev arrived 6 April in Tashkent, the capital of the Soviet republic of Uzbekistan, for a meeting with the Afghan leader ir. Najibullah; A few hours before the news was announced, a Soviet Deputy Foreign Minister confirmed that the Afghan goverriment hed agreed to Soviet troops withdrawal from Afghanistan (BBCFS).

* The Afghan leader Najibullah has said, in view of an accord on the withdrawal of Sovlet troops from Afghanistan, there would be no longer any reason for the mujaheddin to refuse to hold a dialogue with his government (BBCFS).

* The Soviet Foreign Minister Eduard Shevardnadze concluded the last round of his talks with the Kabul leader Najibullah on possible measures to be adopted if the Geneva talks on Afghantstan fall (VOADS).

* In his meeting with the Deputy Chairman of the Soviet Council of Minister in Kabul, the Afghen President Najibullah has pointed out that the NRP enjoyed the support of all the Afghans including those living abroed and "even the ones presently fighting their brothers" (RMDS).

* President Najibullah of Afghanistan has sent a message to the UN Secretary General Perez De Cuellar on the settlement of the situation around Afghanistan. The message has stated, "we request you, the UN Secretary General, to help put positive impact and dynamism on the (success of the) Geneva process not only for the settlement of the Afghan problem but also for strengthening regional and international security, where serious conflicts have been on the increase, exercising your mandate and the mandate of the world organization in accordance with the General Assembly resolution number 42,18 October, 1987" (RA).

* A resolution of the Revolutionary Council about a tax reduction on vehicles owned by the refugees has been promulgated through decree number 66 (RA).

* The US Deputy. Secretary of State, Robert Pock has said in Geneva all parties concermed were working hard for reaching an agreement and the etmogphere in Geneva was cordial and calm (BBCPS).

* Kabul Radio says, on the first day of parilimentary elections, evveral polling stations have 
been attacked in Kandahar, Bamian, Kunar, Kapisa, and Khost (BBCPS).

* Quoting TASS, the BBC has said Kabul regime leader Najibullah, has invited Afghan political parties outside the country to participate in the parliamentary elections. However the mujaheddin have rejected the elections and have described them a fraud (BBCPS).

* According to Radio Kabul, out of 955,000 registered voters, 140,000 voted 6 April. 49,000 people voted in Kabul city and 11,400 in the Kabul province (BBCPS).

* The Independent (Iondon) wrote 6 April if there is no progress in the Geneva talks during the current week, they may fail altogether (BBCPS).

* The Times (London), quoting its Peshawar reporter, says Pakistani authorities have closed down a base training foreigners for the Afghan war. The paper said it appears the US might be behind the closure (BBCPS).

* Pakistan Minister of State for Foreign Affairs Zain Noorani said 5 April in Geneva the representatives of Kabul administration want the Geneva talks to fail, because they think the success of Geneva talks will mean the death of that regime (NWT).

* Senator Gordon Humphrey, a prominent member of the hardline lobby in the US Senate, is believed to have assured 4 April mujaheddin leaders in Peshawar that the Americans are not going to sell them out to earn credit for the withdrawal of Soviet troops from Afghanistan (MLM).

* A Soviet senior official Nicolai Kozyrev hinted 5 April in Geneva that Moscow may modify its opposition to US demands for a simultaneous withdrawal of aid to the super powers' respective allies in Afghanistan (MIM).

* Zain Noorani Minister of State for Foreign Affairs said 5 April in Geneva that all the parties concerned are trying to achieve a durable peace in Afghanistan and added that people should be pationt for a few days more to know the outcome (MIM).

* The Tahrik-e-Nifaz-e-Fiqah-e-Jafferia(TNFJ) Chief, Sayyed Arif Hussain Al-Hussaini has accused the government (of Pakistan) of taking the line of US and USSR in the Afghan conflict (MIM).

* Talking 5 April to newsmen in Islamabad airport, the ANP President said delay insigning the Geneva accound would spell a new danger for Pakistan (MIM).

* Soviet leader Mikhail Gorbachev and the Afghan leader Najibullah have met in Tashkent near the Afghan border (BBCFS).

* A Jolnt Afghan-Soviet communique has stated the Soviet Union would help in the repatriation of Afghan refugees. During their meeting Soviet and Afghan leaders urged other countries to help in the establishment of peace in Afghanistan (RMDS).

* After their talks in Tashkent, Soviet leader Mikhail Gorbachev and the Kabul leader Najibullah said in a communique no obstacles existed any longer for an agreement on peace in Afghanistan

(BBCFS).

* The Kabul regine and Pakistan have indicated their readiness to sign the Geneva agreement leading to the Soviet troops wthdrawal from Afghanistan (BBCFS). 
* President Najibullah retumed home after a brief visit to the Soviet Union for talks with Soviet leader Mikhail Gorbachev (RA).

* The US Secretary of Defense Frank Carlucci concluded 6 April his visit to India. He discussed with Indian authorities issues related to world situation with particular reference to the Afghan issue and supply of sophisticated US arms to the Islamabad regime (KA).

* Frank Carlucci, the US Defense Secretary arrived 6 April in Islamabad with his six-member high powered delegation for extensive talks with Pakistan of ficials on defense-oriented issues and Afghanistan (MIM).

* A big procession of Arghan refugees. which wanted to proceed to Peshawar city after a rally at the Katcha Garhi Refugees camp 6 April was restrained by the police and the Frontier Constablery near the Board of Intermediate and Secondary Education in Jamrud Road. The Police compelled them to move towards the Naser Bagh refugee campa (MLM).

* US Senator Cordon Humphrey, founder of the US Congressional coalition for Afghanistan said 6 April in Geneva the Afghan mujaheddin will not be left alone in their fight against the Soviets and the present ruling faction in Afghanistan (MIM).

* Speaking 6 April to the correspondent of the NWT', the JI former Chief, Mian Tufail Mohamad said in Rawalpindi that if Geneva. accord was signed without the Soviet troops withdrawal and without the establishment of an interim govermment in Afghanistan according to the wishes of the Afghan mujaheddin, the Afghan issue will not be settled nor any agreement could be implemented (NWT)

\section{8}

* A US government spokesmen says President Ronald Reagan has cauticusly welcomed the statement by the Soviet and Kabul leaders on the Soviet troops withcirawal from Afghanistan issued in Teshkent and is waiting for further details (BHCFS).

* President General Ziaul Haq of Pakistan has said obstacles which existed in the Geneva peace accord have been removed and the accord can now be signed in Geneva anytime. But there are reports that the Afghan najaheddin have rejected the accords (BEGFi).

* The UN mediator or Afgharistan Diego Cordovez announced 8 April documents of the Afghan peace accord have been finalized and are ready for signature (RPDS).

* During three days of election for the National Assembly, now in progress in Afghanistan, more than four thousand members of the opposition and armed groups have participated in the elections

* The Soviet First Deputy Foreign Minister Yuli Vorontsov met 8 April in Geneva with the participants of the Pakistan-Afghan talks on a political settlement of the situation around Afghanistan

(RA).

* Addressing party and economic leaders, Soviet leader Mikhail Corbachev said in Uabekistan he had discussed all matters relating to the settlenent of the situation around Afghanistan with President Najibullah in Tashkent.He added Soviet troops withdrawal from Afghanistan should not be regarded as a gift to the American President Reagan on the eve of his visit to the Soviet Union (RMLS).

* The Afghan opposition groups, who have built their nests in Pakdstan, are not wiving to recos? 
nire the Geneva accords on the settlement of the situation around Afghanistan (RMLS).

* The UN mediator on Afghanistan has said that the Afghan peace agreement would be signed on 15 April (BBCFS).

* The US Secretary of Defense Frank Carlucci has pointed out that the US and Soviet Union had agreed that as long as the Soviet. Union continued its ald to the Kabul regime, the US will also continue military aid to the Afghan mujahoddin (BBCFS). "

* The Pormer King of Afghanistan, Mohammad Zahir Shah has said in an interview in Rome that if decisions about the future of Afghanistan is referred to a broadly-based Loya Jirgah, representing all tribes and nationalities, it is hoped major clashes and bloodshed will be prevented, provided there is no foreign interference (BBCFS).

- The Pakistani Minister of State for Foreign Affairs Zain Noorani has said in Geneva he is confident the UN mediator on Afghanistan Diego Cordovez would succeed in persuading the Afghan people to accept an interim govermment comprising the mujaheddin, refugees and elements of the PDPA. He hoped the interim government would be formed through another round of activities by the UN mediator (BBCFs).

- In an tnterview with the American IBC television network, a former US ambassador to Afghanistan Bobert Neuman said the mujaheddin can carry on the war without American assistance. He said the US would continue Its aid to the Afghan mujaheddin as long as the Soviets continue to assist the cabul regime. He added if arms supply to the mujaheddin is even stopped today, the arms already supplied to them will be sufficient for six months and we have stepped up arm supply to the mujahoddin (VOADS).

* In an Interview 7 April in Peshawar, the IUAM President Gulbuddin Hekmatyar said any accord signed at Geneva between Kabul and Islamasad will not be binding on the mujaheddin as they were not Involved in the peace negotiations (MIM).

- Addressing 7. April in the Parliament in Islamabad, President Ziaul Haq said the last snags in concluding the Geneva accord was removed with a reported agreement by the two super powers on the question of symmetry, and the agreement was now likely to be signed in a day or two (MIM).

* A Soviet Foreign Ministry spokesman confirmed 7 April that the issue of symmetry has been roolved between the two super powers (MIM)

* In an interview to The Jang, the President of the proposed interim government in Afghanistan, Engineer Ahmad Shah said a mobile government will be set up in the liberated areas of Afghanistan and It would continue to be shifted from one place to the other and in that way it would be edster to destroy centers of the enemy (JG).

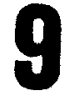

* Merican authorities have welcomed the statement issued in Geneva that the Kabul regime and Pakistan have agreed on the withdrawal of Soviet troops from Afghanistan (BBCFS).

* AS State Department told newsmen 8 April the US will not sign the Geneva peace agreement on Afghaniatan unless it receives a Soviet response to its proposals on balanced military aid to the varring parties in Afghanistan (VOADS). 
* The National Herald says that the NRP in Afghanistan provides the possibility of the creation of a coalition government, consisting of all forces of the Afghan society (FMDS).

* US Secretary of Defense Frank Carlucci has concluded his visit to Pakistan. He said close relations between the U.S. and Pakistan in political and military fields will continue despite a settlement of the Afghan issue (RMLS). .

* The UN Secretary General has said he is grateful for the finalization of the Geneva accords on Afghanistian and called on parties concerned not to take any action contrary to the spirit of these accords (RPDS).

* A delegation of Chinese Muslim scholars visited the Afghan refugees camp at Naser Bagh near Peshawar (PRDS).

* The IUAM has rejected the agreement between Kabul regime and Pakistan on the withdrawel of Soviet troops from Afghanistan. A statement issued in Islamabad says that the agreement will not be binding since it does not provide for the formation of a new government acceptable to all Afghans

(BBCFS).

- High ranking Pakistani authoritios and the UN officials have confirmed that the US and Soviet foreign ministers will be present in the signing ceremony of Geneva accords as the agreenent will be guarantees both countries.

* The Guardian (London), quoting UN mediator on Afghanistan Cordoviez, says agreement has been reached on the withdrawal of Soviet troops nond now efforts will be stepped up for the formation of a new government and a ceasel Le LI Ar'ghanistan (BBCFS).

* A senior yxicR officiul based in Geneva met 8 April the IUA Proaident Culbuddin Hekmatyar in Peshawar and discussed with him matters pertaining to assistance for Afghan refugees and their repatriation in the wake of an Afghanistan settlement (MIM).

* The Hezb-o-Islami leader, Mawlawi Mohammad Yunus Khales has said any accord on Afghanistan at Geneva will be unfair and unjustifiable if it does not take into consideration vital issues concerning Afghanistan (MIM).

* The IUAM President Gulbuddin Hekmatyar nas sajd the Geneva talks have entered sensitive phase and it is possible that the agreement may be signed within a couple of days. But the IUAM is of the view that the agreement will not pave the way for a durable solution of the issue and fighting will not end in Afghanistan (NWT).

* The special envoy of the Prime Minister of Pakistan, the additional Foreign Secretary Bashir Babur held talks with the Iranian Foreign Minister Mr. Ali Akbar Velayati in Teheran and apprised him of the latest developments on the Afghanistan issue (JG).

\section{0}

* A US spokesman says his goverrment has received the Soviet answer to its proposals about Soviet military aid to the Kabul regime and US aid to the Afghan resistance and Washington is now studying the reply (VALS).

* President Ziaul Haq of Pakistan has asked the Afghen mujaheddin to at least support a part of 
the agreement reached between Pakistan and the Kabul regime in Geneva proxinity talks under the UN supervision (VOSDS).

* The IUAM Fresident Hekmatyar called 8 April the Gerieva accords on Afghanistan wrong, ineffective and farce and warned Pakistan that it will lose 1ts credit anong the Afghan people if it signed the accords (VOADS).

* Governments and social circles in many couritries are welcoming the Geneva accords on the solution of the Afghanistan problem (RN.LS).

* Soviet authorities have anrounced their support to Najibullah's remark about the energence of an independent and neutral Afghanistan (RMDSi).

* President Ziaul Haq of Pakistan, while referring to the Afghanistan issue in the OIC sumit conference, has said, as a result of the signing of the Geneva accords on Afghanistan, the Islamic and indeperdent status of that country will be restored (RPDS).

* The Sunday Times (Iondon) has quicted the Afghan mujaheddin as saying that the Geneva accords are meant to be violated. They say that the super powers will violate the provision of the article about the supply of arms to the Afghans immediately after the agreement is signed (BBCPS).

* An Antonow 26 passenger plene flying from Haimana to Mazar-e-Sharif was shct down 10 April by extrenist elements. Twenty two passengers and six crewnen were killed (RA).

* According to reports reaching Peshawar, differences between the Parchami and Khalgi wings of the PIPA have intensified over the issue of their candidates for the general elections and armed clashes have been reported between them in Jalalabad (VOADS).

* The IUAM President Gulbuddin Hekmatyar has said in an interview with The Dawn (Pakistan) in case a mujaheddin governnent is established inside Afghanistan, its first task will be to try to merge Afghanistan and Pakistan to each other and make them one country and, if such a merger was not possible, definite attempts will be made to evolve a confederation between the two (VOAPS). *. The UN Secretary General Perez de Cuellar has said the text of a peace agreenent between Afghan. istan and Pakistan has been completed and now it is ready for being signed. He asked all sides involved in the Afghan issue not to resort to moves which will jeopardize the accords and further increase tension in Afghanistan (VOAPS).

* Kandahar Commander. Najibullah who recently took part in an international conference in Paris, has said in Quetta, Pakistan, that $90 \%$ of agriculture ir: Kandahar has been destroyed and the orchards have been turned intu ruins. However, he said, the mujaheddin morale is still high fighting the eacmy valorously (VOAPS).

* A well-known Afghan diplonat and former Ambassador to the UI and India Dr. Abdul Hakim Tabibi has in an interview in Peshawar opined that the Geneva accords, despite lacking in certain respects, would lead to a cessation of hostilities and open the door toward amicably resolving the Afghan dispute (MIM).

* The JUI Secretary General Maulana Fazlur Rahman has said that Pakistan and the Kabul regimo were acting as agents of super powers in reaching an accord on the lfghan issue. He ariticized government of Pakistan for accepting the Geneva accords on Afghanistan (fur). 
* A mllitary expert of CPSU Central Committee Major General Batenin has said ten years of conflict in Afghanistan denonstrated that it was impossible to $r \in s o l v e$ the Afghan problem by military means (KIM).

* There is no cloubt that the Geneva accords on Afgharistan can pave the way in resorting the status quo ante, 1979. Whether the accords will bring peace and return of refugee in honor and dignity" remains to be seen. (Valeeha IodhI in MIM).

* Fighting between the mujaheddin and Soviet-Kabul forces has intensified in Kandahar and Herat provinces reports VOA (PT).

* Afghanistan Interior Minister Sayyed Mohemad Gulabzoi had a narrow escape 4 April when a bomb planted in his car went off killing his driver and bodyguard on the spot, according to IUAM sources. The reports say another inportant Khalgi figure was also involved in the incident. He, too, was not hurt (PT).

* The mujaheddin fired two missiles at Afghan Ministry of Deferse in Kabul setting ablaze a large part of the structure, the Harakat-o-Islami Farty said 9 April (PT).

* The Soviet Union has stepped up its military supplies to Kabuil regime, VIRA reported (PT).

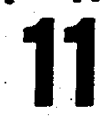

* The IUAM decided in a meeting 10 April to announce its joint stand vis a vis the Geneva accords on Afghanistan during this week (VOADS).

* President Ziaul Haq of Pakistan has told the OIC heads of state in Kuwait that the agreement on Afghanistan will be signed in Geneva soon and the Soviet Union will honor its pledge in cooperating for the establjshment of an Interim goverment acceptable to all parties in Afghanistan(RPDS).

* The Iranian Ministry of Forelgn Affairs in an official statement has condemned the Geneva accords on Afghanistan adding that signing them with a regime which is not supported by the people of Afghanistan and with the foreign powers which supports the treaty, is not legal (BBCPS).

* A correspondent of The Times (Iondon), quoting Pakistani sources say that the Soviet supported government of Kabul was involved in the explosion at a military depot in Islamabad. He says the explosion has taken place at a time when, in the wake of signing the Geneva accords on Afghanistan the delivery of arms to the Afghan mujaheddin might be. halted (BBCPS).

* President Najitullah has sent a telegram to President Zia of Pakistan expressing sympthy for the losses inflicted as a result of a fire in a Pakistani arms depot (RA).

* The Head of the State has endorsed the Law of Government Workers earlier approved by the Revolutionary Coincil (RA).

* Abdul Majid Zabuli, a well-known and famous personality of the country, as a gesture of good-will towards the NRP, in a telegram 11 April has informed government authorities that he has donated three of his private buildings to be used for Herat University (RA).

* According to Bakhtar; the Afghan mujaheddin have attacked govermment polling stations in Kabul city, Kapesa and Kunar provinces (VOADS).

* President Reagan of the United States has said that the withdrawal of Soviet troops from Afghan- 
Istan is a major victory for the Afghan nation and an important factor in improving East-West relations.

* Iran says it seems as though the Afghan war will not end as a result of the signing of an agreement in Geneva. The Iran Ministry of Foreign Affairs said in a statement the purpose of proximity talks between Pakistan anc Kabul regime are only to satisfy the inturests of big powers (VOADS').

* The Christian Science says a number of US Congressmen are worried that the Geneva accords might reoult in a deal against the Afghan mujaheddin. Senator Gordon Humphrey says the mujahoddin

leaders are strongly opposed to these accords and has asked President Reagan not to approve the treaty until the mujaheddin slso accept it (VOAFS).

* The major US dailies The Washjngton Post and The New York Times haye saic it is not likely that the Najib government in Kabul will be able to survive after a Soviet troops witharawal from Afghanistan (MIM, quoting PPI).

* Sources close to the UN intermediary on Afghanistan in Geneve say monitoring of the implementation of the Geneva accords will continue two months after the return of Afghan refugees in Pakistan and Iran (PT).

* The w mediator on Afghanistan Diego Cordovez has told The Dawn that once an accord is signed about Afghanistan; "the whole atmosphere in the region will change" (DN).

- Ronald Reagan, President of United States has called the Geneva accords on Afghanistan an International success. However, The New York Times in its 12 April 1ssue says that while the Geneve accords are important and historic, they will not bring peace to Afghanistan (BBCPS).

* Ceremonies for signing the Geneva accords on Afghanistan will be held in Geneva 14 April. A UN Spokesman has said that the ceremony will be attended by the UN Secretary General, the US Secretary of States and the Soviet Foreign Minister (RMIS).

* US President Ronald Reagan says the US will jotn the Soviet Union in guaranteeing a treaty which seeks the complete withdrawal of Soviet forces from Afghanistan. Speaking to newsmen, ho praised the Afghan mujaheddin and denied that the US is going to abandon its support of the mujahoddin cause (VOADS).

* George Shultz, the US Secretary of States says that the Soviet leader Mikhail Gorbachev has told the US that all Soviet forces will be withdrawn from Afghanistan by the end of currant year. (voids).

* Vawlavl Yohammad Yunus Khales, an Afghtn mujaheddin leader has told the Al-Alam newspaper if the Soviet Union rejects the replacement of the present comminist government by an interim governmat before the withdrawel of its troops from Afghanistan the war will continue. He said only the pushoddth are in a position to administer the counitry (VOADS).

- The IUAY has once again rejected the Geneva peace talks and has said if the UN mediator on the Ifghan issue held talks with the Kabul government about the formation of an interim government, the mujahaidin will reject his new rounds of talk as well (VOAPSi).

- in Afghan source has told western diplomats in Kabul that some people in Kabul are of the 
opinion that after the Soviet troops withdrawal from Afghanistan the Kabul regime will not sustain itself. However, the Kabul regime is sincerely of the opinjon that the Soviet Union will continue to offer military assistance to it (VOAPS).

* The Washington Post says that US Secretary of States George Shultz has described the Soviet decision to withdraw its troops from Afghanistan as an importent issue. He has added that this is an important national and international victory achieved by the unparalleled valor of the Afghan mujaheddin.He said this is the first time in histcry that the Soviet Union has withrrawn from a country after subjecting it to its military invasion (VOAPS).

* The US Secretary of States has told newsmen it is possible that a non-communist federal (stet) government will be set up in Kabul after the Soviet withdrawal from Afghanistan and the United States will assist that goverment as it may feel necessary (VOAPS).

* The ANS, guoting travellers arriving in Peshawar, says that the Soviet Union has begun construa ting a radio station and an airport in the Sar-e-Pij. (a new province). The agency says work on the two constructions had begun one and half month ago and it is said that the Soviets have barred even the Kabul regime officials to visit the area.

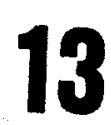

* A.US spokesman has asked the world community to help the Afghan refugees repatriate through the UN from Iran and Pakistan to their homes after the Soviet troops withdrawal from Afghanistan. (BBCPS).

* Prime Minister Mohamad Khan Junejo of Pakistan has told the nation that Pakistan has never recognised the Kabul regime and will never do so in futlre. He said the Geneva agreement has dealt only with the foreign aspects of the Afghan issue and will in no way bar the Afghan people to dotermine their own form of government without foreign interference (RPIIS).

* As a result of violationsi by Kabul regime security forces on a border post in Chaman, an official protest note has been delivered to the Charge d' Affaires of the Kabul Embassy in Islamabad (RPDS).

* The Soviet Ministry of Information and Culture has donated five mobile cultural publicity clubs worth Afs. 12 million to the Cultural Comittee of Afghanistan (RA).

* An agreement on expension of cooperation in air transportation between Afghanistan and India wes signed 12 April in New Delhi. (RA).

* According to reports 350 Stinger rockets have been sent by the US to Afghan counter revolutionories (Rons).

* A close adviser to Mikhail Gorbachev on foreign affairs while explaining Soviet views about conditions in Afghanistan after Soviet troops withorawal has said that his country is to accept the consequences of instability in Afgtianistan (BBPS).

- Gulbuddin Heknatyar, President of the IUAM has said in an interview the Afghans have no other choice than to fight and to continue their resistance, until the last Soviet soldier leaves AfghanIstan, the Najib goverment falls and an Islamic government is formed by the mujaheddin themselves in an independent and free Afghanistan (VOADS).

* Sabahuddin Kushkakl, Member of the CCAR has said that the feneva accoras on Afghanistan is, 
according to us indeed a deceit and he is sure that the Afghan ration would not recognise it (VOADS) - British Prime Minister Margaret Thatcher praised the role played by the Afghan mujaheddin in efforts exerted towards a pill-out of Soviet forces Prom ffghanistan. She said the basic rason for the Sovlets to pull-out their occupation forces from Afghanistan was the valor shown by the brave mujaheddin of Afghanistan (BBCPS).

* In a mammoth meeting attended by all seven leaders of the IUAM in Peshawar 12 April the Afghan mujaheddin, while rejecting the Ceneva accords, said they will continue their strugsle inside Ifghanistan unt1l the departure of the last Sovlet soldier and the ouster of Najibullah. only PIr Sayyed Ahmad Gatlani was not present in the meeting. He is reported to be in Iondon and was reprom sented by his Deputy Dr. Farooq Azam (NCM).

* The Goverment of Pakisten has rejected two Kabul government protests alleging the Pakdstant soldiers had fired on Afghan position (MIM).

* The OIC standing comittee has called for economic aid for Afghanistan's reconstruction. The appeal came in a joint commurilque issued at the end of a two day OIC mini-sumit conference in Kum wait 12 April (MIM).

- In a message to President Z1a and Prime Minister Junejo of Pakistan the IUAV President Gulbuddin Heknatyar has condoled the loss of life and property as a result of an explosion in an arms depot in Rawalpindi-Islamabad (PT).

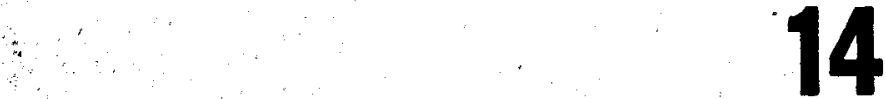

* President Zlaul Haq of Pakistan has termed the Geneva accords on Afghanistan as a historic event. He said the resistance of the Afghan people is going to be recorded in the history as an unprecedented struggle (RPils).

* The UN Secretary General Perez de Ouellar has said the Geneva accords on Afghanistan provicies the opportunity for the Afghans to make use of their right to self-determination which is a value enshrined in the UN Charter (RPIS).

* Soviet leader Mikhail Gorbachev has sald the Geneva agreement on Afghanistan is as important as the ligning of the latest arms agreement between the US and the USSR (RFDS). - The agreement which is to pave way for the withdrawal of Soviet forces from Afghanistan was aigned in Geneva 14 April. The agreement was signed by the foreign mirister's of the US, the USSR, Pakistan and Afghanistan (BBCPS).

* President Ziaul Haq of Pakistar, has said the Geneva accords will end in the downfall of the govormment and Presirient of the Soviet installed regime in Afghanistan.(EBCPS).

- George Shultz, the US Secretary of States has said in a press conference in Geneva the resis tence of the people of Afghanistan, as an heroic struggle, has demonstrated that a big power cannot impose its.will on a small country through use of arms (BBCPS).

* President of the IUAM Gulbuddin Hekmatyar has said in an irterview the Geneva accords is unjust and unrealistic and it is possible that the Kabul regime will fall before the Soviet Union completes the withdrawal of its forces from Afghanistan (BBCPS).

- British Foreign Secretary Sir Jeoffrey Howe has welcomed the agreement reached about the with- 
arawal of Soviut troope Irom Afghanistan and has asked all sides irvolved in the Afghan cgnelict to respoct the independence and neutrality of Afghanistan (BBCFS).

- With the signing of the Geneva agreement of Afghendstun, the Brilish goverimerit has announced its readiness to allocate 10 million sterling pounds for the ropartiation of Afghan refugees

(BBCFS).

- Zalmal Khalilzad, adviser in the US Stat bepartment, says the Najib goverrment will not be able to survive more then a few months after the withdrawal of Soviet troops from kfghanistan. - According to the AP, recently 15,000 Soviet troops have been transferred to Afghanlatan through Soviet borders. Moscow authorities have denied this rediculous claim (RMDS).

* The AP and UPI report that up to 15,000 Sovlet soldi ers have teen sent to Afghanistan in the past week. The nows agencies have based their report on official Amertcan sources (VOADS).

* Pakistan Prime MAnister Mohamnad Than Junejo has said the Geneva accords was to solve the external aspeots of the Afghan issue. olle said, whthout the support and blessing of the mujaheddin no broad based government can be formed in Afghanistan (VOACS).

- The liew York Times says Soviet official have been heard saying they do not want to quit Afghanistan in the same way as the Americans left Vietnam (VOADS). * US President Ronald Reagan has said he expects the Afghan mujaheddin will continue their f1ght despite the signing of the Geneva agreement; arms and the Sovtet Union provided arms to the Kabul regime, the US will also provide arms to the mujaheddin (VOADS).

- Prime Mintster Mohammad man Junejo of Pakistan has assured the Afghan refugees and mujaheddin In a television addregs to the nation that Pakistan will continue its assistance to the Afghans

(VOAPS).

* Radio Tahoren says the Afghen refugees staged a demonstration 13 April in Teheran against the Genova agreement on Afghandstan. In statement which they issued at the front of the UN mission, the demonstratorg called the treaty. 11 legal and rejected it (VOADS).

* Indtan Prime Yiniater Rajiv Gandhi has said in Now Delhi he hopes the agreement on ending the Afghan crists will help consolidate peace in South Asia (VOAPS).

* The former Afghan Konarch Kohamad Zahir Shah has said in a statement he hopea, as a result of the withdrawal of Soviet troops from Afghanistan, conditions will become conducive for the complete Independence, territorial integrity and the right to self-determination of the Afghan people (VOAPS * The Geneva accords on hfghanistan has left a number of important question unanswered. These are:

1. Will a ceasefire come ubout in Afghanistan, 2. how the ceasefire would be effectively policed.

3. how soon the repatriation of refugees will begin and how long 1 t is going to take, 40 will the refugees be disarmed, 5. who will finance the repatriation of the refugees, 6. what mechinism will be adopted for the induction of broadbesed national government in Kabul, 7. at what stage the US and the USSR will stop gfring militery aid to the two sides in Afghanistan, 8, wat will be the status of some 10,000 civilian Sovilet adviser now work in Afghanistan, 9. will the Iranian goverment abide by the terms of thatphemen, 10 , will the Afghan-Soviet friendahip 
treaty of 1978, which paved the way for the Soviet invasion, remain in force? (Kaleem Omar in aN).

* Minister of State for Foreign Affairs Zain Noorani has said Pakistan will take action about the Afghan bases inside Pakistan after a thorough study of the Geneva accords in its entirety. He was replying to a Soviet claim that Pakistan has agreed to close down some 200 mujaheddin bases in Pakistan. The Soviets also have said that Irun has also been asked through diplomatic channels to close dom the 20 Afghar bases in its territory (DN).

* Gennal Gerasimov; chief Soviet spokesman, has said it is very unlikely that the Soviet Union will egain interfere in another nation's civil war as it did in Afghanistan (DN).

* Soviet academician Yuri Baronkov has warned the west against urder-estimating the Kabul regime, the BBC. reported (MIM).

* ANP leaders than Abdul hiali Whan las said the US wants to see a bloodshed in Afghanistan after the withdrawal of Soviet troops and that is why it wants to continue arms assistance to the musaheddin following the pull-out of Soviet army (MIM).

- In a nationwide address, Prime Minister Mohammad Khan Junejo of Pakistan has hoped relations between the Soviet Union and Pakistan will enter a new era after the resolution of the Afghanistan problem (PT).

* Canada has provided Pakistan with $\$ 41.5$ million in aid and $\$ 14$ milion in food in $9986-87$ to enable it carry through its prograns for the Afghan refugees (PT).

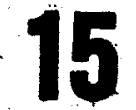

* Abdul Waldi, Foreign Minister of the Kabul regime, has said in a press conference in Gentva soriet millitary assistance to Kabul regime will continue after the implenentation of the Geneva acconds (VOADS).

* Zain Noorant, Paklstani Minister of State for Foreign Affairs, hás rejected charges made by the Kabul Foreign Minister that the mujaheddin are being trained in the refugee camps. The Kabul Poreign vinister, Abdul Wakil has said the Geneva accords obliges Pakistan to close down the rofugee cemps within its territory (VOADS).

* Soviet Foreign Minister Eduard Shevardnadze has said the US did not have a right to provide arms to the Afghen rebels and, if it did so, it will complicate the political solution of the Afghan problem (VOADS).

* President Ziaul Haq of Pakistan has werned, despite the signing of the Geneva agreement about Afghanistan, it is possible that tension and grave conditions will continue in Afghanistan (BBCFS).

* Porwer Afghan monarch Mohammad Zahir Shah has welcomed the signing of Geneva agreement on Afghanistan adding that the accords have opened the way for restoring Afghen independence and nonalioment (BBCFS).

- A BBC correspandent says that a moderate Afghan party which sees positive points in the Geneva accords - - the NIF - - will not take part in demonstrations which are to be held against the Geneva accords in Peshawar 16 April and is expected to be attended by all other leaders of the IuY (BBCFS).

- Po Prime Hinister of Pakistan and the US President in a telephone conversation, after the 
Geneva accords on Afghanistan, have hoped the accords will lead to the realization of the rlght of the Afghan people to self-determination and the establishment of a government of their owm choice (RPDS).

* Pakistan Minister of State for Foreign Affairs Żain Noorani has said in an interview he belioves that finally an interim goverrment will be established in Afghanistan and that govemment will be stable enough to make the refugees feel that they can return safely to their homes (RPLS).

* Pakdstan Minister of State for Foreign Affairs Zain Noorani in a note to the UN Secretary General Perez de Cuellar said 14 April Pakistan will continue its non-recognition of the present Kabul regime (RPDS).

* Prime Minister of India Rajiv Gandhi, told a press conference 14 April he is optimistic the Geneva accords will pave the way for the withdrawal of Soviet troops from Afghanistan (RPDS).

* President Najibullah of the Kabul regime has sent messages to the Soviet leaders and the w Secretary General on the occastion of the signing of the Geneva accords (RA).

* Marking the successful conclusion of elections for the General Assembly and the signing of the Geneva accords, President Najibullah of Afghenistan in a message has called on seven opposition leaders and commanders of the armed opposition groups to accept his invitation for peace (RA). * President Najibullah of Kabul regime has sent a telegram to President Ronald Reagan, of the us on the occasion of successful conclusion of the Ganeva talks (RA).

* The Soviet Foreign Ministry says, next.month, when the Soviet troops withdrawal from Afghanis. tan begins, exact and complete statistics about the number of Soviet troops in Afghanistan will be announced in Kabul (BBCFS).

* The Deputy of the Committee of International Help Operations at the UN has said the repatriation of some 4.5 million Afghan refugees will entail many practical and economia difficulties. He said perhaps repatrlating the Afghan refugees under such conditions is unprecedented in the entire history (BBCFS).

* Our commentator says it can be said that the Geneva accords on Afghanistan are going to be recorded in the history of the UN in golden letters (RMLS).

* An arms depot which was being used to supply the Afghan mujaheddin has exploded in Quettr. Pakistan. Reuter says at least six people have died in the incident. (VOAPS)

* A Sovlet Deputy Foreign Minister says that the signing of an agreenent on Sovtet troops withdrawal from Afghanistan can have positive results on solving the Kampuchian problem as well (VOAPS)

* The Weshington Post says, after the signing of the Geneva accords, the struggle of the Afghan nation has now entered a new phase (VOAPS).

* President Ziaul Haq of Pakistan sajd in Islamabad 14 April that the mujaheddin should not harass the (withdrawing) Soviet soldiers and should uniti in toppling the Kabul regime (VOAPS).

* "Ais far as the mujaheddin are concerned they will not be bound by the outcome of the Geneve agreements and they will continue the war until the Russians and their puppets are present in Afgranistan. We are not afraid of continued military aid to Najib's goverrment because we know what- 
ovar is sent to him will end up in the hands of mufaheddin. We are also not afraid of the signing of Geneva accords because no agreement can be implemented in Afghanistan' without the consent of mujaheddin. The world will see by itself the continuing crisis in Afghanistan until the will of the people of afghenistan is respected and their right of self-determination is restored ...., (Gulbudin Helwatyar in MLM).

- Speakers at a meeting of village administrators of Afghan refugee camps in Mardan, NWF, expressed grave concern 14 April that thousands of camp employees would be rendered jobless after the Geneva accords were signed and the Afghan refugees left Paklstan (VIM).

- Once the bombings have ceased and the immediate burden of supporting the refugees has dimintshed, a dispassionate analysis of the gains and losses of the Afghan policy would be possible.Then It will probably be confirmed that President Zia's policy was not as short-sighted as critics maintained (Husain Haqqanj, in MIM).

* As many as 14 promabul tribesmen reportedly repented their past mistakes and gave assurance of good conduct at a jirgah of uleme held at Hisaro in Mirali tehsil of North Waziristan Agency 14 April (MIM).

* The demand for Afghanistar's national currtncy, efghani, further shot up in Peshawar and elsewhere in NWFP 14 April on the eve of the signing of Geneva accords (MIM).

* The Afghan question has been Pakistan's biggest and most prolonged foreign policy exercise in recent times, with an involvement that was both intense and emotional at the leadership level (S, Khan in NIM).

- The Sind Government has prepared a contingency flan for early and organized transportation of Afghan refugees to the NWFP and Baluchistan for their repatriation (DN).

* The Soviet Union will continue to supply Afghanistan with all its development needs, Soviet Deputy Forelgn Minister Igor Rogachev said 14 April (DN).

- The Afghans are expected to continue their fight despite the Geneva agreement on the Soviet troops withdrawal unitil they topple the Najibullah regime (Mustafa Jafari, in MIM).

* An Afghan national Shabbir Hussain, working for the KHAD, was arrested charged with planning to explode a high intensity bomb at Sadda Adda of Kurram Agency (DN).

* A delegation of Jamiatme-Jleme-O-Islam, led by its chief Maulana Abdullah [arkhawasti, had a meeting with the current President of the IUAM Gulbuddin Hekmatyar 13 April and assured him his party's full support to the cause of Afghan mujaheddin (DN).

* Paldistan's Minister of State for Foreign Affairs Zain Noorani said 13 April that peace in Afghanistan would be restored only when a transitional government representing all Afghan factions was formed (MLY).

* Ten Afghan MIG aircrafts violated the Pakistan sirspace at Arindo, Chitral, 14 ApriI (PT).

\section{6}

* All members of the IUAM in a meeting in Peshawar 16 April condenned the Geneva accords on Afghaniatan (BBCFS).

- TASS says the Sovlet Union has stiongiy criticised the US and Pakistan for their announcements 
that they are intending to provide arms to the Afghan rebels. (BBCFS).

* China has welcomed the Geneva accords calling 1t a major victory for the Afghen people and Iran also has called the agreement on Sovlet troops withdrawal from Afghantatan as a positive step (VOADS).

* Soviet leader Mikhall Corbachev said in Moscow 15 April that the agreement on Afghanistan can also be applied as a model to solving the Kampuchian problem (VOADS).

* Zain Noorani, Pakistan's Minister of State for Foreign Affairs, said on exrival in Islamabad from Geneva that the Geneva accords, which have mainly attended to extemal aspects of the Afghanistan issue, will eventuelly pave the way for a comprehensive settlement of the Afghan problem

*.

(RPDS).

* The WN Chief Comissioner for Refugees has asked the Kabul regime to provide it with special mardate so that the UNHCR will be able to repatriate the Afghan refugees who want to return to their country (RPDS).

* Canada is to consider an official UN request for talarig part in maintaining peace in Afghentetan.A Canadian spokesman has said that the request has been made as part of a UN efforts to pave the way for the withdrawal of Soviet forces from Afghanistan (RPDS).

* According to a VOA. reporter, about 400 Afghan refugees staged a demonstration in NY 15 Aprif expressing opposition to the Geneva accords sayting the accords will not solve the Afghan issue as they are not eliminating the Najibullah regime (VOADS).

* Eduard Shevardnadze the Soviet Forelgn Minister sald after the signing of the Geneva agreenent on Afghanistan that the Soviet Union will abide to its obligation as a guarantor of the accords. However, it will be important for the viabllity of the agreement that the two signatortes - - Afghenistan and Pakistan - - will closely adhere to its provisions (RMrS).

* Prayers were held in 22 mosques "in Karachi, Pakistari 1.5 Aprjl supportirig the conclueion of the Geneva talks on Afghanistan. Afghan refugees, whose number in Karach1 totals 200,000 , in a meeting expressed their desire to return to their country (RMDS).

* The UN special envoy on Afghanistan Diego Cordovez has sald in an Interview with the BBC he had a very firm commitment personally to help the Afghans after the Sovlet withdrawal from their country (DN).

* The Afghan war has intensified in recent weeks despite prospects for a UN sponsored peace accord, Westem diplomatic sources said (MIM).

* Gulbuddin Hekmatyar, President of IUAM has said the IUAM judiclal board has been asked to try all those Afghans including Dr. Najib in absentia who have committed crimes and atrocities against the Afghan people and the verdict of the sharle be announced so that all such people could be brought to book after the withdrawel of Soviet troops (MIY).

* A White House spokesman said 14 April that President Reagen was encouraging the Afghan mujaheddin to fight on if the opposition remains and if the fight is there to maintain (PT, quoting APP).

* Gulbuddin Heknatyar, President of the IUAM has vowed to intensify the armed struggle Inside 
Afghanistan until the resistance achieves its goal of toppling the Kabul regime. He used the Vietnam analogy to stress that Najib's regime would not survive a Soviet pull-out (In interview with MIM).

- - Afghan regulars will soon face the mujaheddin guerrilla forces alone in Afghanistan. - Even if the Soviet trools are heading home, the war is likely to continue in the country, - - The battle for Afghanistan may only be the beginning. (The Time - USA - article adopted in the NWT).

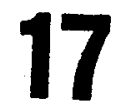

* According to TASS Kabul Foreign Minister Abdul Wakil met Soviet Foreign Minister Eduard Shevardnadze in Moscow 16 April. TASS added, the two foreign ministers emphasize Soviet readiness for the complete reconstruction of the war torned Afghanistan's economy (VOADS).

* The US State department has questioned a Soviet claim that, following the Geneva accords and an end to Soviet military occupation of Afghanistan, the US has no right to supply arms to the Afghan mujaheddin (VOADS).

* The Japanese Foreign Miristier, in a statement, has said a complete withdrawal of Soviet troops from Afghanistan will be conducive to further stability in east-west relations as well as peace in the region (RPIS).

* A Soviet newspaper while praising the Geneva accords for bringing an end to Soviet military intervention in Afghanistan, has, however, added that the treaty will not guarantee peace, as it is not comprehensive (RPDS).

* King Hussain of Jordon has highly praised the solution of the conditions prevailing around Afghanistan and has expressed confidence that the accords will play an important role in consolidating the ideals of peace throughout the world (RA).

* The daily Sunday Express (India), while welcoming the Geneva accords, has added it is possible to solve other regional problems, specially the crises in the middle east, through UN mediation

(RA).

* Perez de Cuellar, the UN Secretary General has annouriced the Geneva accords on Afghanistan is a major triumph. He said he personally is deeply committed to a peaceful solution of the situation prevailing around Afghanistan (PMDS).

* Soviet spokesmen throughout the world are emphasizing that, when the Soviet troops starts withdrawing beginning 15 May within 9 months from Afghanistan, they will not return to that country

(BBCFS).

* A correspondent of The Observer London says families of Soviet soldiers in Afghanistan are impatiently waiting for the retum of the soldiers. He adds masses of the Soviet public do not pay any attention to the consequences of the withdrawal of Soviet troops from Afghanistan (BBCFS).

* The PPP provincial chief, Aftab Sherpao has charged the mujaheddin were being supplied arms from the Faizabad ammunition dump and even some mujaheddin commanders were killed in the recent explosion in the depot (MIN).

* A delegation of Pakistan National Party (PNP) returned here 16 April from Kabul after a 13-18y 
visit to Afghanistan at the invitation of the Peace, Solidarity and Friendship Organization of that country (DN).

* In a survey, conducted by our staff correspondent, big percentage of Afghan refugees living in tented villages and private houses and flats in Karachi, have shown their willingness to go back to their fatherland. However, some of 'the rich refugees who have started their business here said that since they have finally migrated to Pakistan from Afghanistan and invested in business, they would not go back. But the number of such refugees is very small (PT).

* Kabul might withdraw its forces from some parts of Afghanistan where returning refugees wish to settle if they agreed, in turm, not to support rebel activities, Afghan President Najibullah said 16 April in a speech reported by Tass (DN).

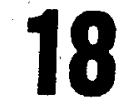

* Pakistan's Minister of State for Foreign Affairs Zain Noorani has said that the conclusion of the Geneva accords is considered a triumph of the foreign policy of Pakistan (RPDS).

* Humayun Chaudhry the Bangladesh Forelgn Minister, while welcoming the Geneva accords has added that the successful conclusion of a treaty on Afghanistan has proved the ability of the un to solve regional issties by peaceful means (RPDS).

* Reuter reports that leaders of the Afghan resistance organizations in a meeting in Islamabad discussed issues related to the interim gevernment of Afghanistan and finding for this government a safe place inside the country (BBCHS).

* The Daily Telegraph (London) reports from Moscow that the Soviet Union is apparently preparing itself for the undesirable chain of events which are expected to develop in Afghanistan after the withdrawal of Soviet troops from that country (BBCFS).

* US and Soviet scholars arrjved $18 \mathrm{April}$ in Kabul to participate in a tripartite conference in Kabul about Afghanistan (RA).

* The Vice Chancellor of Delhi University in an interview with the Soviet news agency NOVOSTY has said that the Afghan problem is a long and complicated issue and solving it has required painstaking attempts (RMDS).

* Abdul Wali Khan, a distinguished personality of Pakistan opposition parties, has blamed President Ziaul Haq for the explosions in an arms depot near Islamabad. He has added that the depot belonged to armed Afghan opposition groups (PMDS).

* The IUAM has announced in Peshawar it is sending delegation to Afghanistan to find a suitable area for establishing the interim govermment within Afghanistan (VOALS).

* The former Afghan monarch Mohammad Zahir Shah told the Nawa-1-Wagt 17 April he is inclined to play a role in the new interim government of Afghanistan but emphasized that in no way he intends to revive the monarchy (VOALS).

* Leader of the PPP Benazir Bhutto, comenting on the Geneva agreements on Afghanistan, said I think the Afghons are going to face a civil war and this will mean more refugees will come to Pakdstan (VOAPS). 
* A commander of the Hezb-Islami Muzaffamidin, who has been in johad since 1979 and has now eight mujahoddin Ironts in Zabul, says our jehad did not atart on the basis of the Geneva talks and it will not stop on that basis. Our jehad began against the communist and unt12 the communiats are In Afghanistan, our jehad will continue (VOAPS).

* The Buropean Community of 12 nations in a statement 17 April paid tribute to the readiness of Pakdstan to Geneva accord and to accept millions of Afghan refugees over the years. They have expressed admiration for the sacrifice both in financial and human terms that Paktstan and the Afghan mujahoddin had to make in resolving the intractable Afghan issue (MIM.).

- Whe greatest responsibilfty (after the signing of the Geneva accords) now rests with the three main parties involved - - Pakistan, Afghanistan and the mujaheddin - - to see the Afghan tragedy is quickly anded. The tho superpowers have each got what they wanteds it is for the three to work out a sensible 'modus vivendi' that will eventually lead to a dursble settiement".(The theleed Times editorial puitished in MLM).

* If the mujaheddin struggle against the PDPA regime turns out to be a protracted one, the IUAM loadership in Peshawar will retain its primacy. For under the symmetry or positive symmetry arrangement worked out at Geneva between the two super powers, the arms flow to the mujaheddin will continue with Padstan remaining the conduit, even though under the non-interference clause of the Geneva instruments it wo. formally be barred from doing so (by Abbas Rashid in MIY).

\section{9}

* The Chief Ninister of NWFF wbbab Mohammad Jahangir Khan said in an interview in Peshawar 18 April that the Geneva agreeme.lt will pave the way for peace in Afghanistan in order to enable the dighan refugee to return home (RPLS).

* The UHACR Chief Comissioner has said he 1s completely ready that his institution play 1ts role In regard to Afghanistan within the framework of the Geneve agreement. He urged all parties invelved in the Afghan 1seve to make sure that the Afghan refugees art able to retum to their country in honor and safety (RPDS).

* The IUAM reports that the mujaheddin leadership has agreed that the firat meeting of the cabinet of the Interim government ought to be held (VOGDS).

* The Afghan mujaheddin sources report from India that abôt 6,000 Afghan refugees living in India are not ready to return home after the Sovilet troops vithdrawal from Afghanistan. They have called the Geneva agreement unjust and say the agreement has failed to provide a political colution of the Afghan issue (VOGDS).

- Afghan mujaheddin sources say that a NIF Comnander Mohanmed Naser has been killed in Peshawar by unlonown assailers. Pollce sources say two of his bodyguards have been irijured (BBCFS).

- The tri-partite conference of Afghan, American and Soviet scholars about a proper understanding of the Afghan 1ssue was oponed 19 April by Sultan All Keshtmand in Kabul (RA).

* Sharif Qureshi, Central President of Joint Labor Foderation, 18 April, demanded immediate disarming of all the Afghan nationals prior to sending them back to their country following the conclustion of the Genevi Accords (DV). 
* While no fundamental change has been reported from 1rislde Afghanistan in the wake of Geneva accords, Sovlet troops have nevertheless begur handing over smalj. garrisons to Kabul government forces. ( $\mathrm{N}$, by its special correspondent).

* The Mnister of State for Forelgn Affairs Zain Noorani, while initiating the debate on tre Geneva accord in the Parliament 18 April, warned that though no presire would be put on the Afghar refugees to return to their homeland after the Geneva accord, the government would in no way tolerate any attempt to impede the return of those refugees who warited to go back to their country voluntarily. He said $90 \%$ of the refusees want to return to Afghenistan (MIM).

* In a survey, conducted by The Muslim in the Munda Camp No.6, Afghan refugees met news of an agrecment for a Soviet troop withdrawal from their homeland with reactions ranging from scepticiem to indifference. However, the majority of the refugees were afraid of being forced to return (Mm)

* Pakistan has spent 1.5 billion doljars from its own resources over the last elght years on the uykeep of the Afghan refuzees, according to an officlal memorandum prepared for presentation at the next Aid to Pakistan Consortium meeting in Par1s on 21 and 22 April (DN).

* In an interview, Engineer Ahmad Shah, President of the Interim government of Afghanistan has made the following points:

- "Bovlet presence (In Afghanistan after its troop withdrawal) will be there in some other form, civilian for instance, in the shape of' advisers. I do not believe they are leaving, because why do they need withdraw (in nine months) when they could come in twenty four hours"n?

- - "Sioning (of an agreement on Afghenistan in) Geneva was not in the Interest of Pakistan. Luckfly it has not meant recognition of the Najibullah Goverrment. Pakistan, coufd be faced with another problem after signing at Geneva because there may be no UN suyport for Pakistan and foeping three-four million refugees will be a big burden on Pakistan".

- "So far, relations between Pakistan and the mujaheddir have been excellent. There is no Indication, and I see no reason, why Pakistan government should ask them to leave. I do not think the goverment of Pakistan will do that".

- - "Porwation of the interim government is a sign of urity. Ieaders were elected unanimously. Political parties all over the world are like this. In our case, the eneny magnifies differences and projects them to tell the world that we cannot rum an administration".

- - We do not accept Nejib or the communists. Anyone who calls himself a communist is not a Muslim. Indeed they are not Afghans elther. They may be Afghans by birth, they are not so by practice because they have sold Afgheristar. ... As for Zahir Shah, he has no place in Afghandstan. No one is willing to have him or seek him any more. In any case, our's is not the problem of Individualon.

- We can have people who have not been in jehad. We will allow them to participate in the reconetruction of Afghenistan. We have no objection to those living outside Afghanistian but not those who found a sanctuary in Soviet Hussia. Leadership (after gaining control) would be for those who shed their blood. For others, we will announce amnesty ..."

- - "If there is no aid from the US, the position wIIl not change. Jehad had started without ald when we were almost empty handed". 
- - There is no other way for us but to wage jehad for the freedom of Afghanistan. If (the) USSR troops are withdram, Najib cannot last. If (the) USSR is there (in some other form), success may take ('longer).

Meanwille, those close to the regime realize that the Kabul government is falling apart. Many are defecting. That. further weakens the (Kabul)regime. There are also about half a million armed Afghans (with the resistance). Despite the Russians havirig a lot of modern facilities in arms, they (the mufaheddin) are fighting better than Russians or commurists of (the) Kabul regimen. (in interview with Dr).

\section{0}

* Pakistan Prime Minister Mohamad Khan Iunejo told Parliament 20 April the Geneva agreement on Afghanistsin eliminates all the concern of the Pakistani govemment in regard to this 1ssue (RPDS).

* UN Secretary General Perez de Cullar has urged the Security Council to approve the appointment of a team proposed for monitoring the withdrawal of Soviet forces from Afghanistan (RPDS).

* Mrs. Lona Hjelm Walle the Swedish Minister for International Aid arrived in Peshawar 20 April. She visited the IRC hospital and discussed with Afghan and Swedish authorities in Peshawar matters related to the facilities for repatriation of the Afghan refugees to their country (RPDS).

* Western diplomats in Islamabad say signs indicate that Jalalabad might be the first major city which the Soviet troops intend to evacuate. Similarly a foint Afghan-Soviet cormittee has been set up to hand over the 121' Soviet bases to the Kabul armed forces (BBCFS).

* The Guardian (Iondon) reports from Kabul that the Kabul government is preparing for a big military parade to mark the 10th annivirsary of the Saur coup. The objective is to show to the Afghan mujaheddin that the Kabul government can defend itself without Soviet forces (BBCFS).

* President Najibullah of Afghanistan in an interview with a Soviet weekly has sald that afghans walcome wth complete satisfaction the Geneva accords and, for reaching a national consensus, we are ready to hold talks with the opposition without prior conditions (RMUS).

* Gulbuddin Heknatyar, President of the IUAM says that the Afghan mujaheddin will continue to . attack Soviet positions even during the withdrawal of Soviet troop from Afghanistan (VOADS).

- Meetings of Afghan, Soviet and American scholars continued 20 April in Kabul. The Americans expressed their readiness for helping the Afghans in the reconstruction of Afghanistan and offered in this respect their proposals (RA).

* A large number of afghan refugees may remain in Pekistan "for reasonably long time" because of political and security concerns, travel problems, and the widespresd devastation to their country, according to Roy Williams, Deputy Director of the International Rescue Committee (PT).

* The ICRC has appealed to donor's to provide funds amounting to $20,212,800$ Swiss francs to enable 1t to look after afghan conflict victims in 1998 (MIM).

* The Judiclal Board, set up by the IUAM, would soon start hearing of the cases in the liberated arcas agatnst the head of the Kabul administration, Dr.Najib and other office-bearers of the ruling party in Afghanistan.A sources of the IUAM has said the head of the Kabul administration and his comrades would be tried under the charges of collaboration with the Soviet aggression; Involvement 
in masis killing of over 1.3 million Afghans and causing harm to the integrity and unity of Afghanistan. According to the sources, the TUAM Supreme Council had already issued direetives to the Judicial Board in this regard. However, the crders would not he applied on the persons for whom the general amnesty had already been announced by the IUAM (MIM).

* "There is a convergence of view between the Soviet Union and Pakistan that the regime in Kabul (stet) should be made more broad-based and that it should enjoy greater acceptability. This can be made a starting point for a new beginning (in relations between the two countries). The mujam heddin should also learn to live with their "heretic" neighbor. If Khomeini's Iran can accept this reality why mujaheddin cannot. The setting up of an interim governnent in Kabul is a complex 1ssue. But given the will and tactful handling the issue can be.dealt with successfully. Much will depend on Pakistan's ability to establish a better equation with the Soviet Union. It is time" for Isiamabad to open the Soviet window. (Khalid Akhtar in MLM)

\section{1}

* The Third World News (LS) says the Afghan resistance is vehemently opposed to the Geneva accords because they leave the Soviet installed government of Najibullah intact in power in Kabul. The Soviets are likely to withdraw their troops from Afghanistan but they are not ready to resign from their Interests in that country (VOADS).

* The tri-partite conference of the Afghan, US and Soviet scholars, which had begun in Kabul to. discuss the Afghan issues, ended in Kabul 21 April. (RA).

* Shariati the Secretary General of the People's Bureau of Iybia met 21 April with Mawlawi Abdul Jamil Zarifi Minister of Islanic Affairs and Endowments in Kabul to discuss furthering brotherly relations and other issues of mutual interest between the two countries (RA).

* A spokesman of the Fijian government says that military officers of that country are going to foin the UN monitoring team in Afghanistan to supervise the withdrawal of Soviet troops from Afghanistan (VOADS).

* Dr. Mohammad Yousuf a former Prime Minister of Afghanistan has said in an interview that

Mohammad Zahir Shah the former King of Afghanistan, due to the confidence which he still holds among the people of the country, can use his efforts as an element of achieving understanding among concerned parties of the Afghan issues and take part in the vital matters of the country in these sensitive times of our history and offer specific: program and ideas about solving the difficulties facing us (VOADS).

* The Indian Government has invited Afghan President Najib to visit New Delhi to discuss the situation in Afghanistan following the signing of a UN sponsored accord, Prime Minister Rajiv Gandhi told Parliament 20 April (PT).

* The Soviet Union continues to step up arms shipments to the Kabul regime in advance of a Soviet troops withdrawal (PT).

* Prime Minister Mohamnad Khan Junejo, winding up the two-day debate on the Geneva accord in the foint sitting of Parliament, 20 April declared that the accord may not be excellent, comprehensive and totally perfect but, within the given situation, no better agreement could be possiblo (MIM). 
* Soviet and Afghan mujaheddin representatives have agreed to a prisoner exchange under which for each Sovist prisoner of war 25 captured mujaheddin will have to be freed, accorifing to a leading American news weekly (MIM).

* The Punjab government has submitted its report containing lists of Afghan refugees residing in Punjab to the Federal Government (MIM).

* Sweden's Minister of International Aid Mrs. Lewa Hjelm Wallen told the IUAM President Gulbuddin Hekmatyar in a meeting in Peshawar 20 April that her country would welcome a proposal for establishment of a mujaheddin office in Sweden (MIM).

* UN Secretary General Perez de Cuellar has asked the Security Council to endorse a UN observer mission envisaged in the Geneva accords to monitor the withdrawal of Soviet troops from Afghantstan, a UN spokesman sald 19 April (MIM).

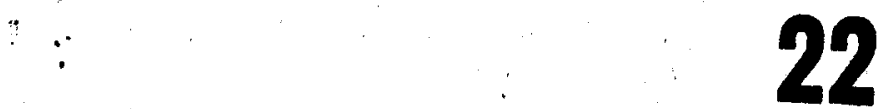

* Ronald Reagan the US President told the World Affairs Counctl 21 Apr-11 as long as Moscow supports the present Kabul regime, Washington will continue to support the Afghan resiatance

(VOADS).

* Vir Chulam Qader Khan Chief Minister of Baluchistan has said the Afghan mujaheddin have launched a heroic struggle and the singing of the Geneva accords is a great victory for them (RPDS). * Zain Noorant Minieter of State for Forelgn Affairs said on arrival in Karach1, by signting the Geneva accords, Pakdstan has gained many things but has not glven-up anything and this is due to foresightedness and political skill of Prime Minister Mohamad Khan Junejo (RPDS).

* A prominent advisor to Sovlet leader Mikhail Gorbachev told Western newspen 21 April in Kabul that the Soviet Union did not Intend to send arms to the Kabul regime after its troops withdrawal and he also advised the US not to send arms to the Afghan mujaheddin (BBCFS).

* Resistance sources in Kandahar say a secret letter, sent by the KHAD to 1ts Kandahar office, has urged the creation of dissension and animosity among resistance forces after the Soylet troope withdrawal in order to strengthen the position of the Kabul regime (VOADS). * Most Kabul residents have welcomed the signing of the Geneva accord perceiving them as the beginning of a real Soviet pull-out, according to western diplomats. However, the diplomats reported residents expect hard fighting in and around Kabul once Soviet forces withdraw from the area (PT).

* U.S. Ambassador Amold I. Raphel in Pakistan 21 April presented cheques to Thomas Yates, IRC In Pakistan for his organization's relief activities amongst the Afghan refugees. This year the v.S. government offered a total of Rs $16,071,044$ to IRSCMIM (PT).

* The explosion at Pakistan's Ojheri ammunition depot last week destroyed more than 75. percent of arms flown in by the US CIA in a last minute weapons build-up to aid the Afghan resistance before the Sovlet troop withdrawal, according to the latest isaue of the Newoweek, magazine (MIM). * "In the ultimate analysis it is time for Pakistan to refrain from burning its fingers any fur ther in the Afghen fires. The goverment can, therefore, keep itself detached from any future plans or resistance struggle of the alliance leaders. On the contrary it should now, when it is free 
from a big external headache, concentrate whole heartedly on revitalizing its sagging economy and fortification of the existing political order into a truly democratic one (Seeed QureshI in MIM).

* There are reports of a secret deal between the Soviet Union and Iran to ensure Teheran's support to the UN-mediated Geneva-accord on Afghanistan, The BBC reported 21 April that Iran has, under a secret understanding, promised to the Soviet Union not to oppose the Geneva accord on Afghanistan and refrain from disturbing the process of Soviet troop withdrawel and return of the Afghan refugees to their homeland (MIM).

\section{3}

* China says the withdrawal of Soviet forces from Afghanistan should pave the way for an end to the occupation of Kampuchea as well (VOADS).

* Representatives of world media and political and social circles of many countries of the world consider the Geneva accords a sound example of solving regional issue (RMDS).

* Mohamad Rashid, Deputy leader of the PPF has emphasized, witl the signing of the Geneva accords, now it is possible for Pakistan to establish amicable relations with Afghanistan and the Soviet Union (BMDS).

* UN officials say in NY that a plan to sent a UN monitoring team to Afghanistan hos now reached. its final phase (RPDS).

* According to Decree No. 116 issued 17 April, all military officers upto the rank of colonel have been given one rank promotion throughout the Afghan armed forces (RA).

* President Reagan said 22 April that a pledge by the Soviet Union to withdraw its forces from Afghanistan did not guarantee an erd to Soviet involvement there, and he gave vent to his concern for the security of Pakistar: (PT).

* US Ambassador in Pakistan, Amold In Raphel has described the Geneva accords as an important and necessary first step to solving the Afghan problem. The agreement was an important step because it secured a firm Soviet withdrawal timetable. But he saw challenges ahead until the achievement of two other objectives: the return of refugees to their homeland and an acceptable government in Kabul. He stressed Washington and Islamabad's interests were similar in this respect: Washington has no interest in having chaos and confusion in Afghanistan. It has no interest in Lebanization of that country (in interview with MIM).

* In view of Geneva accords the government has started the initial work and a comprehensive schedule is being chalked out to repatriate the 3.3 million Afghan refugees with dignity and honor. This was disclosed by the Federal Minister for State and Frontier, Northern and Kashmir Affairs, Syed Qasim Shah, in Islamabad 22 April (PT).

* The OIC has called on Muslims throughout the world to support Afghan mujaheddin and refugees in their struggle to regain their rights (PT).

* Engineer Ahmad Shah, President of the mujaheddin interim govermment in Afghanistan, has said the portfolios will be allotted very soon to the 14 members of the mujaheddin cabinet (PT).

* The Afghen technocrats and intellectuals living in the US and Europe and other countries have started reaching Peshawar (PT, quoting AAP's story datelined London.) 
* The UN Human Rights Commission in a resolution has expressed distress and alarm over allegations of human rights violations in Soviet-backed Afghanistan, including interrogation and killing of political prisoners. (DN).

* The IUAM has expressed resentment over an article in the Newsweek 18 April. The IUAM say the Newsweek, like other Westerm papers, was being used by a lobby in America which prefers a commnist government over an Islamic one. The IUAM has ordered its office in NY to sue the magezine for witing such a piece (MIM).

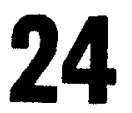

* President Najibullah of Afghanistan met 24 April with American and Soviet scholars who have come to Kabul to participate in a joint Afghan-Soviet-American conference and discussed with them the NRP, putting an end to the war and the Geneva accords (RA).

* President Najibullah of the Kabul regime in a speech in the presence of American scholars has urged the US to cut-off its aid to the Afghan mujaheddin in responce to a similar move by the Soviet Union towards the Kabul regime (VOADS).

* The New York Times said 23 April that 3 million Afghan refugees now living in Pakistan in campa include poople who have lived in exile for 10 years. And now one cannot force then to return to Afghanistan on the basis of a political settlement because in the eyes of many Afghan refugees only a withdrawal of Soviet troops from Afghanistan is not enough (VOAUS).

* Gulbuddin Heknatyar President of the IUAM has said the future government to be formed in Afghanistan after the departure of Soviet troops would be on the basis of elections and would be an independent, non-aligned Islamic goverrutent, reports VOA, quoting The New York Times" interview with Gulbuddin (PT).

* In the aftermath of the Geneva agreement on Afghanisten, one could foresee a new and dymamic relationship between the Soviet Union, Pakistan, Afghanistan, Iran and China (Zahurul Haq in PT). * Three delegations, set up by the IUAM, have left for Afghanistan and would stay there for one month to report on a suitable lncation for the seat of the interim government inside Afghanistan

* The US and the USSR appeared 23 April to move towards an agreed cut-off in weapon supplies to their respective allies in Afghanistan (MiIM).

* The Soviets inspite of their naked aggression against the Afghan people have behaved with restraint towards Pakistan. But President Reagan, while reiterating solidarity with Pakistan against Soviet designs, should have instead expressed solirlarity against Indian threat to Pakistan (editorial MIM).

* The Consul General of the Kabul regime Mohammad Bashir has said in Quetta so far flve countries have recognized the present Afghan regime following the signing of the Geneva agreement (names of the couritries have not been mentioned - - (MIM).

\section{5}

* The Governor of NWFP Fida Mohammad Khan has said he has not observed the deep aenet of love 
which the Afghens have for their country in any other nation (RYUS).

* Afghen diflomats in Islamabad have cancelled their plan for celebrating the 10th anniversary of the 27 April coup because Pakjstani authorities have refrained from providing security for their functions '(VOADS).

* A US State Department spokesm. . has refected the idea of improving relations between Kabul and Washington saydrig that Washingtor does not conkider the Kabu? regime as the legal government of the people of Afghanistan, and, therefore, the question of improving relationsiwith that government is ridiculous (VUALS).

* The IUAV Supreme Council recided 25 April, meetings should be held throughout Peshawar and refugee camps to condemn the $27 \mathrm{April}, 1978$, coup the anniversary of which is being held by the Kabul regime. The Council also approved the furisdiction,domestic and foreign policy of the interim government of Afghanistan (VOLPS).

* The New York Times said 24 April that both the American Department of State and US intelligence officers are of the view that the Najib regime will not last more than a year after the withdrawal of Soviet troops from Afghanistan (VOAPS).

* Afghanistan's Soviet-backed governmerit has said it needs forelgn help to reconstruct the warravaged country and will welcome capital investment even from the US, which backs the Afghan mujaheddin (MIM quoting US News and World Report).

* After the Geneva accold the mujaheddin ere reported to have surrounded the historical Afghan city of Chazni, es a result of which the somcalled elections proposed by the puppet regime could not be held (PI).

* About 130 people have been kj.Jjed during the parliameritary elections jn Afghanirtan, reports $\mathrm{BBC}$ (PT).

* ANP President Khan Abdul Wali Khan and Ghous Bakhsh Bizenjo of PNP 24 April condenned Pakistan government for not showing interest in implementing the Geneva accord in "letter and spirit" (MIM).

* Under the heading "hfter Geneva: How long will the new journey take?" it has been said:"It will be a difficult joumey where Pakistan as well as mujaheddin would have to move along a zigzag path, with utmost courage and care. Soviet forces would, no doubt, be withdrawn, and that itself will improve conditions inside Afghanistan. The understanding of symmetry will also prevent Russia from disturbing balance, and it is possible that, instead of supplying arms to their allies, both superpowers would eventuglly agree to stop such supplies. What Pakistan will have to puroue is the evolution of an interim government in Kabul. Judging from what has already been made knorm, peace may be restored in Afghanistan by the end of the year; also by then the refugees may be able to start returning to their homeland (Shabbir Hussain in - PT).

* The central President of Karakuram National Movement, Mohammad Qasim Sheralyat, while criticizing what he called the US cual policies towards Muslims in the vorld, said, on one hand, the US was providing every kind of assistance to Afghan mujaheddin while on the other, it has started the genoclde of Palestirian Muslims through its pet child Israeil (MIM).

* The Afro-Asian Peoples Solidarity Organization, Pakistan, has condemed what it calls the dissenting voices agiainst Geneva accord specielly in Pakistan and US, one being a signatory and 
the other a guarantor to the accord (MIM).

* According to The Jang reporter fucm New Delhi, M.A. Bj.bi nuaturer uf the Indian Parliament has accused the Afghan refigees in India of being involved in subversive activities along the Indian border. He has urged the Indian Ministry of Interior to investigate reports that the Afghens are helping Sikh extremists and if they were true, they should be expelled from India (JG).

\section{6}

* The Washirgton Post; quoting President Najibulluh of the: Kabul regime, says the fact that Soviet troops are being witharawan from Afghanistan, makes imperative that the armed forces: of the Kabul regime should be strengthened so that the balance of power may not shift in favor of the mujaheddin. The newspaper says this is the first time that Najib is expressing concern about the consequences of the withdrawal of Soviet forces from Afghanistan.

* The UN Security Council has recommerded to the un Secretary General to go ahead with a plan of sending a monitoring team to Afghanistan during the withdrawal of Soviet troops from Afghanistan

(RPDS).

* The goverment of A.fgherijstan has decided to withdraw its border security forces from certain units of thearmed forces near borders:of Pakistan tofacilitatethereturnof refugees to the country (RMDS).

* Westerm analysts say that the withdrawal of Kabul government forces from border ureas is intended to enable the regime deferd important positions inside the country (BBCFS).

* President liajibullah of the Kabul regime in offering his proposalforcreating non-military zones In the border areas, has said the success of the idea is completely related to the government of Pakistan and the mujaheddin. However Pakistani suthorif,jes say the issue has nothing to do with Pakistan and the Kabul government, which is seeking c ceasefire, should deal directly with the mujaheddin (BBCFS).

* Nohommad Hassan Kakar, a professor of history in Kabul University who spent several years in Kabul prison and came to Pakistan after his release, has told the Afghan Information Center that after the April 27, 1978, coup the communists decided to share the power only among themselves and all other Afghans were excluded (BBCPS).

* A member of the Soviet Embassy in Kabul has claimed the withdrawal of.Soviet troops has already begun in Pakt1a, Pakteka and Nangarhar provinces; however, other sources say that 19 April a large Sovlet military convoy was seen moving towards Gardez, Paktia (VOAPS).

* Resistance sources in Quetta say since the conclusion of the Geneva agreement on Afghanistan, Iran has imposed restrictions on Afghan refugee movements and has also been posing difficulties in refugee traffic between Afghanistan and Iran (VOAPS).

* According to Soviet sources, the mujaheddin have now brought the Kabul-Ghazni highway effectively under their control making it impossible for the regime to move freely on the road (VOAPS). * Mhere are still many ifs and buts (in the Geneva Agreement) and all parties seem to harbour mental reservations suited to their own convenience lending an air of ambiguity to the whole affair. Yes it would be unfair not to concede that the Geneva Agreement will be accorded Its place in history as a distinct landmark and that it has many a bright aspects which may erentualiz 
prove to be the proverbial light at the end of the tunnel. (Air Conmodore [Retd] Mahamad Yamin in MIM).

* Leader of the ANP Khan Abdul Wali Khan, in his message of fellcitations to Dr. Najibullah of Afghanistan on the occasion of the 10th anniversary of Saur Revolution, has hoped his national reconciliation program will succeed and the Geneva accord bring peace to the country (MIM). * Afghan artillery 25 April shelled Pakistan border villages in Bajaur Agency ktlling elght people and injuring many others (PT).

* The UN implementation assistance group arrived in Islamabad 25 April to monitor implementation of the Geneva accords in accordance with the Memorandum of Understanding signed in Geneva (PT). * Mr. Chulam Mustafa Jatoi, Chairman of the National People's Party, 25 April expressed reservation about the return of peace in Afghanistan if the Pakistan territory remained a conduit for the supply of arms to what he called the Afghan dissident group (IV).

* The Afghan refugees are unlikely to return home unless the mujaheddin make arrangements for their settlement in the liberated areas or form their own government there. The Pakistan Government also does not want to send the refugees to the camps set up by Dr. Najibullah's regime as it would amount to "throwing the armed (stet) refugees to the wolves" (Pakistani) official sources told Dawn 25 April (DN).

* Shiraz Kayani, the provincial chief of Qaumi Mahaz-a-Azadi and Convener of the MRD in NWFP, has told newsmen insịstence of Afghan mujaheddin leaders to continue their so-called jehad despite the signing of Geneva accord and stipulated creation of congenial atmosphere for their return have exposed their ultertor designs of seeking power instead of rendering any service to the cause of Islam or the people of Afghanistan (IN).

* President of the Mazdoor Kissan Party, Fatehyab Ali Khan has expressed surprise that the Ministry of Foreign Affairs had advised the hotels in Karachi and Islamabad to cancel the booking on 24-25 April for celebration of 10th anniversary of the Saur revolution in Afghanistan (DN).

* The Soviet pull-out should lead to a marked improvement in Pakistan-Soviet relations. Much will, howevar, depend on the conditions in which the Soviets are allowed to withdraw. The cleaner the Soviet withdrawal, the better for Pakistan-Soviet ties. The Afghan mujaheddin are reportedly planning to attack the withdrawing Soviet troops so that the pull-out is "drenched in blood". If such a situation develops, Pak-Soviet relations will be irreparably damaged. We must, therefore, use all our influence with the Afghan mujaheddin to ensure that the Soviet withdraw in peace, without let or hinderance. Huniliating a superpower is extremely dangerous and must be avoided at all costs. (Afzal Mahmood in LN). * The Canadian organization which specializes in providing medical treatment to wounded Afghans has formed a chapter in Ottawa. Previously it only had chapters in Kingston and in Toranto (PT). * The Washington Post analyzing the situation in Afghanistan has said in view of the recent important changes that have been made in the nine provinces of Afghanistan the Majib rogime is trying to make northern part of the country its last fortification, reports VOAC (MIM).

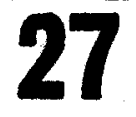

* The Uf Security Council has agreed to send a tir monitoring force to Afghanistan to supervise 
the implementation of the Ceneva accords (VOADS).

* Radio Afghanistan has reported that the Kabul government has ordered the release of all foreigners frow jail who have already served a part of their sentence (BBCFS).

* The Soviet Union has asked Pakistan to observe the provisions of the Geneva accords and do not allow subversive groups to enter Afghanistan from Pakistan (BBCF'S).

* President of the IUAM Gulbuddin Helmatyar has rejected a Kabul government proposal for the creation of demilitarized zoness along the Afghan-Pakistan border (VOCDS).

* Western diplomats in Islamabad report that the Soviet Union has been delivering substantial amount of arms to the Kabul government to enable it to resist the mujaheddin forces after the Sovlet troops withdrawal from Afghanistan (VOGCS).

* The former Afghan King Mohamad Zahir Shah has said he is not of the opinion that after the withdrawal of Soviet troops from Afghanistan a bloodbath will take place in Afghanistan. He urged an end to foreign intervention in Afghanistan after the witharawal of Soviet troops from that country (BBCFS).

* According to our correspondent, on the occasion of the condemnation of the April 27, 1978, military couf In Kabul which brought the communists in fewer in Kabul each one of the seven leaders of the IUAM have separately addressed refugees in camps which they consider their strongholds (BBCFS).

* Prof. Burhanuddin Rabbani leader of the Jamiat-e-Islami Afghanistan told refugees in the Whurasan camp that Islam does not bar women to participate in public affairs or it forces schools and universities closed. He said women and intellectuals will play a major role in the future of Afghanistan (BCCFS).

* Reuter reports from Kabul, western diplomats have noted that the participation of the Soviet representatives in the celebrations marking the anniversary of the communist takeover in Afghanistan has been at a lower level. Some analysts are of the opinion that the Soviet government is trying to dowm-grade its relations with Afghanistan to the level of relations with other third world countries (BBFS).

* As a result of cannon firing by Kabul armed forces 22 April in Bajaur Agency 7 Pakistanis were killed and 5 others injured. Similarly, as a result of Kabul tank firing, 15 April in Landikhana, one person was killed and another injured. The government of Pakistan has lodged a protest to the Charge d' Affaires of Kabul regime Embassy in Islamabad (RPDS).

* President of the IUAM Gulbuddin Helmatyar in a press conference on the occasion of the anniversary of the commuist takeover in Afghanistan said that the past 10 years in Afghanistan one lfghan has died in every four minutes, one Afghan has migrated abroad in every minute, one Afghan has become a wanderer inside the country every minute, one person has been imprisoned every 12 minutes and one person has been injured in every three minutes. In Afghanistan during this war 60\% of houses and $70 \%$ of agriculture has beendestroyed, he said (VOAPS).

* Prof. Burhanuddin Rabbani, leader of the Jamiat-e-Islami Afghanistan has said in the Khurasan refugee camp that the Russian Foreign Minister has sent letters to some Islamic personalities tinat Rusala is ready to accept any kind of government in Afghanistan and does not intarfare in afghan 
affairs and if the Afghans want the Russians to help them, Moscow would readily do so (VOAPS).

* The IUAM President Gulbuddin Hekmatyar has said ir Peshawar that the Russians owe us money and until they do not pay their debts we will not allow them to live in peace (VOAPS).

* Leader of the NLF Prof. Sibghatullah Mojaddedi says there are good poirits in the Geneve agreement such as the withdrawal of Soviet troops from Afgharistan and the decision that neither the Soviet Union nor US will interfere in the internal affairs of Afghanistan. There are also points in the agreement which are neither in the interest of Pakistan nor Afghanistan, he said (VOAPS)

* The White House 26 April described as "most unfortunate" Soviet leader Mikhail Gorbachev's reaction to a recent foreign policy speech by President Ronald Reagan: Spokesman Marlin Fitzwater said evidently Reagan had "struck a raw nerve" when he criticized Soviet policy over Afgharistalı and human rights. Fitzwater was commenting on reports that Gorbachev had complained to Secretary of State George Shultz about the speech when they met in Moscow last week (PT).

* The Nepalese government has decided to contribute soldiers to the w supervisory group in Afghanistan, the Foreign Ministry said 26 April (MIM).

* French photographer Alian Guillo, jailed here for 10 years on charges of spying, could be released soon, diplomatic sources said in Kabul 24 April (PT quoting AFP).

\section{8}

* A high ranking UN official has said the UN monitoring team, which is to be sent to Afghanistan to supervise the implementation of the Geneva accords, could be enlarged. A Finnish General is now heading the 50 member monitoring team (RPIS).

* Maj. Gen. Helminen head of the UN implementation ussiatance group who has come to Islamabad to pave the way for the implementation of the Geneva accords on Afghanistan has said the security of his team should be guaranteed by the Pakistani govermment and Kabul regime during its supervision of the withdrawal of Soviet troops from Afghanistan (RPIS).

* Raja Nadir Pervez, Minister of Interior of Pakistan, has said in Islamabad the Geneva accords are the outcome of the principled stand of Pakistan in regard to the Afghan issue and the sacrifices rendered by the Afghan people. He added unt1l the honorable return of the Afghan refugees to their country, Pakistan will continue its humanitarian assistance to the Afghans (RPDS).

* In New Delhi a large number of Afghan refugees staged demonstrations in front of the Parliament building chanting slogans against the Kabul regime and demanding the establishment of an interim government in Afghanistan (RPUS).

* An American correspondent says that a documentary film, depicting Soviet soldiers' difficulties after their return from Afghanistan, has been cancelled for being shown at the Soviet television (VOADS).

* President of the IUAM Gulbuddin Hekmatyar told a press conference 27 April in Peshawar the government of mujaheddin will soon be formed in a close area inside Afghanistan. He said the miItary committee has been ordered to draw up plans for the security of the area where the government is to be established (vOADS).

- Prof. Burhanuddin Rabbani, Ieader of the Jamiat-e-Islami Afghanistan, has said in an interview 
the people of Afghanistan will not return to their c:cintry $1, n$ fi,j 1 they bave not revdecmec thejr country from Russian cliques or their puppets (VOALi).

* Benazir Bhutto, leader of the opposition in Pakistar, has said a broadly based coalition government should be formed in Afghanistan after the withdrawel of Soviet troops so that war and fighting may be prevented in that country (VOADS).

* Mohamad Kabir, the Minister of Finance of the Kabul regime, who is now in Manila to take parst in the Asian Development Bank meetings, has said his country hopes tc procure financial aid for the refugee repatriation and reconstruction of the country (VOAPS).

* The ANS says, a Kabul militia commander Mohamnad Yousuf defected with his men 20 April to the mujaheddin. He was commanding the protection of seven major military posts between Kabul and Jalalabad (VOAPS).

* President of the mujaheddin interim govermment Engirecr Ahmad Shah has said the charter regulating the jurisdiction and work procedure of the iriterim governmerit has been approved by the IUAM Supreme Council. The charter contains 98 articles (VOAPs).

* Thousands of Afghan refugees 27 April staged protest demunstrations close to their camps and tentage villages throughout the IWFP and its adjoining tribal areas to conderm the Soviet-backed coup in Afghanistan. The meetings were addressed by the members of the Supreme Council of the IUAM separately (PT).

* Secretary General Javier Perez de Cuellar 26 April dismissed the idea that a bloodbath among warring Afghan factions will follow the withcirawal of Soviet troojs from Afghanibtan, saying faithful implementation of the Geneva accords would ensure peace (MIM).

* The head of the UN Implenuntation Assistance Group (UNIAC) Major General Helmirien called on the Minlster of State for Foreign Affairs Zain Noorani in Islamabad 27 April (MIM).

* Pakistan Federal Minister of State for Interior, Raja Nadir Pervez said that Pakistan vill not push back Afghans into their country and will continue its hospitaljty till their safe and honorable return was ensured (MIM).

* A spokesman of the Supreme Council of IUAM Mawlawi Sarfraz President of Sout Western Afghan Provinces Zone told a press conference in Quetta 27 April the Geneva accord was not at all acceptable to anyone of the components of the Afghan seven party alliance and as such the Afghancrusade would continue until the complete evacuation of the Russian army from Afghanisten, termination of Najib's puppet govermment in Kabul and evolution of a true Islamic and independent state of Afghanistan (MIY).

* A Eussian $f l a g$ and effigy of the Soviet leader Gorbachev, were burnt at Karachi 27 April at the conclusion of a protest meeting of Afghan refugees at the Super Highway as a mark of resentment against the Geneva Accords and the Seur revolution (MIM).

* The ANP Pashtunkhwe President Mohammad Afzal Khan has alleged that Pakistan government had violated the Geneva accord soon after its signing by allowing the Afghan resistance groups to hold public rallies on Its soll against the Afghan government (MIM).

- 4 protest rally was staged by Jamiat-0-ULema-e-Islam of Baluchistan to mark 27 April as Black Day" in Afghenisten and to demonstrate its solidarity with mujaheddin (MIM). 
The Pakistan Ambassador at the UN Shah Nawaz met 28 April Perez de Cuellar, the UN Secretary General to discuss issues related to the Geneva accords and withdrawal of Soviet, forces from Afghanistan. During the meeting the UN Secretary General's Assistant Diego Cordovez was also present (RPLS).

* A Swedish government authority says that the governmerit of his country has nominated four military officers to participate in the monitoring operation for Sovlet troops withdrawal from Afghanistan. Issues related to arrangemerts for the repatriation of Afghan refugees are also related to this group (RPDS).

* Benazir Bhutto leader of the PPP says she hopes the United States and Pakistan will be able to evolve some kind of agreement between the various organizations of the Afghan mujaheddin before they start fighting each other. She said it is feared trat the mujaheddin groups might fight each other for occupying Kabul (VOADS).

* Dr. Najibullah, Presicent of the Kabul regime says Soviet advisers will stay with Afghan armed forces after the withdrawal of Soviet troops from Afghanistan (BBCDS).

* An agreement was signed in Geneva between Afghanistan and UNHCR for the establishment of a UNHCR office in Afghanistan in order to facilitate the voluntery repatriation of the Afghen refugees to their country (RA).

* A deputy of the information department of the Soviet Ministry of Foreign Affairs has told a news conference that the AP, quoting an official American spokesman, says the US government has begun emergency shipment of arms to the Afghen mujaheddin to replace the arms lost as a result of explosion in a Pakistani military depot (RA).

* President Najibullah of the Kabul regime in a news conference expressed confidence that with the withdrawal of Soviet forces from Afghanistan no changes will occur in Afghanistan. He sald that government authorities have the situation under their control (Rups).

* A delegation, comprising of the ambassadors of Federal Republic of Germany andGreece, Charge d Affaires of Dentrark and head of the commission of EBC 28 April called on the IUAM President Gulbuddin Hekmatyar and assured him of recognizing the mujaheddin proposed interim government to be established in Afghanistar after the withdrawal of Soviet forces (MIM).

* The IUAM sources say Gulbuddin Hekmatyar, President of IUAM in a meeting with the Swedish Ambassador in Pakdstan and the Finnish Ambassador in Iran said that mujaheddin were not obliged to support the UN observers in their. task as they were not a party to the Geneva accord. He has said the observers were welcome as guests of the IUAM while travelling in Afghanistan and the mujaheddin would guarante their safety in that case. He however, explained that rujaheddin were cormitted to attacking the Sovitet troops ever while they withdrew from Afghanistan and they should not be held responsible if UN observers accompanyirg Soviet and Kabul regime convoys got hurt in such attạcks (MIM).

* The leader of PPP Benazir Bhutto, has said that the Genevi accord on Afghanistan was faulty and insufficient from Pakistan' point of view (DN).

* The Supreme Council of the IUANi held a session 28 April at the IUAN headquarters with Guituddin Hekmatyar in the chair. At the end of the meeting the following decisions were announced: 
- - As upon the withdrawal of the Russian forces most of the important areas will fall into the mujaheddin hands, t.o expedite and launch coordinated mujur.ecicin's attack and boost the morale, leaders of the IUAM Supreme Council will proceed into Afghanistan to specified areas and all the mujehedin jrtisent ir. particular areas will come wider the commerid of these leaders. The areas cannot be disclosed for security reasons.

- - Twelve ministers will be commissioned very soon. The regulations of these mintsters are being worked out by ad hoc comnission blready set up for this puryise.

- The election comilission has been assigned to elect local councils at the district level so that each district gets its elected Sub-Governor (Hakem) and each province has its elected Governor (Wali). - The Jolnt militery connission has becn asked to coorelinate affairs and ensure the security
of areas which the enemy cuits under duress (MIM).

* A well-known mujaheddin commender Mawlawl Jalaluddin Haqgani has suggested that the proposed Interim goverminent shoulc not be confined to one particular area in Afghanistan but ought to be
mobile (MIM).

* A UN tean under the leadership of Maj. Gen. Helminen left for Kabul today to hold talks wtth the Kabul regime authordties on the implementation of the Geneva accords on Afghanistan (RPDS). * The Us has questioned the Kabul regime remarks that Soviet military advisers will remain in Kabul after Soviet troops withdrawal from that country. A state department spokesman in Washington aaid logic wes that the advisers should leave Afghenistan together with the Soviet army (RPDS). * The office of the President reports that President Najibullah is to pay an officiel visit at the head of delegation to India in the first week of May at the invitation of the Indian govermment (RA).

- A Deputy Minister of the Soviet Foreign Ministry after talks with the British Forelgn Secretary and Assistant US Secretary of State has said In Iondon the Geneve agreement on Afghanistan is con sidered as a progress towards colving regional 1osues (RMDS).

* Sovlet newspaper Pravda has praised the Geneva accords on Afghanistan for solving the political 1soues around Afghanistan as a progress towards solving nost complicated regional issues of modern times (RMUS).

* The Guardian (London) reports from Kabul a Kabil Untyersity Professor has said the non-party people of Afghanistan will be able to bring about a real reconclliation between the Kabul regime, the mujaheddin and refugees (BBCFS).

* The IUFC President told newamen 29 Apmil that at least one million Afghans have been displaced 
from their villages and homes inside Afghanistan and they, too, will need assistance after the Sovlet troops withdrawal from Afghanistan (VaAPS).

* One minor girl was killed and another person injured, and six houses were partially damaged when Afghan refugees shelled and rocketed Sateen village in Lower Kurran Agency 29 April (MIM). * Afghan Prime Minister Sultan Ali Keshtmand will probably be replaced in a major cabinet shakeup when the National Assembly me:ts next month, officials and diplomats said in Kabul 28 April (PT)

* Members of Afghanistan's Soviet-backed ruling party are worried about what will happen after Soviet troops leave the country this year, the newspaper "Pravcla" said 28 April (PT).

* Defections of the Afghen troops continue and they are joining the mujaheddin as the date for the pullout of the Soviet troops is drawing nearer (PT).

* The ANP 28 April might brought a big torch light procession in Peshawar to celebrate the signing of Geneva accord and call for its implementation in true spirit (MLM).

* Ghulam Mustafa Jatoi, Chairman of the NPP has proposed a 3-year arm cut-off pledge by the US and the USSR to mujaheddin and the Najib government to ensure peaceful conditions and return of lighan refugees now staying in Pakistan (Mivi).

* "There is a humch that ofter the Soviet forces' withdrawal, New Deind may help the PDPA regime in more ways than one. It may ask 4,5,000 Afghans of Indian extraction to actively heip the Najib goverment, concentrate forces on Pakistan's borders and supply arms to Kabul if the Soviet Union and the US agree to stop supplites of arms to their allies in Afghantstan. The post-Genevi agreements scenario may well, in certain circumstances, be similar to what existed in the days of 2ahir Shah 1.0. Afghanistan and India acting in collusion against Pakistan "To forestall this possibjifty and also to enstre smimoth implementation of the Geneve agreementa Jal amabad should conslder the advisability of arriving at on understending with Moscow (Ahsan Ail than in DV).
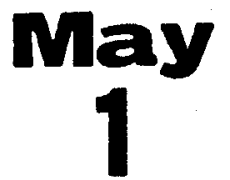

* The Afghan Islamic News Agency has quoted a Kabul regime military commander as saying if the Russians left Afghanistan, the Kabul army will foll apart and the mujaheddin will take over everything (VOADS).

* President of the UN goodwill mission in Afghanistan and Pakistan Maj. Gen. Rauli Helminen, who is now In Kabw, has sairi he has already established an ciffice in the Afghan capital and his team will travel to various parts of Afghanistan under the protecticn of the Afghan almy (RFIS).

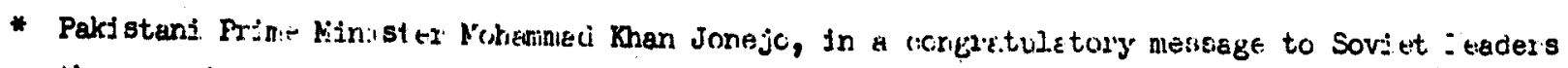
on the occasion of the LOth anniversary of the establishment of relations between the two countries, has called the Geneva agreement as an important step towards the realization of peace in. Afghanistan (RPLS).

* A politicel advisor of the leader of the UN operation team for supervizing the Geneva agreement said in Kabul 1 May that the main perties to the agreement are the parties thenselves. Our duty 10 to oupervize the implementation of the accords and to look in to the claims of violations of 
the agreements and also supervize the return and repatriation of the refugees (RA).

* A UNHCR authority has urged join international action for the repatriation of about 7 million Afghan refugees inside and outside the country who have been dislodged during the seven years old war in Afghanistan (BBCFS).

* The Los Angeles Times wrote 27 April, while only three weeks are left for the Soviet Union to begin the withdrawal of its forces from Afghanistan, Soviet media is now publishing material which admits the failures of the communist revolution in Afghanistan (VOAPS). * A reporter of the Los Angeles Times says the President of the democratic movement of the Afghan Youth of the Kabul regime Farid Mazdak in an interview publish in Moscow 26 April has said the PDPA government failed to unite the people of hfghanistan under the slogan of revolution but, according to him, the government will be able to unite the people under the banner of peace

(VOAPS).

* Former Afghan Prime Minister Dr. Mohammad Yousuf has said in an interview that, despite many shortcommings the Geneva agreement has, the accords ought to be welcomed because this is the only means which leads to the withdrawal of Soviet forces from Afghanistan and restoring the political incependence and territorial integrity are the national objectives of the Jehad (VOAPS). * Benson Sevan, Senior Political Aciviser to Diego Cordovez, the representative of the UN Secretary General on Afghanistan and a member of the UN good offices mission in Afghanistan and Pakistan, flew to Kabul 30 April after a five day stay in Islamabad (MLM).

* The mujaheddin of seven-party Afghan alliance launched an attack on a mjlitary convoy moving along Kabul-Kandahar highway near Gailan town, as a resuit of which heavy loss was caused to the troops and a Soviet helicopter providing air cover to the convoy was shot down (PT).

* Pakistan and other influential nations must encourage formation of a stable, broad based govermment in Afghanistan or that country could turn into another Lebanon, Pakistan opposition leader Benazir Bhutto has said (MIM).

* The Jemiat-a-Islani has clarified that its commander for Herat and southwestern hfehanistan Islamil Khan had granted a general amensty to the members of the PDPA regime on the instructions of the party leader, Prof. Burhanuddin Rabbani (MIM).

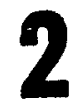

* The UN goodwill mission headed by Maj. Gen. Rauli Helminen has begun its talks with the Kabul regime authorities on providing the logistic for the implementation of the provisions of the Geneva accords (RPDS).

* The Charge d' Affaires of the Kabul regime in Islamabad was summoned 1 May in the Foreign Office and handed protest note about bombardments by the Kabul regime on a number of areas in the Kurram and Khyber agencies (RPDS).

3

* President Najibullah met 1 May with officers, military and political graduates who have recently returned from the Sovilet Union and urged them to convert the armed forces into a trustworthy defense shield for the gains of revolution (RA).

* According to a proposal of the Councll of Ninisters, Abulul Rahim Karwar has been appointed as 
the Minister of Transport and Fateh Mohammad Karim as the Minister of Light Industries and Foodstiff (RA).

* The Vice President of the State Committee of hydrometeorology in the field of ecology of the

Soviet Union arrived in Kabul 1 May for official talks about signing a protocol and extending aidin-grant by the Soviet Union tc the Department of Hydrometeorology (RA)

* The blue prints of construction of motor roads in the country until the year 2000 prepared by Soviet experts have been harded over to the Afghan side. The budget for this project has been estimated at Afs. 3.15 billion (RS).

* Pakistan says, last week Kabul artillery, by shelling positions inside Pakistan from inside Afghanistan, killed ạt least 13 peoples (VOABS).

* Haji Din Mohammad deputy leader of Hezb-e-Islami (Khales), who was present when the communists evacuated the Barikot cantonment in Kunar, has sai that the cantonment was evacuated as a result of mujaheddin pressure. He hoped other communist bases and centers will also be evacuated in the face of mujaheddin pressure (VOADS).

* A Washington Post reporter from Kabul says those who anticipate the downfall of the Kabul regime in a short time, argue, when the Afghan provinces are liberated from the regime, all roads. leading to Kabul will be under mujaheddin control and then the mujaheddin will paralyze the Kabul airport with the Stinger and Blow pipe rockets and at that time Najib will sincereiy negotiate for his life but he will be acturlly signing his own death writ (VOAPS).

* The Afghan Information and Documentation Center says the mujaheddin of the Harkat-a-ingelabmeIslami of Mawlawl Nasarullah Mansoor in their operation against a Kabul regime center 14 and 17 April kllled 28 militiamen and injured 45. Eleven mujaheddin were also martyred and five injured

(VORPS).

* A source, belonging to commander Jalaluddin Haqqani, says the mujaheddin have taken over three security posts built to protect military convoys. In the operation for capturing the posts, 70. government soldiers were killed or injured and the musaheddin recovered large quantities of arms and ammunition (VOAPS).

\section{- 10}

* President Ziaul Haq of Pakistan met 3 May Indian Foreign Secretary K.P.S. Menon in Islamabad and discussed with him regional issues including Afghanistan and the signing of the Geneva agreement (RPDS).

* K.P.S. Menon, the Indian Foreign Secretary held talks 3 May with Pakistani Minister of State for Foreign Affairs, Zain Noorani about normalizing relations between the two countries and the background of peace in Afghanistan (RPDS).

* Mohamad Hassan Sharq, Deputy Prime Minister and President of the Committee of Refugees returning home met 3 May with Gen. Rauli Helmenin, President of the UN goodwill mission for Afghanistan and Pakdistan about measures adopted for the return of refugees. He also met Gen. Mohamad Rafi,

Minister of Defense. Gen. Rafi assured the delegation about the Implementation of the Geneva agreo ment (RA). 
* Nohamad Zahir Shah, the former King of Afghanistan, has said the time has not reached for him to speak of his return to the country. In an interview with a West German newspaper he sald he wanted to retum to the cointry but a date for doing so did not depend on him (BBCFS).

* A representative of the UNHCR has emphasized, centers should be established for the refugees who are returning to Afghanistan and these centers should be able to provide rations for food and other commodities needed by the refugees (BBCFS).

* Sayyed Noorullah Emad, deputy leader of the Jamiat-e-Islami says in an interview that he can never think of a situation that the mujaheddin would fight each other to capture power after the withdrawal of Soviet forces from Afghanistan and the downfall of the Kabul regime. He said all resistance commanders inside Afghanistan will vigilantly follow the conmand of the provisional government of the mujaheddin (VOADS).

* The Afghan resistance is believed to have asked the US and other Western countries to recognize a provisional govermment headed by Engineer Ahmed Shah and close down their missions in Kabul, diplonatic sources said in Islamabad 2 May (KIM).

* The Afghan armed forces fired 26 rounds of mortar on 27 April which landed in Landi Knana, Mhyber Agency. As a result, nine persons were killed including one Pakistani child and eight Afghan refugees and 14 injured, including three Pakistan nationals and 11 Afghan refugees. Mounutile, three Afghan fighter aircraft violated Pakistan alr-space 25 April and dropped four bombs in areas about two kilometers west of Terl Mangal in the Kurram Agency. As a result four Afghan refugees were killed and three injured (PT).

* Maj. Gen. Rauli Helminen, head of the UN mission helping with the implementation of the Geneva agreement has said $2 \mathrm{Kay}$, Pakistan is determined to observe the Geneva accord providing for a pullout of Soviet troope from Afghanistan (PT).

* (In the process of signing the Geneva accords) unfortunately Pakisten has succumbed to superpower pressure. Both the superpowers achieved their goal. The Paldstan government has shown lack of imagination that is going to cost the country, the region and the entire Muslim world. There is going to be bloodshed and chaos in Afghanistan before final victory of the mujaheddin which is destined to be achieved Insha Allah. The government should not take any steps which may jeopardise the goodwill that has been built among the people of Pakdstan and the Afghans (Israr Mhan from Ialamabad in letter to the editor, NIM).

* The Guardien has said Mazarme-Sharif is being converted into a safe shelter for Najibullah's regime in case the mujaheddin occupy Kabul (MIM).

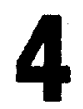

* The Kabul government representative at the UN has asked economic assistance for the reconstruction of Afghanistan after the end of war in that country (BBCFS).

* President Ziaul Haq of Pakdstan has said the signing of the Geneva agreement will effectively help in the consolidation of relations between Pakistan and the Soviet Union (BBCFS).

- The Independent (London), quoting its correspondent, says India never publicly criticized the presence of Sowlet troopo in Afghantstan and it is expected that President Najibullah in his 
struggle against the mujaheddin in the future will ask for substantial ald from India (BBCFS). * Afghanistan has proposed a new issue under the title of economic and social process of Afghanistan in the agenda of the new session of the Economic and Social Council of the UN which began in NY 3 May (RNDS).

* A Paldstand Forelgn Ministry official told : newsmen in Islamabad there were no signs that the Kabul govermment has stored foodstuff or medicine for the refugees or have provided housing for them. The spokesman emphatically rejected the issue of assistance to the refugees through the Kabul regime (VOADS).

* A Pakistan Forelgn Ministry spokesman said 4 May since the Geneva agreement's implementation is going to begin in 11 days time, Pakistan has urged spead in the process of the formation of a broadly based interim government so that the refugees w1ll be able to return to their country (RPDS).

* President Najlbullah arrived 4 May in New Delhi at the invitation of Indian Prime Minister Rajiv Gandhi. The Indian Foreign Minister Natwar Singh met him at the alrport (RA).

* President Najibullah, whije his plane overflying Pakistan on route to India, in a message to President Zlaul Haq of Pakistan expressed hope relations between the two countries will devalop and consolidate after the Geneva accord on the basis of friendship and good neighborlines for the interest of peace and stability in the region anc the world (RA).

* The Pakdstand Charge d' Affaires was summoned 4 May to the Foreign Ministry and told that claims by his government that the Afghen amed forces have shelled some territories of Pakdaten were without any foundation (RA).

* The ANS quoting IUAM sources says that deputy luader of the Mawlawl Khales and Hekmatyar groups - - Din Mohamad and Obaidullah - - have been appointed as two new vice Prealdents of the provislonel government (VOAPS).

* The ANS says the President of the mujaheddin provisional govermment Engineer Ahmad Shah met 2 May a number of ambassadors and ministers of the mujaheddin government (VOAPS).

* Former Afghan KAng Zahir Shah was quoted 3 May as saylng the monarchy could not be restored in his country but he indicated he might be prepared to return as a provisional Presicuent (KIM). * Zain Noorant, Pakistan Minister of State for Foreign Affairs is to visit Moscow 9 May. This will maxk the first high-level contact between the two countries since the signing of the Geneva agreement on Afghanistan (MIM).

* Amnesty International in a report released 3 May has accused the Sowlet Union and the Koscowbecked Kabul regime of comnittirg torture and unlawful killings of innocent civilians in Afghan1sten. The report says during 1987-88 serious violations of human rights were committed by the Sovlet and Afghan troops (MIM).

* The President Gen. Mohammad 2laul Haq of Pakistan has said that the credit of signing of Genova agreement would not $g \circ$ to anybody else but to Soviet Leader Mikhall Gorbachev. He made the renarks at an Iftar reception 3 May in Islamabad.

* One must not forget that the Soviet withdrawal (from Afghanlstan) will be followed by continued 
war between the mujaheddin and those whom the predecessors of Mikhail Gorbachev installed in Kabul. Both the Soviet Union and Pakistan had apprehended that there might be a let-up of the war. It was for this reason that the Soviet Union should have established some rapport with the mujaheddin. It did not, the result is that the Soviet union will not be able to leave Afghanistan with a good conscience. The victims of the Soviet miljtary adventure in Afghanistan - - millions who died and millions who are uprooted - - will always remain a part of Soviet conscience and also of Soviet history (Ibnul Hasan in PT).

\section{4}

* The New York Times says some Indian ofilicials are of the opinion that if the Najibullah regime did not compromise with its opponents, his government will not last until the end of the year. The newspaper adds India at the same time wants to reduce the chance of a capture of power by the fundamentalists in Kabul (VOADS).

* Maj. Gen. Rauli Helminen, President of UN goodwill mission for the implementation of the Geneva accords on the withdrawal of Soviet troops from Afghanistan has completed his visit in Kabul

(RPDS).

* Six Ghanian military officers, who are to be part of the UN observer's team in Afghanistan, have left Ghana for Afghanistan (RPDS).

* Senator Daniel J. Evans of US visited 5 May an Afghan refugee camp in Katcha Garhi in Peshawar. * President Najibullah of Afghanistan discussed in New Delhi with Indian Prime Minister Rajiv Gandhi Afghan-Indian relations, regional and international issues (RMDS).

* Foreign Minister Abdul Wakil met 5 May Natwar Singh the Indian Minister of External Affairs and explained steps being taken for the realization of the NRP and the economic reconstruction of Afghanistan. India reiterated its readiness to take part in the reconstruction of Afghanistan

* The people and the Jamiatul Ujama of the Khyluer Agency have congratulated Fresident Naj1bullah on the occasion of the 10th anniversary of Saur Revolution (RA).

* Maj. Gen. Rauli Helminen, leader of the UN goodwill mission in Afghanistan and Pakistan left Kabuf 5 May for Islamabad via New Delhi (RA).

* The Refugee Administration has so far established more than 300 centers along the borders for receiving refugees and 10,000 refugee compatriots are being received daily in these centers and guest houses (RA).

* President Najibullah of the Kabul regime reiterated his call upon the opponents of his regime to hold talks with him on the formation of a new government in Kabul. He said a loya jirgah will be convened in Afghanistan to decide about the formation of a government after the withdrawal of Soviet forces from Afghanistan (VOADS).

* Leader of ANP Khan Abdul Wali Khan has called upon the government of Pakistan to implement the Geneva accords without creating any hindrances (VOAPS).

* Leader of the JI Qazi Hussain Ahmad has rejected the idea of the return of the Afghan refugees to their homes on the basis of the Geneva accords. He says, until the war is ended and peace and 
order restored in Afghanistan, the refugees will not return to Afghanistan (VOAPS).

* A Pakistani Foreign Ministry spokesman has said India should not have invited Najibullah to pay a visit to India. He said the govermment of Pakistan does not recognize the Najib regime and expects India not to hold relations with that regime.

* President Najibullah of Afghanistan has said in New Delhi the govermment of Afghanistan is ready without preconditions to call upon all the opposition whether in Pakistan, Rome, London, Bonn, USA, or anywhere else they may be, to attend a nationwide peace jirgah for solving the internal aspects of the Afghan problem (MLM).

* The IUAM President Gulbuddin Hekmatyar has said in Peshawar Afghan refugees will not go back until conditions for their repatriation are made satisfactory in Afghanistan (MIM).

* The JI Chief Qazi Hussain Ahmad alleged in a press conference 4 May that the US and the Soviet Union had conspired to thwart the establishment of an Islamic government in Afghanistan at the hands of Afghan mujaheddin (MIM).

* A new Afghan refugees group styling itself as Jehad Fee Sebeellullah" has announced it would hold rallies beginning next month at Thall, Quetta and Kandahar to prepare the ground for holding an Islamic loya jirgah (MLM).

* The moment a mujaheddin provisional government is established in any aree of the $80 \%$ territory which the mujaheddin control inside Afghanistan, the government of Pakistan should announce its official recognition. Pakistan, by taking such an initiative, will not only encourage other friendly countries to the mujaheddin to recognize their provisional government, but, under present circumstances, will be able to provide arms to mujaheddin as it will not be provided to a rebel group - - an act banned under the Geneva accords - - but the arms will be sent to a legally recognized government ( $Z$.A. Sulheri in JG).

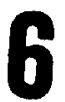

* Pakistani Ambassador at the UN Shah Nawaz in a letter to the UN Secretary General has said a letter to the uN by the Kabul regime on the economic reconstruction of Afghanistan is premature adding that such moves will complicate UN efforts for creating a government acceptable for all parties concerned with the Afghan issue (RPDS).

* India and Afghanistan have signed an agreement on Indian economic assistance to Afghanistan and permitting the export of Indian consumer goods to Afghanistan (BBCFS).

* President Najibullah of Afghanistan, who had gone to India at the head of a high ranking delegation at the invitation of Indian Premier Rajiv Gandhi for an official and friendly visit, ro turmed to Kabul 6 May (RA).

* TASS says a photographer working for The Izvestia newspaper has been killed recently in Afghanistan (BBCPS).

* Renowned Paktia commender Mawlawi Jalaluddin Haqqani has said in an interview he will accept 
any decision by the mujaheddin leaders which is not against Islam. He has said we have not fought for power and positions. He says he is not supporting the idea of a coalition govermment and he also rejected the return of former King Lahir Shah (VOAPS).

* Leader of JI Qazi Hussain Ahmed has said that in the near future an Islamic govermmerit which will be a friend of Pakistan will be established in Afghanistan and Pakistan westerı borders will te become secure. He added such a development was not acceptable to India and it has been for this reason that India asked Najib to visit India (JG).

* Pakistan has firmly but politely turned down India's offer to play a mediatory role in promoting a coalition govermment in Afghanistan. Informed sources in Islariabad say during his recent visit to Islamabad K.P.S. Menon the Indian Foreign Secretary, conveyed to the Pakistan authorities, Delhi's desire to play such a role. But the Indian official was told that Pakistan could not join India in any such effort (MLM).

* Mikhail Leshchinsky, Soviet television's correspondent in Kabul, says he is expiating the guilt of joumalists, including himself for whitewashing events in Afghanistan before the era of Glasnost (PT).

* The British government has promised further assistance for the Afghan refugees and British Secretary for Overseas Developnent, has appealed to the western countries to provide generous aid for rehabilitation of Afghan refugees (PT).

* The following are highlights of an interview with Prof. Burhanuddin Rabbani, leader of Jamiate-Islemi.

- While rejecting the Geneva accords he observed that "each nation knows its own national interest the best",

- Emphasizing the need for an end to the war, he said "we want a new phase in our relationship with Russia to be opened",

- Speaking on his recent visit to Iran he disclosed that Iran, while rejecting the Geneva accords, had assured him that "our doors are open for you" and that "any time you want to come in Iran you are welcome",

- On the possibility of taking up arms against former King Zahir Shah, if he decided to return to Afghanistan, Rabbani said it was improbable he would do so, adding that as a rule we do not want to fight with our own people (MLM).

* Four Pakistan joumalists who wanted to participate in the Saur revolution celebrations could not make it to Kabul because the road at Torkham was blocked by the mujaheddin andof war conditions in the border province of Nangarhar. The authorities admitted that travel was not safe (MLM).

* Two British newspapers - - The Independent and The Time - - said 4 May India is making futile efforts to play a role in the Afghan affairs (PT)。

* A team of Indian experts is likely to visit Afghanistan soon to assess anu evaluate as to what India could do for the national reconstruction of that country (PT).

* The IUAM has decided to contact political parties in Pakistan to explain its position about the latest developments in Afghenistan (MLM). 
* Three small Afghan refugee girls sustained injuries when the bomb which they had found earlier while taking bath in the Kabul river near Michni in Peshawar District exploded after it was tempered with (MLM).

* The US government has said the government of Najibullah has lost its credentials and in no way represents the people of Afghanistan (BBCrs).

* Former Afghan King Mohamuad Zahir Shah has reacted coolly to a proposal by Dr. Najibullah about the formation of an interim government by saying the problem is not to share power but there is a need for a global solution of the Afghanistan issue acceptable to the Afghan people (BBCFS).

* Sayyed Qasim Shah, Federal Minister of Pakistan responsible for the Afghan refugees said 7 May the Federal govermment is working together with a number of international agencies on the cost of the return of Afghan refugees to their country (RPDS).

* Maj. Gen. Rauli Helminen, leader of the UN goodwill mission who has returned from Kabul to Islanabad, says he foresees no difficulties about the Afghan issue (RPIS).

* The cornerstone of a television station was laid in Qala-0-Nau, Badghis, 7 May. The construction is being built through direct cooperation of the Turkmanistan Republic of the USSR (RA).

* An official of the refugee repatriation administration has said the government has transferred through this office Afs. 50 million tio the Ministry of Civil Aviation for the return of refugees

* Afghanistan and India have strongly urged signatories of the Ceneva agreement to respect the provisions of the agreement and help Afghanistan in strengthening the sovereignty and independence of the country (RA).

* The PTI reports the Palistani opposition parties have accused the US and Afghan opposition parties of being responsible about the explosion in a weapons depot in Islamabed and Rawalpindi (RA). * The Pravda in a report fror Kabul says the commander of the limited contingents of Soviet forces in Afghanistan in an interview has said Soviet units will help the Afghans in compensating for the agonies and damages of the war (RMDS).

* The Refugee Studies Program in Oxford, England has wamed, if aid giving countries are to preserve their credibility among the Afghan refugees, they should exercise caution in establishing any kind of relationship with Najibullah governsient (BBCFS).

* The US has refuted rumors that the US is prompting the Afghan mujaheddin to establish a provisional govermment inside Afghanistan (VOAPS).

* The New York Times, quoting a State Department official, says the US government has told the mujaheddin if they established their control over major portion of the country and if they are able to meet their international obligations, the US will support them in their effort for establishing an interim govermment (VOAPS).

* Afghan resistance sources in. Peshawar say the provisional gavernment of the Afghan mujaheddin met 7 May in the IUAM headquarters and considered the reports prepared by the delegations sent earlier to locate an appropriate venue for the provisional government inside Afghanistan (VOAPS). 
* India's role in Afghan dispute is not positive, said voG while commenting on the head of the Kabul regime, Dr. Najibullah's visit to New Delhi (PT).

* Indian Premier, Rajiv Gandhi said 6 May that he had accopted Dr. Najibullah's inivitation to visit Afghanistan (PT).

* The head of the UN mission, mon:toring the Soviet pullout from Afghanistan, said the Geneva agreement on the withdrawal. could be ruined unless there were safety guarantees for his team (PT).

* The UN mediator Diego Cordovez said 6 May he was "deeply committed" to help promote a "broad based government" as Soviet troops withdraw from Afghanistan. "This is a period of reflection but all Afghans should be encouraged to intensify consultations and negotiations among themselves", Cordovez said (MIM).

* Kabul government leader Dr. Mohamnad Najibullah announced 6 May that he was inviting former King Zahir Shah to join in a coalition government in Afghanistan, BBC reported (MIM).

* Return and resettlement of Afghan refugees from Paikistan will cost between $\$ 200$ and 300 million, a senior UN officials aid Geneva 6 May (MIM).

\section{8}

* Najibullah leader of the Kabul regime, before Leaving New Delhi said he will not pardon the two European Journalists who are in prison under the charges of spying because they had entered Afghanistan illegally and had interferred in the Afghan conflict (VOADS).

* Fateh Mohammad Fekri a Commandor of the NLF has said that he and his cousin had, under a scheme approved by Prof. Sibghatullah Mojaddedi, leader of the NLF, handed over themselves to the Kabul comunist authorities and as a result of this"we were able to rejoin the NLF with 600 people of our tribe with their arms and to again continue our jehad against atheism" (VOADS).

* Pakistan lately has clained that the Afghan side has not taken necessary measures for providing facilities for the return of reiugees to their country. The Afghan Foreign Ministry spokesman says that these claims by Pakistani authorities, ained at mis] eading public opinion, are tantamount to creating obstacles in the way of the return of refugees to the country (RA).

* Zain Noorani, Minister of State for Foreign Affairs, has said by "flirting" with Afghan leader Dr. Najibullah and trying to boost him, India has itself ruined its chances of playing a role in the future of Afghanistan (MIM).

* Eight Afghan planes reportedly violated Pakistan's airspace 6 May. Bombardment was reported from Bara Fort, Kandao and Zwar areas. No loss was reported (PT).

* Former NWFP Governor Lt. Gen. (Retd) Fazle Haq has said Pakistan should support those Afghan elements who could ensure friendly relations between Kabul and Islamabad (MIM).

* Abdul Rajak Essaied, head of the UNHCR's Micidle East office in Bahrain has said the Afghan mujaheddin are not recognized as refugees under the UN sponsored truce signed last month (MIM).

* Radio Teheran says the Soviet Union is trying to use its array to strengthen the position of Kabul regime in northern provinces of Afghanistan. The radio, quoting western diplomats, said the Soviet Union has decided to use its troops in northern provinces of Afghanistan along the Soviet border if the Kabul regime failed in consolidating its positions in Afghanistan after the withdra- 
wal of Soviet troops (PT).

* Answering a question regarding recognition of the interim mujaheddin government by the US, the Prime Minister of the proposed mujaheddin interim government in Afghanistan, Ahmad Shah has said the issue largely depended on mujaheddin's gaining extersive popular support and demonstrating that they are capable of running a government (DN).

\section{9}

* Political leaders of the Christian Democratic Party and Social Democratic Party in West German Parliament say West Germany shovild help the Afghans in their effurts towards the reconstruction of the country after the withdrawal of Soviet forces from ifghanistan (VOGDS).

* General Rauli Helminen head of the UN monitoring team for the implementation of the Geneva accord has said in Islamabad he is still busy at establishing communication facilities for monitoring the withdrawal of Soviet forces from Afghanistan. He added so far an exact figure for the number of Soviet troops in Afghanistan has not been given to him (RPDS).

* French newspaper Le Monde in an articles says the downfall of the Najib Soviet puppet regime in Kabul is related to the kind of fate Moscow has in mind for Najibullah. If the Russians feel that Najib is in a position to control the situation, he will enjoy receiving modern weapons and assistance from the Soyiet military advisers (VOADS).

* Rustam Shah Mohmand, Pakistani High Commissioner for the Afghan refugees, has said Pakistan is spending large sums of money for maintaining the Afghan refugees in this country.He said 16,000 Pakistani officials are looking after the Afghan refugees meeting their needs and requirements

(RPDS).

* In a symposium held in New Delhi under the title of "Indian peace initiative about Afghanistan" it has been emphasized that India should extend necessary political and economic assistarice to the Afghan government (RA).

* In Uzbekistan of the USSR preparations are being made to welcome the Soviet forces whose return from Afghanistan will start icven days l'rom nlow, i.e.., 1t; Mày (RMUSi).

* The Afghan Embassy in London has termed a report issued by Amnesty International on human rights violation: in Afghanistan as politically motivated and provocative (BBCFS).

* The Christian Science Monitor (USA) reported 9. May sources close to the American government say Afghan mujaheddin commanders inside the country, including the famous commanders, have coordinated their activities in a way so as to occupy important cities and military bases one after the other following the withdrawal of Soviet forces from that country (VOADS).

* The Christian Science Monitor reports from Peshawar, with preparations underway for the withdrawal of Soviet forces from Afghanistan, mujaheddin commanders inside the country will assume important role in future developments of the country and their role in the Afghan events will be the determining factor (VOADS).

* President of the IUAM Gulbuddin Hekmatyar said in Peshawar 8 May in a meeting that the Afghan jehad was in a satisfactory condition and the mujaheddin are conpletely confident about the future. He said the mujaheddin have scored major victories in recent days (VOAPS). 
* The head of the interim government of Afghanistan Engineer Ahmad Shah in a meeting in Peshawar, attended by leaders of the mujaheddin and leaders of a number of Pakistani political parties, while talking about the Afghan situation said the liussians have been defeated in the battle field. However, they do not stop their hypocracy adding that the jehad will ultimately succeed and an Islamic government will be established in Afghanistan (VOAPS).

* After the signing of the Geneva acconds there has been a sharp rise in the price of arms at Darra Adankhel, near Peshawar. This price hike is one indication that the Afghan issue is far from settled (MIM).

* The IUAM Chairman, Culbuddin Hekmatyar, while strongly criticising New Delni's invitation to Najitullah to visit Inclia has warned New Delhi to refrain from taking an action in Afghanistan similar to its military intervention in Sri Lanka (MIM).

* About 10 Afghan fighter planes once again violated Pakistan's airspace 7 May (PT).

* The Politburo of the ruling PDPA includes 18 members, four of whom are alternate members. An overwhelming majority of the Politburo members (15) are Pashtuns while two are Tajik and one is a Hazara. There is no Uzbek, Turkman, fijmaq, Arab, Nooristani, Kirghiz, Wakhi, Pashai or members of the remaining nationalities or minority ethnic groups which abound in Afgharristan. As many as 13 Politburo members belong to the erstwhile Parcham foction of the PDPA while the remaining seven are Identified with the Khalq. There is no woman in this Politburo presently (Rahimullah Yisufzai, in VIM).

* The prospect of peace in Afghanistan seems to be as far away as it ever was. Moscow's retreat from Afghenistan which is motivated by a global shift in the Russian strategy, will be the onily solid achievement of the accord. The iriterim coalition government comprising the two hostile groups, PDPA and the mujaheddin, even if set up, will be as much of an anomaly as was the CongressLeague interim government of 1946 in India and may meet the same fate to avoid a ferocious civil war or a partition of Afghanistan about which there is more than a hint ir political circles (A.M. Sadullah in DN).

* Mir Ghous Bakhsh Bizenjo, President of PNP 8 May warned of an "International conspiracy" to partition Afghanistan in a bid to establish an "imperialist base" at the backyard of Pakistan (DN). * Islamic Association of Afghan Students (IAAS) in Karachi, has warned India that since somcalled superpower could not succeed to defeat the Afghan mujaheddin, the Indian army will not be able to prolong the last breaths of the puppet govermment in Afghanistan even for a second (IN).

* Ial Gul commander of Hezb-e-Islami of Yunus Khales said the fall of Barikot, Kumar, opens the transportation route to the provinces of Badakhshan, Kunduz, Baghlan, Laghman and Parwan (PT).

* According to The Guardian the seven-party mujaheddin alliance is planning to form an interim government in Afghanistan so that the Ka.ul regime coulc not get international recognition (PT). * Abdul Rehman Vezirov, Russian Ambassador in Pakistan told The Jang reporters that all parties concerned should set around the table to solve the Afghanistan issue and the issue will not be solved by foreign intervention (JG).

* Pakistani Minister of State for Industries, Mian Mohammad Zaman in a statement 8 May said that the Indian leadership was afraid of the establishment of Islamic, independent and non- 
aligned Afghanistan and was busy in intrigues to keep it groaning under the shackles of slavery In conrivance with the Zionists and puppet Najib administration (FT).

\section{0}

* Our comnentator says the weakneses of the Geneva accords signed between Afghanistan and Pakistan about the withdrawal of Soviet forces from Afghanistan is becoming clearer as time passes (VOGDS).

* The UN Ecoromic and Social CounciJ has suspended an eyaluation of a jroposal by the Kabul regime asking for international assistance for the reconstruction of the war-torn Afghanistan

(RPDS).

* Western diplomats in Islamabad say the Indjan consulate in Kandahar has been closed down due to increasing lack of security in that city (BBCDS).

* According to western diplonats in Islamabad, mujaheddin forces in Ghazni in a communique have said as long as the retreating Soviet forces from ifghanistan avoid attacking and looting houses of the people, they will not attack the Russian forces (BBCDS).

* UN special envoy on the Afghan ¿ssue Diego Cordovez, while giving his views about restoring peace in Afghanistan, has said in a newspaper article a loya jirgah of the Afghan people should be held in a neutral place so that the views of all the Afghan are reflected (BBCFS).

* A session of the Central Committee of the PDPA was held 10 May, to consider the firing of several rockets on congested areas of the Kabul ci.ty 10 Nay killing a number of comlatriots. The comnittee assigned the responsible security authorities to maintain the security of the people of Kabul city and province (RA).

* The Wall Street Journal writes now that the Soviet Union has agreed to withdraw its troops from Afghanistan in nine months, the mujaheddin have to attund to two problems: the toppling of the Kabul regime and elimirating differences between the fundamentalist and moderate groups about the type of the future govermment of Afghanistan (VOADS).

* Mullah Malang a mujaheddin commander in Kanclahar says if the mujaheddin leaders wanted to avoia civil war in Afghanistan, they should unite the Afghans so they may be able to live together and happy. He said the appointment of a real leader is the obvicus right of the people of Afghanistan

(VOADS).

* The Kabul government has launched a wido-spread campiagn aimed at preparing the public opinion to accept a new reality - the partition of Afghanistan into two northern and southern halves (PT). * About 30 Afghan planes bombarded the border village of Mrundu in northern district of Chitral 9 May killing two cows and injuring another four (MIM).

* Pakhtoon Students Federation, People's Students Federation and Democratic Student's Federation held a joint demonstration 8 May midnight in Peshawar University campus to press the government for the implementation of the Geneva acçords on Afghanistan (MLM).

* Mujaheddin sources in Quetta say that the Kabul-Kandahar highway has been closed for traffic and the mujaheddin have been attacking all communist centers from Shah Joe to Shar-omSafa. The operation began 8 May (VOADS).

* Chairman of the Pakistani Senate Ghulam Ishaq Khan told Otto Habsburg a member of the European Parliament in Islamabad "the Geneva accord vindicates Pakisten's principled stand on tne 
Afghan issue and its implementation in letter and spirit would go as a miracle because it guarantees Soviet forces withcrawal from an area under their occupation for the first time during the 20th century." (MIM).

* A new report by Human Rights Watch organization on continued violence in Afghanistan casts a disturbing light on the prospects for a peaceful settlement of the Afghan issue (MIM).

* Anti-personnel mines, existing in various parts of Afghanistan, range from three to five million, according to the estimates of American experts and Afghan mujaheddin (MLM).

* India's "enthusiastic and high-profile embrace of Kabul leader Najibullah stemned from its worries that the Soviet pullout from Afghanistan would give new life to Moscow's efforts to improve ties with Pakistan and China" according to Newsweek (MIM).

* The JI leaders have deplored the alleged propaganda of the ANP against the mujaheddin Ieaders and asked the party leaders not to betray the Pashtuns furthermore (MLM).

* The JI Central Deputy Amir Prof。Ghafoor Ahmed has said that Moscow-Islamabad ties would further deteriorate in the wake of the signing of the Geneva accords as it contained inherent weeds of conflict (MIM).

* "By aligning itself with Dr. Najibullah's regime in Kabul, Deihi is conmitting the same mistake that it did at the time of the Soviet intervention in Afghanistan. But Moscow has at least rectified Brezhnev's wrong by announcing the withdrawal of Soviet troops (while India has failed to do so) (Chani Eirabi in MIM quoting Indian journalist Kuldip Nayar).

\section{1}

* The Daily Telegraph (London) quotirig diplomatic sources writes that Sadaruddin Agha Khan former UNHCR Chief Commissioner will be appointed as the coordinator of international efforts for the reconstruction of Afghanistan (BBCFS).

* In continuation of direct assistance by the Farghana Taipa province of the Tadzhikistan Republic of the USSR recently 180 items of goods worth 120,000 mibles have arrived in Kunduz (RA).

* According to TASS, the mujaheddin have increased their attacks in and around Kabul since 5 May before the arrival of the date for the withdrawal of troops from Afghanistan (VOAPS).

* The Vice President of the mujaheddin interin government Zabihullah Mojaddidy in answer to a question as to whether the government cf Pakistan will close down the mujaheddin offices and relationship between the mujaheddin organizations and refugee camps will be severed, has said the govemment of Pakistan has assured the mujaheddin that they would enjoy complete freedom in their. administrative affuirs and there will be no interference in these affairs (VOAPS).

* Western diplomats say five Soviet armored vehicles were demolished by the mujaheddin 2 and 3 May on Kabul-Kandahar highway (VOADS).

* The US Deputy Assistant Secretary of State Robert Peck has said despite the Soviet pullout from Afghanistan the region will continue to face pressure from the Soviet Union. He also called India's recent move in regard to Afghanistan as "curious" (MIM).

* The US is cautioning outsiders against attempting to interfere in the shape of a new government of Afghanistan, according to The Christian Science Monitor (USA) (MIM). 
* The Supreme Council of the IUAM in a meeting 10 May approved a new constitution for Islamic Afghanistan comprising four chapters and 87 articles (MIM).

* Rajiv Gandhi's "wisdom" in having invited Dr. Najibullah to New Delhi at the present juncture would lie in whether or not he was right in his assessment. As reported in a section of the Indian Press his assessment is that the present Kabul regime, contrary to the thinking in Islamabad, was not in any imminent danger of being ousted from power and that the mujaheddin would not succeed in capturing Kabul. (M.H. Askari in DN).

* Gulbuddin Helmatyar, leader of the (IUAM), said 10 May that the mujaheddin were ready to give protection to the UN mission in connection with the implementation of the Geneva accord, but not without a formal request to them (DN).

* Experts agree on the point that several problems, many of them political in nature are still to be dealt with for the Afghan refugees returning home, report VOA from Pakistan (PT). * During his visit to the northern areas the Pakistani Minister for Justice and Parliamentary Affairs Wasim Sajjad said under the Geneva accords the Russians are bound to withdraw from Wakhan

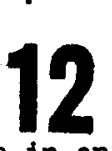

(Jang).

* The former Afghan King Mohanmad Zahir Shah in an interview. has said the formation of an interim govermment after the withdrawal of Soviet forces is desirable. He said the transitional government should be concerned about the internal stability so that the 5 million refugees will return to their country (VOGDS).

(vOGDS).

* Gen. Rauli Helminen, Head of the UN monitoring team, visited 12 May a refugee camp in Kotche Garhi near Peshawar and talked with a number of elderlies living in the canip (RPDS).

* The Kabul regime Charge d' Affaireswas summoned 12 May in Islamabad to the Foreign Office and was handed a strongly worded protest note about bombing in Chitral (RPDS).

* According to corresponcient reports in Moscow, a trip by the AP reporter to Afghanistan has been cancelled. The Kabul regime has raised objections to a question asked by the AP correspondent in a press conference held recently by President Najibullah of the Kabul regime (RPDS).

* The mujaheddin leaders and western diplomats in Pakistan say Soviet soldiers in Jalalabad, whose number was estimated to be 4,000 began 12 May withdrawing from one of their biggest centers in Nangarhar (BBCFS).

* Afghan mujaheddin sources at Peshawar say they have shot down a Soviet helicopter on Kabul Jalalabad highway. The helicopter was on a reconnaisance mission during the withdrawal operation of Soviet troops from Jalalabad to Kabul (BBCFS).

* The Soviet army newspaper The Red Star says the mujaheddin have increased the shipment of arms to the country from Pakistan on the eve of the withdrawal of Soviet forces from Afghanistan (BBCFS)

* The Vice Chief of A.rmy Staff of Soviet Forces has said Soviet forces in Afghanistan are ready to fight battles with the Afghan mujaheddin when they withdraw from the country. He said if a war imposed on us, we will not refrain from fighting it (BBCFS).

* Eeven sewing machines were presented to the elders of Afghan refugees living in camps in 
Karachi for the widows, say a Rotary Club press release (DN).

* Benazir Bhutto, Co-chairperson, of the PPP, has clainied that the signing of Geneva accords has put Pakistan into an awkward situation as regards the issue of continuation of American ald to the Afghan mujaheddin (DN).

* The mujaheddin are ready to move on Kabul, after the withdrawal of Soviet Porces. The Afghan mujaheddin leaders are confident that the departure of Soviet troops would be immediately followed by demonstrations against $\mathrm{Najib}$ administration and acts of sabotage and will set off defections from the Neghan Armed Forces (PT)。

* Dr. Najibullah, leader of the Soviet-backed Kabul regime, will go to NY next month to address

a special session of the UN General Assembly devoted to disamament (MLM).

* With three days left before the start of the Soviet troaps withdrawal from Afghanistan, . refugees at Badaber camps are not making preparations to go home yet (MIM).

* The former President of the IUAM Mawlawi Yunus Khales has opined that the triumph of Afghan mujaheddin over the Soviets in Afghanistan does not mean that they would serve American interests in future (MIM).

* The IRC of the US estimates that resettlement costs for the Afghans will mun about $\$ 200$ per parson. This means 600 million dollars will be needed for Afghanistan in the first year alone (MIM)

* The ANP President Khan Abdul Wali Khan has said the Pakistani rulers were trying to wriggle out of the Geneva accord as is proved by their irresponsible actions in the waks of signing of the agreement (MIM). .

* The US Ambassador to Pakistan Amold Raphel said in an exclusive interview that the mujaheddin would decide about the future of. Afghanistan and the US has no candidate to replace Najib (NW).

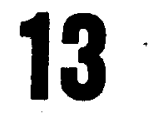

* A decree has been issued by President Najibullah for holding the first session of the National Assembly of Af ghanistan (RA).

* Gen. Mohammad Rafi the Minister of Defense in an interview with Soviet magaztne, Tha New. Times has said following withdrawal of Soviet soldiers from Afghanistan the responsibility will lie upon the Afghan army. He said during the years of the undeclared war, the Afghan armed forces have developed quantitatively and it has become stronger ideologically. Also it has become more experlenced by taking part in battles and has learnt war tactics and skill from Soviet soldiers (RA).

* In Afghanistan preparations have been completed for the withdrawal of Soviet forces which commences 15 May. Armed extremists groups are trying to create difficulties for the withdrawal of Soviet forces (RMDS).

* Our commentator writes that Soviet soldiers were not only lighting in Afghanistan but they were engaged in large scale construction work as well. The value of the houses and lodging centers constructed by Soviet army in. Nangarhar has been more than 20 million rubles (RMDS). * Mujaheddin sources in Peshawar say that famous Paktia commander Mawlawi Atiqullah was killed when the vehicle which he rode was blown up with a mine 12 May inside Pakistan in Kurram Agency. Heven companions of Commander Atiqullah who rode with him in the vehicle were also killed (VOADS). 
* The Afghan govermment replaced 23 of its 30 provincial governors 12 May without giving any ream son for their replacement (MIM).

* The Afghan mujaheddin have shot down three fighter planes of the Soviet-Kabul troops besides wiping out several strongholds and destroying dozens of tanks and armored vehicles in $\mathrm{Nimroz}$, Parah, Kabul, Balkh and Herat provinces, reports Radio Teheran (MLM).

* Two rallies held in Kabul city blämed the US and Pakistan for 10 May incident in which 23 people, mostly children were killed and dozens injured (MIM).

* Three Afghan refugees were killed when some unidentified persons opened fire at a Suzuki pickup in which they were travelling four kilometres from Miranshah Bazar in North Waziristan Agency (MIM).

* The IUAM has made preliminary contacts with leaders of various Pakistan opposition parties in Peshawar to set up meetings between their respective central leaderships for discussing the Afghanistan situation (MIM).

* Prince Sadruddin Aga Khan who has been named to coordinate all international relief and resettiement efforts in Afghanistan, said 12 May he plans to visit the area within the next two weeks to prepare an appeal for funds to accomplish the task (MIM).

* In an answer to a question "will Pakistan recognize Afghan alliance's provisional government," Zain Noorani, Pakistan Minister of State for Boreign Affairs has said we will closely examine it but It is still too early to talk about a provisional government. The mujaheddin leaders w11l have to establish their credibility first. Helmatyar is their leader now. What will happen in the future is yet to be seen. The aliliance should broaden its base. It is for the people of Afghanistan to decide what type of govermment they want. If they want a fundamentalist government, let then have it (MIM).

* Plve Afghan women died and an equal muber sustained serious injuries at an Afghan tentage village in Okar, about 20 miles from Dalbandin in Chagal district, an official spokesman confirmed 12 May. The victims were clearing fire arms shells one of which exploded (DN).

* Dr. Abcul Hakeem Iehri, President of Baluchistan PNP has said that a conspiracy was afoot to divide Afghanistan into two parts and added that the people of Baluchistan would foil all such plans. He said that such plan, chalked out by US and its allies, is detrimental to the interests of both Pakistan and Iran (IN).

* Pake Pakistan currency notes have been printed and circulated by alleged Afghan agents to spread economic crisis in NWFP, (DN).

* Ten Afghan fighter aircraft violated Pakistan airspace 7 May and dropped eight bombs in Arundu, Wirkhani and Drosh. areo in Chitral District. As a result two children (Pakistan nationals) were injured (PT).

* Kohammad Hashim Sheikh Mohammadi, incharge of the Islamic Association of Afghan Students (IAAS), reacting to President, PNP, Mir Ghous Bakhsh Bizenjo's statement that "the mujaheddin, will be welcome if they succeeded in forming a government of their choice with the support of the Afghan peoplow said that this statement indicated that Bizenjo has realized the facts that instead of upporting Najib's government blindly, only those should be supported who enjoyed the eupport af 
the Afghan people (PT).

* In a Press Conference in Rawalpindi 12 May President of the IUAM, Gulbuddin Hekmatyar made the following points:-

- - The mujaheddin were realizing tremendous achievements and have unanimously selected four places to establish interim government inside Afghantstan in the near future,

- - The mujaheddin have had, during last one month, conquered 12 districts and sub districts and over 50 strategic points and military posts. They were conquering various places not only in south but also in the north,

- - India had been supporting Soviet aggression and the puppet regime for the last eight years which was a condermable policy,

- - there is no controversy in the IUAM and 12 ministers who have already been appointed would soon be announced to run their respective ministries (PT)。

- - rejected Diego Cordovez's recent proposal to convene a loya jirgah in a neutral country in $a$ bid to form an interim government in the war-torn Afghanistan (MIM).

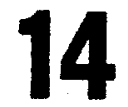

* Gen. Rauli Helminen. Deputy of the representative of the UN Secretary General and leader of the W goodwill mission in Afghanistan and Pakistan arrived in Kabul with his high ranking delegation 14 May to oversee the implementation of the Ceneva agreemerits on Afghanistan (RA).

* The Washington Times in a report about the withdrawal of Soviet troops from Afghanistan says Paldstan hopes in less than four months after the withdrawal of Soviet forces from Afghanistan a new government will cone into power in Kabul (VOADS).

* Mohammad Rafie, the Minister of Defense of the Kabul regine, has once again said the armed forces of the country are capable of facing the anti-government rebels. In an interview with a Soviet newspaper, he has said the armed forces of the Kabul regime are well-equipped and have gained full experience in the battles of the country. He said the government of afghanistan is still in favor of a peaceful settlement of the Afghan issue (BBCFS).

* The Washington Times says that leader of the IUAM, Gulbuddin Hekmatyar told a press conference 12 May his organization has taken measures for a wide ranging military operation, in the wake of Soviet troops withdrawal from Afghanistan. He added, we have not signed the Geneva accords and do not have to observe a ceasefire. He said, if the us observers join the Soviet forces and move with them together they will face the same dangers which might face the Soviets (VOADS).

* A report issued recently by the US Congress says it is not expected that the Afghan refugees will return to their homes simultaneously with the withdrawal of Soviet forces from Afghanistan and they will not return until the end of the withdrawal of Soviet forces by the beginning of next year unless the issue of a new government in Afghanistan is solved (VOAPS).

* Leader of the Jamiat-e-Islami Afghanistan Prof. Burhanuddin Rabbani in an interview about the withdrawal of Soviet forces from Afghanistan has said the Soviets committed aggression against us in order to defeat Afghanistan and they did not hesitate to use any kind of weapons. However, it is now whthdrawing from Afghanistan with shame and disgrace. He said the people of Afghanistan 
have still not achieved their final victory. The finel victory will come when all soviet forces withdraw from Af ghanistan, the Kabul regime is tuppled and replaced by an Islamic government (VOAPS), * The newly appointed coordinator for relief and economic assistance prograns in Afghanistan Prince Sadruddin Agha Khan,says he expects to present a multi billion dollar aid plan to doner countries within the next three weeks (MIM).

* Traders at Darra Adam Khel, the tribal arms bazaar near Kohat, say there will be enough customers for their deadly wares even after the Soviet pull-out from Af ghanistan (MLM).

* The Soviet Union has informed the US it will withdraw up to a quarter of its troops from Afghan istan by the end of May, U.؟. administration and diplomatic sources said 13 May (MIM).

\section{0}

* According to TASS, Soviet authorities have again warned foreign powers not to interfere in the internal affairs of Afghanistan and respect the ceasefire in that country. TASS has said now that Soviet forces are retreating from Afghanistan, the other remaining issue is to end the despotch of arms to the Afghan rebels (BBCFS).

* Geni: Rauli Helminen, leader of the UN observers tean for the implementation of the Geneva accords, has said both Pakistan and Afghanistan have pledged to observe the Geneva accord provisions about the return of Afghan refugees to their homes. Radio Pakistan said the UN authorities are expected to visit 15 May several Afghan refugee camps in Pakistan (BBCFS)。

* Leader of the IUAM, Gulbuddin Hekmatyar, refused to comment on the explosion of a bomb in Kabul city 15 May but warned that the mujaheddin will continue to attack Soviet forces during their retreat from Afghanistan. He said the Afghan mujaheddin did not have any desire and inclination to form a coalition government with the present Kabul regime (BBCFS)。

* Leader of the IUAM, Gulbuddin Heimatyar, said he is advising all the Afghans who have been doceived by the Soviets and forced to fight against their om people to admit their mistake and join the nation and refrain from animosity against Islan and the nation. He pointed out already a general amnesty has been offered to such people. They should surrencler themselves to the mujaheddin wherever they are after four weeks from the withdrawal of Soviet forces and in that case they will become part of the genaral amnesty (VOADS).

* An American official has said the US has asked the Soviet Union to show the areas where the Soviet army has planted mines in Afghanistan so that the refugees who are returning home might not be exposed to dangers. The Soviet side has assured the Americans that the miries will become inactive automatically in a short period of time (VOfDSi).

* The former Afghan King, Mohammad Zahir Shah, has said in his opinion $15 \mathrm{May}, 1988$, which corresponds with the implementation of the Ceneva agreement on the withdrawal of Soviet forces from Afghanistan, is an important day in the history and in the unprecedented jehad of the Muslim and mujahed poople of Afghanistan (VOADS).

* A Soviet soldier, who defected to the mujaheddin 10 months ago, says he had heard his Soviet officer that $\$, 000$ Soviet soldiers had been kifled in Afghianistan and the Soviet people themselves are of the opinion that 25,000 Russians have been killed in the Afghan war (VOAPS). * Western correspondents report from Kabul that when the first batch of Sovlet forces began 
their retreat from Afghanistan to their country, leader of the Kabul regime and a number of high ranking Soviet military officers were present in an official send-off function for them (VOAPS).

* The IUAM, In a statement in Peshawar marking the withcrawal of the Soviet forces Irom Afghanistan, has assured the refugees that until conditions are conducive for their voluntary return to Afghanistan, the Pakigtan govermment, on the basis of religious and intermational laws and the splrit of the Geneva accords, will not force any refugee to go home (VOAPS).

* The Special Revolutionary Court, in 1 ts session $15 \mathrm{May}$, condemned to death Abdul Bashir, resident of Kabul city, District 1, for carrying an explosion in the Ministry of Education in 1987 (RA).

* The first 1,000 Sovlet troops to be withoram from Afghanistan 15 May will be accompanied by a heavy force of helicopters, gunships, tanks, amored cars and field artillery to defend the troops should the mujaheddin attack them, the BBC said 14 May (MLM).

* Countries like Pakistan and Iran, which have been directly affected by the upheaval in Afghanistan, can play a constructive role in bringing peace to Afghanistan. Their earlier support for the Neghans has stool them In good stead, and they are in a losition to extend advice. The successful implementation of the Geneva accords would depend on its day to day progress. The nine-month long timetable, therefore, would be as important as the first day, which is today (Editorial, MIM).

* Pakistan's position vismamis the Genevy accords is not all that enviable. The accord has sharpened and deepened the rift between the Right and Left in the country, the former urging Islamabad to continue supporting the mujaheddin till victory and the latter taking the position that, menought is enough" and calling for the return of refugees and mujaheddin alike to their country. This polarization can deepen the shadow over Pakisten and make the implementation of the Geneva accords a difficult proposition. The ffghan scenario, despite tle Geneva accords, remains rather a bleak one. The way to peace is still strewin with many imponderables. None car predict what will happen during the nine-month period stipulated for Soviet pillout. The miracle of the 20th century - - the resolution of the Afghan tangle - - is stilj to happer (Khalid Akhtar, in MIY).

* Chulam Mustafa Jatoi, Chairmian of the National Peoples Party (NPP) told newsmen 13 May that a coalition government in Kabul was imperative for lasting peace in Afghanistan (MIY).

* The Supreme Counc1l of the IUAM has under selection several sites for the setting up of mujaheddin government in exije in Afghanistan. A spokesman of the Council said 14 May that a decision on one such site would soon be taken. He said location of the headquarters of the governient in exile is still a top secret because of security reasons. He said the exile government headquarters would be set ue at such a place in Afghanistan as shou'd be safe from all points of view (PT). * Joumalists who reached Kabul to cover the Soviet nilitary withdrawal from Afghanistan were prevented $13 \mathrm{kay}$ from leaving their hotel by Afghar security guards (PT).

* Hajee Mohammad Adeel, Central Information Secretary of ANP, has criticized the stand of LS and Pakistan govermments on the imilementation of the Ceneva accords (IN).

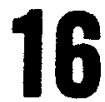

* Abd Rab Rasool Sayyaf, leader of tle Ittehad-e-Islamj. Afghanistan has sald in Peshawar he wil transfer the headquarters of his organization inside Afghanistar. He has said there has been no pressure from the Pakistani side for his decision in this regard (VOGLS). 
* The Ministry of State in the Ministry of Foreign Affairs of West Germany has asked the European Union to Initiate an emergency ald program to reduce the pain aric agonies of the people of Afghanistan (VOGDS).

* A BBC correspondent from Islamabad reports, according to a security post on the Pakistand border, more than 4,00 truclis Joaded with weapons have been transported insile Afghanistan by the mujaheddin (BBCFS).

* A BBC correspondent reports that armored colurns of Sciviet forces have left Kabul 16 May towards the Soviet border. The Unit.s which arrived from Jalalabad is the first part of Soviet forces which are retreating from Afghanistin in accorclance with the Geneva secords (BBCFS).

* A Japanese government spokesmar saill jn Tokyo 16 May that Japan was ready to help in ti.e task of repatriation of the Afghan refugees if necessary (RPDS).

* China has welcomed the pull-out of the Soviet forces from hfghanistan (RPLS).

* The UN observers team on the witharawal of Soviet forces from Afghanistan has been visiting for the last two days various refugees camps in Peshawar (RPUS).

* An official note No.1 conteining five articles has been delivered to the un foint efforts team In Kabul for necessary evaluation and verification about the faijure and violation by Pakistan from a number of the provisions of the Geneva agreement (RA).

* The Japanese government is sending an official of 1ts Foreign Ministry to join the w observers tean to oversee the withirawal of Sovi-t. forces fron Afgharisiston (VOAFS).

* The IUAM in Peshawar has said it is considering a Soviet request about the security of its retreating forces during their passage from salafig. A. spokesnian of the IUAM sald it is possible the Sovi et request might be accepted in the light of conclitions which are still being discussed by the IUAM leaders (VOAFS).

* A huge operation, involving hundreds of vehicles, is currently in progress in Pakistan's tribal belt to shift ammunition dumps rur by Afghan mujaheddir across the Pak-Afghan border on the instructions of the Pakistan government (MIM).

* The Soviet Union and Afghanistan issued a joint statement is May warning against foreign aid to Afghan mujaheddin as the Soviet troojs withdrawal begins. The statement, issued by the Soviet news agency TASS, said Moscow intended to abide by its commitment to begin moving 1ts estimated 115,000 troops out of Afghanistan on 1.5 May (MLN).

* In Kabul exchange markets the US dollar is down. The dollar was quoted at 180 afghanis by Independent traders, down from akout 185 two days ago. One dealer said that returning refugees were expected to bring with them lots of dollars further depressing the dollar (MIN).

* A despatch in The Neri York Times 15 May portrayed as ambiguous the American stance on Afghan1stan. "The contradictions inherent in trying to be involved and uninvolved are expected to confront Washington policy-makers most accutely as the Sovjet pullout gathers monentum, "the newspaper said (PT).

* The Geneva accords mark the renunciation of the military option and the initiation of a process of political settlement at only one level. At another level - - the level of mujaheddin 
and the liajibullah regjne - - peace remains a dim prospect.Much wi.l depend on the diflomatic skill of Diego Cordovez in bringing together the varjous parties to the Afghan conflict in an interim broad-based goverrment, on this front thires have yet to get noving (Editorial, PT). * Speculation that self-exiled Baluch leader Nawab Khair Bakhsh Marri was contemplating leaving Kabul and shifting to Iondon in view of the uncertainty which might grip Afghanistan in the wake of whdrawal of Soviet troops seems premature as gathered from reports emanating from the Afghan capital (MIM).

* Benazir Bhutto, leader of the Fl' ju an interview has saic let us try and back a frucess that somehow takes into accourt the feelings and the sentiments of the people of Afghanistan and Give birth (whether a funclametalist, or secular) to a broad-based government which has the duram bility and the substance to give stability to Afghanistan (MIN).

* On the cccasion of the 10tr anniversary of April revolution 41 officers of the Afghan army were promated to the rank of General (MIM).

* Mawlana Jalaluddin Haqqani, a mujaheddin leader inside Afghanistan, has threatened to form a government of mujaheddin commarders, if the leaders of the IUAM, failed to agree on the formation of an interin government in Kabul (DN).

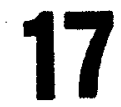

* Rouard Shevardnadze, the Soviet Foreign Minister, in his meeting in Moscow with Zain Noorant Minister of State for Foreign Affairs of Pakistan, has asked all concerned parties with the issue of Afghanistan to observe the provisions of the Geneva accords (BBCFi).

* Diego Cordovez, the UN Special Envoy on Afghanisten, has said the goveruments of Pakistan and Afghenistan have assured hin that measures have already been taken for the implementation of the Geneva accords on Afghanistan (EBCFS).

* Radio Moscow reports that the first batch of the Soviet forces, which is to withdraw from Afghanistan, has returned tc the Soviet Union (VOf.DS).

* A spokesman of the l'S State Defartment has welcomed the beginning of the withdrawal of Soviet forces from Afghanistan sayirig apparently the Soviets. are preparing for a speedy withdrawal. The spokesman said the American support for the mujaheddin continues as before (VOAS).

* Eduard Shevardnadze, the Soviet Foreign Minjster, in his meeting with Zain Noorani, the Pakistani Minister of State for Foreign Affairs in Moscow, has said as far as the Soviet Union is concerned it is determined to eniphatically observe the provisions of the Geneva accords on Afghanistan (RMDS).

* Commander Ismail Khan of Herat has rejected the remarks of one of his representatives that he is in favor of a loys jirgah to decide on the future goverrment of Afghanistan. In an interview wh $\mathrm{BBC}$ he has said he does not want tre convening of the loya firgah and favors a large gathering of mujaheddin commanders (BBCFS).

* A Soviet spokesman has refuted speculation of dividing Afghanistan into two northern and southerm parts after the withdrawal of Soviet forces. The spokesman told a press conference that no plan existed for dividing Afghanistan (RPDS).

H* An overwhelming majority of people are in favor of Pakistan signing the Geneva accords on Af- 
ghanistan. In a survey conducted by The Muslim since April 14 , less than $1 \%$ disapproved. Most expect Pakistan to be the worst affected by the possible continuation of civil war inside AfghanIstan and feel that at least some Afghar xefugees wi]. not retum to their homes. By no means all favorably assessed Pakistan's role in the Afghanistan issue, while only very small numbers belleved that Pakdstan had not been put on the defensive. The 184 survey. respondents were predominantly male, urban (Lahore, Faisalabsd and Peshawar) and with a minimum graduate level education, MIM). * Haji Chulam Ahmad Bilour, Central Vice President of ANP, has urged the Afghan refugees in Pakistan to return to their country (MLM).

* Khan Abdul Wall Khan, Chief of ANP, has urged leaders of the Arghan retugees to stop their interference in the internal affairs of Pakistan. In a statement he criticized the Afghan refugee leaders' statements against leftist democretic groups in Pakistan. Wali Khan also criticized the Afghan mujaheddin threats to India and said it will result in "dangers" for Pakistan (MIM).

* French fournalist Alian Guillo sentenced to 10 years in jail in Afghanistan on spying charges, said 15 May he considered himself to be a hostage of the Kabuit government (MIM).

* UN Under Secretary General Diego Cordovez said 16 May he plans to hold talks with representatives of Pakistan and the Kabul regime in Geneve next week to revlew arrangements for the implementation of the Geneva accords (IN).

* In the wake of withdrawal of the Soviet forces from Afghanistan, the Afghan mujaheddin leaders have called for general mobilization of the mujaheddin to prepare for moving into selected places. inside the liberated regions of the country.

* Chief of the Ittehad-e-Islami Prof. Abd Rab liasool Siyyef, in a statement issued in Peshawar 15 May sald a number of centers have been set up at the border provinces from Kunar valiey upto Helmand and from Nangarhar to Paktia to accommodate mujaheddin offices. The shifting of offices was a voluntary action and there had been no pressure from Paklstant authorities to do so, he $\operatorname{said}(\mathrm{PT})$.

* The Chief of the Soviet troops in Afghanistan, It. Gen. Boris-Gromov, has said Soviet troops in Afghanistan were deployed in 18 garrisons and there were more than 170 military bases in these garrisons, reports VOA (PT).

* According to a report, the Soviet Union had attempted at diplomatic level to know the US reaction about its military invasion of Afghanistan five months prior to crossing over the Oxis River. This was disclosed in an article on the basis of secret documents of the CIA captured during the occupation of the US Embassy in Teheran by the students. The article was carried recently by an Inglish monthly Globe. According to it, the Soviet Union had sent various messages to the Imbasay in Kabul through its Minister, V.S. Safronchuk and an East German commentator making a mention of the Soviet plan of Invasion. The US neither made any protest against the Soviet plen of aggression nor did it apprise the public about it. The resson for the Soviet Invasion of Afghanistan was that it took the US non-reaction as a green signal (JG).

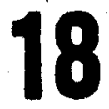

* A commander of Soviet forces in Kabul has reaffirmed that the Soviet Union would also evam cuate the Wakhan corridor which borders China, Pakistan and the Soviet Union (BBCFS). 
* The flrat Soviet military corvoy, which had left Afghanistan, has now arrived in the Soviet Union by land. A Soviet television correspondent has said the convoy was attacked by the mujaheddin with rockets one hour after it had left Kabul. (RPDS).

* Gennadi Gerasimov head of the Information Department of the Soviet Foreign Ministry has told a press conference in Moscow in the Soviet Union it is being thought that the Geneva agreenents will further the cause of NRF in Afghanistan. He described the NFP a.s a prudent policy which gained support as time passed (RA).

* The Commander-in-Chief of Soviet military contingents in Afghanistan says during the 15 days of May about $25 \%$ of the Soviet forces would be returning to their country (Funs).

* The Washington Post says the same way that the aggression of Afghanistan by Soviet forces was a major international event, the withdrawal of these forces is also of world importance (VOADS). * Gulbuddin Hekmatyar, President of IUAM, told The Muslim May 17 all 23 provincial governors in Afghanistan appointed by Kabul last week were supporters of former King Zahir Shah. He said, the Soviets and their "puppet regime" in Kabul now wanted to impose Zahir Shah on the Afghans. "They have realized that communists are no more acceptable to the Afghan people so they want to try a new card. "(MTM).

* The Muslims of Pakistan will continue to support Afghar Mujaheddin uritil a true Islamic government acceptable to them was established in Kabul. This was declared at a public meeting held at Madrassa Nizamie of Mir Ali; a sub division of Miranshah, May 17, by Jamiat Tulabame-Islam (MIM).

\section{9}

* The Pakistani Minister of State for Foreign Affaifs Zain Noorani once again explatned the policy of his govermment saying that no established Afghan mujaheddin military base existed in Pakistan (BBCFS).

* Dr. Hasan Sharq, the deputy Prime Minister of the Kabul regime, has said the government of Kabul is willing to allow the UNHCR to launch its activities in areas not under the control of government. Similarly. the UHHCR can have offices in Jalalabad and Kandahar cities whether they would be under the government control or not (BBCFS).

* A Soviet political commentator in a press conference in Moscow has admitted that between $12,000-15,000$ Soviet soldiers have been killed in Afghanistan. during the presence of Soviet troops in that cointry (RPDS).

* The second official note of the govermment of Afghanistan in connection with the violation of Genevá accords by Pakistan specially related to the despatch of weapons and war supplies to Afghenistan which have recently been intensified has been delivered to the office of joint UN effortg (BA).

* An Arabic newspaper - - Al-Watan - - has said in an editorial that the withdrawal of Soviet forces from Afghanistian should be coupled with a decision on the part of all foreign forces not to interfere in the internal affairs of Afghanistan because the beginning of the pullout of Soviet forces is of vital importance in the sense that it signals the end of foreign interference in the internal policy of Afghanistan (RA).

* A function was held in the Termiz city of Uzbekistan of the Soviet Union 18 May to mark the arrival of the first unit of Soviet armored forces from Afghanistan. Afghan Minister of Defense 
General Rafie in a speech said the Soviet Union helped Afghanistan to defend its soverelgnty, independence and territorial integrity (RMDS).

* The son of Wakil Azam the new governor of Nangarhar Zafar has been appointed as the Kabul regime military chief commander in Shinwar, Nangarhar. He was earlier a mujaheddin commander and about one month ago defected to the government along with his father (VOAPS).

\section{0}

* Michael Armacost, the US Under Secretary of State has said it was too early for the US to suspend its delivery of arms to Pakistan (RA).

* Our reporter from Kabul says in a few days time the first session of the Parliament will be convened in Kabul. Among the 362 deputies who have been elected for the National Assembly, a number of opposition deputies are also included (RA).

* The US has complained that the retreating Soviet forces from Afghanistan are to leave behind military hardware worth $\$$ one billion to the Kabul regime (RPDS);

* Radio Australia, quoting Soviet television, says recently a unit of helicopters flew from Afghanistan towards Uzbekistan in Central Asia. The television did not mention the number of people who might have left in these helicopters (RPDS).

* The Times (Iondon) says the Soviet Union is seeking to establish a pro-Soviet zone in Northern Afghanistan. Howerer publicly it denies the plan (BBCFS).

\section{1}

* The Foreign Ministry of the Kabul regime has refuted the Afghan mujaheddin claim that they had blocked the Kabul-jalalabad highway, adding that traffic on the highway is continuing without interruption (BBCFS).

* In an article in the French newspaper Le Monde it has been said the formula used for solving the Afghanistan issue can be used as an example for solving other regional disputes (BBCFS). * Afghan President Dr. Najibullah has told Indian journalists in Kabul that the last convoy of Soviet forces will leave Jalalabad May 22 (BBCFS).

* The Times (Iondon), quoting reliable Afghan sources, has said that a large number of Soviet officials are to bo returned by air to the Soviet Union alongwith with their families (BBCFS).

* Our comentator says, sending arms from Pakistan to Afghanistan is contrary to the Geneva agreement. Such an action by Pakistan is contrary to the pledges made between the two countries in atopping and uprooting all kinds of rebel and cecessionist activities (PMDS).

* UN Under Secretary General Diego Cordovez arrived in Quito 19 May to meet Ecuadoran Presidentelect Rodrigo Borja, who asked the UN negotiator of the Afghan peace accord to become Foreign Minister (PT).

* Prime Minister Mohamad Khan Junejo has said India did not completely support the resolution with regard to Afghanistan whenever it was tabled. Today when the issue is settling in" favor of the Afghan brethren with all out efforts on the part of Pakistan, India wants to jump into areng 


\section{2}

* President Mohammad Ziaul Haq said 21 May in Islamabad he hopes the implementation of Geneva accords will reinstate the non-aligned status of Afghanistan and peace and tranquillity would be restored in that country (RPISS).

* Before his departure for South East Asia, Prime Minister Mohammad Khan Junejo said in Islamabad Pakistan honors the Geneva accord and would take all measures for its total implementation (RPDS). * The Sunday Telegraph (England) in a recent issue reports now that the Soviet troops have seriously been defeated by the Afghan mujaheddin and are withdrawing from Afghanistan, the NATO should be concemed over the 60,000 Soviet troops who have gained war experience in Afghanistan and a large number of them is presently deployed in East Germany in fronts facing the NATO forces (BBCFS). * A protocol on mutual coopperation in public health was signed recently in Berlin between Afghanis tan and the GDR (RA).

* In an interview with The Washington Post, the Soviet leader Mikhail Gorbachev has ruled out resemblance between Veitnam and Afghanistan and has said the Afghanistan govermment has chosen to achieve a national reconciliation in a coalition government with the participation of all parties of the dispute (RA).

* In an interview to the Indian journalists, President Najibullah of Afghanistan has urged the US to stop arms supplies to the Afghan mujaheddin and to honor the Geneva accords (RMDS).

* Speakers at The Muslim, seminar expressed diverse views on the solution of the Afghanistan problem. The seminar, held 21 May by the The Kuslim, also covered the Kashmir and Palestine issues. On Afghanistan, speakers interpreted the struggle of the Afghan people against alien occupation in different ways and cautioned about the disastrous consequences Pakistan will face if it did not sincerely implement the Geneva accords. Some stressed for the continuation of the Jehad until a single Soviet soldier remains in Afghanistan. Those who spoke at the seminar included the ANP Chief Khan Abdul Wali Khan, JI Chief Qazi Hussain Ahmad, President of the QMA Meraj Mohammad Khan, Chairman of NPP Ghulam Mustafa Jatoi, Chief of Tehrik-e-Nifaz-e-Fiqah-Jafferia, Allama Arif UI Hussaini, President of the Tehrik-e-Amal, General (Retd) Hayat Khan(MIM).

* President Ziaul Haq of Pakistan has expressed confidence that Afghanistan will soon be a peaceful country and the people of Afghanistan will have the government of their choice (MIM).

* A meeting of mujaheddir commanders of Nangarhar province held in the Shamshatoo refugees camp near the Frontier metropolis chalked out a strategy to attack and occupy Jalelabad. An IUAY press release has said the mujaheddin commanders met under chairmanship of commander Zahid of Heabo-Islani (Hekmatyar group) and decided to launch the offensive on Jalalabad shortly (MIM).

* Professor Ghafoor Ahmad, Deputy Amir of JI has said the USSR should talk to the mujaheddin for setting up a representative government in Afghanistan as mere signing of the Geneva accord could not solve the Afghan problem (MIM).

* Speaking 21 May at a seminar of The Muslim in Islamabad, the JI Chief Cazi Hussain Ahmad has said the Soviet troops withdrawal from Afghanistan is not only the victory of the mujaheddin but it is the triumph of the entire Immah (NWT). 
* Speaking at The Muslim seminar, the ANP President Khan Abdul Wal1 Khan said I have never opposed the jehad of the Afghan mujaheddin and have always been of the view that the Afghan mujaheddin should fight this war inside Afghanistan and for this purpose they should not use the Pakistani territory (NWT).

\section{3}

* TASS says all Soviet military personnel have withdrawn from Nangarhar, Afghanistan (VOGDS).

* On his way to Geneva, the Pakistan Foreign Secretary Abdul. Sattar held talks with the Soviet Deputy Foreign Minister in Moscow. He will also discuss with the representative of UN Secretary General in Geneva the implementation of Geneva accord (RPDS).

* TASS has reported a convoy of 1,000 Soviet troops alongwith 100 armored vehicles, have reached Kabul from Jalalabad and are expected to arrive in Termiz 25 May (RPDS).

* The UN mediator on Afghanistan issue, Diego Cordovez has said that he has accepted the offer of his country for appointment as the Foreign Minister of Eicuador provided he could continue his efforts in connection with the Afghanistan issue (BBCFS)。

* The leader of the Chinese Cormunist Party Zhao Ziyang has said his country would continue to support Pakistan on the Afghanistan issue. He has described the Geneva accord as a success (BBCFS). * The Prime Minister of Pakistan, Mohammad Khan Junejo refuted Soviet allegations that Pakistan has folled the utility of the Geneva accord by continued arms supplies to the mujaheddin (BBCFS).

* In an interview with the US journalists, the Secretary General of the Soviet Cammunist Party, Mikhall Corbachev has said the future course of events in Afghanistan after the Soviet troops pullout depends on all the signatories of the Geneva accord as to whether they will fulfill their commitments (RMDS).

* The third memorandun of Afghanistan in connection with the violation of the cormitments of the Geneva accord by Pakistan was handed over 22 May to the UN delezation in Kabil (RA).

* In an interview with the BBC, the TIP Chief Air Marshal (Retd) Asghar Khan has said the US and Pakistan are not sincere in the implementation of Geneva accord and if they co not exercise prudence Pakistan will face great difficulties (RA).

* The New York Times writes Western diplomats and mujaheddin leaders say, following Soviet troops withdrawal, the mujaheddin will capture the Kabul regime cantonments near Pakistan borders one by one and the morale of the Kabul regime and its supporters will weaken (VOAPS).

* The representative of the Herat province mujaheddin belonging to the Jamiat-e-Islami organization in Peshawar, Mohammad Rahim Qazi Zada said there is no indication showing that the Russians will pullout from Herat. The Russians are presently placed in hot waters in Herat and they are conPined in their cantonments and cannot come out from their installations (VOAPS). * Two Afghan nationals were arrested by Quetta police following two explosians in a truck loaded with scrap 22 May on Seriab Road (MIM).

* President Mohammad Ziaul Haq said in Islamabad 22 May while the Soviet Unian has decided

to phyaically vacate Afghanistan, mentally the Russians are still there (KIM). 
* Voice of America in an editorial has said that without Pakistan's resolute support during the last 10 years the dream of an independent Afghanistan could not have come so close to reality (PT). * Dr. Najibullah has authorized a prominent tribal leader Gulab Khan Shainwari to hold talks with the Afghan refugees in Pakistan on reconciliation. Dr. Najibullah has said he is prepared even to visit Pakistan for talks with the Afghan refugees for the sake of peace in Afghanistan (JG).

\section{4}

* The Kabul government officials have given a hint that the newly elected Parliament would convene within a few days (BBCFS).

* Prime Minister Nohammad Khan Jumejo has said in Seoul the Geneva accords on Afghanistan have proved that the world commuity can, under no circumstances, neither tolerate exploitation of small countries by big powers nor interference and military domination can be accepted (RPDS).

* The US Under Secretary of State, Robert Peck has said Washington has requested the UN and other Intermational organizations to exert efforts for the return and rehabilitation of the Afghan refugees. He said such assistance should reach directly to the Afghan refugees and not the Kabul regime (RFDS).

* The 4th memorandum of the Afghan government about the violations of the Geneva accord by Pakistan has been submitted 24 May to the WIAG (RA).

* The National Herald (India) reported 23 May participants at the seminar recently held under 'the auspices of the prominent opposition parties of Pakistan have demanded the Pakistan government to immediately stop its assistance to the Afghen opposition groups and to seriously adhere to the Geneva accords (RA).

* After the signing of Ceneva accords and the start of the Soviet troops pullout from Afghanistan, newsmen are finding it difficult to elicit independant views of the Afghan refugees in camps or any where else. The refugees are found reluctant to comment on the development as if every one has been caught unaware. The Afghan refugees are willing to return to the country provided they are assured of no harm by the Kabul government(special report, MLM).

* The International Parliamentary Union (IFU) is considering a proposal regarding convening an international conference to discuss the issue of resettlement of Afghan refugees, the President of the IFU Dr. Hans Strecken disclosed 23 May in Islamabad (MM).

* President Mohammad Ziaul Haq has said he is encouraged by the mujaheddin success in Afghanistan since the Soviet troops withdrawl began eight days ago and Pakistan may recognize a provisional mujaheddin government even before the fall of the communist regime in Kabul (DN).

* In an interview with a Hong Kong journal, Asia Week, Prime Minister Mohammad Khan Jumejo has said the next four months would be very difficult for Afghanistan as there would be a tug of war in the country and it cannot be dealt with the Geneva accord (JG).

\section{5}

* In his speech in Seoul, Pakistani Prime Minister Mohamad Khan Jumejo hoped that a goverament will be set up in Afghanistan which would be acceptable to all the Afghans so that the Afghan rofugee could return to their country in honor and safety (RPDS). 
* Quoting diplonatic sources, Reuter reports Soviet troops' withdrawal from Afghanistan is not taking place speedily and the mujaheddin have increased their pressure on the southerm regions of the country (RPDS).

* A high ranking Soviet official says in eight years of war in Afghanistan, 13,310 Soviet troops were killed, 35,478 injured and 311 others are missing (VOADS).

* The Political Chief of the Soviet land and Naval forces, says as a result of the Geneva accord signed last month, 10,000 Soviet troops have left Afghanistan. He said the withdrawal of Sovlet troops from Afghanistan continues on a routine basis (VOADS).

* The UN mediator, Diego Cordovez arrived in Geneva to evaluate the progress of the accord on the Afghanistan issue signed last month (VOADS).

* The Soviet Foreign Ministry has accused Pakistan of violating the Geneva accord by continuing support to the Afghan mujaheddin and allowing them to carry their arms inside Afghanistan (BBCFS).

* In an interview with The Red Star (Soviet Union) the Afghan Minister for Nationalities Akbar Shormach said a proposal for setting up a new province of Nooristan has been put up to the Council of Ministers of Afghanistan for approval (BBCFS).

* Diego Cordovez a senior UN official, is to be Foreign Minister of his native Ecuador. But reliable sources indicated 24 May he will continue to oversee implementation of the Geneva accords on Afghanistan (MIM).

* More than half the Soviet soldiers in Afghanistan take drugs, according to a US report which described the Soviet contingents as wracked with disease, internal conflicts and corruption (MIM). * Western countries, especially states within the fold of the European Common Market, are expected to play a key role in the next phase of implementation of the Geneva accord, which involves a massive operation for the resettlement of over three million Afghan refugees when they return home after eight years (PT).

* Arms and ammunition of the Afghan mujaheddin at present is sufficient to continue the resistance movement in Afghanistan for 10 years. So if the supply of weapons was stopped by Americans in accordance with the Geneva accords, it will not affect the armed struggle against the communists

* Mawlana Fazl-ur-Rahman Khalil, the Amir of the Harkat-e-Mujaheddin-e-Afghanistan has said the return of former King Zahir Shah, as King Regent, is not acceptable to the Afghan mujaheddin as he has played no significant role in the struggle for freeing the country. from Russian occupation (DN)

* The US is confident that the mujaheddin will topple the Kabul govemment and a broad-based government will be formed there. This was stated by a member of the US State Department Policy Council, Zalmey thalilzad in a telephonic interview to the journalists of Doha and Oman (JG).

* There are speculations anong private circles in the Soviet Union that action should be taken against the Generals and military policy makers who advised the Soviet Polltburo to invade Afghanistan (NWT).

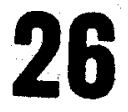

* In a statement by the UN Secretary General, Perez de Cuellar it has been stated that before 
his deperture for a meeting with the scuador President, Niego Cordovez had agreed last week that he would continue his assignnent as the WN Secretary General's representative on the Afghanistan issue (BBCFS)。

* Western diplomats in Islamabad have said two big military convoys consisting of vehicles with ooldiers on board have left Kabul during the last four nights (VOCDS).

* The Sovlet Defense Ministry says the number of 1ts troops in Afghanistan prior to the program for withdrawal was 103,000 (BBCFS).

- The Soviet Deputy Foreign Minister Yuli Vorontsov accused 25 May Pakistan in a hard tone of violating the Geneva accord. He said Pakistan continues to allow the supply of military personnel and hardware to the mujaheddin fighting inside Afghanistan through the Pakistan territory (BBCFS).

* Radio Peking has said about 350 US made Stinger rockets worth $\$ 300$ million have reached the mur jaheddin. According to the statement of the Chinese officials, the mujaheddin and the Kabul government have so much quantity of arms that would be sufficient for one whole year long battle between them (BBCFS).

* The UN Secretary General's envoy on Afghanistan, Diego Cordovez has now started his discussians with various Afghan factions on the establishment of a broad-based government in Afghanistan (RFDS),

* The UN Special Administrator for relief to the Afghan refugees, Sadruddin Aga than will armive 28 Kay in Islamabad to hold talks on the repatriation of Afghan refugees to their country (RPDS).

* The US Deputy Secretary of State (name not mentioned) has told the Congress the US is keeping close watch on the situation in Afghanistan. He said Soviet troops withdrawal is going ahead as planned (RPDS).

* The Afghanistan Foreign Minister arrived 26 May in Moscow enroute to Havana to participate in the Coordination Bureau sessions of the non-aligned movement (RMiSS).

* Under the Presidential Decree for the maximum inplementation of the NRP, and in accordance with soction III, article 75 of the Constitution,Dr. Mohamad Hassan Sharq has been nominated as Prime Ministar and asked to form the new government and according to article 101 of the Constitution to present a statement on the domestic and foreign policies of his government to the House of the People in the first session of the legislative (RA).

* The Political Bureau of Central Committee of the PDPA was convened 26 May to review 1ssues rolated to the formation of new government and the forthcoming session of the national assembly. Rich tributes were paid to Sultan All Keshtmand for his services during 9 long years and awarding the Sun Freedom motal to him was recomended. It was decided that esteemed Keshtmand should, for the time, continue as Secretary to the Central Committee (of the PDPA) (RA).

* An extraordinary session of the Revolutionary Council was held 26 May under the chairmanship of President Najibullah to discuss amendments in some laws. In the session administrative unit of the new province of Sarmo-Pul was also endorsed (RA).

* The special envoy of the French President Mitterand and the Secretary General of the Foreign iffairs of that country arrived 26 May in Kabul with a message from the French President for exeiddent Najibullah (BA). 
* The Charge d' Affaires of the Pakistan Embassy in Kabul was sumnoned to the Foreign Ministry in Kabul and the Pakistani claim that Afghan planes and artillery have bombed Tre Mangal and Landt Khana, was refuted (RA).'

* The Supreme Commander of the Sovlet armed forces, Marshal Sergei Ekhavanev, at a press conference 26 May in Moscow said his country has so far withdraw 9,500 troops, 80 helicopters and more than 1,000 military vehicles from Afghanistan (RA).

* It is understood that under the schedule prepared by the Federal government for the return of Afghan refugees, on the completion of the first phase of the Soviet troops withdrawal from Afghan1stan, the process of the return of Afghan refugees will begin from the 15 th of August to areas under the mujaheddin control to ensure the safe return of the refugees (JG).

* In an interview to an American joumal, Diego Cordovez has said about 1,000 Afghan refugees are returning to their country every day (JG).

* Afghan armed forces fired 6 rounds of artillery 14 May which landed in the Kega aree appraximately, 10 kllometres north of Chakhai in the Bajour Agency. One Paklstani has been kllled (PT). * The Supreme council of the IUAM met in Peshawar 25 May to discuss issues related to elections. The council decided the Election Commission should soon begin its work. In the elections, to be held Inside Afghanistan, the electorate will vote to parties rather than to individuals (vOAPS).

* Leader of the Jama'at-e-Dawe-Al-Afghan Mawlawl Jamil-ur-Rahman has said although Pakistan has ratified the Geneva accord on Afghanistan, its implementation will not be in the interest of jehad. He says that, as a result of the implementation of this accord, the jehad forces will shatter apart and the blood shed by hundreds of thousands of Afghans will go idle (VOAPS).

* The Washington Post wrote 25 May now that the Soviet forces are pulling out of Afghanistan. war. in that country is entering a new phase as a result of which both the Kabul regime and the mujaheddin have to review their tactics (VOAPS).

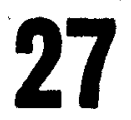

* In an interview the US President Ronald Reagan described the agreement on Soviet troops withdrawal from Afghanistan and elimination of mediun range nuclear missiles as spacimens of Improvement in relations between the US and USSR (RPDS).

- President Najibullah received 27 May the special envoy of the French President Mitterand. In the meeting a message from the French President was delivered to Dr. Najibullah (RA).

* In hls reply message to the French President Mitterand, President Najibullah under a decree par doned the French Cameramar Alian Guillo who was sentenced to 10 years imprisonment and urged the French President for further promotion of relations between the two countries (RA).

* To make preparation for the inauguration of the National Assembly of Afghanistan in accordance with 26 May decision adopted by the Preliminary Sessions of the National Assembly and the Senate, sessions of commissions for examining of credenials were hoid separately $27 \mathrm{May}$ (RA).

* The elfth memorandum of the Afghanistan Foreign Ministry in connection with the centers of eancentration and subsequent transportation of arms and ammunition from Pakistan Into Afghanistan mas submitted $27 \mathrm{Mey}$ to the UN supervizing office In Kabul (RA). 
* The UN mediator on Afghanistan, Diego Cordovez informally told newsmen 26 May he anticipates great dfficulties in the implementation of the Geneya peace accord till the Soviet troops withdrawal from Afghanistan (RA).

* The Department of Councils in the Presidency has asked members of the councils fron Kabul city and Its suburbs to hold a joint session. With candidates for the niayor of Kabul city. (RA).

* At a press conference in Geneva, the coordinator of the Afghan refugee affairs, Sadruddin Age Whan has wamed that continuation of internal war in Afghanistan w1ll jeoperdize the return of five million refugees to their country (BBCFS).

* The Independent (Iondon) writes according to a report, the IUAM leader Gulbuddin Hekmatyar wants the mujaheddin should attack Jalalabad city and thus inflict a blow to the Kabul regime from military as well as morale point of view. But other mujaheddin leaders have warned that an organiged attack on Jalalabad would be premature and might cause large scale casualties (BBCFS).

* Three Chinese made miasiles were recovered and defused by the political autliorities of Hhyber Agency in Ghundi area of Jenrud sub division 26 May before these could be flred at unspectfied targets in Peshavar city (MIM).

* The ICFC delegate-generil for Asia and Pacific region Jean Do Courton said his organtaation istended to establich medicare conters in Herat and Jalalabad for looking after the Afghane wounded In the war (MIM).

* The ANP Pakhtconkhwa has accused Zia-Junejo regime of trying to sabotage Geneva accord on Afghan Istan while it wa earlier compelied to sign it due to international preseure (MIM).

* As the Soviet Union started withdrawing its forces, the Afghan refugees speculated an anbiguous pioture during the operation. Many of the Afghan refugees Iiving in Peshawar feared that Rissia afot be plaming big affensive in another shape after the withdrawel of its forcead $A$ few young Afghan refugees believed that the Soviet forces had faced a defeat and would never think of attacking Afghantstan for the second time in future (MIM).

* In a meeting with the UN mediator on Afghanistan, Diego Cordover in Geneva, the Pakistan Forelgn Searotary Abdul Sattar has stressed the need to accelerate efforts for setting up a broadbased government in Afghantstan (JG).

* It has reliably been learnt that the IUAM has given a final shape to a plan for a full fledged operation to Ilberate Afghanistan from the communist mile (NWT).

* Thore is a great noed for the establishment of a broadbased government in Kabul which ahould enjoy the confidence of the Afghen refugees enabling them a safe and honorable rotum to thetr country (Iidtorial, NWT).

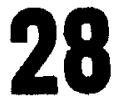

* Prime Minteter Mohammad Khan Junejo appreciated in Manila the principled stand of Phtlippines and all other peace loving countries of the world for supporting Pakistan's stand on the AfghanLetan 1ssue (RPDS).

* The Chinese President paid tribute to Pakistan for assistance to the people of Afghantstan and extending humantarian cooperation to the Afghan refugees (RPDS). 
* The coordinator of international assistance for the repatriation of Afghan refugees, Sadruddin Aga than has said the very size of the Afghan refugees indicates that their country has been ruined and the UN faces a great lask in rebullding Afghanistan (BBCHS).

* A group of Soviet military men requested 27 May the President of Pakistan Mohammad Ziaul Haq to help in the release of. Sóviet prisoners of war presently detained by the mujaheddin. The Pakistan Ambassador in Moscow, Shahid Amin has said Islamabad would spare no efforts in the release of Soviet troops whether they are in Pakdstan or with the mujaheddin (BBCFs).

* The Independent (London) writes the inaugural session of the Parliament in Kabul is a fresh attempt of the Kabul government to convince the mujeheddin to and the war and accept what the government calls the MRP (BBCFS).

* On the basis of Presidential Decree No.284, 46 prominant social figures of the country have been nominated by the President to serve Senators (RA).

* The Department of the affairs of Councils has reported that, Decree No.290 about the establishment of a council of Afghan Constitution has been approved under Article 122 of the Constitution (RA).

* On the request of French President, Francois Mitter and, President Najibullah has pardoned the remaining term of the imprisonment of the French cameraman, Alian Guillo who had illegelly entered Afghanistan and was arrested by the security forces of the country and was sentenced to 10 years imprisonment (RA).

* The Soviet Foreign Minister Eduard Shevardnadze met 28 May Foreign Minister Abdul Waktl who paid a stopover visit to Moscow on his way to Havana to attend the non-aligned countries conference. In the meeting the two Foreign Ministers discussed relations and cooperation between Afghanistan and the Soviet Union under present circumstances (RA).

* The UN Bconomic Council decided 25 May to consider the grant of humantarian assistance to Af- ghentistan. The decision has been taken as a result of consultations held at the request of the Afghan permanent envoy at the UN, Shah Mohammad Dost (RA).

* TASS, quoting the Soviet Foreign Miniater Eduard Shevardnadze and the Afghaniatan Foreign vinister Abdul Wakdl, has reported that piling up and storing arms at the Pakistani territory for the Afghan mujaheddin continues and Pakistan is violating the Geneva accord by supplying arms to the mujaheddin (VOAPS).

* The UN official on the affairs of humantarian and economic assistance to Afghanistan, Sadruddin Aga than says if war continues in Afghanistan, reconstruction of the country and a program of aid to the refugees w1ll face many problems (VOAPS).

* Diego Cordovez, UN mediator in the Afghan peace settlentent said 27 May he plans to meet the Afghan President Najibullah and Pakistan President Ziaul Haq 6 June in NY (MLM).

* The Kabul regime received a blow 26 May when the UN Economic and Social Counctl (ECOSOC) ignored Its proposal for international aid to rebulld Afghanistan, ravaged by 8,5 years of war (MIM).

\section{0}

* The IUAY in a otatement in Peshavar has refuted (stet) the appointment of Mohomad Hassan Sharq as Prime lantater and described him as a communt (BBCSS). 
* TASS reported the Sovlet Union might review the date of the Soviet troops withdrawal from Afghanistan because of the continued assistance to the Afghan rebels (BBCFS).

* The UN coordinator on the Afghan refugees affairs Sadruddin Aga Khan has appealed to the big powers to help in the economic rehabilitation of the people of Afghanistan (BBCFS).

* The Soviet Union has warmed Pakistan of continued assistance to the Afghan mujaheddin. In a atatement the Soviet Foreign Ministry has accused Pakistan of not observing the Geneva accord

(VOGDS).

* In a statement in Rawalpindi, President General Mohammad Ziaul Haq has said the important aspect of the Geneva accords, the withdrawal of Sovlet troops, is being implemented and the remaining two 18sues, the return of the Afghan refugees and the formation of a government acceptable to all the Afghan people, are yet to be worked out (RPDS).

* The first legislative term of the Parliament was Inaugurated 29 May by Najibullah in Kabul (RA).

* The first session of the Parliament comprising the House of the People and Senate, was held 29

May under the chaimanship of the Interim Chairmen of the Senate, Sayyed Jalaluddin Badri for discusation on the draft bill of the Parliament (RA).

* The seventh memorandum about the open violation of clause-II of the first instrument of the Geneva accords by Pakistan was delivered 29 May to the UNIAG office in Kabul (RA).

* The eighth memorandum about Pakistan's violation of the regulations pertaining to non-interference submitted 29 May to the UNIAG office in Kabul (RA).

* President Ziaul Haq of Pakistan has anticipated that Sovlet troops withdrawal from Afghanistan wll accelerate fighting between the Afghan governnent and the mujahedain (BBCFS).

* The Sovlet Union has asked Pak1stan to express prudence and exert all necessary effort.s for the implementation of the Geneva accords on Afghanistan. In a statement the Soviet Foreign Ministry has sald armed Afghan groups with truck loads of arms are entering Afghanistan from Paldstan (FuDS).

* The Prench reporter Alian Guillo who was released 28 May in Kabul and proceeded to New Delhi has sald he was not subjected to physical torture in the prison but had been under mental pressure and not permitted to read newspaper and his private letters were not delivered to him (VOAPS).

* The US President Rongld Reagan has congratulated the Soviet leader Mikhatl Corbachev on the decision to withdrawal Soviet troops from Afghanistan (VOAPS).

* Mr. Sedruddir Aga Khan, Coordinator for the UN aid to Afghanistan hoped 28 May in Islamabad that after the Geneva accord the Afghans would be able to rebuild their homes (PT).

* The garrisons, vacated by the Kabul regime forces along Kabul-Kandahar highway, have been captured by the mujaheddin, reports BBC monttored in Islamabed 28 May (PT).

* Hopes that the former King Zahir Shah will return to unite the bitterly divided Afghanistan appenr to have receded further, diplomatic sources close to the Kabul regime said in Kabul (MIM). * Xinhue reports UN military experts will help remove land mtnes left in Afghanistan by the witis. draining sovlet troops (DN). 


\section{0}

* The UN Ald Coordinator for Afghanistan Sadruddin Aga Khan has said the Afghan refugees should voluntarily return to their country. He also visited an Afghan refugee camp in Peshawar (RPDS). * The US Secretary of State, Ceorge Shultz and Secretary Defense, Frank Carluccl in an intervlew, after the first round of Reagan-Gorbachev talks in Moscow, said the US would continue to give assistance to the Afghan mujaheddin so long as Moscow continued arms supply to the Kabul regime

(RPDS).

* President of the Kabul government Najibullah, while inaugurating the Parliament, announced general amnesty and urged the mujaheddin to immediately observe ceasefire (VOGDS).

* In a statement issued $30 \mathrm{May}$, the conference of the European organizations, supporting the Afghan resistance groups convened in Brussels, asked the UN and the US government not to receive Dr. Najibullah for a visit scheduled to the world body in NY (BBCFS).

* The House of People and the Senate held 30 May separate sessions at the Parliament building durIng which the deputy of Kabul city, Dr. Khalli Ahmad Abawl was elected whth a majority vote as speaker of the House of the People and Dr. Mahmood Habib1 as Chairman of the Senate with one negative vote (RA).

* The House of the People elected 30 May the deputy of the Kabul people, Saleh Mohamad Zairey and the deputy of the people of Badakhshan,Zahoorillah Zahoori as Deputy Speakers and the deputy of the people of Kabul, Sayyed Muzaffaruddin Shah Muzaffart and the deputy of the poople of Jauzjain, Abdul Rahtm Aind as Secretaries of the House of People (RA).

* The OJher1 camp disaster, sectarian clashes in Gilgit and the Afghan issue are being described as some of the factors behind the President's move to dismiss the National Assembly and the federal cabinet, observers in Islamabad say (MIM).

* The JUI provinciel secretary, Al-Haj Amir Nawaz Khar, Advocate, has feared civil war in the region in case the Afghan refugees were forclbly returned to Afghanistan without providing conditions for their return (MIM).

* The Pakhtunkhwa Milli Awami Ittehad (PMAI) General Secretary, Sher Ali Bacha has demanded that the government should honestly implement the Geneva Accord so that peace could be restored in the region (MIM).

* The UN ald coordinator Sadruddin Aga Khan met 29 May President Zlaul Haq of Pakistan in Rawalpindi and exchanged views on the UN role in the repatriation and rehabilitation of the Afghan refugees (PT).

* Addressing 29 May the Afghan refugees at Katcha Garhi refugees camp, the UN aid coordinator, Sadruddin Aga than said the Afghan refugees would themselves decide about their return to Afghan1stan (PI).

* An aide to Soviet leader Mikhail Gorbachev, Vovgeny Primakov said 27 May in Voscow the US has violated the Geneva accord by continuing to ship weapons to the Afghan mujaheddin (DN).

* Mhange of a face in Kabul"... The policy of changing tactics and faces were only effective when 
a aper power was imparting guidance to Najibullah at every step. The situation is going against Najib so fast that no change except his own can change the dimension (Editorial, IG).

\section{1}

* The Japaneese Prime Kinister said 31 May in Tokyo his country would send next month a 9 menber connittee to Pakistan to study ways facilititing the safe return of Afghen refugees to their country (RPDS).

* Itely has sent a high ranking diplomat to Kabul for seeking the release of an Italian journalist who has been sentenced to seven years imprisonment on charges of espoinage and illegal entry into Afghenisten (RPDS).

* The ERG has earmarked DM 20 million as aid to the Afghan refugees in Pakistan, according to the IIG Kinistry of Economic Cooperation (WOGDS).

* Western diplomatic sources in Pakistan and Afghanistan say, Soviet troops are presently busy in retreating from Chazni and Gardez cities (BBCFS).

* In Its session the Senate unanimously elected Sen. Jalaluddin Badri, Balkh, Sen. Shah Ali Acbar Shahrestant, Uruzgan, Vice Chairmen, Sen. Mohamad Omar Shafi, Farah, Sen. Chulam Ahmad Kehdisade, Kundus, Secretaries of the Senate (RA).

* Nineth memorandum of Afghanistan on violations of Geneva accord by Pakistan was delivered 31 May to the office of UNIAG in Kabul (RA).

* A protocol of direct cooperation between Soviet Astra Khan province and Farah province, of Afghanistan was signed 31 May (RA).

* Newemen who have visited the Afghan refugee camps, say so far no body from the Afghan refugee canps has returned to Afghanistan (VOAPS).

* Diplomatic and resistance sources say the morale of Kabul regime soldiers has been badly weakened and many of them join the mujaheddin with their.arms. It is said that Kabul troops defection has caused great concern in the Defense Ministry of the regime. (VOAPS).

* In a statement $30 \mathrm{May}$, in Peshawar, the IUAM President Gulbuodin Helamatyar claimed, following the announceinent of general amnesty by the mujeheddin, a large number of soldiers, military officers and the so-called "custodians of the revolution" have joined the mujaheddin (MIM).

* Telking $30 \mathrm{May}$ in Peshawar to a tribal jirgah, the IUAM President Bngineer Gulbuddin Hekmatyar eaid, with the Iritervention of the Soviet Union in Afghanistan,the balance of power in the region hed boen disturbed (PT).

* Hoscow has despatched kCs troops to reinforce the regular guards in Soviet republics as mujaheddin's armed patrols have begun crossing the Afghan-Soviet borders, The Newsweek has reported in Its latest issue (DN).

* One person was kdiled and five serlously injured in an armed clash between the Kurrem Levies and the Afghan mujaheddin at Asgharo refugee camp some 20 milles fiom Sadda in Kurram Agency

(MII).

* The Janintmenslami Afghantstan has claimed, a pro-Kabul, senator and Chief of Kabul regimes Lodistic depatment General (Retd) Fazal Ahmad has defected to the mujaheddin. The san of tha 
Senater who was Corps Commander of troops in Herat has also defected (MLM).

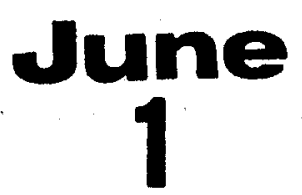

* The US State Department says it has asked the Soviet Union to shipout its military equipment from Afghanisten instead of leaving it at the disposal of the Kabul regime. A vaA correspondent says Wastington is ready to take similar action in providing military ald to the mujaheddin (VOADS).

* Following his visit to Afghanistan, the ICRC President said in Geneva, in view of the political situation in Afghanistan, relief resources will not be able to easily continue their activities in distributing rellef goods to the Afghan refugees (RPDS).

* The UN ald coordinator Sadruddin Aga Khan sald 1 June in Geneva that ald would pertain to those regigns where it is guaranteed that the return of Afghan citizens to them does not entail any danger for them (BBCFS).

* In a statement in the presence of the US President Ronald Reagan in Moscow, Sovlet leader Mikhail Gorbachev sald we are endeavoring to exert all efforts to remain loyal to the Geneva accords. We do not want to increase military supplies to Afghanistan. Recent attempts by Pakistan may entall considerably negative consequences, he said (RMDS).

* President Najibullah received 1 June the Italian President's envoy carrying a message for the release of an Italian joumalist now detained in Kabul (RA).

* Under Decree No.293, President Najibullah has pardoned 1 June Fausto B1loslavo, an Italian citizen who was sentenced to sever years of imprisonment on charges of anti-Afghanistan activities (RA).

* A source of the Depertment of Councils in the Presidency has reported, in continuation of the list of Presidential decree No.284, Haji Ghausuddin, Malek Sharif, and Abdul Sattar Shinwari have also been nominated as Senators by the President (RA).

* Afghan President Najibullah may cancel a planned visit to Czechoslovakta next month, Westem diplomats said 31 , Nay in Kabul (MIM).

* In a statement $31 \mathrm{May}$, the IUAM strongly criticized a statement attributed to the UN envoy on . Afghanistan Dtego Cordovez in which he had claimed that about 1,000 Afghan refugees were returning home dally as they cared the least as to who ruled in Kabul (MIM).

* Telking 31 May to newsmen after the provincial council meeting of afro-Asian Peoples Solidarity Organization Pakhtunkhwa in Peshawar, the ANP leader, Begum Nasim Wall khan alleged that President Ziaul Heq's recent moves were designed not only to sabotage the Geneva accords but also to deepen Pakistan's Involvement in the Afghan imbroglio (MIM).

* Commenting on the dissolution of the national assembly and the government by President Ceneral Ziaul Haq, the Acting President of National Awaml Party Pakhtunkwa, Abdul Kahim Advocate said the whole exercise was carried out with a view to destablizing Afghanistan and to sabotage the Geneve Hocord. He clatmed that the General was flexting his muscles to step up resistance in Afghaniatan dapture Kandahar and Jalalabad for the mujahoddin (MLM). 
* During occupation of Alikhel cantonment the mujaheddin have recovered some most confidential documents which show that the subversive activities in Kurram Agency were directly supervized and directed by Brigadier Mohammad Hashem of the Afghanistan army who had received training in subversive activities in the Soviet Union (JG).

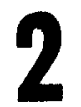

* Quoting the US State Department, in its issue of 1 June, The Washington Post writes, the Soviet assistance to the Kabul regime continues uniterrupted and, thus, the US aid to the Afghanistan resistance also continues (VOADS).

* At a press conference, Soviet leader Mikhail Gorbachev condemned the mujaheddin attacks on the Soviet troops withdrawing from Afghanistan and said the Soviet Union will give appropriate reply in every aspect (VOADS).

* In an interview with the BBC on the conclusion of the two super power summit the Soviet Vice Foreign Minister, Igor Rogachev said continued mujaheddin attacks on retreating Soviet troops will jeoperdize the implementation of Genevy accords (BBCFS).

* The UN aid coordinator for Afghanistan Sadruddin Aga Whan has said, in view of fighting in Afghenistan the Afghan refugees are left in a delimma for their return to the country and one of the main difficulties is the existence of mines (RPDS).

* Quoting 1 June a Soviet Generel, AFP reported that 35,000 Soviet troops have returned to their country 15 - 26 May from Afghanistan (RPDS).

* Soviet leeder Mikhail Gorbachev has alleged that Pakistan wants to undo the Geneva accord on Afghanistan. He referred to the attacks on the Soviet troops and the Embassy in Kabul by the mujam heddin which he claimed was supported by Pakistan (VOAPS).

* In reply to the Soviet criticisn of Pakistan, the US Defense Secretary, Frank Carlucci said Pakistan is doing in the right things. He sdded, so long as the Soviet Unton continues military supplies to the Kabul regime, the mujaheddin should also have sufficient arms and equipment for self defense (VOAPS).

* The AMPC says the Kabul regime executed 7 May 60 political prisoners in Pul-e-Charkhi jafl (VONPS).

* A source of the Hezb-e-Islami (Mawlawi Khales) says, some prisoners have been shifted from Pul-o-Charki jatl to a prison in the Prime Ministry Building and other jails. The purpose of the move is said to be to convince intermationel delegations that only a small number of people are In Afghan prisons (VOAPS).

* Qudratullah Ahmadi, the Afghan Charge d' Affaires in Islamabad called 1 June on Air Marshal (Retd) Asghar Khan at his residence to condole the death of his mother (MIM).

* The Kabul communist administration has set up three Speciel Taek Border Brigades. Informed sources told ANS these Brigades are named Strafic Brigade, 84 State Intellegence Brigade and 523 rd Secret Police Brigade. According to reports, the Red Army KCB instructoris have started the brigede persomel training on emergency basis (JG). 
* A member of the European Parliament Michael Walsh visited 3 June an Afghan refugee camp in Katcha Garhi, Peshawar. He assured the refugees of further assistance from Western countries (RPDS).

* Pakistan has criticized Afghanistan of shelling Chaman 2 June. Pakistan says as a result of: two artillery fires two Afghan refugees were killed and two others were injured (BBCFS).

* The Afghan Foreign Ministry delivered its 11th memorandum to the UNIAG office in Kabul against the violations of the Geneva accord by Pakistan (RMDS).

* Under Presidential decree No.298, the appointment of four Vice Presidents has been ordered. They are Abdul Rahim Hothef, Lt. General Mohammad Rafi, Abdul Hamid Mohtat, and Abdul Wahed Sorabi (RA).

* The Foreign Ministry has informed the UNIAG office in Kabul that 12th memorandum was submitted to that of fice about the violations of Geneva accords by Pakistan (RA).

* A protocol on educational, economic and cultural cooperation for 1988-89 was signed in Herat city between the provincial committee of the Herat Youth Organization and the KOMSOMOL committee of Ishaqabad city, Turkmanistan of the USSR (RA)d

* President Najibullah left for NY 3 June at the head of a high ranking delegation for participation in the third UN General Assembly session on disarmament (RA).

* The Red Cross Secretary General, Par. Stein Dut alongwith the UN relief mission on his return

2 June in Geneva from Afghanistan said if five million Afghan refugees did not receive assistance they would face great hardships.

Meanwhile the UN Secretary General Perez De Cuellar has appealed for funds for the rehabi- litation of Afghan refugees and the UN authorities believe one billion dollars will be sufficient for this purpose (MIM).

* It is quite alarming that the Soviets so far have not contradicted the extensive press coverage of their plan to divide Afghanistan and carve out a separate republic in the northern provinces which will eventually be an extension of their usurpation on the other side of the Oxus. The Russio-American collusion on the mutilation of Afghanistan is the repetition of German episode. However if the mujaheddin leadership and the Muslims of the world do not allow themselves to be cheated, nobody can deny Islam the role it has to play in the affairs of mankind (Dr. Murad Ali Shah in the Musiim):

* Two Afghan refugees were killed and two injured when the Afghan armed forces fired eight rounds of tank grm on May 29 which landed in the Bogra Karez and Kamal in Chaman Baluchistan (MIM).

* In an interview Zabihullah Mojaddidy Vico-President of the mujaheddin interim government has said the future system and government in Afghanistan must be decided upon in accordance with the wishes of the Afghan people assessed through a loya jirgah which could even be held in Peshawar and not through an election for which the tribal structure. of the Afghan society was not yet ready (MIM). 
* The UN Secretary General discussed 3 June issues related to the Geneve accords with the Afghan Foreign Minister, Abdul Wakil. In an interview with TASS, Wakil said the Afghan side has expressed concern over the violation of Geneva accord by Pakistan (RMDS).

* President Najibullah, enroute to NY, met 4 June the Soviet leader Mikhail Gorbachev in Moscow. Gorbachev apprised the Afghan side of the outcome of his talks with the US President Ronald Reagan in Moscow (RA).

* The Foreign Ministry informed the of fice of UNIAG in Kabul that 13th memorandum about Pakistan's violations of Geneva accord has been delivered 4 June to that office (RA).

* UN officials in NY say, the Soviet Union has withdrawn since 15 May 10,000 of its troops from Afghanistan (VOAPS).

* Talking 3 June to newsmen in Kaziabad village, Mansehra, the NWFP Chief Minister, It.General Pazl-o-Haq said, in view of the political situation in Afghanistan, there was every likelihood of increased sabotage activities by KHAD or other such agencies inside Pakistani borders, particularly in the NWFP but we are fully prepared to foil these attempts (PT).

* The UN Under Secretary General Diego Cordovez who mediated the Afghan settlement, is expected to visit Kabul, Islamabad and Teheran at the end of June to begin trying to form a broad-based goverment to take power in Kabul (DN).

* A Kabul court has sentenced two Afghan mujaheddin to capital punishment on charges of murder and dacoity (JG).

\section{5}

* The US President Ronald Reagan has said, during his meeting with Soviet leader Gorbachev in Moscow, he agreed that the Soviet troops withdrawal from Afghanistan is a step which can be used as in example in the settlement of other regional disputes (RPDS).

- The Pravda says the Pakistani government is shifting the bases of the Afghan mujaheddin far from the borders and instead of disarming the rebels it is deploying them in the south of afghan1stan (BBCFS).

* Wostern diplomats and the mujaheddin sources are of the view that a reason that Prime Minister designate Hassan Sharq has not yet introduced his cabinet is a conflict between Khalq and Parcham factions as well as refusal by present ministers to quit their posts (BBCFS).

- A Sovlet newspaper writes, as a result of mujaheddin attack 30 May on a Soviet convoy, five troops including three officers were killed (VOADS).

* Talking 4 June to a delegation of International Citizens Commission in Peshawar, the IUAM President Gulbuddin Hekmatyar wamed of a fresh influx of Afghin refugees into the neighbouring countrLes if they were pushed out hastily into Afghanistan (MIM).

* The ANP has set up a "rabita cormittee" to contact Afghan refugees and impress upon them the plability of the Geneva accord and ascertain the factors impeding their return to Afghenistan in peace and honor. This was disclosed by the ANP district Peshawar President Arbab Mujibur Rehmen (MiM). 
* Bleven Soviet-Kabul troops were killed or wounded when two bombs exploded in the Kabul city and Jalalabad, according to an eye witness. (PT).

* Several Afghan children have died of sun stroke in the Katcha Garhi refugee camp near Peshawar and a large number are reported in a critical condition (PT).

* Mre day the Soviet Unton pulls out of Kabul is the day we are there. Without the Russians, Dr. Najibullah's regime has no chance of survival", the IUAM President Engineer Gulbuddin Hekmatyar told the Swedish newspaper Aftonbladet (PT).

* We understand that need for the establishment of an interim government has further gained intensity. Because the atmosphere of confidence and goodwill gained as a result of Reagan-Gorbachev meeting can be maintained only by providing an opportunity of self determination to the Afghan people and not by leaving Afghanistan engulfed in war for some more time. Since this objective can be achieved immediately through the establishment of a broad-based interim government in Afghanis$\tan$, all the concerned parties should therefore, extend full cooperation in setting up such a governuent (JG - Editorial).

* In an interview 3 June to a private television station the former Afghan King Zahir Shah said he is ready to take part in any referendum for choosing a new government in Afghanistan (JG).

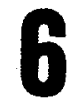

* Charles Wilson a prominent US Congressman held taiks 5 June with President General Mohammad Ziaul Haq of Pakistan in Rawalpindi on the implementation of the Geneva accord and bilateral relations between the two countries (RPDS).

* The BBC correspondent reports from Kabul that President Najibulilah of Kabul goverment is expected to deliver a speech at the US General Assembly session on disarmament and would try to seek. the support of western countries. He will also endeavour to get his government's NRP endorsed (BBCFS).

* The Vashington Times writes a western diplonat in Kabul has said the Soviets want that there should be stability in Kabul following their troops withdrawal. If Najibullah could not implement the plan, the Soviet Union is ready to enter a deal with the mujaheddin (VOADS).

* An NIF spokesman has said the leader of that organization will take up 15 June the leadership of the IUAM on a rotation basis. The spokesman added the military commanders who have in fact carried forward the war should participate in a military council for adopting political decisions ( hocDs).

* The Indian Prime Minister Rajiv Ganaihz has said in Syria the Geneva accords have provided the foundation for the restoration of peace and normalcy in Afghanistan. The aspirations of the people of Afghanistan will only be accomplished when all foreign interference in the internal affairs of that country ends (RMDS).

* The Newsweek (USA) reports, Afghan mujaheddin have recently acquired fresh consignment of US rockets. According to a correspondent of the magazine, the long range rockets can be used to hit Kabul city (FaDs).

The Uashington Times reports the us has not allowed Najibullah's plane to remain in the us 
texritory after landing in NY. So, after carrying Najibullah to NY, his plane stayed in Havana

(VOADS).

* A delegation of the council of ministers of Tadzhikistan Republic of Fussia arrived 6 June in Kabul. The delegation will hold talks with the Agriculture Minister and Minister of State for direct cooperations and trade, on Tadzhikistan's direct cooperation with Badakhshan, Takhar and Kunduz provinces (RA).

* A protocol for providing direct assistance by Tadzhikistan Republic of Russia to Kunduz, Badakhshan and Takhar provinces was signed 6 June in Kabul (RA).

* The fifteenth memorandum of Afghanistar about seven violations of Geneva accord by the Pakdstani officials was delivered 6 June to the UNIAG office in Kabul (RA).

* The ICRC office in Peshawar has said it can help to free the 310 Soviet soldiers who were captured by the armed opposition in the course of the war in Afghanistan (RA).

* In an editorial 6 June about the situation on the borders of Pakistan and Afghanistan, The Pravda writes, while Afghanistan and the Soviet Union are strictly adhering to the Genevá accords, the other parties are inclined to play a game with the implementation of these instruments. As such they are trying to link all the things to an adherence to the timetable of the withdrawal of Soviet limited contingents from Afghanistan (RA).

* The New York Times wrote 5 June the Russians experience in Afghanistan is different from the US experience in Vietnam because the Americans had won the war in the battlefield while the Soviets have lost the war on the Afghan front (VOAPS).

* The Soviet Union again criticized 5 June Pakistan for alleged violation of Geneva accords and warned that if Pakistan did not abide by the provisions of the agreements, the Soviet Union would also be free-to act as it deened fit in the circumstances, the BBC reported (MIM).

* The Toronto Star, Canada's biggest daily newspaper, has written a powerful account of the Afghan war that tells the story of the mujaheddin amazing struggle against the super power that invaded their land (PT).

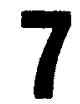

* The UN mediator on the Afghan ịssue, Diego Cordovez held 6 June separate meetings in NY with the Paldistan envoy to the UN Shah Nawaz and the Kabul regime President, Najibullah. The UN spokesman described these talks as confidential (RPDS).

* A three member delegation of the Afghan leuders held discussions 6 June with the NWFP caro-takex Chief Minister on matters of mutual interest in Peshawar (RODS).

- The BBC correspondent reports from Kabul that, foilowing a few days of delay and during the absence of the Kabul regime President Najibullah who is visiting NY for participation in the UN General Assembly session on disarmament, names of the new cabinet members of the Kabul were announced in Kabul (BBCFS).

* Western diplomats in Kabul say a new type of Soviet made bomb has been brought in recently to Ifghanistan. It is a kind of napaln explosive matter which dissolves in the air and has great dest- 
ructive affect. The mujaheddin sources say the bornb has been used in several areas (BBCFS). * President Najibullah met 7 June the UN Secretary General Perez de Cuellar in NY and discussed with him the issue of the solution of situation around Afghanistan (RA).

* In an interview 7 June with the Columbia Broadcasting System (CBS) in NY President Najibullah urged that the US as a guarantor of the Geneva accord should help in the implementation of the accords and should not allow further interferences in the internal affairs of Afghanistan (RA). * Under section 101 of the Constitution, the Prime Minister designate Mohammad Hassan Sharq explained his government's internal and external policy and introduced members of his government to the House of the People for seeking a confidence vote (RA).

* Sixteenth memorandum of Geneva accords violations by Pakis'tan was: delịvered 7 June to the UNIAG office in Kabul (RA).

* Quoting its correspondent, The Christian Science Monitor wrote 6 June that the land situated in the valley of Spin Ghar, Afghanistan, has not been cultivated during the last eight or nine years and most of the villages in the region have been devastated. Observers on Afghan affairs say it was the policy of the Soviets to intentionally upset and disturb the system of agriculture in areas under the mujaheddin control. Moreover, the valley is crucial for cattle grazing but communist forces have planted thousands of mines in the area (VOAPS).

* After the announcement of a general ammensty by the mujaheddin, a large number of Afghan soldiers, military officers, Sarandoy and the so-called guardians of the revolution, have joined the ranks of the mujaheddin, according to a statement of the IUAM Chairman, Gulbuddin Hekmatyar 6 June released by the Hezb-e-Islami in Karachi (PT).

* "It is important that the regime in Kabul, the resistance fighters inside Afghanistan, the Peshawar-based guerrillas and the Afghans in exile in Pakistan and abroad are consulted on a power shering arrangement for the interim period. If such an arrangement is worked out, it would automat1cally resolve the most contentious issue in Afghanistan today, namely that of contiruing arms supplies to the mujaheddin and the Kabul regine, a phenomenon which is incompatible.with the provisions of non-interference and non-intervention in the Geneva accord" (Editorial, DN).

* At a press conference 6 June in the Press Center of the Soviet Foreign Ministry, The Soviet Scientist, Andrie Sukharov said Soviet troops withdrawal from Afghanistan, is an event of historic importance and the pullout should continue under all circumstances (NWT).

* President Najibullah of Afghanistan has all of a sudden cut short his foreign visit abroad as he fears a coup to topple his regime. This was disclosed by The Nashington Times, quoting western diplomatic sources (JG).

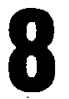

* President Najibullah of the Kabul government has said in NY that more than 34,000 Soviet troops have so far left Afghanistan. He accused Pakistan of violating the Geneva accord (BBCFS).

* In his speech at the UN in NY, leader of the Kabul regine, Najibullah said his regime reserves the right of taking appropriate measures against Pakistan's interference (VOADS). 
* The US State Deprartment says a visit by Najibullah to the UN is allowed as part of US obligation towards the UN and it does not represent any change in the US poljcy towards Afghanistan

(VOADS).

* Western diplomats report from Kabul that special groups of the Kabul communist regime are seen on the streets in search of youngmen over 18 to forcefully recruit them to military service. (VOADS)

* During his farewell meeting with the Soviet Ambassador, Vezirov, President Ziaul Haq of Pakistan said in Islamabad his country will extend full cooperation in the implementation of the Geneva accords (RPDS).

* Hundreds of Afghan refugees in NY staged 7 June protest demonstrations in front of the UN building on the arrival of President Najibullah of the Kabul regime. The demonstrators were chanting slogans against him. They demanded the expulsion of Najibullah and formation of an Islamic government in Kabul (RPIS).

* In his speech at the UN Geneva Assembly on disarmament, President Dr. Najibullah of Kabul government said the war casualties in Afghanistan.including children and women has been 250,000 persons (BBCFS).

* Speaking at the Parliament of Afghanistan, Dr. Hasan Sharq Prime Minister of the Kabul regime, once again reiterated a commitment by the Kabul government to pursue the NRP so, according to him, all rival factions, inside and outside the country, share the government (BBCFS).

* The seventeenth memorandum on Pakistan's violations of the Geneva accord was delivered 7 June to the UNIAG office in Kabul (RA).

* Under the Presidential decree,-65 prisoners were released 7 June from Pul-e-Charkhi Prison (RA). * After their return to their country Soviet troops deployed in Ghazni handed over military hardware worth more than $12,742,000$ rubels to the Afghan armed forces (RA).

* About the appointment of Dr. Hasan Sharq to replace Keshtmand as Kabul Premier, the Hezb-eIslami leader Gulbuddin Hekmatyar has said it is a routine matter and does not have any impact on the general situation. He said Sharq had from the very beginning been at the service of communists. The comminists had confidence in him even during Daoud's tenure and they have now put him forward. The communists are heinously attempting to prolong their rule, he said (VOAPS).

* An IUAM source says a US Congressional delegation, headed by Rep. Charles Wilson met 6 June tr.e mujaheddin leaders in Peshawar and visited the Museum of arms captured from the Russians durirb war (VOAPS).

* The VOA correspondent reports from. Islamabad that the Islamic Alliance Organization of Prof. Sayyaf and the Jamiat-e-Islami of Prof. Rabbani have merged and have formed a united organization headed by Prof. Rabbani (VOAPS).

* The VOA correspondent reports from Islamabad that the mujaheddin leaders gathered 8 June in Peshawar to appoint the remaining members of the interim govermment. The government will be announced this week or a week after (VOAPS).

* The Pakistan Ambassador in Moscow was summcned to the Soviet Foreign Ministry to receive a memorandum saying that the Soviet Union has received reports of Pakistan.violation of the Geneva 
record and such a state of affairs should not continue any longer (NWT).

* Speaking 6 June at a press conference in Islamabad, former Minister of State for Foreign Affairs, Zain Noorani said the Geneva accord was signed with the consent of President Ziaul Haq (NWT).

* A White House spokesman has said the US will rot stop arming the Afghan resistance as long as the Soviet Union continues to arm the Kabul regime (PT).

* A large number of mules airlifted from the us have been sent to Chitral to help Afgrian mujaheddin in the transportation of their arms and food supplies inside Afghanistan (MIM).

\section{0}

* The Indian Prime Minister, Rajiv Gandhi and President of the Kabul government, Najibullah met in NY and afterwards alleged that Pakistan continues to create obstacles towards the inplementation of the Geneva accord on Afghanistan (BBCFS).

* At a press conference 8 June in Islamabad, adviser to the US State Depertment Zalmai Khalilzad said the US is closely watching progress on the Soviet troops pullout from Afghanistan. He said it has been made clear during the course of Geneva talks and in the US-Soviet negotiations that the US will not leave the Afghan mujaheddin alone during the Soviet troops withdrawal. from Afghanistan

(RPDS).

* The UN Aid Coordinator for Afghan Refugees (UNACAR), Prince Sadruddin Aga Khan on his arrival in NY said a vast and comprehensive plan is essential for eradicating the effects of the eight year long fierce war in Afghanistan (RPDS).

* In a message to the UN Secretary General, Soviet Foreign Minister Eduard Shevardnadze has said the Soviet Union and Afghanistan are seriously adhering to the Geneva accords while Pakistan is violating these agreements (RMDS).

* The eighteenth memorandurn about Pakistan's violations of the Geneva accord was delivered 9 June to the UNIAG office in Kabul (RA).

* Installations worth 10 million rubels, built during the stay of the Soviet limited contingents in Jalalabad, have been put at the disposal of the armed forces of the country (RA).

* The Pakistan Ambassador in Moscow, Shahid Mohammad Amin was summoned 8 June in the Soviet ForeIgn Ministry and told that, despite its commitments. in the Geneva accords and assurances for adherance to these accords, Pakistan is openly violating these accords. Pakistan should adopt urgent measures for the implementation of its commitments, the ambassador was told (RA).

* The NIF leader, Sayyed Ahmad Gailani is to take over 15 June as the IUAM President (VOAPS).

* The Indian Prime Minister, Rajiv Gandhi has said the greatest danger after the Soviet troops withdrawal from Afghanistan would be the establishment of a government by Islamic fundamentalists in Kabul. He alleged that Pakistan might become the big supporter of terrorism in the world (BBCPS).

* The former Pakistan Minister of State for Foreign Affairs, Zain Noorani says President Ziaul Haq memoved him due to difference on the Geneva accord. He said a decision to sign the Geneva accord wo adopted after profound differences. He did not give any more details saying, he would might be arrested (VOAPS): 
* Resiotance sources say that Lt. Col. Deen Mohammad, elder brother of Ahmad Shah, General Commander of the Jamiat-e-Islami in northern provinces, has been missing since 2 June in Peshawar (VOAPS)

* Quoting intellegence sources in a report, The Washington Post has said simultaneous with the retreat of Soviet troops, the mujaheddin are making rapid advances and the retreat of Najib troops has perturbed the Soviet Union. The report adds that, after the Afghanjstan war, Pakistan has strengthened its grip in the region. In the report rich trjbutes have been paid to President Ziaul Haq for adopting an accurate policy toward the Afghan issue (JG).

* The UN Secretary General Javier Perez de Cuellar is expected to launch a coordinated appeal this week for humanatarian aid for Afghanistan and its estimated five million refugees, UN officials said 8 June (PT).

* According to the Afghanistan resistance sources, the mujaheddin attacked 12 May a Kabul regime convoy on highway between Jauzjan and Mazar-e-Sharif destroying three trucks and tanks (VOAPS).

\section{0}

* A UN spokesman said the UN will make 10 June an appeal to the rich countries to offer humanitarian and economic aid to the people of Afghanistan (EBCFS).

* In a communique issued in Madrid at the conclusion of the NATO Foreign Ministers meeting, the Geneva accords on Afghanistan and the recent US-Soviet summit in Moscow has been hailed. The participants also announced. their support for a start in soviet troops pullout from Afghanistan (RPDS).

* The Charge d' Affaires of Kabul Embassy in Islamabad was summoned to the Foreign Ministry and a strong protest note was delivered 9 June to him against the tank gun fire by the Kabul troops in Chanian, Baluchistan, injuring a person (RPDS).

* Formal talks between the Afghan and Cuban delegations began 9 June in Havana. The Afghan delegation, led by President Najibullah, apprised the Cuban delegation of the Geneva accords and the NRP and the Cuban delegation expressed its fuli support to the Geneva accords (RA).

* During his stay in NY President Najibullah vișited the construction work of Islamic Research Center in the city and presented a number of carpets as a gift from the Afghanistan government to the center (RA).

* A delegation from the Ukrainian Republjc of the USSR arrived 10 June in Kabul for talks on further assistance by Kharkev province of the Ukrainian Repubilic to Parwan and Nimroz provinces (RA). * In a meeting in NY, the Soviēt Foreign Minister, Eduard Shevardnadze and the Indian Prime Minister, Rajiv Gandhi have said Pakistan is openly violating the Geneva accords and foreign intervention in the affairs of Afghanistan ras not only not been reduced but has escalated (RA).

* The comnissioner of Quetta division, Dr. Akbar S. Ahmad has said that the Pakistan govermment will take every possible step for the welfare of the Afghan refugees and the govermment has stopped not a single refugee from returning back to his hone and will not do so in future too (MIM).

* Ten Afghan planes violated the Pakistani airspace 9 June and bombed a number of villages in North Waziristan Agency (MIM). 
* A protert procession was organized 9 June jolntly by ANP, Baluchiotan and PSF In Guetta in favor of the inplementation of the Genevs accord and against the lawlessness in the country, armed attack on ANP Ieader and dangerous situation in border tom Cheman (KII).

* Addressing 9 June a function in Islamabad, the IUAM President Gulbuddin Helmatyar said the Afghan Jehad will continue as long as a single Soviet soldier is in Afghanlstan. He claimed the mujaheddin have captured 120 cantonements and 27 districts and it is not far off when an Islamic republic will come into being in Afghanistan (JG).

* The AMP says the mujaheddin attacked 25 May a Kabul regime convoy moving from Pul-e-lhumri, Baghlan, to Takhar. In the attack 25 officers and soldiers were killed and 40 others injured and three tanks and a truck destroyed (VOAPS).

* The Heab-e-Islami (Helomatyar) eays in an attack 30 May on a big convoy moving from Pul-e-lonumri. to Takhar the mujaheddin killed 50 soldiers and demolished a tank and a truck and captured two. trucks and two wiraless sets (VOAPS).

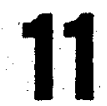

- The Soviet Foreign Minister Eduard Shevardnadze, while speaking to newsmen at the UN, accused the US and Pakistan of violating the Geneva accord on the Afghanistan issue (VOADS).

* The ur has appealed to all 159 member countrles of the tN for a development cid worth 1,000 million for the war striken Afghanistan (VOADS).

* The Pakistan Foreign Ministry has submitted a comprehensive reply to the UNIAG about recent complaints lodged by the Kabul regime.The government has refuted the Kabra regime cauplainto.A For Ministry. spokesman explained that Pakistan cannot be held responsible for the events inside Afghanisten occuring as a result of the mujaheddin actions against the Kabul regime (RPDS).

* An agreement has been signed between Pakistan and the UNHCR in connection with the three clauses of the Geneva accord about the return of Afghan refugees (RPDS).

* The Soviet Foreign Ministry has aceused Pakistan that the mujaheddin are entering Afghanistan from Paldstan without any hinderance and Pakistan is allowing them to maintain their centers of activities and training inside Pakistani territory (BBCFS).

* In an interview to a Cuben daily in Havana, Prasident Najibullah has stressed the need for adherence to Geneva accord and has satd only goodwill and unity of action by the sigmatories of the Geneva accord is needed for the implementation of the said agreement (RA).

* The House of the People met 11 June to express its views on the internal and foreign policy of the goverment and its members (BA).

- Throo memorandums (the 19th, 20th and 21st) were delivered to the UNIAG about Pakisten's violations of the Geneva accord (RA).

* The w announced 10 June in Geneva that the govermment of Norway has pledged one willilion immediate aid for Afghantetan (RA).

- Prosident Najtowillah of Afghanistan atressed in Havana that if Rakiatan's violations of the Ceneve ecoond continued, the Sovist-Kabul side will not consider themselves bound to pave the way. 
for the withdrawal of further Soviet troops from Afghanistan (RMDS).

* Certain mujaheddin sources in Peshawar felt that the fall of Kandahar or any other big city in Afghanistan was not imminent due to continued presence of Soviet forces in these cities (MIM). * The arrival of Najibullah in the US will not entail any change in the US policy about the Kabul government. The US Under Secretary of State for South Asian affairs said we consider the Najib government as unlawful (NWT).

* In a confidential report on Afghanistan prepared by the British Foreign Ministry, it has been stated that, contrary to the US estimates, the Afghan mujaheddin will not be able to topple the government of Najibullah and he will remain in power even af'ter the Soviet troops wathdrawal because of the lack of unity in the mujaheddin ranks (NWT).

\section{2}

* A high ranking Iruiian official has gone to Moscow for talks with the Soviet officials on Afghanistan. According to the BBC correspondent in New Delhi, the Indian Prime liinister, Rajô 'Gandhi recently hinted that India is playing an important role in the developments taking place in Afgharistan (BBCFS).

* In an interview in NY, the Indian Prime Minister, Rajiv Gandhi has warned that if the mujaheddin assumed power in Kabul, they would resort to regional fundamentalist wars and might confront the region to instability. Expressing concern, he said an Iolamic regime in Afghanistan will cast undesirable impact in India which has the second largest population of the Muslims (BBCFS).

* During his official stay in Cuba, President Najibullah of Alghanistan signed an agreement of friendahip and cooperation between the two countries, an agreement of cooperation between the PDPA and Commint Party of Cuba and a protocol of cooperation in the field of culture and education

(RMDS).

* The 22nd menorandum of the Afghanistan government about Pakistan's violations of the Geneva accord was delivered 12 June to the UNIAG office (RA).

* Under decree of September-October, 1987 of the Presidium of the Revolutionary Council, in connection with the purchase of arms from the opposition armed groups, two ground-to-air rockets have recently been purchased (RA).

* In a resolution, the Central committee of the MRD in Pakistan has asked President Zlaul Haq to refrain from sabotaging the Ceneva talks in letter and spirit (RA).

* In an article 11 June The New York Times says while the mujaheddin are at the threshold of a triumph against the Kabul regime, political power is being transferred to the local commanders ir. Afgharistan (VOADS).

* About 220 mujaheddin commanders inside Afghanistan attended 30 May a training seminar in Peshs war. The particfpants, mostly from northern Afghanistan, in a resolution 8 June, announced that the Afghan mujaheddin have achieved further victories against the eneny. In the communique they asked the jehad leaders to establish soon a mujaheddin interim govermment (VADS). 
soon to recapture the Jaji garrison in Paktia which they abandoned in Kay (IIM).

* Soviet Foreign Minister Eduard Shevardnadze accused 10 June the US and Pakilstan of violating the Ceneva accords on Afghanistan and warned that Soviet troops might slow down their withdrawal if the violations continued (MIM).

* The TUAM Suprene Council met $11 \mathrm{June}$ in Islamabad and unanimously decided to hold elections and announce its results by 15 October, 1988 (NWT).

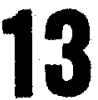

* At the UNGA session on disarmament, the Pakistan envoy to the UN, S. Shah Nawaz urged for the formation of a transitional government acceptable to all the people of Afghanistan in order to facilitate better implementation of the Geneva accord on the Soviet troops withdrawal from Af ghanistan (RPDS).

* The Independent (England), wrote 13 June Pakistan has reiterated that it is observing the Geneva accord. The paper says if the Soviet threat about the withdrawal of its troops from Afghanistan becomes a reality, the Geneva accord will fizzle out and Pakistan's relations with three countries - - the Soviet Union, Afghanistan and India - - will reach a low ebb (BBCFS).

* According to VOA correspondent from Quetta, a 100 member delegation comprizing religious scholars, spirituals, commanders, and tribal chiefs of Afghanistan living in Baluchistan, have proceoded to Peshawar for negotiations with the resistance leaders on convening a loya jirgah and choosing a single leadership for the solution of Afghanistan imbroglio. In a statement they have appealed to the UN for cooperation in convening the loya jirgah (VOADS).

* The Foreign Ministry liaison office with the UNIAG reported that the 24th memorandum on Pakistan's violations of the Geneva accord was delivered 13 June to the UNIAG in Kabul (RA).

* Members of the UNIAG office, serving in Afghanistan, visited 13 June Gardez city and inspected installations which have been handed over to the armed forces following the Soviet troops withdrawal from Gardez (RA).

* TASS says the Sovịet Union has asked Pakistan to take immediate and firm steps for the release of Soviet soldiers who are said to be kept in the mujaheddin camps in Pakistan (VOAPS).

* Begum Nasim Wali has warned that the continued supply of arms to the mujaheddin from Pakdstan would force Afghanistan to bomb Pakistan area in retaliation (MIM).

* A jirgah of hfghan resistance leaders and elders from Paktia have decided that no refugee would return home until a final mujaheddin victory in Afghanistan (MIM).

* The mujaheddin in an attack on the military installations and ammunition dumps of the SovietKabul troops on Kandahar-Kabul highway, have killed a number of Soviet-Kabul troops and caused. heavy losses to their equipment, reports Teheran Radio (PT).

* In a report published in the US, it has been disclosed that during the eight years of war in Afghanistan, one million civilians were killed, reports WOA. (PT).

* The Chief of UNIAG, General Helminen has said the mujaheddin attacks on the withdrawing Soviet tmope are contrary to the Geneva accord. In an interview to a Pakistapi joirmal, he sald the: 
Soviets are returning to their country and they should be let return peacefully (JG).

* The assertions of the Pakistan Foreign Ministry spokesman are genuire that Pakistan could not be hold responsible for the developmants occuring inside Afghanistan due to the mujaheddin activities against the Kabul administration nor it can be expected from Pakistan to impose any ban on the lawful political activities of the Afghan mujaheddin. Under the Geneva agreement Pakistan is only bound to honestly adhere to the agreements of the accord and it is doing so ... The responsibility for the implementation of the Geneva accord in letter and spirit lies on the UN and the world community. They should assess what is the reality in the allegations levelled by the Kabul administration against Pakistan. Because, if despite arriving at an agreement after 9 years of bloody war and the martyrdom or injuries of 1.8 million of Afghans, any attempt to perpetuate the Soviet military occupation of Afghanistan on any pretext, may prove dangerous in the region and pose a threat to the peace and stability in the entire world (Editorial, JG).

* The New York TImes and The Christian Science Monitor have reported that Soviet troops withdrawal is alower than anticipated but the victories of the Afghan mujaheddin in defeating the Kabul troops and occupation of areas vacated by Soviet troops is accelerating than anticipated (VOADS).

\section{4}

* Pakistan has accused the leader of Kabul government, Najibullah of launching anti Pakistan propaganda in order to delay the Soviet troops withdrawal from Afghanistan (VOADS).

* At a press conference in NY, the UN mediator, Diego Cordovez ruled the presumption that the pace of the Soviet troops. Withdrawal is slow. He is scheduled to visit late this month Islamabad and Kabul in order to evaluate all aspects of the implementation of the Geneva accord (RPDS).

* In a report from Geneva, the VOA says after visiting several places in Pakistan the UNIAG has observed that there is no proof that Pakistan has violated the Geneva accord (RPDS).

* Pakistan has once again assured the Soviet Union that in case Soviet soldiers captured by the, mujaheddin are in Pakistan and the Pakistan govermment finds them out, they will be provided an opportunity to return to their country (BBCFS).

* In an interview the IUAM President, Gulbuddin Hekmatyar said the IUAM has decided to keep the Soviet prisoners of war so as to put pressure on the Soviet Union for. the payment of war raparations and sweeping away the mines plented in Afghanistan (BBCFS).

* The MWFP Chief Minister, General Fazle Haq has sald details for the return of the Afghan refugees to their country have been finalized. He did not give any further clarification (BBCFS).

- Following his meeting 13 June with the leader of Kabul regime Najibullah in Moscow the Soviet leader Mikhail Gorbachev accused Pakistan of the violations of Geneva accord and strongly warned Pakcistan of severe retaliatory measures (BBCFS).

* The twanty eighth memorandum of Afghanistan about Pakistan's violations of the Geneva accord was delivered 14 June to the UNIAG office in Kabul (RA).

* The UN mediator Diego Cordovez said in NY that Soviet troops are withdrawing from Afghanistan more speedily than it was expected (RMDS).

* The US President Ronald Reagan met 13 June the UN aid coordinator, Prince Sadruddin Aga Khan. 
The White House spokesman says President Reagan promised that the US would extend substantial aid to Afghanistan (VOAPS).

* President Reagan has urged western industrial countries to extend aid for the rehabilitation of Afghanistan and Phillipines (VOAPS).

* According to the mujaheddin sources in Quetta, 1,200 mujaheddin are presentiy fighting the Kabul goverment soldiers on Kabul-Kandahar highway (VOAPS).

* NWFP Chief Minister, Lt. General (Retd) Fazle Haq has predicted that a bulk of the Afghan rofugees living in the province wolld have returned home before the start of the summer of 1989 (MIM).

* A spokesman for the Soviet Foreign Ministry has said that the Soviet Union never agreed to its military aid to the Kabul govemment in the republic of Afghanistan being linked in any form with arms supplies to the Afghan mujaheddin, the Soviet news agency APN reported (PT).

\section{5}

* UN officials held 14 June their first session in NY with the representatives of countries which have expressed willingness to give immediate aid to Afghanistan (VOADS):

* The countries provicing humanatarian and economic aid:to Afghanistan have asked the uN to guarantee that their assistance would be directly supplied to the deserving people and it will not be put under the unlawful regime in Kabul (RPDS).

* The US envoy at the UN, Richard William said the economic and humantarian assistance should not be put at the disposal of the Kabul regime which does not enfoy credibility anong the refugees and controls on a little portion of Afghanistan (RPDS).

* Through its Jmbassy in India, the US has confirmed the report of The Times of India that the US wlll not leave the Afghan mujaheddin alone in the presence of the large scale Soviet arms supplies to the Kabul regime. The US corfirmation came in reply to an article in the newspaper claiming that the US was violating the Geneve accord by continued assistance to the Afghan mujaheddin (RPDS)

* The Soviet television reported its troops have completed their withdrawal from three provinces - - Nangarhar, Paktia and Logar (RPDS).

* The UN High Comissioner for Afghan refugees held talks 15 June in Peshawar with the NwFF care taker Chief Minister, Fazle Haq on the return of Afghan refugees (RPLS).

* The MIF leader, Sayyed Ahmad Gailani of ficially took over 15 June as the IUAM President in Peshawar, Pakistan (BBCFS).

- A correspondent of The Times (Iondon) in Moscow says by resorting to fresh propaganda, the ifghan mujaheddin seek to carry out subversion among the remaining Soviet troops in Afghanistan

(BBCFS).

- The Law of the Afghanistan Parliament, containing 12 chapters and 91 articles, was approved 15. June by the Seciate (RA).

- The 27th memorandun of Afghanistan on Pakistan's violations of the Geneva accord was delivered 15 June to the uriat office in Kabul (RA).

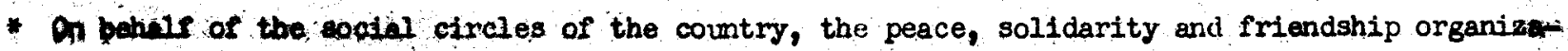


tion of Afghanistan urges the social circles of Pakistan to bring pressure on the Pakistan govern ment to undertake immediate and effective measures through various quarters for the release and transfer of the 311 Soviet troops presently detained by the Afghan opposition (RA).

* Upon the completion of the first nuntl of the accord on Afghanistan 1/4 of the Soviet troops have been withdrawan from Afghanistan (RMDS).

* TASS said 10 Soviet troops were killed and 20 others injured recently in the mujaheddin attacks at various places (BBCFS).

* At a press conference 14 Jur.e in Islamabad, the US Under Secretary of State for Political affairs (stet), Dr. Zalmai Khalilzad said the Kabul regime and the Soviet Union are accusing Pakistan of violating the Geneva accords on Afghanistan because they had been upset by the successes of the Afghan mujaheddin. "They were facing substantial difficulties as a result of the dramatic and quick success of the mujaheddin," he said (PT).

* President Ronald Reagan met 13 June, Prince Sadruddin Aga Khan, the UIIACAR in Washington and called on all countries to contribute for the Afghan repatriation ef forts (PT).

* President Ronsld Reagan pledged 13 June US financial support for an Afghan resettlement fund and called on the Soviet Union to do likewise, the White House said (PT).

* The Commissioner for Afghan Jefugees, NWFP, Faheemullah Khatak disclosed 14 June in Peshawar that the repatriation plan for the return of the Afghan refugees had been finalized (MLM).

* As a result of collusion between India and the former Afghan King Zahir Shah, India is spending huge amounts to popularize Zahir Shah among the Afghan refugees, so that Zahir may once again resume power in Afghanistan. It has lej]ably been learnt that tribal chieftains are being heavily bribed to for smoothen public opinion among the Afghan refugees in favor of Zahir Shah (NWT).

\section{6}

* Leaders of the US Senate have asked for the appointment of a special envoy to have contacts with the Afghan mujaheddin. They have said this will facilitate the process of us familirization with the mujaheddin activities inside Afghanistan and coordinating US policies with them (RPUS).

* A Soviet General has said Soviet troops withdrawal from Afghanistan continues according as scheduled and the timeframe for the Soviet troops pullout will not be changed. He said half of the Soviet troops will be withdrawn by 15 August from Afghanistan (RPDS).

* The VOA says the Soviet Union continues to squeeze its radio programs for Afghanistan in Dari and Pashtu languages (RPDS).

* A prominent Soviet commentator says the Soviet mijitary iritervention in Afghanistan and deployment of SS-20 nuclear medium range rockets were mistakes which began during the leadership of Brezhnev in the Soviet Union (VOADS).

* The House of the People unanimously passed 16 June a vote of confidence to the government of Dr. Hasan Sharq (RA).

* In a meeting 15 June with the NWFP Commissioner for Afghan refugees, Faheemullah Khattack in Peshawar, the US envoy in Pakistan, Ronald Raphel expressed gratitude to the people and gavernment. of Pakdstan for providing succor to more than three million Afghan refugees. He termed the repatria- 
tion of Afghans as a gigantic task and assured every possible assistance to Pakistan for the relief of Afghan refugees and their eventual repatriation to Afghanistan (PT).

* The Baluchistan ANP has started to contact all political parties including students, peasant and labor organizations at provincial level through an eight member coordinating committee, to pressure the government to strictly abide by the Geneva peace accord and give up aggression in the shape of eight year old undeclared war (MIM).

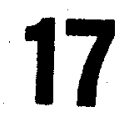

* The Soviet Red Cross has asked the ICRC, Red Crescent in Afghanistan, Pakistan and Iran and the Red Cross in the US to inform the Soviet Union about the fate of the Soviet troops who had been held captive during the last eight years by the resistance forces (BBCFS).

* Mohammad Hasan Sharq whose govermment has received a vote of confidence at the Parliament, says. "we are seeking a solution of the main problem - - ending the war." He said some of the opposition groups regretfully did not take part in the delibrations of the House of the People (RKDS).

* A protocol on direct cooperation between the Afghan Ministry of Electric Power and the Ukrainian Soviet Republic to electrify Parwan and Nimroz provinces was signed 17 June in Kabul (RA).

* Separate protocols between the Nimroz province of Afghanistan and Therson province of the Soviet Union, and the Parwan province of Afghanistan and hharkov province of Soviet Union were signed 16 June in Kabul for promotion and expansion of cooperation (RA).

* At a press conference held for foreign journalists in NY, an international committee was formed for the emancipation of the Soviet prisoners of war who have been missing in Afghemistan. The comittee includes people's dejusentatives fron the US, Soviet Union and Europe (RA).

* Leader of the Afghan mujaheddin, Gulbuddin Hekmatyar says until all the Soviet troops are pulled out of Afghanistan, the Soviet POW's will not be released (VOAPS).

* A spokesman for the US State Department has said the US govemment has provided during the 1988 fiscal year direct aid worth $\$ 50$ million to the refugees in Pakistan (VOAPS)。

* A pro Zahir Shah group is out to mobilize public opinion among Afghan refugees in Frontier camps against what it says undemocratic selection of the head of an interin government for Afghrm istan (DN).

- The Prosident of the Mujaheddin's interim government, Ahmad Shah, said 16 June that heads of the component parties of the IUAM had unanimously decided to set uf the government in Kabul. The precise date and other details in this regard would be arnounced formally within a week, he added

(DN).

Hectic efforts are underway to sort out the 311 Soviet troops missing in Afghanistan. There is a posotbility that these missing soldiers might have been killed in the Afghanistan war (JG).

* Prealdent of the proposed interim govermment of the mujaheddin, Engineer Ahmad Shah has said that after slgaing the Gerieva accord, the former Pakistan Minister of State for Foreign Affairs, Zatn Noorant in a meeting with the Afghan mujaheddin had confessed that Pakistan had committed a

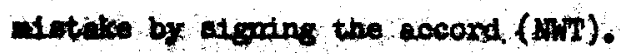




\section{8}

* A US official said 17 June in Washington the UNACAR Age Khan has given assurance to the western donor countries that humantarian end economic aid to the people of Afghanistan will not be given through the Kabul regime (RPDS).

* According to the US officials, despite bilateral negotiations between the US and the Soviet Union the Russians have so far not provided the maps of areas in Afghanistan where mines have been planted. The in is still holding talks on the issue with the Soviets (RPDS)。

* Prosident Najibullah received 18 June Prime Minister Dr. Hasan Sharq and his cabinet members and urged the cabinet members to take measures to curb bribery, embezzlement of the public funds, frresponsibility in performing prublic duties and indifference to the social interests (RA).

- The BBC correspondent reports from Kabul while the new government was seeking the vote of conPidence at the House of the People, one of the deputies from Kabul said what is the reason that none of the "party members" has repented on the past deeds and why there are certain people in power whose hatids are stained with the blood of bur nation (BBCFS).

* The WIFP Comissioner for Afghan refugees, Fahtmullah Khatiok in an interview has said presenthy about 2,200,000 Afghan refugees are living in 250 camps in the NWFP. He said so far, as we are aware, and so far as we are concerned, no body has gone back and most of the refugees say that until the Nafib goverrment is toppled, they cannot retum to their country (VOAPS).

* "Indian Prime Miniater Rajiv Gandhi's outburst against the Afghan mujaheddin during the course of his eddress at the UN cannot be brushed of $f$ as another act of ranting. It betrays Indians deep rooted desire to keep intact its perceived leverage in Kabul and maintain the geo-political balance. The mujaheddin, who can disturb this geo-political balance, are for Indie an unacceptable reality whose progress New Delhi is determined to block whatever means it can command at its disposal, although it may have precious few. And that was the unfortunate message that Rajiv's shrill tone gave at the UN" (Exitorial, MLM).

- The Izvestia, (Moscow) in its editorial has admitted that the Soviet Invasion of Afghanistan in 1979 was a mistake (JG).

- In an interview to the BBC, the Afghan leader Heimatyar has reiterated that Soviot troopo withdrawal from Afghanisten will be complete only when the last unit of the Soviet troops leaves Afghanistan and the Soviet backed Kabul government is done away with (NWT).

\section{9}

* In the statement of the Armed forces of Afghanistan broadcast fram Radio Kabul it has been said Sovlet troops have presently retreated from four provinces and it has been assured that the armed forces are capable to defend the sovereignty and territorial integrity of the country(BBCFS). * The UNACAR, Sadruddin Aga than says the UN aid and development officials are expected to visit next month Afghanistan and begin the economic reconstruction of the coimtry and look after the reNugees who have returned to the country (BBCFS).

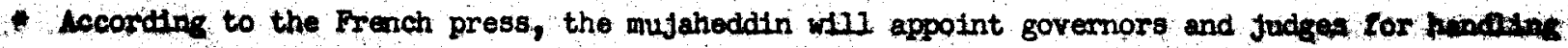


the affairs in the center of Zabul province - - the first city they have captured during the war

(RPDS).

* Two of the Afghan mujaheddin leaders have felicitated President Mohammad Ziaul Haq of Pakistan on the promulgation of Sahriat Ordinance (RPDSO).

* Prime Minister, Dr. Mohammad Hasan Sharq and members of his cabinet attended $19 \mathrm{Jume}$ the Senate session for explaining the internal and foreign policy of the govermment and the introduction of the cabinet (RA).

* The Council of Ministers brings it to the notice of all-citizens that no government official in the capital and provinces has the authority to issue extraordinary and exceptional orders under any circumstances and rights of the people are viewed equally without any discrimination or privilege in the framework of laws already in force (RA).

* The Foreign Ministry liason office has delivered 19 June the 30th memorandum on Pakistan's vialations of the Geneva accord, to the UNIAG office (RA).

* A high level Indian delegation arrived 19 Jume in Kabul to evaluate the work of the eighth IndoAfghan joint comission (RA).

* According to a Moscow Radio correspondent report from Afghanistan, arms are still being sent to the Afghan extremists from the Pakistani territory and Pakistani officials are inciting the undeclared war against Afghanistan (RMDS).

* Quoting a US State Department official in an article 19 June, The New York Times writes the Kabul regime is fastly moving towards a collapse and after the completion of the Soviet troops pullout next year, the Kabul regime will no longer feel safe. But some US experts say the Sovlet installed Kabul regime might survive longer than anticipated (VOADS).

* The UNACAR, Sadruddin Age Whan said 17 June he has reached an agreement with the Kabul regime and the Soviet government that direct aid will be supplied to the refugees in areas under mujaheddin contral (VOAPS).

* The Vioo President of the interin 'goverment, Dr.Zabihulizah Mojaddedi has said Loya jirgah is a good way for solving the Afghan problem. He 'said views of the Afghem nation should be sought in the cormation of government and other important issues. He added the mujaheddin interim government will be creatble only when it is approved by representatives of the nation (voaps):

* The IUAM President Sayyed Ahmad Gailani, says, "I an in favor of elections so that a canpetent council of the peoples' representatives is formed. He said the establishment of transitional government and enacting legislature should be within the jurisdiction of the council (vaAP).

* Speakers at a Jirgah of Afghan mujaheddin and refugees who have come to Peshawar fran Quetta have criticized the IUAM leaders for establishing a transitional govemment without convening a loya Jirgah and for not consulting representatives of the nation. They also criticized the IUAM leadership for deciding to ask the people in elections to vote in favor of one of seven organizations. Speakers at the Jirgah urged the IUAM to consult the nation and convene a loya Jirgah. Any daciston arrived in this way would be acceptable (VOAPS).

* Moscow radio quoting Press Trust of India has announced that a meeting was held between the Irantan representatives and leader of American Military Intelligence Department in Akaran was 
ting resulted in making the Iranian stand clear on the Afghan issue. It was emphasized at the meeting that Iran should agree to extend assistance to the Afghan opposition forces because there is a possibility that Pakistan will stop such military assistance after the signing of the Geneva accords. It was agreed at the meeting that apart from providing assistance to the Afghan resistance on the Pakistan territory, the US would also continue supplying weapons to the Afghan opponents taldng shelter in Iran. It will also provide arms to Iran through Afghan opposition (MIM). * The Afghan mujaheddin have to eyolve: complete unity in their ranks for building a new Afghanistan. The mujaheddin have achieved significant victories after the Geneva accord. More areas have been brought under their control. Now they are in a position to announce the establishment of an interim government in the liberated areas. Iogar and Paktia are close to Pakistan and it is expected that an interim government will be set up in one of these two provinces. The struggle of the Afghan mujaheddin has now entered its final stages. It is not far off when the Afghan mujaheddin will undo the.Geneva accord by setting up an Islamic and free government in Afghanistan (Prof. burhanuddin Rabbani in JG).

- The Pakistan Muslim League (Khawaja Khairuddin group) has stressed, the government should take steps for the return of Af ghan refugees as the Afghan issue has been solved after signing the Geneva accord (JG).

\section{0}

* The IUAM new President Sayyed Ahmad Gailani at a press conference in Peshawar said a transitional government will be established inside Afghanistan but he did not announce the date (BBCFS). * The UN mediator, Diego Cordovez will visil within next 10 days Afghanistan to hold talks on setting up $a \cdot$ government by the mujaheddin with the present Kabul goverment. The mujaheddin have decided not to meet Cordovez (BBCFS).

* The Washington Post writes the IUAM President Sayyed Ahmad Gailani, said elections might be held within 3-4 months among the refugees and the mujaheddin for the formation of a national council so that the interim government may seek vote of confidence from it (VOADS).

* The US Under Secretary of State Richard William says the Soviet troops withdrawal continues as scheduled from Afghanistan. He anticipated that Pakistan would resist threats and pressure (VOADS).

- An experts on Afghan affairs at the Preedom House, NY, has claimed that the Soviet Unton has formed a secret army of 20,000 Afghans to replace the Soviet troops after their pullout from Afghanistan (VOADS).

- TASS has described as a futile attempt the mujaheddin announcement on setting up a transitional government (BBCFS).

* A donor group for Afghanistan alleged 20 Jume in Icndon the Kabul government has ruined the agriculture of the country during the last eight years in order to eliminate the social base of the Mghan mujaheddin (BBCFS).

* An agreement on survey and strengthening of enbankments of the Oxus river in Hairathan port, worth 8,106,000 rubels was signed 20 June in Kabul between the Commerce Ministry and the Soviet attache in Kabul (RA). 
* A Cuban delegation led by the Cuban Communication Minister arrived 20 June in Kabul for attending the sessions of the Afghan-Cuba economic conmission (RA)'.

* Leader of the Hezb-e-Islami Gulbuddin Hekmatyar has said until an Islamic government is set up in Afghanistan, the mujaheddin wili keep the Soviet POW's and later they will be exchanged with those Afghan communists who have fled to Moscow (VOAPS).

* Leader of the Jamiat-o-Islami, Burhanuddin Rabbani has said the Soviet Pow's will be freed anly when the Afghan mujaheddin presently detained by the Kabul regime are released and those 15,000 Afghan children who have been sent to the Soviet Union are brought back (VOAPS).

* Sayyod Ahmad Gailani the new IUAM President has said "I want a unity among all the Afghans and I will complete all tasks started by Gulbuddin Hekmatyar."He said IUAM will be further strengthened and unity will be consolidated in the mujaheddin ranks (VOAPS).

* At a press conference recently in Dina, Jhelum, leader of the Harkat-o-Enqelab-o-Islami, Afghanietan, Nasrullah Mansoor said the Afghan people have now realized that both the super powers are equally against the Islamic revolution in Afghanistan (MIM):

* The IUAY amounced 19 Jume in Peshawar a 12 member cabinet and two Vice Presidents of the prom posed interim government which it hoped would be installed in power after the fall of the PDPA regime in the wake of the Soviet troops withdrawal (MIM).

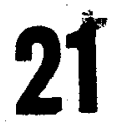

* Leader of the Harkat-o-Islami Afghanistan, Ayatullah Mohsini has said if the new interim goverment which has been announced by the mujaheddin in Pakistan is imposed in Afghanistan in its prosent shape, it would entail internal differences and clashes between the various groups (BBCFS).

* One of the local commanders of the Hezb-o-Islami (Khales), Abdul Haq has called upon the UN not to initiate the financial aid program in Afghanistan until all the Soviet troops are withdram from Afghanistan and the present Soviet backed government in Kabul is dismantled (BBCFS).

* IASS says Pakistan has admitted that the Afghan mujaheddin have detained Soviet soldiers in that country. The Pakistian Ambassador in Moscow Shahid Amin said he has information about the Soviet POW's in his country (VOGDS).

* According to a VOA report, observers have expressed concern over the slow withdrawal of the Soviet troops from Afghanistan. Political observers have said the strong positions of the majaheddin at some places and their rapid victories in other regions, is a reason for the slow pace of the Soilet troops withdrawal (RPDS).

* The Sovilet Union has warned if Pakistan did not honor its commitments in the Geneva accords, it will result in folling the endeavors exerted for signing that agreement (PMDS).

* The Pravda writes that proclamation of a transitional government by the Afghan opposition groups resembles more with the distribution of the skin of a bear which hes so far not been humted (RaDs).

* Afghanistan's 318t memorandum on Pakistan's violations of the Genova accord was delivered 21 Jue the the UING office in Kabul (RA). 
* The first session of the Afghan-Cuba commission on economic, scientific and technical cooperam tions between Afghanistan and Cuba was convened 21 June in Kabul (RA).

* The Times of India has described evasive and meaningless the US clains suggesting that the Geneva accords on political solution of situation axound Afghanistan permits the US military supplies to the opposition groups of Afghanistan (VOADS).

* The leader of Jamiat-e-Islami Afghanistan, Prof. Burhanuddin Rabbani" sald 20 Nme In Peshawar. since the beginning of Soviet troops pullout from Afghanisten the mujaheddin have so far captured more than 30 places including oub divisions and" sub" districts and 150 lobul regime poste (VOAPS).

* The Jamiat-e-Islami Chief Prof. Burhanuddin Rabbani, has said Moscow and Kabul are accusing Pakistan of violating the Geneva accord only to prolong the 'stay of "the Sovtet troope in Afghanistan and hide their new military strategy agalnst the mujaheddin (MIM).

* Two Afghan mujaheddin Mohanmad Ali and Abdul were killed and six others injured as three Afghan aircraft straffed and bombed Mari Kandau, 25 kilometers away from Miranshah, Nonth Wazin istan Agency (DN).

* Contact has been established with Pakistan government for the recognition of the mujaheddin's interim government, while in this connection talks will also so be held with the Arab and other countries. According to the President of the mujaheddin interim government, Engineer Ahmad Shah, earlier the Pakistan govermment had assured the recognition of the government on its completion

* At a press conference 20 June in Peshawar, Prof. Burhanuddin Rabbani leader of the JemiatwoIslami Afghanistan said if the Soviet Union wanted a safe pullout of its troops from Afghanistan it should have a direct dialogue with the mujaheddin. He said peace cannot be guaranteed without the complete Soviet troops withdrawal. (NWT).

\section{2}

* A four member delegation of the World Food Program (WFP) visited 22 June an Afghan refugee camp in Katcha Garhi, Peshawar (RPDS).

* Australia will provide $\$ 20$ million aid to the UN for the Afghan refugees (RPDS).

* The US government plans to despatch a special envoy for talks with the Afghan mujaheddm. The US State Department has said it is inclined for further contacts with the Afghanistan resistance movement to seek more information for the assessment of the current political reports (BBCFS). * The Central Plenum of the PDPA was convened 22 June. Najibullah spoke about the duties of the party organizations in respect to the armed defense of the NRP and democratic achiovements (RA).

* Prime Minister.Mohammad Hasan Sharq met 22 June the Indian External Afitairs Ministry delegation in Kabul. The Indian delegation said on the basis of the discussions between Najibullah and the Indian Prime Minister Rajiv Gandhi in New Delhi, Indian special delegation would visit Afghanistan to specify the fields of cooperation in the rehabilitation of Afghan refugees (RA).

* The Foreign Minister Abdul Wakil in a message to the UN Secretary General Perez de Cuellar has sald that Pakistan had violated until 22 June 213 time the Geneva accord and in this connection the 31st memoradum has been delivered to the UNIAG office in Kabul (RA). 
* A program of cooperation in the television was Blgtied 22 June in Kabul between the Afghan State Camitte for Padio, Television and Films and the Indian Television (RA):

* The UNAGAR, Prince Sedruddin Aga Khan held talks $21^{\prime}$ June with the OIC representatives in Geneva on the UN activities in connection with the reutim of Afghan refugees from Pakistan and Iran (RA). * The Afghan Chief of Army Staff, General Tani" has reported that the Soviet troops have beea with drawn from 18 provinces of Afghanistan. He said one' fourth of the Soviet troops have so far ro turned to their country (RMDS).

* The US state Department says it is trying to promote its contacts with the mujahoddin groups. The source says they want to expand their information and analysi's on the politiced dowalopments In Afghanistan (BBCFS).

- Resistance sources in Quetta say a number of mujaheddin commanders, "religious scholars and -lders in a resolution adopted after a meeting in Spin Boldak have urged the neigtiboring countries including the Sovlet Union to foster Priendly ties with Afghanistan. In the resolution the Uw has been asked to recognize Mohammad Zahir Shah as the leader of Afghanistan for the establishment of peace and security in Afghanistan and in the region (VAPS).

* Afghan Prime Minister, HaSan Sharq has asked members of his family not to come to Afghanistan from Iran (stet) in view of the serious situation in the country (NWT).

* The Charge d' Affaires of the Pakistan Imbassy in Kabuli was sumnoned 22 June in the Foreign Ministry and a Pakistani protest about the bombardment's on' Chaman and Alizai was described baselese and far fron reality (RA).

* Documents on the evaluation of the eighth joint Indo-Afghan comission' of technicen;," comomic, trade and cultural cooperations was' signed 22 June in Kabul (RA):

\section{3}

* An Afghan mujaheddin commander, Abduil Haq has said in NY that the Soviet Union should diroctly contact the injahieddin about the issue of Soviet POW's (BBCFS).

* The Palistan Foreign Minister, Sahebzada Yaqub Khan is scheculed to visit 26 June China. Diplomatic sources in Islamabad say the Afghanistan issue would definitely be a part of his discussions with Chinese leaders (BBCFS).

* A protocol for econonic, scientific and teshnical cooperation was signed 23 Jume in Kabul with the Republic of Cuba under which Cuba will extend assistance to Afghanistan in the fields of public health, higher education, agriculture, radio and television and sports (RA).

* The PDPA Plenum has sent a message to the representatives at the 19th conference of the Soviet Communist Party. In the message it has been stated that, by treading on the path of reconstruction, the Party of lenin has once again vindicated its revalutionary reality of unbreakable link with the people, sincerity with the aspirations of communism, and its historic obligations towards the fate of mankind. Solfdarity between the Soviet Communiat party and the PIPA was consolidated not only in scholarly conferences and international gatherings but in the most difficult days of the undeclared war as well ( $R A$ ).

- Prooldent of the mujaheddin interim government, Engineer, Ahmad shah in a statenent has refutes 
a Moscow radio report suggesting that the mujaheddin interim government is a government in exile. The statement says the mujahiddin interim government will practically start functioning inside Afghanistan (VOAPS).

* The former King of Afghanistan, Zahir Shah, now living in exile in Rome, has said he is willing to return home and head a provisional government (MLM).

- The Afghanistan govermment has anmounced a package of incentives to the returning Afghan rofugees including purchase of all sorts of arms from them on cash payments and the return of all moveable and immoveable property, vehicles and shares in the banks and joint stock companies which had earlier been confiscated by the govermment (MuM).

* Australia is to donate about 16.5 million US dollars to the UN Fund for Humantarian and Bconomic Aid to Afghanistan, Prime Ninister Bob Hawke announced 22 June (PT).

* An official of the Soviet Ried Cross has said Soviet soldiers who were captured churing war in Afghanistan, heve been detained in the US, Iran and Canada (JG).

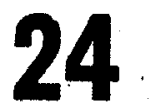

* The US Under Secretary of State, Michael Amacost says he does not think the Soviet Union will implement its threats to change or review Its troops withdrawal scheme fra Afghanistan. He sald the process of troops withdrawal is going ahead according to the schedule (RPDS).

* At the request of the UNIAG, a UN observer team was taken to Quetta and Chaman. The team visited an Afghan refugee camp and al so saw the areas subjected recently to artillery shelling; roeket fire and bombing by the Kabul' side entailing a violation of the Geneva accords (RPDS)!

* Quoting a Soviet Defense Ministry spokesnan, TASS says the withdrawal of Soviet troops from Afghanistan is taking place according to the program of the Geneva accords without any change. TASS sald $1 / 4$ of the Soviet troops have so far been withdrawn from Afghanistan (BBCFS).

* The Kabul Electric Junction No.12 built from the GDR \$38,000 credit and Af's 36 million from the state budget was inaugurated 24 June (RA).

* The UN Secretary General's special envoy on Afghanistan Diego Cordovez met 23 June with members of the international comittee for the emancipation of the Soviet POW's and the Pakistan envoy in NY (RA).

* The Indian Defense Minister said 23. June in New Delhi Pakistan has violated the Geneva accord and is hindering efforts for the restoration of peace in Afghanistan. He said the policy of Islamabad in the region has created difficulties in normalization of Indo-Pakistan ralations (RA).

* Ingight, a us periodical quotes rumours in Peshawar that Washington is plaming to invest the leadership of Afghanistan to Hekmatyar. The magazine writes Hekmatyar himself denies any type of official contact with the US. Hekmatyar says "only a freely elected person and a representative of the people can lead our nation" (VOADS).

- Speaking 23 June at a session of the US Congress, the US Under Secretary of State, Wichael Armacost has said the US does not want to interfere in the formation of next government in AfghapLetan (VOAPS).

The Chatrian of the Afghanistan Comaittee In the US Congress, Gordan Humphrey has asked the 
Reagan government to take a measures to recognize the mujaheddin interim government (VOAPS).

* The US Under Secretary of State, Michael Armacost has said the US State Department keeps in view to appoint a special assistant to the US Ambassador in Islamabad to assist him on Afghan affairs (VAAPS).

* The Red Crescent Society which was requested by its Soviet counterpart to help recover Soviet soldiers allegedly held as prisoners of war by the Afghan mujaheddin in Pakistan; has Informed the Soviet authorities that it could not get any information regarding the presence of any Soviet POW's in Pakistan (DN).

* The IUAM new President Sayyed Ahmad Gailani, on a short visit to Islamabad, met 24 June some diplomats. He is expected to meet 25 June with the Pakistani officials (NWr).

\section{5}

* In an interview to a Japanese newspaper in Rome, the former King af Afghanistan, Mohamad Zahir Shah has said, if all the forces join hands together and form a transitional government, there will be no bloodshed in the country (VOADS).

* Quoting a UN representative in Peshawar, The Christian Science Monitor says mines planted in Afghanistan are the main difficulty in the rehabilitation of that country and there is a possibility that years and even decades might be spent in struggle for the removal of this difficulty

(VOADS).

* The UNACAR Sadruddin Aga Khan has said a team of experts would visit Afghanistan within a fow months to make arrangements in connection with the UN assistance in Afghanistan, (RPDS).

* The Soviet Chief of General Staff, Marshal Sergei Akhromeyev has said more than 20,000 Soviet troops have returned to their country (BBCWF).

* According to the BBC correspondent from Islamabad, in a bomb explosion 25 Jume at a hotel in Peshawar, Pakistan, at least 13 persons were killed and four others injured. The Pakiotani officials believe that the bomb was placed by KHAD elements (BBCFS).

* The 32nd memorandum on Pakistan's violations of the Geneva accords was delivered 25 June to the UNIAG office in Kabul (RA).

* At a press conference, the Afghanistan Ambassador in Moscow reported that violation of the Geneva accords, and arms supplies to the opposition groups from Pakistan have increased. He said Palistan intelligence agencies are inciting the Afghan opposition for attacks on Kabul and other Afghan cities (FMDS).

* A UN kigh ranking official held last week several rounds of talks with Abdul Haq a commander of the Afghanistan resistance. It was the first of ficial contact between the UN and the mujaheddin commanders whose power is constantly increasing (VOADS).

* A commander of the NLF Afghanistan in Mohammad Agha, Logar, who has recently come to Peshawar, says following the arrival of the UNIAG observers in Kabul, Soviet forces have been carrying out heavy shellings from Darul Aman, Kabul on Khairkhana Meena, Hoodkhel and Kabul Customs House.According to eye witnesses, after the inspection of the shells of these rockets, the UN observers have said 
the rockets are Soviet made (VOADS).

* A high ranking officer of the Kabul regime, who has secret contacts with the mujaheddin, infor med the office of the Ittehad-e-Islami that a Soviet decision to shift the general command of the Soviet forces from Taj Baig heights, to Dasht-e-Kelagai, Baghlan, has been postponed due to intensive mujaheddin attacks. Three security belts have been butit since the first week of June around Kabul. The first circle is under the control of the Soviet troopa, the second under the control of KHAD and the third under the command of the Kabul army (VOADS).

- The UNACAR, Sadruddin Age Khan has said 33 millions dollars aid has so far been promised for the rehabilitation of Afghan refugees and reclaimation of agriculture. (BBCFS).

* Soviet Commuist party newspaper The Pravda 24 June denounced a US decision to appoint an envoy to maintain contacts with Afghan guerrillas in Pakistan (MIM).

* Although the Soviet army has started marching north out of Afghanistan, thousands of fresh troops have been sent in to that country to enable Soviet forces to launch fresh offensive. The Soviet linion apparently intends to keep military advisers in the country even after the nine month lang pullout timetable is completed, neutral observers said (PT).

* The UNACAR, Sedruddin Aga Khan has said if the economy of Afghanistan was not improved, the Afghan people wlll fače a food shortage similar to Dthiopia (NWT).

\section{6}

* The Defense Council of Herat province met 26 June to prevent the "criminal activities" of the extremist groups and for the establishment of peace and security in that province (RA),

* The 18th plenum of the Central Council of the Trade Unions of Afghanistan was convened 26 June in Kabul for bringing about improvements in the defense of the country (RA).

* According to reports, four posts have been set up on the route between Landi Kotal to Torkham, wich is the main route for the return of Afghan refugees. The Afghan refugees are to be returned to camps inside the country from these posts (FMDS).

* The UN observers mission for Afghanistan arrived $25 \mathrm{June}$ in Chitral. Besides visiting Darosh, Arandu, and Garam Chashma, the UN team would also visit Afghan refugee camps to get on-the-spot Information about the implementation of the Geneva accords. The team would inspect different routes in Chitral to know whether the mujaheddin were using them for warfare inside Afghanistan (MIM).

* UN mediator on Afghanistan Diego Cordovez is arriving 30 June in Islamabad to undertake the task of bringing together the warring factions in the Afghan conflict for negotiations on the for mation of a broad-based government, The Khaleej Times reported. Cordovez will visit Teheran before flying into Islamabad as part of his shuttle in the region which includes visits to Kabul and consultations with the Pakistani authorities, leaders of Afghan refugees and the mujaheddin groups (MIM)

* The efforts of the Kabul regime to find one of its opponents to head the Defense Ministry have not brought any results so far. A report of AMRC says General Abaul Karim Mustaghani and General than Nohemad Khan have been invited by the Kabul regime to accept the post but there is no information whether they have accepted or rejected the proposal (MIM).

* The IUAY President PIr Sayyed Ahmad Gailant has aatd that the Afghan refugees, the mujaheddin 
and the Afghan people of liberated areas would vote within three months to elect a council which would have the sole right to authenticate the present interim government of the mujaheddin(MIM). * The Afghan mujaheddin have inflicted heavy losses on the Soviet-Kabul troops in many provinces of Afghanistan. According to Teheran Radio in their fresh activities in Badakhshan, Faizabad, Kabur and Kunduz the mujaheddin have demolished six posts, killed more than 50 soldiers and captured 12 others (JG).

* The NWFP care-taker Chief Minister, Fazle Haq has said the Kabul government has once again started subversive activities in Pakistan because of Pakistan stand in regard to the Afghan issue. He said many difficulties will have to be faced as a result of the Geneva accord. He added, jehad will gain further momentum in Afghanistan (JG).

\section{7}

* TASS has reported that mines have been planted by the Afghan opposition forces around the Soviet garrisons and posts. Altogether in 2,131 places mines have been laidd down and 1,571 of these have been planted in the latter part of May (RMDS).

* According to TASS, extremists have caused Afs. 60 billions losses to the economy of Afghanis tan last year. During this period 143 economic units have totally been eliminated (FDS).

* The Pakistan Foreign Minister, Sahebzada Yaqub Khan said 26 June in Beijing his country is adhereing to its commitments in the Geneva accord and is cooperating with the WNIAG for an effective implementation of the provisions of the accord (RPDS).

* Pakistan has submitted a memorandum to the UNIAG about a clear violation of the Geneva accords by the Kabul regime with carrying out bomb explosion in a hotel in Peshawar 25 June killing 14 persans (RPDS)

* In a tank fire $25 \mathrm{June}$ by the Kabul armed forces in Chanan, Baluchistan, a woman was killed and two others wounded. In this connection the Charge d. Affaires of the Afghan Embassy in Islamabad was sumoned to the Foreign Ministry and a protest note was handed over to him. (RPDS).

* The Herat University was inaugurated 27 June (RA).

* According to the decision by the National Council, a joint session of the Senate and the House of the People was convened $27 \mathrm{June}$, and, after listening to a government report about the Geneva accords, the deputies of both houses debated the subject. (RA).

* According to the BBC correspondent from Islamabad, the Afghan mujaheddin claim that the KabulJalalabad highway remained under the mujaheddin control for three days last week. The report says seven government posts were either captured or destroyed by the mujaheddin and 150 government soldiers were killed or injured. Similarly 10 tanks with their crewmen were demolished (BBCFS).

* The Advisory Council of the mujaheddin of the northern provinces of Afghanistan met 4-12 June with Cormander Ahmad Shah Masood in the chair in Farkhar, Takhar. The Geneva accords were condenned by the council and the Soviet leadership was asked to stop assistance to the Kabul regime while withdrawing its troops. The council reiterated to continue armed jehad until an Islamic govmment was set up in Afghanistan (VOAPS).

- The US Senate Comnittee on Foreign Affairs net 23 June to discuss uS aid to the Afghans. Chairwan of the special team on the Afghan affairs, Senator fordon Humphrey said, following the sign- 
ing of Geneva accord, it is now necessary for the US to help the Afghans complete and consolidate their victory (VOAPS).

\section{8}

* According to a mujaheddin report from Quetta, at a gathering 11 May 165 jehad commanders of Kandahiar province issued resolution about the general amnesty and the policy of jehad (VOADS). * In in interview with The Daily Telegraph (London), the head of Kabul government, Najibullah, has warned Pakistan of possible delay in the Soviet troops withdrawal from Afghanistan in case assistance continues to the mujaheddin (VOGDS).

* The first official meeting of the cabinet was held 28 June under the chairmanship of Prime Minister Mohamad Hasan Sharq. At the meeting, Minister of State, Niamatullah Pazhwak was unanimously elected as the Secretary of Cabinet meetings. For the purpose of the implementation of NRP and providing facilities to the cômpatriots, the sale and purchase of non-transferrable properties through courts according to laws already in force was endorsed (RA).

* The world media has reported that at a press conference 20 June the Pakistan based seven party Afghan opposition groups have announced the formation of a so-called transitional govermment. In its memorandum No.32, 24 June the Afghan government has protested to the UNIAG against Pakistan

(RA).

* A spokesman for the Jamiat-e-Islami Afghanistan has said commanders of the Jamiat-O-Islami in 10 provinces participated in their 5 th council in Takahr in the middle of June. The report says the council attaches much importance to the shifting of its power (stet) and control northern provinces of Afghanistian and they are preparing themselves for a new phase of war (BBCFS).

* About the US decision to establish direct contact with the mujaheddin through a US Under Secretary of State as a special envoy, the IUAM President Sayyed Ahmad Gailani sald we have been urging peace-loving countries from the very beginning to establish direct contact with us. (VOAPS).

* The Christian Science Monitor, wrote 28 June the mujaheddin have captured during the recent weeks more than one hundred Kabul regime cantonements and posts and it appears that the pillars of Kabul regime are further weakening in the rural areas. It is however possible the mujaheddin might face stiff resistance from the Kabul communist regime in Kabul and other cities.

* The paper says it might become necessary for the mujaheddin that simultaneous with their war activities, they should convince supporters of the Kabul regime to join the mujaheddin (VOAPS).

* Soviet troops withdrawing from Afghanistan are removing mines they had laid to protect their positions, the Commuist party newspaper Pravda said 27 June. By the end of May, 1,518 of the 2,131 minefields latd had been cleared by Soviet forces, the newspaper said, Another 100 min-fields were turned over to the Kabul regime army (PT).

* Talking 27 June to The Nawa-i-Waqt, the Azad Kashmir President, Sardar Abdul Qayyum said the Soviet Union intends to punish Pakistan for helping the Afghan mujaheddin (NWT).

* Addressing the mujaheddin in Sherzad, Nangarhar, the Chief of Hezb-e-Islami, Mawlawi Mohammad Yunus Thales described Najib's NRP as a conspiracy and said there cannot be any compromize with the murderers of 1,5 milition martyrs (NWT). 


\section{9}

* In an interview in Geneva, UNACAR Sadruddin Aga Khan said one of the most difficult tasks in Afghanistan is the sweeping of mines since refugees want to remain safe in their areas (RPDS).

* The UN Secretary General's special envoy, Diego Cordovez has said the withdrawal of Soviet troops from Afghanistan continues satisfactorily. He said during his two weeks visit to the region he will also look. into the issue of the missing Soviet soldiers (RPDS).

* Leaders of the European Community have said they expect the Soviet Union will homor its promise about the pullout of its troops from Afghanistan and, thereafter, the would be thing to offer humantarian assistance to that country (RPDS).

* The UNIAG observers team visited Chitral and Arandu 25-28 June to investigate into the Kabul regime allegations that Pakistan has been violating the Geneva accords. (RPDS).

* In a gun fire in Shalman, Khyber Agency, 25 June by the Kabul regime armed forces, one Pakistani was killed. The Charge d' Affaires of the Afghan Embassy was summoned $28 \mathrm{~J}$ une to the Foreign Ministry in Islamabad and a strong worded protest note was delivered to him (RPDS).

* The UN Assistant Secretary General, Diego Cordovez will visit Teheran, Islamabad and Kabul to look into the implementation of the Geneva accords on Afghanistan (RMDS).

* Teheran Radio has said the mujaheddin have cut the road link between Kabul and Jalalabad by occupying a part of Kabul-Jalalabad highway, (RPDS).

* Western diplomats say the mujaheddin have put pressure on another two provincial capitals - Mezar-o-Sharif, and Aibak center of Samangan (VOAPS).

* The VOA correspondent reports from Islamabad that in a resolution of the Kandahar mujaheddin signed by 165 conmanders, amnesty has been announced for the Kabul regime soldiers, officials, and employees and waming has been given to the religious scholars who call Najib as Muslim and cooperate with Kabul regime. The scholars are urged to abandon their cooperation otherwise they will be tried in the mujaheddin Islamic courts. Warning has also been given to returning refugees not to cooperate with the Najib regime, otherwise they, too, will be tried. The resolution say when an Islamic government is established in Afghanistan, and 28 ministers are appointed, the education and defense portfolios should be assigned to the mujaheddin (VOAPS).

* The Pakistani President Ziaul Haq declared 28 June he saw a lot of "confusion and bloodshed" in Afghanistan in the post Geneva Accord scenario (MIM).

* The UNACAR Sadruddin Aga Khan has said that in response to the uN's appeal for one billion dollar aid fund for Afghanistan, 33 million dollars have been contributed so far, reports vOA 28 June (PT).

* In an interview with the VOA correspondent, President of the interim mujaheddin government, Engineer Ahmad Shah has said that he will soon send delegations to various countries to press them to recognize the government of the Afghan mujaheddin (PT).

* The Indian Minister for Extermal Affairs, Narisanaroa presently visiting Bulgaria, has expressad the hope that the Geneva accord will be implemented sincerely and added that there are yet 
certain matters to be decided (NWT).

\section{0}

* In a statement in Moscow, the Soviet leader Mikhail Gorbachev has admitted that intervention in Afghanistan was a mistake committed in the foreign policy of that country (BBCFS).

* A spokesman for UNACAR, Sadruddin Aga Khan has estimated that three to four and a half million mines have beer planted in Afghanistan (BBCFS).

* A high ranking Soviet official says during the last eight years the Soviets swept more than 50,000 mines planted by the mujaheddin and foreign forces in Afghanistan (BBCFS).

* At a press conference 29 June in the Afghan Foreign Ministry the chief of political department of the Soviet forces in Afehanistan said 20,000 Soviet troops with their military hardware have so far withdrawn from Afghanistan (RMLS).

* China has expressed the hope that the Soviet Union would withdraw its troops from Afghanistan within the fixed time as specified in the Ganeva accord (RPDS).

* The Comander of Soviet forces in Afghanistan Boris Gramov has said in Moscow that half of the entire Soviet forces will leave Afghanistan by 16th August according to the program (RPDS).

* Participants of an international seminar on Geneva accord about Afghanistan in Islamabad have demanded the immediate formation of a coalition government acceptable to the people of Afghanistan. They have pointed out that without the establishment of such a government, peace in Afghanistan and in the region cannot be restored (RPDS).

* The Law of the National Assembly in 11 chapters and 82 articles was approved 30 June by the joint commission of the senate and the House of the People (RA).

* The Afghan Foreign Ministry has described as baseless the Pakistani accusations that Shalman and Chaman were recently shelled by Afghan forces (RA).

* Western diplomatic sources have said the mujaheddin have during the last three months captured 24 important centers in Afghanistan (RPDS).

* The commander of the Soviet troops in Afghanistan says only 10 soldiers have been killed since 15 May when the Soviet troops started their pullout from Afghanistan (VOAPS).

* In an interview with the Afghan International News Agency (AINA), the IUAM President, Sayyed Ahnad Gajlani has said the mujaheddin's interim government can only shift inside Afghanistan when elections for a Council are held and the elected council approves the government (VOAPS).

* Talking to newsmen from Baluchistan and Azad Kashmir, the NWFP Chief Minister, Fazle Haq said the Najib regime has intensified its subversive activities in Pakistan as a last resort for its survival. He said the refugees will go home in honor and dignity by next summer (VOAPS).

* Commander Ahmad Shah Masood of the Jamiat-e-Islami Afghanistan has set up a supervisory council in Afghanistan. The council held an eight day conference which reviewed strategy in the light of Soviet troops withdrawal from Afghanistan. The BBC reports that the fifth conference of the council was attended by mujaheddin commanders from 10 provinces. It was held in Takhar during the first 15 days of June (DN). 
* Afghan, Pakistan and Arab leaders met in Is]amabad, 29 June to discuss the Geneva accords and "problems left unresolved by or arising out of the accords," as one of the participants to the twoday serninar put it (MIM).

* Pir Sayyed Ahmad Gailani, Chairman of the IUAM and Engineer Ahnad Shah Ahmadzai,Prime Minister of the interim mujaheddin government attended a reception $28 \mathrm{June}$ given in their honor by the Saudi Ambessador in Islamiabad. The reception was also attended by the Ambassadors and Military Attaches of Islamic countries. Mohammad Yasser, Minister of Culture and Guidance of the interim mujaheddin government informed ANA that Engineer Ahmad Shah, accompanied by Foreign Minister, Quzi Najiullah, Finance Minister, Ismail Siddiqi and himself, asked the ambassadors of Islamic countries to recognize the interim mujaheddin government (MLM).

* The mujaheddin's northern command headed by Jamiat-me-Islami Commander Ahmad Shah Masud have divided the 11 northern provinces of Afghanistan into four administrative units. The Agency Afghan Press has learnt through its sources that the north-eastern zone is composed of Badakhshan, Takhar, Kunduz and Baghlan provinces, the northern zone is based in Samangan, Balkh, Jauzjan and Faryab; the central zone consists of Parwan and Bamian while the eastern zone includes Laghman and the Panjshir Vailey (PT).

* The OIC Secretary General, Sharifuddin Pirzada has said that after the liberation of Afghanistan, the Islamic Development Bank will extend all possible assistance for the reclamation and rehabilitation of that country (JG).

\section{CHRONOLOGY OF AFGHAN EVENTS, MILITARY}

\section{April - June}

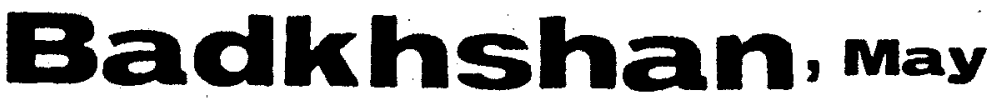

The Jamiat-o-Islami reports the mujaheddin attacked a militiamen unit 2 May in Fargha Monj, Badakhshan, as a result of which eight militianen were killed and more than 100 of them defected with their weapons to the mujaheddin (VOAPS).

29 Resistance sources say the mujaheddin, in an attack on the Soviet military base in Kishmed, des troyed five tanks and trucks and killed or injured about 50 Soviet-Kabul troops (VOAPS).

\section{June}

6 The Jamiatme-Islami Afghanistan has reported that in an attack 11 May in Jurum, Badakhshan, the majaheddin captured the Brigade of Kabul forces. In the attack 30 government troops were killed and 100 others captured by the mujaheddin while seven mujaheddin were killed. The mujahoddin arge quantity of arms in the attack (VOAPS). 
- The Jamiat-o-Islami says in a mujaheddin attack 15 May on a Kabul regime security post in Jurum rogion of Badakhshan, 27 soldiers with their alms joined the mujaheddin and the mujaheddin demo11shed that post (VOAPS).

* The Jamiat- $\theta$ Islami Afghanistan has reported that 70 soldiers with their arms from various posts in Teragram, Zeban and Sarkhdara, Badakhshan, surrendered 22 May to the mujaheddin (VOAPS).

The Soviet Union has deployed more troops in Wakhan near Chitral and declared the area prohibited for Afghan soldiers and other peoples. The Afghan Press Internetional (API) quoted reports from across the border that the Soviet Union has also reinstalled its latest long range missiles in Wakhan (PT).

The Afghan mujaheddin report they demolished four positions of the Kabul troops and killed 19 ooldiera in Faizabad, Badakhshan (RPDS).

\section{Badghis, May}

6 The Harakat-e-Enqelab-e-Islami office in Quetta says a 83 member unit of government militiament have handed over themselves to the mujaheddin in Badghis. The Badghis mujaheddin also launched 4-5 April attacks with heavy weapons on the Robat and Jandost government security poșts during which they killed 11 militiamen and demolished one, tank (VOAPS).*

* The Harakat-e-Enqelab-e-Islami office in Quetta says Qades, Badghis, mujaheddin attacked 5 April government security posts killing 12 militiamen (VOAPS).

* The Afghan resistance sources in Quetta saysthe mujaheddin attacked 10 April government security posts in Morghab, Badghis. T'en government soldiers defected to the mujaheddin during the operation (VOAPS).

\section{June}

10 According to a report of the resistance sources in Quetta, the mujaheddin attacked late May a communist military convoy in Ghormach,Badghis, destroying two tanks and three trucks, killing at least 11 troops and injuring 20 others (VOAPS).

27 As a result of armed clashes between the extremists in Badghis 20 persons from the two sides were killed and scores of others injured (RA).

29 Jamiat-e-Islami has reported, in a mujaheddin attack on communist troops in Ghormach, Badghis, lasting 31 May, 14 tanks and trucks were demolished. Exact details of the losses caused to the communists are not known. However 10 mujaheddin were killed and 15 wounded. In the battles, three security posts were destroyed (VOADS).

\section{Baghlan, April}

4 The mujaheddin sources have said they captured 12 Soviet-Kabul security bases recently in Baghlan (RPDS).

Five Kabul troops were killed and three captured along with thejr arms 31 March at a security post near Baghlan city by the musaheddir. One mujahed is reported to have been killed in the amation. On the same day, in another mujaheddir attzck on Pul-e-Khumri, Baghlan, three Soviat 
troops were killed ( $\left.\mathrm{PI}^{\prime}\right)$.

An Islamic Alliance source says that the mujahedin attacked 25 March a Kabul regime military post in Waziratad, Baghlan. One vehicle with all those aboard was destroyed in tre attack. Among those killed a high ranking military officer of the Kabul regime is also said to be included

(VOAPS).

* An Islamic Alliance source says that the mujaheddin in an attack 2.5 March demolished a gasoline pipeline in Pul-e-Khumri, Baghlan. Also the same day the mujaheddin attacked the Pul-e-Khumri power sub-station killing three militiamen and injuring four others (VOAPsi).

22

The Afghan Information and Documeritation Center says the mujaheddin raided at the end of the month of Hamal (March-April) a meeting of govermment officials in Pul-e-Khumri, Baghlan, injuring nine officials. They also, in a rocket attack on a Soviet post, destroyed three trucks and two tanks. In another attack in the same period in the Shashgaig village of Kalabatoor, Baghlan, they killed eight militiamen and captured four of their officers alive (VOAPS).

26 Afghan Information and Documentation Center says the mujaheddin destroyed 9 April a military security post in the Baladoori of Pul-e-Khumri. During the operation, 14 government troops were killed and the mujaheddin captured another 25 of them. (VOAPS)

31 Afghan resistance sources in Peshawar saythe mujaheddindestroyed 16 April a communist base in Andarab, Baghlan. During the operation six militiamen were killed and 70 were arrested by the mujaheddin (VOADS).

\section{May}

5 The NIF reports the mujaheddin in an attack on a military convoy 24 April demolished one vehicle in Khenjan, Baghlan. The number of casualties are not known (VOAPS).

* Mujahoddin sources say in an attack in Mazardara of Kailagai of the Dooshi sub-division in Baghlan on a goverument post, they have killed the comnander of the post. All other militiameni and soldiers defected to the mujaheddin. Also the mujaheddin set ablaze the Sovi.et oil pipeline at Chashma-e-Sher. The pipeline has been laid down between the Soviet border and Kailagai (VOAPS). 7 An Afghan mujaheddin source says the mujaheddin in a missile attack on a Soviet supply center at Kailagai, Baghlan, damaged four tanks and 18 trucks anc demolished one security post. A large number of Soviet soldiers were reported killed or injured during the operation (RPDS). 11 The Helnatyar Hezb-e-Islami says the mujaheddin have destroyed two militia posts in Baghlan. Another report says during the past week the Russians have withdrawn their troops from the Bano sub-division of Andarab, Baghlan, and the area is now controlled by the mujaheddin (VOAPS).

* The NIF says that 53 Kabul regime militiamen have defected to the mujaheddin in Doshi, Baghlan, during the first two weeks of the month of Saur (vo:ips). * A Jamiat-e-Islami Afghanistan source says the mujaheddin attacked 5 May the Parwan airport during which they destroyed one post and 12 soldiers were captured by the mujaheddin (VOAPS). 14 The Afghan Information and Documentation Center says the Mawlawi Nasrullah Mansoor's Harkat- Enqelab-e-Islami Afghanistan mrjaheddin in the last week of the month of Hamal in their attack on a jeep in Khenjan, Baghlan, killed one Soviet and two Kabul government officers and demolished the vehicle (VOAPS).

The IUAM spokesman jn Peshawar says, the Baghilan musaheddin heve brought under control tho 
highway which leads to the Soviet border. Commarder Bashir has reported to the IUAM trat Soviet regional officials in Baghl an have asked hin to allow safe retreat for the Soviet forces which are withdrawing to Soviet-Union via this highway (VOAPS).

* The mujaheddin have captured an important army center in Baghlan city from where the SovietKabul troops fled away in the dark of the night. It is learnt the mujaheddin conducted successful operations 10 May and captured several parts of the old Baghlan city. The mujaheddin in arother operation captured a security post in the inclustrial arta of Baghlan city. During the clash four Kabul soldiers were killed ( $\left.\mathrm{PI}^{\prime}\right)$.

19 The Jamiat-e-Islami Afghanistan reports the mujaheddin in an attack 23 April on a government convoy on the highway between Pul-e-Khumri and Baghlan city destroyed one Soviet tank alongwith its crew and a truck and captured another truck alongwith its passengers.

21 The Soviet troops are preparing to pull out from the most importantarmy supplycenter in Kailagai 205 kilometers away from Kabul on the Salang highway in view of worsoning conditions in the Baghlan province (PT).

23 Reports of Hekmatyar Hezb-e-Islami from Baghlan province say all the 30 militiamen at two security posts in the center of the province have surrendered to the mujaheddin with their arms (VOAPS). 25 The Islamic Alliance reported 80 militiamen of two posts in Baghlan surrendered 20 May to the mujaheddin. The source says about 500 troops and militiamen of the Kabul regime have surrendered to the mujaheddin during the last week in Baghlan (VOADS).

* The Hezb-e-Islami reported its nujaheddin attacked 24 May the KHAD offices and PDPA committee of Baghlan city killing five KHAD and city committee officials, injuring another and capturing four. The office of Islamic Alliance reported the Baghlan city has now been captured by the mujaheddin (VOADS)。

27 The Afghan mujaheddin besides capturing the valley of Andrab, Baghlan, are reportedto havedes. troyed several security posts in other parts of the province. After the offensives the mujaheddin, are now in a position to close the Salang highway leading to the Soviet Union (PT).

30 The resistance sources say, in an attack 23 May on a Communist post in Ahangran between Salang turnel and Jabal-us-Seraj along the Salang pass, Baghian, the mujaheddin captured 123 soldiers and officers and seized 30 kilashinkovs. The occupation of this post by the Panjshir mujaheddin would make it difficult for the Soviet troops to withdraw through Salang (VOAPS).

\section{June}

6 The Afghan mujaheddin have captured half of Baghlan city reports Radio Teheran (PT)。

9 The commander of Hezb-e-Islami, Abdul Ghayyur reports from Baghlan that the Soviet military Commander in the north eastern region, in a letter 20 May asked him not to attack the withdrawing Soviet troops on Baghlan-Pul-e-Khumri-Sanangan highway. The proposal was rejected by the mujaheddin and the mujaheddin attacked 25 May the center of Baghlan where a government military convoy was heading towards Takhar province. In the attack 60 Kabul troops were killed or injured and four trucks and tanks demolished (VOAPS).

* According to resistance sources, the mujaheddin attacked 29 May a government convoy heading towards Baghlan killing or wounding 20 Kabul troops and destroying two trucks and tanks (VOAPS). 20 HIF reports, in their attack. 1 June, on posts in Kakhel of Pul-e-Khumri, Bachim, the muja- 
heddin killed or injured 13 soldiers and militiamen and captured:30 (VOAPS).

18 The Afghan mujaheddin are striving hard to capture Baghlan city and in the course of fighting during the second week of June heavy casualties were inflicted on the Kabul regime forces (JG).

21 The Afghan mujaheddin report that in an attack on Pul-e-khumri Baghlan, Jail, they have freed 10 prisoners (RPDS).

23 Hezb-a-Islami (Hekmatyar) says the 36 militiamen, who had defected from Andrab sub division, Baghlan, joined 16 June the mujaheodin in Khanjan region, Baghian province. The Thanjan mujaheddin bay a Soviet soldier defected 13 June from the Soviet military base in Khanjan and foined the mujaheddin (VOAPS).

* Hezb-a-Islami (Hekmatyar) says the mujaheddin attacked 8 June a security post in Baghlan province, killing the commander of the post and capturing 12 militiamen with their arms. Similarly, In an attack 7 June on a Kabul regime convoy in the outskirts of Baghlan, the mujaheddin captured 80 soldters with their arms and demolished two tanks (VOAPS).

28 Hezbu-Islami (Heknatyar) reports in their attack 24 June on a militia post in Baghlan, the mujaheddin captured the commander of that post alongwith four militiamen. In the attack, a militia man was killed and others fled away (VOADS).

29 The Afghan mujaheddin sources reported that in an attack last week on a post in Khenjan, Baghlan, the mujaheddin captured $12 \mathrm{Kabul}$ regime soldiers and killed the commander of that post. S1milarly, the crew of a tank were killed in Takhta Sang as a result of the explosion of a mine planted by the aujaheddin (RPDS).

\section{Balkh, June}

9 The NIF says the mujaheddin demolished 18 May three security posts in Chamtal, Balkh. A number of governiment troops were killed or injured in the operation (VOAPS).

12 The Jamat-Islami has reported that in an attack recently, the mujaheddin killed six Soviet coldiers in Marmal, Balkh (VOADS).

* The Jamiat-b-Islami says in mujaheddin attacks on the Kabul regime security posts in Shadian noar Masan-Sharif two officars and four soldiers were killed. Following the mujaheddin attack, the rabul regime evacuated all Its posta from Shadian to Mazar-a-Sharif and the Shadian region is now completely under the mujaheddin control (VOAPS).

i According to the mujaheddin sources in Peshawar, three Kabul regime militia posts surrendered 7 June to the mujahoddin in Sholgara, Balkh (VOAPS).

19 The office of Jamiat-e-Islami Afghanistan says the mujaheddin have killed 14 June eight Soviet troope in Ballh province. In the cambat, three cifllitans were kllled and six mujaheddin infared Wirathan port, the mujaheddin destroyed two tanks, a tanker and killed eight soviet soldiers

99 (Mands). 1. The Afghanistan resistance ounces say the mijaheddin captured 16 June, nine security posts in Soloar, and Balkh aub division (VOAPS). 
* The NIF says the mujaheddin eliminated five government posts in Samarqandian and Charsang, Balkh, and have seized a huge quantity of arms and ammunition (VOAPS).

* The NIF says the mujaheddin attacked 14 June six posts in Sholgara, Balkh. As a result four posts were eliminated (VOAPS).

\section{Bamian, April}

16 s source of Jamiatme-Islami Afghanistan reports that the mujaheddin in an attack 1 April on comminist base in Bamian demolished two enemy tanks, a truck and a major portion of the base. They. killed 16 communist soldiers while five of them defected to the mujaheddin with their arms (VOAPS).

22 The Afghan Information and Documentation Center reports the Harakatme-Enqelab-e-Islami mujaheddin together with mujaheddin belonging to other organizations, destroyed all government security posts 9 April in Shar-e-Gholghula, Bamian, and now the town is in mujaheddin control. Also the mujaheddin have surrourded the Bamian airport causing suspension of flights. They are also reported to have shot down one jet aircraft and destroyed a tank and killed 20 soldiers (VOAPS).

\section{Faryab, April}

The body of General Shah Aqa, the Chief of Staff of the central forces and a number of others who died in a plane crash in Faryab was laid to rest 12 April (RA).

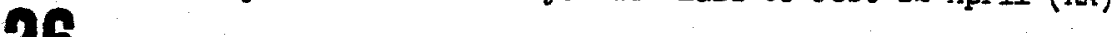
20 The Afghan Information and Documentation Center reports the mujaheddin attacked 13 April a Soviet military unit in Almar, Faryab,killing 13 soldiers and destroying one truck (VOAPS). 31 Afghan mujaheddin sources in Peshawar report that the mujaheddin shot down 9, April a Soviet Antonov plane and a helicopter in Maimana, Faryab (VOADS).

\section{May}

Resistance sources in Peshawar say the mujaheddin in an attack 7 April killed 14 Kabul regine soldiers and injured 44. The report adds the mujaheddin also demolished a security post in the city of Maimana during the last days of the month of Hamal (VOADS).

25 5IX persons were killed and 18 others injured in heavy shelling by the extremist elements 24 and 25 May in Maimana city, Faryab (RA).

\section{June}

9 Two persons were killed and nine injured as a result of heavy gun fire by the extremists in Maimana, Faryab (RA).

\section{Farah, April}

23 The Hekmatyar Hezb-e-Islami says the mujaheddir, in an attack 11 April on communist centers in Qalagai, Parah, destroyed two trucks and killed a number of soldiers and injured five others. * The Afghan mujaheddin are reported to have captured the strategically important town of khak-oSufaid Farah. VOA reported that the fighting which took place there was the most fierce during the last nine years of tho Afghanistan war (PT). 


\section{May}

Afghan resistance sources in Quetta say the mujaheddin blocked the main highway between Farah and Fararoad near the Deh-Haq village to attack the troops which had moved in to open the highway. One tank. was reported demolished by the mujaheddin and two other tarks were blown up by mines alongwith their passangers. In the operation, 18 Kabul militiamen were killed and 29 injured 15 An Ittehad (VOAPS). 15 An Ittehad-o-Islami source in Quetta says, as a result of the mujaheddin firing on the Farah city posts, 18 Kabul governmerit militiamen have defected to the mujaheddin (VOADS).

22 Mujaheddin sources in Quetta say 530 militiamen with 600 items of light and heavyarms have defected in the Qala-e-Kah, Farah, to the Hekmatyar Hezb-e-Islami. The militiamen have now left with their families in 23 vehicles to Iran 16 May and are living in Derjang (VOAPS). 28 According to the mujaheddin sources, a Militia commander alongwith 30 of his men at the Kopal border post in Qala- $-K a h$, Farah, surrendered 22 May to the Hezb-e-Islami (Hekmatyar) mujaheddin

(VOAPS).

\section{June}

3 Reports from Farah say, in their attack late May on a unit of Soviet-Kabul troops in Shimalgah 15 kilometers from Farah, the mujaheddin wiped out two tanks with their crewnen while three Kabul soldiers were killed and eight others injured (VOAPS).

16 The mujaheddin sources in Southern Afghanistan say in their attack 6 June on three posts in Farah city, 30 Kabul regime troops were killed and 60 wounded (VOAPS).

\section{Ghazni, April}

4 A source of the Islamic Unity party has reported the mujaheddin attacked 26 March a Soviet post near Ghazni city, killing two soldiers and injuring three others (VOf.PS).

* The AMBC says the mujaheddin of the eight Zone of Ghazni destroyed 26 March three Soviet tank, by mines in Deh Yak. The Soviets were attempting to set up security posts in the area (VOAPS). 1 The Islamic Alliance (Sayyaf) says their men freed 7 April the mujaheddin who were earlier captured and jailed by the commurist troops in the 14 military division of Ghazni (VOAPS).

* The mujaheddin 29 Merch attacked a government military convoy preceeding towards Kabul from Chazni. Two tanks, and a truck of the convoy were destroyed in the operations (PI).

19 The Afghan mujaheddin attacked chazni airport recently as a result of which eight Soviet-Kabul troops were killed and a helicopter was destroyed. Danage was also caused to the airport. Three KHAD activists were also killed (PT). 26 The office of the Harakat-e-Engelab-o-Ialami in Quettasays the mujaheddin in an attack in Mogor, Ghazni, inflicted heavy damage to the main military base and destroyed ten houses belonging to Russian advisors (VOSPS).

\section{May}

The Harkat-e-Engelab-a-Islami in Quetta says the mujaheddin in the begirning of April in their ettuck on the Shabikhel at Nawa, Chazni, damaged communist military post, killed six Kabul rugino antitamen tod Infured four others. They also attacked the logistic unit of communist troops in 
Hazrat-o-Sultan during which they set on fire two tanks and killed 12 communist soldrers (VOADS). 8 Aftar the announcement of a general amnesty by the mujaheddin in Chazni, 170 officials of the Kabul goverrment have defected to the mujaheddin. Sources of the Hekmatyar Hezb-erIslami have said 70 members of the militia, militury and civil administration have defected to local commander Sarwar than and another 100 to the Harakat-e-Fincjelabue-Islami (JG). The Afghan freedom fighters have shot down an aircraft, destroyed two tanks and killed 13 Soviet troops in Gailan sub-division of Ghazni province (MLM).

24 The Hezb-e-Islami reported, following the pullout of Soviettroops from Shah Joey and Kara Bagh, aub divisions, 40 militiamen have joined the mujaheddin and presentiy these sub divisions are under the mujaheddt' control. Similarly, ANS says the Kabul regime evacuated 16 May its troops from Zunakhan sub division and its suburbs in Ghazni province (VOADS).

26 The Itteha-d-Islami organization says two soldiel's belonging to Ghazni units and having first hand knowledge of the mines laid down by the Russians have defected to the mujaheddin (VOAPS). 31 Reporte from Ghazni say, following the evacuation of Qara Bagh sub division by Kabul troop in clash between the mujaheddin on the distribution of arms and other supplies, s1x persons are now being hospitalized in Quetta. It is said that in the clashes, lasting five days, 33 persons were killed and 51 injured from both sides (VOAPS).

\section{June}

12 The Jamiat-e-Islami says in their attacks 28 May-1 June, on communist posts in Nawa, Ghaznt, the mujaheddin demolished two Kabul regime tanks and military vehicles. In another attack 25 May, on a Soviet military base in Ghazni, the mujaheddin killed six Soviet troops and injured a nimber of others. Six tanks were also destroyed while two mujaheddin were killed (VOADS).

* The Engelab-e-Islami organization says in a rocket attack 27 May on a Soviet milltary base near Ghazni city, the mujaheddin killed 20 Soviet troops and injured 80 others. six tanks and pour trucks were demolished during the operation (VOAPS).

\section{Ghor,may}

The Jomiatme-Islami in Quetta says the mujaheddin in their attacks 6 April on several commnist posts in Tolak, Chor, killed 20 militiamen and injured four others. The source says three posts were demolished and two mujaheddin martyred and three injured during the operatian (VOAPS). 27 The Afghanistan resistance sources in Quetta say two mujaheddin, who had joined the cqmunists under a directive, have surrendered about 200 items of light and heavy weapans to the mujaheddin in Shahrak, Ghor (VOAPS).

- According to resistance sources in Quetta the mujaheddin, in an attack early April an the Kabul regime posts in Cheghcheran, Ghor, killed five government militiamen and wounded a large number of others. In another attack on a government patrol party in the center of Ghor, four Kabul soldiers were killed and nine others injured (VOAPS). 


\section{June}

Forty eight civilians and 23 mujaheddin were reported killed 4 May as a result of bombing by the Afghan aircraft in Tulak, Ghor (MIM). 13 According to NIF report, the mujaheddin jointly attacked 25 May the Khwaja Ghar sub division, Takhar, bringing the sub division and its posts under the mujaheddin control. They captured 26 soldiers and seized 75 pieces of arms and a huge quantity of military hardware (VOAPS).

21 The Hezb-a-Islami (Hekmatyar) office says the mujaheddin captured 10 June $\varepsilon$ Kabul regime mourtain brigade in Ali Baig, Ghor. The mujaheddln killed the Brjgade Commander and captured 200 kilashinkovs, four machine cums, two mortar guns, 10 rockets and a huge quantity of bullets and military equipment (VOAPS).

27 According to a report of the VOIRA, in an attack, on Soviet-Kabul troops in Ghor province the mujaheddin captured a Kabul govermment security post and seized a huge quantity of arms after killing the commander of that post (JG).

\section{Helmand, April}

Afghan mujaheddin say that 55 local residents have been killed, many houses and a major portion of an irrigation network have been destroyed as a result of latest bombing by Soviet aircraft in the Helmand province (VOADS).

11

The Islamic Alliance (Sayyaf) sources say the mujaheddin, in sn attack with heavy weapons on a Soviet military convoy in Sharab, set ablaze 14 trucks, four oil tankers, one armored vehicle and jeep mounted with wireless set. Most of the crew belonging to the vehicles were also killed, the report added (VOAPS).

* Afghan resistance sources say the mujaheddin in an attack 5 April on a government military post In Nad-o-Ali, Helmand, killed four militiamen. The post itself was demolisher. One mujahed was martyred in the fighting (VOf.PS).

* The NIF says, Soviet-Kabul troops recaptured 1 April the Sangin sub division of the Helmand province. However, in a joint mujaheddin operation, 3-4 April on communists centers many soldiers were killed and equipment destroyed. The exact amount of casualties is not known (VOAPS). 1 Alfghan resistance sources report, as a result of clashes with Kabul-soviet forces from $6-9$ Apry in Sangin, Helmand, eight tanks with their crew were destroyed. The mujaheddin have also killed 72 commurists troops and captured :30 Kabul regime soldiers (VOADS).

30 Afghan resistance sources in cuetta say fresh commuri st forces havebeen sent from Shindand and Kabul to northerm Helmand and as a result of communist bombardment of the area, 150 civiliens have been killed and a large number of houses demolished (VOAPS).

* Neghan resistance sources in Quetta say the mujaheddin mounted 25 April heavy attacks in Kajaki, Bangin, Zamindeur and Qala-e-Gaz, Helmand, on commist centers. During the operation 10 Soviet tanks were demolished and at least 40 troops klled. The mujaheddin have rendered 13 martyrs and 18 injured (Voips).

\section{May}

Barkat-Iolami of Sheikh Mohammed Aser Mohsen1 reports It mujahoddin sẹt ablaze two 
communist oil tankers 7 April in Gerishk, Helmand. They also blew up an enemy truck 13 April in Morgir, Helmand, killing seven of its occupants including two officers (VOAPS).

5 Fierce fighting is continuing between the mujaheddin and the Soviet-Kabul forces in Helmand province, reports VOA. The radio said joint forces launched a massive attack on the positions of the mujaheddin in Helmand. But the mujaheddin say they inflicted heavy losses on the attackers. Reinforcement has been sent from Kandahar to the mujaheddin (PT).

9 The Janiat-o-Islami Afghanistan office in Quetta'says fighting has been going on between the mujaheddin and communists in Sarban Qala, Helmand. The mujaheddin have so far destroyed 32 communist tanks and vehicles and the mujaheddin have rendered at least 54 martyrs (VOAPS).

29 The mujaheddin sources report Soviet-Kabul. troops, deployed in the northern Helmand, have now retreated to Lashkargah and Shindand. The mujaheddin also say the Kajaki Dam, recently repaired by the Russians, has once again been damaged and electric supply has been discontinued (VOAPS). 30 The Hezb-e-Islami (Hekmatyar) has said in Quetta, as a result of mujaheddin attack 27 May on a post in Qala-e-Gaz, Helmand, 30 troops with their arms joined the mujaheddin. Similarly, in their attack a few day ago, on a post in Hazar Chughat an armored vehicle with its crew was demolished. A Soviet officer and seven Kabul regime soldiers were also killed in the incident (VOAPS).

\section{June}

Herkat-e-Engelab-e-Islami Afghanistan reports, following the evacuation of Soviet-Kabul troops from Sangin, Helmand, in a mujaheddin attack 20 posts were demolished and 15 militiamen with their arms surrendered to the mujaheddin (VOADS).

According to the Harkat-e-Enqelab-e-Islami Afghanistan, the mujaheddin blasted in mid May a Kabul regime arms depot in Marki, Helmand (VOAPS).

18 The Harkat-o-Engelab-e-Islami says, due to the fierce nrujaheddin attacks, the Hazar Juft base, Helmand, was shifted 12 June to the center of the sub division. Similarly, it said the communists have evacuated Dewalak and Khanshin and have built new posts in Nad-e-Ali (VOAPS).

\section{Herat, April}

12 Mujaheddin sources say that the mujaheddin attacked compurijsts centers 3 April in the Zair-eKoh region of Shindand Herat province as a result of which a number of communists were killed, two tanks demolished and tho other tinks captured (VOFFS).

16 Hezb-e-Islami (Hekmatyar) reports the mujaheddin attacked 26 March the comminist base in Blias Karez, Herat, during which they seized three vehicles and three motorcycles. Nine communist soldiers were killed and five others were captured. The Hezb says the mujaheddin also have captured earlier several KHAD members in Kamana, Herat (VOADSi).

2 Afghan resistance sources say they captured 4 Apri] the Khaq-e-Safaid village near the Shiridand aiport, Herat. In the attack on this strategically important village 129 government soldiers and 12 mujaheddin are reported to have been killed (VOLDS).

* Mfghan mujaheddin sources say in an attack 3 April on a Soviet convoy in Shindand highway, both aides have been inflicted with heavy losses and the mujaheddin have captured 8 Soviet soldiers (VDADS). 2 Resistance sources in Quetta say that morale has been deteriorating among the $10 \mathrm{cal}$ 
communists in Herat and some even try to have reprouchennents with the mujaheddin. The report also speaks of the Russians being busy collecting their almis in the province (VOAPS).

\section{May}

Extremist elements recently, by launching ground-to-ground rockets and cannon fires on the Herat Textile Mills have inflicted damages to the factory costing some Afs. 6 million (RA). 1 Afghan resistance sources in Quetta say the mujaheddin staged 27 April rocket attack on the office of the Herat governor as well as other communist centers during which the office of the governor was demolished and one mujahed was killed and six injured. Figures about communist casualties were not available (VOAPS).

* Resistance sources say the mujaheddin attacked the Shindand security posts, Herat, as a result of which one communist was killed and a number of others were injured, a depot, a vehicle and one armored car were demolished (VOAPS).

1 A truck, loaded with weapons and other supplies belonging to extremist groups coming from abroad, was intercepted in Shindand, Herat (RA).

15

A Soviet general has reportedly asked the mujaheddir ir Herat for a ceasefirewhile the Soviets are pulling their troops out of Afghanistan (MIN).

18 Reports from the Shaheed Afzali Fronts say the mujaheddin attacked 8 May a Kabul govermment security post in the Gazargah region of Herat killing three soldiers. The mujaheddin the same day destroyed a government jeep alongwith its passengers' on the Herat-Torghondi Highway (VOAPS).

* According to a report by the Shaheed Afzali Front,s, the mujaheddin, in a surprise attack 9 May, captured alive member of the provincial PDPA comittee Abdul Rahim. Simllarly the mujaheddin attecked 10 May a militiamen post in the Gazargah area killing or injuring five militiamen (VOAPS).

* The Shaheed Afzali Fronts reports from Herat the mujaheddin brought to a stand-still the traffic on the Torghondi highway 13 May and destroyed a Soviet jeep alongwith its passangers. The mujaheddin also on the same day captured alive 12 soldiers from a security post in the Mir Daoud area. Also the mujaheddin attacked a government truck on the Herat-Torghondi Highway $\mathbf{1}_{4}$ May killing seven soldiers (VOAPS).

23 The mujaheddin sources in Quetta say a senator from Herat city General Fazl Ahmad Salehi who was recently inducted to the Senate by the Kabul regime, has defected to the mujaheddin alonguth nembers of his family (VOAPS).

* Sources of the Afghan mujaheddin in Quetta, Pakistan, say a big arms and ammuntion depot, per taining to 17 division and 11 Birgade of artillery of the Kabul regime in Herat, was exploded 22 May by the promujaheddin officers. The explosion lasted two and a half hours. Exact detafls of the losses are not known. But it is said that the number of dead and the injured was very high

(VOAPS).

* Resistance sources in Peshawar report the mujaheddin carried out operations 2-19 May in Herath In which they attacked the regime posts West of the city. In the attack, four posts were demoliohed, five troops killed or injured and four troops were captured by the mujaheddin. The mujaheddin have also captured 30 items of arms, ftro motor, cycles and a vehicle (vOAPS).

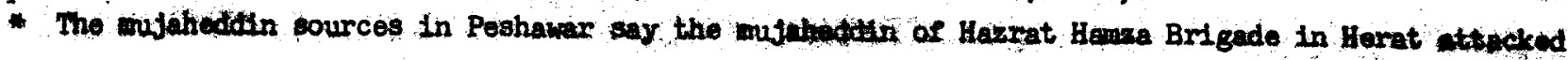


9 May a convoy heading towards Torghundi-from Herat. In the attack a tank with allits crew was destroyed. Similarly, the mujaheddin attacked 4 May the military post of Herat Cement Factory killing a number of troops (VOAPS).

* Resistance sources in Peshawar say the mujaheddtn attacked 11 May the Sayyed Ahmad Militia Post in Rauzah of Bagh-o-Guzari, Herat. Nine persons were killed or injured. Similarly, in an attack on a Kabul regime convoy on Herat-Torghundi highway, the mijaheddin destroyed three trucks and killed or Injured a number of persons and captured another two with their arms (VOAPS).

* The mujaheddin sources in Peshawar report that the mujaheddin attacked 13 May the Sayyed Ahmad militia posts in Herat city capturing eight militiamen. On the same day another group of the muJaheddin attacked the same posts and destroyed one of the posts (VOAPS).,

* Reports reaching the mujaheddin sources in Peshawar from Herat say the mujaheddin killed 17 May the Deputy Chief of the Cement project in Pul-e-Salar and captured his arms. A Kabul regime tank was blown up the same day in Pul-e-Sheikh. In a mujaheddin attack 19 May damages werecaused to KabuI regime three posts in Guzarah and 16 government troops were killed while nine pieces of arms were seired by the mujaheddin (VOAPS).

* Resistance sources report military units of Kabul regine, guarding border posts near Iran, have quit their posts and have returned to Herat city. The mujaheddin say a part of border is totally free and is under the mujaheddin control (VOAPS).

21. Reports from the Martyred Afzali Fronts say all posts belonging to the first and second security belts in Western sector of Herat city hava fallen to the mujaheddin as a result of their wide ranging operation 24-26 May and right now, the western part of Herat city is under the mujaheddin control (VOAPS).

* The mujaheddin sources have said a 50 militiamen group joined 23 May the mujaheddin in Ghorian, Herat. Meanwhile in an explosion in an ammunition dump of the artillery Brigade of the Herat division, $130 \mathrm{Kabul}$ troops and of ficers were killed and about 312 others injured (VOAPS).

* According to a statement of the Afghanistan resistance sources, the mujaheddin attacked 23 Kay a Soviet military convoy heading towards the Soviet Union in Kotal Herat, destroying two tanks and a truck (VOAPS).

29 The mujaheddin sources in Quetta say a Soviet military convoy, heading towards Torghundi from Kandahar, was attacked 23 May by the mujaheddin five kilometers from Herat city during wich a Soviet truck and two tanks were demolished and all persons aboard were killed or injured (VOAPS).

31 Senior Captain Mohanmad Ismail Khan, the Mujaheddin commander in Herat reported 30 May that, in on explosion carried out by the mujaheddin in Herat 33 Brigade, four ammunition depots were completely blown up (BBCFS).

* The mujaheddin commander in Herat, Mohammad Ismail than reported that as a result of mujahedidin recent attiak on the Herat city security belt, two enemy posts were eliminated and seven men captured (BACPS),

\section{June}

the extraust elements, by carryting out an explosion, have damaged a part of the Cauharshad Himol bullidin in Horat (RA). 
According to the Afghanistan resistance sources, the mujaheddin occupied recently a border post in Herat and captured 85 Kabul troops (RPDS).

15

The office of the Jamiat-e-Islami has reported, in an attack 9 June on a post in Chorlan, Herat, the mujaheddin captured 12 Kabul regime troops with their arms and amunition. Following the attack, the Soviet planes bombarded the mujaheddin positions. A Soviet plane was shot down by the mujahoditin in Shiadand, Herat, as a result of these operations (VOADS).

* Jamfat-o-Islami Afghanistan reported in a mujaheddin attack 5 June on a convoy of the commintat. forces heading towards Ghorian, Herat, 32 soldiers were killed and a number captured by the mujaheddin. The source says the Ghorian sub division is completely under the mujaheddin contral (Voups) 27 During an attack by the mujaheddin on the surroundings of the Shindand airoort. three Soviet MIGs were shot down (PT).

* Jamiat-e-Islami Afghanistan says in an attack 24 June on posts near Shindand airport, Herat, the mufaheddin captured 13 soldiers and three officers. In the attack three mujaheddin ware killod and 10 others wounded. While four guns and 12 vehicles of the Kabul regime were also destroyed

(VOADS).

* The office of the Jamiati-e-Islami reports that in a retaliatory Soviet attack near Shindand atrport, Herat, 100 residential buildings have been demolished and a number of civilians killod. The source says the mujaheddin downed three Soviet aircraft (VOADS).

29

According to Afghanistan resistance sources, in in attack on a post in Shindand, Herat, the mpjaheddin ktlled 40 Kabul soldiers and captured another 15. The post was totally eliminated and a large quantity of arms and ammunition captured by the mujahoddin (RPDS).

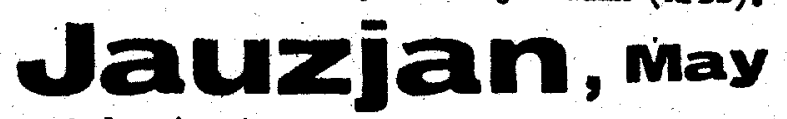

A six man terrorist group belonging to extremist elements were routed 9 May in areas belonging to Jauzjan province by the security forces (RA).

\section{June}

8. According to Afghan resistance sources in Peshawar, $300 \mathrm{Kabul}$ regime militiamen in Jauzjan, nelghouring the Soviet Union, defected recently to the mujaheddin (VOADS).

The AMC reports that the mujaheddin eliminated 26 May a Kabul regime post in the newly created province of Ser-e-Pul killing or injuring 10 troops (VOAPS).

- The AMC reports the mujaheddin attacked a post in Jaffery region in Sar-e-Pul. A number of government troops were killed or injured and two trucks and tanks demolished in the operation

\section{1, April}

(VOAPS).

4. According to ANS the mujaheddin staged a rocket attack 25 March on the Kabul airport Three Soviet jet aircraft were set ableze. The report adds two other rockets landed near Pul-e-Kheshti Noique. The exact number of casualties were not known (VOAPS).

- The ANS reports, the mujaheddin blew up 24 March a bridge comecting Kabul airport with the Soviet poste north of the airport. The agency said a mujaheddin rocket hit 25 karch anternity 
hospital in Shahr-o-Nau, Kabul city, but there was no report of casualties (VONPS).

* According to the Afghan mujaheddin sources in Peshawar, the Kujaheddin blocked last week, the Kabul-Jalalabad highway for 33 hours and attacked a Soviet convoy at Tangl Abreshum in the jegdalek area. The mujaheddi say they destroyed three tanks and k1lled 15 Soviet soldiers during the operation (BBCFS).

14 A powerful car bom once again trembled the Shahr-e-Nau in Kabui 11 Apmil whlins or infim Ing an unspecified number of communist shoppers. Four Soviet advisers were reportedly killied in the blast, AMR said in Peshawar 14 April (PT).

* An unknown gumman shot dead a senior Afghan army brigadier on April 5 in the Pul-a-Hahmoud Whan area in Kabul city, according to AMFiC (PT).

The Afghan mujaheddin say in their rocket attacks on Kabul they recently killed 10 Sovlet soldters (VOADS).

17 The mujaheddin have raided Kabul Radio station, the headquarters of the Soviet amored division and a military center in Kabul simultaneously. During the operation, conducted 7 April, missiló hit Rabul Radio Station in Yake Toot and headquarters of the 15th division as a result of wich thick smoke enveloped the area after severe blasts (PI').

23 Tho Islamic Alliance says its mujaheddin have exploded two more bombs in Kabuli. One bomb was exploded $14 \mathrm{Apr}-1$ in the canteen of the Kabul atrport in which four people were killed and injured. The other bomb axploded 19 April in the apartment houses complex in a joep as a result of which Kabul regine milltary officer and his driver were killed (VOAPS).

24 The Heknatyar Hezb-c-Islani roports that 100 kabuls troops defected 20 Aprilto the Heab mujaheddtn in the Chardi of Kabul province. It says the defection has taken place as a result of the ammesty offered by the IUAM recentiy (VOAPS).

26 Western diplomatic sources in Kabul say that a Soviet military jeep hit a mine in Darulaman 19 April in the front of No.40 unit of Soviet army as a result of which two sovilet soldtere were ldlled and the jeep was demolished (VOAPS).

* Two missiles hit tho headquarters of the ruling Afghan Communist Party in Kabul, damaging a vast area. Shia dominant Harkat-o-Islami resistance party has accepted responsibility for the missile attack. No casualties have beep reported (PT).

27 A huge bomb has exploded in Kabul. TASS says that four persons were killed in the explosion and Kabul authorfties have claimed that the bomb was bought in from Pakistan (BBCFS).

28

The ANS reports the mujahedaln of the Islamic Alliance exploded a bomb 4 April in the Custoon House of the Kabul Airport as a result of which a Soviet girl and three Kabul regime officers were killed and the Airport terminal dameged (VDAPS).

31 An Afghan resistarice source in Peshawar has said in four explosions in various parts of sabuil city 27 April 15 people have been killed (VOADS).

\section{May}

Diplomatic sources (place not given) say during the current week 10 rocket explosions occured. In Kabul and as a resilt of a rocket hitting a diplomatic querter ono offictal of the Bulgarien 
Dmbasay and his son vere injured (RPDS).

4. VoA correspondent from Islamabad reports only 30 kilometers from Kabul city at the Mahipar pass, the mujeheddin attacked a government military caravan demolishing one tank and a number of trucks and blocking the Kabul-Jalalabad highway (VOAPS).

11 As a result of firing of 17 ground-to-ground rockets on the city of Kabul city 9 yay by extremist elements, 23 of our compatriots were martyred and 28 infured (RA).

* A hideout belonging to extremist elenents was discovered and captured 9 May by security forces in Sarobi, Kabul rrovince (RA). Two people were reportedly killed when a bomb went off in a car in Kabul 9 Kay, the BBC repor-
ted (PI).

14 As a result of explosions

by extremists in a Mercedez Benz vehicle near Pul-eMahmood Khan in Kabul eity, 10 people were killed, 13 injured and two houses demolished (RA). * As a result of the ffring of ground-to-ground rockets in the grounds of Baraki of Kabul city two children and a man have been killed and a number injured (RA).

* Bakhtar reports a professional criminal, who wanted to place explosives in the Jalalabad bus explosive (RA).

* The Harkat-o-inqelab-o-Islami Afghanistan office says its mujaheddin in their attack on a Soviet base and an air defence center in Sarobi, Kabul pruvince 4 May, killed two Soviet advisers and 21 soldiers and militianen, demolished three Soviet tanks, five vehicles and a B.M. 13 rocket launahar. Three mujaheddin were injured in the operation (VOAPS). 1 Kabul government officials say, as a result of a bomb explosion in Kabul c
ting Kabul city outskirts, 15 people have been killed and 16 injured (VOAOs). 18 A number of ground-to-ground rockets, planted in Mosaiee, Kabul province, which were to be fired on Kabul city, were discovered and discharged by the security forces (RA).

21 Ahmad Rateb an extremist, who had planned to place explosives with the help of Lady Noor Jahan, If congested parts of the Kabul city :as caught by the securfty forces before they could execute
their plan (BA).

94. According to a TASS report six rockets were fired 23 May on Kabul city ldiling a woman and causing matorial losses (VocDs).

* The Afghan mujaheddin sources said in an attack 22 May on a military cantonment near Kabul city

19 Kabul troops were killed (VoaDs).

41 The security forces of the country discovered and defused 26 May 150 anti-persomel mines hidden in areas belonging to the first district of Kabul city (RA).

- AMC says Sovlet forces evacuated 21 May a big mflitary post in the Qumugh Mountain region southwest of Kabul city (VOAPS).

* According to mujaheddio sources in a mujaheddin attack 11 May on Shakardara, the butlding of tha local addinistration wes demolished, 20 soldiers and a large quantity of arms were selaed by the mujahoddin (poups).

Mghen Gharge d' Affaires, Qudratullah Ahmed1 calonodedged 26 vay In Islamabad that themitahne 
din had twice attacked Kabul with long range rockets since May 15 when the withdrawal of Soviet troops from his country began (MIM).

29 Night flights of the Soviet transport planes and jet fighters from Kabul airport have been observed, apparently aimed at troops withdrawal and bombing mission. The AMRC said 28 May six cargo planes, loaded with Soviet personnel, have been flying homeward at night during the past week, irlifting at least 1,000 soldiers every night under the cover of darkness (PT). 31 Five kilogran explosives, placed in the park of Mir Wais Maidan, Kabul city, was discovered and defused by the security forces (RA):

9 The Jume

29 May Kota-emsangi, Kabul. A bomb went off 29 May in Shahro Whan. Two rocket landed 30 May in Rahman Mina. A large numr-e-Nau and another near Pul-e-Mahmood injured in these incidents (VOAPS).

1 The Islamic Unity of Afghanistan says Kabul regime forces attacked 29 May mujaheddin positions in Karez-0-Kir, Kabul. In fighting between these forces and the mujaheddin, 80 militiamen and three mujaheddin have been killed (VOAPS).

* The Afghanistan resistance sources say in a mujaheddin attack on a Kabul regime post in Paghman, two Kabul soldiers were killed, two officers and three soldiers were captured. The report adds that the mujaheddin from all the organizations have started unitedly extensive operations against government posts in Paghman. The mujaheddin are trying to capture important points to prepare for an attack on Kabul (VOAPS).

10 According to a report of the BBC correspondent from Kabul, the Kabul airport was subjected to a prolonged and intensive attack $10 \mathrm{June}$ by the mujaheddin. No sign of damages caused to the airport has been witnessed (BBCFS).

12 The mújaheddin sources in Pakistan say, in an attack 7 June, they destroyed 10 posts in Chakari, Kabuli province, and soldiers of a post in Khak-e-Jabbar, Kabul province, Joined the mujaheddin. Three tinks and a truck were also demolished. Similarly the mujaheddin destroyed six posts in Khurd Kabul and killed $20 \mathrm{Kabul} \mathrm{regime} \mathrm{troops} \mathrm{and} \mathrm{captured} 10$ (VOADS).

SA uLP report says, following fighting 6 June in Paghman, Kabul province, about 300 troops and militiamen with light and heavy arms and other military hardware from various, posts surrendered to the mujaheddin (VOAPS).

- A NLF source says the mujaheddin attacked 4 June a battalion in Shakardara, Kabul province, capturing 160 items of light and heavy arms, two military trucks and six wireless sets. Nothing has been reported about the casualties (VOAPS).

The Heab-islani (Mawlawi Khales) says in a mujaheddin attack 6 June on a Kabul regime post in Mahipar, Kabul province, 17 Kabul troops were killed and seven others, including an officer, joined the mujaheddin (WOADS).

- The office of Harakat-a Engelab-e-Islami said as a result of explosion of bombs planted by the mujahnddin 26 Kay in Kabul airport and in the Border Corps, the Kabul airport terminal was damaged. vo want was avaflable about the losses caused by the other bomb (VaAb). 
The BBC says,as a result of rocket attack on Kabul, seven persons were killed, 13 injured and a number of houses were demolished (RPQS).

According to Jamiat-e-Islami the mujaheddin crossed over 12 Jume the security belt of Sarobi, and launched attacks on the security posts in Sarobi villages killing 12 Kabul soldiers and damaging a tank and the KHAD building (VOAPS).

91 The Afghanistan resistance sources" saj" the mu flaheddin" attacked" and destroyed a soviet unt in Paghman which planned to laumch an ambush on' the mujaheddin. The' source said Soviet troops laft behind four tanks and a number of machine guns there (VOAPS). ...

23 According to mujaheddin reports, the mujaheddin have recently killed at least 37 Kabul regime soldiers near Sarobi, Kabul and in the suburbs of Kabul (RPDS).

* In an explosion near Serai Shazda, Kabul en extremist who had planted the explosives inside Serai Shazda was killed. In the incident two other persons were injured (RA).

* The IUAY office says, in an ambush 11 Jume on the Kabul regine posts in Arghande of Paghman, Kabul province, the mujaheddin killed the militia conmander of the posts. Two mujaheddin were also injured in the attack (VOAPS).

* The office of Hezb-e-Islami (Mawlawi Krales) says in a battle 16 Jume between the mujaheddin and the Kabul regime forces in Sarobi, Kabul province, 30 soldiers and militiamen including the deputy chief of KHAD, were killed and nine captured by the mujaheddin. In the battle one mujahed was also killed (VOAPS).

* The AMPC says the mujaheddin fired rockets 19 June on the car of the Interior Minister Sayyed Kohamad Gulabzo $i$ at the double road in Shakardara, Kabul province but Gulabzoi was not hurt. The mujahoddin have also shot down a Sóvlet jet aircraft in the region (VOAPS).

* The Afghanistan mujaheddin operative groups conducted successful operations near Sarobi as well as areas near Kabul, according to ANA correspondent from Kabul. In the operations, 37 SovietKabul troops were killed, two tanks, four vehicles, eight buildings and four security posts werealso destroyed. (MIM).

24. TASS reports the mujaheddin fired 24 June four rockets on Kabul. According ta the BBC correspondent, a rocket hit a residential area in the capital as a result of which a person and a house was demeged. The other rocket hit the Kabul airport and caused fire (BBCFS).

* Two persons were killed, two injured and a number of buildings damaged in rocket attacks by the extremlsts at various places in Kabul city (RA).

25 TASS say, the mujaheddin fired 24 June four rockets on residential areas in Kabul city and one of these rockets hit the Kabul airport causing fire (VOCDS).

- The ANS reports the mujahedain fired rockets in the first week of Jure on Kabul city and a rocket hit the PDPA's Central comittee office as a result of which a vehicle belonging to Saleh Mohamad Zairey, Secretary of the Party's Central Comittea and two of his body guards were killed and the building was danaged. Another rocket hit the Kabul Customs House as a result of which goods' wort: Afs. one billion was gutted (VOADS).

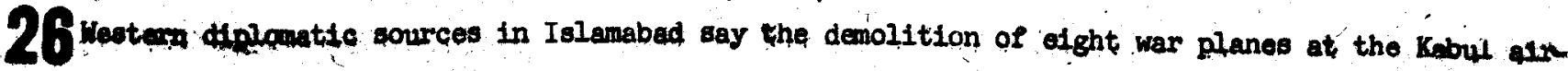


port whicin were equipped with the most sophisticated technology, is considered to be the most serious 1088 to the Soviet forces siuce the beginning of the Soviet intervention in Afghanistan (RPDS). * Reports from Kabul say in a mujaheddin rocket attack last week on the Kabul airport, eight Soviet aircraft. SUL25 were set ablaze and eliminated (BBCFS).

28 Quoting Afghan sources, western diplomats report that Soviet planes are landing at nights in the Kabul airport bringing arms and ammunition for the government. According to the report, two or three big modern Soviet afrcraft have been handed over to the Kabul forces. The planes are flying with the Kabul regime insignia (VOADS).

* Hezb-e-Islani (Mawlawi Khales) says, in their attack 24-26 June, the mujaheddin under the command of Kawlaw Haqgani destroyed eight military posts in Sarobi, Kabul province and demolished a brid80. Wact detalls of losses are not available. In the battle, four tanks and three transport vehicles were also destroyed (VOADS).

* Heab-e-Islami (Mawlawi Khales) says in their attack on Gargar, Sarob1, Kabul province, the mujahoddin demolished three military posts, a tank and a vehicle (VOADS).

* The NLF office reported that the mujaheddin attacked 23 Juie on the security posts in Khurd rebul. In the attack, 37 soldiers and officers were captured, while 40 soldiers were killed and a large number injured. Six tanks and vehicles were also destroyed (VOAPS).

24 Western diplomats say the third security belt around Kabul city has been eliminated by the mujabeddin and now Kabul soldiers are strengthening their positions on the two remaining belts (VOAPS).

* The Afghanistan resistance sources say the mujaheddin are now free to remain active 20 kilometers east and west and 15 kilometers south of Kabul city (VOAPS).

31 The Ittehad-e-Islami reports, in an attack 22 and 2.4 June on a military center in Shakardara, Kabul province, the mujaheddin demolished seven tanks and trucks and militiamen of the regime joined the mujaheddin (VOADS).

\section{Kandahar, April}

5 According to the Afghin mujaheddin sources, they ciestroyed recently a number of communist tanks and captured 100 troops in Punjwaee, Kandahar (RPDS).

6 The Afghan resistance forces in Peshawar say they attacked 22 March the Kandahar airport, destroying one helicopter and damaging the airport building. Forty Kabul troops were killed, two tanks and four militury bases destroyed during the two day fighting (VOADS).

7 Afgan mujaheddin sources report, in a jotnt operation, they attacked and captured one electoral center in Besmillah School, Kandahar city. The mujaheddin destroyed and set ablaze the center

(voans):

* Afghan resistance sources report the mujaheddin attacked 4 April a Ka ul regime base in Kandahar city, destroying two tanks, kJjling 20 militiamen and capturing the base (VOASS).

10 Mujaheddin sources say that the mujaheddin shot down 6 April a Sovitt helicopter in Daman, Kandahar, killing all six Soviet officers who were in it (VOAPS).

- The Hekmatyar Hezb- Islami says that the mujaheddin 7 Aprij in an attack on a polling station In the Kandahar city Mechanical School killed large number of communists. On the same day, the 
mujaheddin also attacked government polling centers in the municipality and the Woolen Textile Factory (VOAPS).

* The Hekmatyar Hezb-e-Islami sources say, in a mujaheddin attack 8 April on a Soviet military convoy in Pashtun Bagh, Kandahar, two Sovlet trucks loaded with explosives were set ablaze and six Soviet soldiers were kjlled (VOAPS).

* Resistance sources in Quetta say the mujaheddir completely demolished a Soviet military post In the Shah Agha Junction in Sinzini, Kandahar, 4 April forcing the Soviets to completely evacuate the area 5 April. In Soviet aerial bombings of th.e Siah Chak, Kandahar, 12 civiliuns have been killed (VOAPS).

* Mujaheddin sources say the Kabul regime Defense Minister, during a visit to Kandahar 6 April relieved the Cormander of Kandahar Army Garrison due to lack of stability in the city. The sources said the minister himself has now taken charge of the Garrison (VOA.PS).

12The Hezbo-Islami (Kheles) says that the mujaheddin' attacked 8 April a Soviet commando uri.t which had blocked the mujaheddin movement in the Makian region, Kandahar. Reports say that many Soviet soldiers were killed in the fighting. The exact number of their casuelties are not known. The rematning of the Soviet force escaped. Meanwhile a militia force belongting to Esmatullah Muslim has been forced to relinquish its positzon in tt:e Kozi regicn and retreat to Spinboldak

* A NIF official has said that in an encounter beta (VOAPS). Yakh Karaez area of Kandahar province two Soviet tanks wert destroyed and an unknown number kflled. The encounter took place when the mujaheddin were attempting to demolish a Kabul government pollIng station in the Kandahar city.The official said the Sovietswere forced to retreat and the mujaheddin in their attacks on the polling station killed 20 communists and injured eight of th:em. He said that the civiliun section of the KFAD anc. Party office were also hit by the mujaheddin rockets. Four Soviet advisers wert among those injured in the attack (VOAPS).

* The Hekmatyar Hezh-0-Islami says that the Sangin, Helmand, mujaheddin captured 2 April six security posts anc 25 pieces of arms. The posts belonged to the Kolai Gak region. Forty military persunniel belonging to these posts were killed and sixty injured. The mujaheddin rendered six martyrs and five injured (VOAFS).

21 Afghan mujaheddin have shot down two helicopters in Jaman, Kandahar. The helicopter's weree carrying Soviet troops to Shakcor Karez. The pilots and the crew were killed on the spot (MLi): 22 Resistance sources in Quetta report the mujaheddin in Kandahar fired 19 April 50 rockets on the Kandahar airport causing fire in several Russian arms depots and destroying their living quarters. Four helicopters, one jet aircraft and ten ofl tankers were also set ablaze during the operations (VOAPS).

* Resistance sources in Quetta say the Mahallajat mujaheddin attacked 15 April Russian military convoyes travelling from Herat to Kandahar in Pashtoon Bagh region setting ablaze one tank and one truck (VAPS).

- Mujaheddin sources in Quetta report that the mujaheddin attacked with heavy weapons 10 April a Sovilet convoy moving towards Kandahar afrport in the Sha-agha road Junction destroying font oil tankers, four lorrles, three armored vehicles and kllling four soviet soldiers (VOAPS). 
- The Harakat-o- inqelab-e-Islami of fice in Quetta says the mujaheddin, in an attack on the Kandahar main prison 15 April, destroyed two posts and killed 15 govermment troops (VOAPS).

* The harakatme-Enqelab-e-Islami office in Quetta says the mujaheddin have raided government posts in the Kandahar Textile Mills, Band-e-Qater; Mir Bazar and posts belonging to the Kandahar security belt. In the Mir Bazar and Band-e-Qater operations they demolished three tanks and killed number of soldiers. In the Textile Kills operation rockets were fired in which two oil tankers were demolished. In attacks on Mahallajat security posts 28 government soldiers were ktlled or injured. Two communist trucks and an armored vehicle were destroyed in Mahallajat operations (VOAPS).

21. Mujaheddin sources in Quetta say the mujaheddin attacked 16 April the border security post and the Spinboldak post in Aurang, Kanclahar, as a result of which 32 goverrment soldiers and militiamen were killed and two trucks and one amiored vehicle were destroyed (VOAPS).

* Resistance sources in Quetta say the mujaheddin shot down 19 April an enemy plane in Daman, Kandahar ( VOAPS).

* The Islamic Alliance says the mujaheddin, during their firipgs on the Teachers' College military base in Kandahar 15 April, killed 12 government militiamen and injured another 19 and inflicted heavy damage to the building (VOAPS).

96 An IUAM spokesman in Feshawar has saic the mujaheddin have captured the Ma'aroof sub-division of the Kandahar province (VUGDS).

\section{May}

Mujaheddi. sources in Quetta say Soviet helicopters have transferred Kabul regime troops from Shahwall Kote to Kandahar city. The reports say that 38 Kabul militia soldiers defected to mujaheddin and foodstuff, arms and vehicles of the Shahwall Kote sub-division have fallen inio mujaheddin
possession (VOAPS).

Afghan resistance sources in Quetta say, as a result of mujaheddin attack on Kandahar Garrison, 27 April 13 tanks were set on fire and 13 commuist soldiers and three militiamen were killed and 20 soldiers injured (VOAPS).

* Mujaheddin sources in Quetta say in a rocket attack by the mujaheddin 27 April on the residence of Kandahar Governor, niris communists were killed and eight injured. An ammunition dump and houses, belonging to two communist military officers, were also hit and demolished during the attack (VOAPS).

* The NIF in Quetta says in a mujaheddin attack on the Kandahar KHAD office at least 17 officials, Including five Soviet advisers, were killed and a jeep burned (VOAPS).

- The NIF in Quetta seys that the mujaheddiri fired rockets and cannon shells on an area between Topkhana and Hazratjee Baba, Kandahar, where the communists were to hold the celebration marking . the saur coup of 1978. Thirty five govermment officials, including 13 comnunists, were killed and one jeep burnt during the operation (VOAPS).

* The NLF' in Quetta has received reports indicating that as a result of mujaheddin operation on the new Garrison of Kandahar province one commint tank and two trucks were set ab ase ard 14 soldiers and a Soviet armored vehicle were also put on fire (VOAPS). 
* The mujaheddin sources in Quetta say communist forces in Kandahar c1ty tired 24 april on houses: whose residents were refusing to participate in the celebrition of the Saur coup as a result of whtch 28 persons were killed and many others injured. During the government operation six mujaheddin wore also killied and 13 injured (VOAPS).

* The Hekmatyar Hezb-e-Islami in Quetta says during the last days of the month of Hemal the mujaheddin besieged a communist regime post in Maiwand, Kandahar, during which nine government militiamen were kjlled and seven captured (VOAPS).

3

The office of the Harkat-e-Enqelab-e-Islami Afghanistan in Quetta reports the mujaheddin stageo a Joint attack 28 April on communists centers in Selo and posts around Ramasi of the Mahallajat, Kandahar, during which they demolished two tanks and one truck. A part of the Selo also caught fire during the attack (VOADS).

* The Hezb-e-Islami of Helmatyar reports in Quetta its mujaheddin in their attacks 29 and 30 April on Timurian and a number of posts belonging to the Mahallajat security belt destroyed three communist tanks and two trucks. They also killed seven communist soldiers (VDADS).

* Afghan resistance sources in Quetta say that Muslim soldiers of KHAD, District 12, Kandahar city, after finding that the KHAD members did not pay any respect for the month of Ramadan, poisoned their food 26 hpril as a result of which live of them were killed despite intense treatment (VOADS).

* Afghan resistance sources in Quetta say in a mujaheddin attack 22 April on the Baba Saheb military post in Kandahar one truck was demolished and five militiamen were killed. One mujahed was also injured during the operation (VOADS).

5 The NLF sources say the mujaheddin launched rocket attacks 30 April and 1 May on the KHAD unit and Mechanical School of Kandahar city during which 15 communists were killed and six injured

(VOAPS).

- A high ranking official of the NLF, Hamed Karzai, has said 600 militiamen, 15 soldiers and four officers of the Kabul regime, defected 4 May to a NLF commander in Spin Boldak, Kandahar. The militiamen also delivered 600 krashinkovs, heavy machineguns (13 Zico-1's and four DASAHKAS) 20 cannons, two wireless sets and eight vehicles to the NLF, (VOAPS).

6 Resistance sources in Quetta say the mujaheddin in an attack 4, May in Shorandam, Kandahar, domolished two communist bulldozers and killed three communists (VOAPS)。

* A mujahoddin source in Quetta reports the mujaheddin, in an attack on the Kandahar hospital, where PDPA members and high ranking military officers are being treated, have killed nine commmists (VOAPS).

* The NIF has said that in a joint attack 30 April on a Soviet ofl tanker in Kandahar at Panjab region, one tanker was destroyed and two Soviets killed. The convoy was heading towards the Kandahar airport. On the same day the mujaheddin attacked communist posts in Mashinkhana as a result of which six cormunists were killed. In both operations 12 mujaheddin were reported killed or injured (VOAPS).

10 ni.

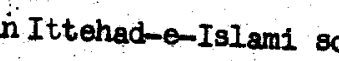

in Quetta reports the mujaheddin brought under fire 5 and 7 May the cle and its cle and its occupants were destroyed in the Haji Nazar post and five Russian soldiers were killed. 
In the Bagh-e-Ghazi post (VOADS).

* Mujaheddin sources in Quetta say recently Russian soldiers in Gargigan base in Kandahar city sent copy of the Holy Quran to the mujaheddin beseeching them not to attack them any more as they were about to leave Kandahar (VOADS).

* A source of Ittehad-o-Islami in Quetta says its mujaheddin in their attack 6 May on the Keshmesh Thana military post demolished two trucks and killed six Kabul militiamen (VOADS).

13 The NIF in Quetta says the mujaheddin of all seven organizations staged a joint attack 9 and 11 May on all posts of the Mahallajat, Kandahar, security belt. The communist forces retreated after being inflicted with heavy losses and men belonging to the posts fled to the city (VOADS).

* A source of the NIF in Quetta says the mujaheddin, in their attack recently on a communist center in the Qeshla-e-Jadid, Mia Saheb and Soviet forces center in Kandahar dernolished four tanks and three trucks. Seven Soviet soldiers were killed and eight injured. Kabul forces casualties were not exactly known (VOADS).

15 Nujaheddin sources in Guetta say a part of commist base in Shiriniof Spin Boldak, Kandahar, has been occupied by the mujaheddin and in mujaheddin firings on the remaining of the camp between 9-12 May 22 government troops have been killed. Ten others have been captured by the mujaheddin with their weapons. Fourteen mujaheddin have been injured in the operation (VOALS).

* An Ittehad-e-Islami source in Quetts says that in fightings 11-12 May, when a rumber of government troop were coming out from the mahallajat, Kandahar, security belt, seven tanks and four trucks were demolished by the mujaheddin (VOADS).

16 The mujaheddin sources in Quetta say the mujaheddin in a joint attack 11 May on eight governmeit security posts in southern outskirts of Kandahar city occupied eight of these posts killing at least 30 militiamen (VOLSS).

17 The Kondahar mujaheddin have captured the Shorabak base in Kandahar 12 May after several weeks of Pighting (VOAPS).

* The Afghan resistance sources in Quetta say that the mujaheddin have captured all Kabul regime posts near Mahallajat of Kandahar city. 700-1000 mujaheddin took part in the operations. The sources say after the operations 51 bodies of the enemy forces were discovered and large quantities of arms and supplies, including four tanks, 12 cannons and heavy machine guns were captured (VOAPS). 18 The body of Gen. Abdul Mutalleb the deputy commander of Kandaharforces was laid to rest 18 May in the Martyrs Hill. He died recently while performing his duty in areas belonging to Kandahar (RA;

21 The organization of Mawlavi Jamil-ur-Rahman which is called The Organization of Invitation to the Quran and Sunnah in a report has said, Last week a battalion of the Kabul regime forces defected to the mujaheddin in Balajoe, Kandahar. The battalion had been surrendered by almost all mujaheddin organizations for eight days (VOAPS).

22 Resistance sources in Quetta say the mujaheddin launched a joint operation on the Kandahar garrison, the center of KHAD, office of the governor, Manzel Bagh and on the Mia Saheb pass in Shorandan where Soviet troops are stationed. In the operation in which heavy arms were also uted, 13 Soviet soldiers were killed and seven injured. In the attack on the garrison, 20 Kabul regue 
diers and officers were killed and 13 injured and in Manzel Bagh two vehicles were put an fire

(VAAPS).

* Reports from Spinboldak, Kandahar, say after the fall of thairi and Saragarey bases to the mujaheddin $15 \mathrm{Mey}$, the communist Air Force bombed $16 \mathrm{May}$ the Loykarez viliage in the area in which 82. people mostly women and children were killed (VOAPS).

The mujaheddin sources said they attacked 18 May a night gatheringof the Kabul regime officers in Kandahar city killing or injuring a number of them. Similarly, the mujaheddin attacked 16 and 17 May a Soviet center in the Kandahar Silo as a result of which at least three Soviet troops were killed and an arms depot was set ablaze (VOADS).

* The Hezb-e-Islami in Quetta reports the mujaheddin attacked 18 May the Kandahar garrison. It is said in the attack 10 or 15 Communist party activists were killed and 13 others injured. Losses were also caused to the garrison buildings and three trucks were also set ablaze (VOAPS).

* The Hezb-e-Islami (Hekmatyar) in Quetta says the mujaheddin attacked 16 May in Pashtun Bagh the Soviet logistic convoy heading towards Kandahar airport. In the attack two trucks and a tank along with all the persons on board were set on fire (VOAPS).

* The NIF in Quetta reports the mujaheddin rocketted 16 May the Soviet bases in Kandahar city Silo. The Silo base was also hit 17 May. In these attacks, an arms depot was gutted and a tank, two trucks and a position of the $86 \mathrm{~mm}$ guns were destroyed. Three Soviet soldiers were killed and tio others injured in the operatinas (VOAPS).

* Resistance sources say the mujaheddin hit 17 May the Kandahar city Mechanical School post killing four Kabul regime soldiers. The mujaheddin also killed five Kabul troops and two officers and destroyed an amored personnel carrier in Kalachi, Ghazian (VOAPS).

* According to Western embassy reports from Kabul only small units of Sovlet troops have so far pulled out since 15th May. It is said a reason for the slow withdrawal is the continued muJaheddin attacks on the troops south of the country (VOAPS).

* According to mujaheddin sources in Quetta many Kandahar city residents haverecently been fleoing their homes as a result of pressure against them by militia forces. The forces had earlier lost many of their posts and fled to the city.

40 Resistance sources in Quetta say 40 groups from all the mujaheddin organizations, in attacks 26 May on the posts between Manzil Bagh, Kandahar and Eid Gah as well as the Mulla Alam posts, the mujaheddin destroyed three tanks in Loya Weyala and two tanks in Taameer-e-qumanadan and a jeep near Sherkat-a Maiwa. Besides, the security posts of Hazratji Baba, Loya Weyala, Damri Bridge and the Mulla Alam Hadira were totally dismantled and all their militiamen killed (VOAPS).

* According to the resistance sources in Quetta, the mujaheddin attacked 23 May a Soviet convoy heading towards Kandahar airport in the Haji Nazar Jan Bagh and destroyed an ambulance with three Soviet troops aboard and a tank with nine crewmen. In the incident four mujaheddin were wounded

(VOAPS).

* The Afghanistan resistance sources in Quetta say, in a three day long combat, the mujaheddin captured the administrative unit of the Shah Wali Kot, Kandahar. In the battle, the muJaheddin destroyed four tanks and captured another two. The mujaheddin sources say, due to the mujahedith presare and defection of a number of militiamen, Soviet troops shifted 24 May the Shah Wallitis 
KHAD Battalion to Kandahar city but administrative staff of the sub division and a number of security forces are still in the sub division (VOAPS).

21 The Jamiat-o-Islami says the mujaheddin hit 25 May the posts in an attack on Dand Kandahar, a tank and a truck were set ablaze and a number of government soldiers killed while three others surrendered to the mujaheddin. Similarly, a Soviet amored vehicle hit a mine the same day and was demolished wth its crew (VOAPS).

31 The Ittehad-a-Islami Afghanistan says, in an attack 27 May on a Soviet convoy in Kandahar city, the mujahoddin demolished four tanks, a truck, and a jeep with their crewmen. It is said the soldiers were driven back to the airport. Subsequently Soviet forces attakked the 5 th district 28 a result of which 15 civilians were killed and a large number of others injured. From the mujaheddin side, six persons were killed and 9 others wounded (VOAPS).

\section{June}

The NLP says as a result of joint mujaheddin attack 29 May on the center of Spin Boldak, Kandahar, two tanks, and two vehicles were demolished while $18 \mathrm{Kabul}$ regime troops were killed and 32 others infured (VOADS).

- Hezb-a Islami reports, in their attack 26 and 27 May inside Kandahar city, the mujaheddin demolished two communist posts, set four tanks and two jeeps on fire and killed 25 militiamen (VOADS). 2 The mujaheddin sources say more than 300 militiamen alongwith their families have recently joined the mujaheddin in Kandahar. It is said these militiamen were under the command of Esmatullah Muslin (VOADS).

3 According to the Afghan mujaheddin sources they have demolished recently a number of positions of the government troops near Kandahar city and Soviet troops, planning to evacuate the Kandahar city,wore forced to quit the city by air (VOGDS).

isco

According to Afghan resistance sources, in an attack on a Kabul regime base in Spin Boldak, Kandahar, the mujaheddin demclished a number of tanks, three military vehicles and killed 18 troops (RPDS).

* The mujaheddin sources in Pakistan say they attacked 29 May a Soviet convoy heading towards Herat. The mujaheddin say their attack forced the Soviets to return back to the Kandahar airport 7 The ryestia (VOAPS). The Izvestis reports in an attack late May on a Soviet military unit withdrawing from Kandahar, the mujahoddin kdlled three Soviet troops (VOCDS).

- The ANS reported 4 June Commander Janan of Prof. Abd Rab Rasool Sayyaf's Ittehad-e-Islami was killod alongwith a companion recently in a land mine explosion near Kandahar city (MLM).

6 An Afghan resistance group Jamaat-el-Dawat-Illal-Quran-wa-Al-Sunnat has claimed that its mujaheddin had blocked the Spin Boldak-Kandahar highway since the past two days after severe fighting wth Kabul regime troops (MIM).

7 According to witness accounts, in recent battles between the Kabul government fonces and the mujaheddin in Spin Boldak, Kandahar, at least 100 persons were killed (VOCDS).

* Teheran Radio has said in a fierce battle, the mujaheddin have captured a number of Kabul regim posta in randahar and blocked the Kandahar-Spin Boldak highway (RPDS). 
(1) Neaten diplanats say the Soviet Union is deferring the withdrawal of its troops from Gandahar due to the mujaheddin pressure. The diplomats, In Pakistan, say the mujaheddin have pushed back the Kabul regime forces to their defensive positions (VOAPS).

- The Hegb-o-IsLami leader Engineer Gulbuddin Hekmatyar, who visjted recently Kendeper province, says all the sub divisions and districts in Kandahar have been conquered and onfy three centers - $m$ the Kandahar city, Arghandab and Spin Boldak are to be captured. The mujaheddin have broken through the security belt from Mahallajat side of Kandahar city and now they are in a position to carry out uperations at any given moment (VOAPS).

* The ANS says all the mujaheddin organizations jointly attacked 1 June the 1988 militia battalIon near Spin Boldak, Kandahar, and captured it with a large quantity of arms and ammunition(VoAP)

* According to AHS, the mujaheddin attacked 25 May a Soviet convoy in Maiwand, Kandahar. The convoy was to pullout from Kandahar. In the attack the mujaheddin demolished two trucks and a tank. Two mujaheddin were killed and eight others injured in the mujaheddin attack on four Soviet posts constmucted between Kandahar city and Maivand (VOAPS).

* The resiotance sources say in an attack 27 Yey near 5 th district of liandahar city on a Soviet convoy, heading towards Herat from Kandahar aimport, the mujaheddin demolished fotr soviet tarts and jeep wth their crewen. In Soviat tropo retaliatory attack 15 civilians and six mujehoddin were killed and 9 others injurad (VOAPS).

* The ARC says the mujaheddin from all the organizations have started joint attacks on the nilit1a posts between Kandahar city and Spin Boldak since 4 Jine. In the attacks the mujaheddin have so fer captured three posts (VOAPS).

- According to a Canadian correspondent, a now aircraft not familiar to the mujaheddin, bombarded during last weak Mahali ajat, Kandahar from a high altitude killing $90 \%$ of the inhabitants of a village in Daman (VOADS).

11 The resistance sources in Quetta say, as a result of mujaheddin operations $4-7$ June on Baba Saheb, Kandahar, four posts and a position of desert guns were eliminated. Nine militianen were killed and seven others injured (VOAPS).

* According to the resistance sources, communist forces bombarded 7 June Kokaran, Kandahar, killing 17 civiliens and injuring 22 others (VOAPS).

* According to the resistance sources in Quetta, the mujaheddin fired 6 June on Soviet troops deployed in the Ghaz1 Baba height, Kandahar. As a result, a truck with four of Its crewmen wes dem nollshed and a number of residential barracks of Soviet troops were destroyed (VOAPS).

* The Heab-e-Islami (Heknatyar) in Quetta says in their attacks last week on the Soviet-Kabul centers and posts in Kandahar city, the mujaheddin hit a Soviet military Jeep k1lling a Soviet coldier and capturing another (VOAPS).

- Weatern diplonats say the mujaheddin are now close to take the city of Kandahar, Afghanistan's second laxgest city, reports VOA (MCM).

12 TASS aays about 20 mujaheddin were killed in battles at Spin Boldak, Kandahar. The mujaheddin ources confirmed 19 mujaheddin casualties in Spin Boldak and said 80 Kabul troops have been kilu It vil flohting (BECES). 
Tho mujaheddin sources say 250 Kabul soldiers and 14 mujaheddin were killed in recent battles In Baba Wali, Kandahar (BBCFS).

- According to resistance sources, at least 90 civilians have been killed in Soviet bombing of oastern parts of the Kandahar city (VOAPS).

19 The Afghan mujaheddin sources say in the mujaheddin continued operation 31 May - 11 June in Spin Boldak, Kandahar, four tanks, a truck, and a desert cannon of the conmunist forces were domollshed while 80 communist troops were killed and 150 others injured. From the mujaheddin side, 19 were killed and 67 injured (VOADS).

* The mujaheddin sources report, in their operation recently in Baba Saheb, Kandahar, 17 militiamen were killed and six others captured (VOADS).

14 Western diplomats in Islamabad say the Chief of Afghan Air Force, General Mohamad Aziz has been killed by the mujaheddin in recent battle in Kandahar. However the Kabul government says he died of natural death (BBCFS).

- The Afghanistan resistance sources say they recently shot down a Kabul regime aircraft in Spin Boldak, Kandahar (RPDS).

15 The office of Jamiat-e-Islami reported that fighting has been going on for the last one week between the mujaheddin and communist troops in Spin Boldak, Kandahar. The reported Soviet troops also began to build 3 June a new security belt, for the defense of Kundahar the airport (VOADS).

* A terrorist group, which had secretly entered Kandahar city and planned to disturb the life of the people of that city, was arrested by the security forces, (RA).

18

Radio Australia reported fierce fighting between the mujaheddin and the Kabul regime forces for capturing the city of Kandahar and the mujaheddin having shattered the defenses of the city (RPDS).

* According to a Teheran Radio report, fighting continues between the mujaheddin and Kabul troops

In Spin Boldak, Kandahar. The area has been sieged by the mujaheddin for several days. Two Kabul regime aircraft have so far been shot and 80 Kabul troops killed.and more than 100 injured (RPDS).

19

Mujaheddin sources in Quetta say, Soviet troops have built a number of security posts in Raigestan, south of Mahallajat, Kandahar (VOADS).

* Afghan resistance sources in Quetta say in an attack 17 June on two comnunist camps in Baba

Baheb, Kandahar, the mujaheddin demolished two tanks with their crewmen (VOADS).

* The office of Harakat-e- Fnqelab-e-Islami Afghanistan in Quetta has reported in a mujaheddin attack 15 June on a communist reinforcement unit heading towards Baba Saheb, Kandahar, four tanks and a truck load of arms were demolished (VOADS).

* The office of the Harkat-e-Enqelab-e-Islami Afghanistan has said, in a battle 10-14 June the mujaheddin captured Ghalchi post in Kandahar. Communist casualties are not yet known but six mujaheddin were killed and 15 injured (VOADS).

- The resistance sources in Quetta have said in a mujaheddin attack 14 June on a Soviet post in Chehl Zeena, Kandahar, seven Soviet troops were killed (VOADS).

2 The Afghan Air Force planes bombarded 19 June a Pakistani village near Spin Baldak kulling five Sthan refugees and injuring eight (VOGDS). 
* The mujaheddir sources in Quetta say the mujaheddin comranders and Soviet officials havo concluded an agreement in Kandahar on the exchange of POW's. Under the agreement 60 mujaheddin can be freed in exchange of one Soviet officer. (VOAPS).

* A three weeks battle between the mujaheddin and the Kabul troops on Kandahanmpin Boldak highway, for the capture of Spin Boldak according to the mujaheddin, has proved inconclusive and the mujaheddin have returned $18 \mathrm{June}$ to their bases. In the battle the mujaheddin shot down three alrcraft, demolished 11 tanks and 17 armored yehicles. More than 150 militiamen and soldiers were killed but, nevertheless, the mujaheddin did not succeed in capturing Spin Boldak. The sources say in the battle 50 mujaheddin were killed. The number of those injured has not been ascertaIned, (VOAPS).

* According to Ittehad-o-Islami sources a Soviet lieutenant in the custody of the mujaheddin in Kandahar, was exchanged 17 June for seven mujaheddin (MIM).

91 Irshad Ahmad Than, correspondent of The Muslim (Pakistan), was killed last week near Kandahar city when the mujaheddin were planning to attack the airport of that city. He had travelled inside Afghanistan alongwith the Afghan mujaheddin (WADS).

24 According to Western diplomatic reports from Pakistan the mujaheddin have sieged the city of Kandahar and have asked the civilians to evacuate the city. The reports say surface as well as ais IInk wth Kandahar city has been cut off by the mujaheddin (VOCDS).

* Reuter says the Kandahar-Kabul highway is under the mujaheddin control. Soviet troops have evacuated Kandahar and are presently deployed in the airport of the city. The mujahedatin have called on civilians of Safa town, near Kandahar to vacate that area (RPDS).

18 The Afghanistan resistance sources have said the mujaheddin attacked $18-19$ June the MHD offlaed in Kandahar city and security posts around Spin Boldak eliminating an arns depot (Rros).

* The Afganistan resistance sources in Quetta say the mujaheddin attacked 18 June on the residential area of the Soviet troops in Kandahar Company setting ablaze a food depot and eliminating a truck. In the attack three Soviet troops were killed and eight others injured (voAPS).

* A comander of Hezb-e-Islami (Hekmatyar) in Kandahar says the mujaheddin attacked late June on the Kechentcal School, Collectorate and Mountain Battalion. As a result, seven Kabul soldiers were dilled and 14 injured while one mujahed was also killed and three others injured (VaAPS). 14 The Afghantatan resistance sources said in a Mujaheddin attack recently in Kandahar city. 40 Tabul ooldiers were killed and four tarks demollshed (RPDS).

- Heab-ialani (Hekmatyar) has said the mujaheddin attacked 18 Jume on all the security posts in Baba Saheb Kandahar. In the attack, 16 mijaheddint were killied and 12 others injured, co conmuniots were allied and 25 others injwed. The mujaheddin have blodked all routes and the conanists have been besteged by the mujahedain. Twelve transport vehicles were also set ablaze (vOADs).

- The Ittehad-Islani ays the mujaheddin attacked 20 June Danan, Kandahar. Pive mujaheddin We injured and kllled during the operation. The sane day soviet helicopters bombarded and

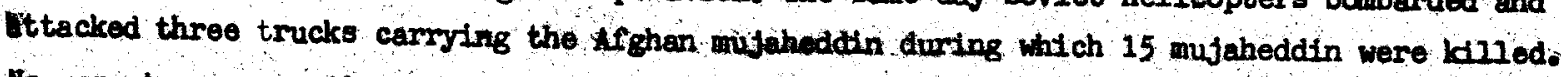

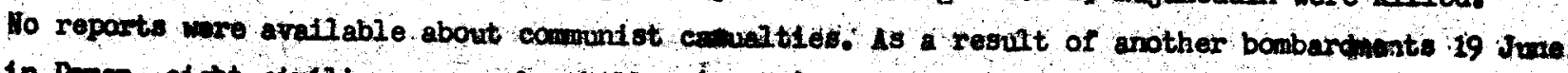

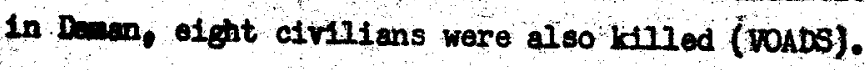


The AlHC says that at the Initiative of the commander of the Soviet troops in Kandahar, a Soviet woldter was exchanged 17 June with seven mujaheddin in Chehl Zeena, five kilometers south of Kandapar city (VOAPS).

\section{$120-0$, June}

8 As a result of the firing of ground-to-ground rocket 7 June by the extremist elements, 13 competrlots were killod and 10 injured in Gulbahar, Kapisa (RA).

8 Hezbe-Islani (Heknatyar) says the mufaheddin attacked 7 June The Gulbahar Text1le kills in Kapisa capturing four posts and arresting their militiamen (VOAPS). 18 rAss says, in an operation, the Kabul government has wiped out scores of the mujaheddin in Kap-
18s. (VOADS).

18 According to resistance reports, the mujaheddin repulsed 2 June a Soviet attack aimod at lifting tho olege around Gulbahar, Kapisa, and after a daylong battle Soviet troops retreated. A number of Sond troops and 19 mujaheddin were kdlled. The report said, the governor and other officials have ned to Kabul (RPDS).

11 The afghan mujaheddin report that they have captured recently 11 posts in Gulbahar, Kapisa (RPDS).

\section{Kunar, april}

9 Due to ground-to-ground rocket attacks by extrentst elenents 1 April on residential areas in villages at Chaski and Sarkani, Kunar, two of our compatriots have been killed and another two infured (RA).

7 The Jealat-1slani Afghanistan roports, in an attack on a commint military convoy 9 April in Deng, Kunar, 25 vehicles were destroyed. During the fighting between the mujaheddin and conmunist forces five clvilitans ti Kudgai villoge were alsa martyred (VOAPS),

9. The wujathedeth of the Kunar province captured 22 April the Barikot Gamison and entered its fertifleations the seme day (PP).

19 The aNS says fron 17-21 April more than one hundred cattle have been killed after they have been stepping over ant1 personiel mirues plented by Soviet-Kabul forces before they evacuatec the Barikot military cantonement in Kunar. Eight mujaheddin have so far been killed, and another 12 Infured as a result of walking on these mines (VOAPS).

\section{May}

Afghen resistance sources in Peshawar say that in Asmar, Kunar, the Kabul regime military unit erecuated its center alang with six Soviet advisors $28 \mathrm{April}$ and moved to Chaghaserai, the center of the province (VOAPS).

valntar says as a result of rocket firings by extremist elements on a civilian bus in 1 sadabad; Thar, 6 Yay lour persons were killed and 12 injured (RA).

1 Realotence sources in Peshawar say Soviet forces heavily bombarded 8 May the Barikot garrison Which was recently ovacuated by the communists, Then mufaheddin were ktilod and of ght Injured in the attiak (roups). 
The Afghan Information and Documentation Center says the Jamat-e-Islami mujaheddin, under tho leadership of Abdul Hakim, in their operations 31 March-24 Arril in Bari and Chenari, Kunar, attacked Kabtat regime military posts in which they killed 80 militiamen and demolished 20 tanks and vehicles (VOAPS).

21 Kujaheddin sources in Peshawar say that tinecommunists again bombed 18 May the Barikot garrison which had already been evacuated. Seven mujaheddin were killed and 9 injured in the raid (VOAPS). * The NIF says that the mujaheddin during their attacks 18 May destroyed the Jalawanan and Haji Mir Zaman Castle posts (VOAPS)。

29 AMR sags the Afghan mujaheddin attacked 5 May the Kabul troops in Dambar regionof Asmar, Kunar: The troops were attempting to repair the road destroyed by the mujaheddin. In the attack, /the mujeheddin killed $38 \mathrm{Kabul} \mathrm{troops.} \mathrm{Similarly,} \mathrm{the} \mathrm{mujaheddin} \mathrm{attacked} 6$ May a Kabul regimemilitary convoy, heading towards Asmar in the same area. In the attack, a tank and five trucks were destroyed and 38 troops killed (VOAPS).

28 Resistance sources report that fighting took place20 May between the villagersof Peshad, Sar kani of Kunar and the Kabul regime troops as a result of which 12 persons were ldlled from the two sides. Peshad village is considered as the center of Kabul regime forces in Kinar. (VOAPS).

June

2 After the evacuation of military garmison of Barjkot soviet backed Afghan regime has reinforced the garrison of Cheghe Saral, the capital of Kunar, though the Afghan government is maintaining aleable military strength in Asmar, another tow of Kumar as well, Afghan resistance sources told The Malin (NIM).

16 In amid clashes between the extremist groups of the NIF and Islamic party in the suburbs of Kunar, four persons were killied and six others injured (RA).

21 The Afghanistan resistance sources in Peshawar said the mujaheddin hit 24 June a plane of the Kabul regime in Manwel, Kunar which later on fell in Kunar river and all its crewmen were killed

(VOADS).

\section{0unoura, April}

26 The Afghan Information and Documentation Center says the mujaheddin destroyed 14 April seven goverrment posts built to guard the main highway near Kunduz city. In the operation, two cormuniots' tanks were demolished and 22 soldiers killed. Twelve militiamen were captured (VOAPS).

21 The Hekmatyar Hezb-e-Islami reports fromKunduz the mujaheddin demolished 3 April two communist tanks and captured one truck in Allabad, Kunduz (VOADS).

\section{May}

11

The MIF reports from Kunduz the mujaheddin have conquered four military posts of the regime in Haerat-aman kiling or wounding 30 soldiers and capturing eight of them. on the same day the. mujakeddin also denolished two Kabul regime posts in Bagh-e-Zakhira, Kunduz during which they eyptured 62 pleces of arms (VOAPS).

- The mujaheddin sources in Peshawar say the mujaheddin in their attacks 1 May on the Bagh Miri unft and their related posts destroyed one of the posts (VOAPS).

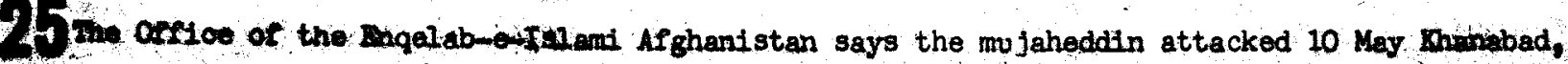


Kundus, killing 40 Soviet-Kabul troops and destroying five tanks and a truck (VOADS).

* Sources of the Harkat-e-Enqelab-Islami Afghanistan have said its mujaheddin attacked 5 May a Sovlet military base in Khanabad, Kunduz, killing four Soviet troops and destroying two tanks

(VOADS).

\section{June}

12

The Harkat-o-Islami organization reported that in an attack 29 May, on a communist post in Archi, Kunduz, the mujaheddin killed six militiamen and captured another 15 (VOADS).

* The AMRC says the mujaheddin launched a rocket attack 24 May on the Archi Club in Kunduz, killing or Injuring a number of Soviet troops (VOADS).

13 According to the Afghan resistance sources, in their attacks 27 May on the posts around Imam Saheb, Kunduz, the mujaheddin dernolished all the posts and three militia commanders with $70 \mathrm{mili}$ tiamen joined the mujaheddin while 40 others were killed or injured. The mujaheddin seized 120 Items of arms and the Imam Saheb sub division now is under mujaheddin siege (VOAPS).

* The NIF says the mujaheddin attacked 26 May communist troops who had come for search in Shahrahwan of Bashtme-Archi, Kundúz. In the combat, two trucks were destroyed, 11 soldiers and militiamen killed and two others captured by the mujaheddin (VOAPS).

18 The AMRC says in a mujaheddin attack 30 May on a post near the center of Kunduz province, the militiamen of the post surrendered to the mujaheddin. They also surrendered 36 kilashinkovs, seven rockets and number of other equipment to the mujaheddin (VOAPS).

* The AMRC says tho mujaheddin attacked 24 May the Kubul troops who had come for search in Shahrwan, Kundua. In the attack, four Kabul troops were killed, seven injured and two with their arms Joined the mujaheddin. A tank and a truck were also demolished (VOAPS).

21 The Afghan resistance sources said in a recent attack on a military post near Imam Saheb, Kundur, 28 Kabul troops were killed and 19 others were captured by the mujaheddin (RPDS).

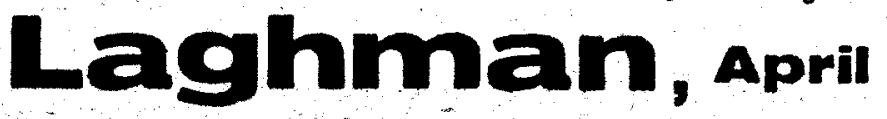

23

Mujaheddin sources report a untt of communist forces in Laghman defected to the mujaheddin 21 April. The unit had first killed their officer. The sources say most of the members of the unit were prisoners who were released from communist jail and directly sent to the battleLleld (vaps).

28 Afghan resiatance sources in Peshawar say that the Soviets have left their security posts in Logman, (votips).

96 The Hezb-ralemi of khales says the mujaheddin shot down 20 April a Soviet hellicopter flying Frou Hangarhar to kabul. The helicopter crashed in Basak, Iaghman, and all its passengers were
kthod (VOAPS).

\section{June}

The NIF ays 10 KabuI soldiers and an officer with their arms surrendered 5 June to the mujabeddin in Tor Ghar, Laghman (VOAPS). 
in Waraikhmin Tangi on Kabul-Jalalabad highway. Militiamen belonging to Kabul regime Joined the mujaheddin (VOAPS).

27 The Afghanistan resistance sources have said the mujaheddin have recently captured a number of sub-divisions in Laghman and the capital of the province might also fall soon to the mujaheddin

(RPDS).

\section{Logar, April}

The AMRC reports the mujaheddin attacked 31 March a Soviet base in Pul-e-Alam Logar, destroying four tanks and killing 12 Soviet troops. The agency said, the Soviet army, in retaliation, shelled Baraki Barak, Baraki Rajan and Patkhab Roghani areas. Six villagers were killed and 16 houses destroyed in the attack. (VOAPS).

12 The Jamiat-e-Islami of fice reports the mujaheddin shot doun 21 March a Soviet jet aircraft in Baraki Barak, Iogar. The plane was on a bombing mission (VOAPS).

* A VaA correspondent says that the mujaheddin operations intensified in Afghanistan last week. He says that 11 April a Soviet military convoy of 450 vehicles of various kinds was seen moving towards Logar. He adds that the purpose of new movements is to counter new mujaheddin operations in Logar and on the city of Gardez where the mujaheddin have been carrying rocket attacks. Meanwhile reports indicate that fighting has also been going on arour.d the city of Khost in Paktia (VOAPS).

3 Sixteen Kabul troops defected to the mujaheddin when the resistance fighters attacked security posts in Logar province 17 April, according to a source at Harkat-e-Enqelabme-Islami (PT).

\section{May}

1 The Armed Forces intercepted 11 May nine ground-to-ground rockets planted by the extremists in Dashtak and the Logar Ainak copper mine for firing on Kabul city (RA).

25 The Jamiat-e-Islami Afghanistan reported the mujaheddin attacked 12 May a Soviet convoy in Mohamad Agha, Logar, destroying six tanks and trucks (VOADS).

\section{June}

1 The Jamiat-e-Islami says the mujaheddin attacked 8 June in Logar a Kabul' regime convoy heading towards Kabul from Gardez. Two tanks, two trucks and a jeep were demolished in the attack (VOAPS). * According to the Jamiat-e-Islami, the mujaheddin in their operations 9 June against the Kabul troops in Aabchan, Dasht-e-Aibak, Kulangar and Tangi, Logar, demolished 17 trucks and tanks (VOAPS).

* The Harkat-e-Enqelab-e-Islami Afghanistan says the mujaheddin attacked a Kabul regime Brigade in Safaid Sang of Mohammad Agha, Logar, injuring five military officers and destroying two barracks (VOAPS).

21 The Jamiat-e-Islami office says the Russians withdrew last week all' their troops from Logar arru the mujaheddin have escalated their joint attacks since 16 June on Pul-e-Alam, the center of Logur. The reports say now the route from Pakistan-Afghan borders on Tre Mangal to Dobandi, Logar, is open and the mujaheddin go and come on vehicles (VOAPS).

26 The MLF reports that in a mujaheddin attack 18 June the residential quarters of the kH4p afilu 
cialo in Mohammad Agha, Logar, were demolished. Exact details of comminists casualties ere not known (VOADS)。

29 The Afghanistan resistance sources said, after several days of fierce fighting in Pul-o-Alam, the center of Logar province, the Afghan mujaheddin have now launched a joint offensive and eliminated the security posts around the city (RPDS)。

\section{Nangarhar, April}

The Hezbme-Islami. (Whales) says the mujaheddin have killed 23 comnunists in Hesarak, Nangarhar. Fighting between goverrment troops and mujaheddir still continues with the mujaheddin capturing three security posts. The mujaheddin have also captured three post in Nazian, Nangarhar (VOAPS). 12 The Hezb-e-Islami (Khales) says that 500 mujaheddin laurched a joint attack on Kabul regime militia and Soviet forces center in Nazian and Ghanikhel, Nangarhar. An eye witness says he saw militiamen abandoning their post and ruming towards the Ghanikhel administrative center (VOAPS).

Resistance sources say that mujaheddin have killed an important member of the government National Front in Nangarhar Province. He is "Sawabdar" Amin Khan who was also a close adviser to Najibullah. He was from Shinwar and killed 11 April in Chanikhel (VOAPS).

* Eye witnesses arriving in Peshawar, say a big Soviet military convoy arrived 14 April - - the day of the signing of the Geneva accords - - in Jalalabad. The witnesses said the convoy brought a large amount of military ware to Jalalabad (VOAPS).

* ANS says that 12 Soviet jet fighters bombarded by air 11 April houses belonging to Kabul regime military officers in the Gari cantonment in Shinwar, Nangarhar, in which 11 persons have been killed and 14 others injured (VOAFS).

22 The Afghan Information and Documentation Center says the mujahideen destroyed a Kabul regime military post in Garo, Nangarhar, 16 April killing at the same time six militiamen (VOAPS).

* According to the Afghan Information and Documentation Center, 20 Russian soldiers and a leader of government militia were killed 18 April when a mine, planted by the mujaheddin, went of $f$ in Chaparhar, Nangarhar (VOAPS).

* The Islanic Alliance (Sayyaf) reports that in mujaheddin attacks on government post in Shinwar, Golaey and the Batikot No.3 Agricultural Farm in Nangarhar 12 April four communist soldiers were killed, one truck was demolished. Also nine soldiers were captured by the mujaheddin along with their arms (VOAPS).

* The Islamic Alliance says the mujaheddin killed two militiamen in an attack 11 April on a regime post in Barak of Batikot, Nangarhar. The same day, the mujaheddin killed three communist soldiers and officers in an attack on three posts in the Raig-e-Khosk, Nangarhar (VOAPS).

* The Afghan Information and Documentation Center says the musaheddin, in atacks on border projects and regions of the government in Landi. Khyber 15 April, killed six milltiamen and denolished one truck (VOAPS).

Resistance sources in Peshawar say two bombs exploded 21 April in the Chanikhel, Nangarha: killing three persons. On the same day a bus, full with passengers, hit a mine in Achin, Nangarhare in which 10 persons were killed and 15 injured (VOAPS). 
26

A large Soviet military convoy left the Samarkhail area near the Afghan border town of Torkhan 21. April for Jalalabad (PT).

21 Mujaheddin sources in Peshawarsay that the nijahedir or garizations. jointly launched operations to disturb the celebration of the arniversary of the comumist coup il Nangarhar provirce. As a result of mujaheddin attecks 60 commurists were killed in various parts of the province. The mujaheddin also destroyed a security post in Daka and, as a result of mujaheddin attack, on Unit No.66 and military posts around it, 30 communist soldiers were either killed or injured (VOALS).

* Afghan mujaheddin say, in two explosions in Jalalabad 27 April, five communists wert killed. The highway between Torkham and Jalalabad is still closed and in mujaheddin attack 28 April on the Basaul post, eight conmurists solciers were killed. (VOADS).

* The Afghan Information and Documentation Center says in a bonib explosion 27 April near the Jalalabad movie house in a miljtary drilling ground one person was killed and four more injured

(VOAPS).

* The ANS says the mujaheddin have been attacking houses belonging to comulust luigh renking officials neor Hadda agricultural farm. The extent of casuelties is not yet known (VOAFS).

11 Mujaheddin sources in Peshawar say that in two explosions 27 April in Jalalabadcity five communists were killed (VOADS).

\section{May}

3 The Islamic Alliance (Sayyaf) sources in Peshawar say their mujaheddin carried 27 April important operations on the Ghanikhel. Garrision and other parts of Nangarhar during which 31 soldiers were killed and 33 injured. They say, the same day, the mujaheddin in their attack on a Kabul regime unit in Batikot set ablaze a jeep and killed 11 persons and injured 13 (VOAPS). 4 Afghan resistance sources in Pakistan report Soviet forces in Nangarhar have handed over one of theirbases to Kabul armed forces. $150-200$ (stet) Soviet soldiers were estimated to have been stationed in the base (BBCFS).

1 The mujaheddin sources in Peshawar say the Kabul regime forces bombed 10May their positions in Khogiani, Nangarhar (BBCFS).

* The Hezb-e-Islami sources say the Kabul regime forces have left the Mamakhelsub-divisionof the Nangarhar province. While withdrawing from the area, two of their tanks were demolished by the mujaheddin (VOADS).

11 The Mawlawi Khales Hezb-e-Islami source says the mujaheddin recently demolished five enemy tanks In Kakrak Nangarhar (VOADS).

* The AMRC says a Soviet military officer committed suicide with his pistol 27 April near the Jalalabad cross-road. Also, the following day, a Soviet officer first killed his wife with his pistol and then killed himself (VOADS).

* Flfteen ground-to-ground rockets installed in Kun and Qatraghai, Nangarhar, were recently discovered and confiscated by security forces (RA).

Resistance sources say that the Kabul regime has withdraw its forces from the Khogiani, Mamakhel, Shinwar sub divisions as well as the Sherzada district and has brought their troops and willtomen to the Samarkhel base In Jolalabad replacing the Soviet sold apa to maintatn the secu 
rity of Jalalabad (VOAPS).

* Two Soviet helicopters were shot down by the Afghan resistance 12 May in Nangarhar provinct. One of the helicopters was shot down in the early morning hours as the Kabul regime attempted to evacuate the garrison town of Hesarak, a resistance commander said. The second helicopter was shot down by resistance forces near Jalalabad. Local commander Abdul Chafoor said two crewmen on board were killed (PT).

14 Bakhtar reports a plan, hatched by extremist groups who wanted to place four kilograms of explosives in Jalalabad No.5 power station and kill a number of our compatriots and cut-off electricity in the area was discovered and foiled by the security forces (RA).

17 Afghan resistance sources say the mujaheddin, after clashes with retreating Soviet-Kabul forces, have now captured the Hesarak sub-division of Nangarhar (RPDS).

* AFP reports, despite the anrouncements abuul the withdrawal of boviet forces Irom Jalalabad, about 1,000 Soviet military uri.ts, irrcluding 600 advisers are still stationed near the city of Jalalabad (RPLS).

19 The resistance sources in Peshawar say the mujaheddin launched 16 Mayrockets attacks on government posts in the Ghaziabad Farm, Jalalabad, killing four soldiers and injuring a number of others. The mujaheddiu also killed three government soldiers in Ghanikhel, Nangarhar, the same day (VOAPS).

* The resistance sources in Peshawar report that the mujaheddin captured 17 May two Kabul government posts in Ghanikhel, Shinwar, in Nangarhar province, during which two mijitiamen were also killed. On the same day, eight people were killed when a bomb exploded in the Mohmandara subdivision of Nangarhar (VOAPS).

21 Spokesman of the Hezb-e-Islami Afghanistan in Peshawar has said the Afghan mujaheddin have blocked all exit routes from Jalalabad city (BBCFS).

* The ANS reports a battalion of special Soviet commandos are still stationed near Samarkhel, Nangarhar. Similarly, 350 Soviet advisers working with 9 and 10 divisions of the Kabul regime are expected to stay behind in Jalalabad (VOAPS).

21. Afghan resistance sources report that 22 Kabul jet fighters in their raids 19 May on the Deh Bala, Kot and Wooch Kotoe of Shinwar, Nangarhar, kilied 35 and injured tens of others. Goverminent fighters bombed 20 May Khogiani and Chaparhar regions. The bombings included the areas the communists had evacuated some time ago (VOAPS).

* The NIF says that the mujaheddin Brigade No.2 in Mohamandara in their rocket attacks on Kankai Khyber and Lalpur have demolished one truck, killed four communists and injured three others. In their operation an arms depot was also demolished in the border security post. The mujaheddin have also sieged the Lalpur sub district (VOAPS).

* Mujaheddin sources in Peshawar report the mujaheddin pressure on Jalalabad city has increased and the comminists are trying to evacuate their families from the city. The communists are also attempting to establish contacts with the mujaheddin and make use of the amnesty announced by tho mujaheddin (VOAPS).

22A correspondent of The Times (Iondon) reports from Peshawar, the Afghan mujaheddin are busy in their preparation to capture Jalalabad city within next 10 days (BBCFS).

* Four mines, planted by the extremist elements in Jalalabad city; were discovered and defused. 
recently before explosion (RA).

* The IUAM office reports the mujaheddin attacked 19 May a big security post of the Kabul regime in Gulai, Nangarhar. In the attack, the post was demolished, six militiamen killed and 9 others injured. The rest of the militiamen fled to the Ghanikhel cantonment (VOAPS).

* The mujaheddin sources say Soviet fighter jet aircraft intensively bombarded 12 May, hoadat and Kot in Nangarhar killing 30 civilians including women and children alongwith four mujaheddin

(VOAPS).

23 The armed forces and security forces of Afghanistan discoveredand foiled 22 May attempts of an armed opposition for exploding four bombs in a residential area of Jalalabad city (PMDS).

* Twenty nine surface-to-surface rockets, meant to be fired on residential places in Jalalabad were discovered and defused 22 May by the security forces (RA).

* An authentic source of mujaheddin reports that the combat strength of Red Army in Eastem Afghanistan still remains unchanged inspite of the pullout of 1,200 troops from Jalalabad last week

26

Twenty-seven civilians, mostly women and children, were killed and 17 wounded in an indiscriminate bombing by eight Russian jets on Kot sub-district of Nangarhar 23 May (PT).

* The Kholes Hezb-e-Islami says soldiers of govermment posts.in Roadat, Nangarhar, after killing two of their of ficers, defected to the mujaheddin alongwith their arms (VOAPS).

27 The Afghan Information Center has said in their attack 19 Mayon theKabulregimeposti in Lalpur, Nangarhar, the Afghan mujaheddin killed two goverment personnel and damaged the premises of the Lalpur sub district. Also two militiamen and three others were injured in Landi Khyber (VOADS).

* The Afghan Information Center reported that a Kabul regime truck with those board was blown in a mine explosion by the mujaheddin in Hasar Mau, Nangarhar (VOADS).

28 A volley of rockets landed on the Torkham-Jalalabad road near the border town of Lands Khyber forcing the traffic to run for cover. Another solvo of rockets targetted an encampment of 66 Afghan Brigade stationed in the area, resulting in a series of blasts when an artillery position was hit and the shells placed there exploded (MIM).

\section{June}

1 The AMRC reports that in a bomb explosion 4 June at Jalalabad Custom House, four officials were killed and 10 injured while damages were also caused to the Customs building and goods were set ablaze (VOAPS).

* The ANS reports a vehicle was blown up 4 June in a mine explosion carried by the mujaheddin in Ghanikhel, Nangarhar, as a result of which four government officials were killed and 9 others injured (VOAPS).

* Tho NS reported that on the basis of a call oy the mujaheddin all movie houses have been closed once late May in Jalalabad. Similarly, Pakistan has closed down its consulate in Jalalabad (VOAPS). 8 Afghan resistance sources in Peshawar say the Kabul regime has deployed 15,000 of its troops in Jalalabad (BBCFS).

* The Afghanistan resistance sources say nine militianen were killed 5 June in a mujaheddin aṭtack 
In Chaparhar, Nangarhar. On the same day, nine militiamen were killed in mine explosions in a post at Zod village, Chaparhar (VOAPS).

* Hezb-Islam (Khales) says in a battle 1 June between the militiamen and the mujaheddin in Roadat, Nangarhar, four militiamen were killed and five injured (VOAPS).

* The AMRC says in the fighting 2 June among the Kabul. regime gendarmarie seven soldiers were killed in Jalalabad city. The report says in an attack the same day, the mujaheddin killed three Kabul soldiers in Ghanikhel, Nangarhar (VOAPS).

9 Teheran Radio reports that the mujaheddin captured recently a military truck in Jalalabad and killed $10 \mathrm{Kabul}$ regime soldiers. The report adds the remaining Soviet troops in Jalalabad have strengthened their positions and have also built new trenches (RPDS).

The ANS says a Kabul regime truck was blown up with mine with its crewmen 6 June in Batikot near Ghanikhel, Nangarhar (VOAPS).

12 The Afghanistan resistance source reports in their attack 22 May on the Jalalabad Security Comand office, the mujaheddin killed an of îicer and injured four (VOADS).

* The Afghan government has withdrawn its troops from the military garrison of Agam, Nangarhar (MIM).

The Afghan regime has stepped up measures to try to fend off any mujaheddin attempts on the city of Jalalabad. This seems to be the impression from the deploytuent of Afghan forces in the province of Nangarhar in general and the city of Jalulabad in particular (MLM).

14 In their heavy shelling 13 June on the residential areas in Kooz Kunar, Nangarhar, the extremist elements killed five compatriots and injured 12 others (RA).

21 The office of Hezb-e-Islami (Khales) says in their attack 12 June on a Kabul regime border battalion in Shaiwa, Nangarhar, the mujaheddin damaged two vehicles and a tank and also killed 16 militiamen and soldiers. The source adds that the mujaheddin also attacked the Kandi post in Shaiwai during which they captured a militiaman and set on fire an oil tank and a vehicle (VOAPS).

* The Islamic Unity says the mujaheddin attacked 15 June militiamen stationed in government posts In Tamo and Lakari of Deh Bala,Nangarhar. The militiamen were planning to shift these posts to Sarshahi. In the attack, eight soldiers, an officer, the Secretary of KHAD with three KHAD activisto were kjlled. One mujahed was killed and five others injured in the operation (VOAPS).

* The office of the Islamic Unity reports the mujaheddin attacked 18 June a Kabul regime jeep in Marko of Battikote, Nangarhar, destroying the vehicle, killing two crewmen and injuring three others, In the attack, a mujahed was also killed (VOAPS).

21 Mines and some quantity of explosives, being smuggled into Afghanistan from Torkhan were seized alongwith their bearers (RA).

29 As a result of heavy shelling by the Kabul artillery in Nangarhar, 300 familles were forced to Ieave their homes (NWT).

* AFP reports that in a mine explosion recently on Jalalabad-Torkham highway 18 persons aboand a bus were killed (RPDS).

21 The ANS has said, in an attack 28 June, the mujaheddin captured Lalpur, Nanganhan Valing 
12 Kabul troops and capturing 15 others (VOADS).

* Hezb-o-Isiami (Hekmatyar) says, in a mujaheddin attack 29 May on Coshta, Nargarhar, six Kabul regime militiamen were killed. Two mujaheddin were also killed in the operation (VOADS). * The AMRC says due to heavy bombardment by the Kabul regime in June about 300 families from Surkhroad, Nangarhar, have migrated to Khogiani and Hesarak of that province. These areas are under the mujaheddin control. In the bombardment, a woman was killed and three children injured (VOADS).

\section{Nimroz, May}

1 The Hekmatyar Hezb-e-Is] ami says in Quetta the mujaheddin recently launched ground-to-ground rocket attacks on the Band-e-Kanial Khan base in Char Borjak, Nimroz. Two tanks were destroyed and buildings damaged in the attack. According to the report, three helicoptors have transferred the dead and wounded of the base to the center of Kandahar (VOADS).

* The Hekmatyar Hezb-e-Islami in Guetta says its mijaheddir clestroyed 7 ApriL two communist tanks in a rocket attack on the Char Burjak Nimroz. The buildings of the base were also damaged in the attack (VOAPS).

31

Resistance sources report from Nimroz that communist forces evacuated Khashroad and some soldiers have gone to Zaranj city and a number of others to Delaram. Similarly, the administrative renter for Gulistan sub division has been shifted to Delaram (VOAPS).

\section{June}

According to Teheran Radio in an attack recently on a Soviet-Kabul troops convoy in Nimroz, the mul jaheddin killed 13 troops (RPDS).

Reports from the Afghanistan resistance sources say the mujaheddin attacked recently the office of Communist Party in Khashrod, Nimroz, killing eight party officials and injuring the governor of the province. Heavy damages were caused to the office building as a result of mujaheddin rocket attack (RPDS).

The Afghanistan resistance sources in Quetta say in their attack 8 June on Charburjak, Nimroz province, all government posts have been captured and later the mujaheddin also captured the subdivision itself. It is said the communists reinforcement reached the area from Kamal than Dam but, seized 80 items of light and 40 items of heavy arms, two tanks and three other vehicles (VOAPS). 2The IUAM military spokesman has said after several days of battle, the mujaheddin captured 16-17 June the Kabul regime Battalion 1918 in Band-e-Kemel Khan, Nimroz. During the battle, the mujaheddin captured eight high ranking of ficers. Including the"commander of that battalion and a KHAD director. Sixteen militiamen have been killed and 20 others joined the mujaheddin. The mujaheddin also captured 70 vehicles, 160 kilashinkovs, three machine guns, two tractors and other military hardware (VOAPS).

29 Hezb-e-Islami (Hekmatyar) says, in an attack 6 June on the security posts in Kang, Nimroz, the mujaheddin killed eight communist troops alongwith the comnander of the post. In another attack on the posts of Haji Gul cantonement, the mujaheddin destroyed two communist trenches and killed 12 allitiamen (VOADS).

\section{Paktia, April}

(1) Mujaheddin sources have claimed they have captured an Indian fillot, Bhagwan Sing, while folling 
with parachuts from an aircraft in Khost $(\mathrm{JG})$.

11 The Jamiat-o-Islami Afghanistan says the mujaheddin in an operation 10 April captured three security posts ${ }^{5}$ of the Dar'wazagai military base. In fighting during the operation 16 mujaheddin were infured. All soldiers stationed in the posts were killed and three militiamen captured (VOAPS). 12 The vOA correspondent from Peshawar has reported that the Kabul-Gardez highway was closed to traffic last week due to mujaheddin operations. Similarly Kandahar, Herat, Ghazni, Urgun, Gardez Salang and Jalalabad highways have also been blocked by the mujaheddin (VOAPS).

* Resistance sources say that the mujaheddin in an attack 29 March on governmerit posts and centers in Urgun, Paktika, dèstroyed a bulldozer and four armorò vehicles (rOAFS).

* ANS reports that as a result of mujaheddin firings 29 March on the Kabul-Soviet joint center in Laki, Paktika, 15 commurists were killed and a number of others injured(VOAPS).

16 The Afghan mujaheddin reports that, as a result of their attack on the Khost military cantonment, seven Kabul regime soldiers have been killed (VOADS).

19 major offensive, launched by the Soviet-Kabul troops on the positions of the Afghan mujaheddin in Jaji, Paktia, just after the signing of Geneva agreement was met with stiff resistance by the Afghan mujaheddin and after a fierce battle, the Soviet-Kabul troops were forced to retreat after suffering heavy losses in men and material (PT).

24 The Afghan Information and Documentation Center seys the Paktiamujaheddinhave attacked houses belonging to govermment militia, organized recently by the Kabul Minister of Interior Sayyed Mohamad Gulabzoi. Forty five of the militia were captured by the mujaheddin and the rest are said to have fled (VOAPS).

\section{May}

Different mujaheddin sources say the mujaheddin have inf]icted heavy blows to a Kabul regime military convoy in Paktia. They say the convoy, consisting of 700 vehicles, was moving 18 April from Gardez to Zadran with military hardware and foodstuff to supply the 18th Division of the regime. The convoy was attacked at its several parts and each section has been besieged by the mujaheddin (VOAPS).

* The Harakat-angelab-e-Islami Afghanistan says the mujaheddin shot down a Soviet helicopter 18 April in Shar-o-Nau, Paktia (VOAPS).

4 The Hezb-e-Islami of Hekmatyar says a communist force which was on its way 20 April from Gardez to Tsamkanai, Alikhel and Zazi and wanted to reach government bases clashed with the mujaheddin 3 May. The mujaheddin captured alive 15 communist officers and soldiers and killed 80 of them. They also destroyed two Soviet tanks. Seven mujaheddin fighters were killed. The government wanted to despatich troops to Tsamkanai and Alikhel bases (VOAPS).

8 Resistance sources in Pakistan say that Afghan government forces havo evacuated the Tsamkani Centoment in Paktia. The center was evacuated with the help of fresh Kabul Regime troops and bombing of mujaheddin position. The mujaheddin say that 30 of them were killed. However, Radio Afghanistan has said the mujaheddin casualties had been heavy (BBCFS).

9 Mujaheddin sources in Peshawar say, in the battle for the capture of the Tsankani cantonement in Paktia, 300 Kabul soldiers were kdlled and a large number injured. The mujaheddin lost 30 of 
their men while 60 of them were injured. The mujaheddin also demolished 12 tanks and 18 armored vehicles (VOAPS).

11 Mujaheddin sources in Peshawar say Kabul regime forces, belonging to No. 18 military unit and the militia, evecuated the the Tsankani cantonment 8 May.he report says 1,500 soldiers, militiamen and 21 Soviet advisors were stationed in the cantonment (VOAPS).

* The mujaheddin sources in Peshawar say, when the Kabul regine forces movet out from Tsankani to go to Gardez, they came under mujaheddin attack. In the battle, one communist helicopter was shot down, 30 tanks and about 100 vehicles were demolished and 200 soldiers killed. One hundred twenty soldiers defected to the mujaheddin (VOAPS).

* The Harakat-e-Enqelab-a-Islami reports that another Russian military convoy, moving towards Zazi is engaged in fiehtjrg with the mujaheddin in the Narai Pass. The convoy is attempting to evacuate the Kabul regime Unit No.36 from Ahmadkhel. The mujaheddin say, they captured 8 May three security posts of this unit (VOAPS).

12 A top Afghan army officer, along with 60 soldiers was killed in a mujaheddin ambush 2 May tn Paktia province. The AMRC said that the officer, a brigadier of the 11th Nangarhar Division based in Jalalabad, was ordered to launch a major attack against the Afghan resistance fighters in Paktia,

16 Resistance between Kabul, Paktia, and the mujcheddin are entering the base. The sources say that, in clashes militiamen have been kjlied or injured the mujaheddin 13 and 14 May, a number af communist troops and trucks (VOAPS).

* Twelve Afghan mujaheddin were killed when a Suzukt plak-up in which they were travelling struck a landmire in the evucuated Tsamkani garrisan in Paktia province (MIM).

17 The mujaheddin sources in Peshawar say the Alikhel base has falien to the Afghan mujaheddin. The Kabul government forces had earlier evacuated the base (BBCFS).

* Afghan resistance sources say that the commuist forces evacuated the Alikhel base in Paktia 14 May. They say, 700 soldiers and six advisers were forced to evecuate the base as a result of the mujaheddin pressure (VOAPS).

According to a report of the Afghan mujaheddin sources in Peshawar, four Soviet advisors were killed by the Afghan mujaheddin when they were hoading towerds Kabul from Ali Khel cantonment. In the attack the mujaheddin captured eight tanks, 450 anored vehicles and shot down two helicopters

19

APhan resistance gounces tn Pesharar (NWT). southern Afghanistan 400 regime forces have defected to the resistence. Similarly 200 govermment soldiera, defected to the mujaheddin after a 9-day battle in Serka Wolja of Paktia (voaDs).

- A cource of the Jalaluddin Haqqani Front repoets from Paktia that the mujaheddin shot down 12 Way a commist jet plane wich crashed in the ahinki region of lhost (WOADS). T. The offlce of Nawlawi Jalaluddin Haqgani says the mujaheddin shot down 16 May a Kabul regime arip plane. Another plane, wich wanted to land at khost, was hit by cannon fire and damaged 
* The ANS says the Kabul regime forces have evacuated the Bayankhel and Khushkoran regions in Paktia. Reports say that the mujaheddin are now busy defusing miries around the area (VOAPS). 20 The Afghanistan resistance sources reported that the mujaheddin, in their operation inside and outside the Zazi garrison in Paktia, have destroyed eight armored personnel carriers, two zequick machine guns and two automatic rifles. The source adds the Kabul regime forces have left behind intact three armored vehicles, 12 vehicles and two foodstuff depots (VOAPS).

* The total army strength of the Kabul troops was shattered by the advance of the mujaheddin after the Soviet pullout from Zazi cantonnent, 20 kilometers off Pakistan's borders, where the mujaheddin also captured huge quantity of arms and ammunition (PT).

Resistance sources in Peshawar report the mujaheddindestroyed 8 May three posts, six tanks and trucks of the Kabul regime in Wazikhwa sub division, Paktia. They also killed 18 troops and captured a large number of others. The mujaheddin also captured four tanks and 400 light and heavy arms and an oil depot (VOAPS).

24 Piles of uniforms, stocks of weapons and dozens of unopened boxes of land mines and anmunition litter the Alikhel Afghan army garrison, abandoned in apparent panic two weeks ago (PT).

\section{June}

Two mujaheddin were killed and another seriously injured when they stepped over an anti-personnel land mine during mine clearing operation in Nari Adan Khel, Paktia (MIM).

5 According to a Kabul Radio report, seven persons were killed in a mujaheddin attack in khost, Paktia. The radio did not report the date of the incident. It has however reported that the mujaheddin had used heavy arms (BBCPS).

6 The Soviet troops, withdrawn from Ghazni province to Kabul, have been sent to Paktika where they were brought under cover of helicopters to Sharan, the provincial headquarters. The mujaheddin, quoting the sources of commander Mohammad Ali Jalali of the Harkat-e-Enqelab-e-Islani Afghanistan (Mawlaw Mansur Group), said the helicopters, protecting the Soviet armored vehicles bombed sites on the way to Hohamad Khel and other localities. Land forces also hit.targets in these areas. The sources sald that a tank and three armored cars of a fresh consignment of troops were destroyed in mine blasts and their crew killed 30 May (PT).

According to a Kabul radio report, continuing their withdrawal from Afghanistan, the Soviet troope have left Gardez for the Soviet Union (RPDS).

14 Reports from Afghanistan say the mujaheddin have recently'blocked all routes leading to Khost, Pakt1a. The thost area, including the airport, is constantly hit by the mujaheddin (RPDS).

16 The IUAM office, reported that about 200 Kabul soldiers and 100 mujaheddin have been killed in the battle of Jajl Maldan, Paktia during the past one month. The report adds more than 1,000 militiamen and the KHAD personnel hav' been despatched for the reinforcement of Jaji Maidan (VOADS).

* The AMRC has reported 40 civilians were killed 16 May as a result of mine blasts planted by the Soviets in Jaji, Paktia. The mines are said to have been planted while the Soviets were evacuating Alikhel. (vOADS).

17 Two childrea were killed and four seriously injured 16 June in a bomb blast near thost, Baktia (RA). 
21 According to Harkat-e-Enqelab-e-Islami the mujaheddin have tightened since 10 June their siege around thost. The mujaheddin have also intensified their attacks on Khost airport and city on the posts belonging to the security belt. In their attack last week on the militia posts in Gurbat, the mujaheddin killed seven soldiers and militiamen and injured a number of others (VOAPS).

* The Hezb-e-Islami (Heknatyar) says the mujaheddin hit 15 June the Khost airport. In the attack a transport plane was destroyed and the airport was mostly damaged (VOAPS). 24 Hezb-e-Islami (Khales) says the mujaheddin attacked 18 June with heavy arms comminists centers in Khost, Paktia, and destroyed five residential houses belonging to members of the Communist Party (VOADS).

26 Western diplomats in Islamabad say the mujaheddin have shot down a transport plane near thost, Paktia. At least 30 persons on board were killed (BBCFS).

28

The NIF says the mujaheddin launched 24 June a rocket attack on the Khost airport, Paktia, k1lling 14 Kabul soldiers and wounding two others (VOADS).

* The Afghan mujaheddin have shot down an army plane killing about 340 (stet) Kabul regime soldiers Paktia province, reports VOA (MIM).

24. mujaheddin news agency says the mujaheddin shot down 21 June a Soviet transport plane near Thost and the pilot of the aircraft alongwith seven soldiers and officers as well as all the persans an board were killed (VOAPS).

\section{Paktika, may}

14. The NIF says soviet forces in an attack on two mujaheddin groups 27 Appil ip the center of Paktika province killed two commanders and 13 mujaheddin (VOAPS).

28 According to Hezb-e-Islani, as a result of a mujaheddin attack 18 May on Hazi, Paktika, 45 goverment soldiers were killed, 300 injured and 200 other joined the mujaheddin. The mujaheddin also captiured 300 pieces of arms (VOAPS).

\section{Panvan, april}

11 The Hezb-O-Islami (Hekmatyar) reports the mujaheddin captured 10 April the Siagerd village in the Ghorband sub district Parwan. The report says the Kabul regime forces which had come to the area to break the mujaheddin siege of the viliage had to asandon their efforts due to stiff mujaheddin resistence. The Hezb says the mujaheddin also shot down a communist jet aircraft in Ghorband

\section{May}

(vasps).

The Afghan Information and Documentation Center reports that the Soviet forces have withdrawn from Astana, Panjsher valley (VOAPS).

* The Hezb-istaml reports from Parwan that the mujaheddin attacked the center of Shakardara, Parwan 27 April during which they killed eight soldters and injured six others (VOAPS).

3 The Afghan mujaheddin have shot down a SU-25 soviet aircraft near Soviet afrbase of Bagram during their attacks carried out in Afghanistan on the oceasion of 10th anniversary of the socalled communist revolution (MIM).

11 the Afghan mujaheddin conducted an attack in Gujelchen, Parwan, 1 has where they captured tio ty posts (PT). 
Mujaheddin sources in Peshawar say the mujahoddin recently launched attacks on several Soviat convoys in Parwan. In one attack they demolished two armored vehicles. They have also attacked a caravan 3 May near Pul-e-Matak. In another attack, a Soviet photographer was killed in the Salang pass and another Soviet reporter was seriously injured (VOADS).

- A Jamiat-e-Islani Afghanistan source says the mujaheddin raided a meeting 27 April held in Gulbahar Textile Millo as a result of which they killed several communist officials. The report adds that Soviet-Kabul forces also came under the mujaheddin attack in Gulbahar Textile Mills. $A$ number of houses were demolished and communist soldiers were killed (VOADS).

14. The Helomatyar Hezb-í-Islami office says the Shafaq Front mujaheddin, led by Engineer Tariq in an attack in Taza Qan, Parwan, on a Kabul regime military post, captured alive one officer, one member of the KHAD and nine soldiers and 11 Klanshinkovs (VOAPS).

The Jamiat-o-Islami Afghanistan says its mujaheddin in an attack 3 May on a Kabul regime security posit near the Baghram airport destroyed the post itself and killed seven soldiers and captured 53 others alive (VOAPS).

18 ifghan mujaheddin sources in Peshawar say, recently 200 government soldiers joined the mujaheddin in pubat, Parwan. (VOADS).

21 The resistance sources in Peshawar say the mujaheddin in their attack in Panjshir is May on Kabul roglme Brigade No.64, the KHAD center and seven military posts, kjlled 60 soldiers and captured another 42. They also captured two tanks, two armored vehicles, five trucks, five cannons and 400 kalashinkovs and other war supplies (VOAPS).

21 1 Jamiat-o-Islami source has claimed the mujahedain have captured the Tambani garrison in the Panjsher valley. The base is located 45 kilometers inside the southern entrance of the valley

(VOAPS).

27 The Afghan mujaheddin have launched a campaign to push Soviet and Afghan forces out of the Panjshir valloy. Afghan deserters had told a local mujaheddin commander, Mahmud Khan that, 5,000

Sovlat troops atill in the valley were planning to withdraw in the middle of June, but 5,000 Kabul goverment troops will still remain there (PT).

31 The mujaheddin commanders say the Soviet-Kabul troope evacuated two big bases in the southern entrance of Panjshir pass, 26 May. With the wthdrawal of the Communist troops from those bases the Panjahir pass has now totally been cleared of comiunists (VOAPS).

\section{June}

According to the Helmatyar Hezb-Islani, the mujaheddin attacked last week a soviet military convoy moving towards Soviet Union from Jabal-us-Seraj in Bouthern Salang as a result of which ten trucks and tanks were demolished and scores of sovlot troops killed and injured (VOAPS).

- Hekmatyar's Heab-e-Islami says the mujaheddin targated 10-25 Nay 16 communist regime posts in the center of Parwan and other areas in that provlince. In the operations, scores of troops were killed or injured and more than 100 captured by the majaheddin (Vars).

* A Heab-Islami report says six Kabul regime poste in the Bagran airport, Parwan, foll 21 vay to the mujaheddin. The commander of these posts had boen himself a mujahed but later he had joind the rothe. He has however now again joined the mujahoddin (roABs). 
Western defense anolysts say following the Soviet-Kabul troops withdrawal from the Panjshtr valley the mujaheddin will now concentrate their attention on other positions including the Salans highway, reports VOA (PT).

The Afghan mujaheddin have captured four security posts near Charikar, center of Parwan province: and Kabul troops surrendered to the mujaheddin without resistance (PT). 7 The mujaheddin have liberated Baghram area in Parwan province of Afghanistan from the Soviet-
Kabul troops, reports Radio Teheran (MLM).

17 According to Afghan News Agency (ANA), Commander Farid of Hezb-e-Islami is quoted to have said in his message reaching the mujaheddin office 15 June that the operative groups under his comarid launched attacks 9 June against the military fortifications of the Kabul regime around Gulbahar Textile Mills and conquered security post (PT).

18

The Jamiat-e-Islami reports that in their attacks 23 May - 2 June on Bagram, Parwan, the mujaheddin demolished all the posts of the sub division. In the 10 day long operation, 20 Kabul soldiers were killed and 30 injured. The mujaheddin have captured a huge quantity of arms and equipment and now they have sieged the Bagram sub-division (VOAPS).

23 The IUAM says in their joint operation, the mujaheddin belonging to all the organizations, attacked last week the security belt of Bagram which also serves a security base for the Kabul city. In the attack, the mujaheddin captured 15 Kabul soldiers. Two Kabul regime officers were killed, five posts demolished, and 24 troops with their arms and ammunition joined the mujaheddin (VOAPS). 27 In an armed clashes between the extremist groups, seven of them were killed in Parwan (RA). 29 The Afghan mujaheddin say in a big explosion recently in Soviet base at Bagram, Parwan, 10 planes were damaged and an arms depot was destroyed (RPDS).

\section{Samangan, May}

The Afghan Information and Documentation Center reports that the mujaheddin have destroyed two enemy posts in Dara-e-Soof, Samiangan. In the operations of the posts, 12 Kabul regime soldiers were killed and 26 captured. Six mujaheddin were injured (VOAPS).

15. The muiaheddin sources report from Samangan that soviet forces have recently evacuated five posts. The posts have been taken over by the Kabu? regime forces. These posts are protecting the highway between Samangan and Soviet border (VOAPS).

*- Mujaheddin sources in Peshawar say the mujaheddin blew up 4 May a gasoline pipeline in the

Rabatak Pass. For several days oil was gushing out from the pipeline (VOAPS).

\section{June}

18 The NIF office says the mujaheddin attacked 25 May the Kabul regime militiamen in Chinzai, Samangan, who had come there for search. In the combat, 18 militiamen were killed and the mujaheddin captured 26 pieces of arms from the militiamen (VOAPS).

25According to a report of the Afghan resistance sources; the mujaheddin attiacked recently the Aibak and Hazrat Sultan tows in Samangan destrovising two comminist" posts" (RPDS).

\section{Takhar, April}

The Afghan mujaheddir have shot down two aircraft of the Kabul regime while bombing their pasi- 
tions in Takhar province, VIRA reported (PT).

96 The NIF says a mobile mujaheddin unit destroyed 13 April four Kabul regime tanks and a truck with their crew in Eshkamesh, Takhar. The mujaheddin also killed eight communist soldiers during their operation (VOAPS).

\section{May}

4 The mujaheddin sources in Peshawar say that the Harkat-e-Enqelab-e-Islami mujaheddin marred the celebration held in the center of Takhar province by the communists on the occasion of the anniversary of the 1978 coup. During the mujaheddin attack 23 communists were killed or injured. On the same day, in the Qalbar of Takhar the mujaheddin demolished two communist tanks (VOAPS).

* Afghan resistance sources in Peshawar say the mujaheddin destroyed a communist base 27 April in Sara-e-Akbar near the center of Takhar province during which eight communists were killed or injured (VOAPS).

Bight mujaheddin were killed and six others injured during an operation in the Dasht-a-Qila district in Takhar province bordering the Soviet Union in which the resistance claimed to have captured 15 military posts (MLM).

11 Resistance sources in Peshawar say the mujaheddin have captured the Dasht-o-Qala sub-division in Takhar. The sources say, the mujaheddin occupied 25 posts in the area and captured alive 150 soldiers and officers during their operation. They have also been staging heavy offensives against the Yangi Qala and Shahr-e-Buzurg sub-divisions (VOADS).

11 A Jamiat-e-Islami Afghanistan source says the mujaheddin, belonging to Hezb-e-Islami, IttehadO-Islami and Jamiat-e-Islami, attacked militia posts in Khawaja Ghar, Takhar, killing 13 soldiers and 55 of them defected with their arms to the mujaheddin (VOAPS).

21 According to a report by Hezb-e-Islami, the mujaheddin launched operations 11 April-6 May on government security posts in Qulabad, Omarkhel and Qelsat in Takhar province. All the posts were destroyed and 80 militiamen were kjlled and 30 injured. Four mujaheddin were also killed in these operations (VOAPS).

* The Hezb-e-Islami reports, in their attacks 9 May on the Yangi Qala sub division, Takhar, with heavy weapons, the mujaheddin demolished 12 Russian tanks and burnt an arms depot. Twenty five communist soldiers and two mujaheddin were killed and the mujaheddin liberated a vast area as a result of these operations (VOAPS).

\section{June}

9 According to the office of Jamiat-e-Islami, in an attack : May on a post in Khwaja Ghar, Takhar, the mujaheddin seized 22 items of arms. Another report says the troops of a post in Khwaja Ghar alongwith 23 items of arms foined 8 May the mujaheddin. The commander of Zard Kanar posts alongwith. 23 pieces of arms also joined 13 May the mujaheddin (VOAPS).

* A source of Jamiat-e-Islami has said, in an attack 25 May on the Samad posts in Khwaja Char, Takhar, the mujaheddin killed or injured 70 militiamen, captured 28 others and seized 56 items of arms-(VOAPS).

- The NIF says the mujaheddin demolished 2 June a number of posts in Takchar province and 25 troops jolned the mujaheddin. The report adds the najor portion of Krwaja Ghar sub division is now under 
the mujaheddin cunliol (VOAPS).

\section{Uruzgan, may}

3 The office of the Harkat-e-Islami Afghanistan in Quetta reports its mujaheddin took under fire 15 April the center of Dehraud sub division, Uruzgan, with heavy weapons as a result of which the posts were demolished and 25 militiamen killed. Five mujaheddin were also killed in the operation

(VOADS).

\section{Wardak, May}

11 The Hekmatyar Hezb-e-Islami says the mujaheddin in Maidan Shahr, Wardak, in an attack on communist offices 27 April killed six communists and burned some weapons. Also the report says Kabul forces were evacuated by helicopters 22 April from Sangi, Wardak (VOADS).

26 Diplomatic reports from Pakistan say the mujaheddin have captured the Sayyedabad sub division of the Wardak province 72 kilometers west of Kabul. Sayyedabad is located on an important startegic route (VOAPS).

\section{June}

8 The Afghan mujaheddin sources in Pakistan say the mujaheddin have sieged Wardak sub division and fighting continues to capture the cantonement evacuated by the Soviet troops (RPDS).

27 The Afghan mujaheddin news agency says the mujaheddin have captured Maidan, the capital of Wardak and since 26 June they are in control of the center. The Pravda has, however, written the in mujaheddin were defeated in their attempt within 24 hours by Kabul forces' (VOADS). .

28 The Harakat-e-Enqelabme-Islami of ${ }^{\prime} i c e$ says the mujaheddin began their operation 26 June in Maidan city, the capital of Wardak and. captured the city. It is said the governor of the province, General Zareef was also killed in the battle. Twenty nine posts have also been eliminated. Ten mujaheddin were killed and four others injured (VOAPS).

30 A commander of the Ittehad-e-Is]ami Afghanistan reported 28 June from Wardak that Maidan Shahr is still under the mujaheddin control. He refuted the Kabul government claim that the city was reoccupied. The report says $23 \mathrm{Kabul}$ regime posts have been destroyed in the mujaheddin operation

(VOADS).

\section{C2010, April}

The Harkat-e-Engelak-e-Islami Afghanistan office says a Soviet helicopter, carrying dead or injured Soviet soldiers from a battlefield, has crashed in the Sheikhák village of Zabul province

(VOAPS).

16 The Harkat-e-Islami Afghanjstan reports the mujaheddin subjected to their attack the Abghar sub-division, in Zabul 29 March-1April as a result of which houses belonging to commuist personnel were set ablaze. The reports reaching until 11 April say the sub-division was still under the mujaheddin seige ( $O O A D S$ ).

19 The mujaheddin in Shinki District, Zabul, captured the Darwazagi Garrison after several days of fighting 16 April, says a report from Zabul province (PT).

24 An TUAM spokesmar in Peshawar has said that the mujaheddin have captured the Atghal submdivi- 
sion in Zabul (VOGDS).

21 Western diplomats in Kabui say Soviet troops have been withdrawn from Qalat, Zabul, and the troops are now preparing to also withdraw from Shahjoy of that province (VOAPS).

\section{May}

5 The Harakat-e-Enqelab-e-Islami office in Quetta reports the mujaheddin, in an attack on the Becurity posts in Janda, Zabul, 19 April killed eight government soldiers and injured another three (VOAPS).

9 The Harkat-e-Enqelab-e-Islami Afghanistan office in Quetta says the Zabul mujaheddin attacked the Rabat-o-Tazi 30 April and by 3 May they captured an important post belonging to the base. The jujaheddin have captured 50 guns and number of other military hardware (VOAPS).

13 The office the Harkat-e-Enqelab-e-Islami Afghanistan in Quetta says the mujaheddin conquered 8 May three communist bases in Rabat-e-Tazi, Zabul. The report indicates that 50 government soldiers and two officers defected to the mujaheddin and the mujaheddin took possession of military and nop-military goods. The mujaheddin also set ablaze an oil depot. Three mujaheddin were killed and seven injured in the operation. According to another report, four soldiers killed the political head of the base and they themselves surrendered to the mujaheddin (VOADS).

15 The Afghan mujaheddin have captured a portion of Kabul-Kandahar Highway, reports VOA. The Radio said the mujaheddin have also destroyed a Kabul regime check-post on a hill in Rabatazai town of Zabul province. The mujaheddin claim that traffic on 1.25 kilometres road is blocked (PT). 20 Mujaheddin sources in Quetta say recently 200 Kabul regime soldiers fled away from their posts in Zabul (RPDS).

* The office of the Harkat-e-Enqelab-e-Islami in Quetta says that the muJaheddin captured 15 May the Rabat-o-Tazi base in Zabul. The base was under attack for the last two weeks. The mujaheddin have captured 415 soldiers and afficers from the base and killed another 85. They also collected large anounts of arms and supplies (VOAPS).

\section{June}

2 The Afghanistan resistance sources say the mujaheddin have recently sieged Qalat, the center of Zabul and have subjected the military centers and depots to fire (VOADS).

* With the mujaheddin ground to ground rocket fire $31 \mathrm{May}$, in the suburbs of Zabul province elght residential buildings were demolished (RA).

3 The Afghanistan resistance sources say the mujaheddin shot down 30 May a Soviet transport helicopter in Qalat airport, Zabul (VOAPS).

* The mujaheddin sources in Quetta say a number of Kabul troops, with four armored personnel carriers defected 31 May to the mujaheddin in Zabul (VOAPS).

8 Hezb-e-Islami (Hekmatyar) says the mujaheddin of all the organizations have started joint attacks ơn Qalat, the center of Zabul province and have shot down a helicopter (VOAPS).

* Resistance sources in Quetta say, despite their intensive bombardments and indiscriminate.artillery shellings, communist forces have not been able to drive the mujaheddin from Kandahan-Herat highway. The sources add the mujaheddin destroyed 1 June three tanks and three armo'ed vehicles. 
with their crewmen inShahjoay), Zabul. In the operation, 32 Kabul soldiers joined the mujaheddin

(VOAPS).

The NLF reported the mujaheddin attacked 4-9 June communist forces planning to enter Zabul province. Ten trucks with all the persons on board were destroyed and eight soldiers with their arms, joined the mujaheddin (VOADS).

18 The Afghan mujaheddin sources in Pakistan say the mujaheddin have captured 17 June Kalat, the capital of Zabul province. However Kakul regime of ficials say the mujaheddin attack has been repulsed (BBCFS).

20 The Afghanistan resistance sources say the mujaheddin have succeeded in capturing the city of Safa, Zabul. In the combat, 22 Kabul troops were killed and 14 others captured by the mujaheddin

(RPDS).

* The Kabul government forces say they have defeated the mujaheddin forces in Zabul. According to a Bakhtar report Kabul forces have killed 25 mujaheddin and demolished their arms depots (BBCFS). 21 The Afghan mujaheddin in Pakistan say they have come out of Kalat city, the center of Zabul province. The mujaheddin have said they could not capture the Balahissar. The source said the mujaheddin came out of Kalat by $2-3$ kilometers (VADS).

24 According to AFP, fierce battle has taken place between the mujaheddin and the Kabul regime forces In Kalat, Zabul, and the civilian people have also joined the fighting. Following the occupation of the city, the mujaheddin have retreated from the city at the request of the local people and the city is virtually with no inhabitants (RPDS)。

24TASS said 25 June two Frenchmen were killed during a clash between Afghan government troops and the guerrillias in Zabul province, reports BBC (MIM).

28 Garanai, a commander of the Hezb-e-Islami has said in Quetta that after 43 days fierce battle, the mujaheddin captured the Safa city, Zabul. The city fell when the commander of militia force was hit with a missile and his men fled away (VOAPS). 


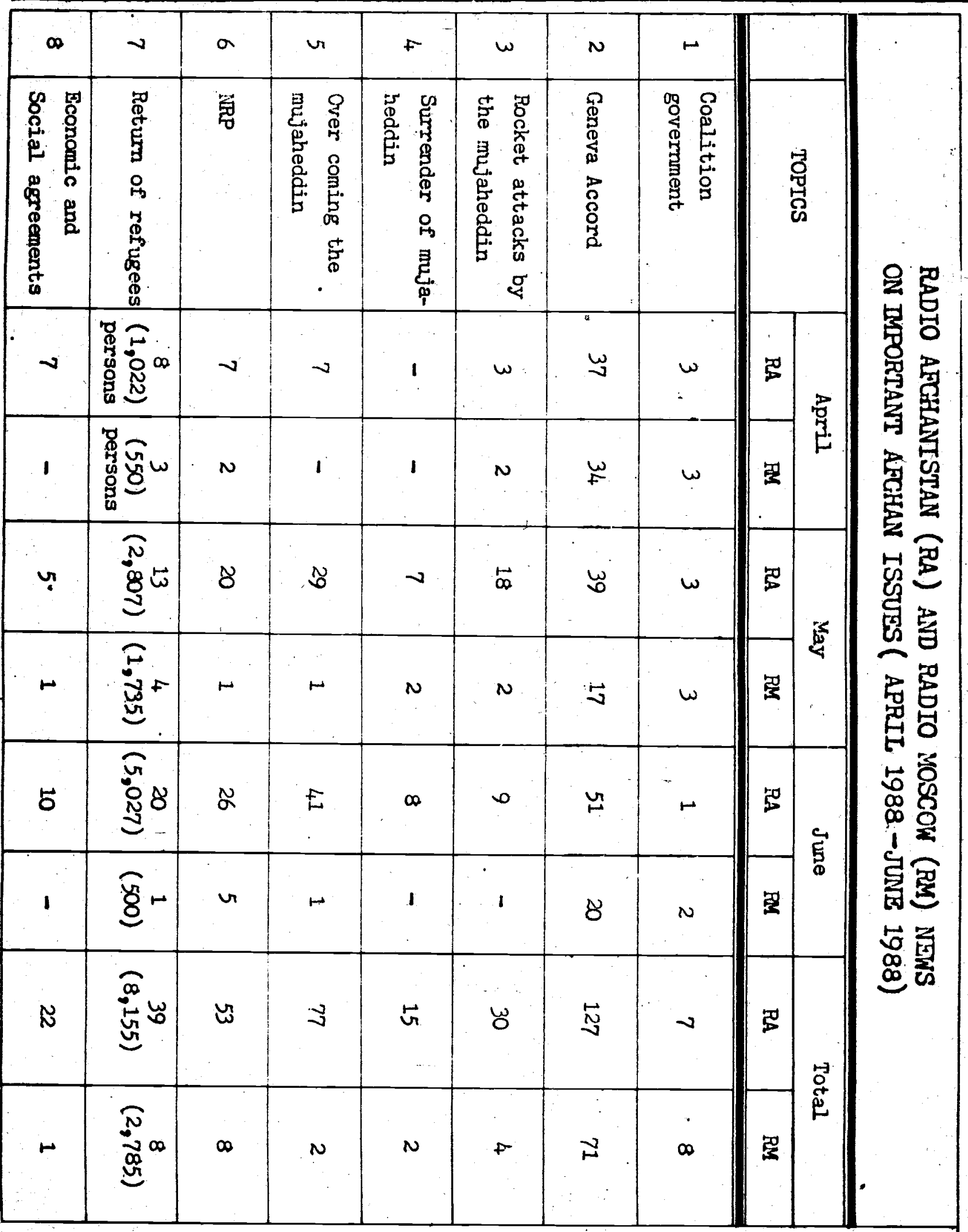

1. The table is based on 9:30PM (Pakistan Time) of RA, Dari News and 8:00 PM (Pakistan Time) of FM Dari News for Afghanistan. 
VOL. $1, \mathrm{NO} .4$

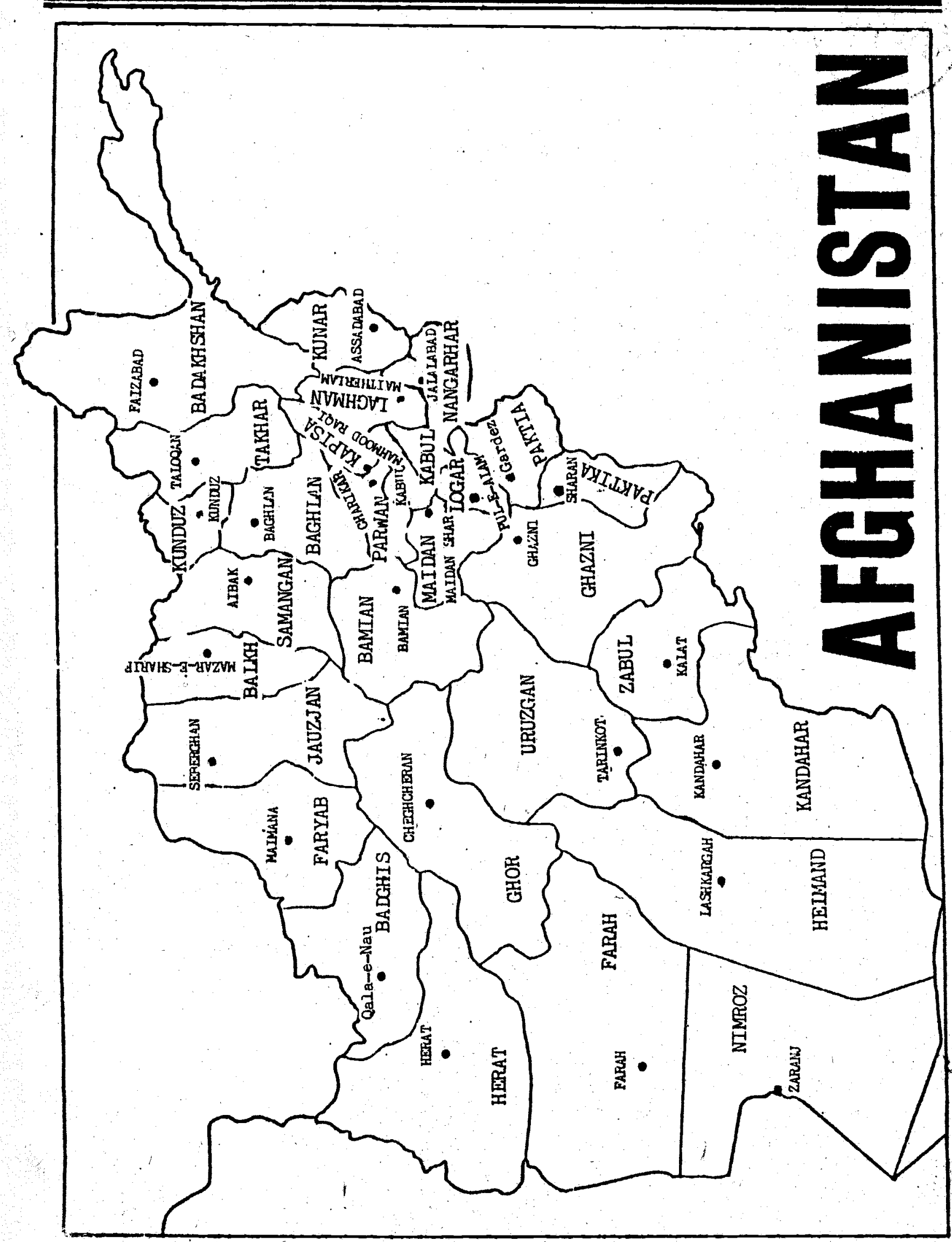

